三

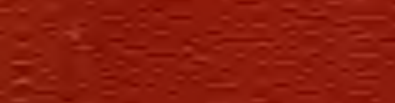

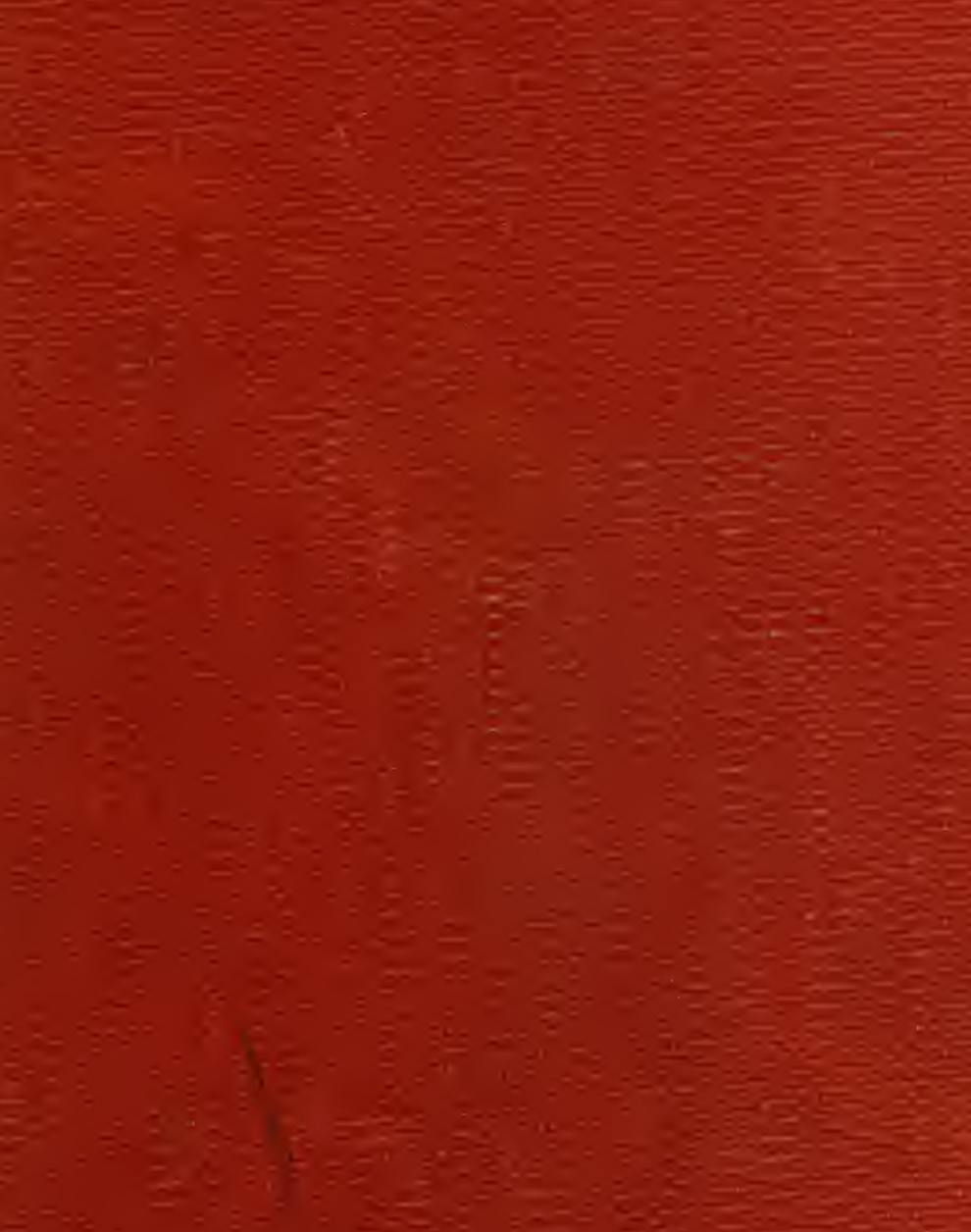

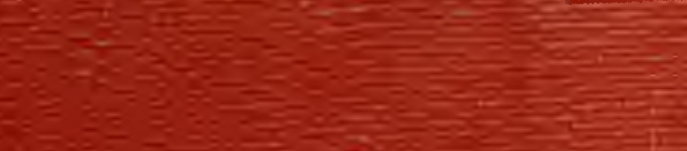

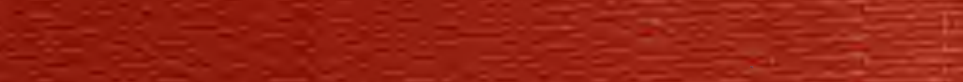
-

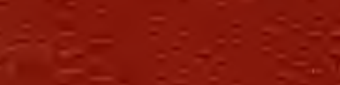

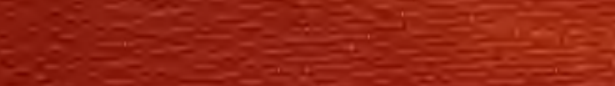

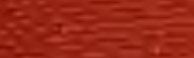

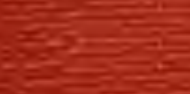
$\rightarrow=$ $\mathrm{Sz}=$ $-5$

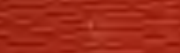
in: 25 주른 $8=$ $=-$ $\mathrm{s}$ 조을

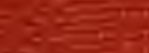
2 흘. $-19=2$ 98 a들 $=$ $x-15$

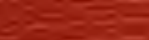
득 政 을 Hos 5

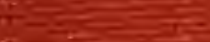


ชै 






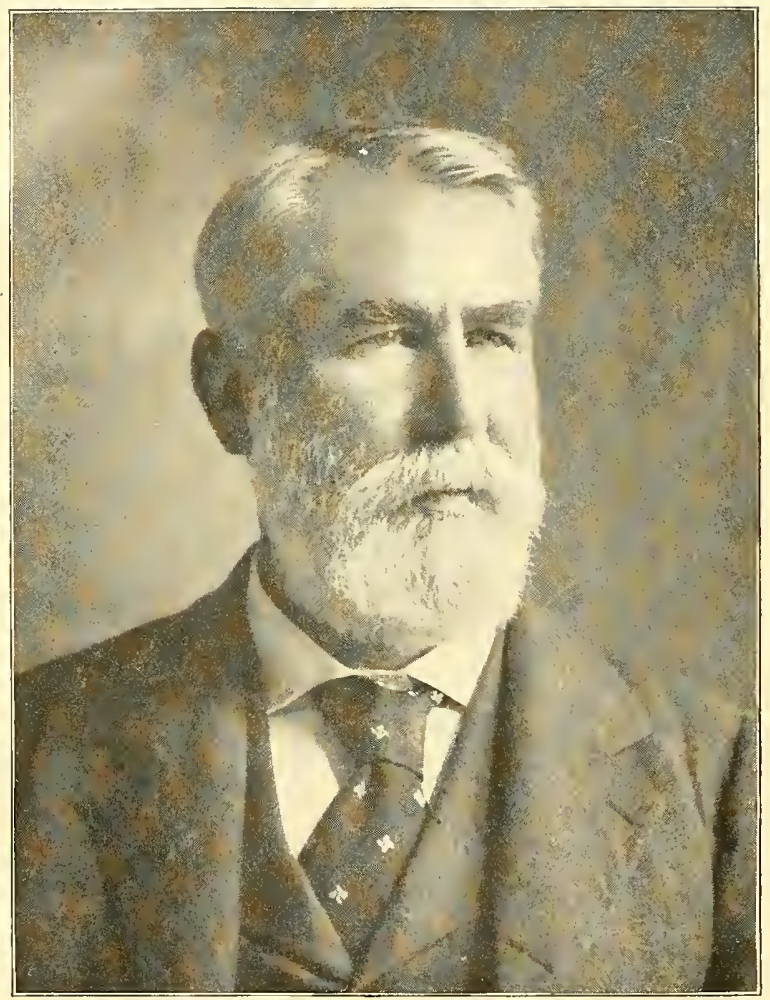




\section{A New Industry,}

O R

Raising the Angora Goat, and Mohair, for Profit.

Embracing the Historical; Commercial, and Practical Features of the Industry; together with Notes from a number of Practical

Breeders giving their experience in handling the animal; with Tables showing the great

\section{Profit in Raising the Angora, or Mohair, Goat,}

$$
\text { ALSO }
$$

A number of Letters from Farmers, and Ranchmen, in lowa, Oregon, California, and other States, concerning the utility of the Angora Goat in

Clearing Brushy Land, and How the Work is Done.

WITH A COMPLETE MANUAL UPON THE

Care and Management of Goats, AND

How to Grade Up the Common Mexiçan Goat, $: \because::$ WITH AN

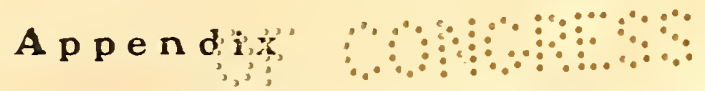

Containing a Paper on the celebrated "Cashmere Goat" of Asia; the "Llama" and "Alpaca" of Peru, in South America; the "Rocky Mountain Goat" of the United States, and the "Ibex" of Asia.

TOGETHEA W:TH A FORMULA FOR

Dressing the Angora Goat Skin.

AND OTHER USEFUL INFOAMATION CONCERNING

THE INDUSTRY.

Fully llistrated.

BY

WM. L. BLACK, OF TEXAS. 


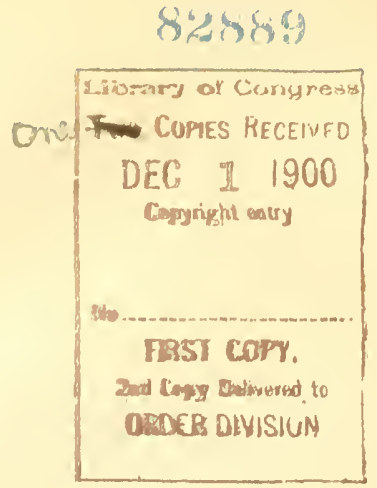

Corymente, 1900 ,

ISY

WM. Г. IBT.ACK.

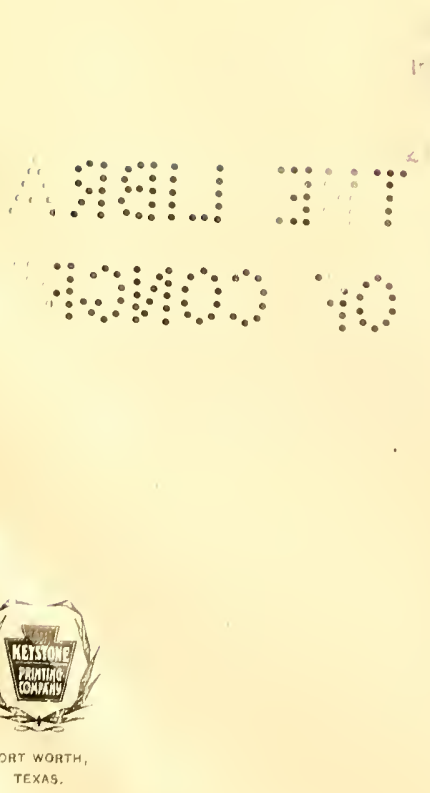


To

THOSE LNTERPRISING AND PERSEVERING CITIZENS

OF'IHE

UN:TED STATES OF AMERISA,

WHO, WITHOUT GOVEITMENTAI, ASSLSTANCE, HAVL LAID TUE

FOUNDATION FOR A BHANCH

TOOUR

AGRICULTURAL INDUSTRY,

IN THE RAISING ()F 'THE ANGORA GOAT, AND MOHAIR,

WHICH PIOMISES TO BE

OF GKEAT

NATIONAL BENEFIT,

THIS WORK IS RESPECTFULLY DEDICATEU

BY THE

A U'THOR. 


\section{Table of Contents.}

PAGE

Introductory remarks $\ldots \ldots \ldots \ldots \ldots \ldots \ldots \ldots \ldots \ldots \ldots \ldots \ldots$

IAAP.

HISTOPICAI.

1. When, where and how; did the Angora goat originate.. 25

II. The Protince oi Angora................... 31

III. Distrbution oi the Angora goat into other countries... 34

IT. Character oi the early Angora goat.............. 40.

1 . Introduction of the Angora goat into the United States. 15

TI. Subsequent importatons into the United States........ 18

III. Spread of the Angora goat industry throughout the

rarious states and Territories................ 52

TIII. Census of Angora goats in the United States.......... 109

IX. Thy the industry has made such slow progress in the

United States and what we can expect in the future. 109

$\mathrm{X}$. Concerning the manufacture of Mohair in Asia Minor.

England and the United States............... 117

\section{COMMERCIAL.}

XI. Where to sel] Mohair and how it is graded......... 135

XII. How to prepare Mohair for market............. 145

$X I I I$. The trade in Angora goat skins and how to prepare

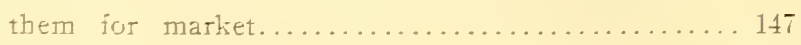

XIT. Concentrating upon one market................ 151

XT. Angora renison. as a salable product.............. 154

XTI. Is there any danger from orer-production........... 159.9

XTII. Tariff on MIohair. live goats, and Angora skins........ 16il

\section{PRACTICAL.}

XTIII. The science of breeding, our past experience, and the result of crossing the common goat with the Angora .............................. 173

XIX. Cross breeding. or how to grade up the Mexican goat. 243 


\section{Index to lllustrations Continued.}

PIATE

PAGE

XXIII. Group of thoroughbred Angora goats (Ham \& Baylor). 30 XIV. Two thoroughbred bucks and one doe (Ham \& Baylor).. 311

NTV. Thoroughbred Angora buck (Hughes) ............ $31+$

XXVI. Thoroughbred three-year-old doe (Hughes) .......... 31 is

XXVII. Angora buck, twenty-one months old (Arnold) ....... 31

AYVIII. A group of yearling Angora goats (Fuchs) . . . . . . . 321

XXIX. A group of thoroughbred Angora does (Houck) .......

TIX. Thoroughbred Angora doe, yearling and kid (Conk-

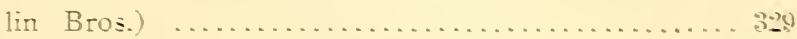

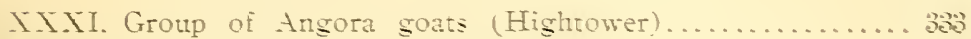

XXII. Yearling Angora Buck (Taylor) . . . . . . . . . . . 333

IXNIII. Ihoroughbred Angora does, twenty-one months oll

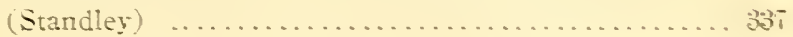

XIXIV. Flock of thoroughbred Angora goats (Harris)........ d4t

XXYT. Group of thoroughbred Angora goats (Harris) ........ 3to

IXXVI. Thoromghbred Angora hids, after weanimg (Harris) .... 303

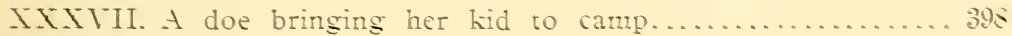

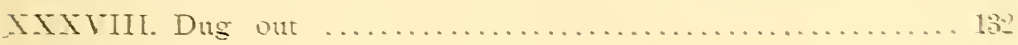

IIIIX. Portable camping outtit................... 1:0

XL. Cashmere (doe) goat.................... t5t

XLI. Rocky Mountain goats................... ti.

XlII. Group of Alpacas...................... triti

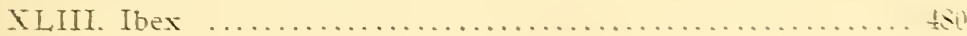




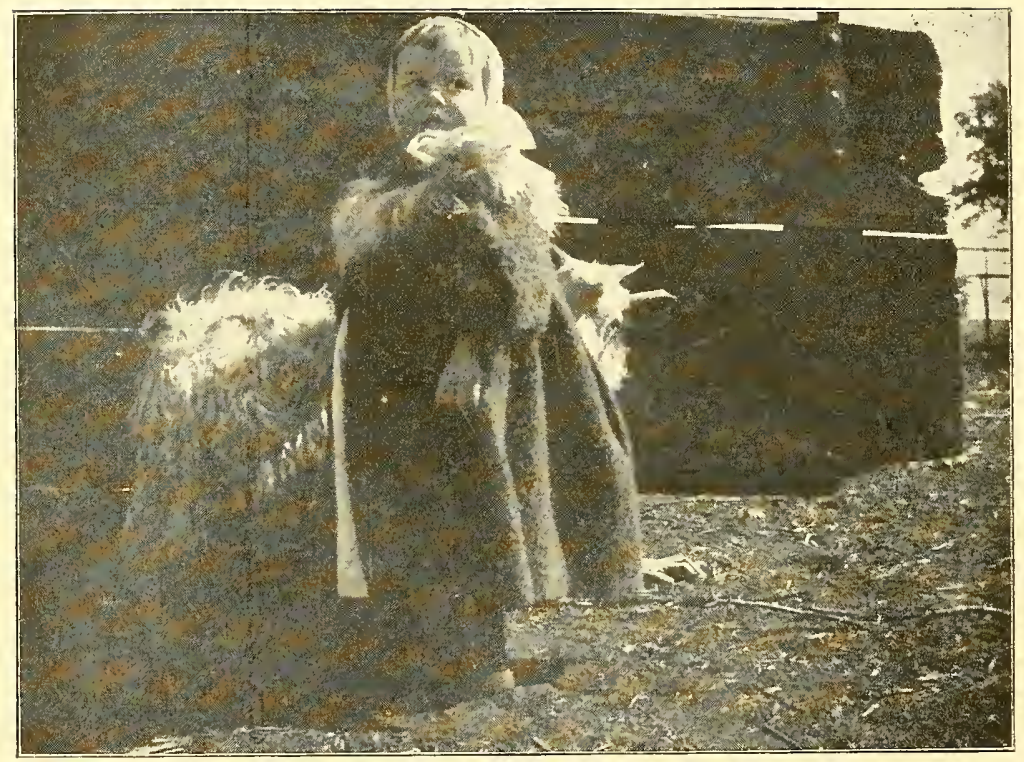

TWO PRETTY KIDS.

liom a photomaph tasen on the ranche of the author. 


\section{PREFACE.}

When this work was commenced, in the early part of 1899 , it was for the purpose of supplying a demand for information from farmers in the Northern states, whose attention had been called to the Angora Goat as a Brish Exterminator. They had heard of the wonderful saving of labor in clearing away briers, and brush, by the use of this animal, and many were anxious to purchase some, but were totally ignorant of their habits, and how to breed them. The great call for information, touching these questions prompted me to write a complete manual, through which a stranger might understand how they are handled; and, as I pursued my work, I learned of the existence of a non-shedding type of Angora, as well as a hornless variety, which I considered to be of such importance to the old breeders. in the industry that $I$ determined to delay its publication until I could investigate more fully into the merit of the matter. I distributed a iarge number of question-blanks over all the States: that had been raising them, asking breeders if they had ever observed any such types of goats in their flocks, and, am pleased' to say, I have received an abundance of testimony as to the existence of the same, and I feel quite sure that the discovery will be received with great delight by all who are interested in this new industry, particularly the non-shedding type: for, if there is any one objectionable part to the raising of the Angora goat, it is the unfortunate feature of casting its hair so early in the spring, necessitating the early shearing of the animal to prevent the loss of the valuable fleece, which so often results in the death of many from a sudden change of weather, or a cold, rainy, season.

Col. Richard Peters, of Georgia, always maintained that, the most serious objection he had ever experienced with the Angora Goat, was its tendency to shed its fleece too early in the spring. 
If they can be made to retain their fleece as securely as the sheep does, so as to admit of shearing at the pleasure of the breeder, a great drawback in the industry will be overcome. That such a type as non-shedding Angoras exist, there can be no doubt; and, whether it has been produced by a freak of nature or has been evolved through the action of the American climate, or by crossing with our short-haired varieties, I cannot say. I realize the importance of the changed condition of the animal, and feel certain that all old breeders will rejoice to hear of it.

The homless variety is another valuable type; and, although not at all new, has been entirely overlooked by most breeders. The horns of an animal were undoubtedly provided by a wise Creator, as a means of defence; and, in a wild state, are very useful, and necessary; but, in a domestic condition, they are a very decided objection in many respects, and should be removed.

The advantages of hornless stock are so well known it is hardly necessary that I should dwell on the subject.

It was to be able to show, by the testimony of practicis breeders, of the existence of these two new varieties of mohairproducing goats (which I have arranged under appropriate headings), and to secure some photographs of representative American goats, showing their full fleece, that compelled me to delay the publication of my work, which I am sure will be more generally useful now than it would otherwise have been.

I regret that many of the breeders were unable to supply me with photographs of their goats, and that so few of those I received show a full year's growth, which is due to shearing twice a year, a custom that, unfortunately, seems to prevail largely with the breeders of our finest animals. Such as I have received, however, will afford a very good illustration of the great improvement that has been made since the introduction of the animal to this country.

WM. L. BLACK.

Fort McKavett, 'Texas, June, 1900. 


\section{INTRODUC'TORY REMARKS.}

I shall not undertake to investigate very closely into the origin of the Angora goat.

This has been attempted by a number of writers, in the past, and there seems to be as much doubt, today, as to how the animal originated, as there is about the origin of man. Some writers believe that the Angora and sheep were, at one time, very closely related to each other; but, if they ever were, there must have been a serious rupture in their family relations at some time or other, for they have not been known to mix with each other for many centuries.

Others claim that it originated from the "Ibex," an animal resembling the goat in some respects; but I am not willing to accept this theory, either, for the reason that, the period of gestation with the "Ibex" is only ninety days, while with the Angora it is about 150 , and I can't well understand how there can be any close family relationship between the two.

Another school of naturalists claim that the Angora sprang from the "Wild Goat," or Pesang of the Persians, an animal found in the mountainous regions of Central Asia, resembling the domestic goat very closely. A wild goat is also found in the Rocky mountains of America, which is no doubt of the same family as the Asiatic wild goat.

Judging from the looks of the two animass, the "Ibex" and the "Wild Goat," I think it more than likely that the Angora goat originated from the latter; but, I confess my entire ignorance of the subject; and, it seems to me, it is of very little consequence how the human family have come into possession of this animal.

We know we have a goat, known to the commercial world as the "Angora," and, whether this particular species belongs to the family, called by naturalists, the Capra aegagrus, or the Capra hircus, makes but very little difference, as far as I can 
see. It is an interesting study, I admit, but there's no money in it, and I shall leave the question to minds more scientific than my own to determine, and will endeavor to show my readers the practical value of the Angora Goat in a purely business sense.

I shall place in my appendix correct photographs of the "Ibex," and "Wild Goat," with a full description of their general make-up, habits, etc., and my readers can form their own conclusion; and, by way of assisting them to reach this conclusion, I refer to the following authorities:

Jno. L. Hayes, L. L. D., "Angora Goat, Its Origin and Culture."

J. G. Wood, "Natural History."

R. Ramsay Wright, Ph. D., "Riverside Natural History."

Lydekker, "The Royal National History."

Mr. S. C. C. Schreiner, of South Africa, has more recently (1898) published a work through Messrs. Longmans Green \& Co., of New York, which is perhaps as complete upon this subject as it is possible to make it. Mr. Schreiner has undoubtedly made a very close study of this matter, and has quoted from all the authorities I have named, as well as others. He also gives a most interesting account of the Angora goat industry in South Africa, and I can commend his book as being one of the most painstaking, with reference to the origin of the animal, of any I have ever read on this subject.

My first experience with goats began in the year of $18 \% 6$ in the State of Texas.

In connection with raising sheep, I learned that Mexican herders preferred to eat goat rather than sheep, and being much the cheaper animal of the two, I purchased a small flock for the purpose of supplying my herders with fresh meat.

About the year $188+\mathrm{my}$ attention was called to the Angora as being a superior breed, and possessing greater commercial value than the common species (Merican), which I had on hand. I found out that I could very easily grade up my common goats by introducing full-blooded Angora sires; and I therefore purchased from Col. Richard Peters, of Atlanta, Georgia, eight males and four females, which cost me close to $\$ 750$ delivered 
at my ranch, or about $\$ 60$ for each goat. This appeared to me as being an enormous price to pay for goats, but the investment turned out a very good one. In a few years I had improved my flock to a condition which justified me in shearing, and I then commenced to enjoy a revenue which I had never counted on; for, in addition to supplying my ranch with an abundance of fresh meat, I received, annually, quite a handsome return from mohair, and my goats increased so rapidly that, in 1892, I had upwards of eight thousand. head of well-graded Angoras, many of them being very superior. I figured that unless I could thin out my stock of goats they would very soon overrun my ranch; disease and poverty would occasionally thin out my sheep and cattle, but my goats seemed to be proof against these two powerful elements, for it was only once in a while that a few old does would die from extreme old age. I inquired of a personal acquaintance, who was engaged in the meat packing business, if he would purchase a thousand fat wether goats; but he declined to do so, and explained to me that goat meat was not at all fashionable; and, although he knew it was quite as good as sheep, he could not venture to slaughter them in large numbers until the people had overcome their prejudice for it.

- I knew I could dispose of them in a retail way, in the small towns in Texas, but the expense, and annoyance, attending this plan was too great for me to attempt, so I determined to slaughter them myself for their hides and tallow, and put up the meat in hermetically sealed tin cans. I procured the necessary machinery for this purpose and slaughtered 3000 head that year (1893), and in 1894 I slaughtered 4000 more, which reduced my number to a more reasonable size. I realized from the sale of canned meat, tallow and hides (the latter I had dressed for making into rugs and robes), about $\$ 3.00$ to the animal, and, considering the fact that $I$ had never regarded the goat branch of my ranch interests as being of any importance, I was well pleased with this result. I found no difficulty, whatever, in finding ready sale for my dressed skins, selling as many as one thousand to a single wholesale house in Chicago; and, the brokers through whom I placed my tallow have been exceed- 
ingly anxious to receive more ever since. They reported to me it was of a superior character, and would command a premium over ordinary tallow for making fine candles.

In 1896 my goats had again increased to a considerable number, and I concluded, rather than resume my slaughtering operation, to dispose of my surplus stock to others who might be disposed to engage in raising them. I had become very much interested in the beautiful little animal; and, from investigation, was convinced that the United States was better adapted to the propagation of this class of livestock than any other part of the world, not excepting Turkey in Asia, where, it is supposed, they originated.

It is true, South Africa has made greater headway in breeding them than we have, but this can 'je very easily explained, and I shall probably refer to this matter later on. We have had ampie time to test the merits of our climate, and the opinion of manufacturers is that American-raised mohair is fully equal, if not superior, to any that is produced in either Asia or South Africa. Some of them claim that the American product makes a smoother fabric, but of course our entire clip will not do this, for the reason that many of our flocks are only partly graded; but the higher grades of American goats will bear comparison with the best in the world, not only as to quality, but in their shearing capacity as well. In addition to this, our goats have never developed any disease, while in both Asia and South Africa (which, by the way, are the only parts of the world where the Angora goat is raised, outside of our own country), they have suffered serious losses from pleuro-pneumonia, scab and other diseases. In Mr. Schreiner's work, on the Goat industry in South Africa, he makes especial reference to the "Pleuro-Pnenmonia Epidemic in the Cape Colony," upon page 219, of his book, and believing it to be of some interest to the breeders in the United States, to know the history of this epidemic, and how it was finally controlled, I shall take the liberty of copying it in full, which may be seen under the head of "Diseases."

In view of the foregoing facts, I considered it acrime tpon my part to put the knife to animals which I believed could be made 
so useful and valuable to others; particularly when there was such a limited number of them in this country, and the cost of importing them was out of all reason. I, therefore, decided to publish a little booklet, setting forth some of the advantages of the goat industry, and calling upon farmers in the Northern States to take advantage of the opportunity offered them in this new, and valuable, industry. It was not long before I had a number of inquiries, asking all manner of questions; whether they would live in a cold climate; what kind of fence was necessary to hold them, etc., etc.

In the early part of 1897 , Dr. J. R. Standley, of Platteville, Iowa, visited my ranch for the purpose of interesting me in shipping some into his State to be sold at public auction. $\mathrm{He}$ explained to me that he had succeeded in clearing about 500 acres of his farm that had been covered so densely with brush, as to be practically worthless until he began running goats upon it, and it was now the finest portion of his farm, being well set with blue grass, and perfectly free from brush and weeds. He was well satisfied I could dispose of all the goats I would send there, and the fact of his having traveled upwards of fifteen hundred miles to see me, and his great enthusiasm on the subject, gave me confidence to make the experiment; and I at once entered into an agreement to ship one thousand goats to be sold at auction on his farm. Our sale took place in July and was. entirely satisfactory.

In the fall, of the same year, I made him a second shipment of one thousand, which were sold in December. 'The following year (18.8) I concluded I could not repeat my shipments in such large numbers, and determined to wait until the purchasers of my goats, at the "Standley sales," had had sufficient time to prove the value of them, fully expecting to be able to sell all that I cared to, from the introduction I had made. In this, I was not disappointed, having reduced my individual holdings to one flock of about a thousand head, and have had to purchase a great many from my neighbors to fill the orders I have received. From - the time that Dr. Standley first visited me in 1897 I have shipped upwards of fifteen thousand goats to the state of Iowa alone; 
and have had inquiries enough from farmers in that State and others to absorb every Angora goat there is in the United States.

I commenced selling at $\$ 3.00$ per head, because it paid me a fair profit in raising them; but, very few ranchmen were situated like myself; and, when asked to sell their smaller flocks, they put a price on them that made it impossible for me to continue my sales at that low figure. I knew, furthermore, that it would be impossible to find enough graded goats to meet the demand that was springing up all over the country, and this gave rise to the idea which prompted me in writing this book. I realized, if the farmers of the United States expected to engage in the Angora goat industry they would have to begin at the bottom like we all had done, and grade up the smooth-haired goat. We have an abundance of full-blooded males to stock the entire country, but the Mexican female must be used as a foundation if we expect to build up the industry in any reasonable time. This was the course pursued in South Africa, except that they used the Boer goat instead of the Mexican, which are practically the same class of stock, strong and vigorous, with smooth hair; and it was followed in Turkey, to a large extent, as soon as the demand for mohair exceeded the annual supply, which took place between 1860 and 18\%0. Mr. Schreiner refers to this in the following language:

"The European demand for mohair became so great, that it was impossible for Asia Minor (which practically had a monopoly of the trade till the early seventies) to meet it merely by the normal increase of the pure Angora goats. It was therefore necessary quickly to obtain a more rapid increase in the number of mohair goats than could be obtained through the normal increase of the pure Angoras; and, at the same time, a larger area of country was essential for the production of the amount of mohair required.

"To secure these ends the Turkish farmers resorted to grading up the commion ewes by means of in-breedirg to Angora rams. The mohair demand being so great, in proportion to the supply, quality ceased to be the first essential; weight of fleece was required and a large number of goats. * * * With this end in view, crossing became very general, and was so persisted in that in the early sixties the original pure Angora was becoming very scarce. * * B By its means, en- 
tirely new districts were rapidly populated, indeed such a hold had this method of increasing the numbers of the mohair goat obtained on the Turkish farmers, and so eager were they to avail themselves of it, that. not content with introducing Angora rams into flocks of Kurd ewes in outsides districts, they actually imported the Kurd ewes into the very center of the mohair region-the home of the pure Angora-and, putting them to Angora rams, graded them up there."

It is very popular with American farmers to want the very best class of stock that can be obtained, and I recognize this as being true economy not only in live stock but in all kinds of farming machinery, as well as in manufactured goods for home use. I think it will justify paying a very high premium to get well-improved Angora goats rather than begin on the smoothhaired Mexican-but, if these cannot be had, there is no other remedy than to begin with the low grade. We have reached a point in the United States similar to that which existed in Turkey, between 1860 and $18 \% 0$, with the exception that, the demand in this country calls for goats to exterminate brush, in place of supplying a larger amount of mohair. The common goat will answer the purpose we need them for, even better than the Angora, from the fact they are stronger bodied, and are not burdened with long hair, which is often torn out on the brush when feeding.

In my chapter referring to Cross Breeding I shall give photographs showing the different grades of Angoras, which will convey a fair idea of the rapid change that can be made in these common goats. There is perhaps no animal that will stamp his progeny so decidedly as the Angora goat will; and, it is only necessary to get full-blooded males to be able to build up a good flock of shearing goats in a very few years.

Referring again to Dr. Standley's work of clearing land, I shall procure and place a photograph of the land he cleared of hazel brush, under my chapter on "Clearing Brush Land, and How the Work Is Done." It is well worth a trip to the farm of this gentleman, in Taylor County, Iowa, to see the marvellous change that was made in two years' time by the aid of goats. Up to the very edge of the wire fence, dividing his land from a neighbor's, the Doctor's 
land is finely set in biue grass, while not a blade can be seen (or any other kind of grass) on the other side. When I first visited this farm it was a revelation to nie. I always knew the goat would eat brush, but I had no idea it could be turned to such a useful purpose as Dr. Standley's work will demonstrate; and, no better evidence than a personal visit to his farm is needed to convince the most skeptical that the goat is the best land grubber on earth. He will not only destroy the brush, but will enrich and tramp the soil more thoroughly than any other anmal can possibly do, winch is so essential in producing a fine stand of blue grass; and, he will thoroughly remove all noxious weeds as well.

The Doctor tells a very interesting story on one of his acquaintances who was rather doubtful about the value of the goat. It was, I think, at one of the annual State fairs in Iowa, and, if I may be excused for digressing a little, I want here, to commend the Iowa system of fairs over any I have ever attended. Instead of coming and going every day, farmers come prepared to camp out for a week, or as long as they care to remain. A certain part of the ground is set apart for campers, and very nicely arranged hotels are provided for those who are not prepared to "camp." The officers are on the ground night and day, during the period of the fair, and an exhibitor can transact any business he may have with them, without the slightest trouble. I had the pleasure of visiting these grounds in the fall of $189 \%$, and took with me a lot of rugs and robes, to show the people what some of the by-products of the Angora goat looked like. I had a number of skins in their natural shape, and others cut into shape for floor rugs and buggy mats. In my exhibit I had a rug arranged with a large wolf slin, in the center, which attracted considerable attention. I also took with me 500 head of goats (the first that many of the visitors had ever seen), and, while I was there, a drizzling rain had made the race track very heavy, and the superintendent asked me if I would allow my goats to be driven around the track to tramp it and put it in better condition for the races in the afternoon. This was an entirely new departure from old customs, and I 
did not know whether my Texas goats would relish it or not. I was afraid they might become scared at the multitude of people, yelling and shouting, as they usually do on such occasions; and the bands of music were also a ncw thing to my country goats; but I told the superintendent that I would have the herder try the experiment, which proved to be very successful. They walked around the track a number of times, and seemed to enjoy the notoriety they were creating quite a good deal, and the races went on as istual. It was at one of these fairs that Dr. Standley was telling some of his friends of the wonderful work the little goat had done for him in clearing his land; and when he told them of the splendid stand of blue grass he had now in place of a hazel-brush thicket two years before, a Mr. - - - . - of county, who also owned a quantity of hazel-brush land, quietly remarked: "Doctor, are you not putting that a little too strong?" The Doctor was surprised, and, very naturally, nettled at this 1 emark; and, after recovering from astonishment at having, his statement doubted, he replied: "Mr. — it will only cost you about $\$ 10$ to make a personal inspection of the land I have been telling about, and you can return here by tomorrow's train; now, I will make you this proposition: if you do not find that I have stated the matter correctly, and fairly, I will return you every dollar you expend on the trip, including your board and lodging." The gentleman accepted the offer, and upon his return to the fair the following day, Dr. Standley asked him how much he owed him. Mr. replied: "Not one cent, Doctor, you did not tell it half as strong as you should liave done."

- I believe that Dr. Standley has done more in the way of bringing the Angora goat into prominence and favor than any individual in the United States. Many men before him have owned goats, and great credit is due to Col. Richard Peters, of Atlanta, Georgia, who was so impressed with the importance of the industry to this country as to pay to Dr. Davis of South Carolina (who was the first to bring any Angora goats into the United States), $\$ 1000$ each for all the pure-bred goats he 
had. An investment of $\$ 1000$ in a little goat calls for considerable nerve, and Col. Peters may be justly called the "Father of the Angora goat industry in the United States," for in all probability if he had not become interested in them they would have been scattered and soon died out. Mr. Jno. S. Harris, of Oakley, Idaho, is likewise entitled to great credit. This gentleman took a deep interest in the Angora goat very early, and made a voyage to Asia in 1875 for the purpose of bringing back some pure-bred stock. He reached America the following year (1876) with twelve head, after having had an endless amount of trouble in getting them out of Asia Minor, and they cost him over $\$ 500$ each before he landed them at his ranch in this country.

There are many other gentlemen in Texas, California and Oregon that are entitled to credit in having given a start to the industry, among whom I recall the names of Parish, Devine, Haupt, Fink, Arnold, Landrum, and Bailey, some of whom are still engaged in the business. Many others are equally entitled to credit, but I do not think there are any who have shown to the world how this animal can be made use of as profitably as Dr. J. R. Standley, of Platteville, Iowa, has. His work is worth millions of dollars to the State of Iowa, and will result in great benefit to every State in the Union where brush and weeds are ruining pasture lands.

The brush question is a most serious one in a great many of our states. As long as land can be kept under cultivation brush can be kept down, but when it is once thrown open to pasture, briars, and brush of all description begin to grow, and soon covers the entire surface. Even in our own State of Texas many millions of acres, in the west, are growing up into brush thickets, which will, sooner or later, become worthless for pasturing cattle; and, in many of the western territories the same conditions exist. It is supposed that this has been produced by an increase in rainfall; but, I am inclined to think it is not altogether due to this cause. That brush and trees are indigenous to many of our, so-called, arid districts can be very easily proven by the great quantities of roots the present inhabitants dig out of the ground for fuel purposes. Not a tree can be seen for hun- 
dreds of miles, yet these great roots can be found almost everywhere, on the prairies, and are a substantial witness to the fact that there were an abundance of trees there at some time or other. Before this portion of the United States was occupied by the white race, it was a common practice of the Indians to burn the high prairie grass every fall, or winter, in order to hunt wild game that was very abundant. Buffaio and deer, were as common then as cattle, and sheep, are now, but the grass was so high, in places, they could not be seen, and the Indian would burn it off to be able to hunt them more readily. This, undoubtedly, destroyed much of the growth of trees; and, in my opinion, is the true explanation of the roots that are now found in many parts of west Texas, New Mexico and other western territories.

The question is a very important one, and if the Angora goat can be used to keep this growth back it is certainly well worth the attention of many of our land owners, who may, in a few years, find their land practically worthless. A personal friend writes me that: "Many pastures are growing up to oak brush, and hazel brush, in the north; and in New England they are bothered with ferns (called brakes), berry bushes, blackberries, raspberries, etc." This kind of fare would be "peaches and cream" to a goat, and in a year or two the owner would be relieved of a great nuisance, the goat would grow fat, and the land would be restored to a proper condition for grazing other stock on it.

Another correspondent in Massachusetts speaks of a certain small island he owned which was so densely covered with brush as to be utterly valueless except to grow mosquitoes. I hear of many parts of the East that are serionsly troubled with brush, where many thousands of acres are of no use for grazing purposes, and the profit in farming will not justify the cost of grubbing it. In the Southern States many farms have become worn out, and are growing up into brush and weeds. In Dr. James B. Davis' report to our government, after he had made his first importation of Angora goats from ' Turkey, he makes use of the following language with reference to brush in the Southerr States. 
"The want of calcareousness in nearly all of the soils of the Southern States, together with the heat of our sun, makes an inaptitude to perennial grasses for grazing animals, hence more suitable for browsing, as both tend to originate shrubbery and weeds."

The Angora goat is the proper animal to employ to put these lands in a proper condition either for cultivating or grazing cattle. But a number of my correspondents have asked me what they could do with the goats after they had cleared their land. In reply to this, I will say they can well afford to slaughter them and feed them to their hogs, but this will not be necessary now. The fashion has changed since I slaughtered goats for their hide and tallow, and there is no trouble now in selling all the goats you send to any of our large meat packing markets. I shall refer to this sibject more particularly under a proper heading, as well as to show the great profit in the incidental or by-products of the animal. 


\section{Historical Facts}

Concerning the Angora Goat

$$
\text { and }
$$

Manufacture of Mohair. 


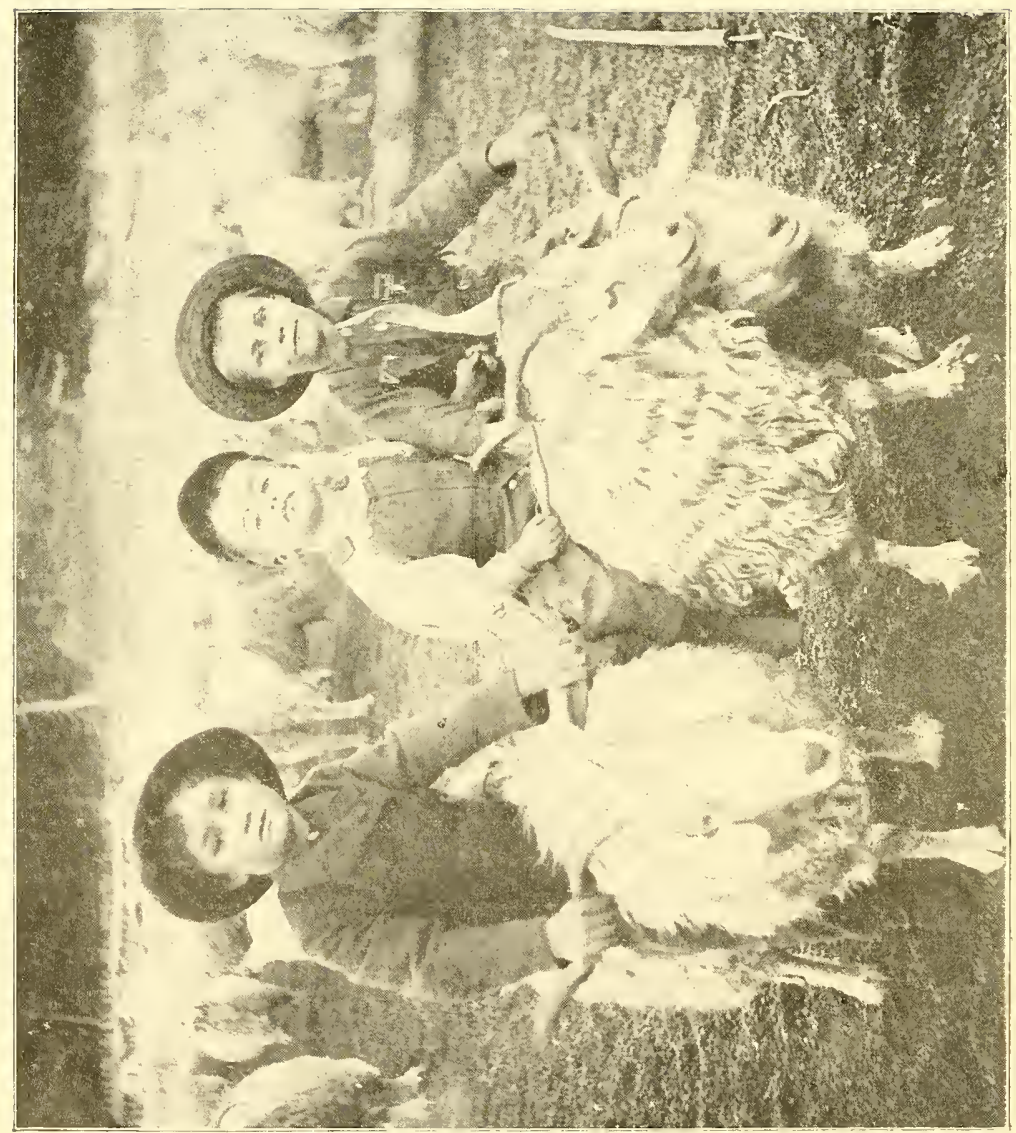

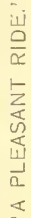




\section{CHAP'TER I.}

WHEN, WHERE, AND HOW, DID THE ANGORA GOAT ORIGINATE.

The exact time, or period, when the Angora goat first originated has never been ascertained.

We have an abundance of testimony in the Bible of the existence of goats, at a very early , yeriod of the world (1800 B. C.), see Genesis, xxvii, 9, but as to whether they were the same class as we now call "Angora" or not, is altogether a matter of conjecture. The account given of them rather leads to the impression that they were of a different character entirely; for, they are, generally, referred to as producing hair (Exodus, xxv, 4), and that they did not shear them (I Samuel, xxv, 2).

But, upon the other hand, we read in Exodus, xxxvi, 1t, “* * * And he made curtains of goats' hair, for the tent, over the tabernacle ****; and, again in Numbers, xxxi, 20 "* * * And purify all your raiment, and all that is made of skins, and all work of goats'hair * * **, which rather leads one to think it was fine enough to be woven into cloth, for wearing apparel. But, it will be observed, Moses does not say raiment of goats' hair, but w'ork of goats' hair, which may have been some kind of coarse material like the curtains over the tabernacle are likely to have been made of.

This opinion is, to some extent, confirmed in Leviticus, xiii, $4 \%$, where he says: "**** Whether it be a woolen garment, or a linen garment * * *," which conveys the impression that goats' hair was not used for wearing apparel, or it would have been mentioned with wool, and linen; for Moses was giving out a law concerning the "cleansing of a leper", and if the people had been accustomed to use goats' hair for clothing, he would surely have included this kind, as well as that made from other material; for, in the very next verse (Lev., xiii, 48) 


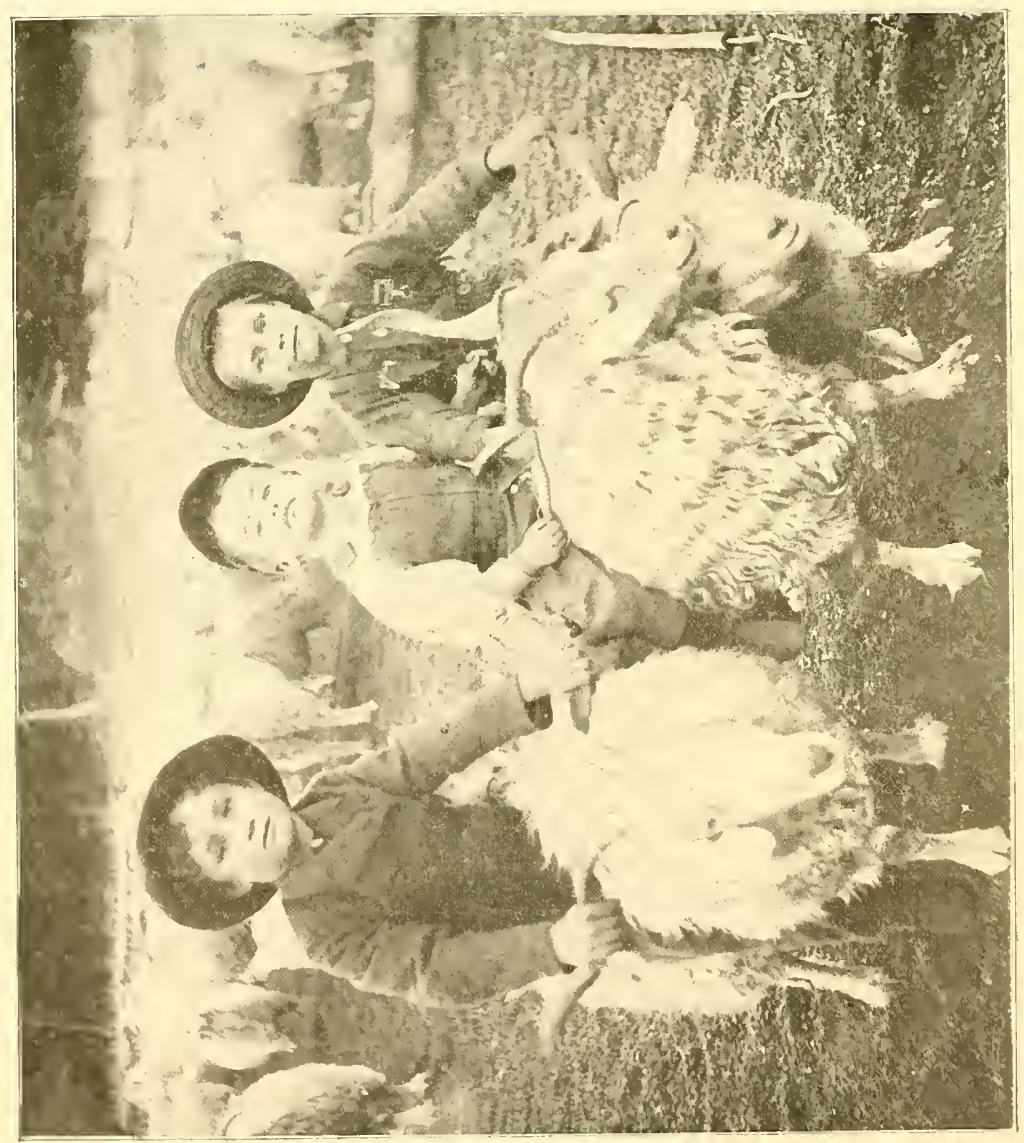

苟 


\section{CHAP'TER I.}

WHEN, WHERE, AND HOW, DID THE ANGORA GOAT ORIGINATE.

The exact time, or period, when the Angora goat first originated has never been ascertained.

We have an abundance of testimony in the Bible of the existence of goats, at a very early period of the world (1800 B. C.), see Genesis, xxvii, 9, but as to whether they were the same class as we now call "Angora" or not, is altogether a matter of conjecture. The account given of them rather leads to the impression that they were of a different character entirely; for, they are, generally, referred to as producing hair (Exodus, xxv, 4), and that they did not shear them (I Samuel, xxv, 2).

But, upon the other hand, we read in Exodus, xxxvi, 1t, “*** And he made curtains of goats' hair, for the tent, over the tabernacle ***"; and, again in Numbers, xxxi, 20 “* ** And purify all your raiment, and all that is made of skins, and all work of goats hair * * *", which rather leads one to think it was fine enough to be woven into cloth, for wearing apparel. But, it will be observed, Moses does not say raimcnt of goats' hair, but work of goats' hair, which may have been some kind of coarse material like the curtains over the tabernacle are likely to have been made of.

This opinion is, to some extent, confirmed in Leviticus, xiii, $4 \%$, where he says: “**** Whether it be a woolen garment, or a linen garment $* * *$," which conveys the impression that goats' hair was not used for wearing apparel, or it would have been mentioned with wool, and linen; for Moses was giving out a law concerning the "cleansing of a leper", and if the people had been accustomed to use goats' hair for clothing, he would surely have included this kind, as well as that made from other material; for, in the very next verse (Lev., xiii, 48) 
he specifically says: "**** Whether it be in the warp, or woof; of linen, or of woolen; whether in a skin or in anythin made of skin * * *."

Coming down to the Greek authors-Homer and Hesiodreferred to by Dr. Hayes-though frequently mentioning the goat, as a domestic animal, they make no allusion to any particular race. Flian, referring to the goats of Lycia, and the practice of shearing them like sheep, says, that the wool is used for cords and cables. Apian mentions the stuffs known under the name of kilikia, from Cilicia (the ancient name of the country in which Angora is situated), as a means of protection against projectiles; implying that, the goats of Cilicia were not distinguished for their fineness. Virgil gives the wool of the goat no other destination than to serve for the necessities of the camp, and for the use of poor sailors.

It was not until the year 1555 that the Angora Goat was distinctly made known, through Father Belon, who had travelled in Asia Minor, by a brief, but sufficiently characteristic description, which has, doubtless, given rise to the popular belief that the animal originated in that country; but there is nothing whatever to support the same beyond the mere fact that the modern world first heard of them in the Province of Angora, which is a part of Asia Minor, belonging to Turkey, and that they have always been known as the Angora goat.

The argument advanced by those who maintain this belief is that the climate of Angora possesses some peculiar characteristic. which has produced the silky hair on the animal, and to strengthen their opinion, they point to the rabbit, and cat, of that country, which produce the same kind of hair as this goat. The theory is certainly very plausible, and would be hard to overcome, if all the goats, rabbits and cats produced hair exactly the same; but, it is well known, they have a low grade of goat, called the "Kurd" goat, which has.black, coarse hair,* and it is not uncommon to find cats and rabbits of various colors,

*Peglar describes the "Kurd" goat as being a black goat, rather larger than the white or Angora proper, the hair of which, although long and of a fleecy nature, being at the same time coarse in quality." 
of hair as well, hence, it would seem that the beautiful hair of the "Angora" goat, is not due to the influence of climate, otherwise, all the goats of Asia Minor would be affectef by it alike.

Upon the other hand, there is a breed of goat that is said to have existed for countless ages, in central and northern Asia, known as the "Cashmere," which has the same kind of hair as the Angora, and, to all outward appearances, is one and the same kind of animal. In 1 eferring to the Cashmere goat, Dr. Hayes* makes use of the following language, in his work on "The Angora Goat, Its Origin, Culture and Products."

"The only goat besides the Angora, which is strictly lanigerous, is the 'Cashmere' or 'Thibetian' goat, which abounds in Central Asia, but whose origin is still obscure, although it has, according to Brandt. affinities with the Angora race. The size of the Cashmere goat is quite large; the horns are flattened, straight, and black, and slightly divergent at the extremities. The ears are large, fiat and pendant. The primary hair, which is long, silky and lustrous, is divided upon the back, and ialls down upon the flanks in wavy masses. Beneath this hair there is developed, in the autumn, a short and exceedingly fine wool, from which, the famous Cashmere shawls are fabricated. See Hays, page 11.

The late Dr. James B. Davis, of Columbia, South Carolina. who resided for a number of years in Turkey, always claimed that the "Angora," the "Cashmere," "Persian" and "Circassian" goats were all one and the same species, changed in some respects by altitude, but little by latitude. (See U. S. Pat. Office Report 1853, p. 20.

Mr. J. S. Harris, of Oakley, Idaho, who, in 18:5, visited Cashmere and Asia Minor for the purpose of buying some pure-blooded goats, is of the opinion that the Angora goat originated in Thibet. Mr. Harris is, perhaps, the only resident

*Dr. Hayes leans to the opinion that the Angora goat was introduced into Asia Minor at a comparatively recent period; he says: "The silence of the classic authors in respect to any goat with fine and white fleece would seem to place it beyond doubt that the progenitors of this animal were introduced into Asia Ninor at a comparatively recent period, when the country was invaded by barbarous and pastoral races, either Turks or Arabs." (See p. 16.) 
of the United States who has ever visited the Thibetian country in search of goats, * and his opinion is, therefore, worthy of great consideration upon a question of this nature. In a recent letter to me he says:

"On the cars, going through Bengal, I saw a great many goats feeding along the road. These goats were very large muleys, with niggerish heads, and when standing, their ex.rs almost touched the ground. When I got up into Central India, on the Eorders of Punjab, I saw a great many goats which were low set, with small ears and cock horns, and had long shaggy hair. It is cold in the Punjab, in comparison with Bengal. When I got to Lahcre, I had to stage it to Rawil-Pindee, and Nurree, the British outposts, which is as far as any vehicle can go. From there I fitted out to cross the Himalaya into Cashmere. I procured a good interpreter, and seven, or eight men to go with me, and went into Cashmere by the Jhelum route, which is the head tributary of the Ganges. In going up the Jhelum, through the Himalaya, I met two English officers, coming down from the Thibets. They had a great many servants and coolies, loaded with trophies of the chase, and they told me, there were a great many Ibex, and wild goats of various kinds, up in the high Thibets. They showed me some of the skins, all of which showed long, shaggy hair, with a heavy undercoating of fur. Some had long horns, and others small ind spirat-shaped.

"My attention was called to two little goats that or:e of the coolies was leading. The officer told me these were the tame goats of Bokhara, and famed for their fur; they were low set, and spry little fellows, with delicate spiral horns; their hair was white, and shone like silver, and was about four inches long, with a very fine undercoating of fur.

"It took me some eighteen days to get over the Himalaya into Cashmere. When I got to Srinagar, the capital, I found there were no goats of the shawl species kept in the vale of Cashmere. They were kept up in the high Thibets, even on the frontier of Siberia, and the goats that were kept on the highest mountains produced the finest fur.

"I visited the Maharaia shawl factory in Srinagar, and found that the goats of Cashmere were not the kind I wanted; so I bouted ship for the sea.

"As I came down through the Himalayas on the Barmula route, in crossing the Basamoolla river, I came to a Buddhist Temple. The priest gave me some fruit, and I gave him some money. Near to the Temple, I saw three or four nice little white goats, the same as I had seen with the English officers. I got my interpreter to inquire of the priest

*Hon. Israel H. Diehl visited Asia Minor, but did not go into Northern Asia. 
as to their origin, and he very devoutly looked up into the heavens, and then bowed to the earth, and said: "The God of Buddha sent them down from heaven."

"Now, I think, if the Angora goat originally came from any place. it was from the high Thibets, and was of the same species as the little white goat that I saw there.

"Long ago, tribes of the Thibets may have been persecuted, and were driven, or, wandered, through Persia, along the Caspian, by the way of Lake Van, into Asia Minor, and took along witin them tineir little white goat, a native of Thibet."

The fur, or "pushm," as it is rechnically called, which the "Cashmere" produces, is evidently a growth called for by the laws of nature to shield the animal from the very severe cold climate of Cashmere, and 'Thibet, for, it has always occurred that, when any of these animals were taken to a warm climate, this fur disappeared in a few years. It is therefore, very reasonable to believe, that the Angora goat, found in Asia Minor, sprang from the Cashmere or 'Thibetian goat, and, through the action of the warmer climate of 'Turkey, the coating of the animal has been changed to its present character.

It will never be known, however, with any degree of certainty, as to when, where or how this animal originated. It may have been a distinct species in the beginning of creation, or, perhaps it came through a freak of nature, in one, or other of the countries just referred to. Naturalists have disputed over the question ever since the science of zoology was first understood, some claining one theory, and others another. It is claimed by some that the animal is a cross between the domestic sheep and the domestic goat; others say it sprang from the "Ibex," the common name of several closely allied species of ruminant manmals, belonging to the genus Capra, or goats, inluabiting the loftiest regions of Europe, Asia and Africa. And still another school claim that the wild goat, or Pesang, of the Persians (which likewise produces a long hair with the fur underneath), is the parent of the Angora.* As stated before, it

*The great naturalist, Chas. Darwin, in his work on the "Origin of Species," page 15 says: "The origin of most of our domestic animals will probably forever remain vague. * * * In regard to sheep and goats I can form no decided opinion. 
can never be learned how this beautiful, and valuable, animal has been handed down to mankind; nor, would it seem to be necessary, or important, that we should know; for, beyond the mere fact of gratifying idle curiosity, we would be no better off, practically, if we were to learn from the Divine source, through which the animal was created, the exact way it was made. It seems to me, it would be more fitting in us to accept the gift from nature's generous hand, as we have found it, and apply the laws for the improvement of the species, that this same beneficent Creator has established, and mould for ourselves such an animal as is best suted to our wants, and best adapted to the climate in which we live. 


\section{CHAPTER II.}

THE PROVINCE OF ANGORA.

The town of Angora is described in the Encyclopedia Britannica as follows: "Angora, or Enguri, the ancient Ancyra, a city of Turkey in Asia, capital of the vilayet of the same name, is situated upon a steep hill, near a small stream, which flows into the Angora, a tributary of the Sukaria, or Sangarino, about 220 1niles E S E of Constantinople. * * * Ancyra belonged, originally, to Phrygia, and afterwards became the chief town of the Tectosages, one of the three Gallic tribes that settled in Galatia about $27 \%$ B. C.

"In 189 B. C., Galatia was subdued by Manliuts, and in 25 B. C. it-was formally made a Roman province, of which Ancyra was the capital. Ancyra was the seat of one of the earliest churches, founded, probably, by the Apostle Paul, and councils were held in the town in $31 t$ and $358 \mathrm{~A}$. D. In $1402 \mathrm{~A}$. D., a great battle was fought in the vicinity of Ancyra, in which the 'Turkish Sultan, Bajazet, was defeated and made prisoner by Tamerlaine, the Tartar conqueror. In 1415, it was recovered by the Turks, under Mahomet I, and since that period has belonged to the Ottoman Empire."

The following description of the surrounding country, from the pen of Mr. H. A. Cumberbatch, British Consul at Angora, in his report to the Marquis of Salisbury, dated the 15th of July, 1895 , and which I have taken the liberty of copying from Mr. Schreiner's book, is of greater value. Mr. Cumberbatch says :

"The vilayet, or province, of Angora, is essentially an ayricultural one; the rural population gives itself up entirely to the cultivation of the soil, and the rearing of cattle, while the inhabitants of the towns, themselves to a great extent owners of farms and vineyards, trade on the result of the cultivators' labors. * * * 
".The entire province is more or less mountainous and furrowed by deep valleys. Its ncan altitude is estimated at 2900 feet, the town itself being 2854 feet above the sea level.

"The elevated masses are here and there shaded with forests, but tha plateaux, which form the most extensive portion of the country, are very little wooded, and consiequently the absence of trees and shrubs give them a dreary aspect. The scarcity of trees permits the summer heat to dry up the little humidity acquired by the soil in winter. and drouths of any length bring about partial or conplete failures of crops.

"Whenever the mountain soil is carried down by the spring fioorts to the valleys and plateaux, it makes them very fertile and suitable for the cultivation oi all kinds of cereals and vegetables. Wherever artificial irrigation is practicable, the fertility is greatly augmented. In this province there are to be found light and friable soils, both suitable for wheat and barley culture, and, although rarely manured. good crops are raised, thus proving their great fertility.

"In many parts, however, and in the Cesarea district especially, the soil is very poor, with no consistency, being nothing but dust and stones.

"Whe climate is extreme. In the months of January and February the thermometer will mark a minimum of 10 degrees Fiahr. for several days at a time reaching as far as 0 degree Fahr., whilst in June and July the maximum readings of 85 degrees Fahr. are maintaned day after day with little or no rain.

"The country is covered with snow in the winter, rain and snow falling frequently. In 1894, the total rainfall at Angora was 8:12 inches, but that was an exceptionally dry season. For the first six months of 1895 the rainfall was $10: 10$ inches, which is somewhat above the average, the heaviest rainfall in twenty-four hours having been $1: 20$ inches.

If Mr. Cumberbatch had been writing a description of Southwest Texas, he could hardly have described it better. 'The only material difference between the two countries is the character of the valleys in Angora, which appear to be subject to overflows, while those in Southwest Texas are not-a feature decidedly in favor of the latter country. The altitude and general contour of the two countries are very similar, and the same will apply to New Mexico, and many more of our Western Territories.

A flock of goats in Turkey usually consists of about three hundred head, which is always attended by a man during the 
day, who is sometimes assisted by several dogs, trained to stay with the flock night and day. Some of these dogs are so ferocious that they will attack anything that approaches the flock, and it is dangerous to go near them, unless the man in charge is with you. 


\section{CHAPTER III.}

\section{DISTRIBUTION OF THE ANGORA GOAT INTO OTHER COUNTRIES.}

The following century after Father Belon had reported the existence of the Angora goat in Asia Minor, or about 1650. Tournefort, the chief Botanist to the French King, reported that

"They rear the finest goats in the world, in the Champaign of Angora. They dazzle with their whiteness, and their hair, which is as fine as silk, curling naturally in tresses eight or nine inches 'ong, is the material of many stuffs." (See Hayes, p. 27.)

Many attempts were made to introduce them into France, England and other parts of Europe, but with no success.

According to Dr. Hayes:

"The first attempt to appropriate the race in Europe was made by the Spanish government, which imported a flock in 1765. Next followed the importation of President Tour d'Aigues, who introduced some hundred upon the Low Alps in 1787. *** Towards the end of the last century, Louis XVI imported a flock of Angoras to Rambouillet, but this, as well as the flocks of Tour d'Aigues, disappeared in consequence of the revolution. The best results were obtained in Spain from the importation of a flock of one hundred, in 1830, by the King of Spain." (See Hayes, p. 34.)

Sir Titus Salt, together with the Earl of. Derby, introduced them into England about $183 \%$, but these soon died out. In 1849. Dr. J. B. Davis brought nine head into the United States. *

They were introduced into Australia about 1850, and promised to become quite a factor in the agricultural pursuits of that country at one time, but from some cause or other, the industry was not kept up.

* Seven grown goats were imported and two kids were born enroute to this country. 
A very unique attempt at localizing them was made in the Fiji Islands by Mr. R. B. Leafe, an English gentleman, who owns the small island of Nannuna, in $18 \%+$. In referring to this, Dr. Hayes copies the following interesting account from a book entitled, "At Home in Fiji," by C. F. Gordon, an authoress, and traveler of high reputation:

- "One of Mr. Leafe's most anxious experiments has been the introduction of Angora goats, lovely white creatures, with long, silky fleeces.

"At great expense he procured two pairs, and. having killed off all the male wild goats on the island, these beautiful strangers were established as monarchs of the isle, so the flock is now exceedingly pretty. There are 230 mothers of all varieties of color, and each has either one or two pure white kids, all, without exception, taking after their fathers. The fine silky hair is not the sole advantage of introducing the Angora Goat-its flesh is said to be more tender than mutton, with a slight flavor of venison, and, moreover, such a flock will thrive where sheep could not find a living."* See Hayes, page 93.

They were first introduced into Cape Colony, South Africa, in 1838, by Col. Henderson, formerly of Bombay, India. See Schreiner, p. 1;0.

In 1856 , and $185 \%$, quite a general interest was manifested on the part of Cape Town merchants, to introduce them upon a large scale, and establish a mohair-growing industry of some magnitude. Sir Titus Salt, who had made a failure in raising them in England, was very glad to co-operate in this movement, as he was then largely interested in manufacturing mohair, and was exceedingly anxious to extend its growth. Every importation that was made to Cape Town found ready sale to farmers, at satisfactory prices, and the importations continued from time to time until upwards of 3000 head had been quietly transferred to the hills of South Africa, which were thriving as well or better there than they had in their native home.

The Turks had been encouraged to believe from the many failures that had been made in locating their favorite animal in foreign countries, that it was not possible to propagate them

*The Encyclopedia Brittanica states that mohair has been shipped to England from the Fiji Islands, but does not give the quantity. 
anywhere except in Turkey; or, in other words, that nature had given to Turkey the exclusive privilege of raising these beautiful animals, and it was not until about $18 \% 5$ that they began to realize their mistake, which they did through the astonishing growth of the mohair industry in South Africa. From practically nothing in 1860 , which was the first shipment made from that country, of only 385 pounds, the exports reached the very handsome total of $2,280,000$ pounds in 1879 ; nearly one-half the amount that Turkey was then producing.

To be more exact:

The Turkish exports to England in 1879 were $4,6+1,000$ pounds. The Cape, or South African, exports in 1879 were $2,280,000$ pounds.

The Turks, for the first time, realized the mistake they had made in thinking they had been selected as the only custodian of the Angora goat. Their jealousy was aroused, and by persistent appeals to the Sultan, they succeeded in having an edict passed, in 1880, prohibiting the shipment of any more of their precious animals, which they all but worshipped. The seed, how aver, had been planted, and the South African industry continued to increase until it is now (1899) greater than that of Turkey-a very fair sample of what intelligence and enterprise can accomplish in competition with ignorance and superstition.

Since the edict of the Sultan, prohibiting the shipment of Angora goats, only two legal shipments have been made from Turkey. Permission for the first one was obtained through the influence of H. B. M. Ambassador to the Sublime Porte Sir Philip Currie. In this connection the following letter from Mr. George Gatherall to the "Eastern Province Herald," Port Elizabeth, dated Constantinople, th Nov., 1895, will be interesting reading. Mr. Geo. Gatherall wrote as follows:

"In Nay last, owing to the presence of H. B. M.'s Ambassador and to a favorable turn in the mind of His Imperial Majesty, the Sultan. I obtained an Imperial concession to export Angora mohair goats, and at the same time the government stated that it would be the very last granted. As soon as the fleece had sufficiently grown to show the 
quality of the mohair, namely, early in August, I sent my experienced men to buy the goats, and during two months I had an unceasing conflict to get the animals safely out of the country. Immediately that it became known that goats were to be exported again, an influential meeting of all the mohair merchants and dealers took place in Constantinople, and decided to oppose the effort by every means in their power.

They wrote to all their agents, up country, to represent to the farmers that export of bucks meant mohair coming back to $14 \mathrm{~d}$ ( $28 \mathrm{c}$ American money): that the reason of the late advance was the prohibition of export to the Cape, which had led to the degeneration of the Cape hair. The dealers also brought influence to bear on the Governor General of the two provinces where purchases werc to be made, and through which the animals had to pass, and these Governors did all in their power to prevent purchases. A monster petition, under the auspices of the Angora Governor General, was drawn up, signed, and addressed to H. I. M. the sultan, begging His Majesty to save their industry from ruin, and to prohibit export. The Governors, moreover, sent officials to instruct the peasants nut to sell any goats. The goats already purcliased were to be given back to the peasants, and, finally, my man was taken off under arrest to the chief town in the district.

The Turkish populace were excited, and this arrest saved my man's life. H. B. M.'s Ambassador, however, took the matter up with firmness and promptitude. Urgent telegrams wore obtained from the Minister of the Interior to the Governors-General, instructing them to remove obstacles and give tny men all needful help. This they at last were compelled to do, and, accompanied by an escort, the further purchases were made, and the flock protected from brigands and thieves. who attempted to seize the animals. After nearly two months, the goats came down, just as Constantinople was in a state of terror and massacre. one of my men being knocked down, bayonetted and left for dead in the street. Finally the flock which had been selected with so much care, and at the serious risk of life, was shipped for Southampton on the 16 th of October last. The flock consists of 115 goats ordered by xlessrs. Mosenthall Sons \& Co., and fifty goats ordered by the Rt. Hon. Cecil Rhodes. The entire shipment is the result of a very careful and painstaking selection by experienced judges, and chosen from thousands of the very best flocks in the very best districts of Asia Minor. Thes z animals should please your judges, I think. I have always pleased them hitherto, and these in my opinion, are the finest that have ever been sent to the Cape."

"Eleven Months later, Mr. George Gatherall sent another consignment of Angoras to Messrs. A. Mosenthall \& Co. They 
were landed at Port Elizabeth, on the 6th of November, 1896, and consisted of thirty-three rams and thirty ewes. See Schreiner, page 214.

These have been the last shipments of Angora Goats from Turkey.

Dr. Hayes refers to an attempt to introduce the Angora on Guadaloupe Island in the Pacific ocean, which he says was well stocked with the common goat; but, the enterprise failed, because, as he puts it,

"In such conditions, as is well known, it is not the best, but the strongest, race (which in this case would be the native) that survives."

This, however, does not seem to have been the reason of the failure, as will be seen from the following account furnished by Mr. Wm. M. Landrum, who was one of the principals engaged in the enterprise:

"GLADALOUPE ISLAND is situated off the coast of Lower California, about 210 miles south by one-half west from San Diego, California. It is about sixteen miles wide, by thirty long, and contains in the vicinity of 300,000 acres of rough mountdinous land, having an altitude in places of 4000 feet above sea level. It is well covered with brush, and is an ideal spot for the goat.

In 1868 and 1869 it was estimated there were not less than 80,000 head of the common short haired variety of goats on this island, which, it is supposed, were first started by the English explorer and navigator, Captain James Cook, during the eighteenth century.

This island belongs to the govermment of Mexico, and was granted to General Valdethe, and Florencea Sevana for services rendered by them; and, in, or about, 18\%0, a company of Americans was formed, consisting of Wm. M. Landrum, Car Abbott, B. Boswell, and others, all of California, at the time, for the purpose of introducing some Angora Goats on this island, with the expectation of improving the character of the common goats by crossing them with the Angora.

By an arrangement with the heirs of General Valdethe and Florencea Sevana, this company got the exclusive privilege of 
using the island, and they placed upon it in 18.2 or ' 13 in the vicinity of 1200 head of high-grade Angora does and 100 purebred bucks, at a cost of $\$ 20,000$, and it was their intention to kill off all the native males as fast as they could for their hides and tallow.

Mr. Landurm was made president and general manager of the company, and he writes me that the Angora did remarkably well and improved rapidly. After they had been on the island sixteen months, he sheared one doe that had mohair 22 inches long, of perfect staple, and the fleece under the belly was much worn by being dragged over the rocks (Mr. Jno. S. Harris, of Idaho, mentions having seen a sample of this hair in Constantinople in 1876, which Mr. Landrum had sent to Mr. Jno. R. Thompson of Constantinople).

Mr. Landrum adds: "The island is especially adapted to the raising of mohair goats, but we made a failure owing to the fact that we did not have honest men to take charge of the work, and upon three occasions they ran off with all the skins they had taken, together with the tallow, and we were finally compelled to abandon the enterprise, after expending upwards of $\$ 30,000$ in labor and expenses."

Mr. Landrum is well satisfied that a great fortune could be made by some one who would be willing to live on the island, but that he was too old to think of living in such a way, and there were none in the company who cared to exile themselves on such a lonely spot.

\section{ANGORA GOATS IN CANADA.}

It is surprising that the Angora goat has never been introdi.ced into Canada, more particularly as they are very fond of the "Canada Thistle" (see "Notes from Practical Breeders"), which is so objectionable to the farming industry in that country, as to require the most stringent legislation to keep it from spreading. The following letter received from Mr. Albert J. Hill, member "Canadian Society Civil Engineers of British Columbia," is interesting, and it is to be hoped that he will be successful in getting the industry started at an early day. 
New IVestminster, B. C.,

Sept. ith, 1899 .

IV. L. Black. Esq.,

Dear Sir-I am sorry to say that, though I have been trying to work up the industry in this Province, other business calls have operated against the devotion of sufficient time to the project to make it, so far a success though recently, offers of capital from England to introduce the industry on a large scale promise an early organization of our enterprise. Up to the present there are practically $n$ Angoras in British Columbia, though the Province, both in climate and otherwise, seems to be peculiarly fitted for them. Splendid insular ranges exist all along the coast. capable of carrying many thousands of head, and free from all predatory animals, or other hurtful conditions, while the interior offers millions of acres of brushy mountain range, well adapted to this industry and nothing else. These lands vary from ocean level to 8000 feet above, providing an ever-changing supply of herbage, and abundance of pasturage, as the snows leave the slopes with advancing summer, or urges the bands downwards as winter approaches.

The insular ranges have practically no winter, the climate being such that the animals will not accept shelter the year round, and in one instance a few of them have actually run wild, and are. I believe, increasing on the higher parts of the island away from any any human care.

Yours faithfully,

ALBERT J. HILL. 


\section{CHAPTER IV.}

\section{CHARACTER OF THE EARLY ANGORA GOAT.}

The character of the Angora Goat in Turkey in the early part of the present century was very different from what it is today. We are told by all authorities on the subject that they were then a very small, delicate animal, shearing from ? to $: 2 / 2$ pounds of mohair, according to sex, and age, * while at the present time it is not uncommon to hear of individual bucks shearing as high as 15 to 18 pounds, and does shearing 9 to 10 pounds. In summing up his investigation upon this subject. Mr. Schreiner says:

"I think it is certain that the original pure-bred white mohair goat was a small. very refined. delicate animal of great beanty. clipping at twelve months' growth of fleece about two to four pounds (according to sex and age - kids considerably less) of dazzling white: fine, soit, silky, very lustrous mohair. curling in ringlets from eight to ten inches long, with merely the minimum of oil in its fleece requisite to the growth of hair of the highest excellence, so small in

*According to a report in the Encyclopedia Brit. (see Tol. X. p. 708): "The Angora goat is often confounded with the Cashmere, but is, in reality, quite distinct from it. The principle feature of the breed, of which there are two or three varieties. is the length and quality of its hair, which has a particularly soft and silky texture, covering the whole body and a great part of the legs. with close matted ringlets. The horns of the male differ from those of the female, being directed vertically, and in shape spiral. whilst in the female they have a horizontal tendency somewhat like those of a ram. The coat is composed of two kinds of hair. the one short and coarse, and of the character of hair: the other long and curly and of the nature of wool, forming the outer corering. Both are used by the manufacturer, but the exterior portion which makes up by far the greater bulk is much the more valuable. The arerage amount of wool yielded by each animal is about $2 \frac{1}{2}$ pounds." 
amount as to be inappreciable to the unskilled observer. It was perfectly clothed in every part; it had short silky, curly hair about the face and down the lower parts of the ltgs to the hoofs, a soft, silky curly "kuif" (tuit on the forehead), and small, thin, light-colored horns, The ewe was, of course. smaller and finer than the ram, and had only one kid at a birth (of this there is abundant evidence). Its delicacy was, no doubt, mainly due to a long coturse of mbreeding, perhaps, also, partly, to the desire that it should yield hair of exquisite fineness. In a goat, refinement and delicacy of body, and fleece, to some extent, go together. I do not think it possible for a large, powerful, big-boned goat to produce such a fleece as it seems evident the original pure Angora carried. This long course of instueding, however, while it renders the goat delicate, at the same time also made it a thoroughbred. in the truest sense of the term.

"1here seenns to be no doubt that, speaking generally, it had been bred true to type for many centuries, and thus has acquired to an almost unique extent, that one distinguishing quality of the thoroughbred-great antiquity of fixed charactcristics. This gave it prepotency of unusual strength, as was shown by the certainty and rapidity with which the rams impressed their peculiar characteristics upon their progeny got by common ewes, a fact fully established, and remarked upon with wonder by all who used them to grade up from common ewes before the breed had lost its prestine purity." (See Schreiner, pp. $58-59$.

There is no doubt that Mr. Schreiner's deductions are correct, and it is more than probable the Turks would have continued the practice of $\mathrm{in}$, and in breeding had it not been for the great increase in the demand for mohair, which began in the year $183 \%$ and continued to grow much faster than it could be supplied. This new industry in England began with the manufacture of alpaca, and the value of both mohair and alpaca naturally, advanced rapidly, from about $20 \mathrm{c}$ in 1836-3\%, to upwards of $\mathrm{i} 5 \mathrm{c}$ to $\$ 1.00$ a pound in 1860 . Under the influence of such seductive chances for profit, the wily 'Turk commenced to cross his Angoras upon the common ("Kurd") goat of his country, which they have kept up to a greater or less extent to the present time. The result of this cross has produced a complete change in the character of the animal, and it is rery doubtful if they have any goats in Asia Minor today that can be called absolutely pure. 
The crossing has, however, been beneficial in more ways than one. It has largely increased the yield of mohair in Turkey, and has changed the goat from a small, dalicate aninal, shearing 2 to $21 / 2$ pounds, to a strong and vigorous one, shea:ing 4 to 5 pounds for the average clipping of ordinary flocks. 


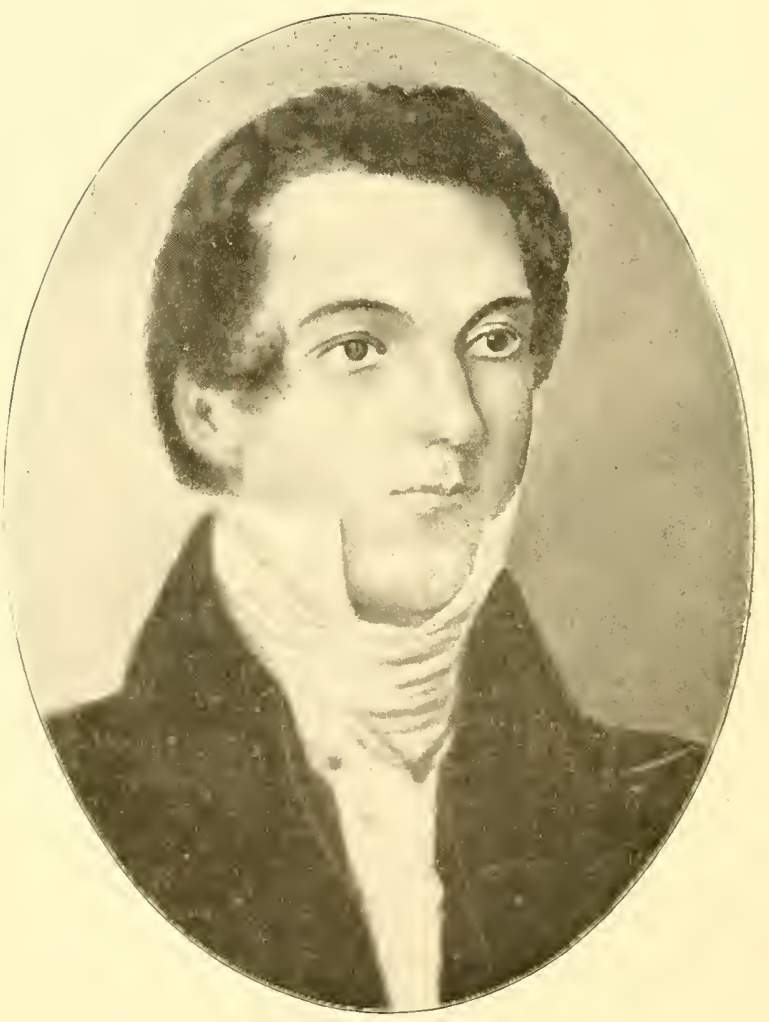

DR. James B. DAVIS. 


\section{CHAPTER V.}

\section{INTRODUCTION OE THE ANGORA GOAT INTO THE UNITED STATES.}

The Angora goat was first introduced into the United States by Dr. James B. Davis, of Columbia, S. C., in 1849.* This gentleman was a native of South Carolina, born December 30 th, 180\%, and was educated at the Columbia, S. C., college. He graduated as a physician in the Medical College of Charleston, S. C., was at the Transylvania University Medical Department in 1829-30, but practiced medicine only two years. On November 2d, 1830, he married Miss Mary Elizabeth Scott, and devoted his time afterwards mainly to agriculture, until he was appointed by President Polk, of the United States, in 1844 , as a proper person to introduce the culture of cotton into Turkey, in response to a request frcm the Sultan. His experimerits in Turkey lasted about three years. His contract with the Turkish Government procured him an annual salary of $\$ 12,000$ in gold, besides a residence, and carriages and horses, and when he was about to abandon his work, the Sultan was pleased to present his wife with a purse of $\$ 20,000$ additional-a portion of which was invested in buyirg a small flock of Asiatic goats, and other animals, among which were a 1 air of Brahmin cattle, some water oxen, and a Maltese jack.

Dr. Davis returned to the United Statcs in 1849 , and remained in Charleston and vicinity for some time, and then

*In sending me the above photograph of Dr. Davis, his daughter, Mrs. H. K. White, now of Bryan, Texas, writes: "Regretting I have no later picture of my father, I send you a small miniature of him, taken in early life-not as I remember him, a grand looking man with large black cyes. black hair, florid complexion, and high white forehead, a man of ctriking appearance and courtly manners." 
moved near Columbia, S. C., and in a few years moved back to his original home near Monticello, in Fairfield County, where he died on the 6th of May, 1859.*

He had a great fondness for agricultural affairs, with a very decided turn for experimenting with different kinds of live stock that he thought would be adapted to the Southern climate-a fact that may be easily inferred from the following. letter to the U. S. Agtl. Dept. in 1853 :

"In 1836, having had some experience in the importation of shorthorned, Devon and Ayershire cattle, into this State, I then summarily advanced an opinion that all cattle brought from a Northern to a Southern climate must necessarily degenerate to the peculiarities of our location, and that it would be easier to improve cattle already acclimated or import animals from a still uarmer region. In my late sojourn in Asia and the East, I had reference to this observation in importing Cashmere, Scinde and Malta milking goats, as well as the Brahmin ox, or Nagore of India; the Asiatic buffalo, or water ox, and other animals." See Patent Office Report 18j3, page 20.

These animals, it would seem, were imported more as a matter of curiosity and experiment than with a view to the establishing of a distinct industry; but, it was not very long before Dr. Davis realized that the Western Hemisphere offered greater advantages for the production of mohair than the East did. In the letter above referred to he makes use of the following language, bearing on this point:

"In locating these animals in different sections of South Carolina, I can see no difference between those reared here and the imported, with the exception that those reared in this state are finer and heavier fleced than those imported." See Pat. Cff. Rept. 1853, page 20.

He continued his experiments with the goats for a few years, during which he sold some of his increase to parties in New York, and other States, where they proved to be equally

*'The foregoing matter is taken from a letter from Col. Zimmerman Davis, of Charleston, S. C., Secretary and Treasurer of the Water Works of that city, who very kindly supplied me with the information in response to my inquiry, and in another letter he contributed some further information touching the real character of the goats that Dr. Davis imported which will appear later under a proper chapter. 
well adapted, and in 1854, he disposed of his entire lot of purebreeds, to Col. Richard Peters, of Atlanta, Georgia, who had been watching his experiments with no little interest from the very beginning.

The late Hon. Israel S. Diehl, in his paper published in the U. S. Agtl. Dept. Rept. of 1863, referring to the Angora goat. says :

"Nowhere, however, has their introduction and breeding been attended with the same cheering results and decided success as in our owa country. and this, after thorough trial, and practical experiments during the last fifteen years, when seven were first imported by Dr. Davis into South Carolina. Since that, some three hundred head have been imported from Angora, at various times and seasons, via Constantinople and Boston, mainly for the South and Southwest, from which, with their crosses, a numercus progeny and various small flocks have descended, now numbering several thousands, and scattered from Massachusetts to California, yet still mainly confined to the Southwestern States, in flocks of from twelve to three hundred, and more, as at Atlanta, Georgia; Gallatin and Nashville, Tennessee; Russellville, Frankfort, Paris and Georgetown. Kentucky; Greenville, Lebanon, Montgomery and Bucyrus, Ohio; Green Coutsy, Indiana; Chicago, Decatur and Evanstown, Illinois; St. Louis, Maramec and Fayette, Missouri; Baitimore, Maryland; Leavenworth, Kansas; Brownsville, Pittsburg, Washington and Philadelphia, Pennsylvania; New York. Boston, Belmont. Massachusetts; Austin, Texas; Iowa, Michigan, Minnesota and California, with other localities, where they have been thoroughly tried, prospered and improved.

"We have either personally visited and examined most of the above-named localities and flocks, seen, or obtained, animals or specimens of the wool, comparing them with what we saw abroad, and the best specimens of wool to be obtained from abroad, or the best imported ones, and are well satisfied and thoroughly convinced that we have succeeded, and can continue to succeed, in raising this valuable wool-bearing animal, with its precious fleece, almost anywhere throughout our country where sheep will prosper, especially in the higher, and colder, localities, producing an animal more hardy, with a heavier and more valuable fleece, than the Angora, or Cashmere, itself in its own country. The specimens of wool in our possession, and raised in this country, are found generally finer, more silky, and fleecy, than the imported, and original, ones." 


\section{CHAPTER VI.}

\section{SUBSEQUENT IMPORTATIONS INTO THE UNITED STATES.}

Collecting correct statistics is a very difficult task at any time, but more particularly when they extend over a period of nearly fifty years, as is the case with our importations of Angora goats; fortunately, however, we have a living nember in the industry who has been intimate with nearly every importation that has been made to the United States since Col. Peters first purchased the "Davis" goats, anc has, perhaps, given closer attention to this matter than any other person in our country. I refer to Mr. W. M. Landrum, now of Laguna, Texas, who was for many years a resident of California, and was the starter of the industry in that State, as early as 1861. Through the courtesy of this gentleman, I am able to give, perhaps, the closest particulars relating to each importation that is possible to obtain, as Mr. Landrum personally inspected many of them, and was in close touch with those who examined others.

According to data furnished by Mr. Landrum: The second importation was made by Mr. W. W. Chenery, of Boston, Mass., about the year 1861, which consisted of twenty head, but they were affected with the Asiatic scab, and all died.

Mr. Chenery made another importation in 1866, and in the spring of $186 \%$, still another, which consisted of twenty head each, and of which about thirty head were safely landed in this country.

Mr. Landrum writes:

"I went to Boston early in '67, and waited for the arrival of the third lot-selected nine head out of the second lot and one out of the third shipment. In $1870 \mathrm{Mr}$. Charles S. Brown, a banker of New York City, associated with Hon. Israel S. Diehl, formerly consul to Batavia, imported 150 head, of which 135 arrived." 
Referring to this importation, he says:

"I was in New York City at the time this association was formed, and contracted for the first choice of the shipment. When they arrived in New York city, I took the first steamer for my goats. I found the goats on Mr. Brown's farm in New Jersey, in low, swampy land. I selected only two bucks, one of which was the notorious hornless 'Castomboul' buck that sheared 20 pounds, but too coarse for anything but wigs. Mr. Diehl arrived in Asia just after the goats were shorn, an! had to guess at what he bought. Some of them were very fine and pure. Out of this importation, only about thirty or forty head survived the Asiatic mange, which they had contracted."*

"The next year, 1871, Mr. A. Eutichides, a Greek merchant, left Asia with 200 head of goats for the United States. The Asiatic scab broke out on the way to this country; the man he had in charge of them died, and only about 100 were landed. These were taken to Virginia, where I visited the flock in 1872 , and they were still afflicted with the scab, which I showed him how to cure. I had caught the disease some years before in my own goats, from an imported buck, and had much trouble and expense to get rid of it.

"In 1873, Col. Richard Peters, of Atlanta, Ga., imported three goats of the 'Geredah' variety, through Mr. C. W. Jenks, of Boston, Mass.

"The next importation was twelve head, made by Mr. J. S. Harris, of Holister, Cal., associated with Mr. Wm. Hall of San Jose, Cal. Mr. Harris visited Asia in person, and selected the animals, which were taken to California, via New York, in 1876."

Summing up the different lots that have been imported, Mr. Landrum gives the following figures:

Dr. J. B. Davis started with $r$ head and had two kids on shipboard.............................. 9

W. W. Chenery, 60 head, of which were landed only..... 30

Chas. S. Brown and Hon. Israel S. Dieh1. . . . . . . . . . 135

A. Eutichides......................... 100

J. S. Harris and Wm. Hall................ 12

An English sea captain sold to W. D. Parish, of Texas.... . 2

Col. Richard Peters, through C. W. Jenks, of Boston..... . 3

Total. ......................... 291

*Mr. Jno. S. Harris, of Oakley, Idaho, writes we with reference to this importation as follows:

"From what I could learri from the Turks, Minister Diehl did not 
Mr. J. R. Dodge, for many years chief statistician in the U. S. Agtl. Dept., refers to an importation that was made into Texas by Mr. Price Maurice, a wealthy Australian breeder. Mr. Dodge states, in a communication to the "Country Gentleman," that MIr. Maurice imported sixteen rams and 168 ewes, for the ranch of his sons in Texas, Maurice Brothers, in 1869, 1872 and 18,3 , but there must be some mistake on the part of Mr. Dodge about this importation, as I can find no one connected with the industry in Texas, or elsewhere, who has any knowledge of it. The fact of Mr. Price Maurice having made such an importation as $\mathrm{Mr}$. Dodge refers to, into Australia rather strengthens the opinion that he is in error in saying it was made to the United States. Refering to this, Mr. Schreiner, on page 25: of his recent work on the Angora Goat, says :

"In 1869, Mr. Price Maurice imported ten pure-bred Angoras into South Australia from Asia Minor, and made further importations in 1871, 1872 and 1873, in all sixteen rams and one hundred and sixtyeight ezves."

Another importation of eight head is mentioned by Col J. Wash. Watts, of Montville, S. C., made by Hon. Wm. Henry Stiles, of Cartersville, Georgia. Col. Watts, in a recent letter to me, says:

"Mrr. Stiles was formerly Minister to Australia, and made an importation of Angora goats just before the war. I saw them and had an ewe from them, but I did not think they were equal to the 'Davis' goats, which I regard the best that have ever come across the sea, though the 'Stiles' goats were larger and stouter than the 'Davis' goats, but inferior in fleece. Col. Stiles died, either during the war, or soon after. Where his goats went I don't know, for I moved, too, from Georgia, to my native land (South Carolina). Col. Stiles told me he assisted Dr. Davis to get his goats out of Turkey."

It will therefore appear that we have received, all told, the following importations of Angora Goats:

buy his goats in Angora, but in Bai-Bazar. I stopped a day and night in Bai-Bazar with an American gentleman who purchased the bulk of mohair grown there for Jno. R. Thompson of Constantinople. This gentleman told me the goats that Mr. Diehl bought were A1 and he had helped to purchase them for him." 
As per Mr. Landrum's statement, 291; as per Co1. J. Wash Watts' statement, 8 ; or a total of 299 , of which it is reasonable to believe many were neglected during our civil war, and died, and a few were doubtless of an inferior character, being hardly entitled to the term "pure bred."

In the past fifteen years about twelve head of Angoras have been imported from South Africa, but the most of these were not considered as good as some of the best stock in our own country.

In 1886, Fink \& Co., of Leon Springs, Texas, imported three bucks and three does. Mr. Geo. A. Hoerle (of which firm he was then a partner) writes me that they had,

"Twenty-five or thirty head of does in their own flock superior in every way to the ones they had imported, and only one of the bucks was considered superior to what they had themselves."

In 1893, Mr. C. P. Bailey made his first importation, and in 1899 he made a second, consisting, altogether of six head. 


\section{CHAJ'IK VH.}

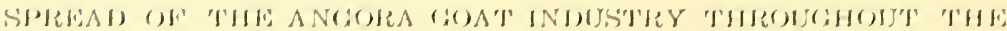

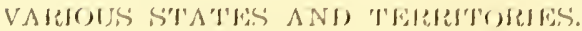

Acererting 10, a pajer furnisherd by the late Hon. Isracel S.

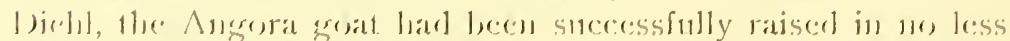
than thirteen of the States cast of the Mississippi River, as early as $186 \%$.

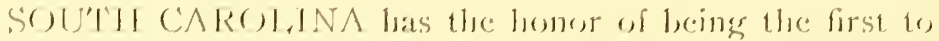
handle: the animal, thromgh J)r. Janes l?. Javis, of Columbia, as rarly as 184!

In 185:, Dr. Davis wrote to the U. S. Patent roffece as folli,ws:

"C) my arrival I inmediately procenred a mumber of our liute diminu

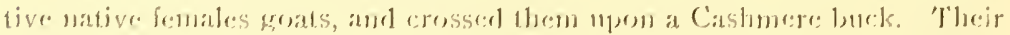

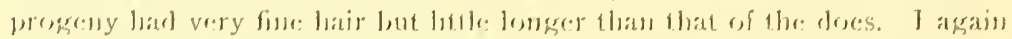
cressed the feolates of this progeny woen the other Cashomere louck and it

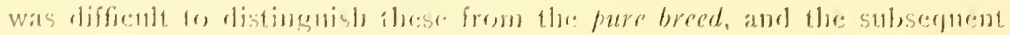
wress cammet be detected. Th the spring, I contemplate effecting still

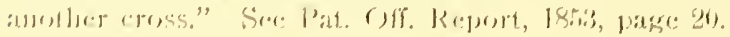

(Mlly a fow sobats were ownerl by f)r. I)avis, and, owing to the very ligh price they commatulest, it is natural that but a

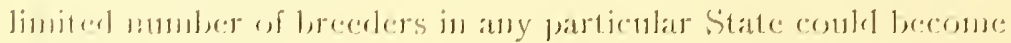
interesterl in then very som. Ujorn this subject, 1)r. Davis writes:

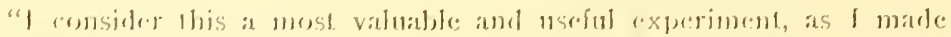

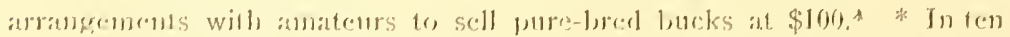
days all the pure brecls were laken, with a demand for many more. *

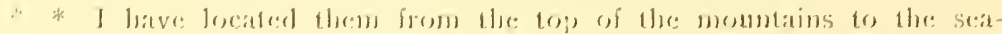

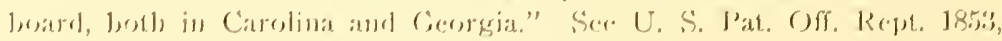
paige: 21 .

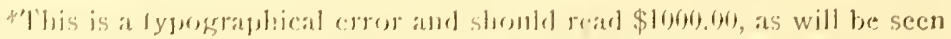
latcer, in at laller from Mrs. HI. K. White, a rlatlghtore of J). Javis. 
Cisl. J. Wash Watts was once of the early luecerlers of the soat in South Carolina, and erentributerl much valualde: informatirn about them throtigh the wrork of Dor. J. L. Hayes, "Ithe Angrora (joat, Jts () risgin, Culture and J'rorlurets." (188\%.) 'lhis gentleman is still enjoying grorel health, at the arlvancerl age of eighty years, and, althrough not personally interested in goats is still a strong le liever in the inrlustry.

In a recent letter to the writer, Cisl. Watts, says:

"I do not know how many gorats are in South Carrolina, but very

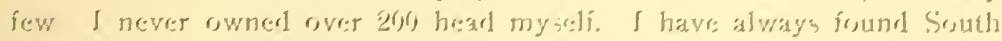
Carrolina well arlasterl to raising them."

Crol. Watts arlds some very interestings and valualde: information alorut the "J)avis" groats, and other matters conerernins" the inclustry which I folieve rught to les preserved, more jarticularly as eroming from so, emincont an authority, ancl one sr, long familiar with the Angrora in this crountry.

Mr. Wm, I, Jilack.

$$
\text { Xiear Montvillos, S. C., Auge 25, lighs. }
$$

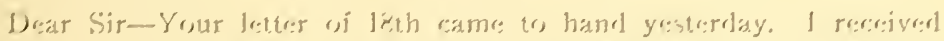

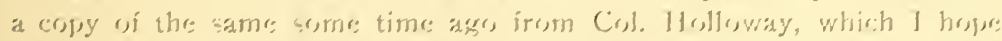
you have receiver leciore now, as 1 answered promplys as 1 always dos such letters, but iror iear youl dirl noet geret it, f will answer this and

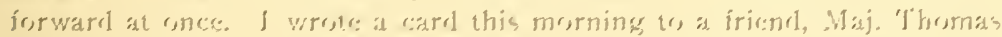

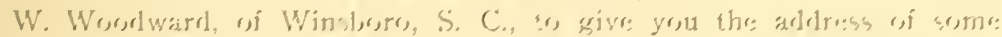

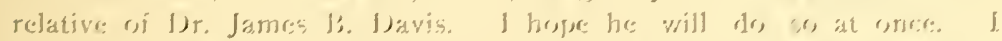

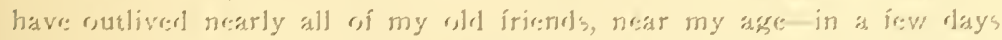
I will lec regehty, and in better heallh than when I was young, throgh I

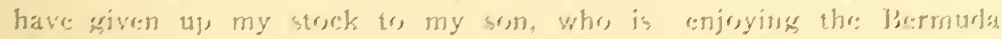
pasture that 1 madre in my prime. My strek has attended every State fair that bas les: h helol heres sines: the war.

"The Hen. Wm. Henry Stiles, decceascel, whos lived near Carter: ville, Cá, formerly Winistes tr, Austria, marles an importation of Aneresa serats, just before the war. I saw them and had an rewe from them, lout 1 do not think they verere ergual to the 'D)avis' sovats, which !

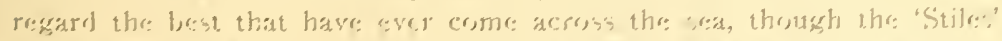

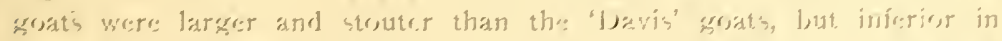

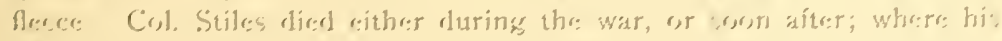

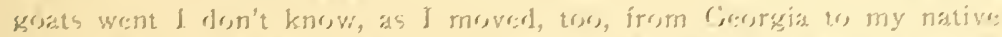

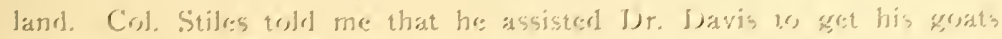

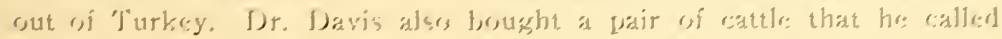


Brahmin. I think they are the Nagore bull of history; also a pair that he called water oxen, perhaps the African buffalo. He sold the former to Eads of Kentucky at a big price; there are many grades of them in this State. You no doubt have read the reports of committees appointed by the 'Georgia Agricultural Society' to determine the proper name of these 'Davis' goats. He called them Cashmere. You will find the reports in the Agricultural Reports from the Patent Office for 185\% and "5i. I don't recollect whether there is anything in 1 sisf. The late Dir. John Bachman, of Charleston, was chairman. He concluded that they were neither 'Cashmere' nor 'Angoras,' but a more valuable animal than either. I was at all of these meetings of the society. After this all parties became satisfied that they are the genume Angora goat. I roomed with Mr. Peters and Dr. Davis, the night they made the trade, which years after Mr. Peters told me paid him better than any other loranch of his farming interest. He was a wonderiul man in his way, and deserves to be on the top of the list of Angora owner', These goats have one peculiarity that is different from all other animals: the bucks and ewes all go out of heat alike, and come in together; a buck will not serve an ewe out of season, which lasts from September, about four months; as this occurs but once a year, a grade buck would have to be used to get the second crop of kids. In crossing to improve the fleece, it is best to use the short-haired goat, as you can breed on the fleece quicker than you can change the long-haired fleece. I believe all the Mexican, and South American, goats have the short hair, and have kids twice a year, which they nurse well. I have been talking to some young friends about getting out from Texas, or Mex$\vdots \mathrm{co}, 500$ to 1000 white ewes to cross with the Angora. You will oblige me by letting me know where the white short-haired goat is to be found, and the price, and how often they have kids, and how many, and what would likely be the freight from Galveston to Charleston, S. C. I had a few of these Texas goats with a flock of sheep, a trio of us owned in Bosque County, before and during the war; they were very large for goats. I would like to see several thousand of these goats in this Siate. I could not answer your query about the brush pastures; ours are generally old fields, with shrubbery growing on wornout lands. We have the Japan clover, or Lespardeza, which grows well on all kinds of lands, and does its own sewing. It is really a wonder to us how it came, and how it spreads. Goats and slneep are very four of it, and after the goats take a run over this pasture they will settle down and take a good bait of this clover and lie down until evening, when they go again. I know of no one, except my son, who is giving the goat of any breed any attention. Cotton is their crop for mrney, so, as this is about to fail them, they will soon be raising goats or shcep, which will pay some profit every year. The goatquestion is coming up, even in the North. It seems that the Patent Office gave 
out lately the letter I wrote to John L. Hayes, which the 'Springfield Republican' published, and other papers, so I am beset with letters from Massachusetts to Florida for information. As I own no goats now of any kind, it is rather burdensome to write an essay on goats every few days. If I can assist you in any way with your book, I will be pleased to do so; so don't hesitate to call on me. When I was last in Texas, some one told me that some person near San Antonio had two thousand of these white goats, that I $3 m$ enquiring after. I have had a few Maltese milk goats that had long coarse hair. I crossed them with the Angora, and the half-breeds would have four kids a year. and one had three at a birh. One was a wonderful milker. I loaned her to a friend to help raise his twins, and she did her part well (See statement in Hayes' book, page 55).

I had also a South American milk goat, short hair; she was a fine milker, and had kids twice a year. I had at one time two hundred pure-breds and grades, sold a hundred at one time, which I delivered on Roane mountain. $\mathrm{N}$. C. Sereral were kids. We drove 175 miles across mountains and rivers. but never lost a kid or goat; though as we had to guard them from eating the laurel, and ivy. which grew abundantly on both sides of the road. I formerly herded them myself, until I grew too old to get about fast enough. I could turn them at my command, they obeying promptly. If our old lands-too poor for cultivationcould be made into goat pastures, and grazed according to their capacity, it would add millions to the farmers' income, but our people have so long depended on the one crop, cotton, it would be hard to change their habits.

Tery truly.

J. WASH WATTS.

GEORGIA was the second Stato to become interested in the Angora goat through Col. Richard Peters, of Atlanta.

Col. Richard Peters was born in the State of Pennsyivania, on the 10th of November, 1810, and passed away in Atlanta, Ga., on the 6th of February, 1859, at the advanced age of seventy-nine years. He was a grandson of Judge Peters, a celebrated lawyer of Philadelphia, Penn., who was Commissioner of $\mathrm{IV}$ ar in 1\%3, afterwards Secretary of Mar for six months, and was a member of Congress in 1:81, and the organize. of the first agricultural society that was started in the United States, in 1 is.j.

Col. Peters was educated as a civil engineer; and, in 184?, he left Pennsylvania for the purpose of locating the Georgit Railroad, of which he was afterwards superintendent of construction, but resigned this position to engage in running a line 
of stages from Covington-the end of the Georgia Railroad at that time-into Montgomery, Alabama. His first residence in Georgia was Augusta, where he lived from 184? until 1848 when he moved to Atlanta, and married Miss Mary Jane Thompson, a daughter of Dr. Joseph Thompson of hotel fame.

He was very successful in his different undertakings, and was identified with nearly every enterprise which had for its object the advancement of Atlanta; and, it is doubtless due, in a great measure, to his practical judgment and enterprise that this city occupies such a prominent position among the cities of the Southern States today. In religion he was an Exiscopalian, and a devout member of that church. In politics, he was conservative at all times; but, having. lived such a long life, was naturally a member of several of the political partiesfirst an Old Line Whig-a Co-operationist-and, after the war of Secession, a Democrat. He was opposed to secession, but having adopted Georgia as his home, was true to the South after his State decided to secede from the Union, and responded liberally to all calls that were made nipon him. He was director for many years in the Georgia Railrued, and took a great interest in all railroad work in the State and was one of the original lessees of the Western \& Atlanta railroad. His thorough education had enabled him to become a practical geologist and chemist, which was a great assistance to him in his many experiments in agricultural affairs, which occupied much of his time; and, the farmers of the present day, are indebted largely to his liberality for the many improvements they now enjoy in farming and stock raising. His inclination towards agriculture was very pronounced, and he was not very long in the State before he had secured a beautiful tract of land in Gordon County, in the Oothcaloga valley. In referring to this land in $18 \% 8$, Col. Peters stated in a newspaper interview:

"I never saw any land I wanted until I saw the Oothcaloga valley. It struck me because it looked like the Chester County lands in Pennsylvania, where I had been at work on the Pennsylvania railroad. I bought 1500 acres in $18 t \%$, from a Cherokee Indian, and learned afterwards that the 


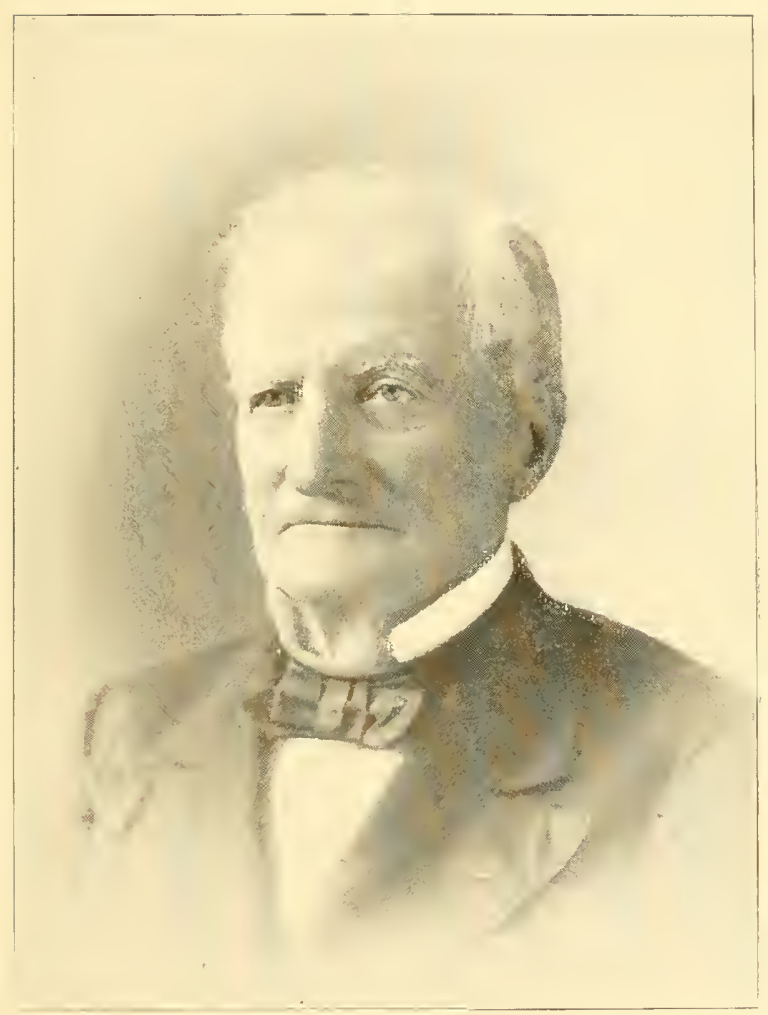

Col. Richard Peters. 

geological formation is 'exactly that of Chester County." On this land Col. Peters established a great farm that was known over a large portion of the South, and was considered the finest farm property in the State of Georgia. It was and is now known as the "Pctcrs' Stock Farm," and was the pride of all Georgians. He spared no expense in improvments, and had the most elaborate barns for his harvest and his live stock, besides a most elegant farm house. Not one acre was devoted to cotton, the entire area of tillable land (about 500 acres) being used in growing grasses, wheat, and grain crops for live stock. It should be borne in mind that when Col. Peters established this farm, in 1847, there was no United States Experiment Station to guide the stranger in all the intricacies of farming. He had to do it all alone, and was a pioneer in many things that are now known to every farmer's boy in the country. To use the Colonel's own language, taken from the newspaper interview above referred to: "I started out on the theory that Wester"1 grasses would not thrive in Cherokee, Georgia; everybody said they wouldn't, and I never thought of trying. I spent years in trying to get a substitute for them. I sent to England, all over Europe, and into Asia, buying grasses, and I tried them all on a liberal scale; at last I have reached a conclusion, that woild have been worth thousands of dollars if I had known it ten years ago, and that is that the best grasses in north Georgia are the well-known grasses of the North and West, orchard grass, red clover, and blue grass, for the shade. Of these, red clover is the best, of which I have planted 250 acres, in the past few years."

The same difficulty was encountered in finding cattle that were best adapted to Georgia, more particularly for milk and butter purposes. Colonel Peters expended many thousands of dollars in experimenting with different breeds before he found the right kind. He paid as high as $\$ 1000$ for a single Brahmin bull, which had been suggested to him by the wellknown naturalist, Dr. Bachman, of Charleston, S. C.; and, after spending considerable money in this experiment, he tried the Guernseys, and finally drifted into Jerseys, which were then becoming very fashionable throughout the United States. 
In hogs we had the same trouble, trying the several wellknown breeds, like Chester White, Poland Clina, Suffolk, Neopolitans, Prince Alberts, Perkshires and Jersey Red, and finally the Essex, which he found to be the most profitable hog for his State. In sheep he spent much money, and also made experiments with bees and chickens. He introduced the culture of silk in the South, and was the first to plant sorghum seed, which has since grown to be a great industry. His aim seemed to be to "bla $\approx$ the way" on all the lines of agriculture, so that farmers could tell how to carry on their business to the best advantage, and there is no estimating the amount of good that has resulted from his generosity and intelligent work.

When he was asked the question, "Does stock farming pay?" his reply was:

"It is hard to answer that question. You see through what untold realms of experiments it has led me. I had to demonstrate by costly trial, many things that are now axiomatic. I spent nearly $\$ 50,000$ for different breeds of animals, only to prove that they were not adapted to our climate and conditions, I have had to search, and explore, for everything, from crops, down to the best fertilizer to feed them with. It lias always been my policy to get the best of everything, regardless, in a certain sense, of the cost."

In the early 50's, Col. Peters' attention was attracted to the Angora goats that Dr. J. B. Davis had imported from Asia Minor in 1849 , and he determined to purchase them it he could. Col. J. Wash Watts, of Montville, S. C., writes me that, he was present at the time Col. Peters made the trade with Dr. Davis, through which he was to get all of his pure-bred Angoras at $\$ 1,000.00$ each, and adds: "Col. Peters was a wonderful man, in his way, and deserves to be on the top of the list of Angora breeders." In referring to this purchase, at a later time, the "Atlanta Constitution" says:

"His venture in the Angora goat was a characteristically bold, and sagacious, movement, reçuiring nerve and foresight; and, while an apparent extravagance, and seeming folly, was a real stroke of genius." 
The following is an extract irom an interview that Col. Peters had, in 1883, with the illustrious Henry W. Grady, of the "Atlanta Constitution:"

"How did you get into the Angora goat business?"

"I bought, in 1855, some Angoras from the first importation made to this country from Turkey in Asia. I paid $\$ 1000$. apiece in gold for Angora ewes, an unequalled price then, or since. 'They were known as the 'Cashmere' goats. I was so' pleased with them that I made two importations myself, buying selected. animals, from the best flocks in Asia Minor. These cost me $\$ 250$ apiece in gold. I then became satisfied that I could not get perfect animals in Asia.

"It is part of the religion of the Turk not to interfere with the natural run of his flocks. The goats are bred carelessiy, some of them becoming parti-colored with heavy manes on the neck and along the back-bone.

"It took me twenty years, breeding by selection, to establish a perfect animal, and get rid of the coarse mane. In breeding up to perfection, I found the males the only ones that had any effect; selected males improved the stock, no matter what the females were. I have now scores of finer Angoras than can be found in Asia. They represent twenty years of breeding by selection, and the cacrifice of every imperfect male."

"What is the advantage of Angoras over sheep?"

"They do not have to be watched as sheep do. They take care of themselves, come home at night regularly with a shepherd, while sheep have to be herded and driven every night to the fold. They are hardier than sheep, and live on less. You can count on a flock doubling every year, while sheep, under the same circumstances, only average 80 per cent increase. They do not need to be put in close stables like sheep; they want a hillside range, where they call browse instead of grazing. In Asia they live on the leaves and shoots of the scrub oak. Pure Angora bucks crossed on native goats, after eight to ten generations, produce animals that you cannot distinguish from the pure-breed." 
"What is the chicf value of the? Angora?"

"l'he wool; it brings from 30e to 60e a pound, and a goat will average three ponnds safely per hearl. Formerly we had to ship the wool to Fingland, but now the 'lingue Nantufacturing Company of Seymonr, Cinnl., will purchase every pound to be hate, patying the highest mated price for it. The use of goats wool is being increased rapirlly. lior a long time only fancy articles were made from it. Now, all the plush you see on the seats of the railioal cars is made from it, and it is ased for a great many other purposes. At last we have realized the significance of the old alage, "going to a goat's house for woul!' In olden times it was spoken in ridicule, but now we aceept it as a verity."

During the civil war, Col. l'eters' magnificent farm was totally rmined when Slerman invaled Ceorgia, and his fine barns were burned to the grommel. He managed to save ins goats by driving them into lilorida before the army had reached Alanta. It wals a serious question with him for some time after the wat, whether he would re-establish his farm or not, but finally decided to do so, and it was managed for some time by his son, Richard l'eters, Jr., with great skill. His daughter, Mrs. N. l'. lilack, the widow of ex-Congressman biack, of Cicorgia, las lately assumed the managenent, and in a recent commonnication she says: "A love of farming seems to have come to me by inheritance, and, for this reason, I assumed the clatege of affatis thee vears ano (1896). The farme is in fone condition, and is a worthy mommonemt to my father's nante. I womld state that we are no longer engaged in the goat business, having sold ont ont entire lot to Dr. J. R. Standley, of l'latt aville, lowa. We are now making a specialty of lissex logs and fersey cattle."

In 1891. Col. Peters, in comprany with Col. C. IV. Aclair, built the furst eleven miles of street railway in Atanta, of which company he was president. Ilis pen was always ready when he believed he combl benefit his fellow-1nen in any of the experinents he had conducted, and he contributed many articles to natgatines and newspapers tupon subjects relating to horti- 
culture, agriculture and live stock raising, on scientific lines. The surviving members of his family are a wife and six children-three sons, Richard, Ralph and Edward; and three daughters, Mrs. Black, widow of the late ex-Congressmar. Black, Miss Nellie Peters and Mrs. Atkinson (H. MI.)

In referring to Col. Peters' death, the "Atlanta Constitution" remarks:

"His children, from iniancy to majority, were his constant companions, and were influenced by him as their character was formed; and no iather ever had better children. His friendship was of the purest type, and wholly unselfish, while his character was unblemished. There was nothing little, or parsimonious, about him. He leaves a large estate, which has long since been disposed of by will, the bulk of it being represented in the "Peters Land Company," of which Edward C. Peters is President."

Reierring to the success of raising the Angora in Georgia, Dr. Hayes quotes the following letter from Col. Peters, dated ?.) of December, 18\%:

"I have had great success in Angoras, and regard them as among the most valuable acquisitions to the resources of our husbandry. They have yielded me more substantial pecuniary profit than any other branch of my extended stock investments. There can be no doubt that in the range of the Blue Ridge, extending irom Alabama to Virginia, they would find all the requirements of their nature, utilize a vast country, and prove a source of great benefit and profit to all interested:" Hayes: page 59 .

The constant demand for pure-bred stock, after the close of the war, kept Col. Peters' flock down, and he was never able to accumulate any large number of goats at one time. It is surprising that the industry was not taken up by the farmers in Georgia, which is doubtless explained by the fact that they were very much impoverished after the war of 1861-65; and, as cotton was high, they devoted their energies to raising this crop alone. From the best information I can obtain, there are not more than three hundred. Angoras in Georgia at the present time. 
KEN'TUCKY was one of the early States to take an interest in breeding the Angora, through Col. Robert W. Scott of Frankfort-since deceased.

\section{In referring to this gentleman, Dr. Haves says :}

"An esteemed correspondent, Robt. IV. Scott, P. O. Frankfort, Ky., better known as the creator of the improved Kentucky sheep, has kindly sent me all his published communications on the Angora goat, of which he has been a breeder from the pure 'Davis,' 'Peters' and 'Eutichides' stock since 186:. Specimens of the fleeces from his purc, and crossbred animals were examined by the distinguished expert on wool fiber, Mr. Henry Mitchell, since president of the Bradford Board of Trade, and myself, as official judges, and were highly commended. From these communications I select the following observations:

"The gay and intelligent appearance of the Angora goats, their cleanly habits, active and playful disposition, make them attractive on a farm; while in their natures they are so docile that they may be raised so as to be familiar about the house and yard, as the dog or cat. Though they have great curiosity and enterprise, they also have strong local attachments, and after wandering all day, will generally seek their usual shelter at night, especially if the weather is inclement. They do not brcak fences, or clear them at a single bound, as most other stock do, but will pass through a hole which is already made; will climb up a rail which leans at about forty-five degrees, or will bound on top of and then over a low fence. Any good farm fence, five feet high, will keep them securely, except a stone fence, which may be made easily goatproof by confining, to timbers placed across the top of the fence, a strip of plank so placed as to project about a foot from the top of the fance on each side, so as to strike the goat in the face, and knock it back, if $: t$ attempts to run over the fence. Hedge fences are not suitable to keep them, as they will browse on the osage-orange, or any other shrub, to such an extent, as to destroy it as a fence, by making it too open at the bottom. Like other stock, they are more troublesome after they have acquired roaming and breachy habits. They bear coupling, hobbling, and tethering, better than any other stock. In their diet they are almost omnivorous, eating in winter often what they have rejected in summer. On large farms much the greater portion of their diet will consist of weeds, bushes, briers, fallen leaves, brush, etc., and they are truly valuable for keeping lands clear of these. In winter, short grass and corn-fodder are all that is required, even by the breccing flock, and I never fed grain of any kind to them, at any saason, except some sheaf oats to old and infirm ones.

"A dry shclter is desirable for them, especially in the lambing season; though my flock of males and wethers, even after they have been shorn in 
April, has never had any other protection than what they could obtain around a hay or straw stack.

"The females have no perciptible and repulsive odor at any season and the males only during the breeding season, when they urinate on their fore-legs and beards; but their habits and odor are much less offensive than in the native goat, and their language of lore is much less demonstrative, and noisy

"In breeding they are precocious, the females being capable of breedat seren months, and the males often still earlier. As the females carry their young only fire months, it is possible for them to have young within twelve months old, but I do not think it advisable either sex should breed in less than twelve or eighteen months old. Generally the pure-bred animals have but one at a birth (while grade and full-blood females will have from one to five), and with reasonable care will always raise as may kids as there are mothers in the flock, and often more. If the weather is pleasant, and the kids at their birt'n can once get dry, and stand up; and suck, they require but little attention afterwards.

"The mothers may sometimes lose or leave them in large pastures, especially if they have more than one, when they are very young. Like deer, they incline to leave their young, and return to, and suckle them at intervals, during the first few days after birth. A protracted cold rain is often fatal to a kid at the time of its birth; it is therefore desirable to house the femaies at night, during the period of parturition. The males should be bred to the females, so that the kids will come in pleasant weather. and as simultaneously as possible: for which, and other reasons, it is preferable to keep the adult males, and wethers, separate from the breeding flock. The bucks are said to be valuable in protecting the flocks from the attacks of dogs; and under my observation the goats are most commonly the attacking party, haring seen them irequently charge, and drive away a loafing dog. They do not, by flight, invite the pursuit of dogs, as sheep do; and dogs do not seem to have the same disposition to morry, or to eat them, which they marifest towards slieep.

"Though goats will often bite, hook and butt each other, yet they are not cross with other stock, and the males do not fight, and injure each other. as the male sheep often do.

"As evidence of their superior hardiness to sheep, a female, which was suckling a kid in July last, got her leg broken; it was amputated, bandaged, got well and she has run with the flock and raised her kid on three legs." ( See Hayes, page 62-63.)

Col. Scott was always recognized as one of the most practical, and conscientious, breeders of his day, and for that reason I have copied his experience with the Angora Goat. It is rery interesting to note some of the points that this eminent breeder 
mentions with reference to the "tico coats of hair" that these animals produced, which I intend to refer to in my chapter on breeding.

Since the death of Col. Scott, very little attention has beer given to the industry in Kentucky; and, although the State affords very great advantages for it, the number of Angora goats owned there, at the present time, is estimated to be only about two hundred head.

VIRGINIA, * with her vast mumntain ranges, offers peculiar advantages for goat raising, and it is surprising that the industry has not been established upon a large scale before this. The "Entichicles" importation was sent to this State, in 18.1; but were sold out in small lots, and were all removed in a year or two. Dr. Hayes makes mention of an attempt upon the part of Gen. Herman Haupt;

"To form a large company for the purpose of raising the Angora goat, but failed, on account of his inability to obtain the necessary number of animals." ( See page $6 \overline{7}$, Hayes.)

There can be no doubt that Vinginia can support an enormous number of goats, ipon mountain lands that are valueless for other kinds of live stock, and it is not unlikely that some one will take up Gen. Hatupt's scheme, in the near future, and carry it out. In a communication to Dr. Hayes, Mr. F. S. Fulmer, of Spring Mills, Apponattox County, Virginia, who was interested in raising the Angora goat in 1875, says:

"Ny goats have always been healthy. The only trouble I have is that they require a first-class fence which is expunsive and when their pasture is once fenced in, I cannot afford to shift them to other pastures as often as would be desirable for they should have a free run in order to do well. I believe that the Angora goat husbandry is bound to succeed in the newer States like Texas; but in the older States the cost of fencing is an objection." (See Hayes, page 100)

In a letter I have received from Dr. M. Barrett, of Maidens. Ta., dated 28th of August, 1899, this gentleman says:

*Col. B. Davenport, of Harpers Ferry, took the first Angora goats into Virginia, which he purchased from Dr. Daris in 1852. 
"I have been raising three-fourth grade Angora goats for the past twenty years. I find them very strong, hearty and healthy; have nerer lost one from disease. They are, I think, the best fresh meat we can raise. They are but little trouble, and no expense. as they do not require feeding if let loose on the farm. They are very prolific sometimes kidding twice a year. I have never made use of their hair except for padding, as it is a little coarse. They grow large, and usually, get their growth by the third year. There is no market for them in this section, once in a ihile, however, I sell a few at $\$ 2.00$ per head. I keep them for table meat as I think it the best fresli meat we can raise, and will soon take the place of sheep as we have no pasture lands.

"The goat lives on briars, brush, weeds, pine and cedar, rarely ever grazing. If once we can introduce them in market they will become very profitable as they can be raised very profitably here at one dollar and fifty cents per head.

"My kids at six months dress 35 to $10 \mathrm{lbs}$, giving a nice lot of tallow, which is superior to mutton tallow, as it keeps even in warmest weather. The skins are very pretty and useful, as they make lovely mats, rugs or robes. I value my goats more than sheep. I have sereral goats now that are serenteen years old, still fat and hearty." **

Tirginia is said to have only three hundred head of goats at this time.

Mr. Diehl makes the following quotations from some of the breeders that he had the pleasure of meeting, or corresponding with, upon the Angora goat industry, in 186?. (See Agtl. Dept. Rept. for 1863. p. 221.)

MISSOURI. Mr. John Walker, of Fayette, a distinguishsed farmer and stock raiser, who has a very superior flock of about serenty, says: "We raised most of them in this State, and so far they have done

*From the description Dr. Barrett gires, it is quite erident that his goats hare degenerated, and that very little of the Angora blood remains in them. The hair of the Angora is alvrays soft, and silky, eren on the three-quarter grades; and the kids very seldom weigh as much as Dr. Barrett says his will dress. Another eridence is, the Angora will never have kids more than once a year. I would inier that the Doctor has a speceies of the "Maltese" goat, which a great many people confound with the "Angora." His experience in handling the goat, howerer, is an assurance that the Angora will thrive in Virginia, and it is gratifying to be able to assure him that there is no longer any prejudice for goat mutton in our Western markets-like Chicago, Kansas City, St. Louis and Omaha-and it is reasonable to believe the Eastern markets will soon fall into line. 
remarkably well. They stood the cold weather of this winter better than other stock we have. They are very hardy and increase rapidly. 'The dots take care of their young. The cost of keeping these goats is less thar any other animal. They graze upon coarse herbs that are not eaten by any other stock, such as iron-weed, dock, mullen, briars, buds and broken sprouts. My buck sheared nine pounds and three quarters, and my pure-bred ewe five pounds."*

But, pursuing my inquiries further, I learned through $\mathrm{Mr}$. Wm. J. Seever, Secretary of the "Missouri Historical Society," St. Louis, that a very considerable interest is being manifested, by quite a number, and that the Angora is now owned, in a small way, by upwards of twenty farmers, throughout the State, and he believes the Ozark mountains, where the timber and brish abounds very abundantly, will afford exceptionally fine advantages for the propagation of the animal.

It is estimated that Missouri has about 1500 head of Angoras now.

TENNESSEE. Col. R. Williamson of Gallitin, agent of the "Sumner Cashmere Company," says by letter that, "so great has been his success in breeding and selling these goats, and their crosses, that during 1838, we disposed of twenty-seven thousand dollars worth, and with an increased success, until the war commenced.

Brig. Genl. E. A. Paine, commanding the U. S. forces at Gallitin, Tennessee, also writes: "I have been stationed at this post for nea"ly eighteen months, and have been deeply interested in making myself perfectly acquainted with the habits, incresse and value of these animals, and am thoroughly satisfied that the 'Cashmere' wool is to be one of the greatest staples of the country. It is to be to the common wool what silk is to cotton." (See Diehl. Agti. Keport 1863, p. 226.)

*In response to a letter addressed to the State Board of Agriculture. asking about the condition of the Angora goat industry in Missouri at the presnt time, Mr. J. R. Rippey, the Secretary, says:

"I do not know of a herd of Angora goats in Missouri. Col. John Walker, of Fayette, Howard County, some fifteen or twenty years ago, had three or four hundred. At that time the wool buyers in this State knew nothing whatever of the value of the fleece and offered practically nothing for it. Then again the owners of the goats knew nothing of the necessary care of the fleece when it should be clipped, or as to the care of the goats for producing the best fleece. If there is a herd in this State I do not know it." 
NEW YORK.* Charles S. Brown of New York, writing of his flock of Angora and Cashmere goats, says: "All these goats can be propagated with great profit. They are easily kept, requiring only the coarsest food, and will thrive better upon low bushes, than green pasture. I have found them robust and liealthy and have never known any sickness among them.” Diehl. Agtl. Report 1863, p. 226.

MARYLAND. The Hon. Geo. A. Porter, of Baltimore, writing of his flock of Angora goats, says: "I herewith send you two numbers of the 'American Farmer' April, 1860, and July, 1861, which will give you some interesting particulars respecting these goats, also some idea of their value. I think you will be convinced that the half-breeds, will prove quite valuable. I have lived many years at Constantinople, occupying the post of United States Consul, and procured and shipped for Dr. Davis the first goats that were ever krought to this country. You will see that Dr. Davis and Mr. Peters, have made a profitable business crossing back to the full Angora." (See Diehl. Agt. Report 1863, p. 226.)

OHIO. $\nmid$ S. S. Williams, Granville, Ohio, writes: "I have about one hundred head of goats. In regard to the breed of my goats, whether Angora or Cashmere, mine belong to that breed first introduced by Dr. J. B. Davis as 'Cashmeres' and which have generally gone by that name to this day. But, if the Cashmere goat is the animal bearing a coat of coarse hair, with an undergrowth of only a few ounces of fine fleece, then mine are not 'Cashmeres' though known as 'Cashmere' in this country: and from the description of Rees, and others, mine are the Angora for they describe my goats as correctly as I can myself. I rest satisfied that our goat, whatever it should be called is valuable, and I care little for the name. I send you a sample of the wool of my buck 'Sampsor.' which clips over six pounds. Of course I think he is more valuable than an animal yielding only three ounces of but little finer quality." ( See Diehl in Agt. Report 1863, p. 226.)

PENNSY LVANIA. † Genl. J. S. Goe, Brownsville, has a fine flock of twenty in a good condition, beautiful and thriving. He says "they have stood the severe winter well, and are promising; and I am encouraged with the experiment and prospect." Also Dr. F. F. Robinson of Freedom, Pa., says: I have been quite successful in breeding from the common goat to my Cashmere buck; find them to be hardy and prolific." (See Diehl Agt. Report 1863, p. 226.)

*The Angora was introduced into New York in 1852 by Dr. D. C. Ambler, of Waterville, Oneida County, who purchased a pair of young pure-breeds from Dr. Davis, of South Carolina, for $\$ 2,000.00$.

$\nmid$ As near as I can learn, there are but a very few goats in Ohio now. † Miller \& Sibley, Franklin, Pa., were more recent breeders in Penn- 
MASSACHUSETTS.* Winthrop W. Chenery, "Highland Farm," Belmont, Massachusetts. one of the most enterprising importers, and stock raisers of the country has made several successful importations, and has a very choice flock of some twenty pure imported Angoras upon his celebrated stock farm, near Boston, in a good and prosperous condition, where they wintered admirably, standing the rigors of the past severe winter and are doing well. Mr. Chenery feels mucli encouraged with his success in importing, and is quite confident of ultimate profit and value. He writes as follows:

"The goats will prove profitable in this country and I would say that, with proper attention they may be bred, and raised as safely, and surely, as ordinary sheep. One gentleman in Western Pennsylvania, to whom I sold a small flock writes me that his goats are about a third heavier than they were and tha: he has no more fear of raising them than pigs." (See Diehl in Agtl. Report 1863, p. 2.27.)

It is estimated that Massachusetts has about 1000 head of goats at he present time.

The foregoing quotations and references, from the paper of the Hon. Israel H. Diehl, who Limself, afterwards, in connection with Mr. Charles S. Browin, of New York, made quite

sylvania, and sold quite a number of goats to breeders in the West. In a letter to me, of recent date, they say they have disposed of all of their goats, and do not know how many are in the State. I presume there are very few.

*Within the past year, more for the purpose of clearing brushy land than for 1 aising mohair, there have been about five hundred head of goats shipped into Massachusetts, and a very considerable interest is being manifested by the owners of lands in this class of stock. The following newspaper extract bearing on this question will be of some interest:

"It looks as if the Angora goat might be the means of the reclamation of a lot of the abandoned farms of New England," said a woolen man from that section yesterday. "Two carloads of these animals have arrived at one of these farms in the interior of Massachusetts within the week, coming from Texas, I believe. The animals thrive on the rough pastures of hilly lands and if the climate proves suitable, there is a fortune in the wool and skins compared with the returns from other animals and products of even the better grades of New England farms. At all events, some friends of mine have bought a couple of these farms and are going to stock them with the goats and see if the scheme is not a practicable one. Yon know we will have to do something to connterbalance the stealing of our cotton industry from us by the people of the South." 
Spread of Angora Goat Industry in the States and Territories. TI

a large importation of goats from Turkey, is quite sufficient to prove that the Angora goat will thrive well in any portion of the United States, and yet it is a remarkable fact that, in each and every one of the States referred to by him, there are at the present time very few goats. There is, perhaps, but very little doubt that most of the so-called "breeders" he speaks of were gentlemen amateurs, who had been attracted to the animal more by its novelty, and beauty, than by any profis they expected to realize from handling it.

Or it may be as Mr. Fulmer, of Virginia, expressed it:

"I believe that the Angora goat husbandry is bound to succeed in the newer States, like Texas; but, in the old States, the cost of fencing is an objection."

At all events, there was no very decided interest taken in the animal by stock raisers until after the close of the war in 1865-66, when the Western States, and Territories, seeing the opportunity for the establishment of a very profitable industry: began to purchase some Angoras, and it is not unlikely that many of the goats that were formerly held in the old States were transferred to the new, as has been the case largely with sheep.

TEXAS is entitled to the credit of leading in the movement of starting this new industry, through her very worthy citizen, Col. IV. IV. Haupt, of Hayes County, a kinsman of Gen. Herman Haupt, of Virginia, referred to by Dr. J. I. Hayes.

Col. IV. IV. Haupt was born in Green County, Alabama, in the forks of the Bigbee and Warrior rivers, on the 10 th of February, 1828, of German-English extraction. His father was a native of Bucks County, Pennsylvania, and migrated to Alabama when he was quite a young man. In 1833 he bought largely of lands on the Bigbee river from the Choctaw Indians: upon which he settled, and died very soon after. His mother was a woman of remarkable energy, and practical sense, as has been clearly demonstrated by the manner in which she reared her son, who was only five years of age at the time of his -father's death. - He received his scholastic education at 
Demopolis, Alabama, and was two years at the Centenary college in Mississippi, and two years at the Washington college, in Virginia, during which he drilled the Cincinnati company of College Cadets, on the Virginia Military Institute grounds. In $18 t 8$ he returned home, married, and moved to Texas, where he settled on a farm in the bend of the Colorado river, just below Bastrop. His wife was a Miss Colguin, who soon died. He then married her cousin, a daughter of Capt. Joln Rugely, of Matagorda County, Texas, and in December, 185\%, he purchased the farm upon which he is now living, near Kyle, in Hayes County, where he ran the first steam cotton gin that was used in Western Texas, constructed with a steam whistle and a pipe from the boiler to the pick-room; to extinguish fire, and discharged the exhanst pipe into the chimney as a sparkarrester-all of which was his own construction. His father was of an inventive turn of mind, and had the honor of digging the first artesian well ever sunk in the United States.

Gen. Herman Haupt, the noted civil engineer, who still lives, at the age of eighty years, was a cousin, and it would scem that a very decided inventive strain courses through the Haupt family.

Col. Haupt was never fond of a city life, and boasts of the fact that he "never lived a day in town in his life." His preference was for a farm life, where he could surround himself with all the comforts of a home, and indulge his fancy for varions kinds of live stock, of which he was especially fond. He introduced the first Essex hogs, and Brahma cattle, into Western Texas, and has invented many appliances for economy in farm work. He has always been a regular subscriber to agricultural papers, and has contributed many valuable articles upon various subjects relating to live stock and sarming.

In 1858, he thought lie would like to try goats, and commerced raising some of the common stock; but, concluded it was economy to raise the best, so ne made arrangenents with Col. Richard Peters, of Atlanta, Georgia, to let him have a small lot cf eight head, for which he pait him $\$ 100$ each. This wa: the commencement of the flock of "Haupt" goats which, in 


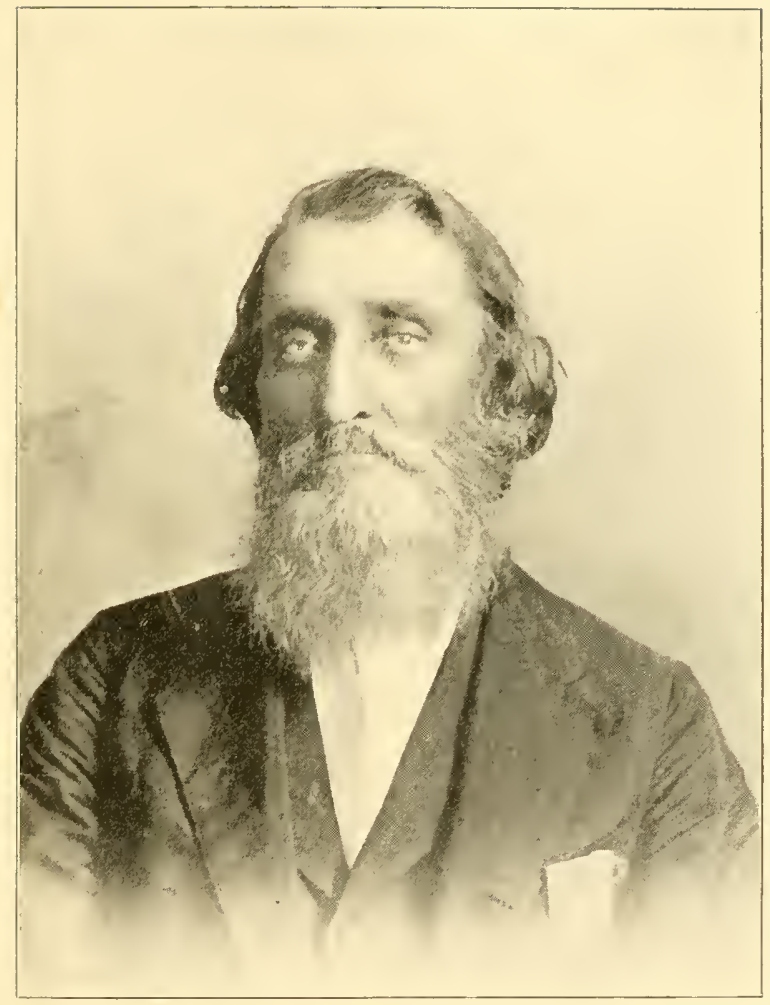

COL. W. W. HAUPT. 

later years, became so popular with other breeders. He was always exceedingly careful in breeding, and kept a close record of the grade of every gor: on his farm; and, it can be said of him, that he never deceiv 2 d a purchaser in the character of the goat he sold. Knowing his own marks of breeding, he conld easily distinguish one from anothe;, and it was his invariable custom to price his animals at $\$ 30$, if $h c$ selected them, or $\$ 25$ if the purchaser made the selection.

In 1895 he concluded to turn his attention to horticultural farming, and was forced to dispense with his goats, for which he had formed a very strong attachment. He, at first, thought of retaining an interest in them, but finally decided to sell them out and out, and Mr. W. G. Hughes, of Hastings, Kendall County, became the fortunate owner, and is still continuing to breed them.

True to his nature, Col. Haupt established his garden upon the most approved plan, and now has under the most skillful cultivation thirty acres, which is said to be the most magnificent sight, in the shape of a garden, that has ever been seen in the Stat 2 of Texas. He has several thousand fruit trees, consisting mostly of plums, which have prove 1 to be most profitable, and a large amount in grapes, which are likewise very productive. But the main product is the dewberry and blackberry, of which he has fifteen acres, which supports a small army of women and children during the "berry time."

Depending upon the elements for water, in West Texas, has always resulted in failure, and Col. Haupt has provided against all contingencies in this respect, by the means of a powerful windmill, and a tank, covering one acre of ground, in the center of his garden, from which he can irrigate his land at will. He is now contemplating the purchase of a gasoline engine, to be used in the event of necessity, which, however: occurs only for a short time, in the hot months of July ane Angust.

His magnificent estate consists of 3000 acres of beautiful land, 2500 of which is a pasture, on which three hundred improved cattle are run, and the remainder, between 400 and 500 acres, in farm and garden. 
Col. Haupt has a peculiarity of always imagining he is "hard up," and, with a man of his activity, it is not likely he would keep much loose cash around his house, yet he is recog. nized by all who know him as being as nicely situated in the comforts that this world can supply as any one could wish to be, and his ranch is the envy of all who have had the pleasure of risiting it. He enjoys the good will of his neighbors, and is always glad to entertain his friends. He visits town about once a month, but rarely takes a seat, and is back at his ranch in a very few hours.

At the advanced age of seventy-two, he is as active in mind and body, as a man of forty, and bids fair to live a considerable time, which is, doubtless, explained by the even tenor of his life.

In a recent letter, with reference to others who took an early interest in the Angora goat, Col. Haupt writes:

"In regard to the Angora industry in Texas from its inception, I was at one time perfectly familiar with the names of all of the early breeders, but my memory is treacherous and I find difficulty in recalling names of most familiar faces. If Col. Parish is alive le can supply you with this information, and a nicer gentleman never lived. The Arnold Bros. in the Frio Canon, were among the beginners, as was also Judge J. P. Devine of San Antonio. Mr. J. V. Abrams was another breeder in the Frio Canon, but he sold out and moved back to the north. His brother, M. C. Abrams, now lives in Manor, Travis County. MIr. R. R. Claridge, formerly of the 'Stockman \& Farmer' did much with his pen, and paper, to encourage the industry and I regret very much I cannot give you the names of many more who should be referred to in this connection."

The Rev. D. S. Babb was one of the early breeders, having started his flock in the seventies from Col. Peters' stock of goats. Mr. Babb is still engaged in the business, and has a fine flock near Sonora, Sutton County.

Mr. R. H. Lowry, of Canp Sur Saba, was another of the early breeders, who started with some of the "Haupt". stock, and later some from Messrs. Peters and Landrum.

The success which attended the introduction of the Angora goat into Texas was qu1te remarkable in the increased weight of fleece over the goats that had been raised in Georgia. 
Referring to this subject, Judge J. P. Devine, of San Antonio, in a letter to Dr. J. L. Hayes, says:

"Col. Peters expressed much surprise when I told him of the heavy clips sheared from the same class of goats that in Georgia sheared much less. As the goats have an inexhaustible quantity of rich evergreen food, all during the winter, they are in better condition than at same season elsewhere, and consequentiy the clip is heavier; and the dry atmosphere gives the same gloss, or lustre to the hair that it has in Asia; and some think, our production is the glossiest. The heaviest fleece I have ever taken from a pure nanny, was three and one-half pounds, also from Col. Peters' stock, whose pure-bloods, I think, cannot be rivalled for gloss, a id length of staple, by any pure bloods I have ever seen, and they compare very favorably with other pure-bloods in the weight of their clips.

"The heaviest fleece I have ever seen clipped from a grade goat was from one of my original breeding billies, which sheared six and a half or seven and a half pounds, I forget which, at three years of age in 1877; and I have sheared four and five pounds from several other grades.* So yos will see that a high grade will shear fully as much, and even more, hair than the best specimens of pure blood, and have all the distinguishing marks of a pure blood: and without you take a strong glass, you cannot distinguish any difference in the fibre; and, consequently the great difficulty of discovering a fraudulent 'pure-blood' except you put him to nannies, and then blood rwill tell. (See Hayes, page 112. )

Tudge Devine took a great deal of pride in his goats up to the day of his death, which occurred shortly after that of Col. Richard Peters, between whom there seems to have grown up quite an attachment. I have been informed that it was always the wish of Col. Peters that Judge Devine should control his flock of goats after his death: but, it was ordered otherwise, and these two leading lights in the Angora goat industry of this country passed away very close together, and their re-

*It should be borne in mind that this letter was written about twenty years ago and it is proper to state that the shearing capacity of Angoras has increased considerably over what Judge Devine then referred to. Attention is called to the "Notes of Practical Breeding" upon this subject.

Plate XVII represents two full-blood does, raised by Judge Devine, which sheared four and a half pounds in 1896. 
spective flocks have gone into other hands, to be improved on it is hoped.*

Great credit is due to Col. W. D. Parish, of Seguin, Texas, who is mentioned by Col. Haupt as being one of the early breeders. This gentleman secured two very fine goats from a sea captain, who had brought them direct from Constantinople to Galveston in $18 \% 5$, but he had been interested in the industry several years before this. The impression prevails in the minds of many breeders that Mr. Parish made a direct importation himself; but this appears to be a mistake.

Mr. Jno. S. Harris writes me that when he was in Constantinople, in $18 \% 6$, he investigated all the shipments of goats that had been made to this countr? up to that time and there were none mentioned as having been exported to Mr. Parish in person.

Mr. Jno. S. Brown, of Sonora, Sutton County, 'Texas, a personal friend of Mr. Parish, says he remembers distinctly that in 1868 or 1868 he (Mr. Parish) stopped with him after having gone somewhere for the goats that he first started his flock with. There were two or three wagon loads of them, and they were at his ranch two or three days resting. Mr. Parish was then going to his ranch in Kendall County.

Mr. Geo. WV. Baylor, of Montell, Uvalde County, writes me that

"In his opinion Mr. Parish did as much towards starting the Angora goat industry in Texas as any one. After he sold his ranch in Kendall County, he moved to Old Mexico and engaged in mining."

There is very little doubt but the goats that Mrr. Parish brotight into Texas in 186\%-68, referred to by Mr. Brown, had been purchased by him from one of the importations that had been made about that time by Mr. W. W. Chenery, of Boston. It matters very little, however, where they came from They were exceptionally fine goats, and the "Parish" stock of Angoras figures extensively as a pure-blooded strain in many of our flocks today, the owners of which are very proud of.

* The flock of Col. Richard Peters was sold to Dr. J. R. Standley of Platteville, Iowa, and the "Devine" goats were parcelled out to several breeders, Mr. Gunzer buying quite a number, and Mr. J. W. Garrett of Mountain Home, I understand, purchased some also. 
The industry in Texas made but very little progress until within the past tew years, when the demand for Angoras to be shipped into the Northern States, more especially Iowa and Kansas, commenced; and it is safe to say it is now upon a very firm foundation, and will continue to grow rapidly from this time forward.

There is a vast stretch of territory in the western border of the State that is unfitted for any other class of stock, which will sooner or later be occupied by gyat breeders.

It is estimated there are at least 100,000 head of Angoras now 11 'Texas, ranging frcm one-half bloods up to full-bloods, besides a number of pure flocks started from the "Peters," "Haupt," "Parish," "Devine," and "Harris" (\& Baylor) goats.

CALIFORNIA was second to begin raising mohair, and too much credit cannot be paid to Mr. IVn. M. Landrum for the enterprise, and perseverance, that he displayed in carrying the first Angora goats into that State. He had thought of the matter some time, and, in 1860 , decided to make the experiment, and arranged with Col. Richard Peters, of Atlanta, Georgia, to let him have a couple of young bucks from his breeding of the "Davis" goats. He had expected to return to California by way of the Isthmus of Panama, but the rate of passage having been advanced enormously ( $\$ 600$ for himself and the same for live stock, which embraced his iittle goats), he was forced to abandon the ocean route and go overland, a distance of oxer 3000 miles that he had to travel by wagon, at the slow average of 21 miles per day. He reached California in the year 1861 , with his two goats, and began improving some common short-haired goats at once. The climate proved to be admirably adapted to them, and from that day to the present he has been closely identified with the industry. His name has been so long associated with that of the Angora goat they have almost become synonymous.

Mr. Landrum is a native of Genrgia, and was born near the line of the Cherokee Nation, on the 10th of April, 1829. His father, James H. Landrun, was borri, and raised, in Rutherford 
County, Tennessee, and moved back to his native State when II. M. was quite a small boy, and he was sent to school at Versailles. In 1845 the family returned to Forsyth County, Georgia, and in $184 \%$, at the age of eighteen, he engaged in the agricultural implement business, making everything used by a farmer in those days, from his gun to a crowbar-plows for cotton cultivation being a specialty. In May, 1850, he and his father went to California where the father remained until 1852 and then returned to Georgia. W. MI. stayed there, and engaged in farming and hog raising. He was one of the first men to sow grain in the great San Joaquin valley, in the fall of 1852. Dr. Ash, Dr. Chambers, Judge Emory, Leorge Islip and himself sowed the first grain in that noted valley, and had to pay 25c per pound for seed, and $\$ 5.00$ per day for labor. He made a number of improvements in machinery for plowing, and harvesting, and was successful generally.

In 1860 he returned to Georgia for the purpose of getting some of the Angora Goats from Col. Peters, which he carried all the way to California by the overland route, as above stated.

In 1863 he went into Mexico under contract to build some mining machinery and a grist mill. He returned to California in 1866, and took charge of his goats, which he had placed in his father's care during his stay in Mexico, and determined upon making a second importation, which he did in 1S6\%, bringing eight selected goats from the IV. IV. Chenery importation to Boston, Mass.

The following year Mr. Land:um sold a one-half interest in his goats to Butterfield \& Son, and the business was then conducted under the firm name of Landrum, Butterfield \& Son. The new firm added two choice bucks to their flock from the Diehl \& Brown importation, one of which was the celebrated hornless "Costamboul." The same year Col. Peters shippec' twenty-five head of choice pure-breeds to the Pacific coast in charge of Mr. E. Holland, seventeen of which were purshased by Landrum, Butterfield \& Son. In $18 \% 0$ Diehl \& Brow1 shipped out the most of their flock, of which about sixty head survived and were placed in the hands of Butterfield \& Son to be kept on shares, and sold on commission. 


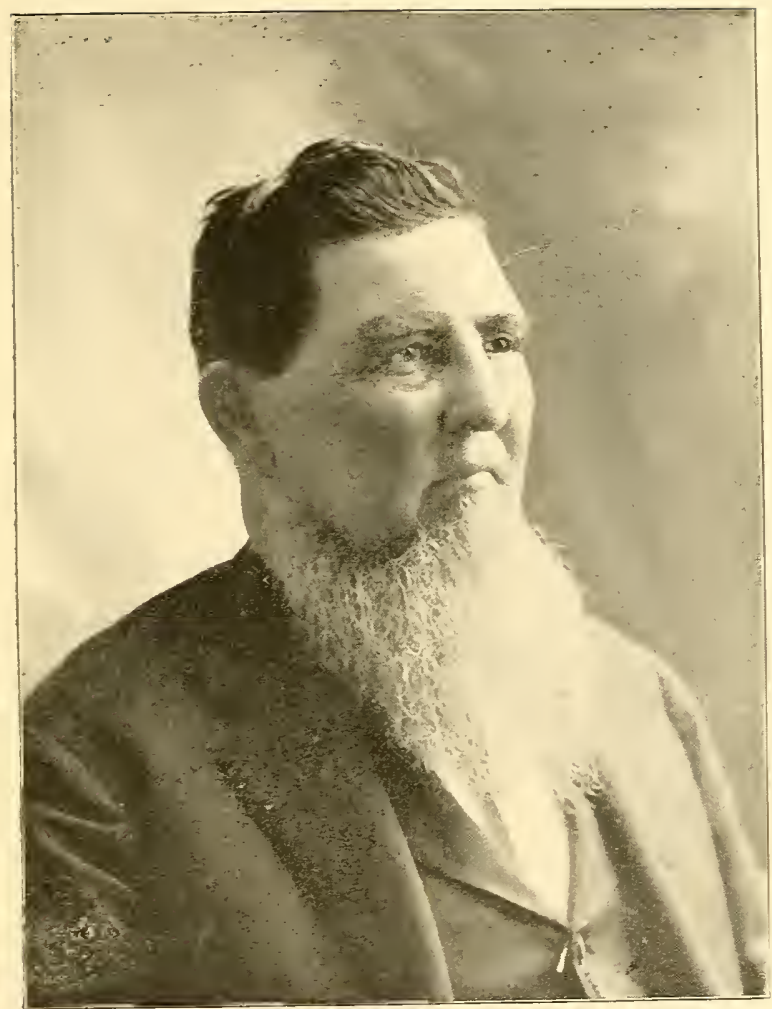

WI: í. LINDRUIV. 

The firm was sorn after this dicsolverl, and Mr. Landrum securerl, ly purchase, the largest number of the firm's goats: among which was the hornless "Costambroul" luck above menlioned.

In loil) Mr. Landrum formed a partnership with James M. Rorlgers, selling him one-half interest in his govats and sheep, and the lusiness was aiterwards carried on under the name of l.andrum \& Roclegers.

In 18i\% the new firm marle a large purchase from the "Peters" flock, which save them the prominence of leeing the largest holders of pure-1)rer Angorat groats in the Lnited Siates at that time.

Mr. landrum was instrumental in starting the industry in ()reeron, New Mexico and Liah.

In (jegon he harl great success, and deciderl tr, move his entire flock to, the State. In 188 : he shipjeed his pure blocorls to, 'Jexas and established a ranch in Cvaldr. Conty where he now resirles, enjoying eycellent health at the arlvancerl age of seventy-one vears, in full prossession of his great enersy, which has leen one of his chief characteristics throush life. Jfe is a strong belicver in the industry, and is actively engaged in breeding and distributing his groats, in which his sons, Wr. E. and fi. (). Landrum, are of great assistance.

In addition to the grats taken into California by MIr. I.andrum and his business associates, Mr. Lirock importerl a few from a flock owned loy Mr. ()gden in ()hirs, in the year rif $186 \% 1$.

In J8fir, Cray \& Cilmore imported nine head from the W. W. Chenery flock, in Porstron, and the frollowing year thes brought in seven more; and lilint and Sargent three: all of which were rut rif the "Chenery" Alock.

In 18a1, Shirland \& Thrmas improrted eight hearl from the "litutichurles" flrck, and in 1 xi\% they marle a secend importatirn.

In 189r;, Mr. Jne. S. Harris, in cennection with Mr. M'm Hall, imperterl twelve head from Asia Minor, crnsisting of twer bucks and ten roes, which, with the increase of three kirls 
on the way to this country, made fifteen head. 'These goats were selected by Mr. Harris in person, and were considered to be very superior animals.

In 1893, Mr. C. P. Bailey imported from South Africa two bucks, one of which was consiciered very fine. and in 1899 this same gentleman made a second importation of severa! m $\lrcorner$ re.

At the present time it is estimated there are fully 40,000 head of well-improved goats in California, which, as a rule, are held in large flocks.

OREGON began raising the Angora in 1869 or $18 \% 0$, and the credit is due to Mr. Ari Cantrell for having started the industry, which has proven to be very profitable to all who have engaged in it. Mr. Geo. A. Houck, of Eugene, Oregon, writes under recent date that,

"Mr. Ari Cantrell brought the first goats to the Willamette Valley sometime in the latter part of ' 69 or ' 70 's. He bought 150 head of threefourths and seven-eighths nannies from Mr. Butterfield of California at $\$ 12.50$ per head. He also bought a pure-bred billy, 'Old Boxer' and a one-year-old nanny, giving for the two the price of $\$ 1500.00$ or $\$ 1000$ for 'Old Boxer' and $\$ 500.00$ for the nanny. Mr. Cantrell brought the common goats overland, and had the fine ones shipped, and stopped with the whole band near Corralles in Burton County. He afterwards bought purebloods from Landrum and Rodgers, and from other parties but I have heard him say that none were as good as 'Boxer.'

The climate of Oregon has proven to be admirably adapted to the production of the Angora, and it is believed by many that the character of mohair from that State is superior to any in Anerica.

The industry has grown very steadily. The flocks are not large, as a general thing, ranging from fifty to 250 head (with a few large ones), which are used chiefly for cleaning up brushy lands for farming and grazing purposes.

It is estimated there are at least 80,000 head of highly improved goats in the Statc at the present time.

The industry was organized at Independence in 1896 under the name of "The Oregon Angora Goat Breeding Association," 
of which Mr. J. H. Hawley, of Monmouth, is president; Hon. Ino. B. Stump, of Monmouth, vice-president, and L. G. Garnett, of Portland, is secretary.

NE $\backslash A D A$ has in the vicinity of five thousand head of Angoras, many of the owners residing in California.

NEW MEXICO offers very fine inducement for the breeding of goats in many parts of the Territory.

Mr. Maxwell, of the "Maxwell Land Grant Farm," took seventy head into the Territory in 1872, and Mr. Frank Garst took five hundred fine goats from California in 1882, but has since that time moved his entire holdings into Texas.

It is estimated there are 30,000 head at this time in the Territory, among which are several very superior flocks.

The "Onderdonk Live Stock Company," of Iamy, $\ldots$. holders of about eight thousand lifad of the common shortharred Mexican goat, and it has been reported that they have iust made a beginning, and intend to increase the number to fifty thousand, which they expect to breed for the hide, principally.

This report, however, is groundless, as may be learned from the following quotation from a letier addressed to me by Mr. Ciras. S. Onderdonk, the general manager of the company.

"It has been the general impression in the West that we are raising common goats for their skins alone. This impression gained ground from the fact that the President of our Company is the largest tanner of goat skins in the world; is very prominent in the East; and the newspapers, knowing that he is connect d with us naturally supposed that we were raising goats for the purpose of supplying him with skins. You can appreciate the absurdity of this when I tell you that he has a capacity for tanning fifty thousand goat skins every ten hours. From this you can se that the whole territory of New Mexico could not supply him, if it was all devoted to goat raising. We starte 1 in to raise the common goat, both for the skin and for the meat; but, we are now also turning our attention to the raising of the Angora, the skin of which you know, is of very little value for leather furposes."

Mr. D. C. Taylor, of Lake Vailey, is a breeder of the Angora, and speaks in the highest terms of the Territory as adapted to the raising of them, and there is very little doubt but the industry will extend very rapidly. 
Mr. I. C. Hightower, of Ruidoso, is another very successful breeder.

It is estimated that New Mexico has upwards of sixty thousand goats of all kinds, of which, perhaps, one-half, or thirty thousand, are graded Angoras.

IDAHO has but few breeders of Angora goats, but is quite prominent in the industry, from the fact that Mr. Jno. S. Harris, who formerly ranched in California, and who visited Cashmere and Asia Minor, in 18\%i, and brought back twelve head of very fine Angoras from the latter conntry, selected this territory as combining more of the characteristics of Asia Minor than any portion of the Northwest, where lie moved in 1884 .

Mr. Harris was born in Scotland, in 1836, went to California in 1862 , and married Miss Josephine Whittin, of that State, engaging in cattle raising in San Benito County. In the early seventies, his attention was first attracted to the Angora goat. Referring to the subject, in a recent letter, he saỵs:

"It was in the early 70 "s that I first got interested in the "Cashmere goat,' as it was called in those days, and the newspapers, and those who were engaged in raising them at that time, represented that the fieece was manufactured into fine Cashmere shawls. Butterfield and Landdrum had some of them which they kept on the mountains at Mr. But. terfield's place on the San Benito river, some fifteen miles from where I was living. Landrum lived in Watsonville, in the same county, Monterey. I lived on the edge of a farming district and kept a small bunch of cattle. In the fall, after the grain was cut, Mr. Butterfield used to bring his goats and sheep down to be pastured on the wheat-stubble, and I became greatly interested in the goats, and traded cattle with him for about seventy-five head of his grades, which was my first introduction to the 'Angora.' I estimate the cost of the goats I received from Butterfield sixteen dollars each and am well satisfied now that they were notmore than half-breeds. Mr. Butterfield afterwards asked me to take care of his entire lot of goats consisting of some thoroughbreds which had been shipped to him by Diehl \& Brown to be kept on shares. There were about sixty head of the Diehl \& Brown goats, being the last of the importation made by Hon. Israel H. Diehl in 1870. I had them in my care for some time and tried to learn all I could about them. Mr. Butterfield would sometimes come to see them and would always pick out indiridual ani- 


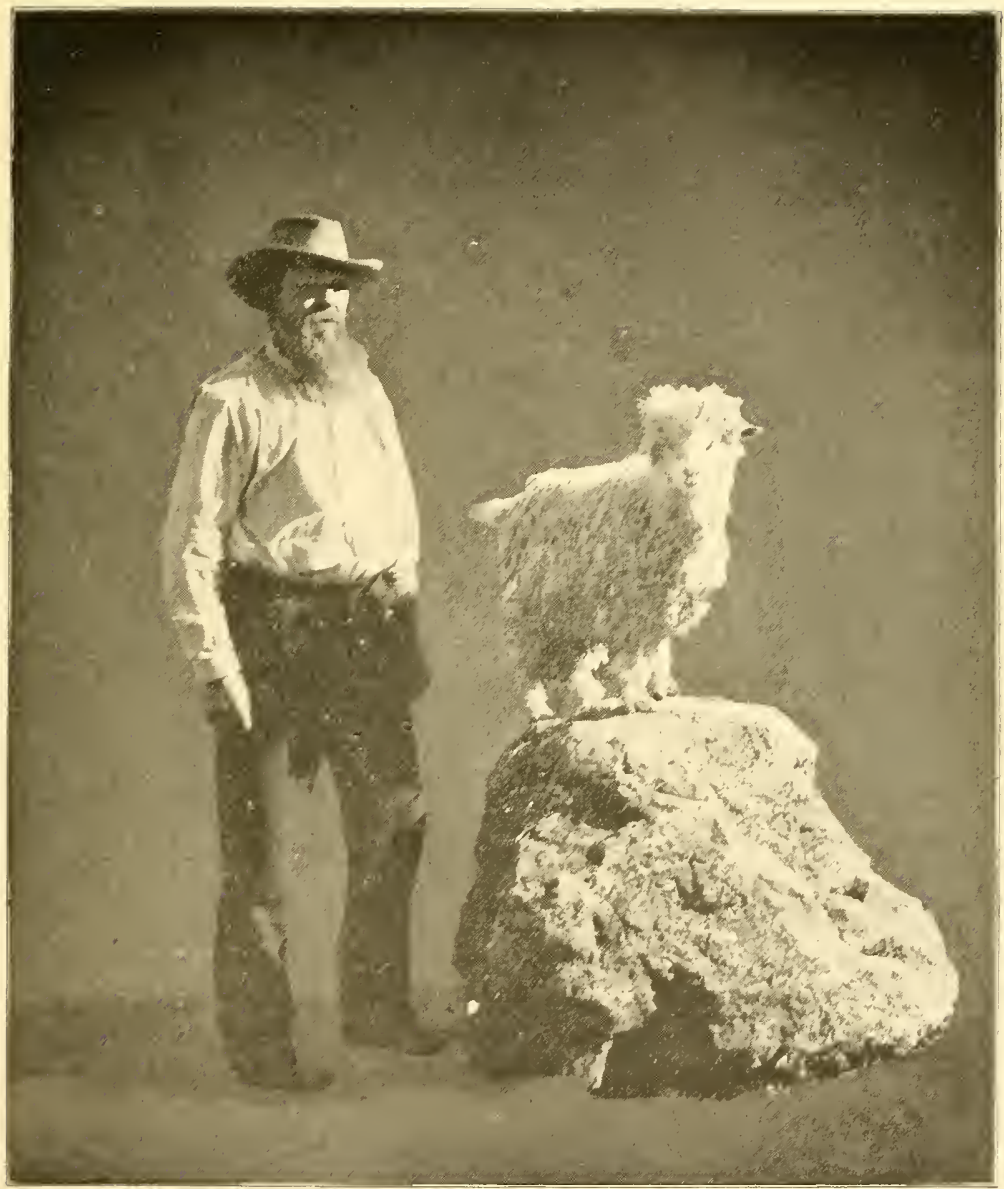

JOHIJ S. HARPIS 

mals and say that is a 'Thibet,' and this is a 'Cashmere,' and those you see there are 'Angoras,' 'Bei-Bazar,' and 'Kastamboul.' I am well satisfied now that Butterfield did not know anything at all about them. Upon one of his visits, he brought with him a Mr. Wm. Hall of San Jose, Cal., who purchased all of the goats (140) and about one hundred and fifty head of Buck sheep for $\$ 19,000.00$, which he asked me to continue to care for until I heard from him again.

"I had made up my mind to try and learn something about these goats from headquarters, and as I had an old schoolmate living in India I wrote to ask him what he knew about the 'Cashmere' goat. He wrote me that it was a long way from where he was (Madras) to Cashmere, but he sent me a sample of their wool which was so beautiful, and fine, that I at once determined to have some of the animals direct from their native home.

"In the meantime I had sent a sample of the hair from a buck which Butterfield had valued in the sale at $\$ 500.00$ to Paisley, Scotland, which they reported to me was too coarse for them to use but it was estimated to be worth twenty cents per pound in Bradford, England.

"This convinced me that the goats that I had in charge for Mr. Hall were not the real stuff, and I set my house in order to visit Cashmere where I intended to make a purchase of some, for my own use.

"I notified Mr. Hall that I wanted io see him and he wired me that he would be at San Jose on a certain day. In my letter to him I had enclosed the reply I had received about the goat hair I had sent to Paisely, Scotland, and stated to him I was preparing to go to Cashmere.

"When we met, he remarked that, he had no acquaintance with the Angora goat, and had bought them from Butterfield upon speculation, with the expectation of establishing a large goat ranch in old Mexico upon a grant of one million acres of land which he was then arranging to have legally fixed in the State of Chihuahua. He stated that, if I would go to Cashmere he would be glad to join me in the undertaking, which was then and there agreed upon, and I was to be the general manager of the ranch upon my return. But 'man proposes and God disposes,' for, when I was in the City of Angora a telegram was flashed across the ocean that the Bank of California had failed, and the few commercial men in that city seemed to think that the whole of America had gone under. $\mathrm{Mr}$. Hall was largely interested in the bank, and was also a large owner in Virginia City both in property and mining stock; the bottom went out of 'Comstock' which caused Ralston, the president of the Bank of California to commit suicide; a revolution in Mexico occurred about the same time, which upset our Mexican grant of land, to say nothing of the loss of money spent in getting the bill passed; and to make a long story short the great castle we had built in the air had tumbled all into littie pieces, and when I returned to the United States with twelve head of as fine goats as ever came across the water, into any country, I was 
very glad to settle down on my old rancin in California. The twelve head of goats had cost us $\$ 6500.00$ and Mr. Fiall was partner with me in the business unil 1880 when I bought his interest and have gone it alone ever since that time."

Referring to his trip to India, and into the Hymalaya monntains to reach Cashmere, Mr. Harris mentions it with as much unconcern as one would a journey over our own Rocky mountains into California, little dreaming that his life was in danger every moment of the time he was there. The following letter from the governor's secretary of Punjab, an English official at Lahore, India, which was very kindly given to him by that gentleman, by way of assisting him in his travels, will be interesting:

My Dear Jenkins:

Government of India, Lahore, 9th Sept., 1875.

I give this to a very intelligent man named John S. Harris who came all the way from California to get a dozen Cashmere buck goats to improve his stock in the former country. Considering the man knows nothing of the language $I$ think it shows he is a very sporting character to come so far on such a speculation, and deserves every assistance. The man is game to go into Cashmere to buy the goats himself, but he has only a month left before he must leave the Valley again. I have advised him to go and see you as I have no doubt you will admire the fellow's pluck, and do all you can to help him, or if you send a man up to Jehlum either with him, or alone, you could get from the Maharaja's peoplo, the goats. He has money to pay. It is really a very enterprising thing and you are just the man to appreciate and encourage it so I do not hesitate to ask you to help him. Best regards,

Yours sincerely,

M. MAUGHER.

Mr. Harris, very fortunately, made the journey without trouble, and then decided to go into Asia Minor and look at the goats in that country before purchasing any. Passing through the Suez canal, at Port Said, he took passage on a vessel that was manned entirely by Russians, and there was only one passenger, besides himself, who seemed to be an educated person. No one on board was able to speak English until they reached Tripoli, when a young lad of fifteen got on, 
who proved to be a Greek, and had attended an American mission school at Smyrna and had been on a visit to his parents, and was on his return to school.

"This boy," Mr. Harris writes, "was kind enough to act as my interpreter, and I was pleased to learn that my fellow-passenger was a scholar of great learning, and was a native of the interior of Asia Minor. The boy told me he was a professor of a language that was now nearly dead. belonging to tribes that formerly inhabited the interior of Asia Minor. an! he had been for the past ycar at Cyprus studying ancient Greek. The people of the Isle of Cyprus had originally been driven from Asia Minor by the Mohammedans. He said he was well posted on the Angora goat and if the weather was good the next day, he would get out a book on the ancient history of Asia Minor and it had in it some beautiful steei engravings of the original Angora goat. The young lad read the book and interpreted to me, the Turkish gentleman sitting beside us and explaining:

"The book stated that about Alexander the Great's time, before Mohammed, and his Arab followers conquered Asia Minor, there lived a tribe of people in those mountains that kept beautiful mohair goats, and made from their fleeces fine fabrics and disposed of them to the nobility of the neighboring countries. The engravings showed the family in their rude dwelling fondling and playing with their goats, and the book stated that it was custoniary to bathe the animals in the wine of Cyprus, and comb their hair with ivory combs dipped in olive oil.

"In my travels through Asia Minor I saw evidences of large cities, that had existed at some period, or other, but were now totally ruined, being in a desert, waste place, where there was no sign of vegetation or life of any kind, yet the ruins of the city was proof that this great plateau country was one time largely populated.

"It has often occurred to me, since I left Angora that, there was a time when a beautiful, perfect mohair goat existed in that country very different from any that I saw there or that has been imported into this country. The engraving I saw in the book just referred to showed no long pendant ears; but small ones and the animal seemed to be small, and very intelligent. If it would be of any benefit to trace the history of this beautiful animal I feel quite sure that much information can be had in Greek history."

Mr. Harris has devoted great care in the breeding of his goats, and has never used any bucks but those of his own raising, and by careful selection has greatly improved the general appearance of them, besides adding largely to their mohair-producing qualities. His original goats sheared 9 pounds for bucks and 4 pounds for does; and he has raised one buck 
that sheared as high as $18 \mathrm{~s} / 2$ pounds and does as high as 9 pounds. The tuft on the forehead is pure mohair, six to seven inches long, and as fine as any portion of the fleece, which is a strong evidence of the great strength of blood they possess.

For a number of years he did not offer any bucks for sale, making wethers out of them, and deriving his profit from mohair alone. but he has recently divided his flock into three parts, placing one in Texas, in partnership with Mr. Geo. W. Baylor, at Montell, Uvalde County, ad another at Salem, Oregon, in connection with Mr. J. B. Early, keeping the remaining third at his home in Oakley, Idaho, for the purpose of supplying other breeders with males, for which he receives a great many orders; and, it was for the purpose of supplying his customers at a distance with bucks that he determined on dividing up his flock.

Although Mr. Harris is on the shady side of sixty, he cannot be called an old man, for he is as full of vigor, and enterprise, as a man of forty; and, if he thought he could find any better stock of goats than he already has, he would not hesitate to make another journey to the remotest corner of the earth to get them.

He has been blessed with three children, two girls and a boy, who take the same pride in his fine flock of goats as he does himself.

There are probably not over one thousand head of Angora goats in Idaho, the majority of which belong to Mr. Harris.

UTAH got her start in $18 \% 2$ or $18 \% 3$ through Brigham Young, President of the Mormon Church. He purchased two pure-blooded animals from Mr. Wm. M. Landrum, since when other stock has been imported and it is estimated they now have 3000 to 4000 head.

WYOMING has paid but little attention to the industry, and has only about 3000 goats.

WASHINGTON has only a limited number, perliaps 2,500 They were first started there in 1881. 
MONTANA has but few breeders. They were first introduced about 1881, by Mr. '1. C. Miles of Silver Bow. Mr. H. A. Bramnin of Marysville, has a small flock and speaks very encouragingly of the climate, etc. It is estimated they have one thousand Angoras now.

MINNESOTA has only a few. Mr. C. D. Tuthill of Tuthill, Anoka County, was perhaps the first to become interested in them in 1894 and his experience is assuring that Minnesota is well adapted to their propagation. It is estimated there are about 500 head in the State at this time.

NORTH CAROLINA. Mr. T. K. Bruner, Secretary Board of Agriculture, writes that:

"The Angora was introduced into North Carolina about twenty years ago by Mr. Jno. A. Boyden of Salisbury, N. C., but very little attention was paid to them and they strayed off into the mountains and were shot by mountaineers as wild game. Mr. Lafayette Holt of Burlington, N. C., is interested in a small flock, which he started in 1893."

One hundred head will probably cover the number of goats in North Carolina at present.

NEBRASKA has no Angora goats, but a correspondent from Gering, in that State, who seems to be very much interested in the industry, writes:

"We have the best goat country in Northwestern Nebraska that can be found anywhere."

ARIZONA received her first goats in 1882 through Col. Wm. Hardy, of Phoenix, and, it is estimated, there are upwards of ten thousand in the Territory at the present time

NOR'TH DAKO'TA. Mr. O. O. Johnson, Dep. Com., Agr. writes: "There are no Angora goats in North Dakota."

SOU'TH DAKO'TA. Dr. F. A. Spofford, of Flandreat, writes :

"From my connection as Regent of Education with the State Agricultural College, I must say that, so far as I can ascertain no one has engaged in raising goats ir! this State. A year ago we corresponded with different parties with a view to their introduction upon the College farm, but up to this time nothing has been done. I am personally very much interested in this question." 
COLORADO has taken but little interest in the Angora ip to this time, and has perhaps six thousand head of goats.

KANSAS has just commenced breeding the Angora goat, and, judging from the interest that is being manifested by her people she will play a very prominent part in the industry very somn. Mr. R. C. Johnson of Lawrence, writes me under date o؟ 15th February, 1899:

"I have handled 3500 head of Angora goats, since September and expect to handle that many more before 1 st of June of which I have 2000 now on the way from Texas. I had no idea of the demand for goats when I entered the business, and it is on the increase. I purchased the "Gunzer' flock of goats for my own breeding. They are said to be one of the finest flocks in the State of 'lexas."*

It is estimated that Kansas has at least 5000 goats at the present time.

OKLAHOMA recieved her first Angoras in 1890, and has pernaps two thousard head.

ILLINOIS has very few Angoras, and has only recently taken any notice of the animal. In reply to a letter addressed to the Secretary of the Illinois Statc Board of Agtl. in August, Mr. W. C. Garrard writes:

"I don't think they are raised here at all."

But Mr. C. S. Horn of Chicago, informs me that he

"Imported a car load in the early part of 1899 for the purpose of cleaning some brush land, he had purchased near Quiacy, and that he has been remarkably well pleased with his investment."

I suppose three hundred head will cover the number owned in Illinois today: but, to judge from the vast amount of brushy lands that are in the State I am quite sure many others will follow in the footsteps of Mr. Horn.

MICHIGAN. Mr. C. D. Smith, Director of Michigan Experiment Station, writes:

*The "Gunzer" flock of goats was started from "Di rine" stock, and $\therefore$ re said to be a very superior lot of Angoras. 
"I am now looking up the question of Angora goats for some of our poorer lands in Crawford and adjacent counties. I know of no extensive Ereeders of goats in this State."

One hundred head will probably cover all the Angoras now leeld in Michigan.

INDIANA. According to a "Report of the Indiana State Board of Agriculture," published in 1866, an effort was made to encourage the raising of the Angora goat in Indiana and the "Committee on Awards" strongly recommended the raising of this class of animal because they were found to be very profitable. See Agtl. Rept. for $186 \%$, p. 353.

Mr. Charles F. Kennedy, the present Secretary of the Indiana State Board of Agriculture, writes under date of 9th August, 189?, that

"There are very few Angora goats in the State of Indiana."

Dr. P. C. Plaster of Indianapolis, writes me that interest in the animal is being revived, and it is not inlikely that considerable numbers will soon be introduced into the State.

MAINE. A report was circulated some years ago by an Eastern newspaper that a strong syndicate had been formed to raise the Angora goat upon a mammoth scale, and that they contemplated starting with one hundred thousand goats.

In reply to an inquiry about the matter, Mr. B. Walker McKeen, Secretary of the Agtl. Dept. of the State, says:

"Whatever you may have seen in print in relation to the matter originated in the fertile brain of a newspaper reporter and has no foundation whatever in fact. We have no Angora goats in our State."

NEW HAMPSHIRE. Mr. N. J. Bachelder, Secretary of Board of Agriculture, writes:

"We know nothing about Angora goats."

VERMONT. Mr. C. J. Bell, Master of Termont State Grange, writes :

"I do not know of any Angora goats in the State." 
CONNECTICUT received some Angoras soon after they were first introduced into the United States, as did Massachusetts; but there was never any very general interest taken in the industry, and only a very few farmers have kept them.

Mr. James A. Bill of Bill Hill P. O., writes me that, he

"Has been breeding a few for thirty years, and has found them the most profitable part of his farm."

It is estimated Connecticut has three hundred Angoras.

ARKANSAS. Has no Angora goats, but has some common stock.

ALABAMA. Has no Angora goats, but has some of the common stock.

LOUISIANA. Has some common and probably three hundred head of Angoras.

MISSISSIPPI. Has no Angora goats, and a few thonsand common.

The last named States have all got more or less of the common short-haired goat and there is no doubt but that the Angora can be made very profitable in many sections of these States except where the land is low and swampy.

IOWA did not take any particular notice of the Angora goat until 1893, when Dr. J. R. Standley of Platteville, in Taylor County, imported between three and four hundred for the purpose of clearing some hazel-brush land, and his success was so remakable that it has resulted in making Iowa the third largest Angira State in the Union. It is cstimat d there are at least forty thousand head of Angora goats in this State at the present time, which have been shipped principally from Texas; and, to judge from the great number of inquiries that are being made by farmers who think of patterning after Dr. Standley's very practical way of clearing land, it is saf a to predict that, Iowa will soon outstrip all other States, in point of numbers. The amount of good that has resulted, and will result hereafter, from this gentleman's enterprise, is immeasurable. It has not only been of immense benefit to the owners of land in his own State, but 
has extended into other States as well, and has injected new life into the industry in all of the States that have been raising Angoras for mohair. There is not a single State that has not already felt the influence of his work, and the demand that has been created for goats, to be used in clearing brushy lands alone, will call for more animals than can possibly be furnished from the present supply, which will result in the building up of a very large industry in all of our Western States and Territories, where suitable lands can be controlled at a reasonable expense.

Dr. Standley was born in Hendrix County, Indiana, 22d December, 1831. His parents moved to Putnam County, in the same State, when he was an infant, and in 18 t5 they moved to Pike County, Illinois, where they remained until the spring of 1850, and then moved to Davis County, Iowa, where the Doctor reached his majority. He was partly educated in Indiana, Illinois and Iowa, entering the Iowa State University at Keokuk, from which institution he graduated as a Doctor of Nedicine in 1855, and he secured a second diploma, as a physician, in 1859, from the Kentucky School of Medicine, at Louisville. On the 4th July, 1854, he was married to Miss Racheal Hornback of Pittsfield, Illinois, with whon he settled on a large tract of land he had acquired in Jefferson, T. P., Taylor County, where he has resided ever since.

He practiced his profession, more or less, but laving a great fondness for agriculture devoted much of his time to farming and stock raising, which he always conducted upon scientific lines, and pricled himself upon having the most improved strains of cattle, sheep and hogs, that could be purchased.

With his characteristic enterprise he established a store, to supply himself, and neighbors, with merchandise, which had to be hauled, by wagon, from the Missouri river at St. Joseph, Mo., a distance of seventy-three miles. He set aside a certain part of land for school and religious purposes which has resulted in the building up of the thriving little village of Platteville, sitnated about midway between Blockton, on the "Chicago \& Great Western R. R.," and, Bedford, on the "Chicago, Burlington \& Quincy," which is now supplied with a daily mail and telephone service. 
About six hundred acres of his farm had been left in tinber, for pasture purposes, but the hazel-brush soon became very thick, and interfered greatly with the growth of grass. The common method for getting rid of this nuisance was, to cut the brusl down, and run sheep, and cattle, on it, but the Doctor only succeeded in clearing eighty acres of it in fifteen years, and for a man of his progressive ideas this was altogether too slow a way. The cost of grubbing up the roots would be expensive and for a time he was undecided what course to follow. He had always heard that the goat was very fond of brush, and decided to give this animal a trial before resorting to the more expensive method of grubbing it out. He visited Texas and purchased about three hundred and fifty head of graded Angoras in 1893, and the shipment created considerable comment on the part of all who saw them. Many of his neighbors thought it was a piece of folly, but in a short time they realized that his judgment was good, and by fall, the portion of the land that had been used to hold the goats, looked very much like a prairie fire had passed over it; and in less than three years, this lot of goats, with their increase, had destroyed every hazel-brush on his farm, and the blue-grass had taken a stand far superior to any in the vicinity which is doubtless explained by the rich fertilizing quality of the droppings from the goat.

Dr. Standley does not believe in "keeping his light under a basket," he therefore, proclaimed the great success he had achieved through the press, so that his fellow-farmers might profit by his experience; and, in 189\%, he imported two thousand head more, which he sold out in small lots at auction, and in less than twelve months after, the demand for Angora goats was almost universal among Iowa farmers. The Doctor was convinced that this demand would continue, so he concluded to engage in raising the animal for profit, and in $189 \%$, succeeded in purchasing the entire flock of pure bred Angoras from the estate of the late Col. Richard Peters of Atlanta, Georgia, who had been a conspicuous breeder of thoroughbreds from a very early period. He has since shipped breeding bucks into the Dominion of Canada, and to many of the States as well and, at the present time has a little over one hundred of the "Peters" "goats on 


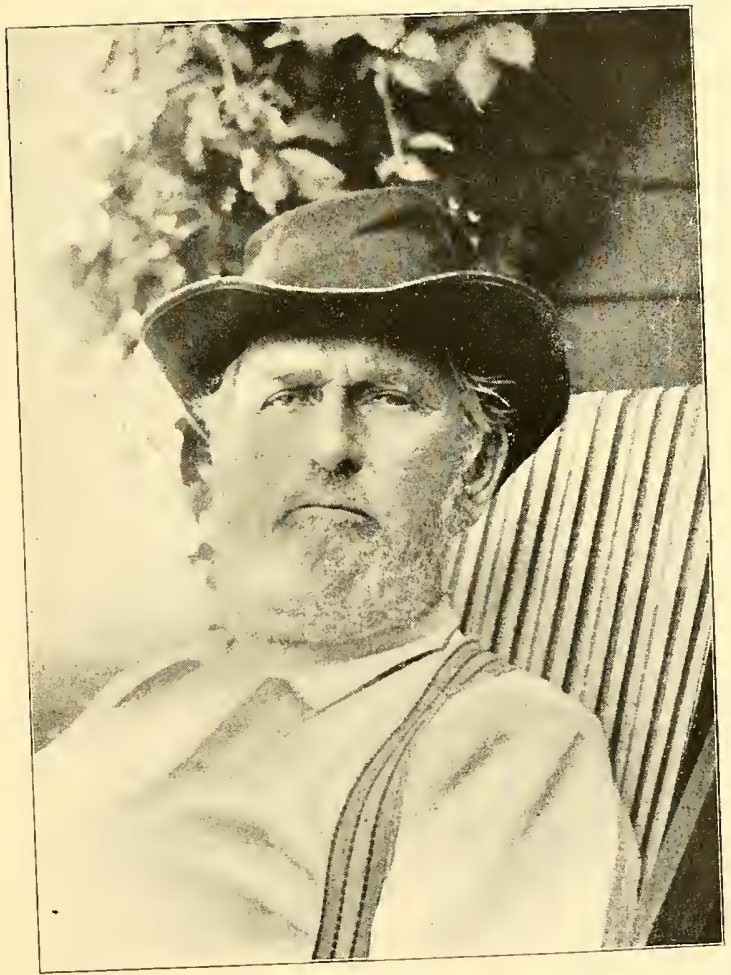

DR. J. R. STANDLEY.

L. of C. 

hand, which he takes great pride in breeding, and is confident be will be able to improve their high standard, in the climate of Iowa, over what they had attained in the warmer climate of Georgia. The following is a copy of the opinion of an expert in Bradford, England, who examined some of Dr. Standley's clip of 1898 :

Calverley, Ni. Leeds,

August 5th, 1899.

Mr. J. R. Standley, Platteville, Iowa.

"Cerificate of Merit."

I beg to acknowledge receipt of the sample of Mohair grown by yout and sent through Messrs. Wm. R. Payne \& Co. of New York.

Permit me to say that the sample of mohair is first-class in every respect. I showed it to several of our largest users, and was asked if I had any for sale, all being agreed, it was a very useful style of hair and well suited to the present requirements of the trade of Bradford. It was a very good quality, capital length, good lustre, very free of kemp, and on a par with average Turkey.

Yours faithfully,

S B. HOLLINGS.

Wool Expert.

There is no doubt that Dr. Standley's long experience in handling live stock will greatly assist him in his new undertaking, and the Angora goat breeders of the United States have good reason to congratulate themselves in having so practical a member in the industry.

Dr. Standley had the misfortune to lose his wife in 1898 , who had been his constant companion for nearly half a century. His two children, Mrs. Asa Terrel, and Dr. Joe Standley, Jr., have farms close to their father's; and between the three families, they occupy in the neighborhood of five thousand acres of as fine blue grass land as can be found in the State of Iowa.

Among others who have become interested in Angoras may be mentioned Dr. Bevington of Wintersett, the owner of about six thousand acres of fine land, some of which was unproductive until he invested in goats. This gentleman first bought a few; and, when he realized their great value, he imported about one thousand head from Texas.

Mr. Benj. F. E:bert of Des Moines, is another prominent convert. He had heard of the wonderful work of the animal, 
and decided to make a purchase of a few hundred at one of Dr. Standley's auction sales; and, afterwards, invested in eight hundred well improved goats, which he rums upon his farm, and is now a strong advocate of the Angora.

Mr. J. C. Morton, of Indianola, imported a carload fron Texas in 1898, and has not only accomplished the work of clearing his farm of brush but is breeding them for profit as well.

Mr. S. S. McKibbin of Earlham, was another early convert. He had heard of them through Dr. Standley's work, and made a purchase of some in 189\%. He engaged in dealing in the animal and has disposed of upwards of five thousand head, if not more, within the past two years. Mr. McKibbin noticed a "hornless" male kid among some of the shipments he received, and decided to keep him, and sec if he could not develop a "hornless" breed, which has been very satisfactory and I intend to refer to the matter more particularly 'ater on, as I deem it of great importance to the industry.

Capt. J. Murray Hoag, of Maquoketa, is another who saw the opportunity of dealing in Angoras and has been quite an active agent in distributing them for the past year, sending come as far East as Massachusetts, and he feels very much encouraged. This gentleman has engaged in breeding, as well. and it is reported he has recently taken steps to import some stock from South Africa.

Many others have purchased Angoras upon a large scale, but the bulk of the holdings, in Iowa, run from twenty-five up to one and two hundred head. The demand has been so steady for the past few years, it is now very difficult to find any improved goats for sale, in Texas, and buyers are beginning to look to California and other States for a supply. I am quite sure it will soon become necessary to buy the short-haired "Mexican" goat, and grade them up as the early breeders had to do. 


\section{CHAPTER VIII.}

CENSUS OF ANGORA GOATS IN THE UNITED STATES.

The number of Angora goats in the United States is entirely problematical. There has never been any census taken of them by the U. S. authorities and it is impossible to arrive at any absolutely correct number, but we can come to a reasonably fair approximation through the agency of the amount of mohair that is marketed, which is the basis of the following estimate, and I feel under obligations to Messrs. Wm. R. Payne \& Co. of New York, for the information.

In sending me this estimate Mr. Payne writes:

"We have yours of the 10th inst. and regarding your query as to the number of Angoras in the country, you doubtless know that there is no statistical data at all to base on. The census returns give goats of all kinds in, together, with sheep, and the proposition is, therefore purely hypothetical, and about as near guess work as anything can be. The only way we can arrive at a remote, and very unreliable, approximation is to get as near as possible the mohair grown in each State, so far as can be ascertained, and average the flecces to represent the probable number of goats represented. This is next to an impossible matter and the whole estimate is crude and uncertain. We would not want to be committed to the figures or in any sense be responsible for their correctness, and they are subject to criticism thereiore as we give them."

Through the medium of the question blanks, that I distributed among the breeders, which I have summarized in Chapter XXIV, I am able to approximate the weight of our shearing per capita in each State, and in this way I reach the following estimate of the number of Angoras in the different States at this time, or say, on 1st January, 1900. 


\begin{tabular}{|c|c|c|c|c|}
\hline STATE & CLASSIFICATION OF FLEECE & $\begin{array}{l}\text { PRODUCT } \\
\text { OF } \\
\text { MOHAIR } \\
\text { IN } \\
\text { POUNDS }\end{array}$ & 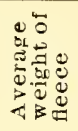 & 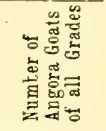 \\
\hline Texas. & 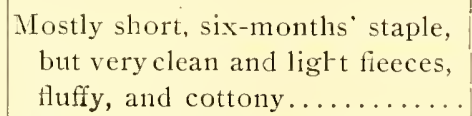 & 250,000 & $21 / 2$ & 100,000 \\
\hline $\begin{array}{l}\text { Oregon } \ldots . . . \\
\text { California } \ldots\end{array}$ & $\begin{array}{l}\text { Mostly bright, and good condition } \\
\text { Heavier in condition, earthy and }\end{array}$ & 225 & 0 & 75,000 \\
\hline & Wost & & & 40,000 \\
\hline New Mexico... & $\begin{array}{l}\text { Mixed grades, and condition } \\
\text { (dusty) } \ldots \ldots \ldots \ldots \ldots \ldots \ldots\end{array}$ & 10 & 2 & 40,000 \\
\hline Arizona ..... & $\begin{array}{c}\text { Heavy average carding, very } \\
\text { earthy } \ldots \ldots \ldots \ldots \ldots \ldots \ldots\end{array}$ & 20,000 & 2 & 10,000 \\
\hline Colorado $\ldots$. & Ordinary carding, dusty ....... & 15,000 & $21 / 2$ & 6,000 \\
\hline Nevada ...... & $\begin{array}{c}\text { Mostly averige carding, some } \\
\text { earthy } \ldots \ldots \ldots \ldots \ldots \ldots \ldots \ldots\end{array}$ & & $21 / 2$ & 5,000 \\
\hline Cansas & Heavy and earthy ............. & 12,500 & $21 / 2$ & 5,000 \\
\hline$\ldots \ldots$ & alkiline and frowsy ..... & 0 & $21 / 2$ & 3,500 \\
\hline yoming $\ldots$ & Average carding $\ldots \ldots \ldots \ldots \ldots$ & 7,500 & $21 / 2$ & 3,000 \\
\hline Washington .. & Poor carding, hard fibrerl, low.. & 6.000 & $21 / 2$ & 2,500 \\
\hline Oklahoma ... & Fair carding $\ldots \ldots \ldots \ldots \ldots \ldots$ & 5,000 & $21 / 2$ & 2,000 \\
\hline Missouri ..... & $\ldots \ldots \ldots \ldots \ldots \ldots \ldots \ldots \ldots$ & 3,000 & 2 & 1,500 \\
\hline$\ldots \ldots$ & Mostly bright, and good condition & 4, & 4 & 1,000 \\
\hline Montana... & Good carding $\ldots \ldots \ldots \ldots \ldots$ & 3,000 & 3 & 1,000 \\
\hline Massachusetts & $\ldots \ldots \ldots \ldots \ldots \ldots \ldots \ldots \ldots \ldots$ & 2,500 & $21 / 2$ & 1,000 \\
\hline Georgia ...... & . $\ldots \ldots \ldots \ldots \ldots \ldots \ldots \ldots \ldots \ldots$ & 750 & $21 / 2$ & 306 \\
\hline Virginia $\ldots .$. & 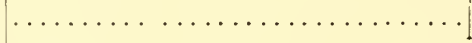 & 600 & 2 & 300 \\
\hline Ohio $\ldots . .$. . & $\ldots \ldots \ldots \ldots$ & 600 & s & 300 \\
\hline Pennsylvania . & .. & 600 & 2 & 300 \\
\hline Connecticut .. & . & 900 & $\vdots$ & 300 \\
\hline$\cdots \cdots$ & & 750 & $21 / 2$ & 300 \\
\hline ssee .... & $\cdots$ & 400 & 2 & 200 \\
\hline & $\cdots$ & 400 & 2 & 200 \\
\hline $\mathrm{Min}$ & .. & 50 & $21 / 2$ & 200 \\
\hline Inc & . & 250 & $21 / 2$ & 100 \\
\hline & . & 250 & $21 / 2$ & 100 \\
\hline New York. & & 250 & $21 / 2$ & 100 \\
\hline N. Carolina... & & 200 & 2 & 100 \\
\hline TOT & & 876,450 & & 329,300 \\
\hline
\end{tabular}




\section{Mr. Payne adds :}

"Of the above 876,450 which may be called Mohair, perhaps about one-half will run to a Combing staple of six inches and above. About twenty per cent. Medium staple five to six inches, and about thirty per cent. short kid Cording and Blanket hair.

"There are, probably, of cross bred goats, yielding a very coarse, kempy, hairy fleece, only suitable for low carpet yarn, in addition to the above (which may be called Angora) some 40,000 pounds to 50,000 pounds, scattered throughout the Southwest and Territories."

Mr. H. M. Williamson, editor of the "Oregon Agriculturist, and Rural Northwest," of Portland, Ore., says :

"I have not enough facts at my command to justify a close estimate of the anount of mohair produced in the United States in 1899 , but believe the figures to be a little larger than the estimate of Mr. Wm. R. Payne. I do not think the amount was less than one million pounds. Mr. Payne certainly underestimated materially the amount produced in Arizona and New Mexico.

"From the best information available, the mohair clip of Oregon last year was about 200,000 pounds. The four buyers who handle nearly all the mohair grown in the State claim to have bought in the aggregate nearly 260,000 pounds. One of these dealers claims to have bought more than I think he got and most of the mohair grown in Idaho and Washington, and part of that produced in Northern California, was included in these figures. On the other hand, some Oregon mohair was consigned direct to the East, by growers. For the present year, I estimate the clip of the State at 240,000 pounds."

It will be seen that with few exceptions every State and Territory in the Union has had the Angora goat at one time or other, and there has never been a failure in raising them. The more Northern States have an advantage over the Southern in a greater weight of fleece, which is doubtless explained by the action of the colder climate. If the industry were to depend altogether upon the demand for mohair it is not likely the increase would be very rapid; but, with the demand for goats to be used as brush exterminators, there is hardly any way of estimating the number the United States will probably have within the next decade. It is very reasonable to believe we will have to export a surplus of mohair sooner or later for we can hardly expect our manufacturing industry to keep pace with our inmease in goats when we take the brush feature into consideration. 
The South Africa breeders are evidently afraicl of this result from the fact that they haye recently introduced a measure in the Colonial Parliament placing a duty of $\$ 500$ on all Angora goats that are exported from that country, which however is not likely to become effective, as the adjoining colonies will have to co-operate with Cape Colony to carry out their purpose, which undoubtedly is, to prevent the American breeders from purchasing any of their goats. It is gratifying to know that we already have quite enough of pure blooded stock to be entirely independent of this selfish country, provided proper care is used in breeding, which is more than likely to be followed by those who are fortunate enough to own a stud flock.

But, as above stated, it is not at all likely that the law will ever become operative and we may expect quite a considerable trade with the breeders of South Africa, who have pure stock, which will assist us greatly in developing our own industry and be a source of profit to breeders in that country.

In justice to the broad minded gentlemen who were opposed to the placing of an export duty on goats, I take pleasure in copying the following extract from the "Midland News and Karoo Farmer." of Craddock, Cape Colony: (Taken from the "Oregon Agriculturist and Rural Northwest.")

\section{SOUTH AFRICAN OPINIONS ON THE EXPORT TAX.}

"The bill to prevent the export of Angoras has passed the Legislative Council, but as the export duty will not come into force until Natal and Mozambique have passed similar laws. it will be inoperative for some time to come. In the Upper House an amendment was introduced by Mr. Maasdorp, and carried, stipulating that a similar restriction be placed on exportation from German West Africa, before the act takes effect in the Colony. When all the maritime states have agreed, no export will be allowed to the Inland Republics and Rhodesia, unless they agree to sinilar restrictions. It will thus be seen some time must elaspe before exportations can be checked, and meanwhile a more liberal policy will probably find favor amongst our farmers. The. Farmers' Association, that has far away the greatest claim to be heard on this subject, the Zwart Ruggens Association. has pronounced against this bill; such well known farmers as MIr. C. Lee in the Lower House and Mr. G. H. Maasclorp in the Council spoke strongly against the measure, but the "dog in the 
manger" policy is the popular one in both houses today. We are convinced that the more our enterprising stock breeders (the man who have done more practical co-operative work in developing their industry than has been done in any other branch of farming) are encouraged to continue the improvement of their stud flocks the higher will the standard of Cape mohair be raised. At the last Angora ram sale in GraffReinet, there was no sale for a large proportion of the animals. offered; this was of course partly in consequence of the drought, but the fact remains that unless a fresh outlet is found for our best bred rams, some breeders will go out of the business; competition will be lessened, and a check given to that continued improvement that has been such an encouraging feature during late-years. The average quality of our staple will only rise as the average quality of stud flocks rise. The standard can only be raised by widening our market for rams. We repeat our belief that whatever rams go abroad, the best will be retained in the Colony, and from personal knowledge of our stud. breeders have every confidence that they will hold their own against Americans, Australians and all comers."

The "Oregon Agriculturist" makes the following comment on the above:

"From reports of the debates in the Legislative Council and Assembly, published by the same paper, it appears that the leading opponent of the bill in the Legislative Council was Hon. Mr. Maasdorp, a group of whose goats are illustrated in Cronwright Schreiner's 'Angora Goat.' He said it was not a fair principle to restrict the trade. If trade in mohair is extended and taken up by other countries, mohair, instead of being as now an article of luxury and fashion, will become an article of clothing and we will have a stable price. He also pointed out the fact that the only practical effect of the bill, if it became operative, will be to prevent Cape Angora breeders who have spent a large sum of money on their stock from getting a good price for a ram from an occasional American buyer. The bill would, however, be inoperative because it depended on the governments of Natal and the Province of Mozambique adopting similar legislation. Even in the remote contingency of their doing so there would remain the chance of goats working out through the German West Coast Territory.

"Hon. Mr. Van den Heever, who supported the bill, charged Mr. Maasdorp with self interest in opposing the bill, because he was a breeder and if the bill did not pass might sell goats at high prices to Americans. If the bill did not pass the result would be that within a year or two 30,000 Angora goats would be exported to America. No words were strong enough to describe the action of his honorable friend who was animated only by self-interest and did not care what became of the Colony or even of the Maasdorp family in the near future provided he made his ten or twenty or fifty thousand pounds. 
In the Legislative Assembly the bill was opposed by Mr. C. Lee, (who is undoubtedly the Mr. C. G. Lee who is secretary of the Angora Goat Breeders' Association of Cape Colony), and by Mr. Hockly, who represents Somerset East, the district which contains more Angora goats and produces more Mohair than any other district in Cape Colony, and Sir P. Faure. The leading advocates of the bill were Messrs. Van Heerden' and Wienaud.

The great interest that has been manifested for the Angora goat in the past few years has encouraged our very efficient Secretary of Agriculture, the Hon. James Wilson, to incorporate in his report for 1898 a bulletin which was prepared by Mir. Almont Barnes of the Division of Statistics, with great care, and covers a vast amount of valuable information, touching, "Value of Goat Skins, Imported," "Number of Domestic Goats in the United States," "Goat Products," "Available Pasturage," "Supply of Labor," and many other matters of importance, which can be seen by reference to the Agricultural Report for 1898 . 


\section{CHAPTER IX.}

WHY THE INDUSTRY HAS MADE SUCH SLOW PROGRESS IN THE UNITED STATES, AND WHAT WE CAN EXPECT IN THE FUTURE.

Considering the fact that we have imported upwards of three hundred head of Angora goats from Asia Minor during the past fifty years, and that it is possible to grade up the short haired goat to a mohair producing animal with four or five crosses from a pure bred sire, it is quite evident that something must have interfered seriously with the growth of the industry in this country or we would be able to make a much better exhibit than we do.

Our total production of mohair at the present time is less one million pounds, while South Africa had passed the two million pound mark early in $18 \% 9$, and is today producing more than twelve million pounds of this valuable fibre.

What has been the reason for such slow progress on the part of American breeders, when the industry was so quickly developed in South Africa? In 1882 Dr. Hayes, referring more particularly to the efforts of Col. Richard Peters of Georgia, and Col. Robt. W. Scott of Kentucky, says:

"The most valuable result they have accomplished is the preservation, and acclimation, of undoubtedly pure stock, which may serve as a foundation of a more systematic enterprise in this direction than has hithreto been attempted in this country. That these breeders, skilful as they are, have not accomplished more, is due partly to the fact that residing in the South, their enterprise was retarded by the war, but more to the circumstances that perhaps, without abundant capital they have sought to derive their profit rather from selling animals than from increasing the flocks and selling their fleeces. The increase having been sold in scattered pairs, have got mixed up, with the common breed, and have been 
practically lost. Thus the greater part of the enterprise devoted to the Angora goat culture, has been frittered away. The majority of breeders (always excepting such as I have above naned) who have crossed pure animals upon common goats have sold the grade animals, as if they had all the excellences of absolutely pure goats. The purchasers, in their turn, breeding the grade bucks to common goats have been naturally disappointed in the results, and have let the breed run entirely out." See Hayes, p. 65, 66.

I think Dr. Hayes' conclusion is correct with reference to the injury caused by the sale of giade sires for pure bred, but he is certainly wrong in attaching blame to either Col. Peters or Col. Scott, for the slow growth of the industry. These genileman never contemplated raising mohair, as their surroundings did not admit of their holding any large number of goats. Their purpose, evidently was to breed pure blooded stock and sell to others, who were differently situated, and who were in a position to engage in carrying on the goat business upon an extended scale; and, in this, I think they were eminently successful, for a great many flocks of Angoras in the United States can be traced back to either the "Peters" or "Scott" blood.

Both the Texas and California industries can be traced directly to Col. Peters' efforts, which resulted in the importation of all the goats that were brought into this country by others, for it is reasonable to think the importers would not have ensaged in such an undertaking, if they had not believed they would be able to sell their stock to breeders upon arrival. With the single exception of the J. S. Harris importation (which was for his own personal use), every one of the others was on speculation, and they were all sold at very satisfactory prices. 'That the selling of high grades called "full blood" for pure bred stock has had a tendency to retard the growth of the industry, there can be no doubt, but this cannot be the only cause, for there has never been an American industry established yet that has not lad to contend more or less with fraudulent practices, even to the selling of wooden hams and nutmegs. Referring to the industry in Australia, which was started in 1858, only four years after Col. Peters bought the Davis goats. Dr. Hayes quotes some very interesting observations from Sir Samuel 
Wilson, a very eminent breeder of sheep in that colony, who had encouraged the introduction of the Angora goat, and was exceedingly anxious to see the industry fully established.

\section{Dr. Hayes says:}

"The evident preference of this enlirent breeder is for the system of increase from absolutely pure flocks, a preference which I regard as a strong justification of the orig nal views in the text of my essay. Sir Samuel seems to think that, from a National point of view, the time required to create immense flocks of pure animals is of little moment. His calculations of the result which can be attained in four decades will astonish the reader, he says:

"The flock of Angora goats, now (1873) on the Wimmera, is $108 \mathrm{in}$ number, besides a few young k:ds. From calculations carefully made, and which, as well as other figures in this paper, have been verified by Professor Strong of the Melbourne University, this small flock, if carefully managed, and sufficient pasture allowed for it to graze upon, will, at the ordinary rate of increase, reach in thirty years the very large number of 442,368 . This number should be sufficient to displace most, if not all, the common goats in the Colony. In forty years, at the same rate: the pure flocks would increase to over $7,000,000$.

"The pure flock should, if possible, be kept in one district and not scattered about. From this point, as a centre, th : great profit to be obtained from them should enable them to push their way and drive out the common goat. The abcve estimate of increase I arrive at by the simple calculation of doubling the number of the flock every two and one-half years. This was found to be about the rate of increase which sheep were observed to make on their first introduction into Australia. I have reason to believe that the Angora, will, with care, increase in an equal ratio.

The calculation is as follows, showing the estimated number at each period of two and a half years:

Present number of flock......................... 1018

Estimated number in two and one-half years..............

Estimated number in five years...................... 432

Ëstimate 1 number in seren and one-half years.............

Estimated number in ten years .................... $\overline{1,128}$ 
Estimated number in ten years, carried forward ........ 1,728

Estimated number in twelve and ore-half years........... $\frac{2}{3,456}$

Estımated number in fifteen years................. $\overline{6,912}$

Estimated number in seventeer and one-half years......... $\overline{13,824}$

Estimated number in twenty years................ $\overline{27,648}$

Estimated number in twenty-two and one-half years........ $\frac{2}{55,296}$

Estimated number in twenty-five years. . . . . . . . . . 110,592

Estimated number in twenty-seven and one-half years. . . . . $\overline{2 \cdot 21,181}$

Estimated number in thirty years................ $442, \overline{468}$

Estimated number in thirty-two and one-half years years...... $\overline{884,736}$

Estimated number in thirty-five years............

Estimated number in thirty-seven and one-half years. . . . . . . 3,538,944

Estimated number in forty years. . . . . . . . . . . . . $\overline{7,07 \pi, 888}$

"By calculating the rate of increase at 80 per cent., yearly, on the number of does, of any age, to produce kids; and, making the proper allowance for deaths, irom age, and other causes, the result would be still greater. and the above calculation would seem moderate in comparison. As a matter of fact, the flock has actually been doubled in number by natural increase in the first two years, and with sufficient pasture and proper care and management, would doubtless reach the large number of 442,368 in the year 1903, and upwards of $7,000,000$, in the year 1913." See Hayes, pages 52 and 53.

Dr. Hayes then proceeds to show that,

"If the United States had followed the above theory with the 'Chenery' and 'Diehl' importations alone, we would today be enjoying the fruits from a large industry of pure-bred Angora goats, which, he estimated (so early as 1882) would reach 2,792,000 animals producing 11,000,000 pounds of merchantable mohair." (See Hayes, p. 54.) 
I would here remind my reader, that an industry, and more especially an agricultural industry, requires something more than dry theory, and mathematics, to feed upon. The first thing, in my judgment, is a market for the product; and, the next is a complete knowledge on the part of all who engage in it, as to where that market can be found, together, with a perfect understanding of how to produce the article, and how to pre pare it to meet the wants of consumers.

Of all these essentials, our early breeders were in total ignorance, with the exception, perhaps, of a very few of the leading members; and, even at the present time, not one farmer in ten thousand has ever seen mohair; has no idea of what an Angora goat looks like, and has not the remotest idea of how to handle the animal, or how to prepare the fleece it produces for marketable purposes.

The following letter written by Mr. J. R. Rippey, Secretary of Missouri State Board of Agriculture, in reply to an inquiry I made with reference to the industry in this State, is a very strong confirmation of what I have just stated:

"Columbia, Mo., August 15th, 1899.

Mr. Wm. L. Black, Ft. McKavett, Tex.

Dear Sir-I do not now know of a flock of Angora goats in Missouri. Col. John Walker of Fayette. Howard county, some fifteen or twenty years ago, had three or four hundred head, but I think they proved unprofitable and he disposed of them. At that time the wool buyers in this State, knew nothing whatever of the value of the fleece, and offered practically nothing for it. Then again the owners of the goats knew nothing of the necessary care of the fleece, when it should be clipped, or as to the care of the goats for producing the best fleece. If there is a herd in this State, I do not know it.

Respectfully,

J. R. RIPPEY.

The prime reason for the slow growth of our Angora goat industry, in my opinion, is due to the fact that breeders could not make is as profitable as raising other kinds of livestock. If they had started with goats that would pay their way with mohair at the commencement, and had known exactly how to handle the stock, and where they could market their nohair, as above mentioned, conditicns might be different; but, 
it must be remembered, the early breeders nad to begin with conmon goats, and grade them up; and, even many of those, who used nothing but absolutely pure bred sires, found it unprofitable, for the reason that their first and second crosses would not pay to shear, and there being no sale for goat meat in our large markets, were forced to accept ruinously low prices (often as low as fifty cents per head) from local ranchmen, who used them for ranch meat purposes. This had a tendency to discourage others from engaging in the business, and the result has been, that only a few have had the confidence and ability to hold their goats, until they had graded them up to a paying basis, while the many gave up in despair, very early in the struggle, and their goats have been sold out and slanghtered. My personal experience, which is outlined in my "Introductory Remarks," is, I think a very good illustration of this condition. I had accumulated as many as 8000 head of goats of all grades, from the common "Mexican" to very high grades, and was compelled to thin out my goats for two reasons: 1st, my old goats would soon die of old age; and, 2nd, my range was not sufficient to accommodate so many goats, with my other stock. I triec. faithfully to find a market for one thousand fat wethers, and the following letter received from a Chicago packing house will show what poor success I met with, (the name of the writer is omitted for obvious reasons):

Wm. L. Black, Ft. McKavett, Tex.

Chicago, Ill., Sept. 25th, 189?.

Dear Sir-Yours of the 15th inst. offering to sell us 1000 fat wether goats is at hand and we regret to say we c nnot use them. We recognize the fact that grade Angora mutton is fully equal to sheep, and we do not hesitate to slanghter them in a limited way, when we receive them with a flock of sheep, but the prejudice for goat meat is so strong, that we do not feel justified in slaughtering them in such large numbers as you propose to ship.

Very truly yours,

Tieing compelled to do something, I resorted to the scheme of slaughtering them myself for their hides and tallow.

The American farmer is impulsive and will often sacrifice years of labor spent in grading up stock that he finds to be un 
profitable in a moneyed sense. It is the dollar that influences him and not sentiment. During the two periods of depression we have had in our sheep industry in the past 17 years, (1883 to 1886 , and 1890 to 1894 , both caused by adverse tariff legislation) which resulted in a temporary decline in wool, millions of fine shearing sheep were sent to the shambles, and sold for a trifle, because the proceeds from wool did not pay for keeping them. Horses, too have been sacrificed in the same ruinous way, during the past few years, for the same reason, which has resulted in setting back both of these industries very seriously.

That our country is well adapted to the culture of the Angora has been clearly proven, and all who held their goats until they had reached a shearing capacity, of say two pounds per head, have made money, and are now enjoying better results from this branch of their livestock than any other; but, it is not reasonable to suppose that all breeders would have the patience, and financial strength to hold on to stock for a number of years at a loss when they could use their land, and their energies with a different kind of stock that would yield them better results.

Because South Africa has been so remarkably successful is no reason to think they have a country better suited to the Angora goat than the United States is. Conditions in the two countries are very different.

In the United States we have a large home and export demand for fresh meat, and farmers naturally prefer raising such stock as will meet with ready sale.

In South Africa the sale for fresh meat is limited, and farmers are compelled to rely more upon incidental products like wool and mohair, which can be easily transported to market. But, matters in this country, respecting the Angora goat, I am pleased to say have changed very materially within the past few rears, and it is now possible to sell these animals in any quantity, at any of our large meat packing markets as readily as sheep. Besides this an unexpected demand has recently sprung up from Northern and Eastern farmers who want to use the animal as a brush exterminator, which will call for more goats than we can supply in many years to come; and if all 
signs do not fail we shall soon begin to show our South African friends, and others, the way Americans can develop an industry when all their disabilitics have been removed, and they make up their minds to go to work. As for the breeders who sell "full-bloods" for pure breeds, these will soon be found out and will disappcar from the field, as all frauds have had to do in the past.*

*It is perhaps proper for me to say that, I do not share the opinion that, all breeders, who sell graded goats for breeding purposes, are necessarily rascals, or frauds. I do not think it possible to trace the lineage of any goat either in America, South Africa, or Turkey, to an absolutely pure-blooded sire and consequently it is impossible for a breeder to know if his goats are "pure bred," in the strict sense of the term, or not. The Turks have interbred with common goats for many years, and so have South Africa breeders, as well as ourselves. What I should have said, perhaps, is that, all who sell grades, that, they know are grades, having only the appearance of pure-bred goats, without the strength of blood to transmit, and impress their proyeny, as they should, will soon be found out in their rascally practice and disappear from the field. I believe we have many "Angoras" that have been graded up from the common goat that, have greater power to transmit mohair blood, than many goats bred in Turkey, and entitled to the proud title "thoroughbrecl." Blood will tell, and, I think, it has been the experience of all breeders of stock, in the past that when an animal has been bred a sufficient length of time so as to thoroughly fix his type, he can be relied upon to reproduce his kind with absolute certainty, but, I shall say more on this subject, when I get to the "Practical Parts of the Industry." 


\section{CHAP'TER X.}

CONCERNING THE MANUFACTURE OF MOHAIR IN ASIA MINOR, ENGLAND, AND THE UNITED STATES.

IN ASIA MINOR. Although goat hair has been used for clothing by many of the Eastern Nations for a great many centuries, it is, comparatively, a new textile in the manufactures of the present age.

It is referred to as early as 1600 B. C. In Exodus, xxxv, chapter, 23, verse, we read:

"And every man with whom was found blue, and purple, and scarlet and fine linen, and goat's hair brought them."

Again in Exodus, xxxvi chapter, 14th verse:

"And he made curtains of goat's hair for the tent over the tabernacle eleven curtains he made them."

Mention is made in other parts of the Bible, of fine linen and "goat's hair" being spun by the women, which leaves no doubt that the ancients had learned a way of utilizing this fibre at a very early period in the history of the world.

The Turks, in Asia Minor, at one time employed as many as 1200 looms in working up the fleece of the Angora goat, which was called by them "tiftik." It was not allowed to be exported in a raw state, in order to give employment to many of the laboring classes of that country, through whose hands the fibre had to pass in order to prepare it for the loom. As may well be supposed their methods were very primitive, and it is surprising to read of the beautiful fabrics that these ancient people made with their crude machinery. An English traveller, by 
the name of Capt. Conelly, referred to by Mr. Southey in his work on "Colonial Wools," gives a very interesting description of the manner in which this "tiftik" is manipulated. Capt. Conelly says:

"The women of Angora moisten their carded goat's hair with much spittle before they draw it from the distaff, and they assert that the quality of the thread much depends upon this; nay, more, that in the melon scason their yarn is incomparably better, as eating this fruit imparts a mucilagenous quality to the saliva."

The spinning of the thread is performed by men on a loom which is descibed by the Hon. Israel H. Diehl in a report made to the $\mathrm{U}$.S. Department of Agriculture, as follows:

"The fleece is first taken to a running stream, where it is washed by hand and tramped under foot in the water. It is then spread upon the sand to dry and bleach, after which it is assorted according to fineness, length, and purity. It is then hackled on a simple old-fashioned hackie consisting of a few dozen long iron nails driven through a board. After hackling, the fleece is placed in bundles or rolls and spun into yarn, mostly by the women and children. For this purpose a common distaff is used. or a stick from 12 to 18 inches in length, with cross pieces, rendering it about equivalent to a large spool. It is then ready for the loom. This instrument in Angora is of the simplest and rudest construction, and of the same unvarying type, that has been used by countless generations. Asiatic industry is frugal in labor-saving processes; when once machinery is hrought to such a degree of efficiency as to render it barely possible ior an unlimited amount of labor to supplement and supply its deficiencies, no further improvement is made. Nen then subject themselves, their minds and muscles, to a training which makes them almost a part of the machines they operate. Caucasian mind seeks to emancipate itself from all unecessary labor by transferring it to machinery, thus leaving the mental faculties free for intellectual labor. Each of its tasks it devolves successively upon inanimate matter, while it continually ascends to higher results. But this function of intelligence seems to be entirely ignored by Asiatic mind, and Asiatic art.

"The Angora loom, of which engravings are presented, consists of two upright posts, from four to six feet apart. planted in the ground and running up through the floor (if there is one) to the roof of the house. Near the top of these posts a cross bar is rudely fastened, often with ropes, from which the simple weaving apparatus is suspended by pulleys and worked by treadles. These are located beneath the level of the floor, on the edge of which the weaver is seated. The woven eloth, passing 


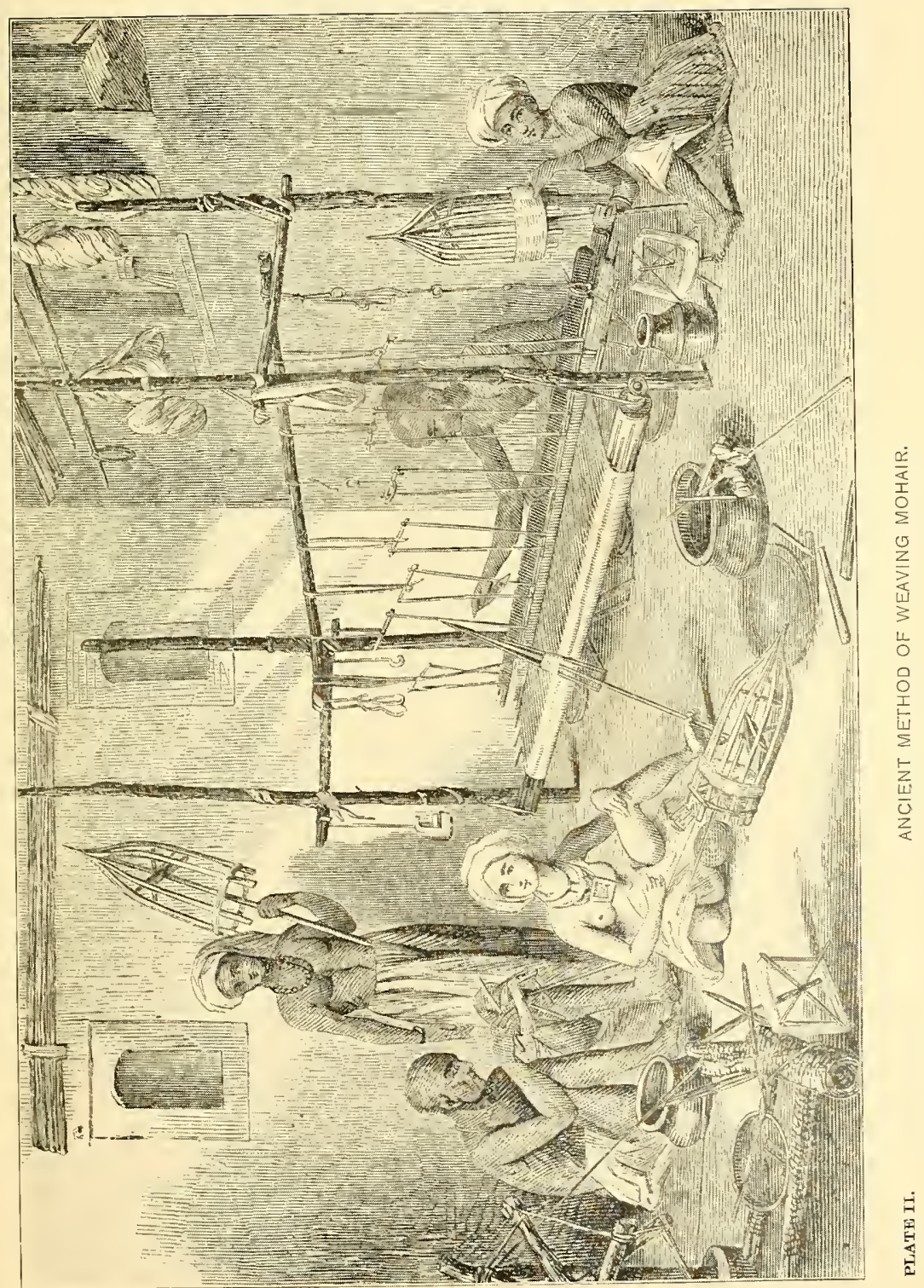



round a roller in front of the weaver, is then drawn by weights over another roller above his head. These looms cost from $\$ 5.00$ to $\$ 25.00$, some of them being ornamented with rude carving.

"The ordinary expense of a loom is given at $\$ 20.00$ per month. A number of these looms are strung along the sides of the house, some houses containing as many as twenty looms." See Agtl. Dept. Report 1867, page 2.29 .

\section{Dr. Hayes says :}

"The natives displayed great skill in making gloves, hosiery, and camlets, for exportation, and summer robes of great beauty, for the Turkish grandees. The town of Angora flourished, and the whole population was busy and happy in the pursuit of their beautiful industry.

"After the Greek Revolution the Turkish government was tempted by British influence to admit free of duty, the products of European machinery and to permit the export of the raw 'tiftik.' This fatal step was the deatin blow of the town of Angora.

"The whole product with the exception of 20,000 pounds only, still worked at home, was exported to England. The looms employed were reduced from 1200, to not more than 50; and the town, although having at its command the raw matcrial for a most important and characteristic manuiacture, offers, in its sad decline, another monument to the desolating influence of that system which would make the raw material of every country tributary to the one great work-shop of the world." See Hayes. page 33.

When we consider the fact that the Turks are now enjoying benefis from a much greater number of goats than they would, probably, have ever had any use for under their primitive way of weaving mohair, it seems to me Dr. Hayes was hardly iustified in making the above statement. My personal opinion is, the entire world has been largely benefited through the enterprise of English capital, and are today permitted to enjoy the privilege of using fabrics made from this valuable textile, which would not be the case if Sir Titus Salt had not invented proper machinery.

IN ENGLAND. Nohair was first shipped to England in a raw state in 18:0. In that year a few bales came to that market but so little was the material appreciated that it only realized 10d per lb. (see Vol. XVI, Encyclopedia Britannica, page 514.) 
It was fifteen or twenty years later, before any decided interest was taken in the fibre, or about 1836, when Mr. (afterwards "Sir") 'Titus Salt, a wool broker and manufacturer in Bradford, purchased a quantity of Alpaca in Liverpool at Sd per lb. and set himself to discover its capabilities (see Vol. I. page 598, Encyclopedia Britannica.) Dr. Hayes quotes from "James' History of the Worsted Manufacturer," the following very interesting account of the matter:

"The first marketable fabric from alpaca wool produced in Europe was made about 1832 by Benjamin Outram, a scientific manufacturer of Greetland, near Halifax, England, who surmounted the obstacles encountered in spinning the slippery fibre and eventually produced an article for ladies' carriage shawls and cloakings which were sold at high prices on account of the novelty of the fabrics. Owing to the cheapness of the wool during the first years of its consumption, about eight pence, it was occasionly employed, instead of 'Lincoln hogs' wool for manufacturing lastings and camlet warps. In 1832 some enterprising merchants in Liverpool directed their agents in Peru to purchase, and ship to England all the parcels of alpaca wool they could meet with, which being sent to the Bradford district was spun and manufactured by several parties there. The pieces chiefly made were figured goods with a worsted warp, and alpaca weft, the figures being raised and lustrous. They did not remain long in vogue. The use of alpaca wool with the worsted warp, the only combination hitherto tried, would doubtless have declined, like that of other mere novelties in the textile manufacture, if a new combination of alpaca wool had not been suggested by the introduction of the cotton warp from France into England in 1834, the most important event of the century in the worsted industry of the world. The credit of combining the cotton warp with an alpaca weft, and of finally overcoming the difficulties of preparing and spinning the alpaca wool, is awarded, by common consent, to Mr. (afterwards Sir) Titus Salt, who in 1839 was the only spinner of alpaca yarn in Bradford. The first successful manufacture was in the production of what was termed 'Alpaca Orlea.xs,' and the first considerable order was in June, 1839, for five hundred and sixty preces. twenty-seven inches wide at forty-two shillings per piece. From this period the manufacture rapidly extended, giving rise to the magnificent establishment of Sir Titus Salt at Saltaire, employing over 3.000 hands in the manufacture of alpaca and mohair goods exclusively, nearly doubling the price of English lustre wools which were employed in making imitacion alpacas, developing in Bradford the most characteristic and important of its industries, and giving, in the black alpaca lustres, and its imitations, with wool from Lincoln sheep, the most valuable fabric which has been created for female wear during the present century." See Hayes pages 153 and 154 . 
The quantity of alpaca imported into England from 1836 to 1840 averaged only 560,800 pounds yearly. (See Encyclopedia Britannica, Vol. I, p. 598.) The character of this fibre being very similar to the fleece of the Angora goat in length, lustre, and fineness, Sir 'Titus naturally looked to Asia Ninor for their supply of mohair, and even with the addition of this product, which in 1836 (the first record of imports into England) reached 680,000 pounds, he did not have a sufficient stipply of raw material to meet the demand for his manufactured fabrics, and it was this that encouraged the culture of the Angora goat in other countries. The supply of alpaca it would seem is limited to Peru. It has been nearly uniform for many years, and is estimated to be about 5,000,000 $\mathrm{lbs}$. per annum, at this time, with very little probability of its ever being increased very largely.

Stimulated by the increased demand for mohair, which advanced very steadily from abont $20 \mathrm{c}$ per $1 \mathrm{~b}$. in 1836 , to $90 \mathrm{c}$ in 1863 , the Turls rapidly increased their number of Mohair goat by crossing on the common ("Kurd") goat of their count"y, and with the successful culture of the animal in South Africa, the supply of raw material increased quite as fast as was necessary, the annual product of both kinds (Alpaca and Mohair) being estimated now at $25,000,000$ lbs.

In 1853, Sir Titus Salt erected in Bradford, England, the largest Mohair mill in the world, which practically gave him the control of the trade, of which he continued to be the head up to the time of his death which took place in 18\%6. This great establishment received its first check in prosperity with the introduction of the fine all-wool French Cashmere goods, which finally caused the firm of Sir Titus Salt, Bart \& Co. to suspend in 1880 (see Bulletin Natl. Ass. Wool Mfr. Dec. 1895, page 320).

A statue of Sir Titus Salt was erected in Bradford, in honor of the man, and as a slight recognition of the great service he had rendered the world, and the direct benefit he had been to his own home, during an active life of more than half a century.

IN THE UNITED STATES. The United States was slow in taking hold of this new textile, and it was not until a 
quarter of a century after it hat heen introdnced into Fugland that any attempt was made by American mantufatmers to use it. In Mr. Thichl's rery interesting paper on "llue Goat." pubslisted in the Igtl. 1)ept. Report of listi3. he says:

"Machinery is now heing erected, and perfected by the I,owedl, latcilic, and oller mills, to work mp this fleces, and mambincture the finest falorics, thos only awating the wools adapted and establishing a marke." see LT. S. Agtl. Report isti?, page ese?.

It womkl secm howeree that these mills did mot aceomplists very much. In listi, muler the ammistration of P'resident.

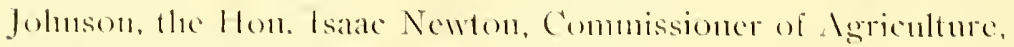
called allention to the matter in his report for that year, as follows :

"Two mounted specimens of the Angoral goat hatre been added to the muscm, together with samples of the wool, and rations fabries made from the same. 'Tle importation and breding of these amimals have attracted much attemion in ertain sections of the comntry; their heees command a high price and the value of their mantaluctures would secm 16) wartant the eneouratging attention of the Depattment." See Report of Agll. Lisiti, page II.

11 had becu represented for a lome time by those inter-

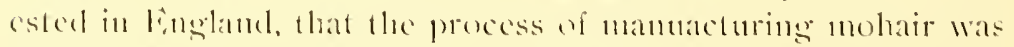
very expensive, and llat its manipulation was kuown only to a very few, but these representations were fombl to be false, and were douhtless circulated to discomrage other commlries from en-

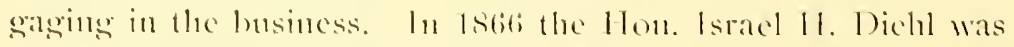

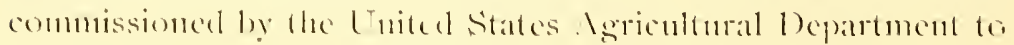
visit litnope for the purpose of investigatims lle matter, and, if possible, to sectre sted infommation and patticulats as would

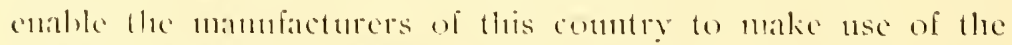
Angorat poat fleces. He saw at the exhibition in l'aris, a great

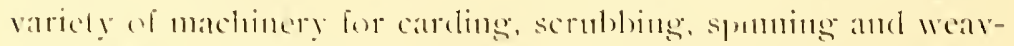
ime the libe which was clamed lo have becm male laregely in Bratered, Fingand, and Rombeanx, France, and in his report to

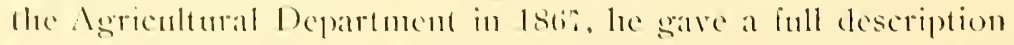
of these machimes logeller with the mames of mambiatmers, cte. 
Commissioner Newton ards the following with reference to Mr. Dichl's work:

"Mr. Diehl visited the Paris Iixposition, where he directed his attention to the fabrics of varions kinds of goat fleece. He was astonished and delighted at the extent, variety, delicacy and exquisite beauty of the specimens contributed by the looms of Asia Minor, India, France, England, Germany, and other mountries represented in this department of the Exposition. These manufactures consister of shawls, camlets, challis, mohairs, poplins, velvets, delaines, hosiery, yarns, gowns, robes, rugs, fur trimmings, tassels, etc. Some of them were made of pure goats' fleece, and others, of the fleece mixed with wool, cottons, silks, and other fibres, imparting to these compounds a lustre, strength, and durability, which no other fibre, except silk, will secure. Nearly every nation represented at the Exposition presented some beautiful manufactures of goats' fleece. India, England, France, and Austria, seemed to excel in the more delicate iabrics, while Turkey exhibited the greatest variety and richness of the raw material." See Agtl. Dept. Report, 1876, p. 2266.

And in conclusion lie says:

"'The manufacture of 'Cashmere,' camels' hair' and other shawls, once so flourishing in Asia, is greatly impaired, and, in many places, entirely discontinued. But few of the once famous Cashmere shawls have been manufactured since the rise of the fatal competition of Lyons, Paris, Paisley, Vienna, and other manufacturing centers in Europe. Caucausian capital and skill, aided by the elaborate contrivances of machinery, can now produce, at much lower prices, fabrics as delicate, and beautiful, as the famous Cashmere shawls, though, doubtless, not so durable. The immediate introduction of this shawl weaving into the United States is perhaps impracticable, though its final success here is but a question of time. The obstacles to be overcome are lack of skilled labor, of machinery, and of active home demand for fabrics of goat fleece.

"None of these, however, are very formidable. Sufficient labor and machinery can be imported to meet present necessities, while the ready intelligence of our workingmen and the profound and subtle genius of our inventors may be relied upon to surpass, very soon, our imported models.

"The increasing taste and luxury fostered by the rapidly accumulating wealth of the American people, and the enormous reduction in the cost of manufacturing this beautiful staple from the fancy prices hitherto commanded by Oriental manufacture, will soon create a permanent home demand. This will give a comfortable support to a large industrial population, and assist in arresting the increasing drain upon our circulating medium, caused by large importations of manufactures of wool, cotton, s:lk, and flax, a matter of no small importance in the present financial condition of the country." See Agtl. Dept. Report 1867, page 230. 
Through the influence of this information quite a number of American manufacturers decided to import machinery for the purpose of manufacturing Mohair, and the use of it has steadily increased ever since, and is constantly being applied in making new fabrics which are always attractive and popular. Referring to the "Application of Products" in 1868, Dr. Hayes says:

"It lias been already stated that mohair is not a substitute for wool, but that it occupies its own place in the textile fabrics. It has the aspect, feel and lustre of silk, without its suppleness. It differs materially from wool in the want of the felting quality, so that the stuffs made of it have the fibres distinctly separated and are always brilliant. They do not retain the dust or spots, and are thus particularly valuable for furniture goods. The fibre is dyed with great facility, and is the only textile fibre which takes equally the dyes destined for all tissues. On account of the stiffness of the fibre it is rarely woven alone; that is, when used for the filling, the warp is usually of cotton, silk or wool, and the reverse. It is not desired for its softness in addition to silkincss, such qualities as are found in Cashmere and Mauchamp wool; but for the elasticity, lustre; and durability of the fibre with sufficient fineness to enable it to be spun. Those who remember the fashions of thirty or forty years ago may call to mind the camlets so extensively used for cloaks and other outcr garments, and will doubtless remember that some were distinguished for their peculiar lustre and durability, which was generally attributed to the presence of silk in the tissue. These camlets were woven from mohair. Its lustre and durability peculiarly fit this material for the manufacture of braids, buttons, and bindings, which greatly outwear those of silk and wool. The qualities of lustre and elasticity particularly fit this material for its chief use, the manufacture of Utrecht velvets, commonly called furniture plush, the finest rualities of which are composed principally of mohair; the pile being formed of mohair warp, which are cut in the same manner as s $1 \mathrm{k}$ warps in velvets. Upon pass'ng the finger lightly over the surface of the best mohair plushes, the rigidity and elasticity of the fibre will be distinctly perceived. The fibre springs back to its original uprightness when any pressure is removed. The best mohair plushes are almost indestructible. They have been in constant use on certàin railroad cars in the country for over twenty years without wearing out. They are now sought by all the best railroads in the country as the most enduring of all coverings, an unconscious tribute to the remarkable qualities of this fibre. The manufacture of Utrecht velvets at Amiens, in France, consumes 500,000 pounds of mohair, which is spun in England, 10,000 workmen were employed in weaving these goods at Amiens, in 1855, the product being principally sent to the United States. The mohair plushes are made of yarns from No. 26 to No. 70 ; the tissues made of the former num- 
ber, are worth four francs per metre, and of the latter ten francs per metre, showing the importance of preserving the fineness of the fleece. A medium article is made extensively in Prussia, of yarns spun from an admixture of mohair with combing wool; but it is wanting in the evenness of surface and brilliant reflections, or bloom, of the French goods. Mohair yarn is employed largely in Paris, Nismes, Lyons, and Germany, for the manufacture of laces, which are substituted for the silk-lace fabrics of Valenciennes and Chantilly. The shawls frequently spoken of as made of Angora wool are of a lace texture, and do not correspond to the Cashmere, or Indian shawls. The shawls known as Llama shawls are made of mohair. I have seen one at Siewarts' wholesale establishment, valued at $\$ 80.00$, weighing only two and one-third ounces. Mohair is also largely consumed at Bradford, in England, in the fabrication of light summer goods. They are woven with warps of silk and cotton, principally the latter, and the development of this manufacture is due principally to the improvements in making fine cotton warps the combination of wool with mohair not being found advantageous. These goods are distinguished by their lustre, and by the rigidity of the fabric. All the mohair yarns used in Europe are spun in England, the English having broken down, by temporary reduction of prices, all attempts at spinning in France. Successful experiments at spinning and weaving Angora fabrics have been made in this cotuntry, as shown by the samples of yarn spun by Mr. Cameron, and the dress goods spun and woven by Mr. Fay of the Lowell Manuficturing Co., from Angora wool grown by Mr. Chenery of Belmont, Mass. Before the demand for this material for dress goods, and plushes, mohair was largely used in Europe, and this country, for lastings for fine broadcloths, the lustrous surface acting as a frame, in a picture, to set off the goods. This use is now abandoned. Mohair is now extensively used to form the pile of certain styles of plushes used for ladies' cloakings; also for the pile of the b. st fabrics style ${ }^{1}$ Astrachans. Narrow strips of the skin of the Angora, with the fleece attached, have been recently in fashion for trimmings, and greatprices were obtained for a limted number of the pelts for this purpose. The skins with the fleece attached will always bring high prices for foot rugs, on account of their peculiar lustre, and the advantages they possess over those made of wool, in not being liable to felt." (Sce Hayes, pp. 37, 38, 39.)

\section{And in a subsequent edition of his work in 1882 he adds :}

"I have but little fo add to the observations in my original essay upon the various applications of mohair. I have mentioned its application at Bradford in the manufacture of light dross goods. I did not mention the far more extensive use to which mohair until very recently has been applied, for more substantial fabrics, which for a time were in great vogue for ladies' dress goods, called 'brilliantines' or 'lustres,' a black fabric 
of peculiarly brilliant lustre. Fabrics of this class, composed of mohair, made by the Arlington Mills of Lawrence, Mass., and the Farr Alpaca Company of Holyoke, Mass, received high commendation from the English judges at our Centennial Exhibition. Through a singular freak of fashion, more particularly referred to in the appendix, the lustre fabrics have ceased, temporarily, to be in demand, thus dispensing with the most important use of mohair, and causing its present reduced price at Bradford, which rules the prices for the rest of the world. Another very important application of mohair, as affectei by fashion, is in the manufacture of black fabrics for the lining of men's garments, of the more expensive class. I have a great-coat with a mohair lining, which has been in use for five years. The cloth is worn out, but the lining, which at first glance would be mistaken for silk, does not show the slightest trace of wear or fraying in the most exposed parts. There could be no more conclusive evidence of the exªordinary wearing qualities of this fibre, and of its adaptation to hundreds of uses to which it has not yet been applied. The Englisli letter given below shows that mohair is still extensively used at Bradford for making yarns for Utrecht velvets, generally called in this country 'mohair plush.' This fabric has of late come into greatly increased demand, both for furniture coverings and railroad car upholstery, as it is not only sightly, but the most enduring fabric produced by the textile industry. The manufacture of Utrecht velvets has not been attempted in this country; it waits only for an abundant home supply of mohair. The consumption of this fabric by the railroads of the United States alone would require the mohair from many hundred thousands animals. Other applications of mohair would suggest themselves to manufacturers if there were an assurance of an abundant supply of raw material. That but slight difficulties are to be encountered in the manipulation of this material is shown in the following letter from a practical English manufacturer, whose modesty forbids the mention his name, but whose entire reliability I can vouch for.

"John L. Hayes, Esis., 95 State Street Boston: England, Aug. 16th, 1881.

". Doar Sir-Your estcemed favor of the 3rd inst. is duly to hand. I hasten, as a practical man in the manipulation of mohair, to give you a sketch, or short essay, on its spinning and working.

"Its growth, as you well know, is from two districts, or I may state three, viz. :

1. Asia Minor, about ..................4,800,000 pounds

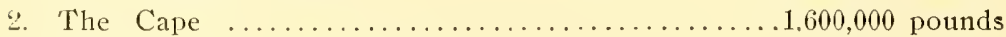

3. California........................... 350,000 pounds

Austra! ia and the rest of the world.............. 25,000 pounds

Gingeline, also Asia Minor.................. 120,000 pounds

Vær. also Asia Minor.................... 240,000 pounds 
With a chance of this seven millions being doubled in a few years, not by the Turks, but by the Natalians, or South Africaners, and the Americans, whose countries are endless for its growth. So far, therefore, as to the quantity now produced.

" 'Its manipulation is similar to the Linccln wether wool. It is sorted into various qualities or grades, both for color and dyeing, but these may be said to be really

No. 20 , the breech, amounting to ............2 per cent.

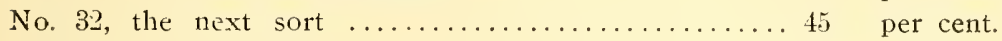

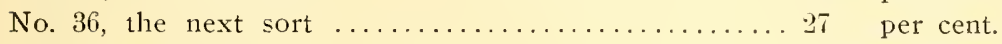

No. 40, the next sor $\ldots \ldots \ldots \ldots \ldots \ldots \ldots \ldots \ldots \ldots \ldots$ per cent.

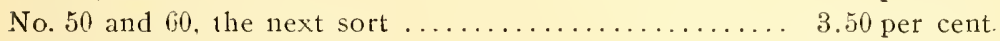

Shorts and kempy pieces .................

100

" 'As many as twenty-four sorts are sometimes made, but really about nine sorts are enough. Its combing is simplc. Lister's machine is all you require. In order to get your top quite clear of kemp, you take what is called a milking, or backing noil out, and this either recombed or mixed off with the low sorts. To get clear and good tops it is necessary to comb them twice.

" Its drawing is perhaps the most difficult operation, as you must have a perfectly even and level roving so as to prevent curl.

"Its spinning requires nothing more than the ordinary skill. Be sure and avoid curl. You must have the common flyer. Cap, or ring, spinning won't do; the hairs, or kemps, fly so, and make your thread rough. Speed not more than 2,500.

"'Its truisting also must be done on fly twisters, for the same 'smooth' reasons.

" "The Yarn and its Uses-T1 e chief use is for Utrecht vclvets and imitation seal skins, then braids, etc.; in former fashions, alpaca lustres. Yarns for Utrecht velvets, seals and braids are all 2-fold, and the counts vary from 2-fold 32's, to 50's, for Utrecht velvets; from 2-fold 18's, to 60's, for imitation seals; and also single 1's, and 2-fold 6's, for nigger heads, and astrachans; from 2-fold 32 's to 60 's for braids, and also 2 -fold 32 's for 'ice yarn,' used for ladies' fingerings, and single 30 's to 40 's for alpaca lustres and mohair glaces.

" 'So far, then, I give you a rough sketch of the sorting, combing drawing, spinning and twisting; and for your inspection, send you the enclosed list of samples, with such remarks as may be of interest to you. Always at your service, and thanking you for past kindnesses,

$$
\text { “I am, yours, faithfully, }
$$

(See Hayes, pp. 72, 73 and 74.) 
It is estinnated we have in the United States at the present time forty-nine manufacturers, who are using mohair, distributed as follows:

In Connecticut................... 1 Mill

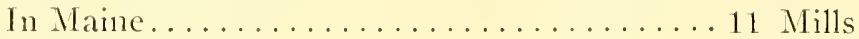

In Massachusetts................13 Mills

And six woolen mills who use some mohair

at times for dress goods.

In New Jersey...................... 1 Mill

In New Jork...................... Worsted Mills

In New lork................... I Braid Mill

In New Vork....................3 Hatters

In P'ennsylvania................. . Mills

In Rlodle Island................... 3 Mills

In adclition to the above, are a inmmber of dress goods manufacturers who occasionly use mohair either raw, or in yarn, to mix witl wool in clress goods and fancy effects, also about a lo\%en knitters and some cap manufacturers who consume some.

'l'he amount of moliair consumed by the above mills is difficult to learn, as a considerable amount passes through the hands of dealers in the interior and some is shipped direct to milis by the grower. The following table of imports is taken from the National Issociation of Wool Nanufacturers' Bulletin for December, 1895, which is now very efficiently edited by Mr. S. N. D. Nortl, the suceessor to Dr. John L. Hayes, who tied in the spring of $188 \%$ :

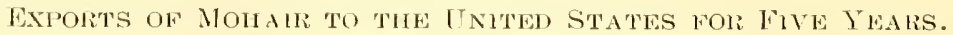
First of danuary to Thirty-tirst of December. 1890 io 184.4.

\begin{tabular}{|c|c|c|c|}
\hline & Packages & Pounds & Value \\
\hline During the year $18: 0$ & 1,624 & 437,319 & $£ 24,604$ \\
\hline During the year 1891 & 8,594 & $1,536,105$ & 87,577 \\
\hline During the year 1892 & 7,117 & $1,166,473$ & 67,537 \\
\hline During the year 1893 & 2,767 & $5+1,770$ & $.27,094$ \\
\hline During the year $1894 \ldots$ & 4,743 & 861,123 & 48,229 \\
\hline Nlso 1st Jan. to 30th Sept., 1895. & 12,297 & $2,061,549$ & 130,196 \\
\hline Average Exports per Annum, 1890 to 1894. & 4,969 & 908.558 & 51,008 \\
\hline
\end{tabular}


It will be observed that the importations from year to yeat vary largely, which is explained by the changes in fashions for ladies' dress goods. It is safe to say however, that the annual consumption of mohair at the present time (1900) will average 2,000,000 $\mathrm{lbs}$. of which about 1,200,000 1bs. is imported and 800,000 lbs. is produced in our own country. Plushes, upholstery goods, linings and buggy robes, are regarded as standard, and affords a regular demand, for a very considerable amount of the product, which is steadily increasing.

In 1882 Dr. Hayes estimated that 562,000 1bs. of molnair was required annually for making plush for the covering of railroad car seats alone; and it is safe to say that $750,000 \mathrm{lbs}$. of this fabric are consumed for this purpose at the present time (1900) if not more. In addition to this, upholsters goods, linings and buggy robes call for fully as much more, which 1 epresents 1,500 , $000 \mathrm{lbs}$. of this material, taken for standard goods, consumed in the United States alone.

Other countries will soon learn of the lasting qualities of this fibre, and it is very reasonable to believe that a large export trade will spring up for American manufactures of mohair as soon as our supply of raw material will justify it. Besides this, a great variety of other goods will be made, such as hosiery, knit unflerwear, etc., which will constantly increase the demand from. manufacturers, and if a proper tariff is maintained that will encourage American farmers to engage in raising the Angora goat, there is little doubt but we will soon be enjoying a very great benefit from this new industry. 
PLATEXXXVIII.

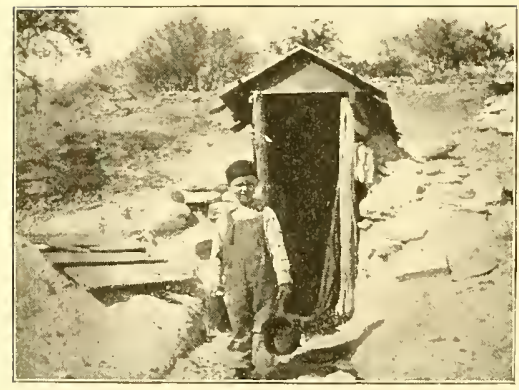

DUG-OUT.

Often used in place of tents, for shepherds, in permanent eamps. 
Commercial Features

$$
\text { of the }
$$

$$
\text { l ndustry. }
$$




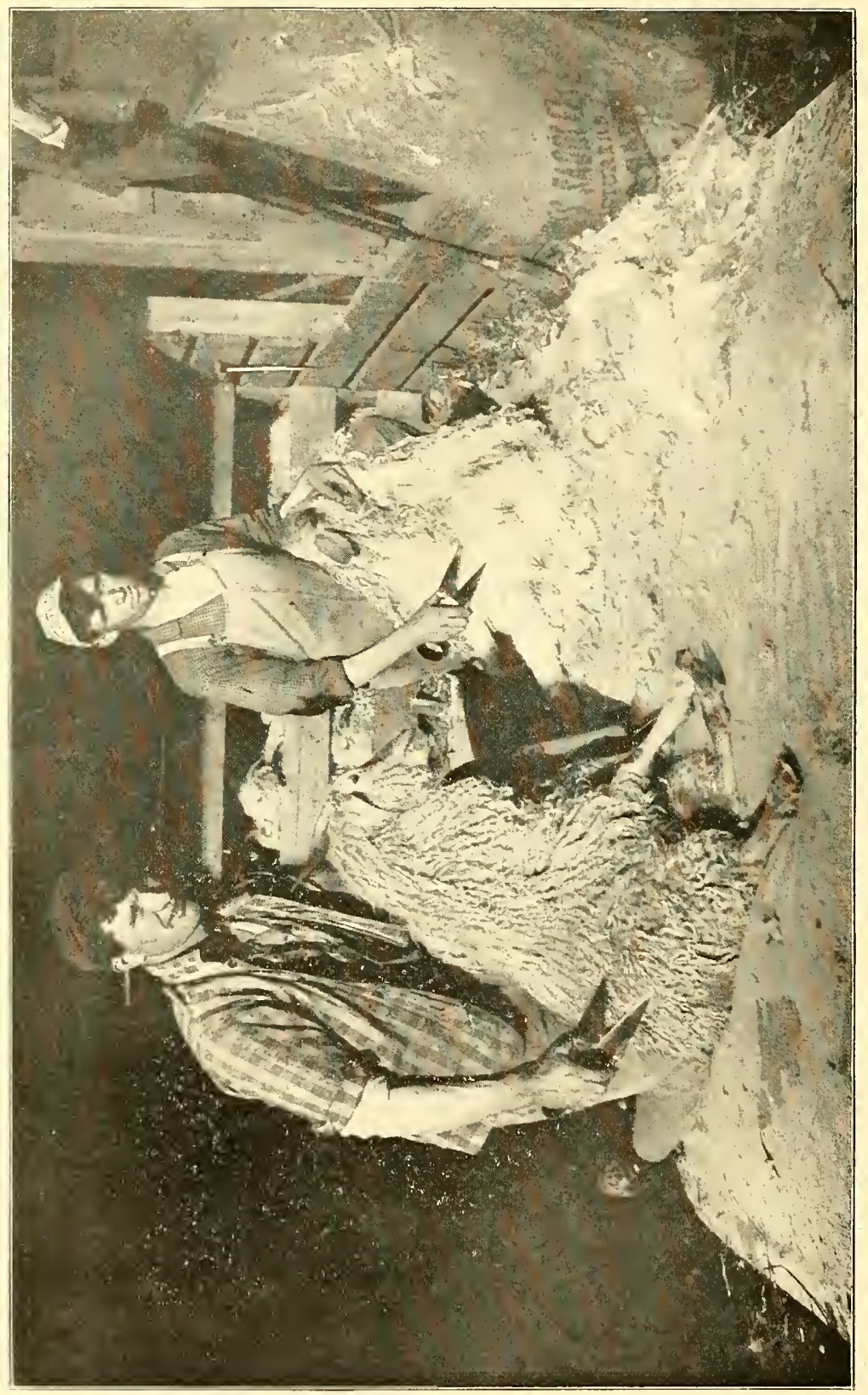




\section{CHAPTER XI.}

\section{WHERE TO SELL MOHAIR, AND HOW IT IS GRADED.}

I do not think I exaggerate when I say that, not one merchant, in one thousand, has ever seen a bag of mohair, and not one, in fifty thousand, has any knowledge of the grades of it, how it is manipulated, or where it can be sold. A comnission merchant, unless he makes a specialty of some certain product, wiil receive anything on earth upon consignment, from a bushel of wheat to a steam locomotive, but it does not necessarily follow that he is competent to handle the same. I recall a circumstance of this nature, during my residence in St. Louis. It was in the year $18 \% 4$ that a commission merchant received several large bags of Angora goat hair from one of his constituents. which he had offered for sale to every one he could think of, but to no purpose. No one seemed to know what it was, and it remained in store year after year, and was finally disposed of for a pittance, as filling for mattresses, or something of the kind. I remember, distinctly, seeing the stuff, but at that time I did not know anything about mohair, and I only make mention of the matter now, to show how important it is for a producer to select a competent representative to sell his products through.

During the time this mohair was lying in a warehouse in St. Louis, the market value of it in England ranged between roc and $90 \mathrm{c}$ a pound and the manufacturers in that country would have been glad to have bought it at that high price. There was little or no demand for it in this country, but if it had been consigned to a proper market, and to a molhair merchant, he wonld have shipped it to England, and have realized a proper value for it. 
A great many owners of small flocks sell their clips, even at this late day, either to some speculator in the interior, or to their local merchant, and, as a rule, receive a very small sum for it. I have heard of mohair selling in this way for $1 \% \mathrm{c}$ per pound in 'Texas, when I received $30 \mathrm{c}$ to $32 \mathrm{c}$ for a like kind through my selling agents in New York.

The value of mohair is largely governed by the caprice of fashion. If the fashion for ladies" Iress favors "lustre goods." mohair is in greater demand and prices advance considerably. If fashion does not favor this class of goods, the trade is confined to stanclard articles, such as plush, upholsteries, linings, etc. for which there is always a demand at a more or less uniform price. The experience of many years in England has established the fact that $25 \mathrm{c}$ to $30 \mathrm{c}$ per pound is as low as good mohair will decline to, under most adverse conditions; and, at this price, with well improved goats, the profit in raising then 1 s very satisfactory.

Liverpool, London, and Bradford, England, are the great centrai markets of the world for this product. The entire outpur of Turkey and South Africa is sent there for sale, and it is then distributed to manufacturers in this country and Europe. Through the courtesy of Messrs. Thomas \& Cook, I append a list of imports into England, from the very incipiency of the trade. These gentlemen appear to have been connected with the business from the very beginning and shared liberally in the spirit of enterprise which extended the growth of this valnable fibre into South Africa. Indeed, Mr. Cook was named by Sir Titus Salt as the selling agent of all the mohair that was to be produced from one of the first flocks of goats that was sent to that country in $185 \%$, and from that day to the present time. his firm has been closely, and prominently, identified with the trade.

The following is a list of the annual imports of mohair into England from Turkey since the year 1836 ; and, from South Africa, since the year 1860 : 
IMPORTS OF MOHAIR INTO ENGLAND FROM TURIEY.

\begin{tabular}{|c|c|c|c|c|c|}
\hline 1836 & 680,000 & $185 \%$ & $2,826,000$ & 1878 & $\pm, 6 \pm 1,000$ \\
\hline $183^{r}$ & 400,000 & 1858 & $3,212,000$ & $18 \% 9$ & $5,831,000$ \\
\hline 1838 & 995,000 & 1859 & $2,160,000$ & 1880 & $8,245,0010$ \\
\hline 1839 & $1,250,000$ & 1860 & $2,016,000$ & 1881 & $4,221, \% 80$ \\
\hline 1840 & $1,300,000$ & 1861 & $2,800,000$ & 1882 & $9,065,250$ \\
\hline 1841 & $\% 81,000$ & $186 ?$ & $3,186,000$ & 1883 & $\%, 256,960$ \\
\hline $18+3$ & $6 \% \%, 000$ & 1863 & 1,985,000 & $188 t$ & $9,019,860$ \\
\hline 1843 & $5 \% 5,523$ & $186 t$ & $3,450,000$ & 1885 & $6,373,640$ \\
\hline 1844 & $1,290, \% 71$ & 1865 & $5,000,000$ & 1886 & $9,825,320$ \\
\hline 1845 & $1,013,000$ & 1866 & $3,960,000$ & $188 \%$ & $5,612,550$ \\
\hline $18+6$ & $1,28 \%, 320$ & $186 \%$ & $1,080,000$ & 1888 & $7,509,0 \% 0$ \\
\hline $18+\%$ & $1,219,000$ & 1868 & $6,71+, 000$ & 1889 & $8,8+1,080$ \\
\hline 1848 & $2,101,000$ & 1869 & $\pm, 103,000$ & 1890 & $4,120,220$ \\
\hline $18+9$ & $2,38 \%, 000$ & $18 \% 0$ & $2,3 \pm 0,000$ & 1891 & $6,495,115$ \\
\hline 1850 & $2,019,000$ & $18 \% 1$ & $\gamma, 488,000$ & 1892 & $8,7 \% 4,541$ \\
\hline 1851 & $2,122,000$ & 1892 & $5,501,000$ & 1893 & $8.005,887$ \\
\hline 1852 & $1,918,000$ & $18 \% 3$ & $7,666,000$ & $189 t$ & $6.889,165$ \\
\hline 1853 & $2,916,509$ & $18 \% t$ & ₹.992,000 & 1895 & $11,900,000$ \\
\hline 1854 & $1,178,560$ & 1875 & $5,321,000$ & 1896 & $4,900,000$ \\
\hline 1855 & $2,520,000$ & $18 \% 6$ & $1,430,000$ & $189 \%$ & $10,700,000$ \\
\hline 1856 & $2,430,000$ & $18 \%$ & $5,984,000$ & 1898 & $10,200,000$ \\
\hline
\end{tabular}

IMPORTS OF MOHAIR INTO ENGLAND FROM SOUTH AFRICA.

\begin{tabular}{l|r||r|r|r|r}
\hline & & & & \\
1860 & 385 & 1873 & $\gamma 65,700$ & 1886 & $5,420,000$ \\
1861 & 784 & $18 \% 1$ & $1,030,000$ & $188 \%$ & $7,153,000$ \\
1862 & 1,030 & $18 \% 5$ & $1,150,000$ & 1888 & $9,598,000$ \\
1863 & 1,300 & 1876 & $1,330,000$ & 1889 & $9,440,000$ \\
$186 t$ & 8,100 & $187 \%$ & $1,43 \%, 000$ & 1890 & $9,230,000$ \\
1865 & 6,990 & 1878 & $1,360,000$ & 1891 & $9,950,000$ \\
1866 & 21,000 & 1879 & $2,280,000$ & 1892 & $10,516,000$ \\
1867 & 51,000 & 1880 & $2,590,000$ & 1893 & $9,458,000$ \\
1868 & 103,000 & 1881 & $4,140,000$ & 1894 & $9,600,000$ \\
1869 & 261,000 & 1882 & $3,7 \% 6,000$ & 1895 & $11,100,000$ \\
1870 & 405,000 & 1883 & $4,440,000$ & 1896 & $10,000,000$ \\
1871 & 536,000 & 1881 & $4,320,000$ & $189 \%$ & $12,583,000$ \\
1872 & $8 \%, 700$ & 1885 & $5,250,000$ & 1898 & $10,000,000$ \\
& & & & & \\
\hline
\end{tabular}


In the United States, the City of New York is the central market. Mr. Wm. R. Payne of the firm of $\mathrm{Wm}$. R. Payne \& Co., is, perhaps, more intimately connected with the trade, than any other merchant. He appears to have had a natural fondness for the business for there was very little profit in it for many years, yet he has always used his best efforts to build up the breeding industry, and has worked, unceasingly, to encourage our government to bring in new blood from Turkey. He has written to the press, and has been, and is now, always ready to give information to breeders, no matter how small they may be, relative to the business. He has very kindly assisted me in yetting information concerning the manner in which this product is handled, and has aided me largely in other matters, for which I feel under great obligation.

Messrs. Kitching \& Bicknell have also been prominent factors in building up the mohair industry, and enjoy the confidence of a large number of breeders. In addition to these may be mentioned:

J. C. L.inde \& Co., New York.

Jno. M. Emnott, New York.

John Finnigan \& Co.. New York.

Hutchins \& Co., IBoston.

J. S. Fislie \& Co., Philadelphia.

Who handle more or less of the product.

The amount of mohair consumed annually in the world can only be arrived at through the importations into England from the Cape of Good Hope, and from Turkey, added to the clip of the United States.

The following table will, therefore, give a very fair idea of the world's present consumption:

Imports from South Africa to England.... . 10,000,000 pounds Inports from Turkey to England........ 10,200,000 pounds Preduct of the United States.......... 800,000 pound.

Total,................21,000,000 pounds 
This includes all classes, and, as much of the product of South Africa and the United States, is of a low, cross-bred, order, short in staple, and kempy, much of it is only entitled to be called mohair "by courtesy."

Every indication points to a large increase in the uses of this product, as may be readily inferred after reading the foregoing chapter on manufacturing, and, that the raising of the Angora goat offers great inducement to the American farmer, admits of no argument. Indeed, conditions are more favorable for the culture of this animal in the United States, than any other country, not excepting its native land, Asia.

That the climate of the United States is peculiarly adapted to the growth of both animal and vegetable fibre is evidenced by, the wonderful development of our cotton product, a plant introduced in this country iess than two hundred years ago, and for the past century has maintained supremacy over all other growths. The development of the Spanish Merino sheep was attempted first in England, as early as 1788, by King George III., but was abandoned, (see Ency. Brit. Vol. I, 303) and was taken up by Americans early in the 19th century, and carried to a successful termination, resulting in the established breed of "Amcrican Mcrinos," which have been celebrated the world over for density of fleece, and fineness of fibre, for the past thirty years or longer. It is, therefore, not unreasonable to think that we will, sooner or later, take the lead of all nations in the product of moliair, as we have done with cotton, and would certan1ly have done with wool, if it had not been for the vacillating policy of our law-makers relating to a protective tariff. As before stated, the demand for mohair is largely governed by the freaks of fashion, but for staple goods, such as plushes, upholstery goods, linings, etc., there is always a regular demand for such grades as are suitable for this class of manufactures, but, the dress goods, and braid trade is uncertain and variable. The following extract from Dr. Hayes' work will convey some idea of the enormous demand for plush alone, and it should be borne in mind that the great increase in railroad building since $\mathrm{Mr}$. 
Poor's estimate was made (1882) will justify a very large increase on his figures at the present time. I think, too, that his estimate should have been made upon the basis of three pounds of fleece, in place of four, which will largely increase his estimate of the number of goats.

"Mr. H. V. Poor, the best American authority on railroads, informs me that not less than three thousand new passenger cars are built in the United States annually for old roads, and the number is increasing as new roads are built. Each passenger car has sixty seats, Four yards of mohair plush are required for each seat. There are nine ounces of mohair to a yard of plush, making 562,000 pounds of mohair for the three thousand cars. This divided by four, the average weight of the fleece, shows that about 150,000 Ang ras would be required to furnish the raw material for this single fabric, which will never go out of fashion." (See Hayes, p. 118.)

As a rule, most of the American clip of mohair has to be graded to prepare it for sale, which is done by the commission merchant who receives it upon consignment. Very few breeders have been so careful in breeding as to have a perfectly uniform lot of goats, and their clips naturally show different strains of blood, which makes grading a necessary feature in handling it, when it reaches market. This shows the importance of having an experienced merchant to consign to. for it is pure gues. work to determine the value of a lot of mohair ungraded, yet, it is often, and I nay say, universally done in the interior, when it is sold to local merchants or to speculators, who generally buy in a lump, which explains the low price they ustually pay.

By a careful assortment of the clifferent grades, the producer receives full compensation for h s product, and the manufacturer is better satisfied, even after paying a premium over what he had figured on.

The characteristics which govern the grading of mohair are :

1st. The finest fibre.

2d. The longest staple.

3d. The brightest lustre.

tth. The cleanest condition. 
Each merchant has liis own method of grading, which I consider wrong in principle. There should be a standard grade, in niy opinion, so that when quotations are named for any particular grade of mohair, you may know it is not of this, or that, merchants' grading, but a "National standard grade," agreed to by all concerned in the trade. This is a very confusing element in many of our agricultural products, notably wool, which is handled very much in the same manner as mohair, and it is really impossible to determine what the market value of wool is by reading a market report of prices, muless you happen to be familiar with the grades of the market. Each selling market of this product has a distinct and separate set of terms for different grades of wool, which the merchant and dealers in that market, of course, understand, but to the people at large is a perfect enigna. If "standard grades" could be agreed upon, as is followed by the cotton trade in cur country, it would simplify matters, and would result in great benefit to producers. Of course, this reform can only come about by concert of action on the part of merchants engaged in the trade, and it is to be hoped, after our mohair industry has reached proportions to justify it, they will unite upon some uniform plan for grading which will be agreeable to ail.

The method of grading mohair at this time is to first classiiy it into three large divisions, viz:

1st. Combing.

2d. Carding.

31. Coarse.

These are again sub-divided by grades into the following:

\section{COMBING NOHAIR.}

XX Combing, or very finest, of 6 inches, and above.

No. 1 Combing, or second finest, of six inches and above. No. 2 Combing, or third finest, of 6 inches, and above. Braid Combing, or fourth finest, of 6 inches, and above.

Fine baby combing, a No. 1 medium staple, 5 to 6 inch staple.

Medinm Combing, a No. 2 medium staple, 5 to 6 inch staple. 
Carding No. 1, and kid, less than 5 inches.

Carding No. 2, less than 5 inches.

Blanket-All cross-bred, of a low medium grade.

$$
\text { COARSE MOHAIR. }
$$

Carpet-Next lower quality.

Common goat-White and gray.

Burry, and seedy.

Black Fleeces.

Locks, Breech, and Manes.

In determining value of mohair it is manifest that a fleece liaving the

V'ery finest fibre.

The longest staple.

The brightest lustre, and

The cleanest condition

would be considered the most valuable, and form a standard by which all other qualities are fixed. As there are variations from this ideal standard, in respect to all four points running through the whole scale of grades, so the values vary.

\section{THE 'TURKISH SYS'TEM.}

In 'Turkey, as a rule, each Province, or Vilayet, produces mohair that differs in character, condition, etc. The stock is is sually assorted in Constantinople, and classified as tonows:

"Choice."

"Superior."

"Good Average."

"Average."

"Ordinary."

The white hair is separated from ycllow, and stained; and, all gray, brown, and faw1, colors, are graded out. Then each Province's hair is sold under its own name, such as "Angora," "Tscherkess," "Kastombol," "Ishkissier," “Geridah," "Beibazar," etc. 
But, in addition to these factors in fixing value there is another feature that has to be considered. Mohair, being chiefly used in the manufacture of "Worsted" yarns, has to be "combed," the proportion of short, woolly, and kempy, undergrowth, and all short fibres of pure mohair, therefore, has to be considered. This is called "Noilage." When the mohair at the mill has been sorted it is called "matchings;" and, after scouring, is put in a machine called a "comb." The first operation takes out the very bottom of wooly fibre, and whatever kemp there is, with, very often, specks of vegetable fibre, seeds,etc., which is called "first combing noils."

The second passage through the comb, separates all the mohair fibres, too short to spin into worsted yarn. This product is called the "second combing noils," and is a mohair fibre, but quite short.

The long fibres are arranged parallel in a long, continuous band called "Top," from which it is spun into yarn. It is quite evident that the less "noils," and the more "top," a lot of mohair yields, the more profitable, and valuable, it is.

Turkish mohair averages from 10 per cent. to 20 per cent. "noils," while the American clip ranges from 22 per cent. to 40 per cent., hence the relative difference in value.

A few American clips are quite as free from "noils" as the Turkish mohair, and commands an equal price in market; and, there is no reason, if proper care is used in shearing the goats, why a large amount of our clip should not occupy the same position. The value of combing hair increases with every inch in length, other factors being equal.

The very coarse-fibred hair, from old bucks and wethers, when twelve inches and over is used for doll's hair, for wigs, and artificial gray hair for ladies, and ranges in value from $50 \mathrm{c}$ to $75 \mathrm{c}$ per pound.

The following table will give the price at which mohair has sold in England since 1856, which is taken from the Bulletin of the National Wool Manufacturer's Association for December, 1895 : 
PRICES OF MOHAIR IN ENGLAND SINCE 1856.

\begin{tabular}{|c|c|}
\hline (1) & $18 \% 6$ \\
\hline $55 \% \ldots \ldots \ldots 66$ cents & $18 \%$ \\
\hline $58 \ldots \ldots \ldots \ldots \ldots 60$ cents & $18: 8$ \\
\hline $.72 \mathrm{c}$ & $18: 9$ \\
\hline $30 \ldots \ldots \ldots \ldots 76 \mathrm{c}$ & 1880 \\
\hline $1 \ldots \ldots \ldots \ldots$ & $1881 \ldots$ \\
\hline 2............ & $188 \% \ldots$ \\
\hline $83 \ldots \ldots \ldots \ldots .990$ & .. 40 to 43 \\
\hline$\ldots 78$ o & .37 to 45 \\
\hline$\ldots \ldots \ldots \ldots 66 \mathrm{c}$ & $1885 \ldots \ldots \ldots 28$ to $38 \mathrm{c}$ \\
\hline $66 \ldots \ldots \ldots . \ldots 8$ c & $1886 \ldots \ldots 23$ to 32 \\
\hline$\gamma \ldots \ldots \ldots \ldots \ldots 90 \mathrm{c}$ & $1887 \ldots \ldots \ldots 25$ to $29 \mathrm{c}$ \\
\hline$\ldots 5 \pm$ & $188 s \ldots \ldots \ldots 24$ to $28 \mathrm{c}$ \\
\hline $9 \ldots \ldots \ldots \ldots 86 \mathrm{c}$ & $1889 \ldots \ldots \ldots 25$ to $42 \mathrm{c}$ \\
\hline$\ldots \ldots \ldots \ldots \ldots$ c & $1890 \ldots$ \\
\hline$\ldots \ldots \ldots \ldots$ is c & $1891 \ldots$ \\
\hline$\ldots \ldots \ldots \ldots 0$ cents & $1892 \ldots$ \\
\hline$\ldots \ldots \ldots \ldots 66$ cents & $1893 \ldots \ldots \ldots$ \\
\hline$\ldots \ldots \ldots \ldots \ldots$ & $1894 \ldots$ \\
\hline 82 & $1895 \ldots$ \\
\hline
\end{tabular}




\section{CHAP'TER XII.}

HOW TO PREPARE MOHAIR FOR MARKET.

In shearing goats it is very important that the clipping should be as close to the skin as possibie, as the longer the hair is the more money it will command in market. One of the recently patented shearing machines is probably the best method of taking off the fleece as it will insure a uniform staple, which is a very important feature. If ordinary wool shears are used, try and make one clip of the shears do the work. It is quite common with nearly all professional shearers, when they are paid by the head, to run ever their work as fast as they can, in order to earn as much as possible during the day. Quite a rivalry exists among a gang, ustually, as to which one can shear the fastest, and it is quite common for them to cut the hair into several pieces unless you are watching them, and insist upon their being more careful. The short hairs are of very little value, as explained in the foregoing chapter, and, when too short, will fly away in handling, which is a complete loss. If the fleeces are of different lengths, the longest moharr should be kept separate. Coarse, kempy, hair (quite common in low grades of goats), should not be mixed with the better grades, as it will reduce the selling price of the finer hair. The beard of the animal is of but little value and should not be removed.

The most approved method for shearing, perhaps, is to first shear the locks, and short belly hair, and then take off the fleece proper, which should be kept in tact, as far as possible, folding each fleece separate, and placing it in a bag as soon as shorn. 
It is not necessary to tie the fleece with twine. If any of the hair contains burrs, or any vegetable, or foreign matter, it should be packed separate; anc! all black, and off-colored fleeces should be kept together.

Kid fleeces will command a preminm; and, if there are enough of them, to make a package of any reasonable size, it is well not to mix them with the older hair.

The ordinary wool sack is commonly used for shipping. and between 150 to 175 pounds is quite enough to pack in a six foot sack. More than this can be tramped into it, but it is best not to pack too tight.

Some breeders, more particularly in New Mexico, put their mohair up in compressed bales like cotton. This is a very poor plan, as it must be assorted, and classified by the merchant, when it reaches its destination, and if it is loosely packed, it facilitates the handling of it, and always presents a better appearance than when all the life has been squeezed out of it by pressing. 


\section{CHAP'TER XIII.}

THE TRADE IN ANGORA GOAT SKINS, AND HOW TO PREPARE THEM FOR MARKET. skins.

Quite an extensive trade is carried on in Angora goat

No less than twenty thousand felts are imported every year through the port of New York, alone, from Turkey and South Africa, which are graded according to the length of hair, fullness of fleece and weight.

Turkish skins usually range from $\$ 1.50$ for five pound skins up to $\$ 3.50$ for a ten pound skin.

The Cape skin (the term "Cape" is applied to it because it is shipped through the Cape of Goor Hope) is sold by weight, and ranges from twenty-five to thirty cents per pound.

The Domestic skin is very much like "Cape's," and sells for about the same price; though, if they are well fleeced and properly cured will bring $\$ 2.00$ to $\$ 2.50$.

The kid skin sells at from 25 cents to 50 cents each, according to quality and condition.

Curing, is a very important matter, and the market value is largely governed by it.

It is not at all uncommon for the American breeder to throw his raw skin upon a fence rail, a barbed wire fence, or in the crotch of a tree, if that should be the most convenient place, and then he wonders why it is that the Turkish skins bring so much more money in market than his do.

The Turks are very careful to remove all flesh, and to salt the skin thoroughly, and then dry it in a shady place. If it is Jried in the sun it will get sunburned, which is injurious. 
If salt is not to be had, they can be cured nicelybystretching them out on the floor of a room, and tacking them down by the edge of the skin, where it should remain until perfectly dry. If it is not stretched out and tacked lown, it will curl t1p into all kinds of shape, which explains the reason why many of the domestic slins sell so poorly.

Skins that are dried in the manner last mentioned are liable to be damaged by the hide bug; and should be sent to market promptly if the weather is hot.

They can be poisoned, however, by sprinkling the flesh side of the pelt with a solution of arsenic ( $1 \frac{1}{2}$ ounces of arsenic to 1 gallon of water), and can be kept for some time in this way.

The dry-salt method is nutch the more convenient, as they can be salted in a store room and placed on top of each other until you decide to send them to market, when they should be laid out on the floor, the salt carefully removed, with a broom, and then thoronghly dried, when they are in condition to be bundled, or baled, for shipment.

Fifty skins make a very convenient sized bale.

It may not be generally known that the goat family is supplying nearly all of the so-called fur that is now being used by on1 fashionable people. If you will ask any (honest) furrier he will tell you that the great bulk of his carriage robes, overcoats, capes, etc., are made from the common goat skin, and this alone should be encouragement enough for farmers to become interested in the Angora, for there is no product that commands such good prices as furs.

The buffalo, which were once so conmon in the United States as to be hardly worth the skinning, are now not quoted at all, owing to the complete extermination of the animal.

Bear, are likewise, very scarce, and sell at prices ranging from $\$ 10.00$ to $\$ 50.00$. There are very few seal, otter, and beaver: and, at the present rate of $c$ nstmption, and the high prices that are being offered and paid for them, these will soon be exterminated as well.

The "Hudson's Bay Company," and similar concerns, have been supplying a demand for furs for the past hundred years or 
more, which has come from all portions of the globe; and, when we reflect upon the enormous number of wild animals that existed on this continent in the early days, a fair idea can be formed of the unlimited extent that this trade possesses. The buffalo, for instance, roamed from the North to the South in droves that were, at times, so enormous that, when they were on the run, would make the very earth tremble. $U p$ to within twenty years these great droves of buffalo were often seen in Texas, but they have all disappeared, and the animal is not to be seen now anywhere, except in some city park or menagerie.

Is there any wonder then, at the fabulous prices that are being offered and paid for furs? The great advance in price is indicative of how sorely the human family miss this great gift from nature. But they are all gone or will be very soon, and a substitute, in the form of manufactured fabrics, will have to be used to afford the warmth that these wild animal skins have done for so many centuries.

'The orr, and the cor', are being largely employed in this respect; and, the cat, and rabbit, are also being brought into use, which were seldom ever used before, owing to the delicate nature of their skins. Individuals have resorted to propagating the black skunk, and have found it a very profitable business, and, if it were not for the great expense of feeding the animal a $d o g$ ranch would pay as large a profit as raising cattle.

In the Angora goat, we have, perhaps, the most perfect substitute for animal fur that can be found. 'The skin can be taken at various stages in the growth of the hair, and can be made to represent very many of the wild animal skins so perfectly that they can hardly be detected from the genuine. The monkcy skin muff and boa, that are so commonly worn by young ladies, are nothing else but the straight-haired goat, dyed black; and, much of the so-called "Astrachan," is the curly-haired Angora skin, taken when the hair is only about one month's growth.

The bear is another skin that the goat can duplicate, and, when properly dyed, will defy the most expert furrier to detect.

In addition to this there is a great demand for floor rugs. Angora lace trimmings, muffs, capes, boas, etc., for ladies' and children's wear, and the furriers who supply this trade, have 
never found any skin so suitable as that of the Angora goat, with its lustrous, curly hair. Such rugs are very ornate and attractive, and are the envy of all ladies who are tasty in furnishing their dwellings. As compared with a woven rug, they are, as a Cashmere shawl would be to one made from cotton, and the demand for them will always be sufficiently great to return a fair profit on the cost of producing the animal. 


\section{CHAP'TER XIV.}

\section{CONCENTRATING UPON ONE MARKE'T.}

The members of nearly every branch of commercial, and industrial pursuits, have within the past thirty years, come under some form of organization for their mutual interest and benefit. The merchants have their "exchanges," or "boards of trade;" the railroads their "combines," to maintain a higher rate of freight: the manufacturers and miners, have "trusts," and the laboring men their "unions." All seem to recognize the fact that it is necessary to work together, upon some uniform plan, in order to receive the full benefits irom their capital and labor; under the law of supply and demand.

The farmer, and stock-raiser, alone, stand out; and, although many attempts have been made to inite them under some practical organization, nothing has come out of it, as yet.

The nost important part of agriculture, perhaps, is that which relates to the commercial features of it. The late Secretary of Agriculture, Hon. J. M. Rusk, in one of his annual reports, very wisely said:

"It requires as much skill to market a crop, as it does to produce it."

A farmer who has not the proper knowledge of the trade he is dealing with, should select some competent merchant to represent him in converting his products into cash; he may be ever so skilful as a farmer, may be able to make "two blades of grass grow, where only onc grew before;" but, if he has not the commercial ability to cope with the experienced and shrewd buyer, he is compelled to trade with, he may find that he does not realize as much as his less skilful neighbor, who consigns his produce to some capable merchant. 
The selling of wool, for instance, seems to be simple enough. but there is more of a science in it than appears on the surface. The calling of the wool merchant is equally as difficult to master as that of any other profession. He must know the way in which wools are graded in different markets, and what they are worth, both in this country and abroad. Mr. Rusk says again :

"In these days, there is ro distance limitations to possible competition, $* * *$ There is no section in the civilized world which may not at some time, and in regard to some product, be found to be a competitor of the American farmer." U. S. Agtl. Report, 1891, p. 39.

He must also be familiar with the supply of wool in stock, and in the hands of manufacturers, in order to know whether he should hold it longer, or sell what he has on hand at the price he is offered.

The average wool grower of the United States, however, does not recognize these facts. He either undertakes to sell his own wool, or will entrust it to some popular friend who has, perhaps, made a failure as a wool grower, and has painted his sign "wool morchant;" or, he may select some conntry cross-road grocery keeper to represent him; some "jay," who has never seen the inside of a connting-room, and possibly has never been beyond the bounciaries of his own State, whose business is usually advertised upon the panels of the country road gates, in such a conspicuous way as "Bring your wool, and mohair, toand get New York prices for it." These are the kind of "micrchants" that are frequently employed in the interior to sell wool to the cxpert wool dealer, from the large markets of the East, who has made a life-time study of his business, and is familiar with all of its details.*

*It does not necessarily follow that we have no competent wool merchants in the interior of our States; but, I maintain, the great majority of those who are engaged in that business have never received the necessary training to justify them in conducting it properly. And, furthermore, no matter how competent a merchant may be unless he has access to information relating to the statistics, as well as the grades of wool he cannot trade intelligently: 
In the absence of "standard grades," no one but an experienced dealer can tell what the different market reports mean Some grades of wool may be quoted in one market at a very low price, that are of a better quality than another grade, which is quoted at a much higher value in another market.

A shrewd buyer will select just such market quotations as suits his purpose the best, when driving a trade with the inexperienced merchant, and after he has made a trade, will leave him in blissful ignorance of the fact that he has parted with his wool at much below its real value.

If wool-growers would unite upon a single market, and concentrate their wool in the hands of the merchants of that one market alone, they wonld profit very largely by the change, for they would eliminate the two hundred and sixty-five different market quotations, which are, perhaps, the most disturbing element in this trade at the present time. The London wool market is a very fine illustration of this system, and indicates clearly the wisdom of the Australian, New Zealand, and Argentine, wool-growers in adopting it.

Their wools are concontratcd in London, and sold at regular intervals, which has a tendency to increase competition, and results, very naturally, in higher values. They use but one set of grade terms, which is, practically, the same as a standard.

This system has been followed for years, and is admitted to be the most desirable one for a producer of an agricultural product to follow, and if the mohair growers of the United States will unite on New York City, as the mohair market for the United States, in place of shipping to several markets, and still worse, selling here and there in the interior, there is no doubt but it will result greatly to the benefit of every producer of mohair in our country. 


\section{CHAP'TER XV.}

ANGORA VENISON AS A SALABLE PRODUCT.

A few years back, the prejudice for goat meat was so strong. it was impossible to find sale for any considerable number of Angora goats at any of our large meat-packing centers, though it was not uncommon for packers to slaughter a few when they were shipped in with a lot of sheep.

Today there is no difficulty in selling them in any quantity. provided they are fat, and the sheep feeder stands ready to take as many as the packers reject; hence, it may be safely stated that the Angora is now recognized, on our markets, as a standard class of meat.

In 1895-6, a difference of $\$ 1.00$ per hundred was made in favor of sheep, but this has been steadily narrowed down until there is little or no distinction marle between well-graded Angoras and the fincst sheep, and it is not unlikely that in a few. years morc, a premium will be paid for the Angora. Indeed, I am morally certain of this, for the simple reason that a butcher can realize more profit from the Angora than he can from the the sheep. The pelt of a highly improved Angora will net the butcher fully twice as much as the pelt of a sheep; and it is quite common for a two-year-old Angora to "break at the joint" (the 11sual test applied to lamb), which makes it more salable.

Put, apart from this, the meat is superior to that of the sheep, and will naturally take precedence in market, on its merit alone, and will soon be sold unde: its proper name: "Angora Tcnison," instead of being palmed off for "Choicc Lamb." Very few people have ever tasted a young Angora wether that do not want more, and it is not at all surprising that the prejt:dice against them is being so rapidly removed. 
In 1856, the late Dr. John Bachman, an eminent naturalist of Charleston, S. C., was selected by the "Southern Central Agricultural Association of Georgia," to make a report on the goats inported by Dr. Davis in 1849, then in possession of Col. Richard Peters.

This report was published by the United States Agricultural Department in $185 \%$, from which I extract the following:

"We have never indulged in the extravagant luxury of feasting on" a full-blooded animal of this variety but we have, on several occasions, made a hearty meal on the quarter, half, or three-quarter bloods, and all who dined in company, pronounced the meat of the halE-breed wethers superior to lamb; and an eighteen-months' old, superior to mutton. The havor approaches nearer to venison, than to mutton. They remain fat nearly throughout the year, and in November, are almost too fat for the table. We observed a great improvement in the progeny of the full-bloods over their imported parents, both in fatness, and in size." (S ze Agtl. Dept. Report 1857, pase (:-)

Mr. A. L. Johns, a prominent salesman of sheep, on the Kansas City Stock Yards for many years, but who has recently moved to Chicago, has, very kindly, written me the following letter upon this subject:

"Chicago, I11., Dec. 1st, 1899.

"Mr. Wm. L. Black, Fort McKavett, Texas:

"Dear Sir-In reply to your inquiry as to the present status of the Angora goat upon the Kansas City and Chicago markets, I beg to say that the conditions, as they exist now, compared with ten years ago, are very gratifying indeed. At that time, the Angora goat was hardly known in the North, and was seldom seen upon our markets; they were supposed to be only good for barn yards, and if a butcher had dared to offer for sale even a leg of goat meat, his market would have been' blacklisted, and his patrons would have looked elsewhere for their mutton chops. Today, thousands of the little white animals are to be found in nearly every State in the Union, and are as much a source of revenue to their owners as the better grade, of their kin-folk, the sheep family.

"Recently, in conversation with Mr. Tyson, of Blair, Neb., who, during the past three years, has fed and marketed four thousand of the grade Angoras, he stated that his profits had been fully as great, taking into consideration the money invested, as he ever made in feeding sheep. Continuing, he stated that they are not at all susceptible to disease, such as foot rot, scab, etc., with which breeders and feeders of sheep, have to contend; and that, as scavengers, they are invaluable, and in his.opin- 
ion. every farmer having rough and brushy pastures should have a small flock to keep it cleaned up; and that they would be repaid ten times over the cost of their flock.

"In conclusion, I will say I firmly believe the time has come when breeders and feeders of the grade Angora goat, will be counted among our successful and prosperous stockmen; producing a wholesome, nutritions meat that will meet with ready demand upon any of our large markets; and, in place of salesman begging buvers to bid on them, as in years gone by, there will be active competition from all the packers, and sales can be readily made within thirty to forty cents per one hun. dred pounds of the best mutton.

"Yours very truly,

A. L. JOHNS,

"Sheep Salesman, Union Stock Yards, Chicago"

And the "Chicago Live Stock Commission Company," of Chicago, Kansas City, and St. Louis, add their testimony to the growing popularity of this animal on our meat markets, in the following very courteous reply to an inquiry I recently sent to them:

"Chicago, I11., March 10th, 1900.

"Mr. Wrn. L. Elack, Ft. MeKavett, Texas:

"Dear Sir-Your favor, in answer to mine of recent date, at hand and contents carefully noted. The information contained therein is very acceptable, for which I sincerely thank you. I have taken a great interest in the goat industry for the past six or seven years, and as you are undoubtedly aware, we have handled more of them than any other commission firm in the United States. We have had them of all kinds and sizes, and all breeds, but the Angora stands at the head of the list, and is gaining in favor yearly on this market. Recently a double-deck of 100-pound, two, and three-year-old, wether goats, sold here at 4.75 per cwt. This was when the top of the market for our best sheep was about 5 cents per pound. Seven or eight years ago this same load of goats would not have sold within $\$ 1.00$ per cwt. of sheep in the same condition. The load referred to, understand, were well finished and althongh we have had none here recently, several hundred could be sold every week at prices which would be very satisfactory to the owner. We have had numerous inquiries from farmers, throughout the country tributary to this market, asking where they could get stock goats, the most of them being wanted for the cleaning up of brush land, but so far as we have been able to judge the demand for them has far exceeded the supply during the past year or two. I am of the firm opinion that the meat of the well 
finished Angora goat ranks well up to that of our best mutton, and I predict that, ten years from today, this industry will be carried on in the United States much more extensively than at present.

"With kindest regards, I remain,

$$
\text { "Yours to command, }
$$

\section{E. R. JOHNS, \\ Sheep Salesinan for " Chicago Live Stock Com. Co."}

It is not possible to arrive at a correct estimate of the number of Angora goats sold, for the reason they are classified with sheep, and are included in the receipts of that class of stock in all of the leading stock yards. It is very common to see them in lots of one thousand, and over, and it is to be hoped that our stock yards will soon adopt a different system, and keep a record of each class.

It is surprising to note the wonderful growth in the demand that has been created for mutton in the past quarter of a century in our country. In referring to this, in 1889, the late Hon. J. M. Rusk, Secretary of Agriculture, in his report for that year, says :

"The rapid increase in consumption of mutton is indicated by an enlargement of the receipts of sheep at Chicago and St. Louis from 541,627 in 1875 to $1,971,683$ in 1888 . The increase in New York, during the same period amounts to 750,000." (See Agtl. Dept. Report 1889, p. 43.$)$

The following table will show the total receipts of both cattle and sheep at Chicago during the past thirty-three years:

\begin{tabular}{|c|c|c|c|c|c|}
\hline YEAR & CATTLE & SHEEP & YEAR & CAtTle & SHEEP \\
\hline $1865_{\mathrm{DAXS}}^{\mathrm{FIVE}}$ & 613 & 1,433 & 1875 & 920,843 & 418,948 \\
\hline $1866 \ldots$ & 393,008 & 207,967 & $1 \times 76$. & $1,0.46 .745$ & 364.095 \\
\hline $1867 \ldots$ & 329,188 & 180,888 & 1877 & $1,033.151$ & 310,240 \\
\hline $1868 \ldots$ & 324,524 & 270,891 & 1878 & $1,083.068$ & 310,420 \\
\hline $1869 \ldots$ & 403,102 & 340,072 & 1879. & $1,215,732$ & $3=5,119$ \\
\hline $1870 \ldots$ & 532,964 & $349,8.73$ & 1880. & $1,382,477$ & 385,810 \\
\hline $1871 \ldots$ & 543,050 & 315.053 & 1881. & $1,498,550$ & 493,624 \\
\hline $1872 \ldots$ & 684,075 & 310.211 & 1882. & $1,58 \cdot .530$ & 628,887 \\
\hline $1873 \ldots$ & 761,428 & $=91.734$ & 1883. & $1,878,944$ & 749,917 \\
\hline 1874. & 843,960 & 3.345. & & & \\
\hline
\end{tabular}




\begin{tabular}{|c|c|c|c|c|c|}
\hline YEAR & CATTLE & SHEEP & YEAR & CATtLe & SHLер \\
\hline $188 t$ & $1,81 \%, 69 \%$ & 801,630 & $189 \%$ & $3,571,796$ & $2,145,079$ \\
\hline 1885 & $1,905,518$ & $1,003,59 \mathrm{~S}$ & 1893 & $3,133,406$ & $3,031,1 \% 4$ \\
\hline 1886 & $1,963,900$ & $1,008,790$ & 1894 & $2,97 \pm, 363$ & $3,099,725$ \\
\hline $188 \%$ & $2,382,008$ & $1,360,862$ & 1895 & $2,588,558$ & $3,406,739$ \\
\hline 1888 & $2.611,543$ & $1, \tilde{5} 15,01 \pm$ & $1896 \ldots$ & $2,600,176$ & $3,590,655$ \\
\hline 1889 & $3,023,281$ & $1,832,469$ & $189 \%$ & $2,55 \pm, 92 \pm$ & $3,606,640$ \\
\hline 1890 & $3, \pm 8+, 280$ & $2,182,66 \%$ & 1898. & $2,480,89 \%$ & $3,5 \$ 9,439$ \\
\hline 1891 & $3,250,3,59$ & $2,153,537$ & T'otal & $|56,850,960|$ & $40,866,855$ \\
\hline
\end{tabular}

It will be observed from the above table that, while the receipts of cattle, at Chicago, increased from 393,007 in 1866 , to $2, \pm 80,89 i$ in 1898 , or a little more than six times; those of sheep incr zased from $20 \%, 98 \%$ in 1866 , to $3,589,439$ in 1898 , or over seventeen times.

\section{INGORA VENISON.}

It took a long time to bring the sheep into the prominent position it now occupies upon our markets, though the English recognized the superior qualities of the meat at a very early day.

The prejudice against the coarse, common goat has had a tendency to restrict the use of Angora venison, owing to the fact that the animals have usually been classed together as goats, but they are not at all alike, which is clearly shown in the sale of their skin for tanning into leather. The skin of the common goat is coarse grained and thick, while that of the Angora is very thin, and fine grained, and is not at all suitable for leather. The difference in the quality of the meat is still greater. Angora venison being as much superior to the common goat as the Pelgian hare is superior to our wild native jack rabbit. 


\section{CHAP'TER XVI.}

IS THERE ANY DANGER FROM OVER PRODUCTION?

The one element, in agriculture, to be dreaded above all others is "over-production."

The losses sustained by farmers from all our severe drouths and overflows, are as nothing compared with those from this single cause.

In the past thirty years, the value of cotton has been dragged down from fifteen cents per pound in 18\%0, to about six cents (and it was down to four and one-half in 1898) in 1899, a depreciation of $\$ 45.00$ per bale, or nearly twice as much as the entire bale of cotton is now sold for; and the shrinkage in the value of wheat has been no less severe.

The cause of over-production is due to a scramble among farmers to raise the most salable products. When cotton meets with favorable demand, every farmer is anxious to grow as much as he possibly can the following season, and the result is a glutted market and decline in price.

Remedy, after remedy, has been suggested, to regulate matters, but as yet nothing of a practical nature has been found. If it were possible to control acreage, there would be no trouble in solving the problem, for the farmer would then have an organization in the nature of a "trust," which would enable him to supply the demand, with as much, or as little as was wanted. But this is not practical, and, it is doubtful, if there will ever be any remedy for this terrible evil to agriculture until the nonproducing class of our population is so largely increased as to create a greater demand for farm products than the acreage will justify. That this time will be reached sooner or later, there is 110 doubt, but it is too far removed from the present sufferers to admit of serious consideration. 
Dizersification of products is, nerhaps, the most practical system for a farmer to operate on, and in this new branch of agriculture, which it is my privilege to call attention to, I think we have a product that is as free from the danger of over-production as any that I know of.

The annual yield of mohair in the United States, at the present time, amounts to about 800,000 pounds; and the demand from our manufacturing industry $2,000,000$ pounds, which will admit of an increase in our supply of $1,200,000$ pounds, requiring an increase of 400,000 head of goats having a shearing capacity of three pounds each. It will take but a few years to cover this gap, and in all probability the supply of mohair will sooner or later exceed the demand, and the market price be forced down under the inexorable law of supply and demand, the same as in our cotton and wheat products. But, we have a safe-guard in this new industry, which does not exist in any other branch of farming. There are three outlets for the product, either of which can be supplied that offers the greatest inducement.

One is through the manufacturer, for mohair.

One is through the butcher, for meat.

One is through the furrier, for pelt.

As long. as it will pay to produce mohair it can be done; but, if the price should decline to an unprofitable point, the animal can be fattened for market, and sold to the butcher, and the pelt to the furrier, which will correct the evil of over-production, and restore a fair market value for mohair.

The demand for the product, from either branch I have. mentioned, is quite large enough to support a great number of goats.

In mohair, we have the world before us, and a constantly increasing application for the product.

In meat, we have an unlimited clemand, at a price that will always afford a satisfactory profit in raising the animal, more especially when the skin, or pelt, is taken into consideration.

The pelt supplies a denuand from the furrier, which I have made the subject for a separate chapter (No. XIII). 


\section{CHAPTER YVII.}

TARIFF ON MOHAIR, LIVE GOATS, AND ANGORA SKINS.

The molair-growing industry has never received the attention from nembers of Congress that its importance to the country would seem to justify.

It was first placed upon the tariff, by the act of August 30. $18+2$, when a duty of one cent per pound was placed upon "'Thibet, Angora, and all other goats' hair, or mohair, unmanufactured." See S. L.. Vol. 5., Chap. CCLXX.

The act of July $30,18 \pm 6$, changed the duty to twenty per cent. ad valorem. See S. L., Vol. 9., Chap. LXXIV.

The act of March 2,1861 , levied a duty of nine cents per pound on "Hair of the Alpaca, goat, and other like animats," if it exceeded 24 cents per pound in value at the place from which it was exported. See S. L., Vol. 12, Chap. L.XVIF1.

By the act of June 30th, 186t, the tariff was changed to read as follows: " *** on all hair of the Alpaca, Goat, and other Like Animals, *** exceeding thirty-two cents per pound, twelve cents per pound, and in addition thereto ten per cent. ad valorem, making the duty equivalent to a trifle over fifteen cents per pound. See S. L. Vol. 13, Chap. CLXXI, Sec. 4.

The act of March 2nd, 186\%, divided "all Wools, Hair of the Alpaca, Goat, and other Like Animals," into three classes, for the purpose of fixing the duty to be charged, to-wit:

Class 1. Clothing wool.

Class 2. Combing wools.

Class 3. Carpet wools, and other similar wools.

The hair of the alpaca, and goat, were placed in class 2 , and the duty was made, ten cents per pound, and eleven per cent. ad- 
valorem, when of the value of thirty-two cents per pound of less; and above thirty-two cents per pound, the duty was to be twelve cents per pound, with ten per cent. ad valorem added," which was, practically, the same as the duty in the former tariff See S. L., Vol. 14, Chap. CXCVII, Sec. 1.

By the act of March 3rd, 1883, the tariff was again altered, so as to reduce the duty on goat hair to "ten cents per pound when of the value of thirty cents per pound, and twelve ce.i's per pound when the value should exceed thirty cents per pound." There was no ad valorem duty connected, as in the act of 1867 which practically reduced the tariff on mohair about three cents per pound. But, the most significent change in this tariff, was that of arranging the duty according to the conditions in which wool, alpaca, and goat's hair, was imported. If it was imported in its "natural condition," the above duties of ten, and twelve cents, respectively, were to be paid: but, if imported in a "washed" condition, the duty was to be double, or twenty and twentyfour cents per pound ; and, if "scoured," it was to be three times as great as if it were to be imported in its "natural condition," which would be equivalent to "thirty cents per pound on wool of a value of thirty cents per pound, and thirty-six cents per pound when the value exceeded thirty cents per pound." See S. I., Vol. 22, Chap. CXXI, Schedule K.

The act of October 1st, 1890. levied a specific duty of "twelve cents per pound on goat's hair, alpaca, and camel's hair," making the same provisions as in the act of 1883 , for wools and hair, that are imported in a different form than the original condition. See S. L.. Vol. 26, Chap. 1244, Schedule K.

The tariff act of August 27th, 1894, under Mr. Grover Cleveland's administration, placed wool, and goat's hair, upon the free list, and the succeeding administration of $\mathrm{Mr}$. Wm. McKinley restored it to the tariff, together with wool, and other animal fibres, imposing a duty of twelve cents per pound, with the same terms respecting conditions, etc., as in the act of 1883 and 1890 , which is in force at the present time.

The general purpose of the tariff, of course, is to obtain a necessary revenue to support the government upon, and from 
a review of the foregoing extracts from our several tariff laws it is quite evident that mohair has never attracted the attention of Congress in any other sense than as a revenue-producing article. The fact that it has always been classified with the "hair of the camel, alpaca, and other like animals," neither of which have ever been introduced into this country, with a view of propagating the animal, for their hair, is prima facie evidence of this. But, there is another purpose in the tariff, as I understand it, which is, to foster, and encourage, such industries as our country is capable of carrying on successfully, and I think the experience of the past thirty-eight years in the United States: has clearly demonstrated the wisdom of such a policy. If the United States is capable of producing an article it is certainly great folly to purchase it abroad; and, if we are capable of producing mohair, there is certainly no sense in buying it from Turkey, or South Africa. The American farmer is entitled to the revenue from this branch of agriculture, and it is an injury to the country at large if we do not produce it upon our own soil.

The question to be considered then, is: "What amount of duty should be placed on mohair?"

As a rule, the tariff upon all products is governed by the cost of producing it in other countries, and is adjusted so as to place the United States producer upon an equal footing with the most favored nation on the globe. For instance, wool can be produced, and sold, profitably, in some countries for five cents per pound, whereas, the American farmer cannot produce and sell it for less than seventeen cents per pound; hence, unless a duty of twelve cents is levied upon foreign wool, it is evident the American farmer will not be able to compete in producing it, and will gradually drop out of the business.

As to the cost of raising moharr, I have no doubt the present tariff of twelve cents is quite enough to equalize this country with both Turkey and South Africa (the only competing points that we have), but it should be borne in mind that we have but a small number of mohair-producing goats, and if we expect to develop the industry rapidly, we will be compelled to grade $1 \mathrm{p}$ 
the common goat, which will require several years of patient labor, with little or no revenue, before we can produce much mohair; and, to encourage farmers to undertake this tiresome task, some additional duty should be levied that will satisfy then they will be compensated for the delay in grading up the animal to a revenue producing basis.

There is, perhaps, no product on our tariff that can so easily support a high duty as mohair, for it is consumed altogether by the rich, and largely by wealthy railroad corporations for plush coverings to railroad coaches, who can well afford to pay a liberal subsidy to the hard working farmers of our country.

Another view to take of this matter is the spinning capacity of mohair, as compared with other fibres, which are on the tariff. Wool pays a duty of eleven cents, in its "natural condition," and when "washed," it pays twenty-two cents; and, when "scoured," thirty-three cents per pound. One pound of mohair in its "natural condition" will go nearly as far as one pound of "scoured" wool, owing to the fact of there being no grease in mohair.

If "scoured" wool pays a duty of thirty-three cents per pound, it wonld seem to be only fair to make the tariff twenty-five cents on mohair, which would be only a trifle over what is now paid on "washed" wool; and, I feel certain that a manufacturer will spin as much working yarn from a pound of mohair, in its "natural condition," as he will from a pound of "washed" wool.

The present duty on siik (raw) is forty cents per pound. Mohair is largely used to mix with this fibre, and it is often very hard to detect the adulturation.* Indeed, it is so very closely related to silk, in general appearance, that a tariff of twelve cents on one, and forty cents on the other, would seem to be entirely out of proportion.

Still another reason why the govermment should aid in developing this industry is, because the Turkish government,

*Dr, Hayes says: "Mohair yarn is employed largely in Paris, Nismes, Lyons, and Germany, for the manufacture of laces, which are substituted for the silk lace fabrics of Valenciennes, and Chantilly." (See Hayes, p. 39.) 
at the present time, prohibits the exportation of any of their mohair goats, and the breeders in Cape Colony, South Africa, have recently had an act passed by their Colonial Parliament placing an export duty of $\$ 500.00$ upon those that they have in their country. This will practically force the American breeders to rely upon the limited number of Angora goats that we now have in the United States, which, however, will be quite sufficient to build up a very large industry, provided the business can be made profitable to the present owners of stud flocks, which can only be accomplished, however, by encouraging others to improve the common (Mcrican) goat, a course that was taken by South African breeders in the early days of their industry, with the Bocr goat of that country.

In addition to the great benefits that will result to our country from mohair, as a textile product, it will add to our supply of meat producing animals, which will have a tendency to keep the price of this product within reach of many of our poorer classes, who are being taxed severely now, owing to the scarcity of beef.

It is to be hoped that Congress will take a liberal view of this subject, and give such encouragement to the producers of mohair as the industry is worthy of.

\section{TALIFF ON LIVE GOATS.}

In connection with this subject, it would probably be well for Congress to remove the present import duty on the common Icrican doe goat, when imported for the purpose of crossing with the Angora.

Our present supply of Mexican goats is limited, and the value of them will naturally be greatly enhanced under active competition from farmers, who will, doubtless, be attracted to this new industry, which will result in benefit to very few, while the removal of the duty, altogether, will benefit a great many and will greatly facilitate the development of our mohair-growing industry.

"All other live animals not specially provided for in this act, twenty per cent. advalorem." 
The present tariff prevents the importation of these animals rxcept upon the payment of a duty of twenty per cent. advalorem, under the following clause in Schedule G:

It is true this is not a high duty to pay, yet it will encourage the importation of many of the Mcrican does if it is removed altogether, and will lay the foundation for a much more profitable and useful animal. It can in no way conflict with the interest of any of the producers of goats in the United States; but, on the contrary, will creatc a demand for thoroughbred, or full-blooded Angora sires which will be required for grading up these common goats, and this will result in much benefit to a large number of the present breeders of the Angora goat who are now members of the industry.

\section{TARIFF ON GOAT SKINS.}

The present tariff on Angora goat skins is as follows:

"The duty on wools on the skin shall be one cent less per pound than is imposed in this schedule on other wools of the same class, and condition, the quantity, and value, to be ascertained under such rules as the Secretary of the Treasury may prescribe." (See Schedule K, Clause No. 360, Tariff law 1897.)

The above action was, doubtless, intended to protect the raisers of Angora goats from the importation of mohair, on the skin, by manufacturers, which was very proper. But, there is another trade into which the skin of this animal enters very largely, which is of vastly more importance than that of the manufacture of mohair.

I refer to the making of carriage robes, buggy robes, floor rugs, overcoats for men, etc.

This trade does not give employment to very many of our people at present, which I shall endeavor to explain later on, but it can be made to do so, for the magnitude of the business is simply inmense, and may be surmised when I say there is hardly a house furnishing, or saddlery store, in the United States, that does not handle more or less of these goods.

The Angora slin is, perhaps, more suitable for making this class of stock than any other kind, but the supply of them is 
not large enough to meet the demand, and they are more expensive than some other varieties of long-haired goats raised in China, India, Persia, and other portions of Asia, consequently these are used as a substitute. These have a coarse, outer-hair, with an under-down, or fur, which is fully described in the paper I have added concerning the Cashmerc goat (see Appendix), and cannot, therefore, be classed as mohair skins, which admits of their being brought into this country at a very low rate of duty.

Indeed, they are permitted to come in frec, if they are inported in a raw state, which is provided for in the tariff, as follows :

“*** Skins, of all kinds, raw (except sheep skins with the wool on) free. ***" (See Free List Clause No. 664, Tariff Law, 1897.)

But the labor of dressing them in the United States is so much more expensive than in Asia that they are always imported in a finished condition, ready to be made into robes, rugs, and garments, as soon as they are received.

The tariff does not seem to have provided specifically for "goat skins, dressed, with the hair on," but, under the schedule referring to "leather, and manufactures of it," says :

*** * dressed kangaroo, sheep and goat skins * * * 20 per cent. ad valorem. * * *" (See Schedule N, Clause No. 438, Tariff Law of 1897.)

Which appears to be the only clause that these dressed Asiatic goat skins can be classed under.

When we consider the low price at which such skins are sold (for they are not desirable for making into leather), and the very low scale of labor that is paid in China for dressing them, the duty of twenty per cent. ad valorem will not exceed more than five cents per skin, which practically amounts to nothing to the American importer.

If, for no other reason than to protect American labor, the tariff on these goat skins should be revised.

But, I maintain that, the American producers of Angora goats are made to suffer serious loss by permitting this inferior 
class of stock to be sold in competicion with their own product, which is often represented as being one and the same, and very nany people do not know any thing to the contrary.

I was attracted not long ago by the advertisement of a large department store in Chicago, who claimed to have "real Angora goat skin rugs" for sale, and being interested in the business I called upon them and was shown a "white Chinese goat rug," for which they asked $\$ 4.00$.

I remarked to the clerk that I wanted an Angora goat rug, when he frankly said they did not have any, and added: "A real Angora rug. like this one, would cost you $\$ 8.00 . "$

The following is the style used in advertising these "Chinese goat" rugs :

"China goat rugs, made in designs : $s$ shown in cuts $\mathrm{A}$ and $\mathrm{B}$. The combination of colors are black and white; black and gray; white and gray; or red fox and white. These rugs are lined and odorless, and landsome enough for any room. We also have the same rug plain, or solid colors, white, black or gray." (See Montgomery \& Ward's catalogute, Chicago, I11.)

It seems to me, it is an outrage upon American labor and enterprise to permit this tariff to remain as it is. The American furrier is entitled to the labor of dressing these slins, and the American grower of Angora goats is entitled to the sale of the raw skin. They are both entitled to protection from such unfair competition; and, while it is quite true the grower's are not able; at the present time, to supply the demand that exists for such a product, they very soon can be; but, as long as the tariff will admit of the Chinese product being imported at such a ridicuously low duty, as above stated, the American product will naturally be depreciated in value.

But, another view to take of this matter is, who are the beneficiaries under existing conditions?

The entire trade, I understand, is monopolized by a single concern, or syndicate, in New York City, who guard it with such a jealous care as to keep out all competition. If any one dares to engage in it (which has been done on several occasions) they immediately reduce their price list to a point that will force the daring adventurer to sell his importation at a loss, and 
the result is that, this single concern have managed to enjoy all the benefits from a trade that should be national in character.

The present duty of tionty per cont. advalorem, as I have endeavored to explain, amounts, practically, to nothing. It should be made spccific, and placed at such a point as will equalize the cost of dressing a goat skin in the United States, with the cost of dressing one in China; and, while the raw skin of the Chincsc, or Asiatic, goat is not the equal of the Angora, they belong to the same species, and should be classed as the same, when they are used for the same purpose, viz: that of making robes, rugs and garments.

It would seem, therefore, if the tariff was so revised as to compel these importers to pay aduty, equal with the present duty paid by the manufacturer, who may import the skin for the purpose of cutting off the mohair to use in manufacturing, it would be more just, and reasonable, to all concerned.

On this hypothesis, the duty would be, assuming the skin will shear: four pounds of mohair:

Duty of 12 cents per pound, on four pounds mohair...\$.48 Difference in labor, of dressing a goat skin in this country,

with that paid in China, say ............. .52

Or, a total, on each skin of .............. \$1.00

This would afford a fair degree of protection, both to the American laborer, and producer, and would not injure the consumer, inasmuch as the importers of these Chinese, or Asiatic, goat skins, demand a price equivalent to American labor for dressing, and producing the skin in the United States, as soon they pass through our custom house. 
PI.ATE XXXIX.

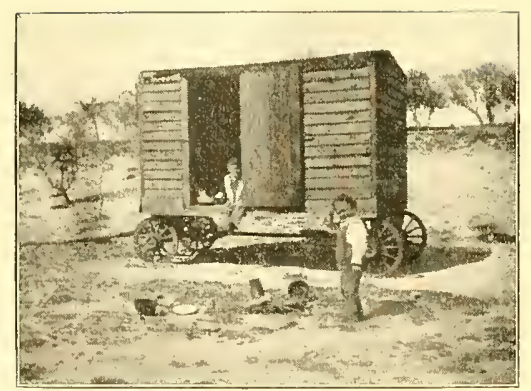

POR'TABLE CAMPING OUTFIT.

Made of plank; a substitute for the tent, when flocks are moved to different ranges. 


\section{Practical Parts}

$$
\text { of the }
$$

\section{Industry.}




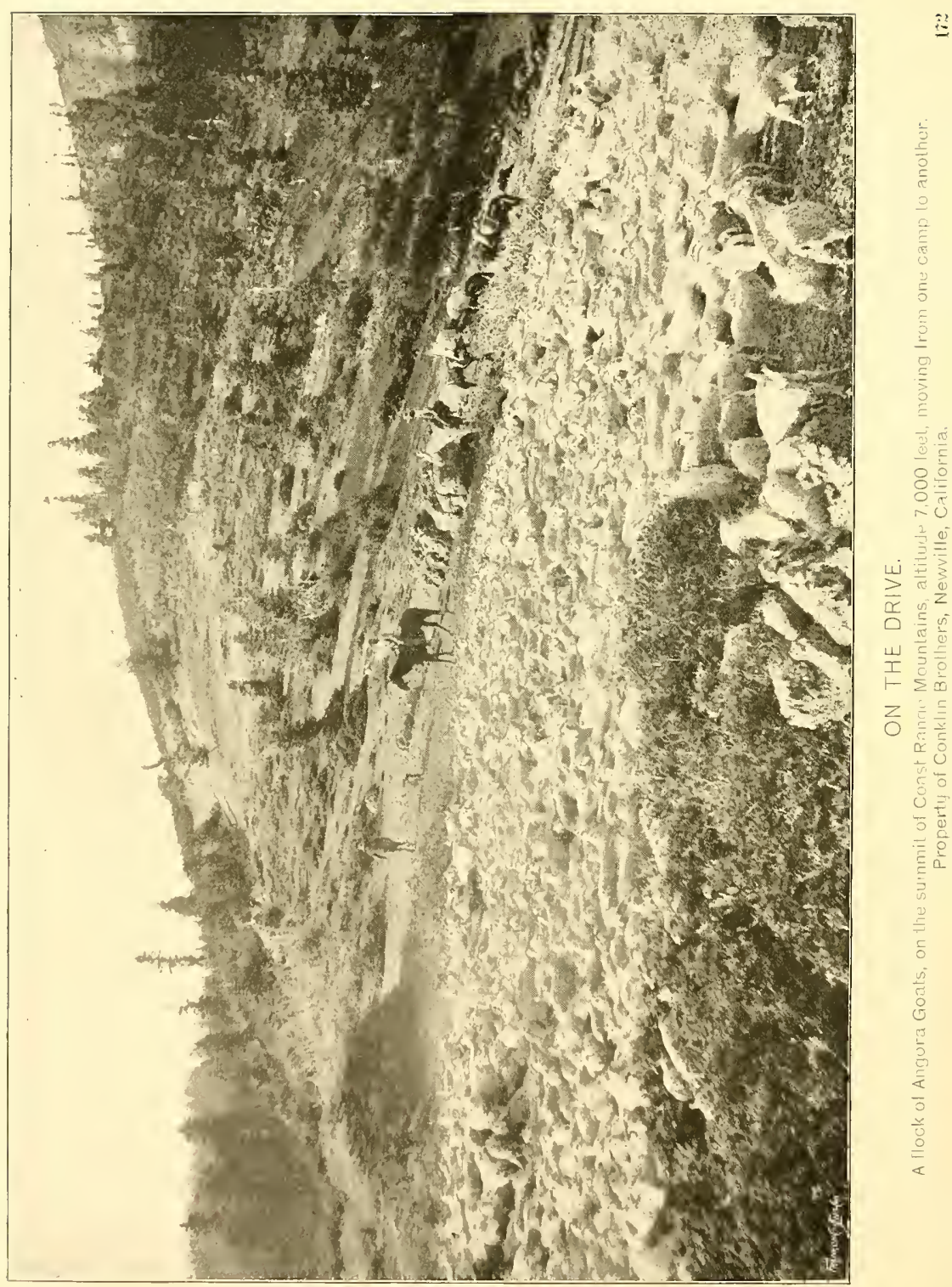




\section{CHAP'TER XVIII.}

THE SCIENCE OF BREEDING, OUR PAST EXPERIENCE, AND THE RESULT OF CROSSING THE COMMON GOAT WITH THE ANGORA.

The science of breeding any of cur domestic animals is, simply, knowing how to mate them, in order to obtain such a type as the breeder is wanting to produce, and this knowledge can only be acquired through a series of experiments coupled with the very closest observation.

During the past hunderd years, certain well defined principles in mating have been established that have assisted the breeders of the horse, cow, and sheep, in bringing these animals up to a very high degree of perfection. The principle of "like begets like," for instance, teaches a breeder that, by the selection of animals of any particular size, form or color, it is possible, in the course of time, to create a distinct type, or breed, very different from the original. Upon one occasion, in referring to the wonderful change that had been made in the sheep of Great Britian. Lord Sommerville is said to have remarked that :

"The modern sheep breeder appears to have drawn a perfect form, and then to have given it life."

The same might be said, in speaking of the horse, the cow and the hog, for there has been a great variety of breeds in all these animals, practically created by man in the past century, and in fowls and vegetables, the changes have been no less surprising.

There is, perhaps, no animal so susceptible of being improved as our common short-haired goat; but, this principle, or law of, "like begets like," does not seem to operate the same 
with it, as with other wool, or hair producing anmais. Fo: example: the mating of a long, coarse-wooled ram with a short, fine-wooled ewe sheep, will result in producing a medium wool, both as to length and fineness of fibre; while the mating of a long, coarse-wooled buck, with a short-haired common doe; goat will produce a kid having a thin covering of short, but pure, mohair, together with more or less of the coarse, short hair of the mother. In other words, the two kinds of hair will not mix with each other, as is the case with the sheep. And, very strange to say, it does not appear to make any difference how coarse, or how long, the hair of the mohair goat may be, the cross will always have the same thin covering of pure mohair, of a short, uniform length, and much finer in fibre, than that of the sire.

The only explanation I can advance for this strange condition of things, is that, the flesh and blood (the soil, and fertilizing elements, of the fleece) of the mohair goat are of an entirely different character from that in the common goat; and, the production of this thin covering of pure mohair is an indication that only a certain amount of the mohair-producing blood has been implanted by the one cross; for, it seems to be increased by a second cross, and the fourth, and fifth, crosses, will make the two animals of the same nature, at least as far as outward appearance shows.

The cxperiment has never been made, that I know of, but I am well convinced that if a mohair goat, producing a coarse hair, should be mated with a mohair goat of equal purity, producing a fine hair, the issue will have hair the medium of the two; and, the length of hair, I am sure, can be gradually increased in the same way, by crossing a long-haired buck with a shorthaired rloc, the same as with sheep.

But, as before stated, the only way we can ever hope to arrive at anything like scientific knowledge in breeding the Angora goat, is by experiment and observation. If breeders will exercise the same degree of interest, and intelligence, as their predecessors in the sheep industry have done in improving that animal, there is no doubt we can make some wonderfu! 

changes in the Angora goat in a comparatively short time; and, perhaps, if we were to investigate closely into the experience of those who have handled the animal during the past fifty years, we may be able to obtain a great deal of valuable information from their work.

In 1853 , Dr. J. B. Davis reported his first experiment with those he imported from Asia in 1849. He says:

"On my arrival, I immediately procured a number of our little diminutive native female goats, and crossed them upon a Cashmere buck. Their progeny had very fine hair, but little longer than that of the does. I again crossed the female of this progeny upon the other Cashmere buck, and it is difficult to distinguish these from the pure-breed, and the subsequent cross cannot be detected. In the spring I contemplate effecting still another cross." (See Agtl. Dept. Report for 1853, p. 20.)

And, in a letter to Dr. J. L. Hayes, Col. Richard Peters says:

"One of the most, valuable, interesting and remarkable traits of the Angora is the rapidity with which fleece-bearing goats can be obtained by using thoroughbred bucks to cross on the common short-haired ewe goats of the country. The second cross produces a goat with a skin valued for rugs, mats and gloves. The fifth cross (known by many breeders as "full blood") will yield a fleece not inferior to much of the mohair imported from Asia Minor. The fifth cross can be readily obtained in five or six years. Thoroughbred bucks should always be used, because the progeny of the so-called "full-blood" bucks varies greatly, and the upward progress is by no means satisfactory." (See Hayes, p. 51.)

All the early breeders in Texas, California, and Oregon, have met with the same uniform success except where the sire used was a graded animal, called "full blood," as Col. Peters remarks.

As may well be supposed the breeding of the Angora to the short-haired goat, has produced a very different class of animal from the original; and, as the same custom has prevailed in Turkey and South Africa, it is very doubtful if there are any of the original type in existence, at the present time, in the world.

Mr. H. O. Binns, a resident of Turkey, addressed a very interesting letter to Mr. Schreiner on this subject, relating to the crossing in that country, in which he says: 
"I cannot say when crossing began to be general. When 1 went to the Angora distrets in 186t, it was in inii swing, and must have been commonly practiced for sone years, as here were even then many more cross-bred goats than pure-bred. The lact that these cross-bred goats were in large number; and yiclded excellent hair shows that crossing had been generally resorted to a good many years back. Even at that time; the original pure Angora was becoming very rare. 'Today, he is probably extinct, or almost so. The districts outside the mohair-producing region were thronged with the "Kurd" goat. Angoras were introduced anongst the various flocks of these goats, which in due conrse were all graded up, and yielded white moheir. From inquiries made, I concluded that the Angoras were first generally crossed with the common goat when a large Furopean demand for mohnir sprang up, after ummanufactured moliair was allowed to be exported, and lustre goods became iashionable. I'the result is seen in the Angora of today, which is a product of the cross. 'The greatest endeavors 10 increase the numbers of Angoras and to produce them in other parts of the comntry, by means of grading up the common guats, were made from atout 1863 :o 1876 , when, not only the other district, where the Angora had never been before, were induced to buy rams to cross with the common ews, but so eager were the farmers, in Angora itself, to incresase the number of their mohair goats, that common ewes were actually imported into that, and ncighboring disricts, and graded up there by means of pure rams. No wonder goats became mixed, and the pure goat eliminated, replaced by his heavier-fleceed, more prolific, more remunerative cross. These endeavors were due to the great demanu iur mohair during these years, for the price per pound was never lower than 2s. 9d. (68 cents) except for a short time in 1868 , when it teuched 's.' : id. (56 cents) and was generally, at from 3s. $3 \mathrm{~d}$. ( 81 cents) to $3 \mathrm{~s} .9 \mathrm{~d}$. (93 cents). Thus there was a large increase, not only in the numbers of white mohair goats, but also in the area over which they were distributed. The common goat was then first graded up in such districts as Eskischehr, in Broussa, Soungourlou, in Yozgat, Devriken, and Tosia, in Kastamouni, and sundry other districts. So gencral has been the crossing that not only is the original pure Angora extinct, or almost so, in Asia Minor, today, but even in Eeibazar, one of the very purest districts, hardly a flock is to be found which does not contain one or more gray, black or white common ewes, and their various crosses.. Such common goats and the various grades between then and the modern Angora, are much more common in less central, less pure districts. Thronghout the whole of the molair districts, any ewe (or ram) which has originally come from a cross (and almost all have now) is liable to have colored, kemped kids, red. blue, black, or other colors; and in almost every flock in Beibazar, as well as in other districts, colored kids, the progeny of white sires and dams are to be found." (See Schreiner, pp. 83, 81 and 85.) 
The "Kurd" goat is described as a coarse, straight-haired animal, usually black, brown, red, of blue, in color, and much larger and heavier-boned than the Angora.

Crossing in South Airica was carried on very much in the same way with the common goat of that country (the "Boer"), which is represented by Mr. Schreiner as iollows:

"The 'Boer' goat of today strikes one as an animal peculiarly South Airican, as it browses on the arid kopies or the Great Karoo. It is a large animal with poweriul legs, a grand carriage: a bold, iree step, and will, prominent eyes. The coat is shot smooth and coarse. of almost any colo: of combination of coiors, frequently b ing dappled. It is extremely hardy, iatuens readily, and carries a lerge amount oi fesh, which, howerer, is pungent and strong: and unpalatable $20 \mathrm{z}$ refined taste. But, in upcountry districts, in desert-like parts of the Karoo, they are the most raluable for there they are often the only kind of stock fit for slaughter: as they keep iat when other stock are thin or die. In the early days the 'Boer' goat and the Afrikander sheep were the only small stock possessed by the colonists, and this goat was iusty held in high estimation by the old pioneers, Eo it increases with great rapidity (triplets at a birth being by no means inireguent and its skin makes rey superior leather. as is evidenced by the constant demand in the tanneres o: the Colony ioday" See Schreiner page 17?

\section{And Mr. Schreiner adis:}

"Such are the 'Boer' goats which here supplied the mothers of neerly 211 the Cape Angoras. The service they have rendered to the Angora industry of South Airice. is almost incelculable. But ior the fact that there were sereral millions of 'Boer' goats. thoroughiy accustomed to the country. to iumish innumerable ewes for grading-up purpos s, the indusiry would still have been in its iniancy. As it is, instead of increasing out Angores solely by breeding from a iew imported animais, re have been able, witin a Sew years. to grede up some millions from the good old 'Boe: goat motine stoc'- whose progeny, already outnumbering the mohair goats of Turkery and neary as well bred now yeld more Hat than Turkes of a quality on the whole nearly equal to Turkish und in many instances quite equal to the rey best that Turker can produce." See Schreimer. pages 171 and 10\%.

Hence, it would seem that the Angora goats oi the present ime. in the only three countries where they are being propagated to any extent, consist oi a cross-bred animal, as iollows: In Turkey, with tine biack, zed, or bive, "Iurd" goat. 
In South Africa, with the short-haired, mixed-colored "Poer" goat.

In the United States, with the short-haired, mixed in color, "Mexican" goat.

It is quite true that, the progeny, from all the above crosses, presents the same general characteristic as far as relates to the producing of mohair; but, to a close observer, it is evident there is great difference in the length, and fineness, of the fibre, some of it growing twelve to fifteen inches, while others only reach the length of six to eight inches; some of it is very coarse in fibre, and others very fine; some have wavy hair, while in others it hangs in beautiful ringlets.

The same relative difference exists in our sheep family with reference to wool, and it would be very surprising if such was not the case with mohair, for, with the indiscriminate crossing that has been going on for the past forty or fifty years, it would be a most remarkable phenomenon if the Angora goat had retained its original purity.

As far as I have been able to learn, there has never been any endeavor to improve the animal beyond that of raising the greatest possible amount of fleece. The size and form of carcass appears to have had little or no influence with breeders: and, as long as the one feature, mohair, was not lacking in quantity, any goat was considered proper to breed.

From the illustrations in Mr. Schreiner's book on the South African industry, it is quite evident a very great difference exists, even in the selected animals that he has used to represent the type of the South African Angora.

The C. G. Lee goat, for instance, on page 119, with its straight back, and w1niform growth of fleece, is as different from the one bred by Mr. R. Featherstone (page 105), as the difference is between two types of Merino sheep. Both are very superior animals no doubt, yet, after reading a description of the C. G. Lee animal, it is quite clear they belong to very different species, and should not be classed together. And, on page 145, are two very handsome young Angora bucks, bred by John Rex, and the late J. B. Evans, which show very different points. One has 
Brecding-Past Ex.pericnec-Result of Crossing the Angora. I8I

a very full tuft of mohair on the forehead, while the other is perfectly bare on the forehead.

Referring to the Lee goat, Mr. Schreiner says: "Mr. C. G. Lee certainly possesses some of the purest, finest, and most remunerative goats in South Africa. He recently wrote to the 'Eastern Proince Herald,' remarking upon the undergrowth in his goats, adding that it is the finest, and most valuable part of the fleece, being used by manufacturers in the place of silk." See Szhreiner, page 101.

Writing about the difference in the Angora goat of Turkey, Mr. Diehl, in inis report to the Agricultural Department in 1863 , says:

"There is also a second, or other, variety of Angora, or shawl wool, goat besides those generally described. This goat has an unchanging outer cover of long, coarse hair, between the roots of which comes in winter an undercoat of downy wool that is naturally thrown off in spring, or is carefully combed out for use. A remarkably fine species of this breed exists throughout the area to which the white-haired goat is limited, and similar br eds prevail all over the highlands of Turkish, and Persian Armenia, Koordistan, and at Kirman; and, although some flocks yield finer fleeces than others, it is called the same wool, or underdown, as the wool of Cashmere and Thibet, and samples of the wool of the Thibetian, and the double-wooled goat of the banks of the Euxine show them to be but varieties of the same species.

"This goat is of a larger size than those of the more southern Turkish provinces, and its wool finer, and is probably the variety introduced by Dr. Davis from Asia Minor as the 'Cashmere,' and now erroneously so-called throughout the country, as all the importations to this country, as far as we can learn, were shipped from ports on the Mediterranean, or Constantinople, several thousand miles from Cashmere, or Thibet, through inhospitable and almost untravelled countries for Europeans, which gous far to prove the so-called 'Cashmere' goat to be the 'Angora." See Agtl. Dept. Report for 1863, page 223.

(If we are to understand from "unchanging outcr-cover of hair," mentioned above by Mr. Diehl, that it does not shed in the spring, it may explain, to a certain extent, the existence of a "non-shedding typc" of mohair goats which I intend to refer to later on.)

Mr. H. O. Binns states there are no less than thirty (Mr. Diehl says there are forty) different kinds of mohair produced in Turkey, but attributes it to diversity of climate. He says: 
"With such a wide diversity of climate, it cannot be expected that the mohair from the whole area will be of one uniform kind. In fact, about thirty different kinds are produced from as many different Tocalities. These localities I shall call 'goat districts.' The following table gives a list of these different goat districts. Each name is that of a locality which produces its own peculiar kind of mohair. It may be taken as a practically complete list of the principal goat districts. After each name there is indicated in brackets, whether it is a kaza, which gives its name to the goat district, or a town, a village, or merely a place where a weekly bazaar is held. The distances between many of the localities are given, as well as the distance of each from the town of Angora. These distances are only approximate, but are accurate enough for the purpose to which they are applied. Turkish roads are reckoned by hours, as at the Cape, and the Turkish 'hour' is stipposed to be three miles (at the Cape it is six.) This has been taken as the basis of computation in reckoning the various distances.

"It is at once apparent from this list that, as has already been said, the mohair area is practically comprised in the two provinces of Angora and Kastamouni; and, one is immediately struck by the fact, how short are the distances that separate many of the different goat districts from one another.

"In some of these goat districts there are district markets, where each of the leading mohair merchants has his agent: there are, Eskischehr. Sivrihissar, Beibazar, Ayash, Nallikhan, Geredeh, Cherkesh, Changura, Koniah, Sivas (and Van); Angora and Kastamboul being, of course, the two great markets. But every goat district mentioned in the above list is characterized by its own particular variety of mohair; the hair grown in each, has some special characteristic which enables an expert at once to distinguish it from all others.

"This seems strange, considering the short distances that the various centres are from one another; but there can be no doubt of its correctness, for all authorities are agreed upon it. For instance, Mr. Gavin Gatheral, in his paper, read before the Royal Colonial Institute in 1878, says that the mohair area (he makes it somewhat smaller than Mr. Binns) produces more than twenty varieties of hair, each of which is easily recognized by experts. Mr. Binns is very clear upon the point. He says that each district impresses some local peculiarity upon the hair grown in it. He adds: Goats in Turkey are constantly being sold round in small lots, so that an intermixture continually goes on. Nevertheless, though out of each of many parcels of mohair from every district in Turkey I could pick out many places which would so much resemble each other as to defy the best expert to tell which was which; yet, were lots of a few bales of the average mohair of each district placed in a row, and cut open at the side, any one of our Constantinople merchants could tell which was 
$\frac{5}{0} 0$
30
3
3

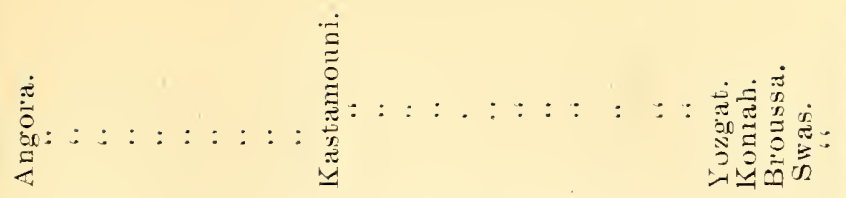

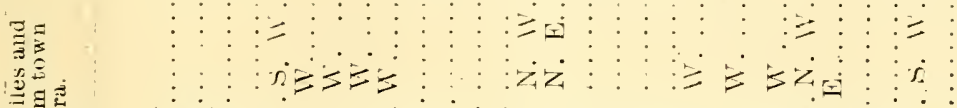

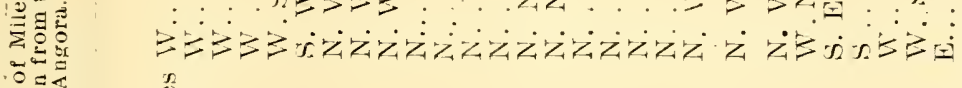

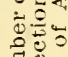

范 $\frac{\mathfrak{D}}{\stackrel{D}{\Xi}:}$

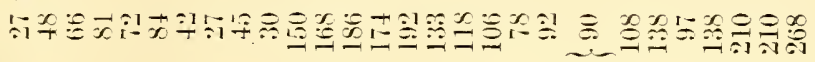

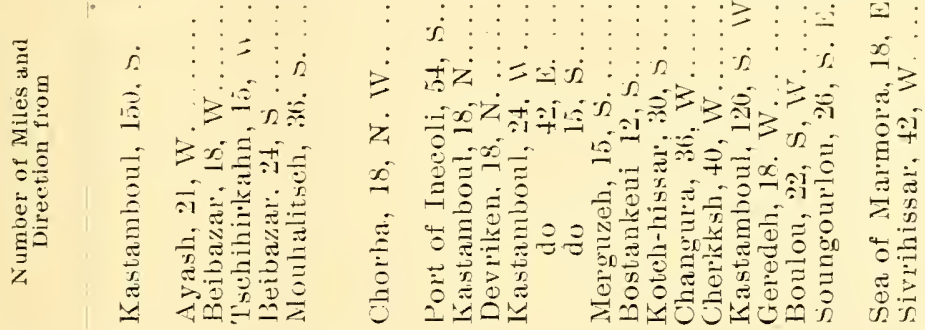

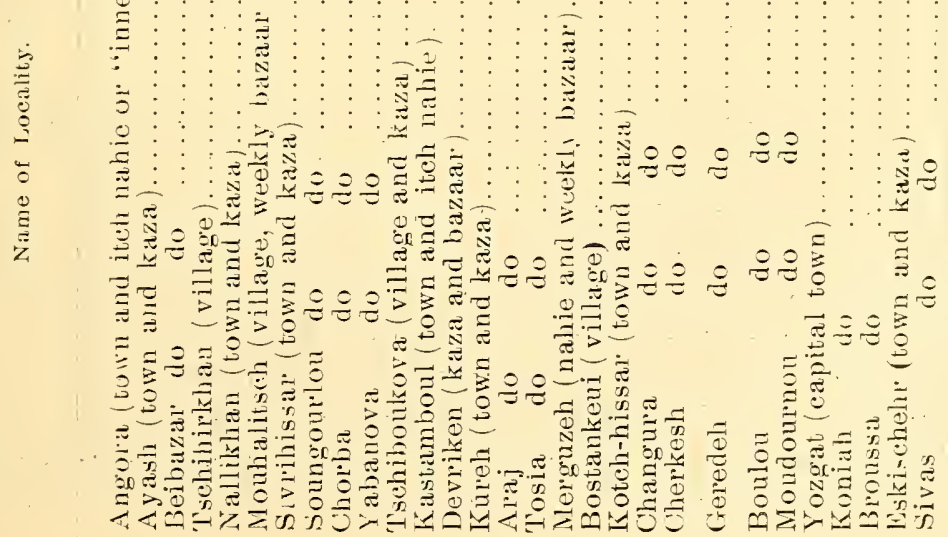


which. And we who have lived some years in the town of Angora, could tell whether a small lot came from Hymane, Elma-Dagh, Stamos, etc., though in some cases but a mile or two might separate the villages. But this, of course, the Constantinople merchants could not do.

"Again, regarding varieties of mohair (and necessarily of goats) he says: 'One cannot say they are exactly so many types, definitely fixng - he number, for there are endless subdivisions; but, a connoisseur in mohair can tell you, from the bulk of the bales, when opened, from which particular district it has come, provided it has been sent separately irom the purchasing centre town of the same name. Each district displays a general type of its own, yet, in each, or most of them, there are again other subdivisions from the class, or type, of which a local agent can always tell, in a moment, where the mohair originally came from.

"Again, each district has its own peculiarities in class of molnair sufficient to enable a mohair expert to tell at a glance from which district, or village, a parcel had come. But there is sometimes a difficulty on the Constantinople market in identifying a lot of hair with any particular district, for the hair obtains its name from the town from which it was sent to Constantinople, irrespective of where it was grown or purchased. Thus, the clips get mixed, many different kinds being ranked under one name, for the travelling agents go from village to village making their purchases and then lump the different clips together, and take the hair to the best market, under whose name all that lot of hair is henceforth known. Thus, if the Angora local market be higher than the Kastamboul market, the hair grown in the kazas, in the Ulgaz-Dagh mountains, goes there, and vice versa; and thus, a part of the same clip might one year be known as Kastamboul hair, and the next as Angora hair. It seems, therefore, clear that the only reliable testimony as to where the hair really is grown and comes from in the first instance, is that of the local merchants and buyers in the towns of Angora, and Kastamboul." See Schreiner, pp. 110-114.

This is certainly at variance with all authorities upon the subject of climatic influence on anmmals that I have ever read, and has been clearly disproved by the experience we have had with the Angora goat in the United States, which has been reared in nearly every State in the Union, in lowlands and highlands, in hot climates and cold climates, and there has been no perceptible change in the character of the fleece (except, perhaps, that some has a much smoother feel and more lustre than others), and I am inclined to attribute this great difference in the quality of mohair in Turkey, mentioned by Mr. Binns, 
rather to the course of breeding that has been followed, than to the influence of the climate. It is well known that the color of soil has a tendency to stain the fleece of an animal like a sheep or goat. It is quite possible indeed, for any one familiar with the different sections in Texas, to determine where certain wool was raised, by its color, or the dirt in it. I know, too it is claimed, that the West Indies, or any tropical climate, has a tendency to change the character of wool to that of hair, but I am not prepared to believe this until I see it.

There has never been any scientific effort to produce wool in any of our tropical climates, and, because the sheep that are raised in Mexico have a coarse, hairy fibre, is no evidence that the heat of that country is the cause. The Mexican is known to be a very careless breeder, generally permitting his stock to interbreed at will, and it is not unlikely, a large amount of this supposed climatic influence is chargeable to a want of system It seems to me if climate had any material influence upon the hair of an animal, it would have a similiar influence upon the hair of a human being, and, we all know, this is not the case, as for example, the African, and Asiatic, races, who continue to produce the same kind of hair the world over.

The Encyclopedia Britannica, Volume I, page 84, says:

"Animals, especially the higher forms, are much less sensitive to change of temperature, as shown by the extensive ranges from north to south of many species. Thus the tiger ranges from the equator to northern Asia, as far as the river Amour, and to the isothermal of 32 degrees Fahrenheit. Wolves and foxes are found alike in the coldest and hottest parts of the earth."

There is no doubt that a cold climate has a tendency to increase the quantity of wool that an animal produces, especially the sheep; and, the experience we have had with the Angora goat in the United States shows that it has the same influence on this animal. A warm cliniate, too, has a tendency to reduce the quantity of wool, or hair, but the quality is always the same in both climates; at least, such has been my observation with these animals in the United States. 
Food, in my opinion, has had more to do in shaping the outcome of an animal, than climate has ever done. Not many years ago, it was believed to be impossible to breed any of the improved kinds of cattle in Texas, but the experience of the past few years has demonstrated that they can, not only be produced as well, but can be fattened, to as high a degree, as in any of the colder States. This impression doubtless originated through the many failures of ranchmen who turned thoroughbred stock on the open range to hustle for their living with native stock. The result was, very naturally, disappointing; but. as soon as proper care was taken to get the animals accustomed to the change of food, they thrived quite as well as any of the natives did, and, in some instances, much better.

It is a well known fact that some cattle raised in Texas have been made to develop into larger animals by transferring then to the range of Montana, and other Northern Territories. This is, doubtless, explained by the more nourishing kind of grass the animals received in the Northern 'Territories and not by the change in climate. The best evidence of this is, that if a horse is kept up in the North, and another in the extrene South, fed and cared for in the same identical way, they will both present the same general appearance.

If climate has the effect to increase the size of an animal, why is it that in many parts of the South may be found larger men and women than in some parts of the North?

It is, in my opinion, the blood that makes both man and beast; and, if proper food is provided, the development of the frame will be governed entirely by the class of blood the animal has.

Water, I think, has more or less to do in the matter of development of both man and beast, and, when we reflect upon the wonderful medicinal qualities that water possesses, it is not at all unlikely that many of the failures in raising the higher grades of live stock in the South is due to impure water, as well as a poor class of food.

$1 n$ parts of Virginia, and Tennessee, native-born children grow to be larger, and heavier-boned, men, and women, in one 
County over those raised in the adjoining County, which is supposed to be caused by difference in water. Limestone existing in one, and freestone in the other.

That a very different kind of a goat from the original has resulted from these several crossings there can be no doubt In referring to this subject, Mr. Schreiner, quoting from Mr. Henry O. Binns, describes the

"Original pure Angora ram, in his prime, as about the size of a five months' old Cape kid, with small thin horns, wooled all over the body, the hair almost covering the eyes, exceedingly delicate, and so subject to disease that no one cared to keep him. What is today called the purebred Angora is like the English thoroughbred horse, the result of crossing and re-crossing, until body, class, points, etc., have attained to what is generally considered that the thoroughbred Angora ought to be. This pretty little animal did well to give $21 / 2$ pounds of hair." See Schreiner page 5.5.

And, referring to the effects of the crossing, Mr. Schreiner admits

"There is at tmes some considerable variation in the shape of horns. * * The ears, though the lop ears predominate there is much difference in their droop; and, in their size, 'mousc cars' being by no means infrequent; * * and such defects of covering, style of locks, etc., are evidently, in the main, due to the Angora having been crossed with the common goat, and to a less extent (at any rate in Asia Minor) with other varieties. Another different effect of crossing may be mentioned as of great importance, which is that the modern Angora often has two kids at a birth." See Schreiner, pages 103 and 101.

It is Mr. Schreiner's opinion, too, that,

"This breed which is not yet quite fixed, but is gradually tending to become so, is a larger, somewhat coarser, hardier breed, with an oilier and much heavier fleece, which, though, not attaining to the high level of that of the original pure Angora, is nevertheless, in the best specimens, of great beauty and excellence, and equal to the most exacting demands of the purest mohair manufacturing trade. ** The ideal goat in Turkey, today, has a leady-white tint of fleece, while, in the Cape, the tendency is towards straw color." See Schreiner, page 106.

\section{CASHMERE, OR ANGORA.}

In connection with the breeding of the Angora goat in the United States, it may be proper to state, that at least a portion 
of the goats that Dr. Davis imported in 1849, were of the Thibet, and Cashmere, breed, for he says, in his letter to the Agricultura! Department in 1853:

"I will now introduce the Thibet shawl goat, belonging to the coldest regions. I accidentally came into possession of a pair of these animals, but lost the male. I have a considerable increase from the female, bred with a 'Cashmere buck.' 'The 'Thibet'* goat has, under a long coarse hair, a coat of beautiful white wool, which when combed, makes about a pound to the fleece. I had these specimens with me at the Zoological Gardens in London, and, in comparing them with a stuffed specmen of a Rocky Mountain goat, I could not discern the slightest difference, nor do I yet see any change of the first cross of the 'Cashmere' buck upon my 'Thibet' doe, but in the third cross upon the 'Cashmere' we may expect a valuable experiment by changing the fine under wool or down, into a conjoint and uniform covering of wool.' See Agtl. Dept. Report for 1853 , page 21.

Bearing on this matter, the following letter from Col. Zimmerman Davis, Secretary and Treasurer of the Charleston Water Works, and a nephew of Dr. Davis, wilı be interesting.

Charleston, S. C., Sept. 8th, 1899.

Mr. Wm. L. Black, Ft. McKavett, Texas.

Dear Sir-I am in receipt of your favor of the 1st inst. in regard to the 'Cashmere' and 'Angora' goats imported by my uncle, Dr. James B. Davis, in 1849.

"I was a lad, fifteen years old, when my uncle and his family returned from Turkey, with the animals he imported. He staid for some time at my father's house here in Charleston, and the animals were kept in the yard. They were a small flock of 'Cashmere' goats, one large 'Thibet' and a Maltese Jack.

"The 'Thibet' goat had two qualities of hair, the coarser quality being the longest, the finer quality being under, and next to the skin. I remember that my aunt and her daughter would separate the two qualities by hand, so as to get a higher price for the flecce. I never heard the 'Cashmere' called 'Angora' by him.

"After a residence for some time in Charleston and vicinity, Dr. Davis moved to the vicinity of Columbia, S. C. and after some years he moved back to his original home in Monticello, in Fairfield county, where he died about the beginning of the Civil war. I remember that he, several times sold a trio (a buck and two ewes) for $\$ 1500.00$. He was also the first to cross the 'Cashmere' upon the native goat in order to make them

\footnotetext{
*See plate III.
} 


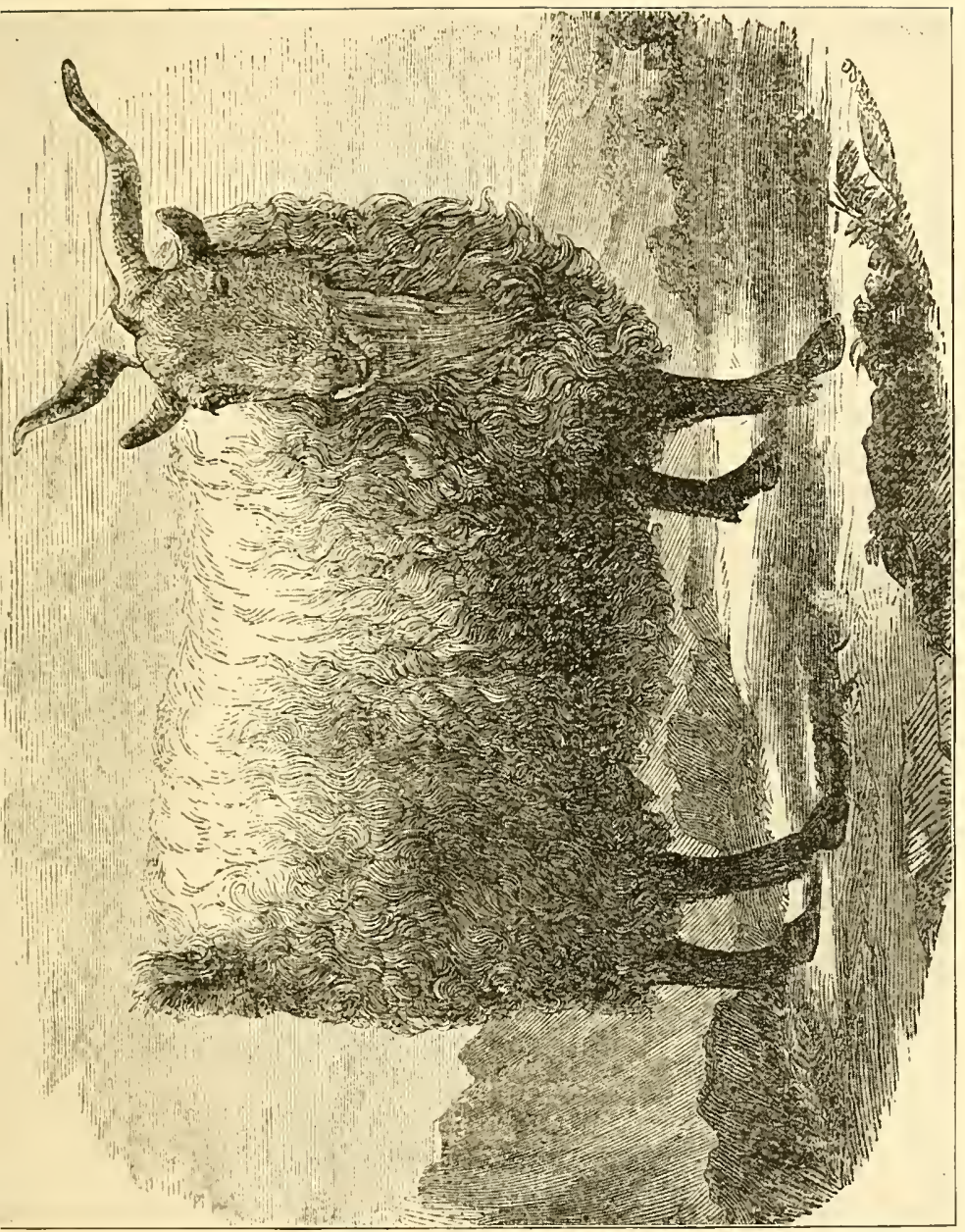

(

$=\quad 3 \frac{1}{3}$

山

西

$\sum$ का

I 0 ○

分 d

U is

$=$ वहत्त

- 흐효

I.

$\sum \begin{aligned} & 0 \\ & 1\end{aligned}$

ᄃ

ร

을

क त $\frac{1}{2}$

颌U士

他范

힘

क्ष

बa.

हूँ

पु.

$\Rightarrow$

空

邹

$\frac{1}{2}$ 

hardy and acclimated, and, I think that he considered the 'seven-eighths Cashmere' as good and hardier than the full blood. He sold out his entire stock to Col. Richard Peters, of Atlanta, Ga., previous to his death.

Yours very truly,

ZIMMERMAN DA VIS.

Dr. J. L. Hayes (1868) gives the experience of Col. Robt. W. Scott, of Frankfort, Ky., who was celebrated as a scientific breeder, and the creator of what is known as the "improved Kontucky shecp," who describes the animals he had "as having two coats of hair;" but, of a very different kind from the sort Col. Davis describes; and, as his goats came from the Davis imporlation, it is quite evident that a change had taken place in the character of the fleece they produced since he had been breeding them.

The following report on the "Davis goats" (then owned by Col. Richard Peters, of Georgia,) was made at the New York State Fair, held in New York City in 1854:

"The undersigned cannot avoid the conclusion, that in the goats imported, and whose descendants have been the subjects of this examination, we have the first known specimens of that valuable race of animals from whose hairy fleece the celebrated shawls are manufactured, known in commerce by the inappropriate name of 'red camci's hair.' As the fleece does not appear to have deteriorated in the comparatively warm climate of South Carolina, the distinctive character of the race is hard to be obliterated, while in the northern region of the United States, this character can not well fail to be permanent. Viewed in this light, the introduction of this animal promises to be of more value to the agriculture of the United Sates than that of almost any other domestic animal." See U. S. Agtl. Dept. 1863, page 228.

JAMES REN WICK,

JOSELH R. CIHLTON,

W. II ELLIOTT'

Here is an extract from a report of the special committe appointed by the "American Institue," at their exhibition in Nevi lork City, in 1855:

"They have examined with much interest the fleece subm:tted to them, and, as well from their own observations, as from the results of a microscopic examination made and certified to by several gentlemen of scientific eminence well known to them, are convinced that the fibre of these 
fleces is identical in character, and fully equal in value to that from which the highly prized Cashmere slawls are made. The fleeces on exhibition, and now under examination, amount to from four to eight pounds each. The enterprise cxhibited by the introduction of these animals into this country, and their propagation, cannot be too highly regarded.

First 'lhese animals are long lived. such being the case with the whole goat race.

Second. They are prolific, breeding at the age of one year, with a period of gestation of about five months and yielding twins almost universally after the first birth.

"'Third. They are harly, experience having shown that they will thrive well in onr climate from Ceorgia to New England, and that they require coarse and cheap food, as the inferior grasses, briers, bushes, ete., such as is refused by other grazing animals.

"Fourih. They produce a Heece of trom four to eight pounds, valned at from $\$(j) 00$ to $\$ 2.00$ per pound in France or Paisley, Scotland, for Whe manufacture of those high-priced shawls. These fleeces can be produced when the animals become numerous, at a less cost than the common sheep's wool, and far superior to it.

"Another fact of great practical value to our agricultural interests is the facility with which the Cashmere goats breed with the common goats of our country. From these, and other, considerations, of the correctuess of which your committe have entire confidence, it will be obvious that every encomagement should be shown this new enterprise-a bold, and judicions, movement." (Sec U. S. Agtl. Report, 1863, 1. 2.28.)

B. P. JUIINSON,

CHARLES J. GOODRIC[],

JAMES J. MAPLS.

IV a ald a few extracts from some of the various and valmable published reports made upon this subject, showing the interest it las attracted from time to time.

T'he following report on Cashnere goats was marle at the exhibition of the Lnited States Agricultural Society, held at l'hilaclelphia, l'a., in 18.56 , at which a special premitum of $\$ 100.00$ was awarted to Richard l'oters, of Corrgia: (From Diehl's paper on "lihe (ioat.")

"'l'hey hat become known as 'Cashmere' goats from the pure white color, and funcness of their fleces, and their undoubted Eastern origin. I'he Heeces from the matured bucks weigh from six to seven pounds, those from the ewes from three to four pounds. The flesh of the crosses 


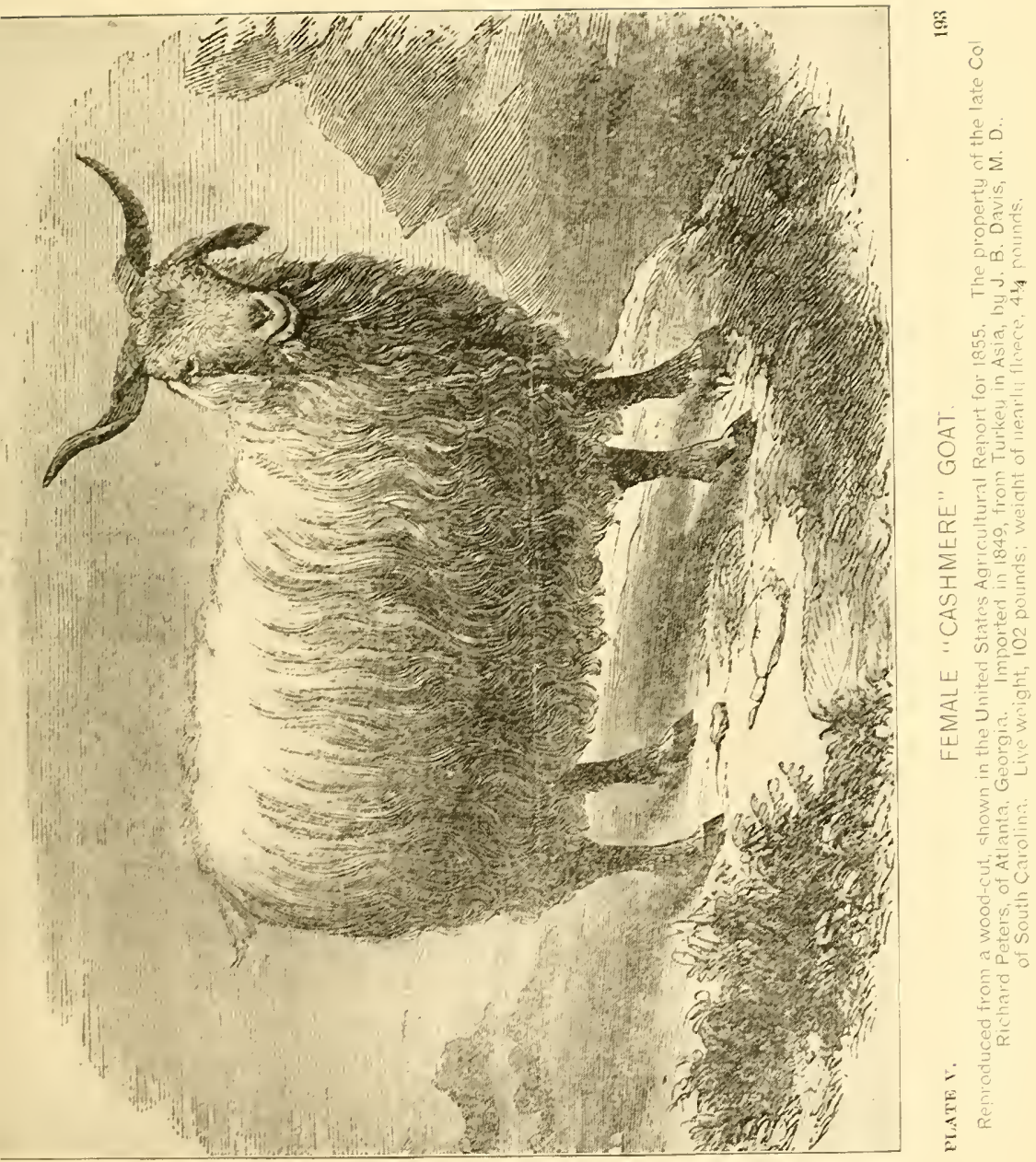



is superior to most mutton, tender and delicious, making them a desirable acquisition to o11r food-producing animals. The ease with which they are kept, living as they do on weeds, briers, browse, and other coarse herbage, fits them for many portions of our country where sheep cannot be sustained to advantage, while their ability and disposition to defend themselves against dogs, evidence a value peculiar to this race. They are free from all diseases to which sheep are liable, hardy and prolific, and experience has proven that they readily adapt themselves to all portions of the United States. The bucks breed readily with the common goats the second cross yielding a fleece of practical utility, whilst the fourth is but little inferior to that of the pure brced. A flock of valuable woolbearing goats can be raised in a few years, by using grade bucks." See Agtl. Dept. Report 1863, page 227.

In 1856, by a resolution of the Southern Central Agricultural Association of Georgia, a committee was appointed to report on the goats now in the possession of Mr. Richard Peters, of Atlanta, (these were the same goats referred to by Dr. Davis in 1853, he having sold them to Col. Peters in 1854) and in compliance therewith, presented through Dr. John Bachman, the eminent naturalist, of Charleston, South Carolina, their Chairman, an elaborate report, from which the following is an extract :

"Familiar as we have been through is long life with the changes produced by erosses among varietics of domestic animals and poultry, there is one trait in these goats which is more strongly developed than in any other variety that we have ever known. We allude to the wonderful facility with which the young, of the cross betweeen the male of the Asiatic goat, and the female of the common goat, assumes all of the characteristics of the former. It is exceedingly difficult to change a breed that has become permanent in any of our domestic varieties, whether it be that of horses, eattle, sheep, or hogs, into another variety by the aid of the male of the latter. There is a tendency to run back into their original varietics; hence, the objection to mixed breeds. But in the progeny of these Asiatic, and common goats, nine-tenths of them exhibit the strongest tendency to adopt the characteristics of the male, and to elevate themselves into the higher and nobler grade, as if ashamed of their coarse, lingy hair, and musky aromatics, and desirous of washing out the odorous pertume, and putting on the white liverv of a more respectable race. Mr. Peters has not bred any quarter-breeds. He made wethers of all his half-breed males, of 1856 , and sold his three-quarter blood bucks. $\mathrm{He}$ now owns 15 in half-blood females, seventy-five three-fourths blood 
females, and six seven-eighths blood females. He has also four females three-quarters Asiatic and one-quarter Thibet shawl. There appears to be no improvement in this mixture with the Shawl goat, over that produced by a union with the common goat; indeed, the product which we saw in Charleston from what was called the 'Cashmere,' and the Asiatic goat, was decidedly inferior.

"The half-bloods, as we have stated, have an undercoat of fine, downy wool, closely resembling and equal in quality, and quantity, to the fleece of the 'Thibet Shawl' goats imported into this country. The three-quarter breeds in mid-winter show an undercoat of greater quantity and length. In both grades this under-fur drops out in summer. The fiteen-sixteenths, or one-sixteenth common goat resembles the Asiatic goat in quantity and quality of fleece and size of carcass so closely that we found it impossible to distinguish them from the full-bloods. Another advantage is likely to result from this admixture with the common goat: The half-blood females produce two kids at a birth, and the three-quarter blood females, generally, althongh not always, two. Thus the breed may be rendered more prolific. We here perceive in how short a period of time our whole race of now almost worthless goats may be converted into a breed valuable for its flesh and wool." (See Agtl. Dept. Report, 1857, pp. 63-64.)

It will be observed that Dr. Davis, as well as other authorities referred to above, mention these goats as being of the "Thibet," and "Cashmere,' breed, and for a number of years they were called "Cashmere" by every one interested, but it appears that through the action of cross-breeding with our common goat the fur underneath the hair disappeared to a great extent in a few years, and finally, disappeared altogether.

It then becameaquestion with many as to whether they were the "Cashmere" or the "Angora." Dr. Davis, unfortunely, died, or perhaps he could have explained the cause of the changed condition of his goats. At all events, the matter remained in doubt for a number of years during which a very considerable interest was taken to decide upon their breeding. In Dr. Bachman's report on then, he says:

"This animal differs also from the 'Angora' goat to which it has a nearer approach, and from which this improved variety has probably descended. In the few specimens of the 'Angora' which we saw many years ago in Europe, and in the figures now extant of this variety, the ears, compared with those of the goats of Mr. Peters were smaller and 
less pendulous; the tail much longer; the neck covered with a mane of almost straight hair, reaching the shoulders, and uniting with the beard under the ehin; the body was larger and more goat-like, and had less the appearance of a sheep than the present variety. The fleece was equally white and glossy, but more than twice as coarse. By what local name this breed of goats, owned by Mr. Peters, is called in the East, remains for some future naturalist or traveler to determine. It will probably be found among some of the varieties spoken of by Hodgson, and other travelers, who have given very imperfect descriptions of the varieties existing in the hilly regions of Nepal and Thibet, but who say of them: 'One character they all have in common-pendent or semi-pendent ears, more or less prolonged, and in all the hair falls in long masses, sometimes twisted into spiral ringlets.' "'

We have adopted the usual rule among naturalists in designating animals by the common names under which they were sent, leaving it to time, and further observation to determine their true place in science. Hence, we have continued the name under which it was imported, which may have been 'Cashmere' in one of the languages of the East, as it is a general term, the name of the country which is known to possess several distinct varieties, both of the goat and sheep. At present, we can only designate them by the general term 'Asiatic goats,' or, to be more definite, as the 'Davis Cashmere goats,' from the individual who introduced them." See Agtl. Dept. Rept. 1857, p. 59.

Col. Peters himself was long in doubt as to their real character, for he says in a letter to the Agtl. Dept. in 1855:

"They differ materially from the 'Thibet-shawl' goats, and also from the 'Angora' goats, although they may prove to be of that variety, changed by climate, breeding and selection. They are, in my opinion, the true 'Cashmere' goat, a variety never before introduced into Europe, nor America." See Agtl. Dept. Report 185.5, page 54.

But later he decided on their being the "Angora," and they have gone by that name ever since. Dr. Davis seems to have anticipated that there would be a decided change in the character of their fleece; for, he stated most distinctly, in his letter to the Agt1. Dept. in 1853, above referred to:

"In the third cross we may expect a valuable experiment by ehang ing the fine underwool, or lown, into a conjoint and uniform covering of wool." (See Agtl. Dept. Report 1853, page 21.)

It should be borne in mind that, the goats of Dr. Davis, produced onc pound of under-hair, which is much more than the 
"Cashmere" goat produces and would indicate that his animals, while possessing the same characteristic as the "Cashmere," were of a different, and far superior, species, as the latter are only saicl to produce about tio ounces of undercoating. (See Appendix on Cashmere goat.) The double coating, as above stated, disappeared entirely in a few years, and there has never been any evidence of such an animal in the United States since* that time, which gave rise to much doubt as to whether Dr. Davis' statements concerning the character of his goats were correct.

In a newspaper interview, with Col. Richard Peters in Atlanta, Georgia, in $18 \% 6$, that gentleman says:

"Dr. Davis had fallen into error as to the native country of his goats, and believing them to be 'Cashmorc,' quoted their fleeces as being worth from six to eight dollars per pound while in reality they were ' $A n$ goras' whose fleece, known to commerce as 'mohair', has been an article of import into Great Britian, and this country, for years, and held at from sixty cents. to one dollar, per pound."

Wishing to obtain the most anthentic information upon this subject that was possible. I addressed a letter to Mrs. Harriett K. White, a danghter of Dr. Davis, asking if she did not have among the papers of her deceased father some evidence that would be likely to explain this matter, and the following is that lady's reply:

\section{“Bryan, Tcxas, Xarch $26,19990$.}

"Mr. W'm. L. Black, Ft. XeKavett, Texas.

"Dear Sir:-Since the receipt of your letter I have been trying to obtain the information you asked for. I have recently come into possession of a small trunk of letters, and papers, and I think it will aid you in your work, to give you the result of my researches.

\section{Yours very truly,}

"HARRIET K. WHITE"

The following are among the extracts from the newspapers that Mrs. White so kindly has supplied me with which were printed in 1856 .

* Since the foregoing was penned, Mr. I. C. Hightower, of Ruidosa, New Mexico, has sent me a sample of hair from a ten-year-old buck, which shows the two coats of hair very distinctly, which I shall refer to more particularly later on. 


\section{From the "New York Country Gentleman:"}

"We are under obligations to R. C. Foster, Esq., of Nashville, Tenn., for samples of wool from 'Cashmere' goats, from the flock of Mr. Williamson of Sumner County, Tennessee, who Mr. F. informs us, has about thirty of these goats. The wool, or hair, as we suppose it may more properly be called, is a beautiful, soft, silky, article, from ten to twelve inches in length. We should be glad to have the history of this flock, the amount of produce, etc."

Then follows:

“The following report was made by Col. Richard Allen, late of Kentucky, and long and favorably known as a wool grower, under whose care these animals were placed during the winter of $1855-6$, being the first winter after they were brought to Tennessee."

\section{"Gallatin, Sumner County, Tennessee, June 5th, 1856.}

'To the Editors of the 'Cultivator' and 'Conntry Gentlcman:'

'I have been thinking for some time of calling your attention, and of the numerous readers of your widely curculated agricultural journals to the recent importations of the "Cashmerc" shawl goat, an animal, as remarkable for the extreme fineness of its fleece, as for the enormous prices which it at all times commands in market. The first, and only importation to the United States, was made a few years since, from Turkey in Asia, by Dr. James B. Davis of Columbia, S. C., who resided some years in the East, and procured them under great difficulties, and at much cost, and personal hazard. They have been recently introduced into Tennessee by Messrs. Williamson, Adams \& Co., an enterprising firm of public spirited gentlemen at Gallatin, Tenn., and are now on my farm near this place. The company have a charter of incorporation granted by the last Legislature of the State which is doing all in its power for the encouragement of the farming interests, having in successiul op eration societies under the direct charge of a State Bureau, in the three grand divisions of the State in connection with the County societics in most of the large and populous counties. The fact is, Tennessee, so long behind-hand in that public countenance to these interests, is now far ahead of most of the older States in the encouragement and fostering of associations for the advancement of agricultural and meclianical arts.

Most of your readers are doubtless familiar with the history of the 'Cashmere' goat, and it is scarcely necessary to speak of the intrinsic value of the wool over that of any other fleeced animal known. The most fabulous prices at which the shawls have sold is known to almost every one, often approaching thousands of dollars each. One of the chief causes of its high value is the unperishable nature of the goods manufactured from the 'Cashmere-wool' surpassing in durabil- 
ity of wear all other articles. The adaptation of the animal to our climate has now been fully tested, while its hardy and lively nature; its habits and self-protection from dogs, and other enemies, are qualitie. which highly recommend them. They can be raised advantageously, and thrive upon weeds, and briars, etc., which are rejected by other animals. Not the least remarkable is the manner of gathering the fleece which is pulled, instead of being sheared. I have recently weighed the fleece from one, and it turned out three pounds, ten ounces (3 1bs. 10 ozs.) semi-annually.

The entire yield of the Company's stock has been engaged in the City of New York at $\$ 8.50$ per pound, from which point it will be sent to Paisley, in Scotland, for manufacturing into the shawls. I beg leave to enclose a sample of my raising.

It may not be out of place in this connection to remark that great credit is due to Dr. Davis of South Carolina, for the enterprise he exhibited in the introduction of the goat to this country. He was, at the time in the employ of the Turkish government, at a salary of $\$ 15,000.00$, engaged in experiments upon the growing of cotton in the Sultan's dominions. He went out upon the recommendation of President Polk, to whom application was made by the Turkish government for the services of some competent Southern gentleman familiar with the cotton culture.

While there, he determined to procure the goat from its native wilds. 't he story of the journey would be tedious for my brief letter, and I will merely add that, with an expensive outfit at Constantinople, a perilous journey of months, and the loss of many men and camels, he succeeded in capturing, and carrying off, eleven of the famous animals whose fleeces in the shape of shawls are so highly prized, and coveted by the ladies of all civilized nations, and for which prices almost startling have been paid by the wealthy.

On his return home Dr. Davis visited London and exhibited his flock at the British Musemm, attracting great attention, an account of which may be found in the files of the 'London Times' of that date. 'They were, also, afterwards exhibited at Paris.

After a careful examination of the whole subject I can not avoid the conclusion that the introduction of the animal will constitute an era in manufacturing which can not fail to result in great profits, to those engaged in it. There has not been a single instance, up to this date, where a 'Cashmere shawl' goat has brought at sale less than $\$ 1000.00$ each.

"RICHARD ALLEN."

Extract from a microscopic examination of the hair of the Asiatic goats, by George L. Schaffer, M. D., U. S. Patent Office : 
"As the history of these goats has already been given in the agricultural reports of the Patent Office for 1853, as well as in other pubkications by Dr. J. B. Davis of S. C., it is deemed unnecessary to repeat it here.

"The full-bred animals of this importation, as well as their crosses on the common goat, have been sent to various parts of the country. Dr. D. C. Ambler of New York, who has introduced them into that State, has presented the specimens for examination at this office.

"The value and good points of these animals have been so well reported upon at the various exhibitions, at which they have taken prizes, that I shall say nothing upon this subject, but proceed at once to the immediate object of this paper.

“'The first specimen examined was irom a full-bred 'Davis' female born in South Carolina, and carried when three months old to Waterville, Oneida County, New York, by Dr. Ambler, by whom it is now owned. The fleece was taken when twelve months old. The lock examined shows a very beautiful curled, or wavy hair, of silvery whiteness, with a fine downy wool at its base. The hair selected for representation was ten inches long, and magnified iuur hundred times. The next specimen, was, from a full-bred female, born in South Carolina, and carried to Harper's Ferry in Virginia, when four months old, owned by Col. B. Davenport. The fleece was taken when twelve months old. In this lock, the down-wool was somewhat more abundant than in the former, the hair being nearly as long and a little finer. The third specimen was from a full-bred male born in South Carolina, similar to the former in the hair, with less down-wool.

"The fourth specimen was from a second-cross between the fullbred, and common goat, born in South Carolina, and carried to New York, when four months old. The fleece was taken when twelve months old, five inches in length, exceedingly beautiful in color, and texture, and about equal to the finest saxony wool, all of which were compared with different hairs from a piece of shawl stuff, imported from Calcutta, and said to be the finest evcr brought to this country." After which, Mr. Schaffer states: "It is gratifying to be assured that the fleece may be raised in this country, with a fineness closely approximating to that which it has ever attained in Asia under the most favorable circumstances.

From the "Weekly American Banner," Yazoo City, Miss.:

"We have in our sanctum a specimen of the fleece of the genuine 'Cashmere' goat. Nothing of the kind, which we have ever seen, approaches it in softness, fineness and beauty. It is long, silky, silvery, finer than spun-glass, and quite as glossy: Those of our friends who have a taste for such things are invited to call and see it. 
"The 'Cashmere' goat is not sheared like a sheep. but the fleece is pullcd off twice every year. An ordinary fleece weighs between three and four pounds. The New York price is $\$ 8.50$ per pound making at Jeast $\$ 51.00$ a year for each goat, while there is no cost in feeding them, for they are as frugal and hardy as the common goat. How much better would it be for a company of our citizens, letting cotton alone, as much less profitable to introduce the 'Cashmere' goat. 'The cost at first would be considerable; the goats selling about $\$ 1000.00$; but each one would make a return of five per cent. while the increase is so rapid that the profit would soon be a hundred per cent.

"The cross with the common goat, even the second cross, yields a fine, and beautiful fleece, though not so long, and fine, as the pure breed.

"Our country is indebted to Dr. J. B. Davis of Columbia, S. C., for the importation of the 'Cashmere' goat from 'Turkey in Asia. He was formerly employed by the Sultan to experiment upon the culture of cotton in Turkey, and while there he succeeded in capturing and bringing home eleven goats. No others have ever been imported, but the 'Cashmere' goats are already becoming numerous in the United States. The fabric manufactured from its fleece is not only beautiful, but the most durable in the world, and it is the union of these two qualities which makes it so costly."

From the "Presbyterian Herald," Louisville, Ky. :

"Expensiz'c animals. Among the 'passengers' by the Hudson River Railroad on Saturday were two 'Cashmere' goats bound for 'Tennessee. The Albany Times says they were purchased in South Carolina at $\$ 2600$, and have been exhibited in New York. Admitting the two animals to weigh sixty pounds, for they are diminutive creatures, they would cost about forty-four dollars per pound, which is a rather extravagant price, almost equal to what Esau paid on one occasion for a mess of pottage, made from similar meat. As the wool of these goats. however, sells for cight dollars per pound, the specimens above referred to may prove a good investment."

\section{From the "Philadelphia Ledger:"}

"It is not as yet generally known that the 'Thibet' goat, from whose wool the famous Cashmere shawls are made, has been introduced successfully into the United States. This enterprising undertaking was achieved a few years ago after difficulties by Dr. J. B. Davis of Columbia, S. C., at that time employed by the Ottoman Porte in experimenting on the growtl of cotton in the Sultan's dominions. Dr. Davis succeeded at z'ast crpense in securing eleven head of pure breed which, on his way home, he exhibited in London and Paris. Since that period the goat has been introduced from South Carolina into Tennessee, where it is said to thrive. 
Brecding-Past Expericnce-Result of Crossing the Angora. 203

\section{From the "Sumner (Tenn.) Flag:"}

"The value of a flock may be estimated from the fact that no real 'Thibet' goat has ever been sold for less than one thousand dollars. 'This enormous price, moreover, is not a speculative one, for no fleeced animal has wool of such fineness, softness, and durability. The wool of all 'Thibet' goats in Tennessee, for example, has been engaged in New York this year at eight dollars and a half per pound. The purchasers desiring to send it to Paislcy. Scotland in order to be manuufactured into shawls."

From the "Examiner," of Gallitin, Tenn.:

"High-priced wool. The first lot of 'Cashmere' wool raised in 'Tennessee was sold last week in this place by the agent of the Sumner Cashmere Company for $\$ 8.50$ per pound. We learn it is to go to the Shakers of Kentucky, where it will be combed, and probably manufactured into textile fabrics."

We were shown, a few days ago, a specimen of fleece from a halfblood 'Cashmere' goat raised by Dr. James MI. Head, of this County.

"It is about three inches long, of a silvery whiteness, and about equal to the finest Saxony wool. It is interspersed with a few coarse hairs, which will disappear with another cross, each increasing the length and fineness of the fibre.

Dr. Head has refused $\$ 200$ on for the kid, the dam of which cost him onc dollar about a year since."

Numerous other quotations might be made, but the above I think are quite sufficient to prove the fact that the "Davis" goats did not comc from Angora in Turkcy: but, were undoubtedly, a different variety of goats, which Dr. Davis had probably learned of during his stay in the employ of the Turkish govertment. I reach this conclusion from two circumstances that are abundantly substantiated by the testimony I have just given:

First. Mr. Richard Allen states: "While there he (Mr. Daris) determined to procure the goat from its native wilds. The story of the journey would be tedious for my brief letter, and I will merely udd: With an expensive outfit at Constantinople, a perilous jomrney of months, and the loss of many men and camels, he succeded in capturing, and carrying off eleven of the famous unimals..$\%$ *

Second. The price that the fleece of these animals sold for is uniformly placed at $\$ 6.00$ to $\$ 8.50$ per pound, and was sent to Paisely. Scotland, to be made into fabrics. 
It is well known and must have been known to Dr. Davis, who resided for three years in Turkey that, the ordinary "Angora" goat was obtainable with little or no trouble, within a few hours travel of Constantinople. Hh!l then should he have fitted out such a large and expensive expedition, ama have consumed months in a perilous jom me!!

And, as to the value of the fleeces. It is well knowin that ordinary mohair was an article of export to Great Britain at the time Dr. Davis was living in Constantinople, and he must have been familiar with its market value.

It was quoted at 48 cents per pound in 1856 , when the committees of gentlenen, appointed by the various fairs and agricultural associations, reported it as being worth $\$ 6.00$ to $\$ 8.00$ por ponnd. It is idle to strppose that these honoral)le gentlemen were ignorant of this commercial fact; and, to suppose that they would sit upon a committee for the purpose of attesting to the merits of an article, and fail to investigate very fully into that feature of their report, is too silly to admit of argument.

That the animals referred to were of the character described, there cannot be the shadow of a doubt; and, the only explanation that can be advanced for the cliange in the nature of the wool, or Heece, is that, throngh the rossing of the pure breed animal, with the common showt haived iariet! of this country,

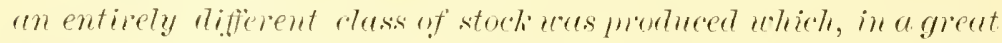
measure full! zimdicates the oprimion expressed by Dr. Davis in 18.5.), when he reported to the Agricultural lopartment that:

"In the third cross upon the Cashmere, we may expect a valuable experiment by changing the fine under-wool, or down, into a conjoint and uniform covering of wool."

Bearing further and with much greater force on this question, Mrs. White writes me as follows:

$$
\text { "Bryan, Texas, April 17th, } 1900 .
$$

"Mr. W. L. Black, Fort McKavett, Texas:

"Dear Sir-Your valued letter of April 8th, has been received, with my father's report to the Patent Office in 1853 . Thank you very much for both. I return the printed extracts which you can lieep as long 98 you please. T shall now answer your other questions. 
"Bishop Southgate, of the Episcopal Church, was Bishop of Turkey, and while the Sultan was having a residence built for my father on the farm where the cotton experiment was going on, my father and mother lived with the Bishop. The conversations were varied and interesting, and my father's interest in animals being known, the Bishop told him of these 'Cashmere' goats, which he had seen in Persia and India. He had a native friend in Persia who could procure these 'Cashmerc' goats. A messenger who could be trusted was sent with a letter to Bishop Southgate's native friend in Persia. He obtained the pure-blooded 'Cashmere,' and one pair of 'Thibet' goats. Of course, camels-generally led by a donkey-were as much used in those days as pack horses were once used in Texas. They came to Constantinople from all quarters, and 'camels and men' were employed for all purposes. It was several months before the goat messenger returned, but he came back finally. The goats originally cost, in the remote regions of Asia, from four to six dollars apiece, but by the time they were brought to where ny father met them and brought them to the farm near Sin Stefans, Turkey, and then brought them to this country, via London and Paris, the cost was large. He sold the goats at $\$ 1,000.00$ each-I know-the $\$ 100.00 *$ was an error.

"'These goats werc pure 'Cashmere' and one pair of 'Thibet.' My father was very particular on this point because the 'Angora' goat had coarser hair. Col. Peters and my father discussed this question, and I do not believe in that reported interview in which he said they were not 'Cashmere,' The 'Cashmere' had very long fine white silk locks. The 'Thibet' had an outer coat of blue-gray hair, and under this an extremely fine white fleece. I do not think the goats shed their fleece. The graded goats had fine, beautiful fleece, and in some crosses the only way to detect the cross was down the spine where some coarse hair betrayed the mixture. Animals are like plants, more affected by altitude than latitude, and of course, in the process of crossing on common goats there would, sometimes, occur a 'reversion of type,' that might look as if the 'Cashmere' was not all that was claimed for it, but before Darwin this was not understood as it is now. There were two or three importations of goats purporting to be 'Cashmere,' but my father said they were 'Angora' goats, and of a coarser fleece. His long reidence in Turkey-three years-gave him time, and his position gave him an opportunity to get what he wanted, and what he imported to this country-'the true Cashmere goat.' I know he sold the graded goats for $\$ 200.00$ each, and of course he got more for the higher grades, and one thousand for the fullbloods.

*This refers to a report in the Agricultural Report of 1855, quoted heretofore, which I remarked must have been a typographical error. 
"The 'Scinde' goat is in the picture," also the "Thibet' ewe, 'Cashmere' goat, 'Water Buffalo' and 'Brahmins.' The Earl of Derby said to my father: 'What will you take for a pair of those 'Cashmere' goats? I want them more than anything you hav...' My father answered: 'You may have a pair for a certain 'Brahmin' cow in 'Surrey Gardens,' and : male 'Bralumin' (in some other noted collection).

“'You shall have them,' said the Eari of Derby.

'A pure white Brahmin bull and a beautiful sort of sorrel heifer was obtainerl, and exchanged for one pair of goats. These two Brahmins were afterwards sold for $\$ 4,000.00$ for the pair. You will see how highly these goats were valued.

The water o.tch my father brought from Turkey, having originally been brought there from some other country. I have a beautiful group of these painted from the original importation. I took the picture of the goats, etc., from the irame and carried it to the photographer, and he will have it in a lew lays ready to send you. I have an engraving of $\mathbf{2}$ goat that I will also have photographed, and I will send them to you as soon as they are finished.

"My father was in Europe three years, ranging from somewhere in 1846 to 1849 .

"If there is any other information you woudd like, I shall be glad to give it.

\section{"Very truly yours.}

"HARRIET E. WHIT.,

\section{SOME MORE CHANGES.}

In 1sti:, Mr. S. S. Williams of Granville, Ohio, in a letter to the Hon. Israel H. Diehl referring to his own goas, says:

"I have about one hundred goats. In regard to the breed of my goats, whether 'Angora' or 'Cashmere' mine belong to that breed first introduced by Dr. J. B. Davis, as 'Cashmeres,' and which have generally gone by that name to this day. But if the Cashmere' goat is the animal bearing a coarse hair, with an undergrowth of only a few ounces of fine fleece, then mine are not 'Cashmeres. though known as 'Cashmeres' in this country; and, from the description of Rees, and others, mine are the 'Angora, for they describe my goats as correctly as I can myself. I rest satisfied that our goat, whatever it should be called, is valuable, and I care little for the name. I send you a sample of the wool of ny buck. Sampson, which clips over six pounds. Of course. I think he is more valuable than an animal yielding only three ounces of but little finer quality." (See Agtl. Dept. Report,

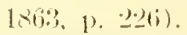

\footnotetext{
* See plate IIT. on the extrente right hand side.
} 


\section{Dr. Scott's description of the changed condition in the ani-} mal is peculiarly interesting. He says:

"Like some furred animals, these zoats wear two distinct, and different, suits of clothing, and mainly at different seasons. One is short, stiff, coarse, and of no commercial value; the other is long, in proportion to the degree of blood, and is lustrous, soft, silky, and elastic. The animal. is born with the covering of the first, which, in a iew weeks, drops out. and is simultaneously replaced by the second, or the fine wool, which, in its time, also drops out, and is similarly superseded by the first; the animals wearing the short, coarse hair in the spring and early summer, and the long, fine wool in summer, fall and winter. When the wool of the Angora goat is being sled, the cups or bulbs in the skin, which produced the fibres, are also shed, as well as the cuticle, or outside skin. This is a great peculiarity of the 'Angora' goat; but a still greater one, and of far more practical importance, is the capacity of the bucks to transfer, or impart, this rare quality to other goats which do not possess it. The males certainly have this power in a high degree, and the femaie 'Angora,' bred to a common male, will, no doubt, impart to the offspring the same quality, but probably not in so high a degree. The kid of an 'Angora' buck, out of a native ewe, invariably has in its skin those bulbs, or cups, which produce and secrete the fine wool of the 'Angora,' or wool-bearing goat, while it has the power to secrete the hair also, as its ancestry, on the dam side, always had. The wool of goats is finer, longer, or thicker, in different individuals of the same blood, just as is the case with sheep; and like sheep, also, the same animal produces finer wool when young than when advanced in life. But the wool of the half-blood kid, or goat, is of a standard fineness of full-blood, or of purebred, Angora goats' wool, but it is short. The wool and the hair of the half-blood grow together and seem to constitute but one covering; but a close inspection shows the different fibres issuing from different bulbs in the same skin: but, when the shedding season arrives, the fine z'ool may be combed out of the hair on the animal's back, and on being separated from it, bears a close resemblance to the finest fur, or to Saxonv wool, or to the 'Angora' mohair. A friend who was traveling in Europt. sent me a sample of mohair which exactly resembles this fine wool of the first cross, having also some of the coarse hair and of the cuticle in it, showing that it had been shed and not shorn. The two products of the half and of the three-quarter blood, being nearly of the same length, they cannot be separated by shearing, and to gather it by combing it out of the hair on the backs of the animals is too tedious. The specimen to which I have alluded, is probably the product of some other species of wool-bearing goat, and not of a half-blood cross of different species.

"If the half-blood female kid is bred to a pure "Angora" buck, the product will be similar, except that the wool will be longer, and some- 
times long enough to be separated by being shorn from the animals, so as to be cut off over the ends of the coarse hair. The wool will be fine and long enough for many uses in manufacture, but there will generally be so much of worthless hair in it as to make it of little value. On animals of the third similar cross, or of seven-eighths Angora blood, the fine wool will always be so much longer than the hair, that it admits of practical separation by shearing; and so of those of the fourth cross; while those of the fifth cross and above it, bear wool which, in every essential particular, resembles closely that of pure-bres or importe! Angora, and admits of application to all the uses of the best imported wool, or of homeraised wool from pure-bred animals, though involving some trouble in separating the hairs from it." (See Hayes, pp. 64-65.)

Having had a very extended experience with goats in the United States, covering a period of twenty-four years, during which I have had as many as eight thousand head at one time, ranging from the common short haired goat of Mexico to the purc-bred Angora purchased from Col. Richard Peters of Georgia, in 188t, and having operated a tannery for the purpose of dressing the Angora goat skin, which has given me a most excellent opportunity to notice all the peculiarities in the fleece of this animal, I will state some of my personal observations.

I have seen many goats that produced two separate coats of hair, as described by Dr. Scott, one being short and coarse, or kempy, white in color, the other fine and silky, and of different lengths. 'This type however is not common in flocks that have been highly improved, and I attribute it to the fact that the base blood of the common goat had not been entirely removed; or, in other words, that the period of breeding with the Angora had not been long enough to thoroughly implant the mohairproducing blood.

Mr. Hoerle refers to his experience with this type in a circular letter lately distributed by Mr. Wm. R. Payne, of New York, as follows :

"The goats, which, after shearing, had an uncommonly long undergrowth, raised my suspicion, and, anxious to see whether it would be best to cull such animals or not, I stained the undergrowth of some of them. When the mohair began to grow, it appeared perfectly white between the bluish-black undergrowth, and remained there visible for months, until it gradually faded out. This experiment convinced 


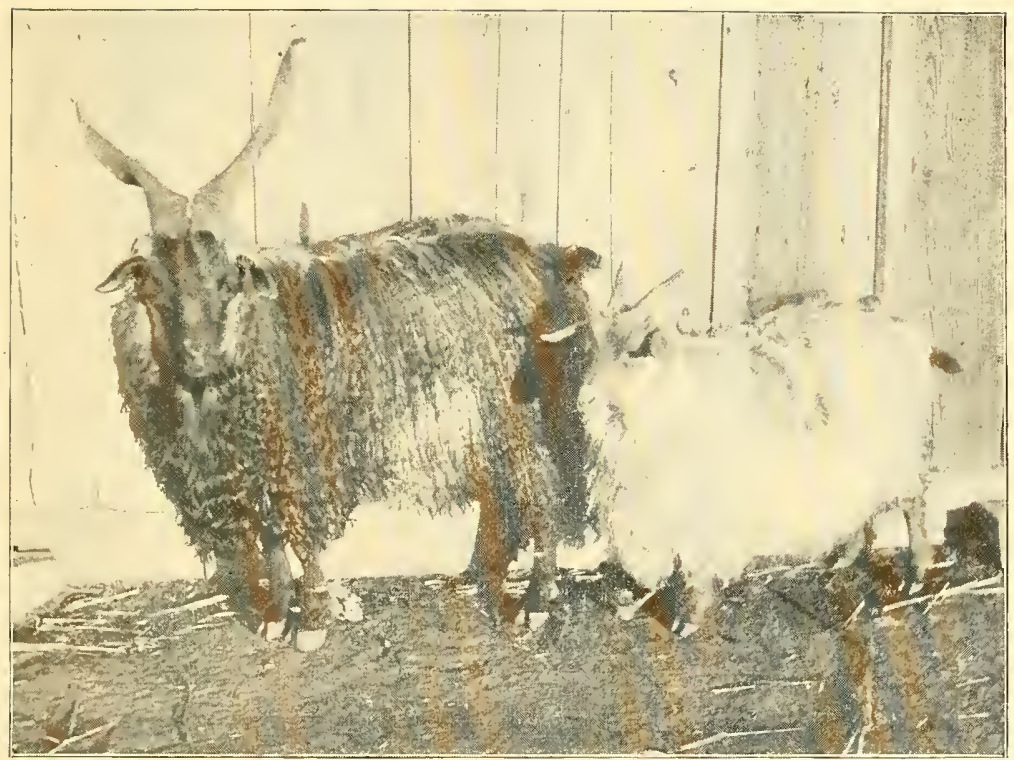

PLATE VI.

OFF-COLORED ANGORA GOATS.

The black buck, has been bled, but failed to produce any other than white kids.

The white goat has a red face, and legs: was red all over when a kid, and, after shedding, exposes a coat of coarse, short red hair, like the head and legs. The black goat appears to have but the one coat. 

me that the 'mohair is not the ordinary undergrowth elongated,' as Mr. Schreiner, and other breeders, seem to believe, but an entirely different kind of hair."

Another type of goat I have seen has a coarse, kempy, yellowish under-hair, and sometimes of a bluish, or gray, color with a white mohair covering, and after the covering of white molnair had shed off, it would be difficult to believe that such an animal could possibly produce a fine covering of long, white mohair; yet, in the growing season, (which I have found to differ very greatly, some animals beginning to produce as early as April and May, while others would not commence until June and July), the white mohair would show itself, and soon cover the entire body.

The head and legs of these animals being of a dark color, gave them somewhat the appearance of a Shropshire sheep, (when the white mohair was grown out), and, as a general thing, these would always yield a very large fleece.

As a rule, my improved goats only produced one coat of hair. To satisfy myself upon this point, I examined upwards of five hundred dressed Angora goat skins, in my tannery, and found the double-coated ones confined entirely to the colored goat, and a few partly improved white goats, as above described. Col. W. W. Haupt refers to this feature in a communication that he wrote to the "Southcrn Farmcr," in 1889, at the request of Col. Richard Peters, who was anxious to learn what experience he had met with in the thirty years he had been breeding the Angora. Col. Haupt says:

"Now where do we get this very fine mohair from? From the pureblooded Angora alone? No. This belief is a common error. The finest mohair you can find is from the half-breed from the coarse Mexican nanny. The origin of this belief is in the fact that heredity teaches that the peculiarities of two parents are equally (in the main) divided in all the different features, in the off-spring. This doctrine is literally true, for it is the stamp of nature. But there seems two exceptional phenomena in regard to the Angora. First, whilst a fine-wooled sheep crossed on a coarse-wool, makes a medium grade fibre, from the fact that the fibres themselves partake of the cross. Yet, in the goat this crossing of fibres does not take place. The mohair on the half-breed simply displaces (or grubs out) a portion of the short, coarse hair, and supplants itself 
in its place, and each successive cross continues this encroaciment until about the sixth cross they are about all gone. The first cross gives about an inch in length of mohair, and each additional cross adds greater length, until finally it gets the extreme length of the pure-bloods; is as fully set on the animal, and will shear as heavly, and it has the fineness to start on, and is, in cvery essental, the equal of the pure-blood, and, so far as flecce is concerned (and that is all you want), it is in fact a pure-blood Angora goat."

Another peculiarity 1 have noticed is, the great difference in the lengths to which mohair will grow, and the general appearance of it when in full fleece. Some goats will have hair only six to eight inches in length, while with others it will grow to be twelve to fifteen. Some will have a milk-white color of hair, whilc with others it will be morelikecrean. The mohair of some goats will be wavy; while in others it will hang in beautiful ringlets and a few will present an appearance very similar to a lady's hair that has just been released from a crimper; the longest molair, as a general thing, being in little ringlets, hanging as distinct from each other as the curls from a young lady's head. ()ccasionally, a black, yellow, or bluish goat will produce black, yellow, or bhish molair; but in nearly all cases, the outer covering will be white. I have seen some pied, or variegaterl goats, each color producing its own color of mohair, sone of which, when shed off entirely, would expose a spotted skin. I have at the present time a black male* with a beatiful hair hanging in ringlets not less than ten inches long.

Still another peculiarity is in the size of carcass, and gencral appearance of the animals. Some are heavily-bodied, with a coarse bone, the wethers often reaching one hundred and fifty to one hundred and seventy-five pounds, while others will be slender bodied, with small bone, reaching only about eighty pounds, when fully developerl. The latter, I find to be the more common varicty, which I suppose is tue to the fact that they usually have longer hair hanging in ringlets, and are more attractive to the average breeder. As may well be supposed, the horns of the heavier variety are much longer and coarser looking than the smaller type, and the hair is wavy.

\footnotetext{
* See plate: VI.
} 
The general opinion among breeders, both in Turkey, South Africa, and our own country, is that a pure-bred "Angora" must be small and delicate, with thin horns, wooled all over the body, with ringletted hair, ranging from ten to fifteen inches, barely touching the ground, and produce a tuft of mohair on the forehead, which will cover the eyes. Dr. Hayes says:

"An infallible proof of purity insisted on by many writers is, the curling of the hair which is observed upon the young individual, only when they are of pure blood, so that all young bucks are rejected from the flocks with the utmost care as not being of the pure race whose hair is not curled." (See Hayes, p. 32.)

Mr. S. H. Pegler, author of the "Book of the Goat," and a professional breeder in South Africa, says:

"The correct points of a pure-bred Angora, are head fine with fleece growing well over the forehead, ears thin, wide and pendulous; not long, and hanging down direct from the head, but standing out, and then lopping over, more resembling the ears of a mastiff, on the alert, and best described as semi-pendant. Horns flat shaped, set fat apart on head, and tapering gradually towards the tips. Direction depends on the sex. Malc inclines first $t o$, the rear, with a slight twist outward, and the ends pointing upward. Female, they take a lateral direction, spiral more decided, and the ends point downward. The chief feature consists in the length, texlure and character of fleece. In the best of animals it is of a fine silley nature, growing in thickly matted flakes near the skin, and then separating into long, corkscrewshaped ringlets, covering the animal to the hocks. The best fleeces from a full grown animal of jrime age, and blood, should average six pounds weight, and the staple or strands averge eight inches in length."

Mr. H. O. Binns, a Turkish authority, describes a purebred Angora as being,

"About the size of a South African kid, five months old, with small thin horns, wooled all over the body, the hair almost covering the eyes, and exceedingly delicatc."

Dr. Hayes makes mention of a certain specimen, which I presume, must have been considered very perfect at the time (18.55) that a M. Brandt, director of the Museum at St. Petersburg, and distinguished among the zoologists of Europe for his conscietions work and profound knowledge described as follows : 
"The magnificent example of the Angora goat which the Museum of the Imperial Academy owes to $M$. Tchihatchiff produces at first sight the general impression of a domestic goat, when attention is not directed to its thick and silky fleece, to its flat ears, turned downwards; and its inconsiderable size. But it is precisely these traits which impress upon this animal a distinct seal, which give it the character of a peculiar race, whose origin is, perhaps, not the same as that of the domestic goat. The extremity of the snout; the cheeks; the nasal and frontal bone as well as the ears, and lower part of the legs, below the tarsal articulation, are covered with the external hairs, which are shorter and thicker than those which cover the above mentioned parts in other species of goats. The forehead has soit hairs of less length, less applied to the skin, and, in part curled. The hair of the beard, which is pointed, and of moderate dimensions, being six inches in length, is stiffer than the hair of the rest of the body, but less so than that of the beard of the ordinary goat. The horns, of a grayish white tint. are longer than the head; at their lower part the interior marginal border turns inwards in such a manner that they appear broad viewed in front, and narrow when seen exteriorly; at half their extension they direct themselves moderately backwards, and turn spirally outwards, so that their extremities directed slightly upwards, are very much separated, one from the other, and circumscribe a space gradually contracting itself. The whole of the neck, as well as the trunk, is covered with long hairs which, particularly upon the neck and lateral parts of the body, are twisted in spirals, having the appearance of loosened ringlets, it being observed at the same time, that they unite themselves into rolled tufts, a disposition which is less marked in the anterior part of the neck. The hairs which exhibit the greatest length, are siturated above the forelegs, and are, almost nine and one-half inches long. Those of the neck are a little shorter, and are nine inches long. and those of the belly eight inches three lines. The length of the hair with which the lateral parts of the body, as well as the back, are covered, is oniy seven inches, six lines; and that of the hair of the hind legs six inches to seven inches. Finally, the slight stiff hair of the tail is about four inches in length. The color of the robe of the animal is a pure white, here and there slightly inclined to yellow. The hoofs, somewhat small, in proportion, are, like the horns, of a grayish white tint. The hair is, without exception, long, soft, and fine; it is at once silky, and greasy, to the touch, and shows, distinctly, the brilliancy of silk." (See Hayes, page 8.)

The dimensions of the specimen above referred to by M. Brandt, are given by him as follows: 
Ft. Ia. L.

From the point of the snout to the root of the tail......5 42

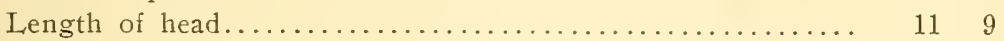

From the point of the snout to the eye............. 51

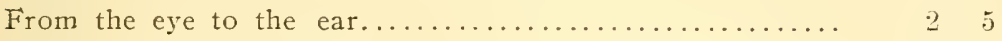

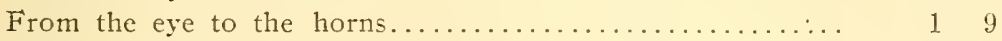

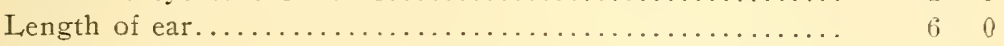

Length of horns, in direct diameter................ 20

Length of horns, following the cutvature............. $1 \quad 6 \quad 6$

Distance between horns, taken at the roots............ . 21

Distance between their terminal point............... $1 \quad 9 \quad 9$

Width of horns, at their roots.................. 2 '1

Length of tail, including the hair................. 99

Height of anterior part of the body................ 24

Height of posterior part of the body...............2 22

(See Hayes, page 10.)

The Hon. Israel H. Deihl, in a paper on "The Guat," published in the United States Agricultural Department for 1863, quotations from which have heretofore been made, says:

"The Angora goat has a very beautiful curled or wavy hair, of silvery whiteness, with a fine downy wool at its base, and this hair is disposed in long, pendant, spiral ringlets on the whole body. The horns of the female, instead of spreading as in the male, turn backwards, and are much shorter in proportion; those of the male are long, spirally twisted, but the size and direction are very different from the common goat, being generally extended from fifteen to thirty inches in height on each side of the head. while those of the female end near the ears. The hair or wool often sweeps to the ground and is from five to twelve inches long, especially in the older bucks, but then not so fine.

"The fleece of the ewe shears from three to five pounds and that of the buck from five to nine. The tail is shorter than that of the Cashmere, and usually carried erect. These goats have the hair very long. thick, and so fine that stuffs have been made of it almost as handsome and glossy as our silks, and have been known under the rarious names of Cashmeres. Camlets, etc. This brief description will apply to alniost all we saw in Western Asia. Europe, and in this country, (say of several thousands) save some difference in the ears; for, while many have the pendant ears, others we examined have ears exceedingly small and short."

Mr. G. A. Hoerle, in a pamphlet published about 1885 or 1886, during his connection with the industry in Texas, has given the following description of a perfect specimen of an Angora goat:

"The shape of a perfect Angora goat, when in full fleece, should appear like a right-angled square (parallelogram). The body should be 
iull and long and of straight build. It should be densely and evenly covered with fine curly, and lustrous, silky hair, appearing form a distance as if it had been trimmed off below the body. The chest and shoulder, especially with the male animals should be broad and strong, the legs straight, and chunky, the head clean cut and trim, not coarse, like that of the common goat. The horns of the buck are long and strong, inclined toward the back and of a spiral-like shape, some almost perfect spirals; the horns of the ewes, short and thin, and curved backward. Hornless Angoras exist but are rare. The ears are almost always what are commonly called lcp-ears, and differ very much in size; those of some animals are over a foot long, and about four inches wide. However, the existence of so-called fox-cars, or monse-cars, is by no means, an evidence of impurity of blood. Some of the ewes coming from Col. Peters' thoroughbred stock, as well as the very best nanny (ewe) of Mr. W. D. Parrish's importation, which sheared, after being acclimated, a little over five pounds of mohair, had these, generally, so much despised 'for-cars.' We consider the prejudice against this kind of ears, certainly a very foolish one, at least, as long as we are breeding for nohair, and not for long ears, to obtain which, the donkey would be a better subject for our experiments." (See Hoerle, page 11.)

My personal opinion is, that the fine delicate frame of the pure-bred Angora described by the above authorities has been produced by a very long course of in, and in-breeding, which is known to have been universally practiced by the 'Turkish breeders in the early day, and this opinion is strengthened, in a great measure, by the fact that, the Turks were accustomed to cross their white Mohair goats with the common black goat of their comntry (the "Kurd"), in order to give them greater strength and vitality. Dr. Hayes, quoting from M. Boulier, in a report of a mission to Isia Ninor presented to the French Minister of IVar, says:

"In severe winters, while the common goat of the country is unaffected, the mortality among the goats of the pure race is frightful. *** The delicacy and lymphatic temperament of the white Angora which seems to be inherent to this race, appear to be closely related to their color. Some physiologists see in the color, and delicacy of this animal the evidence of an imperfect albinism." And Dr. Hayes adds, referring to a statement made by M. Tehilhatcheff that "when the losses are very considerable the people of the country repair the.s by crossing the Angora with the common goats, and that purity of the race is ragained in the third gereration." (Sze Hayes, page 30.)

If the reader will turn to plates $T^{\gamma}$ and $V$ and examine the cuts of two goats imported from Asia Minor by Dr. J. B. 
Davis in 1849, which have been admitted, by all anthorities who have ever seen them, as being perhaps, the purest bred mohair goats that have ever been exported from Turkey, he will find that they do not correspond in any one particular with either of the foregoing descriptions of a pure-bred "Angora," unless it be in the shape of the ears of the female. The hair of these animals does not hang in "closely matted ringlets, nearly touching the ground," but is wavy. The ears of one lop; while, in the other, they are like a fox-ear. The horns of the female are certainly not the delicate little horns, described by Mir. Hoerle, and which I have observed myself, on many of our goats that have been bred a long time, the tendency seeming to be for the horns to become smaller, as the animal ascends in the scale of mohair qualities. Moreover, the shape, and weight, of the "Davis" goats, does not correspond with the diminutive little animal which Mr. Binns says only "grows to be the size of a five months' old Cape (African) kid." In place of weighing, perhaps, sixty or seventy pounds for a male, the "Davis" male goat weighed 165 pounds and the female 102 pounds, probably as large again as the so-called pure Angora. The shearing capacity of the "Davis" goats is represented as having been seven pounds in the male, and four and a half poinds in the female, which, in 1855 , was above the reported average of any goats in Turkey.

The conclusion I have come to from observing these peculiarities is that the wavy hair is largely confined to the heavyframed, coarse-horned animal, and the long ringletted hair to the smaller-framed animai. I will now call attention to still another change in our mohair goat, which I believe is due to the peculiar type, or breed, of goat which Dr. Davis first introduced into the United States in $18+9$, crossed with our common Mexican variety.

\section{NON-SHEDDING ANGORA GOATS.}

Notwithstanding the fact that no reference is made to the shedding feature of the "Angora," by any of the authorities I have quoted from, it has been the opinion of all breeders, up to within the past few years that they shed their hair every spring, as certainly as the horse, or the cow, does, and a very large number of them have this opinion still. 
Col. Richard Peters, in a letter to Dr. Hayes, says :

- The greatest drawback I have experienced with Angoras has been the shedding too early of their fleeces. Of late years, by good keep, during the months of February and March, and by their not running through brier patches, I have been more successful in saving the fleece in good condition." (See Hayes, page 79.)

Dr. Robert W. Scott of Kentucky, says:

"The animal is born with a covering of short, stiff, coarse hair of no commercial value, which, in a few weeks, drops out and is replaced by a growth of mohair, which is long in proportion to the grade, or blood, of the animal, and is lustrous, soft, silky, and elastic, which, in its time, also drops out, and is similarly superseded by the first; the animals wearing, the short, coarse hair, in the spring and summer, and the long, fine wool in the fall and winter." (See Hayes, page 64.)

Having observed in my own Hucks, a great many kids that did not possess the peculiarity mentioned by Dr. Scott, I determined to investigate further and see if any of my grown goats retained their fleece in the spring, and was gratified to find such an animal among some that I had sold to parties in Iowa, and I have since found quite a number in my Texas stock. My find was so at variance with the accepted opinion of all breeders in our own country as well as in Turkey and South Africa; and, fearing that the circumstance which I had noticed, was caused perhaps, by some peculiar condition of the animal and was not a common occurrence, I felt a hesitancy in presenting the information unsupported by the testimony of others, so I decided to send out the following list of questions to a number of breeders, throughout the States:

1. Have you ever observed any Angora goat that had two distinct coats of hair?

2. Have you observed that some Angora goats shed their hair sooner than others?

3. Have you observed that some Angora goats do not shed their hair at all?

4. Have you ever observed any Angora kids that do not shed their first, or "kid"' hair?

5. How do you decide on a buck, by pedigree or merit?

6. Have you had many hornless Angoras goats?

It is quite interesting to note the several replies to the above questions. 


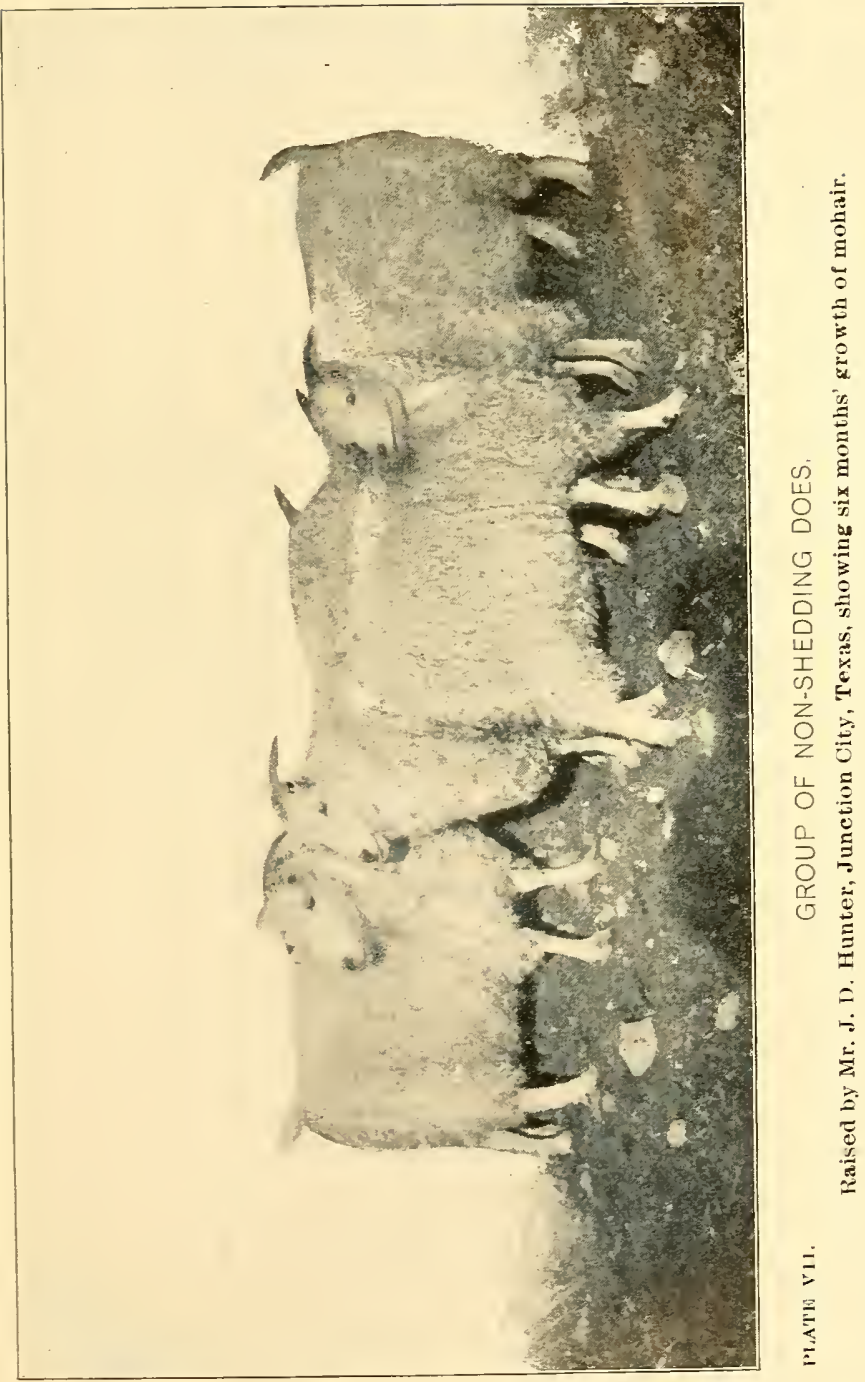



With only a few exceptions, every one of the fifty breeders who sent me their replies, say th. $y$ liave nevel seen an andimal with two distinct coats of hair, and the e few describe the undereoat as being "kemp." *

The following is a list of the answers I have received to the foregoing questions:

\begin{tabular}{|c|c|c|c|c|c|c|c|c|c|c|c|c|c|}
\hline \multirow{2}{*}{ 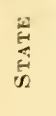 } & \multicolumn{2}{|c|}{ No. 1} & \multicolumn{2}{|c|}{ No. 2} & \multicolumn{2}{|c|}{ No. 3} & \multicolumn{2}{|c|}{ No. 4} & \multicolumn{2}{|c|}{ No. 5} & \multicolumn{2}{|c|}{ No 6} & \multirow{2}{*}{$\begin{array}{l}\text { NAME AND ADURKGS } \\
\text { OF BREEIJIT }\end{array}$} \\
\hline & $Y \neq 8$ & No & Yes & No & Yes & No & Yes & No & $\begin{array}{l}\text { Pedi- } \\
\text { gree }\end{array}$ & $\stackrel{2}{\sharp}$ & Yes & No & \\
\hline 告 & $\begin{array}{c}\cdots \\
\cdots \\
\cdots \\
\cdots \\
i \\
\cdots \\
o \\
\cdots \\
\cdots \\
\cdots \\
\cdots \\
\cdots \\
0 \\
\cdots \\
\cdots \\
\end{array}$ & {$\left[\begin{array}{c}0 \\
0 \\
\cdots \\
0 \\
0 \\
0 \\
0 \\
\cdots \\
0 \\
\because \\
0 \\
0 \\
\cdots \\
0 \\
\cdots \\
0 \\
0\end{array}\right.$} & $\begin{array}{c}0 \\
\ldots \\
0 \\
0 \\
0 \\
0 \\
0 \\
0 \\
0 \\
0 \\
0 \\
0 \\
0 \\
\cdots \\
\cdots \\
\cdots \\
0 \\
0 \\
\end{array}$ & $\begin{array}{c}\cdots \\
\cdots \\
\cdots \\
\cdots \\
\cdots \\
\cdots \\
\cdots \\
\cdots \\
\cdots \\
\cdots \\
\cdots \\
\cdots \\
\cdots \\
\cdots \\
\cdots \\
\cdots \\
\cdots \\
\cdots \\
\end{array}$ & $\begin{array}{c}0 \\
0 \\
\ldots \\
0 \\
0 \\
0 \\
0 \\
0 \\
0 \\
0 \\
0 \\
0 \\
\ldots \\
\cdots \\
0 \\
0 \\
0 \\
0 \\
0\end{array}$ & $\begin{array}{c}\cdots \\
\cdots \\
\cdots \\
\cdots \\
\cdots \\
\cdots \\
\cdots \\
\cdots \\
\cdots \\
\cdots \\
\cdots \\
\cdots \\
0 \\
0 \\
\cdots \\
\cdots \\
\cdots \\
\cdots \\
\cdots\end{array}$ & $\begin{array}{c}0 \\
\ldots \\
\cdots \\
\cdots \\
0 \\
\ldots \\
0 \\
0 \\
0 \\
\ldots \\
\cdots \\
0 \\
\cdots \\
0 \\
\cdots \\
0 \\
0 \\
\end{array}$ & $\begin{array}{c}\ldots \\
\cdots \\
\cdots \\
\cdots \\
\cdots \\
\cdots \\
\cdots \\
\cdots \cdots \\
\cdots \\
0 \\
0 \\
0 \\
0 \\
\cdots \\
\ldots \\
\cdots \\
\cdots\end{array}$ & $\begin{array}{c}\cdots \\
\cdots \\
\cdots \\
0 \\
0 \\
\cdots \cdots \\
\cdots \\
\cdots \\
0 \\
0 \\
\cdots \\
\cdots \\
\cdots \\
\cdots \\
0 \\
\cdots \\
\cdots \\
\cdots \\
\end{array}$ & $\begin{array}{c}0 \\
0 \\
\ldots \\
0 \\
0 \\
0 \\
0 \\
\cdots \\
\cdots \\
0 \\
0 \\
0 \\
\cdots \\
\cdots \\
0 \\
\cdots \\
\cdots \\
\end{array}$ & $\begin{array}{c}0 \\
0 \\
\cdots \\
\cdots \\
0 \\
0 \\
0 \\
\cdots \\
\cdots \\
\cdots \\
\cdots \\
\cdots \\
\cdots \\
\cdots \\
\cdots \\
\cdots \\
\cdots \\
\end{array}$ & $\begin{array}{c}\cdots \\
\cdots \\
\cdots \\
\cdots \\
\cdots \\
\cdots \\
0 \\
0 \\
\cdots \\
\cdots \\
\cdots \\
0 \\
\cdots \\
\cdots \\
\cdots \\
\cdots \\
\cdots \\
\end{array}$ & 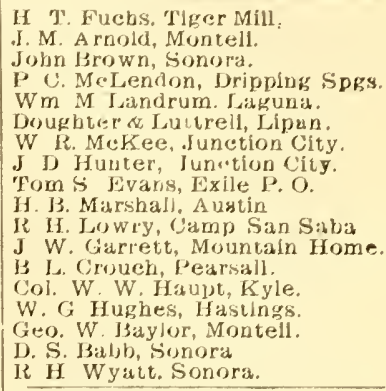 \\
\hline 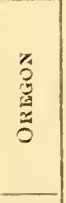 & $\begin{array}{c}\ldots \\
\ldots \\
0 \\
\ldots \\
\cdots \\
\cdots \\
\cdots \\
\cdots \\
\end{array}$ & $\begin{array}{c}0 \\
0 \\
\cdots \\
0 \\
0 \\
\cdots \\
0 \\
0 \\
\cdots \\
\end{array}$ & $\begin{array}{l} \\
0 \\
0 \\
0 \\
\cdots \\
0 \\
0 \\
0 \\
0 \\
\end{array}$ & $\begin{array}{c}o \\
\cdots \\
\cdots \\
\cdots \\
o \\
\cdots \\
\cdots \\
\cdots \\
\cdots \\
\end{array}$ & $\begin{array}{c} \\
\cdots \\
o \\
\cdots \\
\cdots \\
\cdots \\
\cdots \\
\cdots \\
\cdots\end{array}$ & $\begin{array}{c}\cdots \\
0 \\
\cdots \\
0 \\
0 \\
0 \\
\cdots \\
0 \\
0\end{array}$ & $\begin{array}{c}0 \\
0 \\
0 \\
\cdots \\
0 \\
0 \\
0 \\
0 \\
\cdots\end{array}$ & $\begin{array}{c}\bar{\cdots} \\
\cdots \\
\cdots \\
0 \\
\cdots \\
\cdots \\
\cdots \\
\cdots \\
\cdots \\
\end{array}$ & $\begin{array}{c}0 \\
\cdots \\
\cdots \\
0 \\
\cdots \\
\cdots \\
\cdots \\
\cdots \\
\cdots \\
\cdots \\
\end{array}$ & \begin{tabular}{|c|}
$\ldots$ \\
0 \\
0 \\
0 \\
0 \\
0 \\
0 \\
$\cdots$ \\
\end{tabular} & $\begin{array}{c}\bar{\cdots} \\
\cdots \\
\cdots \\
\cdots \\
\cdots \\
\cdots \\
o \\
\cdots \\
\cdots \\
\end{array}$ & $\begin{array}{c}0 \\
0 \\
0 \\
0 \\
\cdots \\
0 \\
\cdots \\
0 \\
\cdots \\
\end{array}$ & 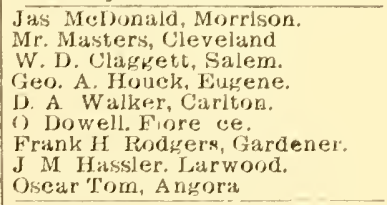 \\
\hline $\begin{array}{l}3 \\
z \\
z \\
z \\
z \\
0 \\
0 \\
0\end{array}$ & $\begin{array}{c}\ldots \ldots \\
\ldots \\
o \\
\ldots \\
\ldots \\
\cdots \\
\ldots \\
\ldots \\
\ldots \\
\cdots \\
\end{array}$ & \begin{tabular}{|c}
0 \\
$\ldots$ \\
$\ldots$ \\
0 \\
0 \\
0 \\
$\cdots$ \\
0 \\
0 \\
0 \\
$\ldots$ \\
\end{tabular} & $\begin{array}{c}\ldots \\
\cdots \\
0 \\
0 \\
0 \\
0 \\
0 \\
0 \\
0 \\
0 \\
\cdots \\
\end{array}$ & $\mid$\begin{tabular}{l|}
$\cdots \cdots$ \\
$\cdots \cdots$ \\
$\cdots$ \\
$\cdots$ \\
$\cdots$ \\
$\cdots$ \\
$\cdots$ \\
$\cdots$
\end{tabular} & $\begin{array}{c}0 \\
0 \\
0 \\
\cdots \\
\cdots \\
0 \\
0 \\
\cdots \\
\cdots \\
\cdots \\
\cdots \\
\cdots\end{array}$ & $\begin{array}{c}\cdots \\
\cdots \cdots \\
\cdots \\
0 \\
0 \\
\cdots \\
\cdots \\
0 \\
0 \\
0 \\
0\end{array}$ & $\begin{array}{c}0 \\
\cdots \\
0 \\
\cdots \\
\cdots \\
0 \\
\cdots \\
\cdots \\
\cdots \\
\cdots \\
\cdots \\
\end{array}$ & $\begin{array}{c}\ldots \\
0 \\
0 \\
\cdots \\
0 \\
0 \\
0 \\
0 \\
0\end{array}$ & $\begin{array}{c}\cdots \\
\cdots \\
0 \\
\cdots \\
\cdots \\
0 \\
\cdots \\
\cdots \\
\cdots \\
\cdots \\
\cdots \\
\cdots \\
\end{array}$ & $\begin{array}{c}0 \\
0 \\
0 \\
\cdots \\
0 \\
0 \\
\cdots \\
0 \\
\cdots \\
\end{array}$ & $\begin{array}{l}\ldots \ldots \\
\cdots \\
\cdots \\
\cdots \\
\cdots \\
\cdots \\
\cdots \\
\cdots \\
\cdots \\
\cdots \\
\cdots \\
\cdots \\
\end{array}$ & $\begin{array}{c}0 \\
0 \\
0 \\
0 \\
0 \\
0 \\
0 \\
0 \\
0 \\
0 \\
0 \\
\end{array}$ & $\begin{array}{l}\text { Tonklin Bros, Newville. } \\
\text { Jas Wilder. Paskenta. } \\
\text { A. Moon. Ono. } \\
\text { Jaeob Oaks, Paskenta. } \\
\text { Ptilo Opden, Upper Lake. } \\
\text { No Name, Ioo. } \\
\text { James H Dunison, Upper Lake. } \\
\text { A. J. Linton, Ager. } \\
\text { Wm. Riehter, Ieo } \\
\text { XYZ, Ono. } \\
\text { O. P. Balley. San Jose. }\end{array}$ \\
\hline$\sum_{x=1}^{3}$ & $\cdots$ & $\begin{array}{l}0 \\
\cdots\end{array}$ & 0 & \begin{tabular}{|c|}
$\cdots \cdots$ \\
$\cdots$ \\
his
\end{tabular} & $\begin{array}{c}0 \\
0 \\
\text { lette }\end{array}$ & & & 0 & $\left(\begin{array}{l}\cdots \cdots \\
\cdots\end{array}\right.$ & & $\bar{\cdots}$ & $\overline{0}$ & $\begin{array}{l}\text { I U. Hightower. Ruidosid. } \\
\text { D. C. Taylor, Lake Valley. } \\
\text { S. C. Hightower. Ruidosa. }\end{array}$ \\
\hline है & $\begin{array}{l}0 \\
\cdots \\
\cdots \\
\end{array}$ & $\begin{array}{l}\cdots \\
0\end{array}$ & $\begin{array}{l}? \\
? \\
?\end{array}$ & $\left|\begin{array}{l}\cdots \\
\cdots \\
\cdots\end{array}\right|$ & $\mid \begin{array}{c}\cdots \\
\cdots \\
o\end{array}$ & $\left|\begin{array}{c}0 \\
0 \\
\cdots\end{array}\right|$ & $\begin{array}{l}0 \\
0 \\
0\end{array}$ & $1 \ldots$. & $\left|\begin{array}{cc}\cdots \\
\cdots \\
\cdots\end{array}\right|$ & $\stackrel{0}{\cdots}$ & $\left|\begin{array}{c}\cdots \\
0 \\
\cdots\end{array}\right|$ & 0 & $\begin{array}{l}\text { I J Laoth, Cresco. } \\
\text { Morgan \& Morgan, Clay. } \\
\text { J. R Standley, Platteville. }\end{array}$ \\
\hline Idato & $\ldots$ & 0 & o & $\bar{\ldots}$ & $\cdots$ & 0 & $\cdots$ & $\ldots$ & $\cdots$ & & $\ldots$ & $\ldots$ & J S. Harris, Jaklev \\
\hline Arizona & $\ldots$ & ? & o & $\bar{\cdots}$ & $\ldots$ & 0 & $\bar{\cdots}$ & $\bar{\cdots}$ & 0 & o & $\bar{\cdots}$ & 0 & I. S Jiarnette Glohe. \\
\hline Mont. & $\ldots$ & 0 & 0 & $\cdots$ & $\ldots$ & 0 & $\cdots$ & $o$ & $\ldots$. & $\ldots$ & 0 & $\ldots$ & S. S Jrannin. Marvilile. \\
\hline Utah & ? & $\ldots$ & (9) & $\ldots$ & 0 & $\cdots$ & $\underline{\cdots}$ & $\ldots$ & 0 & 0 & ") & … & Jos. I llamblin, Knab \\
\hline Wash. & $\cdots$ & $?$ & 9 & $\cdots$ & $\cdots$ & $?$ & $\cdots$ & 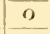 & $\ldots$ & 0 & $\bar{\ldots}$ & 0 & No, Name, Hucuda \\
\hline N. C & $"$ & $\ldots$ & 0 & $\cdots$ & 0 & $\ldots$ & $\ldots$ & 0 & $\ldots$ & 9 & $\ldots \ldots$ & $\rho$ & Lifavette Holt. Burlington \\
\hline W. Va. & $\vec{\cdots}$ & $\cdots$ & 0 & $\bar{\cdots}$ & $\bar{\cdots}$ & 0 & (1) & $\cdots$ & $\cdots$ & 0 & $\ldots$ & 0 & O. D Hili. Kendalia \\
\hline Penn & $\cdots$ & () & $\cdots$ & $\because$ & $\ldots$ & o & & 0 & $\ldots$ & 0 & $\ldots$ & "1) & Miller \& sible.y. Franklin. \\
\hline Okla. & $\bar{\cdots}$ & $?$ & ? & $\bar{\cdots}$ & $\cdots$ & 0 & $\ldots$ & 0 & 0 & $\cdots$ & 0 & $\cdots$ & J. K. Yourg. Woordwald \\
\hline Mo. & $\ldots$ & i) & $\begin{array}{l}0 \\
0\end{array}$ & $\cdots$ & $\begin{array}{l}0 \\
0\end{array}$ & $\cdots$ & $\cdots$ & & $\cdots$ & $\cdots$ & 0 & $\ddot{o}$ & $\begin{array}{l}\text { W. I. See } \\
\text { A. Lippinc }\end{array}$ \\
\hline Mun & $\cdots$ & $n$ & $\ldots$ & ? & $\ldots$ & 10 & $\ldots$ & $o$ & 0 & $n$ & $\ldots$ & $n$ & A. G. Wileox, Hugo \\
\hline
\end{tabular}

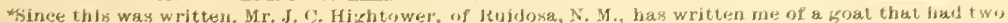
coats of hair. His letter muy be found under the head of New Mexice frecders' Rejorts. 
GENERAL SUMMARI.

\begin{tabular}{|c|c|c|c|c|}
\hline FORM OF QUESTION ASKED. & $\begin{array}{l}\text { Number } \\
\text { Who } \\
\text { Replied } \\
\text { YES. }\end{array}$ & $\begin{array}{c}\text { Number } \\
\text { Who } \\
\text { Replied } \\
\text { No. }\end{array}$ & $\begin{array}{c}\text { Number } \\
\text { who failed } \\
\text { to make } \\
\text { any reply. }\end{array}$ & TOTAL. \\
\hline 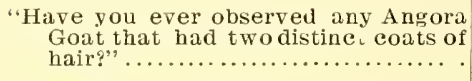 & 12 & 35 & 9 & 56 \\
\hline $\begin{array}{l}\text { "Have you observed that some An- } \\
\text { gora Goats shed sooner than } \\
\text { others?" } \ldots \ldots \ldots \ldots \ldots \ldots \ldots \ldots \ldots \ldots \ldots \ldots \ldots \ldots \ldots \ldots\end{array}$ & 42 & 4 & 10 & 56 \\
\hline $\begin{array}{l}\text { "Have you observed that some An- } \\
\text { gora goats do not shed at all?".... }\end{array}$ & 30 . & 24 & 2 & 56 \\
\hline $\begin{array}{l}\text { "Have you observed that some An- } \\
\text { gora kids do not shed their first, } \\
\text { or 'kid,' hair?" } . . \ldots \ldots \ldots \ldots \ldots \ldots \ldots \ldots \ldots \ldots \ldots\end{array}$ & 24 & 20 & 12 & 56 \\
\hline 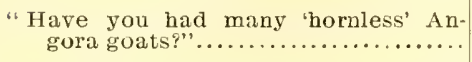 & 11 & 31 & 14 & 56 \\
\hline $\begin{array}{l}\text { "How do you decide upon the quality } \\
\text { of an Angora Buck?"................ }\end{array}$ & Pedigree. & By Merit. & $\underset{10}{\text { By Both. }}$ & No Reply. \\
\hline
\end{tabular}

It will be observed that some of our oldest and largest breeders are among those who have never seen a non-shedding goat; and, some even go so far as to affirm that such an animal does not exist; but in the face of the testimony I am now prepared to lay before my readers, on this question, I think it is idle to make such a statement.

I regard non-shcdding a most important feature as the shearing of Angoras in the month of February or March (which is made necessary, in many sections, in order to avoid loss from the shedding of the fleece), is usually attended with more or less loss in life from the cold rains and wind storms that are common at this season of the year.

The following communication, from Mr. J.C.P.McLendon, of Texas, will, I think, convince many of the doubters of the existence of this type of Angoras:

"Dripping Springs, Hays Cotunty, Texas, Oct. 16, 1899. "Col. Wm. L. Black, Ft. McKavett, Texas.

"Dear Sir:-Y Yours of the 4th received. Yes, you can tise anything in my former letter I may have said about Angora goats, or in this. Certainly, we have different types of so-called ptire-bred Angoras. Any breeder 
oi close observation can but be convinced of that fact. In regard to shedding, I know that climatic influences and the condition of the animal may have some influence, but my experience proved to my satisfaction, that there are Angoras that do not shed their mohair any more than sheep shed their wool, and I think all breeders should aim to secure and perpetuate that type. Col. Robt. W. Scott's stock farm was near Frankfort, Ky. He died some seven or eight years ago. He was a scientific, conscientious breeder, a true type of the Kentucky gentleman. I never knew him personelly, but my dealings and correspondence with him, enable me to accord him all honor.

"I don't know whether I mentioned it or not in my former letter, but all of my goats that did not shed their mohair, were pure white to the skin. Many were white that did shed, but none that had a yellow tinge near the hide held their coats, but shedded off clean with an undercoat of fine short hair, aIso yellow. Those that were white and shedded, had white, short hair.

"Any direct questions you may wish to ask, will be answered to the hest of my knowledge. I believe, though, I have condensed all I know of importance.

Respectfully,

J. C. P MCLENDON:

Messrs. Conklin Bros., of Newville, Cal., write as follows:

"Newville, Caliiornia, Aug. 19, 1899.

"Mr. Wm. L. Black.

"My Dear Sir:-In reply to questions you ask, will say to No. 1: We have never known a goat to produce fur as an undercoat, but have read that such goats are produced in Turkey, and that the finest Cashmere shawls are made from this undergrowth, after the long hair is separated therefrom. But they are not considerer profitable, as they only shear a iew ounces, and the heavy: coarse hair is of but little value.

"Nc. 3. We have a number of goats that do not shed their hair in the spring, have a continuous growth, and their kids do not shed their kid hair either. This we know, for during kidding, we oiten paint the twin kids with red paint, and they carry that paint until shorn in the fall, and we believe that by careful and correct breeding, we can secure a flock of that kind. This is one point that we are working for now. W We have no hornless goats but are informed that there is a breed of that kind in Asia Minor, but do not know whether it is a distinct breed or not.

"I can not see why there should not be a thoroughbred Angora, as well as a thoroughbred horse, cow, sheep, hog or dog. My idea of the term 'thoroughbred, is an animal that is bred for points ior a period of years, until the type is fixed, so that the offspring will be of the same kind, bred year after year, and not degenerate, or if bred to inferior blood 
will reproduce themselves in six crosses and make a full blood animal. This might be a different type from any other in Turkey, and called the 'American type.' Our goats have been bred for over thirty years, and a systematic record of them kept; each goat numbered, and character noted by points, so that now we can choose a pair of goats, and tell almost exactly what the progeny will be as to fleece, covering, weight, and constitution, etc. This, we think, is pointing to thoroughbred standard.

"There are so many different grades of goats that I think that each individual will have to work out his own type, or strain, and among all of them, therc will probably be but few that will produce anything of value. Only very few can succeed in improving any kind of animals. It requires a certain kind of tact and continual effort, and long perseverance, perhaps a life-time to accomplish one certain idea, as it was with the Merino sheep. One hundred years ago, all sheep in America shed their fleece, more or less; now, such a thing is unheard of unless by disease, and, I am sure that Angoras can be brought to this point, perhaps in a very few years more.

Yours very truly,

CONKLIN BROS., Per M. L. Conktin."

A close neighbor to my ranch, Mr. W. F. Luckie, whose postoffice address is Fort McKavett, Menard County, Texas, stated a circumstance, a short time ago, which is very conclusive testimony on this subject. He had placed all of his bucks on the ranch of a neighbor, and failed to shear them with his other goats. One of them carried his Heece perfectly through the entire summer, and, with the exception that it matted in places on the hind quarters, it was just as nice in appearance as the ones that had shedded off and grown a new fleece.

Mr. Hoerle, also, refers to having seen non-shedding goats during his experience as a breeder in Texas in the early eighties. Mr. Hoerle says, in the circular letter addressed to Mr. Wm. R. Payne, already referred to:

"I observed right in the first year, that after shearing, quite a number of my goats would not shed, others showed after shedding, quite a long undergrowth, which looked entirely difierent from mohair. Amongst the goats which did not shed their mohair, were, so to speak all the offspring of the Maurice importation, and quite a number of the other thoroughbreds, as well as a few of the high grades. This observation brought me to the conclusion, that the original pure Angora probably did not shed, if shorn at the proper time." 
The following remarks, with reference to non-shedding and other peculiar types of mohair goats by breeders who appear in the tabulated list of replies, will, no doubt, be interesting as well as instructive upon this question.

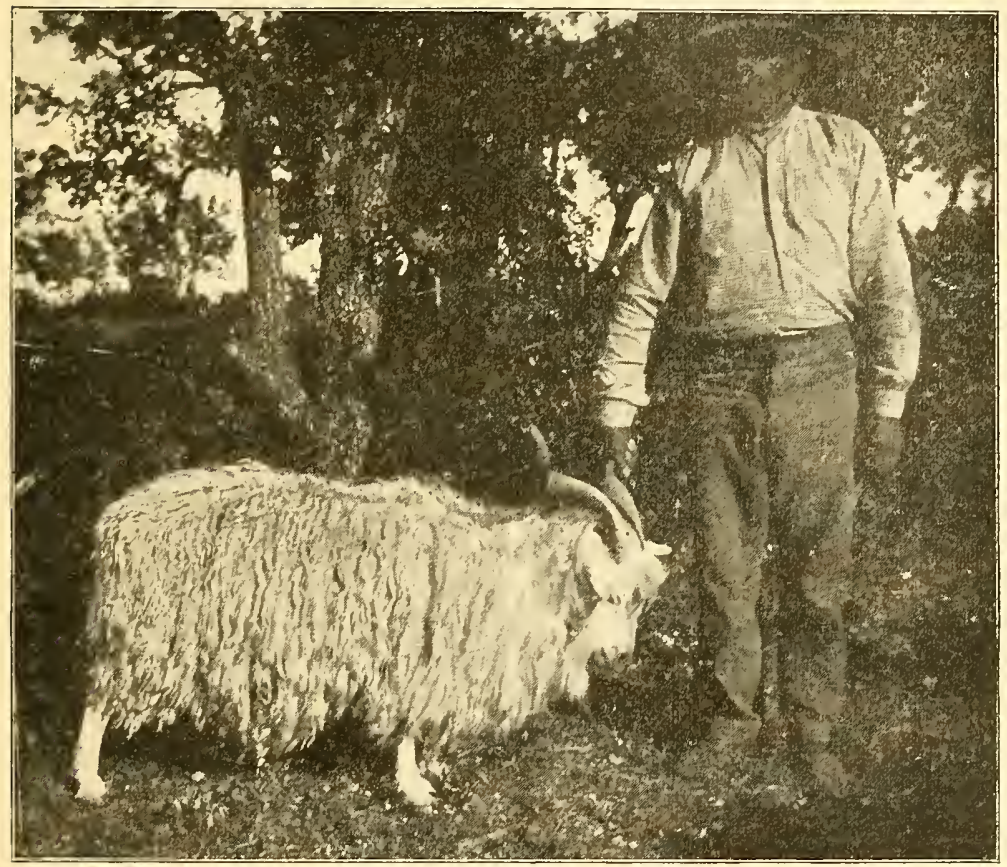

PIATE VIII.

\section{NON-SHEDDING ANGORA BUCK.}

Property of the author; raised by Mr. J. D. Hunter. Junction Cily, Kimble County,

'lexas. He was sheared October 15, 1899, and the above photograph was taken June 15,1900 , being eight months' growth of fleece. There seemed to be very little growth to the mohair. after December I, until about April 1, when it made a second growth. The spot on the neck, which appears $t$, be bare of hair, is caused by the shadow from the horn.

Mr. H. T. Fuchs, of Tiger Mill, Texas, says:

"The better they are graded up the less different kinds of hair they have. I have observed that they are less liable to shed their hair after they have passed the fifteen-sixteenth grade. I do not have many kids that do not shed their first kid hair. I have had, perhaps, as many as three per cent. of hornless kids. They are very good shearers, not quite so silky, but are excellent for milk, and are very hardy. 
"I do not like these goats with two kinds of hair. I think we should try and raise them to produce only the long, silky, mohair."

Mr. J. M. Arnold, of Montell, Uvalde County, Texas, says :

"I have never seen any Angoras with fur next to the skin. Some of our goats have escaped shearing and passed the shedding season without casting their hair until fall; but the most of them shed.

"I do not know that the 'hornless goat' is a freak, and feel surc that by using natural hornless bucks and does, their progeny will soon be hornless and breed so. We always select our bucks on merit."

\section{Mr. Jno. Brown, of Sonora, Sutton County, says:}

"With regard to 'non-shedding' goats, I have seen goats that shed but very little, hard to be noticed in fact, but they all shed more or less. The kids that do not shed their first kid hair, are very rare with me. The great majority of them shed. I have luad but a few hornless goats. I always select bucks both by pedigree and individual merit."

Mr. W. G. Hughes, of Hastings, Kendall County, Texas, says :

"I do not remember ever having seen any Angoras with fur under the hair. resembling Cashmere wool, (or 'pushm') nor can I believe that it would be advisable to propagate it if found. First, because of the difficulty of separating it from the other part of the fleece; second, because it would be so light that the cost of raising it would be so great, we could hardly expect to get a remunerative price year in and year out, owing to the fact that sale for it would largely depend upon temporary fashions, and not permanent demand, and fashions are proverbially fickle.

"As to goats that do not shed. Most Angoras that have come under my notice do not shed, though some will shed one year, and not in another, I believe that if the goat is poor in the winter and fattens rapidly in the spring, it is more apt to shed than if it comes through the winter in good shape. The same remarks apply to kids; that is, those that are six montlis or a year old when first shorn. I like to see them retain their stubble, and believe it to be a sign of thrift.

"I have noticed in some of the flocks a tendency to grow a fleece with considerable oil in it. Those I have seen have invariably had a coarser fibre of hair than the 'non-oily' ones, and I have always tried to avoid this class of goat, having reason to believe that there is no advantage in it, and that the excess of weight is only an unnecessary drain on the goat, because if there is no intrinsic advantage to the staple, buyers must sooner or later discriminate against it, when purchasing, to the extent of the shrinkage, just as they now do with wool. My present opinion is also largely based upon the same estimate of its value placed 
by Mr. Schreiner in his very interesting work, 'The Angora Goat,' (published by Longmans, Green \& Co., New York,) and on similar information which that gentleman very kindly gave me some years before his book appeared in print. Indeed, it was largely due to this that $I$ have been able to avoid what I now regard as a pit-fall, as our breeders are, at present, going through experiences which were gone through years ago by the Cape farmers.

"The latter have tried the excessive oil extrene which is now avoided by the best breeders."

Mr. W'm. M. Landrum, of Laguna, Texas, says:

"I have never seen an Angora with but one coat of mohair, but often an undercoat of kemp. The difference is, 'kemp' is a white, smooth, coarse hair, hollow in the centre, with cells, or scales, on the outside, filled with glue and transparent oil, in all healthy, fat goats. I have seen goats that never shed, and when shorn, would grow hair from the stubble like a sheep. I sheared a doe in 1875 on Guadalupe Island, off the coast of Lower California that measured twenty-two inches long and had grown for two years.

"I have had kids dropped with two and one-half inches of pure mohair on them, and never shed, any more than a Merino sheep.

"Regarding bueks. I first look to a goat's ancestors, and if all is right, then to the covering and character of fleece, the form, constitution, and individual merits generally.

"I purchased the only hornless buck that ever came to America, bred him to 250 does, mostly grades. I think they are a distinct breed, for they have no kemp, and only one kind of hair. The one I had was a very heavy shearer, but rather too coarse. I sold his hair, generally, for wig-making."

\section{Doughter \& Luttrell, Lipan, Hood County, Texas, say:}

"Our observation has been that it is owing to the time of birth of a goat, that makes it shed at different times in the spring. We have some goats that do not shed at all."

\section{Tom S. Evans, Exile P. O., Texas, says:}

"If pure-bred bucks are used and the same style of hair, or sire is used continually, flocks can be bred to uniformity in hair, and to shedding, too. If one gets a good buck, who marks his kids, they should keep him, and do all they can to get another of same stock and appearance. The test of all pure-blood animals is the power to transmit its qualities to its offspring. Most grade animols are better than their sires." 
Mr. H. B. Marshall, Austin, 'Texas, has only seen a wery feco goats that do not shed.

Mr. B. F. Lowry, Camp San Saba, Texas, has also seen wery for' non-shedding goats.

Col. IV. IV. Haupt, of Kyle, "Nexas, says, that up to the lime he disposed of his goats to Mr. W. E. Hughes, he had nerer observed that any of them retained their stubble after shearing He always stipposed they all shed their fleece regularly.

Hon. B. L. Cronch, Pearsall. Texas, says:

"As to the Angora goats shedding their fleece my best bred goats shed their fleece every spring if not sheared early, and it always seemed to me that those thriving most rapidly; shed first, though in this I may be slightly in error. But I also observed, that if there came rains in October sufficient to make new regetation abundant, many of my goats would shed their fleeces partial in October and Norember, and for this reason I adopted the practice of shearing twice a year-in September and March."

Mr. Geo. MI. Baylor, Montell, Texas, says:

"I have nerer observed any iur under the mohair. Plenty of goats do not shed in the spring. It is generally some goat whose hair is in good groming condition when shorn, and it keeps on growing. But it is better for then to shed in the spring. 'Ther saed sleet in Angora, in the spring, as soon as it gets warm, and the green feed comes. I think all kids shed their kid, or first hair. They are not born with mohair on them. It is rather a coarse hair, more resembling kemp.

"I have not a hornless goat in my flocks. I rather think it a freak. In breeding. I first am sure of the pedigree, and then I pick for individual merit."

\section{Mr. James McDonald, Morrison, Oregon, says:}

"I think condition governs the shedding of an animal. None of my kids ever shed their first hair." ,

Mr. Geo. A. Houck, Eugere, Uregon, says:

"I attribute shedding of goats at different periods in the season to the condition of the animal. As to goats not shedding at all, I have never observed such, but all of my good goats sprout new mohair almost 
Broding-Past Erforienci-Result of Crossing the -1ngera. 2xa

as soon as the old stubble sheds oft. The hids all shed their hid hair with me. I have a few nannies and wethers without horns, but I consider it a ireak. These goats I bought from other breeders. Mr own goats all have horns."

\section{Mr. D. A. TValker, Carlton, Oregon, says:}

"My opinion has been that ii a goas is rey lousy it will shed early. and if not. it will shed when it begins to thrite in the spring."

\section{Mr. Tas. MTilder. Paskenta. Cal., says:}

"I had three bucks that were not sheared last spring. that carried their fleeces till the shearing in the fall."

\section{Mr. J. C. Highrower. Ruidosa. M. M., sats:}

"I have obserted that a number of my goars do noI shed their hair ofter they shed their irst hid hair, and their first ileece oi mohair grows on until they get to be two or three years old, and after the! pass that age. they shed restilarly every year. I have obserted. too. that after they pass that age that some crly shed orer a portion oi their body.

\section{Mr. Oscar Tom. Angora. Oregon, sats:}

"I have neter obserted an Angora goat that did not shed. nor anyfordy $\epsilon^{\prime}$ e. unless it was dead poor, and would die beiore the second rear. Any healthy goat will shed in the spring the same as a horse."

\section{Mr. D. C. Taylor. Lake Talley, A. M.. says:}

"I have about 2000 goats. and but a rery few oi them shed any."

\section{DT. T. R. Standley, Platteville, Iowa. says:}

"I am quite positive about some Angoras not shedding, having observed it oiten; also hids that do not shed their first hid hair. I have seen some few goats that had a double coat. but the under one was kemp."

Mr. I. C. Hightower, under data of Miay 3rd. 1900, writes as follow: :

"In the questions which I endearored to answer for you last iall I believe I stated I had not observed any undergrowth of the wool in the goats in this country. I wish to state now, that, since that time I have observed such a growth on one oi my goats which came from Col. Richard Peters flock in Atlanta, Ga. The animal is a buck ten rears old 
and I send you a sample * of his fleece which you can see has two very distinct kinds of hair. The hair was plucked from him while he was shedding."

\section{In a subsequent letter, Mr. Hightower says:}

"The under-hair, as near as I can judge, developes in the winter. As to the outer-hair shedding I will say this spring is the first time the guat has shed. This year he shed off sleek and clean, the outer-coat as well as the under-coat."

Mr. Jno. S. Harris, of Oakley, Idaho, writes me that when he was in Constantinople he saw a sample of mohair that was sent by Mr. W. M. Landrum to Mr. Jno. R. Thompson. The mohair had been grown in Guadalupe Island, off the coast of Lower California, and was two years' growth.

With reference to two distinct coats of hair, he says:

"I never saw such a goat, but it is quite common for some to have more or less 'kcmp' in the hair. Some years, a goat will have more, and another year it will have much less. It all depends on the condition of the goat, and the kind of scason we lave.

"After I came back from Angora to California, an old gentleman, that lived on the coast at Monterey, wrote to me that he wanted to exchange two hundred common goats for two high-graded Angora bucks, so I went to see him and his goats. I lived about seventy miles on the west side of the San Joaquin. When I looked at his goats, they were long-haired Mexican goats, and through curiosity I caught one and examined its hair, and it had an undercosting of fur like the Tarsus goats. I said to the man the only objection I had to his goats was tha. they were long-haired. As the party I wanted to trade them to preferred short-haired Mexican goats, as they were more suitable to cross with the Angora. He stated to me that when he first took a notion to get goats some fourtecn years before, he went to the east side of the San

*The sample of outer-hair, referred to by MI*. Hightower, is about twelve inches in length, and quite coarse; the under-hair is rery fine and about four inches $i_{2}$ length, resembling fur at the base, and about one-half the diameter of the outer neece at the cxtreme end.

The hair is very straight and very much like Mal'uese goat hair, but this is doubtless owing to the age of the animal. It was very thoughtful in Mr. Hightower to call attention to this matter, and it is quite evident that the animal is a descendant of the "Cashmere" goat. 
Joaquin and bought him two hundred head of Mexican goats. The hair, at that time, of these goats was short, and every generation with him the hair was getting longer. He showed me hair he had clipped off his goats for the making of hair rope, that was eight inches long. Now, according to my opinion, it is climate that influences and controls every thing that lives, man or beast, trees and herbs, of every kind. What I mean by climate, is the air, water and the elements that are in the earth."

Bearing upon this question, the following letter from Mr. John Kennedy, a prominent breeder of sheep and Polled-Angus cattle, in Menard County, 'Texas, will be of interest:

"Mr. Wm. L. Black:

"Deervale Ranch, Menard County, Texas.

'Dear Sir-Referring to 'non-shedding' Angora goats, I have never observed such an animal that I know of, but I can see no good reason why such a type should not exist. We have, in our sheep family, a very great variety of wool-bearing animals, and I should think the same peculiarity would be entirely natural with the moliair goat. The Cheviot sheep, for instance, always sheds its fleece, and so does the Lincoln, and perhaps others that I have had no particular acquaintance with, but, with the types I have mentioned, I have had more or less experience in Scotland, and I know it is natural for them to shed off their wool every spring, and it is the custom always to wait until the new wool begins to grow before shearing them. If they are not sheared the wool will peal off in flakes, and will very soon all disappear, and the new growth take its place.

"With some varieties of sheep, this is not the case, as, for instance, the Merino, and the Shropshire, which will hold their wool from year to year, and, as above stated, I see no reason why there should not be a type of the same character in the Angora goat family.

"I consider the matter a very important one, and shall watch the result of your experiments with great interest.

"Yours truly,

"JNO. KENNEDY."

"HORNLESS ANGORAS."

The hornless type is not so remarkable as they are known to exist in Turkey, yet are very rare, both in South Africa and this country.

Mr. Schreiner says: 
"There are other varieties in the modern Angora, due, I believe. to the original Angora having been crossed with other breeds. For instance, Conolly says: 'A curious statement made to us at Angora was, that only the white goats which have homs wear their fleece in the long, curly locks that are so much admired; those that are not horned having a comparatively close coat, I can not add anything to this statement, not having had the point suggested when I was farming goats, but Mr. Binns says it is devoid of fact. It may, however, be remembered that the female of Capra Aegagrus is occasionally hornless, though I cannot see that this has any bearing on the statement made to Conolly. It will be interesting if observant men engaged in the industry will notice if hornless goats (which, by the way, are very rare in this colony) have not, as a rule, the curled locks in so pronounced a degree as those that are horned. 'This peculiarity, if it does exist, may not, of course, be due to the influence of some cross; the variations may simply be collateral. Further, crossing has been so universal and has had such an overwhelming effect that a variation which might have been pronounced in 1840 (the date of Conolly's paper), might be almost obliterated now, especially in the Cape, where the Boer goat has exercised such a powerful and far-reaching influence." See Schreiner, p. 100.

\section{Br. Bachman says:}

"In the northern provinces of China there are goats of a small size which yield wool as abundantly as the sheep of the same country. Extending over the varied surface of Hindustan, the goats assume a prodigious diversity of color, aspect and form. Sometimes they have horns, and sometimes they are destitute of them; sometimes they have long, pendulous ears; sometimes they have a short fur, like that of a fawn, and sometimes fine, silky hair, falling in glossy ringlets on each side of the dorsal line. The largest of the goats of Hindustan are brought from Cabul, Thibet, and the highlands of Persia. The varieties in form, color, and quantities of pelage, under which these various breeds of goats are presented will account for the great difference in the figures of what are called Cashmere goats. 'The same may be said of the Thibet shawl, and the Angora goats. In a word, they are all of one species, but under many varieties; breeds have become permanent, and some are infinitely more valuable than others. Local names have attached to these various breeds, many of which are still confined to the herdsmen of the East. To the farmer, the possession of the most valuable breed of goats is of far more importance than the name by which it is designated." (See Agtl. Dept. Report, 1857, p. 58.)

Mr. Diehl imported a hornless Castomboul buck in 1870 , which was sold to Mr. Wm. M. Landrum, who took it to California. Mr. Landrum writes me on this subject, as follows: 


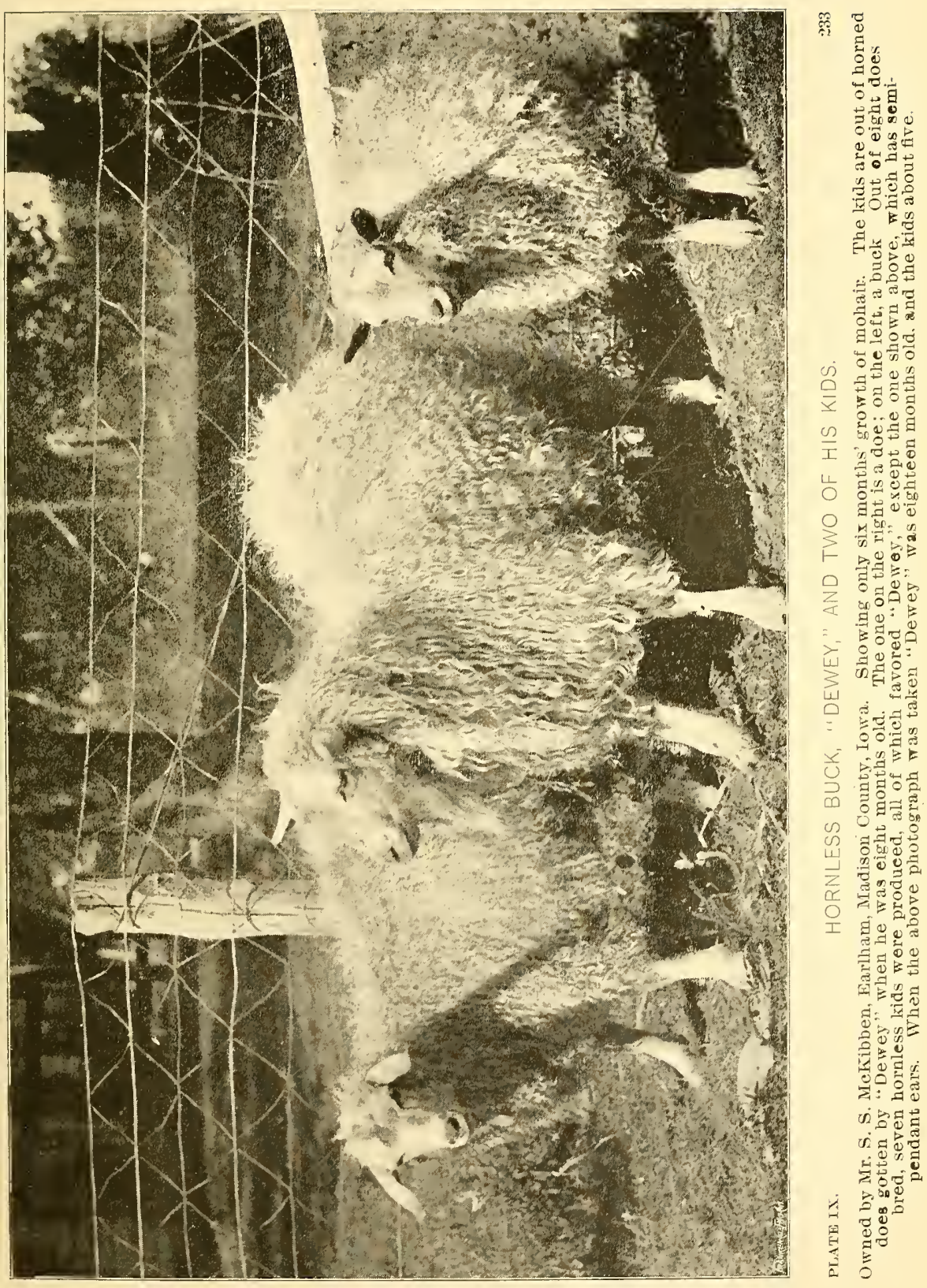



"I selected two bucks from the Diehl \& Brown importation, one of which was the celebrated Castomboul hornless buck which sheared twenty pounds, but too coarse for any use but for making wigs. I bred him only one year, mostly to graded ewes."

"In Fitzinger's Natural History (German), figures 212-215, there are four good views of the hircus capra pillosa, the roughhaired domestic goat, the Cashmere, and the Thibetian, in which the Cashmere is represented with a black neck and white face, almost straight, round, pointed horns, long, coarse, white hair, tail six inches long; while the Thibetian goat is represented with a long smooth neck, a shape-like head, hornlcss, short hair, with an immense udder, indicative of a good nilker rather than a fleece-bearing animal." (See Agtl. Dept. Report, 1863, p. 221.)

Mr. S. S. McKibben, of Earlham, Madison County, Iowa, secured a hornless goat from a lot he had purchased in Texas, and, having a preference for polled stock of all kinds, he concluded to breed him to see if he would breed true to type. His first experiment was in the spring of 1898, with eight horned does, and the result was seven hormless kids, and one that had horns.

Mr. McKibben writes me the following description of this animal, which he has name "Dewey," and whose photograph is here given:

"Earlham, Iowa, Sept. 10, 1899.

"Mr. Wm. L. Black, Fort McKavett, Texas:

"Dear Sir-Referring to my hornless buck, 'Admiral Dewey,' he was dropped in the spring of 1898 , and came to me with a lot of Angora goats that were shipped from Texas, in July of that year. I concluded not to sell him, as I had a preference for polled stock of all kinds, and was anxious to see if I could perpetuate the type. At the age of about eight months, 'Dewey' showed to be a very well developed animal, and was much larger and heavier-boned than any of the horned goats of the same age. In December of 1898 , I bred him to eight horned does, and they dropped eight very finely developed kids, the May following, seven of which were hornless, and very much like 'Dewey' one had the same kind of (lop) ears like the does, the remainder having (fox) ears, like himself.

"I herewith enclose you a photograph showing 'Dewey' and two of his kids. I shall breed him in December to about seventy-five does/; and feel quite confident the result will be equally as favorable as above stated. 
"Referring to the general disposition of 'Dewey' I would state he is very gentle, and never shows the slightest inclination to fight, or buck, which is a common characteristic with the horned goat, often resulting in the breaking of a leg by hooking each other in play.

'The hair of 'Dewey' is of a wary character, very fine in fibre, and well distributed over the entire body. It grows to about the length of eight to ten inches. Dewey promises to be much larger than any goat I have ever seen, and I shall not be surprised if he should reach a weight of 175 pounds.

Yours truly,

"S. S. MeK1BBEN."

To my own mind, it is not surprising that these different types of Angora goats exist, for it has been the experience of all cross-breeding of domestic animals, in the past that, some new type has cropped ont from time to time, which, when preserved, and bred with care, has been developed into a distinct breed.

\section{Darwin says:}

"The many breeds of dogs and cattle may arise from nore than one species, but probably those of horses and fowls; and, clearly those of rabbits, ducks and pigeons are each descended from a single species. In this respect the breeds of pigeons are of peculiar inportance, since not only carrier and tumbler, runt and barb, pouter and fan-tail, but at least a score of varieties might be chosen which differ so thoroughly, internally, as well as externally, that an ornithologist treating them as wild birds would be compelled to grant them specific, and even distinct generic, rank. Yet, since all these have indisputably arisen from the wild rock dove (Columba lizia) it is clear that naturalists, who admit a unity to such domestic races, which professed breeders have often laughed to scorn, should, in turn, be cautious before deriding the unity of wild ones.

"How then have domestic races been produced? By external conditions, or habits, alone. One of their most renarkable features is, in exhibiting adaptation, not to their own good, but to man's use or fancy We know that all the breeds were not produced as perfect as we now see them, ant the key is man's power of accumulative selection; nature gives successive variations, man adds them up, making for himself useful breeds.

"Skilful breeders speak of the organization as plastic and under control, and have effected extensive modifications within our own generation. Unconscious selection, which results from every one trying to possess and breed the best individuals, is even more important. This 


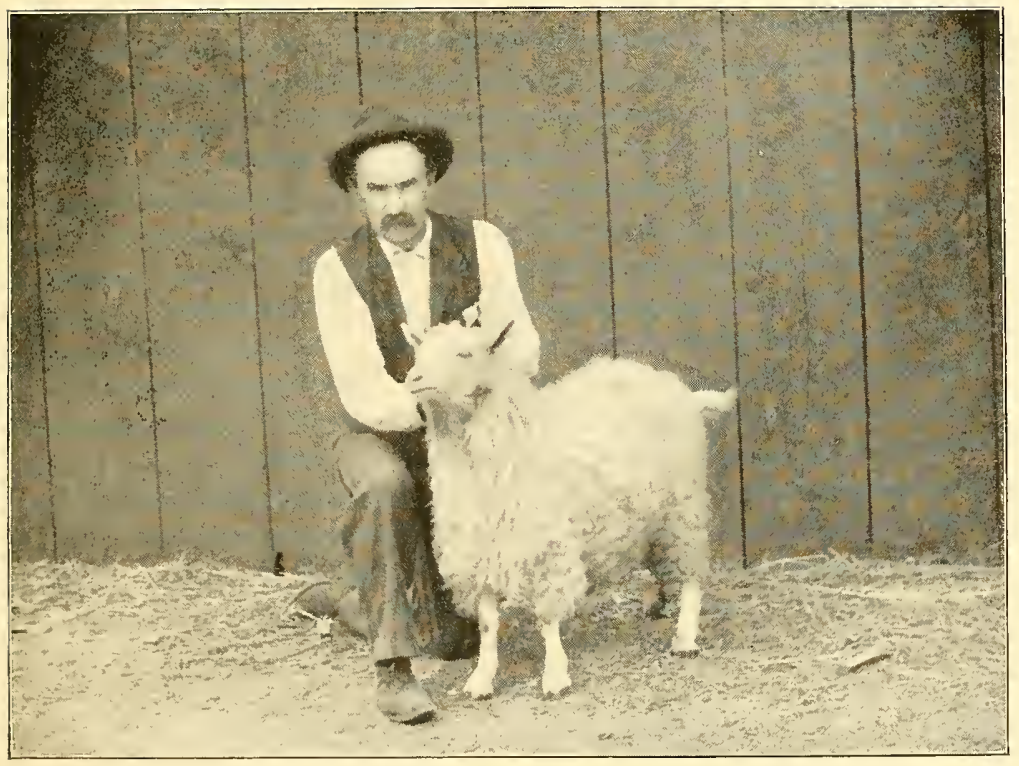

S. S. MCKIBBON.

Skowing one of his Hornless Kids, four months old. 

accumulated change explains why we so often cannot recognize the wild parent stocks of our cultivated plants, while its absence in countries inhabited by uncivilized man, explains why these never yield plants worth immediate culture. Man's power of selection is facilitated by keeping large numbers, in which variations are more likely to occur. Facility in preventing crosses is also of importance, as of pigeons, contrasted with cats; some species are, however, less variable than others, e. g., the goose."

He also says:

'A race of cattle called 'Dutch buttocked,' was formed in Yorkshire by selecting in each generation the animal with the largest hind quarters. When the breed began to be established, it was found that the large size of the calves' hind quarters increased the dangers of parturition to a considerable extent. This case is interesting as showing that hurtful peculiarities may be inherited just as leadily as those which are beneficial, and, as bearing witness to the improbability of the view that there is an innate tendency to vary in the right direction."

In his work on the "Origin of the Species," this renowned 1)aturalist says:

"I have discusser the probable origin of domestic pigeons at some, though insufficient length, Jecause, when I first kept pigeons, and watched the several kinds, well knowing how truly they breed, I felt fully as much difficulty in believing that since they had been domesticated they had all proceeder from a common parent, as any naturalist could in coming (o) a similar conclusion in regard to the many species of finches, or other groups of birds, in nature.

"One circumstance has struck me much, namely, that nearly all the breeders of the various domestic animals, and the cultivators of plants, with whom I have conversed, or whose treatises I have read, are firmly convincer that the several breers to which each has attender are descended from so many alooriginally distinct species. Ask, as I have asked, a celebrated raiser of Hereford cattle, whether his cattle might have not descenderl from long-horns, or both from a common parent stock, and he will laugh you to scorn. I have never met a pigeon, or poultry, or duck, or rabbit fancier, who was not fully convinced that each main breed was rescended from a distinct species." (See "Origir of the Species," p. 23.)

liut is quite unnecessary, I think, to dwell upon this, for it is known to all American and English breeders that most of our present fine types of horses, cattle, sheep and hogs, have been produced by selecting the finest specimens and breeding them separately. Some may have originated from so-calleri 
sports, or freaks; but, is it not reasonable to believe that these sports or freaks, would not have been produced, if it had not been for the cross-breeding which had been followed before?

In the face of such convincing testimony as I have referred to, it is idle, in my opinion, for anyone to undertake to describe a "thoronghbred Angora goat" at this time. An animal with wavy hair, measuring six inches in length, and with fox-like ears, may have as much right to that proud title as one which has hair hanging in beautilul ringlets twelve or fifteen inches in length, with long pendant ears.

The valuable American Merino sheep of today bears but little resemblance to the Spanish Merino which was improved by careful selection of the best types; and, the French Ramboullet owes its origin entirely to the same course of breeding.

Mr. Henry Stewart, in his recently (189S) published work on "The Domestic Sheep," says:

"Every existing breed of sheep has been differentiated from the wild race by human agency." (See Stewart, p. 239.)

It is therefore quite possible to bring about the same result with the mohair goat, if the same care is exercised in selecting and breeding.

Mr. Bachman, in concluding his report on the "Davis" goats, says:

"Since it possesses the characteristics of all the other domesticated animals, we have reason to believe, that, by judicious breeding and devoting to this subject the same attention that breeders in England bestow on their horses, cattle, sheep and swine, an equal number of improved varieties will be produced. TVe are, at present, unacquainted with any superior variety of goat, with which this might be crossed to improve the fineness of the wool. Improved individuals, however, spring up in these varieties themselves, without any foreign admixture; and, by selecting these, and separating them from the common stock, we have at once a new breed, which soon becomes a permanent race.

"Let us, in these matters, follow the teachings of Nature, in all her departments. How were the varieties of Sea Island cotton, or large rice, or prolific corn, wheat, etc., produced? A few stalks of these superior qualities were detected in the fields. Thus far it was the free gift of a beneficent Creator. Man, his agent, now selıcted and cultivated them separate from the others. Thus, a valuable variety was obtained 
that may, by proper care, be perpetuated. In the 'Courier des Eitats Unis,' we have a long and interesting account of a Merino sheep in France, which, instead of wool, produced fine silken hair. The breed was perpetuated, and goes under the name of 'Cashmere sheep.'

"At the Universal Exhibition, in Paris, it was affirmed by the judges of one of the shawls made of this hair that "they found this (as they named it) native Cashmere, as soft and as brilliant as the imported and that it was superior to the latter on account of its regularity of detail." (See Agtl. Dept. Report, 1857, p. 65.)

\section{WEIGHT OF CARCASS.}

Is an important feature that should not be lost sight of by the American breeder. The reports I have received upon this subject, which may be found in detail under the head of "Notes From Practical Breeders," indicate the weights of Angora goats as ranging from 75 pounds up to 175 pounds. It is manifestly to the best interest of the industry that as large an animal as possible should be propagated, and it is well that breeders should keep this in view, when it is possible to combine it without too large a sacrifice of the more important essential, a good class of combing mohair.

In a letter from Mr. S. S. Brannin, of Marysville, Mont., he says:

"There is no doubt but what they grow larger in the Northern country, than farther South, as my three-year-old muttons average ten to fifteen pounds more than in New Mexico, where I brought them from. I have also noticed an increase in quantity, and quality, of mohair.

"I made a trip, last summer, through the western part of this State, for the purpose of learning what I could of the wild goat. We succeeded in finding a good many, and killed one so as to more closely examine them, and I find they are a genuine goat in every particular. The greatsst difference from the domestic goat being in the head and face which is much longer and thinner. They are much larger, however, the bucks weighing as much as three hundred pounds. In color they are entirely white, and in winter they are covered with an immense coat of fine wool, with long, coarse hair on the neck, legs, and withers. The bucks have a long beard under the chin. Horns are black, and smaller than the domestic goat. Legs are short. Feet near the size of a yearling calf. They inhabit the high rocky ranges, their habits being exactly the same as that of the tame goat. 
"A person will have no trouble in locating their range as the country is completely strewn with wool. I send you herewith a sample of this wool."

It would, indeed, be interesting to see what a cross from this wild species with an Angora goat would result in, and it is to be hoped that some of the breeders in Montana, or neighboring Territories, will endeavor to make this experiment. (See Appendix for plate and particulars of the Rocky Mountain goat.) 


\section{CHAPTER XIX.}

\section{CROSS BREEDING, OR HOW TO GRADE UP THE "MEXICAN" GOAT.}

The "Mexican" goat consists of three very distinct varieties, which are mixed in color, the white predominating. As a rule, they are thin bodied, $\log g y$, and have very much the shape of a Mexican sheep. One of the varieties has short, coarse hair, but bright and glossy. Another has short hair, which has a dead, "kempy" appearance; and the third has long, straight hair, sometimes five or six inches, and is undoubtedly a descendant of the Maltese. It is advisable always to avoid this latter kind, as they are hard to improve. Indeed, it is next to an impossibility to completely change their character. Many breeders, especially in the early day, have attempted it, doubtless attracted by their long hair, which, although coarse in fibre, is very pretty and glossy, and would seem to indicate a near relationship with the long-haired Angora, but they are no kin at all, and the fact of their having retained their individuality for several centuries, in Mexico, where they have been bred and interbred with the shorthaired goat, is very strong evidence of their great strength of blood.

Col. J. Wash. Watts, of South Carolina. appears to have had some experience with this kind of goat, he says:

"I began with the milk goat; had two varieties-the long-haired 'Maltese,' and the short-haired 'South Amcrican.' About the year 1872 I came in possession of three 'Angoras,' one buck and two does, obtained from the Hon. D. Wyatt Aikcn, our member of Congress, who got the buck from Col. Peters, of Georgia, and a splendid animal he was. The does were from the flock of the late Hon. W. H. Stiles, ex-Minister to Austria, who made an importation about the year 1860. I bred the buck to my milk goats; the result was a beautiful lot of large, well- 
formed half-breeds, showing no fleece. He was bred to his kids the next fall, which produced a pretty animal with considerable fleece, which grew to be about three inches in length. Those descended from the shorthaired goat had a much more uniform fleece than those from the longhaired goat; and, some of those retained their long, straight hair through the fourth and fifth crosses."

Col. Watts attributes the difficulty in improving the Maltese goat to the fact that, "it is easier to breed up a fleece than to change one," which is a very reasonable conclusion.

PLATEZ $\mathrm{X}$.

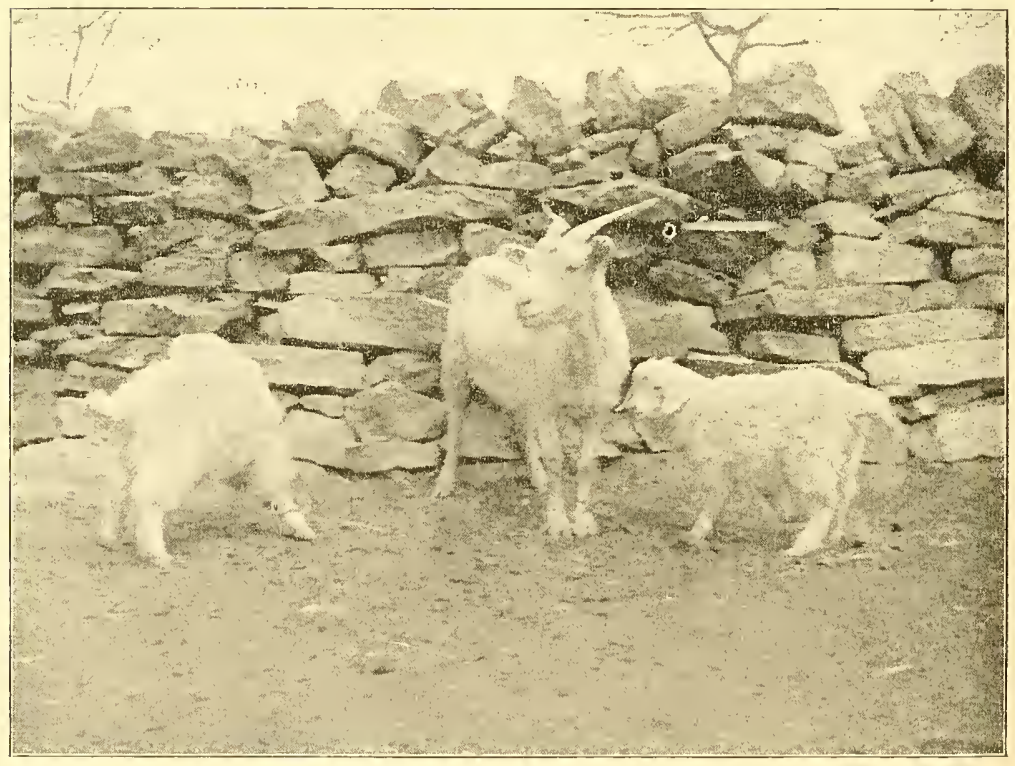

MEXICAN DOE, WITH TWO A'NGORA KIDS.

Dr. Hayes calls attention to the experience of M. de la Tour de Aigues, president of the Royal Society of Agriculture of France, who, in 1\%8\%, introduced some hundreds of the Angora goats into Europe under care of Turkish shepherds, where they greatly prospered. He affirms that:

"Even after the sixteenth generation the hair of the crosses, obtained by crossing the Angora buck with the female of the common goat, remained hair; and, although it was elongated, it could not be spun; 
and, although they procreate with our goats, we can never hope tc multiply them by crossing the races, because the vics of the mother is never effaced.

"If some individuals approach more or less the race of the sire, the hair will always be shorter, and tow coarse to be worked." (See Hayes, p. 25.)

At the time (1S68) that Dr. Hayes published the first edition of his work on the "Angora Goat, Its Culture and Products," he was decidedly of the opinion it was not possible to cross the "Angora" upon any of the lower species of goats successfully. He was undoubtedly influenced in his judgment by the opinion of that eminent breeder of sheep, Dr. Randall, who always maintained that:

"Base blood runs out rapidly by arithmetical calculation; but, practically it stays in, and is ever and anon cropping out by exhibiting the old base characteristics, in a way that sets all calculations at defiance."

He also referred to the illustrious naturalist, M. de Quatrefages, who had recently discussed, in his lectures at the Museum d'Historie Naturelle, and in the Revue des Deux Mondes, the principles which govern the formation of races, thus:

"There is one law in crossing which is constantly verified: each of the two authors tends to transmit to the products, at the same time, all its qualities, good or bad." (See Hayes, p. 21.)

But this same high authority also says, and Dr. Hayes quoted it immediately following the above, but does not seem to have been at all influenced by the opinion that

"When the power is equal in the two parents, the product will have an equal mixture of the qualities of the parents; there will be a predominance of the qualities of one, where this power of transmissabilits is unequal.

"The inequality of the power appears to be much greater when the races are nearest each other; for, sometimes, the crossing between such races gives a product which seems to belong entirely to one of the two."

In a subsequent addition of his book (1882) he admits the error he had been led into, and frankly says:

"The facts at my command in 1868, seemed to justify the adoption of the theory of pure breeding; but, theory must yield to inexorable facts. I, independently, came to the conclusion, in $18 \mathrm{ri}$, that I had pushed the 
theory too far, by the observation of a remarkable commercial fact: The Messrs. Bowes, in their statistics of wool in 1876, referring to the acclimation, in the Colony of the Cape of Good Hope, of the Angora goat, and the production of mohair, say: 'The progress made during the last dozen years has been very satisfactory, not only as regards the quantity produced, but the quality, which has been very much improved. The first shipment was made in 1865 , and consisted of 6,804 pounds; in 1869 two hundred and forty-five thousand pounds were shipped; and, in 1876 , the quantity reached one million, two hundred and ninety-eight thousand, four hundred and fifty-five pounds.'

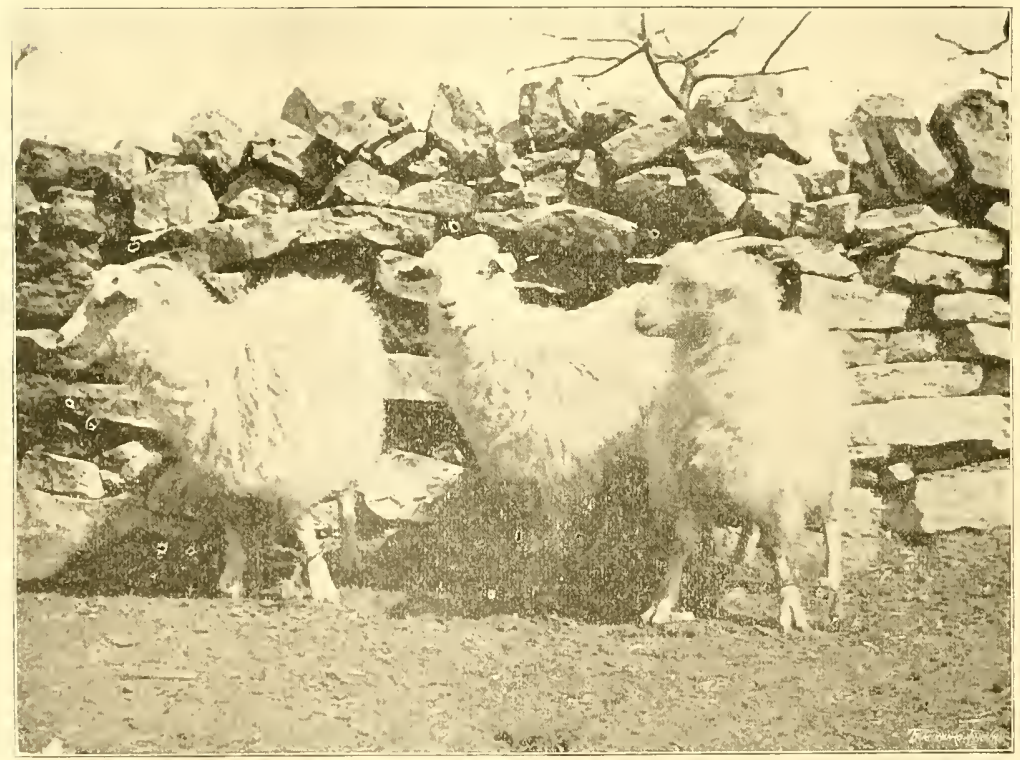

SECOND CFOSS ON THE MEXICAN GOAT BY A THORCUGHBRED ANGORA BUCK.

"It was evident to me that this quantity, at four pounds of fleece to each, requiring over 300,000 head, could not have grown upon pure animals, as they could not have been procured in sufficient numbers; and, that it must have been the produci of graded animals.

"A conclusive test of the quality of the mohair thus produced, was the fact that it became a regular article of export, or a marketable product." (See Hayes, p. 50.)

It was quite-reasonable for Dr. Hayes to have formed the opinion that he did, in 1868 , after reading of the experience of 
M. de la Tour de Aigues. There had been little or no advancement made in the industry, either in South Africa or the United States, up to that time; and, it was quite natural that he should have shared the opinion of those who had made the experiment in France. The only explanation that can be advanced for the failure of M. de la Tour de Aigues is that, the "Maltese" goat was the foundation upon which he was trying to build up his flock of grades.

PLATE XII.

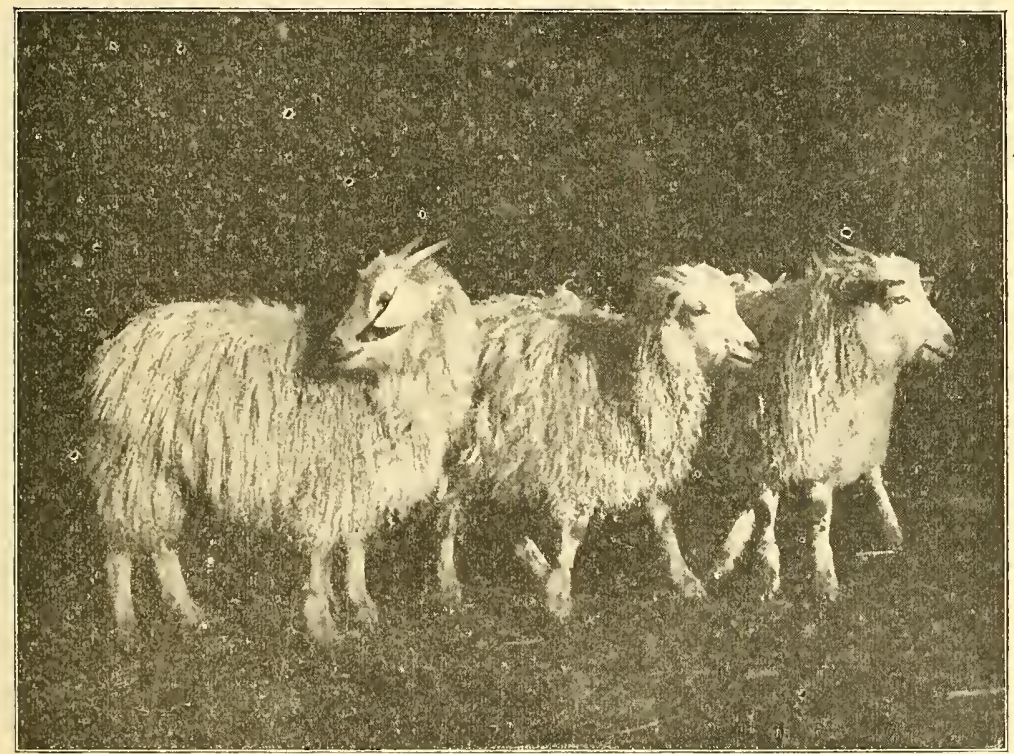

THIRD CROSS ON THE MEXICAN GOAT BY A THOROUGHBRED ANGORA BUCK.

$A$ difference will be olservel in the ears, while the fleece $\mathbf{j}$

pratically the same on all thret.

The short-haired "Mexican," that presents a dead, "kempy" appearance is much more difficult to improve than the bright, "glossy" variety, a fact which will doubtless explain the great difference in time taken by, some raisers in this country to grade up their goats. It is quite common to hear of goats having been bred up to a condition of absolute freedom from 


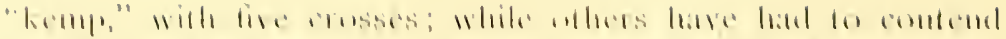

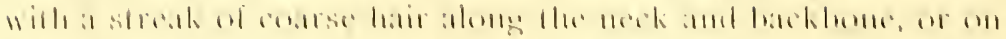

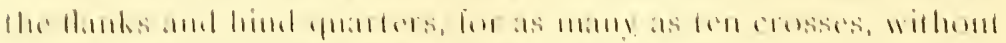

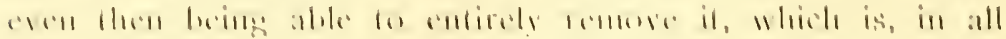

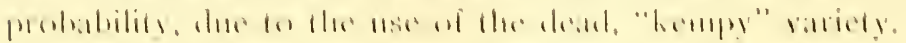

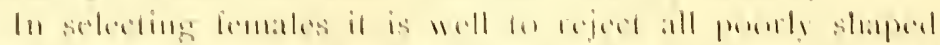

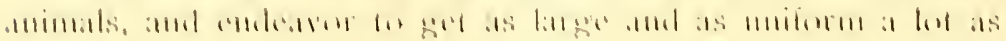
pusilile.

11.11111

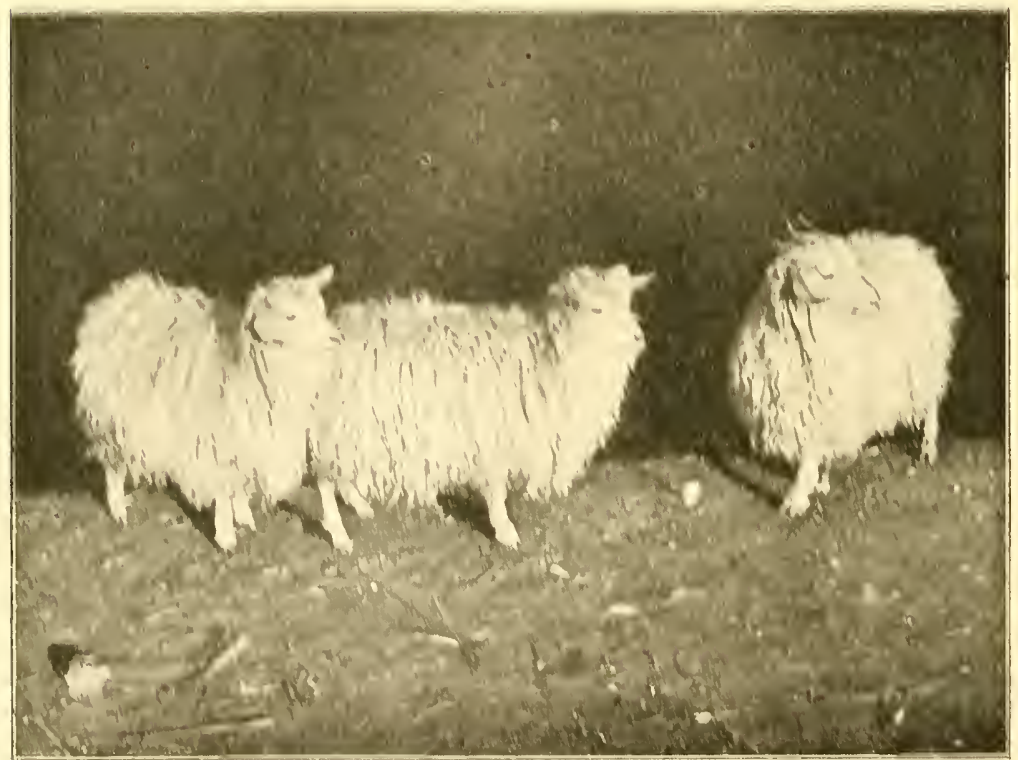

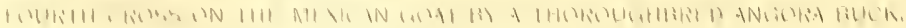

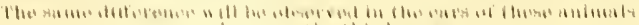

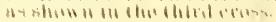

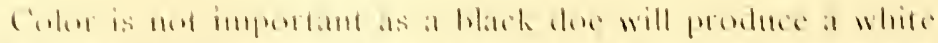

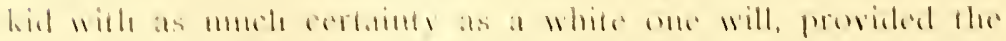

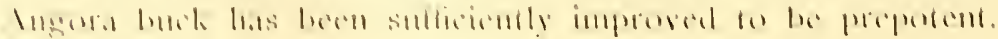

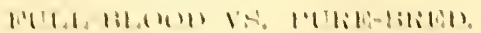

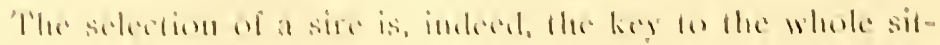

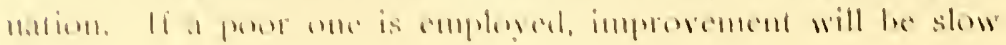




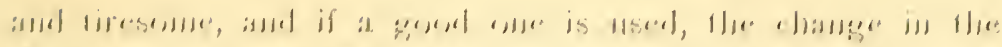

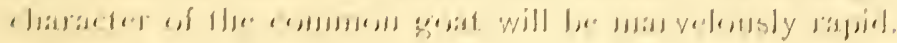

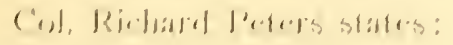

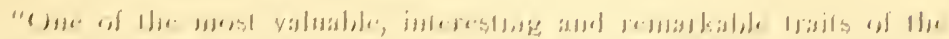

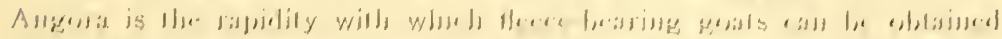

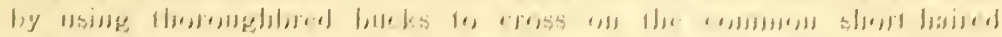

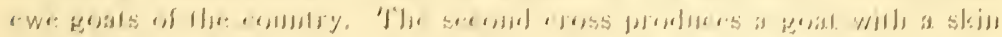

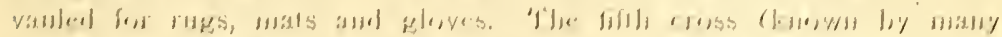

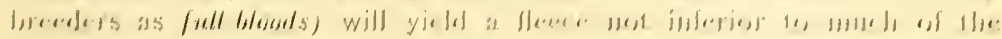

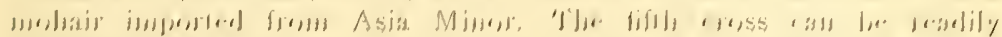

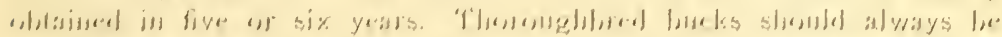

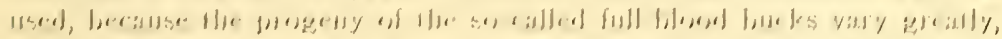

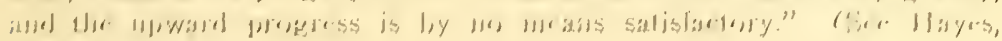
1. il.,

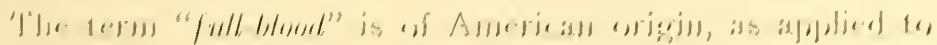

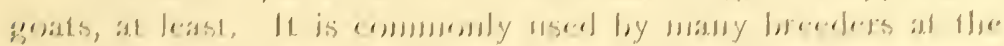

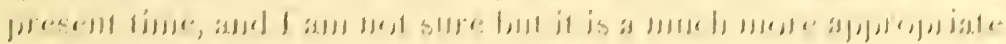

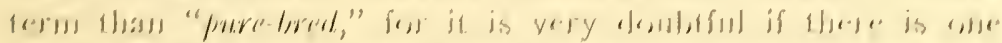

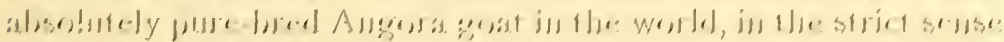

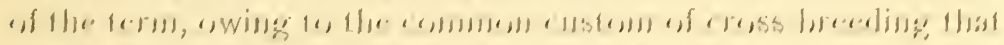

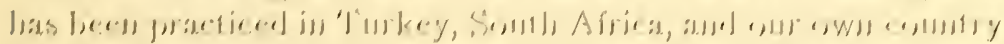

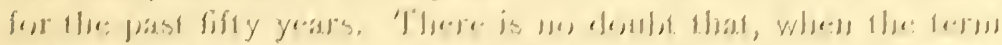

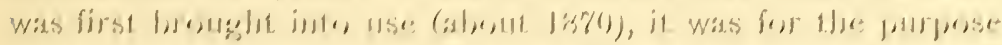

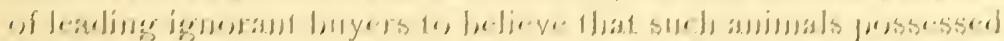

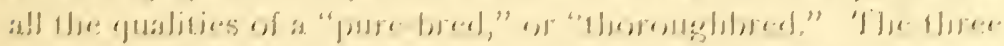

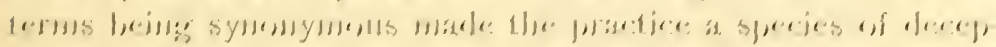

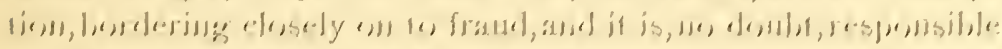

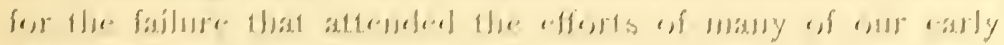
lirenelers.

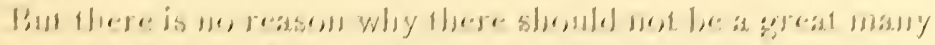

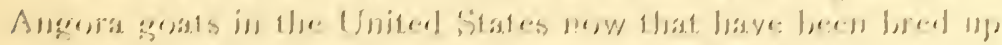

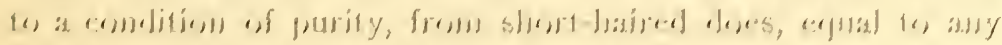

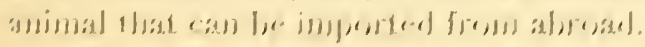

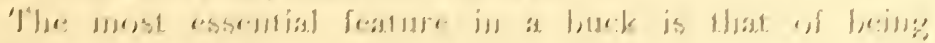

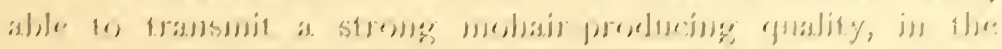

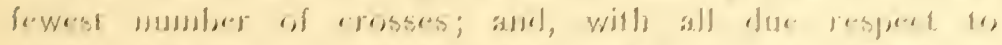

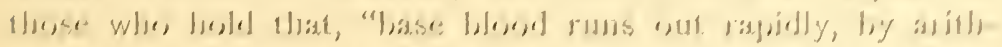

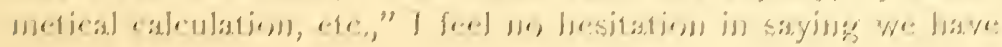


many cross-bred bucks in the United States today that are superior to many of the so-called "pure-breds," not alone in the power of procreation, but in excellence of fleece as well.

If,ashas been clearly proven by the experience we have had in breeding this animal, the coarse, short hair on a common goat an be transposed into a complete covering of mohair, withont the slightest existence of any of the original hair, commonly called "kcmp," I cannot well understand how it is possible for any of the original base blood to remain in the animal.

I am certainly supported in this opinion by the illustrious naturalist, M. de Quatrefages, quoted by Dr. Hayes, who says:

"When the power of transmissibility is equal in two parents, the produce will have an equal mixture of the qualities of both; but, where one predominates in certain qualities over the other, the power of transmissibility will be unequal.

"The inequality of the power of transmissibility appears to be much greater when the races are nearest each other, for sometimes the crossing between such races gives a product which seems to belong entirely to one of the two." (Hayes, p. …)

If any evidence of "kcmp" can be found on the animal it is, in my judgment, an indication of impurity and such a sire should be rejected; but, as before stated, if he is covered all over with nothing but mohair, there is as much certainty of such a sire begetting his like as there would be if he conld trace his lineage to the original sire of the Angora race.

I an aware of the fact that in making this statement I set at defiance the opinion of many of our old and able breeders who take a clifferent view of it-as for instance, Col. J. Wash. Watts of South Carolina, who says:

"I would not breed from a graded male at all if I wished to attain perfection." (See Hayes, p. 96.)

And Col. Richard Peters' opinion was:

"It is a fact that, no breeder, however experienced he may be in raising the Angora, can, by his eye, select a so-called full-blood from a flock of thoroughbreds, but the get of the full-blood buck will, invariably, cnable any intelligent shepherd to detect the fraud upon the thoroughbred." (Sze Hayes, p. 96.) 

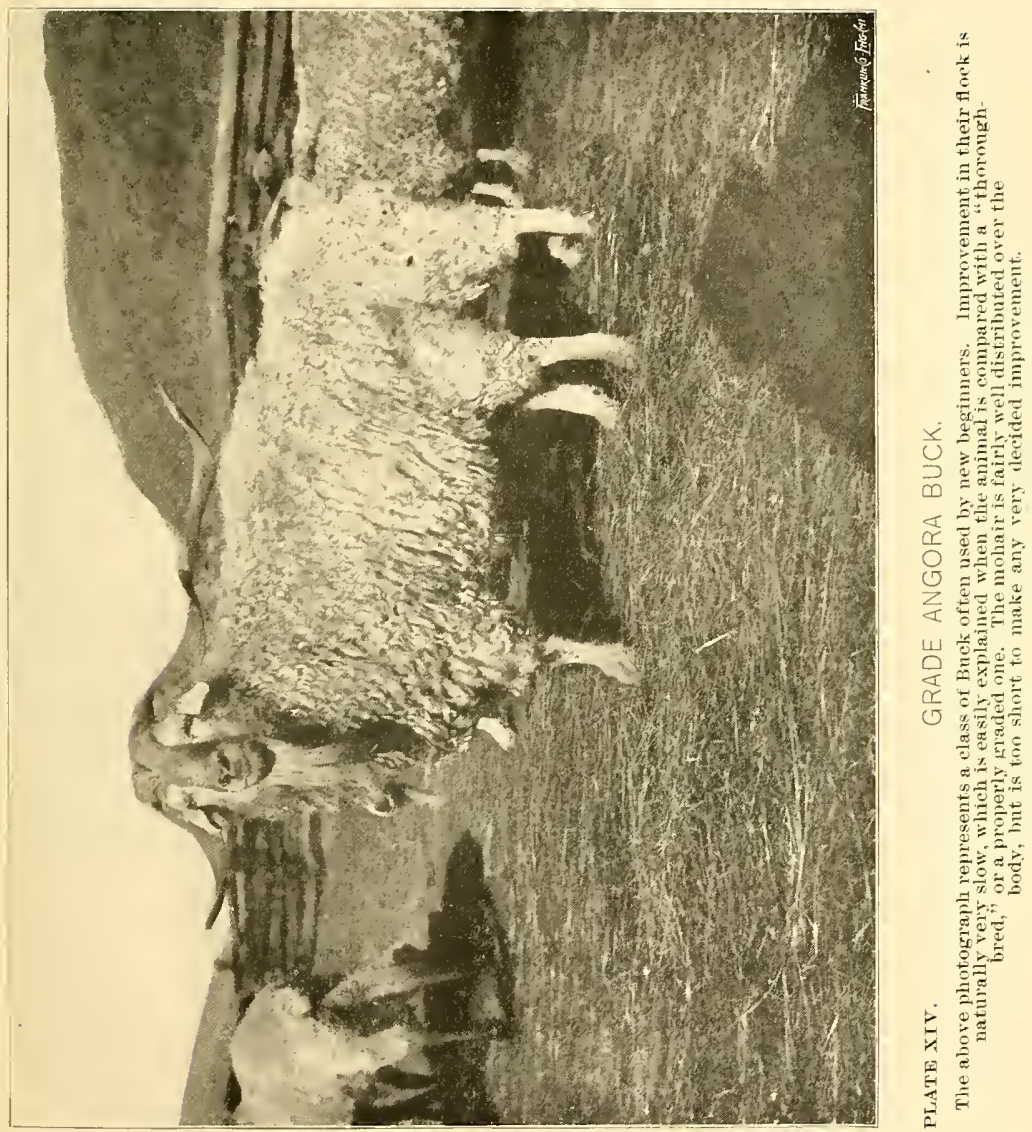

But, I would remind the reader that, nearly twenty years have elapsed since the eminent atthorities referred to, expressed these opinions, and that it is not unreisonable to believe there has been great changes made in the character of the "full-blood" during this long period of time.

Referring to Turkey, Mr. George Gatherall, of Constantinople, says :

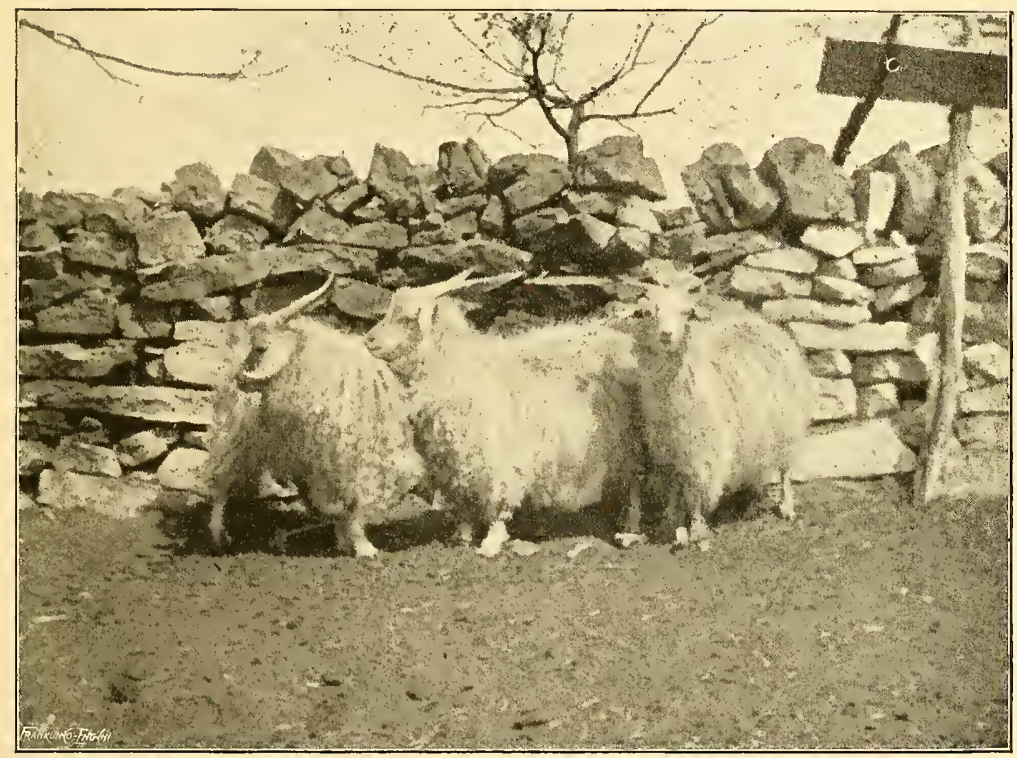

PLATE XV.

"FULL-BLOOD" YEARLING ANGORA BUCKS,

Showing different kinds of ears.

"It has been, and still is, the custom to cross the black, or brown, or, white, straight-haired goat with the mohair goat, to give the latter a stronger physique, the fifth cross being considered thoroughbred." (See Schreiner, p. 82.)

And M. Boulier says the same thing:

"Purity is regained after in-breeding to five generations, and thus describes the effects of crossing, and the gradual elimination of the inferior qualities of the Kurd goat in the successive generations: 
"1. The cross of a black female with a white buck will present a fleece marbled with a yellow color upon an impure white foundation. The flanks, the shoulders, and the head, will preserve more particularly the marks of the color of the mother, the fineness of the fleece will be sensibly ameliorated.

"2. The cross of this first product with a white buck will cause all the dark tints to disappear; the fleece will become white; the shoulders and flanks will be covered with wavy ringlets; but the whole line of the back and the forehead will remain furnished with coarse, straight hairs.

"3. On coupling this new cross, always with a buck of the pure race, we shall obtain a greater fineness in the long ringlets of the flanks and shoulders; the dorso-lumbar portion of the vertebral column will no longer retain coarse hairs, which will remain, still, on the upper part of the neck and forehead.

"4. A fourth cross, carried on with the same precautions as before, will fix a stamp of purity on the product; the coarse hairs will have disappeared on the forehead and neck.

" 5 . The consecutive crossings will render more stable the modifications already formed, and already, after the fifth generation, the individuals will be able to reproduce as if they were pure blood." (See Schreiner, pp. 76-77.)

Referring to the power of a graded Angora to transmit the mohair characteristic, Col. W. W. Haupt expresses his opinion in the following very logical manner:

"That the law of astavism applies to cross-breeds is not doubted. But, if in two species of animals, of inter-breeding relations, you could find in one of them a trait or feature, which the other did not possess, nor ever did, then the cross-breed, from these two species, could only inherit this feature from the parent which did possess it, and none whatever from the parent which did not. Let the mohair of the Angora represent this feature, and the common goat, which we will assume to be the mother in this case, to represent the deficient side. Then, if it can be shown that such a feature can be found in animals of the same species, and that the cross-breed can not inherit any portion of it from the dam's side, and that mohair will not cross with the hair of the dam, don't this solve the question that hair, and mohair, are dissimilar, and that, the cross-breed cannot breed back toward the dam's side, through his progeny, any portion of a feature, none of which he obtained from his dam, though he will do so in any other feature common to both, as color, form, etc.? And so, in point of mohair, he can impart only that which he obtained pure, and unmixed, from his sire. It has been fully shown elsewhere, that, whilst the finest bred sheep will cross its fibres with a coarse, hairy sheep, and produce a medium wool in the offspring, 
that mohair will not cross with the hair of the common goat, or the long hair of the Maltcsc goat, showing the two fibres to be unlike, and that mohair is implanted in the offspring to the eviction of the hair, and through no influence of the dam; and that the mohair, on the first cross, is short and fine, proving there :s no cross of the mohair with the hair, as is shown in the fibres of the sheep. If these premises and conclusions are correct, then it further follows that a cross-bred or grade buck will impart an amount of mohair to his offspring in the ratio of his grade to a pure-breed; that is, a sixth cross or sixty-three sixtyfourth grade will impart to his offspring all the mohair a pure-blood would, less the one-sixty-fourth part he lacked of being pure, and that what mohair he produces in his offspring, though it would be in less quantity, would be equally fine, as from a fure-blood, crossed on the same dam. Whilst to other features in the offspring of this sixth cross, they would be imparted in proportion as he received them from both of his parents. And, continuing on this line, would further say that, in a high-grade, the fraction of common blood is so very small in a twelfth cross, for instance, being only one in 4,096 parts, that, as elsewhere stated, they became the equal, or in fact, purc-bloods, to all purposes of mohair." (Southern Farmer, 1889.)

And I can point to the eminent breeder, Dr. Robt. W. Scott, of Kentucky, who, when asked the question "Will highgrade bucks known as "full-bloods," i. c., those of the fifth cross and upwards, produce this wool when bred to native females, similarly as with pure-bred or thoroughbred bucks? said:

"This question has been affirmatively settled by the experience of every breeder of Angora goats in the United States, so far as I have ever known or heard; yet, while similar, yet not so perfectly as the pure-bred males, the fleeces which are produced by the full-blood bucks being more subject to long and coarse hairs in them than those which are pure-bred bucks." (Extract from Atlanta, Ga., Constitution.)

After referring to a few breeders who were opposed to the use of full-blood bucks, one of whom was a Texas grower, who stated that "he would not buy a goat if he knew it was a grade, and knew it had fifteen crosses in it." (Dr. Hayes very charitably omitted the gentleman's name.) Dr. Hayes says:

"Let me caution the reader against pushing the : rgument, contained in the preceding paragraphs, too far, as I did myself in my original essay. I am now convinced that after a provision of a certain supply of thoroughbred bucks, the most effectual and profitable means of advancing the Angora culture is through a proper use of graded animals." (See Hayes, p. 97.) 
It is not surprising that the early breeders should have dreaded the "full-blood" for, I am well convinced, they were totally unfitted to be used as sires in many cases; but there is certainly no comparison between the goats of $1870-1880$, and those of 1900. A greater number of breeders are now engaged in the industry and greater care has been exercised in improving the character of the animal, why then should we not have approached closer to purity?

It is, perhaps, proper that I should make myself more fully understood with reference to the use of bucks that show "kemp." As has been shown by the testimony of several authorities, this feature is gradually removed by proper breeding with males that do not possess any $k c m p$ and it ought to be entirely eliminated by the fifth crossing-which, however, applies to " $k c m p$ " that usually shows on the neck, or backbone, the shoulders and flanks. But there is another kind of hair which is called " $\mathrm{kcm} p$ " by many, and is referred to by Dr. Scott in the description that he gives of a purc-bred Angora, viz:

"Like some furred animals these goats wear two distinct and different suits of clothing, and mainly at different seasons. One is short, stiff, coarse, and of no commercial value; the other is long, in proportion to the degree of blood, and is lustrous, soft, silky and elastic." (See Hayes, p. 64.)

It does not necessarilly follow that such goats as these are impure, and while I doubt very much if there are any such animals in the United States at the present time (Dr. Scott wrote the above description about 1881 or 1882), if any should exist and a breeder of reputation can give assurance that the animal had been bred true to his type for a long time, the mere presence of this undercoating of coarse hair is in no way detrimental to the animal as the hair is so short as not to mix with the mohair when the animal is shoril.

And while I agree perfectly with all Col. Haupt has said, with reference to the power of a graded goat to impress his progeny with as much of the mohair qualities as he possesses, my conviction is that any animal should be rejected as a sire that shows coarse, "kcmpy" hair on the neck or mane, the back- 


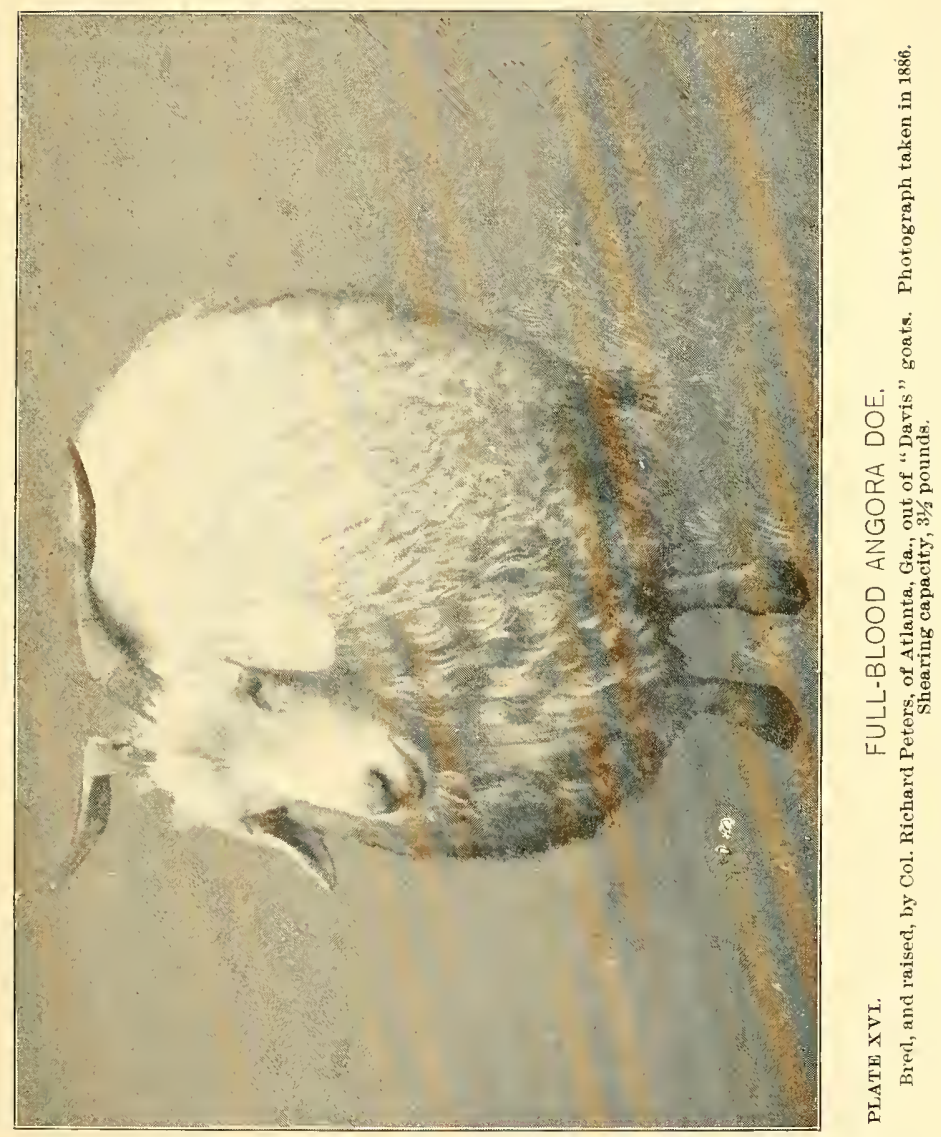



bone or flanks. There are plenty of goats that can be had that are totally free from these objections, and it is always safer to select animals that do not show them.

The flece of a breeding sire should be well distributed over the whole of the body, on the chest, and belly.

The greater the weight, of course, the more rapidly will the mohair seed be implanted in the hide of the common goat. The character of the fleece whether wavy or in ringlets, creamy or white, is altogether a matter of fancy. Weight of fleece, combined with fineness, lustre, and length of fiber, are the chief essentials. The most salable length is six inches and above, which is known in the trade as "combing mohair."

The character of horns is not material; or, the tuft on the forehead. The latter is very pretty, and is an undoubted evidence of great purity of the mohair blood, yet we have many equally fine animals that do not show such a growth.

The size of carcass I think is a feature nearly as important as fleece, and should not be overlooked. A big frame is certainly more capable of producing a larger amount of mohair than a small one: and it should, therefore, be the aim to breed up the carcass at the same time as the fleece.

A breeder should never loose sight of the fact that it may sooner or later become necessary to curtail the production of mohair, and if he has large bodied animals he can realize more for the meat and pelt than if they were small.

In-breeding is admitted to be a wrong principle except in cases where one is endeavoring to fix a certain type; but it does not appear to operate very injuriously with goats, and has been recommended by some breeders-at least to a limited extent. I think all authorities agree it is best to avoid it where it is possible; and, particularly, if you are aiming for a large, strong constitution.

Style of car is also a matter of taste. Those that hang down, called lop-ears, or semi-lop-ears, are generally preferred, though I would not condemn an animal that had the smaller for-cars, provided he had other good qualities; and, his progeny are just as likely to have the lop-ear as not, provided the dam has such ears. 
The shearing capacity of the various grades depends entirely upon the character of the sire and the class of does used. Always bear in mind that the glossy, short-haired type of doe with the heaviest shearing sire obtainable, will yield the best results.

The cost of a buck ought not to influence a breeder when he finds what he wants. Breeders in South Africa have paid as high as $£ 450$, sterling, or $\$ 2,250.00$ of our money, for a single animal; and, when it is considered that the male is the creator of the flock, it stands to reason that his cost is very soon returned, provided he has the proper qualifications to breed up the flock quickly.

It is a very common error of new beginners to buy cheap bucks, sometimes as low as $\$ 10.00$, which they think ought to be enough, but the breeders of fine stock cannot afford to worry with this class of animal unless they are paid properly for the trouble involved. Very good bucks ought to be had for $\$ 25.00$ each, shearing say six pounds, yet I consider an animal with extraordinary good points, shearing ten pounds to twelve pounds, is cheaper at $\$ 100.00$ than an ordinary one would be at $\$ 25.00$.

Wattles will sometimes appear on graded Angoras, though I have never observed them on a very highly graded one. They are a little sack, like a teat, that hangs under the chin, and may be removed without any danger or injury to the animal. It is not uncommon for the shearers to clip them off when shearing the fleece.

Bcard is common in both the buck and doe, but is greatest in the former. There are some instances where the goat has had no beard at all. I have never observed such an animal myself, though I have noticed that the higher grades are inclined to grow a smaller amount of beard in both sexes and I have no doubt that it could be easily bred off altogether if it was deemed advisable. 


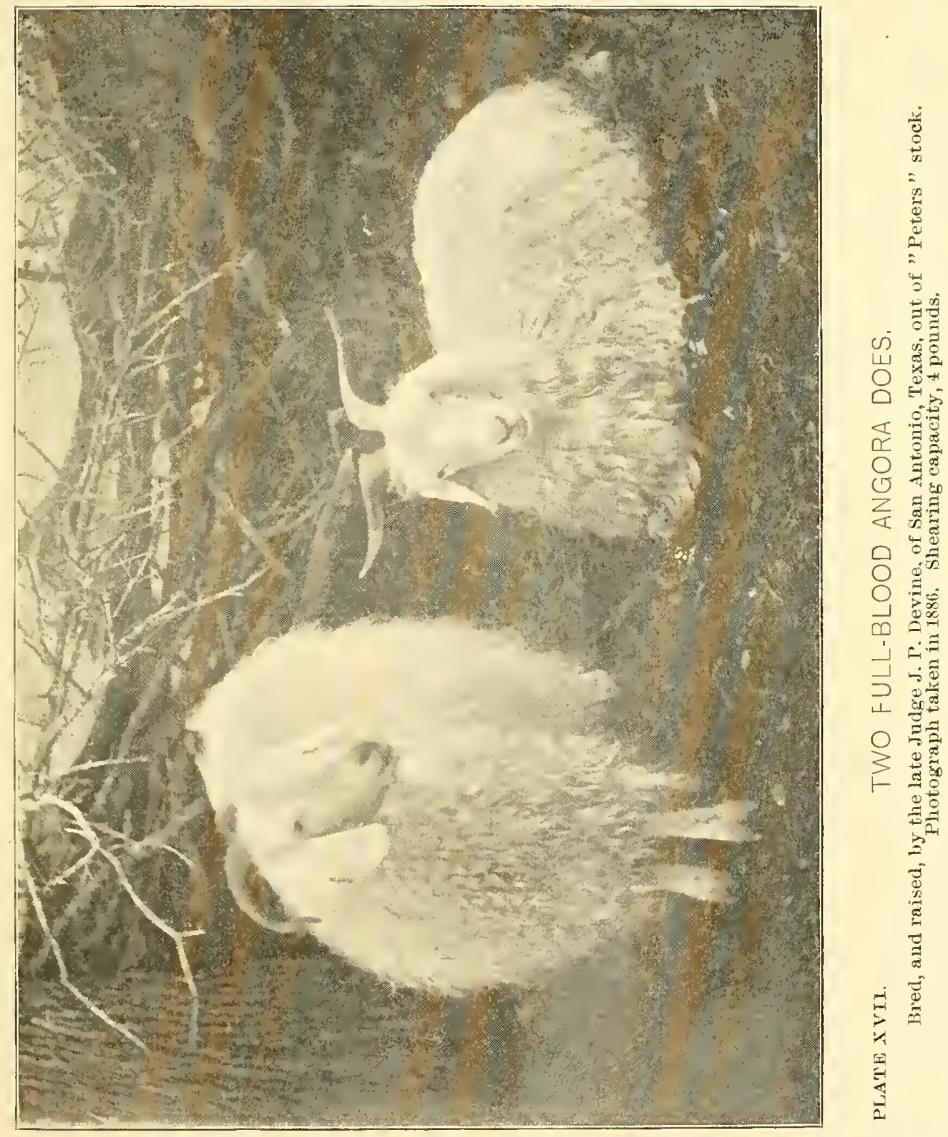





\section{CHAPTER XX.}

PROPER TERMS FOR ANGORA GOATS.

It was very common at one time, and is, to some extent in the present day, to apply the term "billy," and "namny," to distinguish the male goat from the female, but, in later years, some writers use the terms ram and ewe; others buck and cwe, while a few will refer to them as buck and doe. The term kid seems to have been applied to the young from the very carliest period of which we have any record.

Even in the days of the Patriarchs, Rebekah said unto Jacob:

*"Go now, to the flock, and fetch me from thence, two good kids, of the goats, and I will make them savory meat for thy father, such as he likıs." *** See Genesis xxvii, 9.

The term "Billy," or "Nanny," is no where to be found in the Bible, although frequent reference is made to this class of stock, which appears to have been very highly prized by the ancients, and were considered quite the equal of the $o x$ and the sheep, as food. (See Duet. xiv., 4). Indeed, they must have been regarded with greater favor; for, we find, in Leviticus iii, 12, that Moses said unto the children of Jsrael, *** "and if his offering be a goat then he shall offer it before the Lord.*** Again, in Numbers xv, 27, He says:

"*** And if any soul sin through ignorance, then he shall bring a she goat, of the first year, for a sin cffering. * * *'

It will be observed that Moses does not refer to the female goat as a "Nanny" goat; and in another passage of scripture we find in the book of Ezra vi., 17 verse: 
“*** ** And offered at the dedication of this house of God, an hundred bullocks, two hundred rams, four hundred lambs; and, for a sin offering for all Israel, twelve he goats, according to the number of the tribes of Israel. ***"

Solomon refers to the boldness and strength of the goat, in Proverbs xxx, 29 to 31 , as follows:

“* ** There be three things which go well, yea, four are comely in going: A lion, which is strongest among beasts, and turneth not away from any; a grey hound; an he goat, also; and a king, against whom there is no rising up. *** *',

This doubtless gave rise to the opinion that the goat is good on the defensive, when attacked by dogs or wild animals.

The prophet, Ezekial, in chapter xxxiv, 1\%, speaks of “* * * rams, and he goats."

.. And in chapter xxxix, 18, he says:

"**** Ye shall eat the flesh of *** rams, of lambs, of goats, id of bullocks. ****"

And I might quote a number of other references to goats, in both the Old and New Testament, but I would fail to find any mention of a "namny" or "billy" goat.

From the quotations I have made it will be seen that the term "ram" and "lamb," as now applied to sheep, are of very ancient origin; as are also " $\boldsymbol{x}^{x}$ " and "bullock," which are still applied to cattle. But there seems to have been no other distinguishing terms for goats than "hc-goat," "shc-goat" and "kid." "These are quite forcible enough, it is true, and are easily understood; but, the more modern languages seem to call for separate, and distinct, terms in speaking of the sex in our different kinds of live-stock, as for instance: Bull, cow and calf for cattle; ram, ewe and lamb for sheep; boar, sow and pig for hogs, etc.; and, with all due respect to our ancient brethren I think these are an improvement on the custom they seem to have adopted for goats, for it would certainly sound very peculiar if we were to speak of he-cattle, and she-cattle; he-sheep, and she-sheep; hehog, and she-hog, which, hovever, would be quite as proper as "he-goat," and "she goat." 
Dr. Hayes, in his work on the Angora goat, in 1882, considered the term "buck" and "cac" most appropriate.

Mr. Schreiner, in his more recent work, (1898) does not seem to have made any special reference to this question and invariably uses the terms "ram," and "crve;" and, sometimes, "Angora ram," or "Angora croc," as does also Mr. Binns, an eminent Turkish authority, frequently quoted from by Mr. Schriener. The distinguished French traveler, M. Bonlier, quoted both by Dr. Hayes and Mr. Schreiner, speaks of them as "bucks" and "female goats." Col. Scott of Kentucky, and Col. Peters of Georgia, appear to have adopted the terms "buck" and "erve;" and, with the ordinary writer, it is common to use any of the terms I have mentioned. This is certainly confusing, as will be seen by reading over a passage in Mr. Schreiner's work, referring to the plenro-pneumonia epidemic in Cape Colony. He refers to :

"Several of Mr. Evans' rams which had so far been healthy, contracted the disease and died."

It is left for the reader to decide whether this is intended to mean ram-shcep or ram-goats, as I believe Mr. Evans was a breeder of both. And it is not unlikely that, the absence of a distinet term for goats may sooner or later give rise to much trouble in law stits, and it would therefore be well to decide upon a proper term as early as possible.

My personal opinion is that, "buck," "doe," and "kid" would be the most appropriate terms which I think are not applied to any other class of domestic stock, except the rabbit, and deer.

I prefer these terms, too, because they are applied to deer. There is certainly a greater similarity in the meat of the Angora goat to venison, than to the common "billy" and "namygoat;" which, when generally known by all lovers of good eating, will have a tendency to remove much of the prejudice that many people have heretofore entertained for the flesh of this valuable animal.

Wcther, for the castrated male, will answer every purpose, to distinguish animals intended for slaughter. 
$V$ cnison would seem to be the more proper term to apply to the meat of the Angora, as it approaches the flavor of deer meat (when naturally fed) more closely than any other; and, it would seem, we have Biblical authority for so calling it, as will appear from the following quotation:

"And Rebekah spake unto Jacob, her son, saying: Behold, I heard thy father speak unto Esau, thy brother, saying: Bring me venison, and make me savoury meat, that I may eat and bless thee before the Lord, before my death. Now, therefore, my son, obey my voice, according to that which I command. Go now to the flock and fetch me from thence two good kids of the geats and I will make them savoury meat for thy father, such as he loveth." (Genesis, xxvii; 6 -9.) 


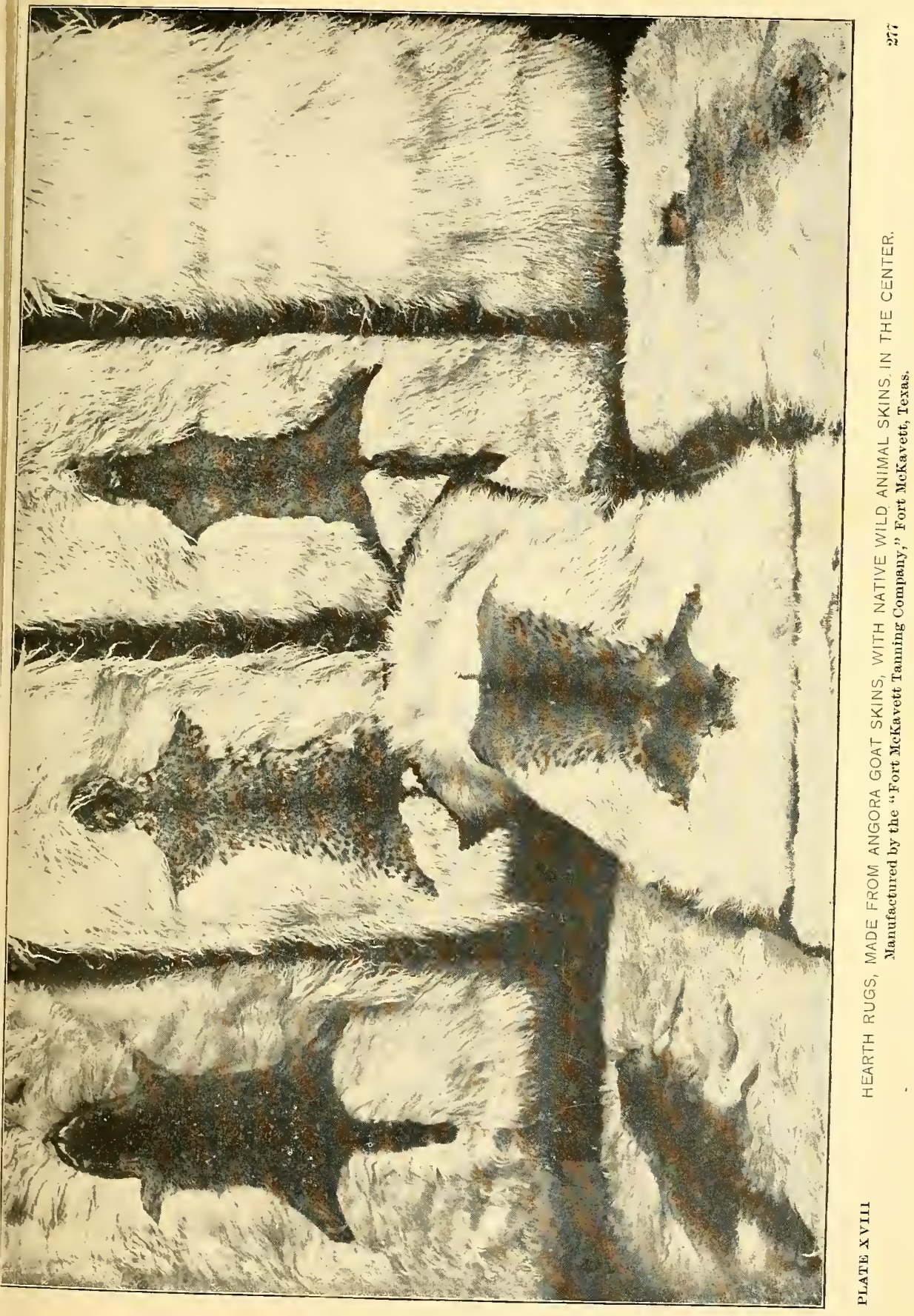



'The quilt I have referrerl to was made entirely at home, and was arranged like patch-work, some square, others diamondshaped, with a few black and yellow skins intermixed with pearly white, which gave it a very rich appearance.

'lhe process for tanning, or dressing, the goat skin is very simple and when they are put in this condition, can be kept indefinitely. (See "Formula for J)ressing Angora Skins" in appendlix.)

Valural shaped skins are preferred by a great many housekeepers for rugs, but only the higher grades can be used in this form. The lower grades often show short, or crarse, hair, along the line of the back-bone, which presents an uneven appearance, when the rug is placed on the floor. The skin should be covererl evenly to make an attractive rug.

The lower grades can be better made into shapes for the leearth, or for buggy robes, which is done by cutting the skins into uniform pieces, and placing them together, so that the hair will over-lap, as it does on the animal.

Saddle pockets are often covered with a piece of Angora skin to shed the rain, and are very popular with cow-boys. Indeed, a cow-boy thinks his saddle is not fully "rigged" unless it has this appendage. The hair, in this case, is ustrally dyed black, or brown, to avoid showing dirt, but many use them in their natural color.

Muffs for children are quickly made, as well as boas for the neck, or a cape for the shoulders.

Lace trimming is another product of the skin which is very commonly used for trimming children's cloaks. This should be made from a yearling goat skin, as these are much thinner than the older ones, and more easy to sew. The trimming is made in narrow strips from one-quarter up to one inch in width, and is sold by the yard.

Lamp mats, for the table, can be marle out of the smaller pieces, so that very little of the skin need be wasted.

The fleece can be worked into many useful articles on the farm or ranche, and, when a flock is being graded up it will pay best to make use of a small clip in this way rather than ship it to market, as there are always more or less kempy hairs scattered 
through low grades, which is objectionable to manufacturers of cloth. I know one industrious lady, in 'Texas, who works up her entire clip from a flock of about three hundred head of goats in making cinches or saddle girths, which she sells readily for $\$ 6.00$ per dozen. Any child, of ordinary intelligence, can soon learn to twist the mohair into cords of the proper thickness and weave them into the large iron buckles at either end (a pattern can be had from any saddlery or harness maker.) They are quickly and easily made and are considered superior to any other kind for the reason that they do not get hard and stiff after being used. Besides the saddle girth, a coarse saddlo-blankct can be woven and yarn can be made for knitting socks, making blankcts, and cloth for home use. The stuff is very durable, and, although homemade goods are not always so attractive to the eye as machinemade, the satisfaction of having them wear woll, compensates largely for looks, and finish.

In Dr. Davis' letter to the U.S. Commissioner of Agriculture in 1853 , he makes reference to the fact that, "he had worn socks six years, made from Angora goat hair, and they were still perfectly sound." There is practically no wearing out mohair goods, and, a pair of pantaloons, or a dress, made from it will last as long as you care to wear them. The lady referred to above is of the old school; she has her spinning wheel, and makes her own yarn; and has a home-nude loom for weaving cloth. She and her children make the girths at odd times during the year. and she has often told me that her small flock of Angora goats were of more practical value to her than any other class of stock she had, as they cost little or nothing to keep, and furnished meat and clothing for the entire family, besides a considerable sum of money from the sale of saddle-girths.

Pcts. I would not recommend making a pet out of a kid, although it is very cute, and can be taught nearly everything but to talk. They seem to possess more intelligence than many other animals, but are inclined to become very mischievous in the house when they get to be a few months old and it is hard to control the little rascals. I would not advise you to take one from the flock. They will follow, like a dog, and come at the call of their name. It is quite common for Mexican herders to 
!nave one or more of these pets, which they call "Sancho;" and it is quite amusing to see the little fellows run out of a large flock when they hear their names called. Their cry is much like that of an infant, and, I have no doubt that this lias given rise to the Americanism "Kid," so commonly applied, at the present time, to nearly all American children.

They can be made very useful, however, if well-trained, in drawing small wagons, and, in many parts of the world, are largely used for this purpose.

In his paper on "The Goat," the Hon. Israel H. Diehl says:

"They are not infrequently harnessed to small wagons or carts, for marketing or pleasure purposes, or made to pack small loads, as beasts of burden. Their use and importance have thus become valuable, and indispensable over large portions of Europe and Asia." (See Agtl. Dept. Report, 1863.)

It is quite common to see trained goats at any of our large city parks, but, as a general thing, they are of the common species. I am very sure that a considerable profit can be realized by the sale of trained Angora wethers, owing to their more attractive appearance.

They are often trained to lead sheep into cars when being loaded for market; and, from the stock pens, to the large slaughtering louses. A notable animal of this kind, called "Judas Iscariot," has very recently died, after many years of useful service, in Chicago.

Milking qualitics. The milk of the Angora goat is of superior quality though they do not yield as much as some of the common varieties. The Spanish or Mexican goat is, however, a very good milker, and many of the Angoras that have been crossed with this breed make excellent milkers. In the report of Mr. Diehl, above referred to, he says:

"'The 'Scinde,' the 'Maltese,' the 'Assyrian,' the 'Syrian,' the 'Swiss,' and other varietics, especially in Europe, have become most valuable milkers; and, for convenience and economy to the poor, or where feed is high and pasturage scarce, it has, in many places and instances, supplanted the cow, as it is kept about the house almost anywhere. Especially about towns and villages and cities, where there are so many vacant lots and commons, where they can browse on the coarsest of food and herbage, or that which is left, or refused, by the horse, cow or sheep, is this the case. 
"The goat, in fact, is an indiscriminate feeder, cropping even poisonous plants with entire impunity and relish, as there are, comparativcly ew plants or weeds that are either injurious or poisonous to it, and no herbage, leaves or grasses, seem to affect the quality of its milk, only, rather to give it flavor; and, in traveling through Asia, Africa and parts of Europe, it is quite common to have the goat brought to the door. tent, or camp, and milked for our use in our presence, whenever milkwas required, giving us the assurance that the milk was. genuine as that of goats. It is much used both by travellers, and families, and especially by the inhabitants of the tropical, low, marshy, bilious and fever countries, as a preventative and cure for those, and other diseases, incident to such countries. The medicinal qualities of goat's milk has long been known and acknowledged, especially in the old world, and in some portions of this country, it being not only very wholesome, but less liable to curdle on the stomach; and, by those who have tested the different kinds of milk, it is much esteened, and preferred for tea and coffee, and is largely used for children's use, the making of whey, and the various medicinal drinks for invalids, especially at the various hospitals, wateringplaces, and institutions of Europe, and a few of our own, where it has been duly appreciated. It is also said to be highly bentficial to consumptives, dyspeptics, and other like invalids.

"Still, an undue, and unnatural, prejudice has, and does, exist in the minds of many people of this country against both the animal and the use of its milk, but without any good reason.

"Vaulable varieties of the Asiatic goat have been largely introduced into Europc, where they are quite extenisively raised, and used for milk, from which butter, cheese and whey are made, to a considerable extent.

"But, notwithstanding, varieties of these goats have been imported into the United States by emigrants, and people of this country for their own use, the animals have been subsequently neglected, mainly on account of the cheapness of cows, and the easy facilities of pasturing them upon: the extensive public domains, cheap pasture lands or commons.

"But, as the land has become occupied, and more valuable, the expense of purchasing, and keeping cows has increased, and the value of butter, milk and cheese is enhanced by the enlarged demand, the attention of thousands of our people, especially of the poor, and laboring classes, has been turned to the breeding, and keeping, of goats; their milking qualities have been greatly improved and their value so increased that we have recently seen common milking goats bought and sold at the price of an ordinary cow, a few years ago, namely, from $\$ 10.00$ to $\$ 25.00$, and any ordinary milking goat is valued at $\$ 8.00$ to $\$ 10.00$.

(I would state that upon one of my trips to the State of Iowa with a lot of breeding goats, I met an Italian who was surprised that we did not make use of goats' milk in Texas. He was then living near Chicago. and told me he had paid $\$ 10.00$ each for a lot of does from which he inade a good profit in making cheese at 25 cents per pound, and could 
not stuply the demand for it. Cows are, so abundant in Texas it is not surprising that goats are not used for milking purposes, but it is a fact that, in Mexico, the goat's milk is preferred above that of the cow, and the Mexican herders employed on our Texas ranches will go to great trouble to get milk from a goat if it is to be had at all, rather than use cow's milk.)

"Most of the milkers give from two to threc quarts per day, especially if well ferl, tethered, and milked three times a day.

"General J. S. Goe, of Brownsville, Pennsylvania, reports' an Assyrian goat in his possession, milking a gallon per day, after the weaning of its kid. A similar goat, now in possession of the writer, is reported to have yielded twenty dollars' worth of milk during the season, after selling two kids at $\$ 3.00$ each. The milk was mainly sold to physicians for patients, at ten and twelve cents per quart. A number of the famed Naltese milkers, which we examined, we were assured, yielded nearly the same results, and we have obtained ten cents per quart for some irom onr Maltese and Cashmere grades; for medicinal purposes. "Thus, around the suburbs of our large cities, in many of the smaller towns, in our coal and mineral regions, and along many of our public works, great quantities of the common goat can be seen in use, while their value is being materially cnhanced by more attention to good breeding and valuable crosses. Among the most valuable milkers we have, the 'Maltese,' the 'Swiss, 'the 'Assyrian,' the 'Syrian,' the 'Scinde,' the 'Spanish,' and the 'Welsh' goats.

"Under many circumstances, the goat is found more valuable than either shcep or swine, as goats will live and thrive where they would starve; yielding milk, wool, kids, mutton and skins. A gooj goat wil! yield milk nearly all the year, or within a tew weeks of parturition, if fed and cared for. The kids should be allowed to suck two weeks, and then sold, especially the buck kids. The goat should then yield a quart of milk at each milking, or meal, three times a day, say at $7 \mathrm{a}$. m., at noon at 7 or 8 p. m. About three months subsequent to parturition the supply of milk falls off to about two quarts daily, and continues so until within about three months of the next kidding, when it falls off to about one quart a day. The goat should be milked three times daily, in consequence of the want of capacity of her udder, for, when the udder becomes charged with milk, the goat lies down, ceases feeding, and no further secretion of milk takes place; but, relieve her by milking, and she again proceeds to feeding, and secretes a fresh supply of milk, far more nutritious, and nourishing, and easier of digestion than that of the cow. It is not generally known that a goat tethered to a certain spot will yield more milk than when permitted to roam at large. without restraint, but 'sucl is, nevertheiess, the fact. The tether should be attached to a long pin driven in the ground, furnished with a swivel, in order that entanglement may be avoided, and shifted where a fresh supply of herbage may be obtained. 
"As goats are often disposed to be mischievous, and trespass upon forbidden property, either by climbing or creeping, a yoke may be made consisting of three pieces of wood, put over the goat's neck, and fastened there in a triangular form, which is found useful to prevent their getting finrough hedges or fences, while a side-line, attaching the fore foot to the hind one, of the same side, prevents them climbing or leaping.

"With these two simple contrivances, a goat may be allowed to go anywhere without being able to enter a garden or field. The goat may be milked fifteen days after parturition, when the milk is sweet, nourishing and medicinal, having an agreeable, aromatic flavor, no doubt impartcd by tlic herbs and wild food upon which it feeds and delights to pasture; and this quality renders it peculiarly appropriate for the manuiacture of chcese and butter, delicions specimens of which we ate in Asia and Europe.

"There is, perhaps, more difference among goats than any other class of animals, their milk varying both in quality and quantity, the latter from one pint to four quarts daily." See U. S. Agtl. Dept. Rept. 1863, p. 217.

\section{Referring to the subject of "goats," the Encyclopedia Brit- tanica, says:}

"The value of goat's milk, as a source of household economy, is much greater than is generally supposed. This is so well shown by Cuthbert IV. Johnston, Esq., in an article in the 'Farmers Magazine,' that we shall cuote from it at some length:

" 'The comfort derived by the inmates of a cottage from a regular supply of new milk need hardly be dwelt on. Every cottager's wife, over her tea, every poor parent of a family of children, fed ainıst entireiy on a vegetable diet, will agree with me ihat it is, above all things, desirable to be able to have new milk as a variation to their daily food of bread and garden vegetables. The inhabitant of towns, and of suburban districts, we all know, is at the mercy of the milk dealer; the milk he procures is rarely of the best quality; and, under the most favorable circumstances, he receives it with suspicion, and his family consumes it with sundry misgivings as to its wholesomeness.

" "Having personally experienced these difficulties, and having, about three years since, commenced the attempt to supply my family with goat's milk, and, as our experience is cheering. I desire, in this paper, to advocate the claims of the milch goat to the attention of the cottager. and the other dwellers in the suburban, and rural districts.

“ 'Few persons are, perhaps, aware of the gentleness, and playfulness, of the female goat, how very cleanly are its habits, how readily it accommodates itsclf to any situation in which it is placed. Confined in an cuthouse, turned on to a common, or into a yard, tethered on a grass plat, it seems equally content. I have found it readily acommodates 
itself to the tethering system, fastened by a leathern collar, rope and iron swivel, secured by a staple to a heavy $\log$ of wood. The $\log$ is the best (and this with a smooth, even surface at the bottom) because it can be readily moved about from one part of the grass plat to another. The goat, too, uses the $\log$ as a resting place in damp weather. The goat should be furnished with a dry sleeping place, and this, in case of its inhabiting open yards, can be readily furnished, anything that will serve as a dry dog kennel will be comfortable enough for a goat.

". The milk of the goat is only distinguishable from that of the cow by its superior richness, approaching, in fact, the thin cream of cow's milk in quality. The cream of goat's milk, it is true, separates from the milk with great tardiness, and never so completely as in the case of cow's milk. This, however, is of little consequence, since the superior richness of goat's milk renders the use of cream almost needless. The comparative analysis of milk of the cow, and goat, will show my readers how much richer the latter is than that of the former; 100 parts of each, according to $\mathrm{M}$. Regnault, gave, on an average:

\begin{tabular}{|c|c|c|}
\hline & cow & Gost \\
\hline Water & 84.7 & 82.6 \\
\hline Butter ........ & 4.0 & 4.5 \\
\hline Sugar of milk and soluble salts & 5.0 & 4.5 \\
\hline Caseine (cheese), albumen and insoluble salts & 3.6 & 9.0 \\
\hline
\end{tabular}

"' 'So that, while the milk of the cow yields 12.6 per cent. of solid matter, that of the goat produces 17 per cent. Goat's milk yielding rather more butter, rather less sugar of milk, but considerable more caseine (cheese) than that of the cow.

"It must not be supposed that the taste of the milk of the goat c.iffers in any degree from that of the cow; it is, if anything, sweeter, but it is quite devoid of any taste which might very reasonably be supposed to be derivable from the high-flavored shrubs and herbs upon which the animal delights to browse.

"'The amount of milk yielded by the goat varies from two quarts to one quart per day; it is greatest soon after kidding time, and this gradually decreases to about a pint per day, a quantity which will continue for twelve months. This is not a large supply, it is true, but still it is one which is available for many very useful purposes; and, be it remembered, that when mixed with more than its own bulk of luke-warm water, it is then in every respect superior to the milk supplied by the London dairymen. 
" 'In regard to the best variety of goats to be kept, I would recommend the smooth-haired kind, which are quite devoid of bear s, or long hair. In this opinion I am confirmed by an experienced correspondent, Mr. W. H. Place, of Hound House, near Guildford, who remarked, in it recent obliging communication: "I found that the short-haired goats, with very little beards, were the best milkers; but from these I seldon had more than four pints a day, at the best (I should say three pints were the average) and this quantity decreases as the time of kidding approaches (the goat carries her young twenty-one or twenty-two weeks). They. should not be fed too well near the kidding time, or you will lose the kids. In winter I gave them hay, together with mangel-wurzel globe, and Swedish turnips, carrots, and, sometimes, a few oats; and these kept up their milk as well as anything; but, of course, it was most abundant when they could get iresh grass. The milk I always found excellent, but I never had enovgh of it to induce me to attempt making butter, except once, as an experiment; my cook then made a little, which was easily done in a little box churn; the butter proved very good. I found the flesh of the kids very tender and delicate.

"I ax ado Jittle to Mr. Place's information as to their food; mine have generally fed out of the same rack as a Shetland pony, with whom they are on excellent terms. The pony, throughout the summer, is soiled with cut grass, and I notice that the goats pick out the sorrel, sow thistle, and all those weeds $w 1$ ich the pony rejects.

". In the garden (if they are, by chance, allowed to browse), I notice that they s lect the rose trees, common laurels, arbutus, laurestinas, and he laburnum. Of culinary vegetables they prefer cabbages and lettuces; they also bite pieces out of the tubers of the potato.

".They carefully pick up the leaves, whether green, or autumnal, of timber trees; of these, they prefer those of the oak and elm, and delight in acorns and oak apples. We are accustomed to collect and store the acorns for them against winter, spreading the acorns, thinly, on a dry Hoor, to avoid mouldiness, which follows the sweating of acrons laid in a heap.

"As I have before remarked, none of these astringent substances affect the taste of their milk, and I may here observe, that, with ordinary gentleness, thcre is 110 more difficulty. is so much, in milking a goat, than a cow.

.. 'The manure of a goat is, perhaps, the most powerful of all our domestic animals.

".Such are the chief facts which I lave deemed likely to be useful in inducing the extended keeping of the milch goat.

"It is an animal, I feel well assured, may be kept with equal advantage by the cottager, and the dwellers in larger houses. It is useless to compare it with the cow, or to suppose that the goat can supplant it in situations where the cow can be readily kept; but, in the absence of pas- 
tures, and in places where there is too little food for cows, I feel well convinced that, with ordinary care and attention, and a moderate firmness in overcoming the prejudices of those unaccustomed to the goat (and unless these are found in the owner, live stock never are profitable), the value, and the comfort, of a milch goat are much greater than is commonly known.

.. The waste produce of a garden is exceedingly useful in the keep of a goat. By them almost every refuse weed, all the cuttings and clearings, which are wheeled into the rubbish yard, are carefully picked over and consumed. To them the trimmings of laurels, and other evergreens, Fea haulm, and cabbage stocks, etc., are all grateful variat'ons of their food. In winter, a little sainfoin, hay, or a few oats, keeps them in excellent condition. In summer, the mowing of a small grass plot, watered with either common, or sewerage water, will, with the aid of the refuse garden produce, keep a goat, from the end of April until October." " (See Ency. Brit., Vol. I, p. 399.)

\section{Col. J. Wash. Watts, of South Carolina, says:}

"A cross, mace with a pure Angora buck with a Maltese doe goat, produced a doe that gave me four quarts of as good milk as any cow on my plantation. The feed of one of my cows will keep twelve goats. My cows must have certain food, or they will not thrive. My goats will eat anything, almost, and do well, and with this advantage, that their milh and butter are not in any way affected by their diet. The milch producing qualities could be developed in the Angora, by careful and continuous breeding to this end, without crossing, so that excellence of fleece might be preserved. If this could be effected, the Angora, furnishing a double profit in fleece and milk, could take the place of the common goats kept in and around the large towns." (See Hayes, p. 69.)

Solomon evidently thought highly of goat's milk, for he says :

"And thou shalt have goat's milk enough for thy food, for the food. of thy househcld, and for the maintenance of thy maidens." (Proverbs, xxvii:27.)

I have quoted at considerable length from other writers upon the milking qualities of the goat because, I believe, the time has arrived in the United States when it is almost a necessity for many of our citizens who live in large towns and cities to discontinue the use of cow's milk. The character of milk that is commonly sold by dairymen is poor, but this is nothing compared with the risk that is taken by consuming milk from cows that are diseased. 
It is a well-known fact upon the part of cur well-informet physicians that much sickness is produced from using milk from cows fed upon swill and impure food: and, it stands to reason that nearly all dairynen who undertake to carry on their business in the crowded vicinity of a large city must necessarily resort to means in the feeding and housing of their animals which is injurious to their constitution.

Only within the past few months a lot of dairy cows were licovered in the State of Illinois to be diseased, which were condemmed and slaughtered by the legal authorities, and it was clearly pioven that they contained the germs of tuberculosis. These animals had been supplying milk for a long time before any action was taken, and it is not nulikely that a number of sufferers from that fatal disease. consumption, are still suffering from the consequence of using the impure milk sold from these cows.

Vigorous efforts are being made in Great Britian to introduce goat's milk in the cities and towns of that country for the same reason that I have just referred to.

The Baroness Burdette-Coutts is the President of a society known as "The British Coat Society," the purposes of which are stated as follows:

"This society has been instituted in order to bring more prominently forward the utility and adaptability of the goat as a milk supply. It is a well established fact that in rural districts the families of the poor rarely taste other than skim milk, in consequence of the difficulty of procuring the pure article as it comes from the cow. It is either sent wholesale to London or the nearest town, or utilized at once in the manufacture of butter and cheese. On the continent and in Ireland the goat is regarded as the poor man's cow, supplying as it does many a peasant family with this most importart article of diet, the deficiency of which, among our own laborers' children, must act detrimentally in regard to their physical devclopment. The goat is especially adapted for such a purpose. It supplies just enough milk for the ample requirements of an ordinary household during the greater part of the year, and as it eats with avidity almost every kind of herb and vegetable, and is besides of a hardy nature it is kept with little trouble and at almost nominal expense."

"The prevalence of tuberculosis in cows is a cause for alarm, and the attention of the medical fraternity and the general public is attracted 
to the utility or goat milk. Consumption of the bones or some particular organ of the body frequently results from taking into the system milk Irom tuberculous cows.

In a recent address before the Hudersfield Technical College in England, Sir William Broadbent said: "Cows are very subject to tuberculosis, and at a certain stage of the disease tubercle bacilli are present in the milk. It is through milk so contaminated that children come to have tuberculous disease. The discase of bones and joints to which children are subject are probably also traceable to milk; humpback. hip-joint disease, and the diseases of knees, elbows, etc., which cripple so many children; perhaps so is lupus; and no doubi tubercle is often implanted by milk in early life, which developes later into consumption."

"Sir William Broadbent subsequently goes on to say: "It is interesting to note that asses and goats do not suffer from tuberculosis, and to bear in mind that the shrewd physicians of past days used to order asses' and goats' milk for persons threatened with consumption.'

"S. Holmes Pegler, Secretary of the 'British Goat Society,' and author of 'Advantages of Goat Keeping,' in speaking of Sir Wm. Broadbent's address, says: 'In France this subiect has received more attention. Professor Nocard stated some seven or eight years since that out of 130,000 goats and kids brought to Paris for slaughter at the shambles of La Villette every spring, the meat inspectors of that city failed to discover a single case of tuberculosis. He even added that inoculation fails to introduce the fatal bacillus into the system of the goat, although I believe the statement has since been questioned; any way, I have been told by veterinary authorities in this country that attempts made in England have failed. Goats' milk as a diet for children has many advantages over cows' milk, as I have often demonstrated, but this one great virtue transcends all others, and it is inconceivable that parents knowing this, and liaving the opportunities and accommodation for goat-keeping, should not avail themselves of so simple and economical a means of at once providing their children with the most easily digestible, and most nourishing of food, and safeguarding them from one of the greatest evils that civilization of the present day is subject to.'

"Dr. Adolph H. Allshorn, Licentiate of the Royal College of Physicians, Licentiate of the Royal College of Surgeons, and Physician to the Homoepathic Hospitals, Manchester and London, says: "As a substitute for the mother's milk to children deprived of that necessary, goats' milk has no equal; and notwithstanding the similarity in composition (as revealed by analysis), no one who has seen its effects can doubt its superiority to cows' milk. In diseased conditions of infancy, when there is a tendency to deficient assimilation in tubercular disease, Rachitis, Exophthalmic Goitre, I have proved its success, and have succeeded in rearing a third or fourth child of a family, the previous children of which have died in infancy from hereditary diease. Children brought up on 
goats' milk for a time after weaning from the mother, will compare more than favorably with those brought up under like conditions on cows' milk. I believe that goats' milk in senil conditions is of the tumost value, and know that it has a retarding effect in cases of Atheroma, whether this is due to the peculiar acid (Hircie) which it contains I am wnable to sıy with certainty."

“Dr. R. J. Lee, M. R. C. P.. Plysician to the Children's Hospital, Great Ormand Street, London, in his lecture on 'Goats' Milk as a Food for Infants and Invalids;' read before the members of the British Goat Society, said: 'What we desire to prove is, that whilst equal to that of any other milk-yielding animal in its nutritive properties, it is specially valuable for children. On this point I have not the least doubt whatever: and an quite ceriain that if a hundred children were fed on goats' milk: and compared with an cqual number of corresponding ages (all circumstances being similar) who were fed on any other milk, except that of their mothers, the goats milk children would, in comparison at least with those fed on cows' nilk have an advantage. 'This opinion has been formed partly from my own observation. for the children that I have seen fed on goats' milk hav thriven in the most satisfactory way, even when they had not thriven on cows milk: partly also from the experience of those who have kept goats and brought up large and healthy families upon the milk. I will give one instance among many that have come mader my notice of the value of goats milk as a food for young children. It was that of an infant three months old. whose mother was obliged to wean it, with the not infrequent result of serious illness to the child. After trying the usual plans of fecding children under these circumstances, I advised that goats' milk shonld be tried before resorting to a wet nurse. A quart of fresh goats' milk was obtained daily from the country, was boiled and at first mixed with a small quantity of water. The child drank between three pints and two guarts daily till he was six months old, when his father went to Pan for the winter. There was, however, no occasion to make any cliange in his diet, for the milk can be obtaned very casily indeed in Pau, as goats are driven in herds through the town every day, and are milked before the houses. Till the age of nine months the child was fed on nothing but goats' milk. and thrived in the most satisfactory way. He has grown into a fine boy, and if his parents had not becn leaving town this morning, his mother would have liked him to have come here and shown himself for our satisfaction."

"Dr. Charles Edward Shelly, B. A., M. B., Medical Officer to Haileybury College, says: 'For infants, I belicve goats' milk to be the best substitute for their natural ailment, when that is for any cause nut obtainablc. Not the least of its advantages is due to the fact that, owing to its superior digestibility, it requires less dilution than does cows' milk; and hence the child takes the requisite amount of nourishment in a smaller bulk, and thereby escapes much of the sickness and irritation which are 
apt to result from too frequent feeding and over-distension of the stomach and bowels. As in the case of cows' or asses' milk, it is usually better .to sweeten it with a little glycerine rather than with cane sugar, which is prone to favor fermentation in warm weather. For invalids, for convalescents, and in many of the diseases of the old age, it is most valuable; and a liking for it is usually soon acquired. In cases of impaired general nutrition, where there was nothing which could be definitely termed disease, it has proved a most useful addition to the dietary. If its use can be extended amongst the poorer classes of the community, I believe that it will not only prove a distinct boon financially, especially in country districts, but that it will be a powerful agent in tending to lessen the present lamentably high rate of infant mortality; and that it will help to lay the foundations of a sronger and more vigorous manhood and womanhood than can be expected to result from the kind of dietary which is now almost universal amongst the children of the poor."

There is very little doubt but that there would be quite a demand for milch goats if farmers in the neighborhood of our large cities and towns were prepared to furnish them. It often occurs that an infant is left without a mother to nourish it, and, in such cases, almost any sum would be paid for a goat rather than resort to the risk attending the use of the dairyman's stuff.

I teel sure that this branch of the industry is susceptible of very profitable returns, and, in grading up a lot of common (Mexican or Spanish) goats, a very good market can be found for the old does, after they have heen used to propagate the Angora.

Leather from the Angora goat is not considered as good as that produced by the common kind, owing to the more delicate nature of the skin. A reduction of 25 per cent. is usually made in the price.

The Homs of the Angora are also made use of for handles to knives, and for ornamentation. I have seen a pair of horns, from a full-grown male that were very handsome when polished, and set on a panel for wall decoration. As a source of revenue, however, this amounts to litt'e or nothing. 


\section{CHAPTER XXIII.}

\section{WHERE TO RAISE THE ANGORA GOAT TO GREATEST ADVANTAGE}

As far as climate is concerned, the Angora will do well in any of onr States or Territories where the soil is not marshy or swampy. A dry, rocky, mountainous country is the best; but one can hardly make much of a mistake in selecting a location that is free from the objection just mentioned, as it will generally possess more or less of the rolling, hilly land, which the goat naturally delights in.

The first question to be considered is: What number of goats are intended to be handled? If only a small flock, of fifty to one hundred and fifty, is contemplated, these can be more profitably cared for on any farm ranging say from two hundred acres up to six hundred. They will not only thrive well on the weeds in the pastures and old fields, but will grow fat, and be of great advantage to the owner in kecping down briars, and brush; that so constantly make their appearance along the fences and crossfences of farms. The labor of removing these "eyesores" is a contintual source of expense, and a small flock of Angora goats will make the fence lines look as clean as a lawn, and return a large dividend on the investment in the animal. If there should be any brush land on the farm, the goats will much more than pay for their cost in the improved character of the land, but I shall refer to this more particularly under a separate chapter.

My present purpose is to discuss the matter of "ranching" goats as a separate and distinct branch of live stock, as is now commonly carried on with cattle, sheep and horses.

A suitable range at a low cost or rental is the first great essential. 
The Southern States, perhaps, offer the greatest advantage in point of economy in handling the animal, owing to the mild climate; but, against this, the Northern States have a tendency to increase the product of mohair, hence, what is gained in one section is offset by an equal gain in the other, and it may be said there is no advantage to be had, in a pecuniary sense, by locating in the milder climate, provided you can afford to build shelter for your stock in the colder States.

With a limited amount of capital, the West, and Southwestern part, of Texas, offers more advantages for breeding than any other portion of the United States. The section lying west of the Colorado River, and south of the thirty-third degree of north latitude, is, perhaps, as close a duplicate of Asia Minor as there is in the world, possessing all the characteristics of that country respecting a dry, arid climate, and high altitude; besides, a large amount of evergreen foliage, and nutritious weeds, which afford an abundance of green feed the year round, together with canons, bluffs, and thickets of brush, to shield the animals from the cold winds of winter.

Up to a few years ago, this vast area of Texas, equal in size to the State of New York, was considered to be valueless, owing to the absence of water; but, this has been overcome by the digging, or boring, of wells, which range from one hundred to four hundred feet in depth, and pumping the water thus obtained by the aid of windmills. The land is owned partly by the State, and partly by individuals, chiefly railroad corporations, who received it from the State years ago in the way of subsidies for building railroads. Much of it is very rough, rocky and mountainous; so rough, indeed, that a cattleman cannot well handle cattle on it, and it is therefore largely vacant and unoccupied. The uniform rental for State lands is three cents per acre, but individual owners are often willing to take less, and will accept an offer of two cents rather than have their lands idle and unproductive of some revenue.

The Legislature has recently placed a large portion of the State lands upon the market, for actual settlers, at $\$ 1.00$ per acre, upon the payment of one-fortieth, or, two and one-half cents per acre cash, and the remainder, in payments of one-for- 
tieth annually, with three per cent. interest. Any one who intends to be an actual settler, on the land, can secure four sections, of six hundred and forty acres each. The payment of two and one-half cents per acre, and three per cent. interest, is such a very small sum to pay out annually that it practically amounts to a gift. Information can be had as to where these lands are located by inquiring from any land agent at Austin, Texas. Mr. E. Cartlidge, who was formerly connected with the State Land Office, and is now engaged in the real estate business at Austin, win be glad to answer any questions concerning this matter.

In many other parts of Texas now occupied by cattle raisers, there is a large amount of brushy and hilly land, suitable only for goat raising and, if the owners do not handle goats themselves, an arrangement can, usually, be made to rent the privilege of range and water at from one cent to two cents per goat per month. This is a very good way for a stranger to begin with. as it will afford him an opportunity to investigate more closely into the various parts of the State, where he can secure a permanent location.

The section I have referred to is capable, in itself, of stupporting several million head of goats; but, it is as nothing, conpared with the great nndeveloped area of the United States. in New Mexico, Montana, Idaho, Wyoming, Colorado and Oregon, through which passes the great range of Rocky Mountains, the natural home of the Wild Mountain goat, and an ideal spot to develop one of the greatest and grandest industries for producing mohair that exists on the globe. The larger portion of these lands are fit for nothing but mining and goat raising, and the latter would be a great advantage to the former in supplying fresh meat to the miners. They are subject to entry and pre-emption, under the United States land laws, and it is safe to say no other industry will ever encroach upon them, which has so often been the difficulty with out sheep raisers. Many goat ranches are now established in this belt of territory and are doing well. By writing to any of the breeders whose names and addresses can be found under the chapter on "Notes From Practical Breeders," any needed information can be secured. 
In addition to the almost unlimited available space already referred to, we have, in nearly every one of our Eastern and Southern States, a large amount of mountainous land, as well as many millions of acres in abandoned farms made vacant by the vigorous competion of the more fertile west.

These farms have been long idle and are overgrown with briars and brush to such an extent as to render them utterly valueless for either cultivating or stock raising, and are a source of expense to their owners.

The following letters that I have 1eceived from the Secretaries of the Agricultural Department of some of these States: will convey a fair idea of the advantages offered for Angora goat culture in the same:

MAINE. Hon. B. Walker McKeen, Secretary of the Agricultural Department, writes me as follows:

Augusta, Me., April 13, 1900.

"Mr. Wm. L. Black, Ft. McKavett, Texas.

"Dear Sir:-Replying to your esteemed favor of recent date, in relation to land in Maine suitable for raising Angora goats, $I$ beg to say that there are sections in the State that are somewhat overgrown with briars and low shrubs, but not in locations so that large areas could be purchased in any one place. I know of no stump land that can be purchased cheaply, as most of it is new land, and is, withont doubt, being held for cultivation and the raising of those farm animals that are usually kept in the State.

"Yours very truly,

B. WALKER McKEEN.

Extract taken from "The Oregon Agriculturist and Rural Northwest," of Portland, Oregon :

"J. W. Bailey, Dairy and Food Commissioner for Oregon, recently visited his old home in Maine, after an absence of twenty-five years. He found there in the logged-off sections, thousands of acres of land which had grown up with brush, and suggested that it could profitably be used as a pasture ground for Angora goats. An interview with him was published in a Bangor paper, in which he talked about goats in such an interesting way, that since his return he has been deluged with letters from Maine enquiring about Angora goats, what they will cost, etc. $\mathrm{He}$ is satisfied that a number of carloads could be sold there if they could only be had at a reasonable price." 
NEW HAMPSHIRE. Hon. N. J. Bachelder, Secretary of the Board of Agriculture, very kindly sent me a catalogue of New Hampshire farms that are offered for sale at prices ranging from $\$ 1.00$ per acre, up, with very good improvements, from which I extract the following:

\section{"State of New hampshire. Board of Agriculture, IMMIGRATION DEPARTMENT. \\ "Concord, N. H., January 1, 1899.}

"The numerous inquiries received at this office in regard to the $a$. tages of New Hampshire and the opportunities for purchasing farms for agricultural purposes, or for summer homes, have led to the publication of this pamphlet. During the past ten years much discussion has occurred in regard to the abandoned farms of New England, and so numerous have these inquiries been that no less than five of the six New England States have found it advisable to issue publications upon the subject, for the information of inquirers and possible purchasers of such properties, and a large number of farms have been sold and become occupied through these agencies.

"Many persons who have become interested in these farms, and in some instances have become purchasers, have teen attracted by the advantages surrounding them, rather than by the remarkable fertility of the soil itself, and the greater the advantages in the matter of roads, schools, and general transportation facilities, the larger the number that will become repopulated and thereby aid in the further extension of public facilities.

"The farms to which we have called attention, and which are brought to notice in this pamphlet, are those upon which are fairly tenantable buildings without occupants,-iarms which have become abandoned from various causes, none of which militate against the farm itself, for these farms generally compare favorably in fertility and natural productions with the occupied farms of the same localities. They are abandoned only in the sense that the buildings are without occupants. The title to the land is still held by some one who pays the taxes, gathers the fruit, and cuts such portions of the grass for hay as circumstances warrant. The buildings, still in fairly good condition, will shelter a good-sized fanily from winter's snows or summer's sun, and afford the foundation for establishing a home in one of the most favored spots on the globe.

"N J. BATCHELDER, "Secretary."

VERMONT. Hon. C. J. Bell, Secretary Board of Agriculture and Cattle Commissioner, writes me as follows: 
“East Hardwick, Vt., April 14, 1900.

"Mr. Wm. L. Black, Ft. McKavett, Texas.

"My Dear Sir:-Answering yours of the 3rd inst., there are many acres of pasturc land grown up more to bushes, not briars, and also many acres of pastures in many towns back upon the hills that can be bought from $\$ 2.00$ to $\$ 4.00$ per acre.

"I should presume in many instances where lumber has been cut off clean, and covered with brush, land could be bought for one dollar per acre.

\section{"Yours truly,}

\section{J. BELL.}

MASSACIIUSE'T'TS. Hon. J. W. Stockwell, Secretary State Board of Agriculture, writes:

"Boston, Mass., April 12, 1900.

"Mr. Wm. L. Black, Ft. McKavett, Texas.

"Dear Sir:-Replying to your inquiry would say that we have issued no farm catalogue since December, 1897, and the supply of that issue is exhausted. We are now making plans to issue an entirely new edition and hope to have copies for distribution this coming summer or early fali. Will file your request for a copy.

"There is no uestion but that we have areas adapted to the raising of Angora goats; land which can be purchased at from $\$ 5$ to $\$ 10$ per acre; and presumably our climate would be reasonably favorable.

"Respectfully,

J. W. STOCKWELL, Sec.

CONNEC'T'ICU'T. Hon. T. S. Gohl, Secretary Board of Agriculture, State of Connecticut:

"Mr. Wm. L. Black.

"West Cornwall, Conn., April 13, 1900.

"My Dear Sir:-There is plenty of land in Connecticut that is well adapted to both sheep and goats, but the dogs, and poor fences at present rule.*

"Yours respectfully,

T. S. GOHL, Secty.

PENNSYLVANIA. Hon. John Hamilton, Secretary of Agriculture, writes :

*'The difficulty mentioned by Mr. Gohl can be overcome very easily, by putting up a woven wire fence. 
"Commonwealth of Pennsylvania,

"Harrisburg, Pa., April 12, 1990.

"Mr. Wm. L. Black, Fit. McKavett, Texas.

"Dear Sir:-Yours of the 3rd instant is just at hand. We have plenty of land that is grown up with brush, and that could be had at very low rates. It is scattered in many districts throughout the State, at prices ranging from $\$ 1.00 \mathrm{up}$.

Very respectfully,

"JOHN HAMILTON, "Secretary of Agriculture."

NEW JERSEY . Hon. Franklin Dye, Secretary State Board of Agriculture, writes:

“Trenton, N. J., April 16, 1900.

"Mr. Wm. L. Black, Ft. McKavett, Texas.

"Dear Sir:- I have yours of April 9th making inquiries concerning the Angora goat and mohair industry so far as it applies to New Jersey. In answer I must say that for myself I know absolutely nothing about the industry in this State nor whether it prevails to even a limited extent; no doubt there are Angoras goats kept in some localities but, evidently, not to such an extent as to be considered by reporters worthy of sending to this office, for no such items have been furnished me in any of the aninual reports from the counties.

"It is an industry, however, which I think could be very successfully carried on in various sections in this State. We have much scrub and brush lands in the southern sections which are, to some extent, sandy; and quite extended areas of similar lands in the hilly and mountainous regions of the northern part of the State. Furthermore, these lands are held at a very low price and could be utilized, as I have no doubt they will be in the very near future, for this industry, the poultry industry and small fruits to a larger extent than at present prevails. Sorry I have not the information at my command to answer your questions in detail.

"Very respectfully yours,

"FRANKLIN DYE, "Secretary."

NEW YORK. Hon. Charles A. Weiting, Commissioner Department of Agriculture, writes:

“Albany, N. Y., April 19, 1900.

"Mr. Wm. L. Black, Ft. McKavett, T'exas.

"Dear Sir:- In reply to your communication of the 3rd inst. I have to say, there is considerable land in the State of New York that can be 
bought for prices ranging from three to six dollars per acre on which goats would probably thrive. This is back country land on hills, some rocks, but has good productive soil.

"Very respectfully yours, "C. S. WEITING."

MARYLAND. The President of Maryland Agricultural College, writes as follows:

"College Park P. O., Maryland, April 13, 1900.

"Mr. Wm. L. Black, Ft. McKavett, Texas.

"Dear Sir:-Your communication received. There is the greatest amount of land in Southern Maryland of the character to which you refer, and it can be bought from four to ten dollars an acre. If you would correspond with R. B. Chew, No. 512 F St., N. W., Washington, D. C.; or, with the Bureau of Immigration, Baltimore, Md., I think yon might learn something to your benefit.

"Very truly yours,

"R. W. SENERLEY. "President."

VIRGINIA. Hon. G. W. Koiner, Commissioner Department of Agriculture:

Richmond, Va., April 13, 1900.

'"Mr. Wm. L. Black. Ft. McKavett, Texas.

"Dear Sir:-In reply to your inquiry of the 3 rd inst., I beg to say that there is a good deal of cheap land in this State that could be used in raising goats.

"Yours truly,

G. W. KOINER,

"Commissioner."

WEST VIRGINIA. Hon. J. B. Garvin Secretary Department of Agriculture:

"Charleston, W. Va., April 26, 1900.

"Nr. Wm. L. Black, Ft. McKavett, Texas.

"Dear Sir:-I have been getting ali the information available on the Angora goat, and would be glad to see it introduced into this State. The Apalachain mountain ranges running northeast southwest through the Eastern portion of the State affords a wonderful range of brush lands, admirably adapted, as I understand, for the Angora to feed upon. In addition, our numerous hill lands arc covered with the growth of bushes and. briars and alders, which can only be eradicated by some such 
process. Mr. O. D. Hill, of Kendalia, Kanawha, County, W. Va., has the only herd of Angora goats in the State, and it is a small one.

"I send you by this mail, our fourth biennial report, which may be of some interest to you.

"Yours truly,

J. B. GARVIN."

TENNESSEE. Hon. Thos. H. Paine, Commissioner Department of Agriculture:

"Nashville, Tenn., April 10, 1900.

"Mir. Wm. L. Black, Ft. McKavett, 'T'exas.

"Dear Sir:-Yours to hand in regarci to goats. As to area of land for raising goats you can purchase lands at three to ten dollars per acre, well watered. We have very iew wild animals to molest goats, and what we have are in the Eastern part of the State. To be near the market I do not think a more suitable place can be found than some of the counties of the middle section of the State. Now as to gentlemen who have raised goats the following live in the middle section, viz: Messrs. Jos. Phillips, care Berry DeMoville \& Co., Overton Lea and John A. DeMoville, all of Nashville, Davidson County, Tenn.

"Yours respectfully, "THOMAS H. PAINE.

The following letter from Mr. W. E. Hughes, a very successful Angora goat breeder in 'Texas, is taken from "Claridge's Stock Farmer," of San Antonio:

"Not long ago I went up through the Eastern end of Tennessee in the Cumberland mountains and was much impressed by the adaptability of the whole of that section to the raising of goats. Hitherto it has been regarded as being of but little worth except for its coal mines and timber; besides those who are engaged in these industries there are scattered here and there through the hills a few small farmers, for the most part what are known as 'natives' or old settlers, who, in addition to a small farm, often have a small flock of sheep which is allowed to run at large, and also raise, perhaps, three or four calves and a colt or two and enough hogs to keep them in meat.

"It seems strange that in a country which is hilly and practically covered with underbrush that goats have scarcely ever been thought of as a feature of farming. The fields are mostly on a hill-side, so steep that they say you have to use stilts on the down-hill side of a horse in ploughing. This may be romance but, joking aside, it comes as near being a goat's paradise as any conntry I was ever in. While the hills are very steep they produce a very luxwriant herbage among other bushes, 
of which goats are fond; there is sumac in large quantities scattered throughout, and the tops of the hills seem to be just as rich as the bottoms-generally speaking a so1 $\{$ of sandy loam with sufficient clay in its composition to keep it from washing, and here and there a reddish shade, indicating the presence of iron in the soil.

"Another feature which is valuable is the presence of smail springs which are to be found in large numbers, and also very pretty and clear streams. I believe that it would be impossible to take an hour's walk in any direction without coming across one or the other of these water supplies. The winters are not severe, and the broken character of the country furnishes ample shelter for stock. One peculiar condition that also adds to its attractiveness as a goat country is the absence of wolves. The scattered sheep which the settlers allow to run out and mix with one another are only rounded up for marking and shearing or for some such special purpose, and for the rest of the time are running out like so many cattle."

I.OUISIANA. Hon. Leon Jastremski, Commissioner Board of Agriculture and Immigration:

\section{"Baton Rouge, La., April 24, 1900.}

"Mr. Wm. L. Black, Fort McKavett, Texas.

"Dear Sir:-Your letter on the subject of the raising of Angora goats has been received. I am not aware that any one in Louisiana is now engaged in this industry but believe that it could be successfully carried on in the greater portions of the State. I mail you to-day a descriptive pamphlet* of our State from which you may gather all requisite information.

$$
\begin{gathered}
\text { "Very truly yours, } \\
\text { "LEON JASTREMKSI, } \\
\text { "Commissioner." }
\end{gathered}
$$

WASHINGTON. Mr. E. J. Hermans, Giencoe, Washington, writes :

"We have a heavy growth of timber and brush, so dense that the brush of other countries in comparison is mere nothing. To clear this land for farming costs from $\$ 50.00$ to $\$ 200.00$ per acre. We also have a large amount of land that is not good for farming but that raises two

Note-The pamphlet referred to by Mr. Jastremski, is beautifully illustrated, and contains very full information respecting every parish in the State. There appears to be considerable quantity of U. S. land that is stibject to preemption in many of the Counties; and a great deal belonging to private individuals that can be purchased as low as $\$ 1.00$ per acre. 
varieties of brush known here as salal, and huckleberry, both evergreen and pectuliar to this country, which cannot be made to produce anything without great expense, can be made to yield a fine revenue with goats. I would not stock such land to kill the brush, but just enough to keep the range permanent. I am enthusiastic on the subject. The only trouble I have heard of with goats here is 'foot-rot,' and that only occurs in the bottom lands. The class of lands I have mentioned is never muddy, and would therefore be free from this trouble."

\section{Mr. Jno. S. Harris, Oakley, Idaho, says:}

".There are a great many difficulties to contend with in this.section; yet, in a measure, it is the climate, in my opinion, that is likely to make the moliair goat hold out the longest in producing a fleece similar to that of its native land.

"I think Texas climate will cause a deterioration in the fleece.

"I am confident we can compete with South Africa or Turkey in raising mohair.

"I think perhaps Colorado is the best all-round State to raise the Angora goat in. Oregon is going to raise a great deal of mohair, and it is of a very fine character; very similar to that of Angora.

A very complete write-up on Colorado, Oregon, Dakota, Montana, Idaho, Nashington, Utah, New Mexico and Arizona appears in the report of the U. S. Department of Agriculture: for 1869 , pages 602 to 623 .

And, Mr. Almont Barnes, of the Division of Statistics, makes the following interesting statement concerning "Available pasturage for goats," in the year-book for 1898, of that Department, on pages 425 and 426 :

\section{AVAILABLE PASTURAGE.}

"Relative to areas suitable for goat keeping upon any scale, from a few for milk or cheese to large flocks for their fleeces or skins, it may be confidently asserted that wherever there is a suitable climate there are also suitable uncultivated lands. Over 42 per cent. of the land in farms in the United States is unimproved; how much of it is uncultivatable, is unknown. The total mimproved land amounts to $265,600,000$ acres, against more than $375,600,000$ improved. This presents a vast field for selection of favored localities in every part of the country; and much of the field invites the primitive occupation of herding, which preceded and prepared the way for agriculture in many countries, with inestimable benefit to the soil. 
"It is true that, considerable portions of the unimproved farm land is in valuable forests, which invite preservation as such for various economic reasons; but it is equally true that a large proportion is usless as a present or prospective timber reserve, and can be utilized only in some way as is herein suggested. In the aggregate, millions of acres of poor, rough, rocky, or bushy land, distributed through all the States, call for subjugation and enrichment through animal occupation, preferably of the goat, which would not only destroy the growth that invites recurrent confiagrations, but would result ultimately in the introduction of nutritious grasses.

"In order to present the areas of unimproved land in farms in true relation with the improved and to show the farms of which they are a part, and at the same time the wide basis upon which the interest herein considered may be established, reference may be made to the report on agriculture of the Eleventh Census.

"The State of Maine, for instance, lias $6,000,000$ acres in farms, of which $3,000,600$, or 50 per cent., are improved and an equal number uncultivated; there are 62,000 farms therein, averaging 100 acres each. A logal deduction is that, there are about 62,000 farmers in Maine who have, on an average, 50 acres each of unimproved land. Observation shows that portions of such land are useless for farming purposes, and often are in extended areas defined by natural limits. They are, however, well adapted to goat herding even when good for nothing else, and would almost invariably be made better thereby.

"Relative to Georgia, it may be said that there is an acreage in farms of over $25,000,000$, of which $9,500,000$ are improved, and over 15 ,500,000 , or nearly. 62 per cent., unimproved, with 171,000 farms, and an average of 147 acres to the farm. The evidence of the former commissioner of agriculture of that State as to the fitness of its mountain lands for goats of the Angora breed has been cited, and the same holds good over most of the other lands in the State for the common goat, including the average of $73 \frac{1}{2}$ acres per farm of tmimproved land. Similarly, the lesson may be applied to each State, according to fitness, without materiai change.

"There is, however, in the United States a large, continuous area, embracing over one-third of the States and Territories, which invites particular attention in connection with this subject. It includes the South Atlantic and South Central divisions and a part of the Western division of the Census groupings, * or twenty States and Territories,

*South Atlantic division, Delaware, Maryland, District of Columbia, Virginia, West Virginia, North Carolina, South Carolina, Georgia, Florida; South Central division, Kentucky, 'Tennessee, Alabama, Mississippi, Lonisiana, Texas, Oklahoma, Arkansas; Western division, Montana. Wyoming, Colorado, New Mexico, Arizona, Utah, Nevada, Idaho, Washington, Oregon, California. 
which, together, contain, nearly 28,5,000,000 acres in farms, of which over 122,000,000 are improved and over $162,000,000$, or 57 per cent., unimproved. The average size of farms and the average amounts of unimproved land are greater in this area than elsewhere, and the climatic conditions are more uniform.

".This area includes nearly all the central, and a part of the western miountain regions, and lics principally within the belt of at least little or no snow. It is in general the most temperate region of a temperate zone, and peculiarly suitable for wintering all kinds of farm and range stock. not only as to climate, but as to subsistence. It furnishes an abundance of such forage as is suitable, and preferable for goats, available to them, in most parts during the entire year. Under such circumstances and conditions whatever profit can be derived from herding them comes nearest to a net profit. There is the additional incidental benefit that whatever foul land is regularly pastured by these animals for a few years becomes clean, weedless, and brushless, and usually, being evenly fertilized by them also, rums into nutritious native grasses."

The following article, taken from the "Montana Stockman and Farmer," of January 1st, 1899, will be interesting:

\section{ANGORA GOATS IN MONTANA}

"Little attention has been paid to raising Angora goats in Montana. Some years ago a small band was brought into Beaver County and turned loose near Dillon. No attention was paid to them. They were sold a few at a time to a butcher, some of them died and others were lost, and finally the band disappeared. Another small band at a later date was taken to the vicinity of White Sulphur Springs and turned loose, being finally sold to the butcher because they liked to stay in town too well and would not keep out on the range. Another small band was turned out in Madison County. They kept in the mountains; became wild, and were supposed to have been killed by hunters.

"The only person, as far as we can learn, who has made a business of running goats in Montana is Mr. H. A. Brannin, of Marysville. He keeps the goats in the mountains about a mile below Empire. Last winter he had about $450^{\circ}$ and he brought them through without feeding hay. He says, however, that it would have been better if they had had a little hay, but he would not have required to exceed four tons. With that amount they would have come through the winter in excellent shape. As it was, they were a little thin, but none died. During the heavy snows of March they waded through snow up to their backs to reach the brush and fir trees that were cut down for them to feed upon. 
Under this treatment none of them died. According to Mr. Brannin's experience the goats are much hardier than sheep, and will stand a hard winter with less care. They will also live on much coarser food.

"Mr. Brannin was in the goat business in New Mexico, and is enthusiastic on the possibilities of the goat industry in Montana. Hc believes it to be much more profitable than sheep raising. He says the goats shear heavier here than they do in New Mexico and Texas, and also that they attain greater size. It will also be remembered that this is also true of sheep, and that cattle also attain a greater size here. He also claims that goats are more prolific than sheep, and that the kids are easier to raise than lambs. Goats are certainly much easier to handle than sheep. The kids can be kept in the corral in the morning and the old ones turned out and let go by themselves, and the latter will come home in the evening like cows. The life of a goat is two or three times that of a sheep-a consideration in estimating profit.

"Coyotes may occasionly get a goat if it strays from a flock, but in a band they are well able to take care of themselves, so far as the coyotes are concerned. Mr. Brannin has not lost half a dozen in two years, and they have run alone in the mountains where coyotes are plentiful." 
CHAPTER XNIV.

WHERE THE ANGORA GOAT CAN BE PURCHASED, WITH STATEMENTS FROM BREEDEHS ABOUT THE SHEARING

CAPACITY OF THEIR GOATS.

Realizing that very few people, not engaged in breeding the Angora goat, have any knowledge as to where such stock can be purchased, I decided to send out the following list of questions to a number of breeders in the different States:

1. What is the average shearing capacity of your goats?

2. What is the length of the staple of your mohair?

3. What will your wethers and does weigh?

The following is a tabulated ist of the replies received: and, following this, will be found a more particular reference to the character of the animals by the breeders themselves.

It must not be supposed that these represent the aroragc shearing of the Angoras in the United States, as there are many breeders who have only commenced grading up the common goat within the past few years, and have not reached a very high grade. Others have been using very ordinary bucks, and cannot possibly increase their shearing capacity very rapidly.

The breeders I have selected, have been engaged in the business for a number of years, or have purchased flocks from others who have, and they will serve as a fair index to the Angora in this country, where reasonable care and attention has been used for a period of ycars; and, judging from the experience of the past, I do not hesitate to say that a shearing capacity of twelve pounds for wethers, and eight pounds for does, is likely to be a very common yield within the next twenty-five years.

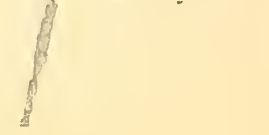




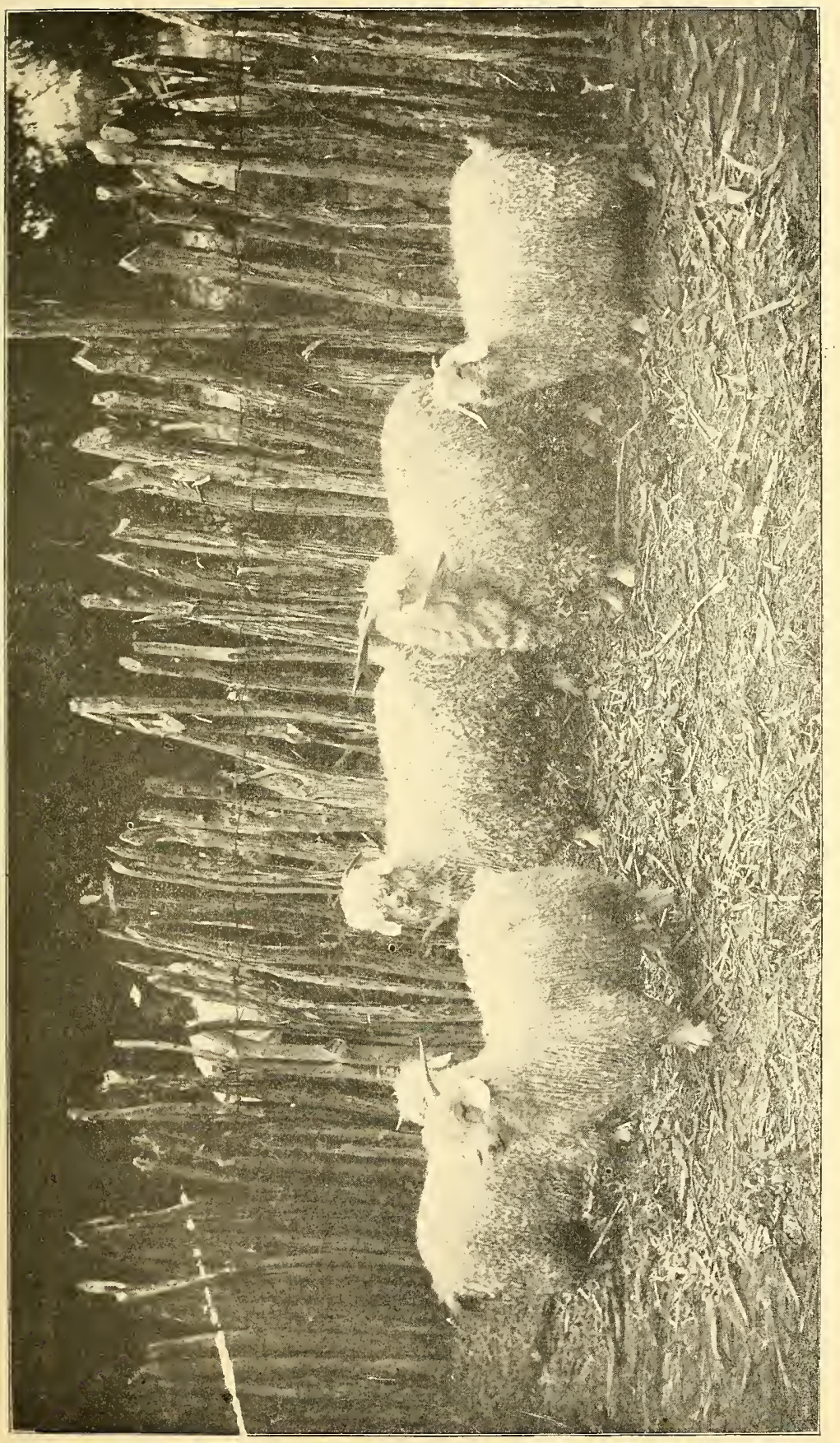

岀

4

is

I!

$z$

이롫

$z \stackrel{9}{\square}$

岁䙵要

ए

(5) 4 可

Z

$\sum=\bar{I}$

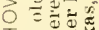

虽

- 9

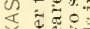

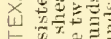

$>$ 更

$z$ a

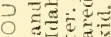

4 .

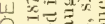

的可

$3 \quad 0-3=$

-

击

占政

$5:-5$

O

三

$x$ 는

$\checkmark$ 光跣

$\bar{x}$

x:

1 药

$\infty 2$

$11:-3$

$3 \forall=7$

○梌行

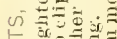

0 要通

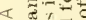

\&

0 政

$\sum_{4} \cdots$

<

แ

$\infty$

$\frac{I}{0 \pm}$

$\supset$

药

=

듬

4

3 


\begin{tabular}{|c|c|c|c|c|c|c|c|c|c|c|}
\hline \multirow[b]{3}{*}{ SJATE } & \multirow{2}{*}{\multicolumn{2}{|c|}{$\begin{array}{l}\text { No. } 1 \\
\text { Shear- } \\
\text { ing }\end{array}$}} & \multirow{2}{*}{\multicolumn{2}{|c|}{$\begin{array}{l}\text { No. } 2 \\
\text { Mohair }\end{array}$}} & \multicolumn{4}{|c|}{ No. 3} & \multirow[b]{3}{*}{ BREEDER'S ADDRESS } & \\
\hline & & & & & \multicolumn{2}{|c|}{$\begin{array}{c}\text { Live } \\
\text { Weight }\end{array}$} & \multicolumn{2}{|c|}{$\begin{array}{l}\text { Dressed } \\
\text { Weight }\end{array}$} & & \\
\hline & $\begin{array}{l}0 \\
0 \\
0 \\
\frac{1}{3} \\
0 \\
y\end{array}$ & 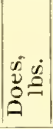 & 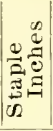 & 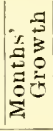 & 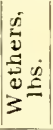 & $\begin{array}{ll}\infty & 0 \\
2 & 0 \\
\varrho & 0\end{array}$ & 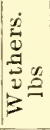 & 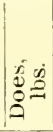 & & \\
\hline Texas. & $\begin{array}{c}5 \\
6 \\
4 \\
61 / 2 \\
4 \\
5 \\
6 \\
4 \\
9 \\
4 \\
4 \\
6 \\
4 \\
3 \\
8-10 \\
4(a) \\
6(\omega 7 \\
6 \\
7 \\
4(a)\end{array}$ & $\begin{array}{c}3 \\
41 / 2 \\
31 / 2 \\
41 / 2 \\
3 \\
3 \\
4 \\
3 \\
6 \\
3 \\
3 \\
5 \\
3 \\
2 \\
5(a 8 \\
4 a 6 \\
3 a 4 \\
4 \\
5 \\
3(a)\end{array}$ & \begin{tabular}{|l}
12 \\
13 \\
13 \\
13 \\
13 \\
12 \\
12 \\
7 \\
8 \\
9 \\
10 \\
14 \\
8 \\
$61 / 2$ \\
$131 / 2$ \\
15 \\
11 \\
12 \\
12 \\
15
\end{tabular} & $\begin{array}{r}12 \\
12 \\
12 \\
12 \\
12 \\
12 \\
12 \\
6 \\
7 \\
12 \\
12 \\
8 \\
12 \\
12 \\
12 \\
12 \\
12 \\
12 \\
12\end{array}$ & $\begin{array}{r}\ldots \\
100 \\
130 \\
\ldots \\
\cdots \\
100 \\
\ldots \\
90 \\
90 \\
105 \\
\ldots \\
60 \\
\ldots \\
120 \\
90 \\
100 \\
80 \\
100 \\
100 \\
100\end{array}$ & $\begin{array}{c}\ldots \\
80 \\
90 \\
\ldots \\
\cdots \\
75 \\
\cdots \\
65 \\
65 \\
85 \\
\cdots \\
50 \\
\cdots 95 \\
95 \\
75 \\
75 \\
60 \\
80 \\
85 \\
75\end{array}$ & 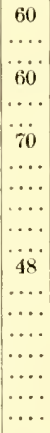 & $\begin{array}{c}45 \\
\ldots \\
\cdots \\
45 \\
\ldots \\
\cdots \\
50 \\
\ldots \\
\ldots \\
\ldots \\
\cdots \\
\cdots \\
30 \\
\cdots \\
\ldots \\
\ldots \\
\ldots \\
\ldots \\
\cdots \\
\cdots \\
\ldots\end{array}$ & $\begin{array}{l}\text { John Brown, Sonora. } \\
\text { Jefi Pepper, Rock Springs. } \\
\text { D. G. Avery, Marathon. } \\
\text { K. H. Lowry, Camp San Saba. } \\
\text { J. W. Garrett, Mountain Home. } \\
\text { Doughter \& Luttrell, Lipan. } \\
\text { W. W. Haupt, Kyle. } \\
\text { J. M. Arnold, Montell. } \\
\text { G. W. Baylor, Montell. } \\
\text { Tom S. Evans, Exile. } \\
\text { J. Dis-ler. Juno. } \\
\text { H. T. Fuchs, Tiger Mill. } \\
\text { H. W. Galbraith, Montell. } \\
\text { Jas. Patterson, Junction City. } \\
\text { W. M. Landrum, Laguna. } \\
\text { R. H. Wyatt. Sonora. } \\
\text { Henry Fink, Leon Springs. } \\
\text { W. I. Hughes, Hastings. } \\
\text { W. R. Mclíe, Junction City. } \\
\text { Rev. D. S. Babb, Sonora. }\end{array}$ & 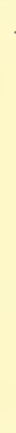 \\
\hline Oregon. & $\begin{array}{c}53 / 1 \\
\pi \\
4 \\
6 \\
4 a 5 \\
7 \\
5 \\
4 a 8 \\
5 a 8 \\
6 \sigma a 8 \\
6 a 8 \\
5 a 9 \\
61 / 2\end{array}$ & $\begin{array}{c}43 / 4 \\
5 \\
33 / 4 \\
4 \\
3 a 4 \\
4 \\
2 a 3 \\
3 a 6 \\
3 a 7 \\
4 a 6 \\
4 \\
5 \\
4\end{array}$ & $\begin{array}{l}141 / 2 \\
12 \\
31 \\
11 \\
10 \\
10 \\
111 / 2 \\
1 \% \\
10 \\
13 \\
10 \\
121 / 2 \\
12\end{array}$ & $\begin{array}{l}12 \\
12 \\
\ldots \\
12 \\
12 \\
12 \\
12 \\
12 \\
12 \\
12 \\
12 \\
12 \\
12\end{array}$ & $\begin{array}{c}75 \\
100 \\
\cdots \\
\cdots \\
\cdots \\
\cdots \\
185 \\
\cdots \\
\cdots \\
\cdots \\
\cdots \\
\cdots \\
\cdots \\
\cdots\end{array}$ & $\begin{array}{c}18 \\
80 \\
\cdots \\
\cdots \\
\cdots \\
\cdots \\
145 \\
\cdots \\
\cdots \\
\cdots \\
\cdots \\
\cdots \\
\cdots \\
\cdots\end{array}$ & $\left\{\begin{array}{c}\cdots \\
\cdots \\
\cdots \\
\cdots \\
\cdots \\
\cdots \\
\cdots \\
\cdots \\
\cdots \\
\cdots \\
\cdots \\
\cdots \\
\cdots \\
\cdots \\
\cdots \\
\cdots \\
\cdots \\
\cdots \\
\cdots \\
\cdots \\
\cdots\end{array}\right.$ & $\begin{array}{l}\ldots \\
\cdots \\
\cdots \\
\cdots \\
\cdots \\
\cdots \\
\cdots \\
\cdots \\
\cdots \\
\cdots \\
\cdots \\
\cdots \\
\cdots \\
\cdots \\
\cdots\end{array}$ & $\begin{array}{l}\text { Scott Obye, No Yamhill. } \\
\text { Geo. A. Houck. Eugene. } \\
\text { Frank H. Rogers, Gardner. } \\
\text { A. Blackburn, No. Yamhill. } \\
\text { J. M. Hassler, Larwood. } \\
\text { J. H. Hawley, Monmouth. } \\
\text { O. Dowell, Florence. } \\
\text { N. Woodward, Dallas. } \\
\text { Mr. Masters, Cleveland, } \\
\text { W. L. Claggett, Salem. } \\
\text { Oscar Tom, Angora. } \\
\text { Jas. MeDonald. Morrison. } \\
\text { D. A. Walker, Carlton. }\end{array}$ & \\
\hline
\end{tabular}




\begin{tabular}{|c|c|c|c|c|c|c|c|c|c|}
\hline \multirow[b]{2}{*}{ STATE. } & \multicolumn{2}{|c|}{$\begin{array}{c}\text { No. 1. } \\
\text { Shear- } \\
\text { ing. }\end{array}$} & \multicolumn{2}{|c|}{$\begin{array}{l}\text { No } 2 . \\
\text { Mohair }\end{array}$} & & $\begin{array}{l}\text { No } \\
\text { eive } \\
\text { eight. }\end{array}$ & $\begin{array}{l}3 \\
\text { Dres } \\
\text { Weig }\end{array}$ & $\begin{array}{l}\text { essed } \\
\text { ight. }\end{array}$ & \multirow[b]{2}{*}{ BREEDER'S ADDRESS. } \\
\hline & 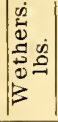 & 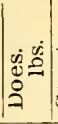 & 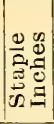 & 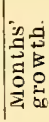 & 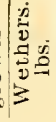 & $\mid \begin{array}{l}\dot{n} \Xi \\
\dot{g}\end{array}$ & 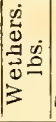 & 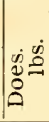 & \\
\hline 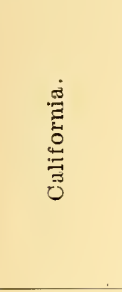 & $\begin{array}{l}7 \\
6 \\
6 \\
5 \\
6 \\
51 / 2 \\
4 \\
4 \\
31 / 2 \\
4 \\
4 \\
3 \\
31 / 2 \\
\end{array}$ & \begin{tabular}{|l|}
5 \\
$51 / 4$ \\
4 \\
3 \\
4 \\
4 \\
$21 / 2$ \\
$31 / 2$ \\
$21 / 2$ \\
$21 / 2$ \\
$31 / 2$ \\
$\ldots \ldots$ \\
$\ldots$
\end{tabular} & $\begin{array}{c}13 \\
13 \\
8 \\
12 \\
\ldots \ldots \\
10 \\
12 \\
6 \\
10 \\
10 \\
8 \\
9 \\
13\end{array}$ & $\begin{array}{c}12 \\
12 \\
12 \\
12 \\
12 \\
12 \\
12 \\
12 \\
0 \\
12 \\
6 \\
12 \\
12 \\
\end{array}$ & $\begin{array}{c}100 \\
165 \\
\cdots \\
\cdots 100 \\
100 \\
\cdots \\
\cdots \\
\cdots \\
\cdots \\
\cdots \\
\mathrm{Av} \\
\mathrm{Av}\end{array}$ & 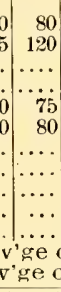 & 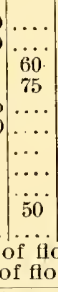 & $\begin{array}{l}\ldots . \\
\ldots \\
40 \\
60 \\
\cdots \\
\cdots \\
\cdots \\
\cdots \\
\ldots \\
40 \\
\ldots \\
\text { ock. } \\
\text { ock. }\end{array}$ & $\begin{array}{l}\text { Philo Ogden. Upper Lake. } \\
\text { Conklin Bros., New ville. } \\
\text { Wm. Richter, Jco. } \\
\text { Jacob Oalies, Paskenta. } \\
\text { E. L. Maize, Upper Lake. } \\
\text { C. P. Bailey, San Jose. } \\
\text { E. R. Williams, Redding. } \\
\text { R. J. Linton, Ager. } \\
\text { Jas. Wilder, Paslienta. } \\
\text { F. G. Smith. Skaggs Springs. } \\
\text { A. Monn, Ono. } \\
\text { J. M. Wimmer, Millville. } \\
\text { Jos. H. Dunison, Upper Lake. }\end{array}$ \\
\hline $\begin{array}{c}\text { New } \\
\text { Mexico }\end{array}$ & $\begin{array}{l}7 \\
6 \\
6 \\
5 \\
\end{array}$ & $\begin{array}{l}5 \\
4 \\
4 \\
31 / 9\end{array}$ & $\begin{array}{l}15 \\
11 \\
11\end{array}$ & $\begin{array}{l}12 \\
12 \\
12\end{array}$ & $\cdots$ & $\left|\begin{array}{c}\cdots \\
\cdots \\
100\end{array}\right|$ & $\left|\begin{array}{c}50 \\
60 \\
\cdots\end{array}\right|$ & $\begin{array}{c}30 \\
40 \\
50 \\
\ldots\end{array}$ & $\begin{array}{l}\text { E. Weistrand. Cooney. } \\
\text { D. C. Taylor, Lake Valley. } \\
\text { J. C. Hightower, Ruidosa. } \\
\text { O. D Norcup. Sepan }\end{array}$ \\
\hline Iowa. & $\begin{array}{l}7 \\
5 \\
4 \\
5 \\
5 \\
\end{array}$ & $\begin{array}{l}5 \\
4 \\
3 \\
3 \\
3\end{array}$ & $\begin{array}{l}13 \frac{1}{2} \\
10 \\
10 \\
14 \\
11 \\
\end{array}$ & $\begin{array}{l}12 \\
12 \\
12 \\
12 \\
12\end{array}$ & $\begin{array}{l}100 \\
100 \\
100 \\
100\end{array}$ & \begin{tabular}{|c|c|} 
& 80 \\
0 & 85 \\
75 \\
75 \\
95
\end{tabular} & $\begin{array}{l}\cdots \\
\cdots \\
\cdots \\
\cdots \\
\cdots\end{array}$ & $\begin{array}{l}\cdots \\
\cdots \\
\cdots \\
\cdots \\
\cdots\end{array}$ & $\begin{array}{l}\text { J. H. Standley, Plattevilie. } \\
\text { S. S. MeKibben. Earlham. } \\
\text { I. J. Booth, Cresco. } \\
\text { Morgan \& Morgan, Slay. } \\
\text {.I C. Morton. Indianola. }\end{array}$ \\
\hline Arizona. & $\begin{array}{l}4 \\
4 \\
4 \\
21 \%\end{array}$ & $\begin{array}{l}3 \\
21 / 2 \\
21 / 2 \\
11 / 2\end{array}$ & $\begin{array}{c}12 \\
12 \\
6 \\
8\end{array}$ & $\begin{array}{l}12 \\
12 \\
12 \\
12\end{array}$ & & $\begin{array}{l}\cdots \\
\cdots \\
\cdots \\
\cdots\end{array}$ & $\begin{array}{c}50 \\
55 \\
\cdots \\
40\end{array}$ & $\begin{array}{l}35 \\
40 \\
35\end{array}$ & $\begin{array}{l}\text { J. F Holder. Pays.n } \\
\text { J. R. Harnette. Globe. } \\
\text { Ira Harper. Clifton. } \\
\text { Wm. Horn. Camp Verde. }\end{array}$ \\
\hline Montana. & $\begin{array}{l}5 \\
5\end{array}$ & $\begin{array}{l}3 \\
31 / 2\end{array}$ & $\begin{array}{r}11 \\
9\end{array}$ & 12 & & $\begin{array}{l}\ldots . \\
\ldots \\
\ldots\end{array}$ & 65 & $\begin{array}{l}45 \\
45\end{array}$ & $\begin{array}{l}\text { S. S. Brannin, Marysville. } \\
\text { T. Clome Miles, Silver Bend. }\end{array}$ \\
\hline Idaho & 9 & 6 & {$[2$} & $\tau$ & $\ldots$ & $\cdots \cdots$ & $\cdots \cdot$ & $\cdots$ & J. H. Harris, Oakley. \\
\hline
\end{tabular}

\begin{tabular}{c|c|c|c|c|c|c|c|c|c|}
\hline Washingtin & 8 & 6 & 13 & 12 & $\ldots$ & $\ldots$ & 55 & 40 & Dr. Tuttle, Tacoma. \\
\hline Wyoming. & $61 / 2$ & 4 & 12 & 12 & 140 & 120 & $\ldots$ & $\ldots$ & Chris. Nilson. Burlington. \\
\hline Utih. & $31 / 4$ & $\because 1 / 2$ & 15 & 12 & $8 ;$ & 70 & $\ldots$ & $\ldots$ & J. K. Irumblin, Kanab.
\end{tabular}

\begin{tabular}{|c|c|c|c|c|c|c|c|c|}
\hline Minnesota & $\begin{array}{l}5 \\
5\end{array}$ & $\begin{array}{l}4 \\
4\end{array}$ & $\begin{array}{l}12 \\
13\end{array}$ & $\begin{array}{l}12 \\
12\end{array}$ & 150 & 125 & $\cdots$ & $\begin{array}{l}\text { C D. Tutbill, Tuthill. } \\
\text { the Wileox Co, Hugo. }\end{array}$ \\
\hline Kansas. & 7 & $51 / 2$ & 12 & 12 & 100 & (i.) & $\ldots$ & R C. Jo'nvton. Lawrence. \\
\hline Missuuri. & 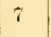 & 5 & 8 & {$[2$} & & $\cdots$ & $\ldots$ & A. Lippincut. Sheridan. \\
\hline Oklahoma. & 5 & 3 & 13 & 12 & 100 & 75 & $\cdots$ & J. K. Youns, Woodward. \\
\hline $\begin{array}{l}\text { West } \\
\text { Virginial. }\end{array}$ & $\tau$ & 5 & 18 & 12 & $\cdots \cdots$ & $\cdots$ & & O J) Hill. Isenualia. \\
\hline Connectic $\mathrm{t}$ & $5 \ll 7$ & $3 \pi 5$ & 10 & 12 & 93 & 23 & & Jas. A. Bill, Bill Hill \\
\hline $\begin{array}{l}\text { Nurtu } \\
\text { Carolina. }\end{array}$ & $11 / 2$ & 1 & 10 & 13 & 90 & 6.5 & & Lafivette Holt. Rurlington. \\
\hline
\end{tabular}




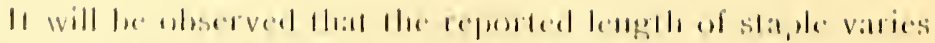

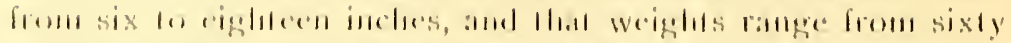

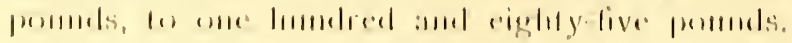

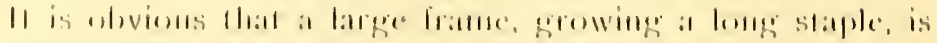

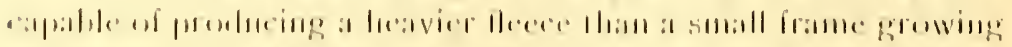

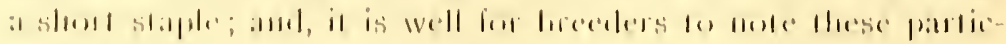

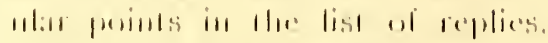

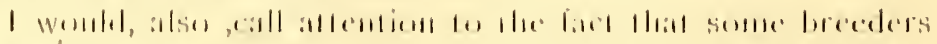

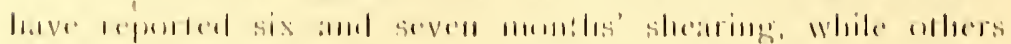

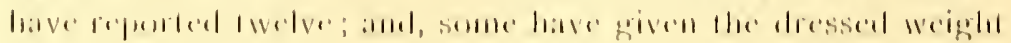

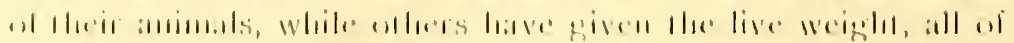

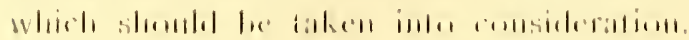

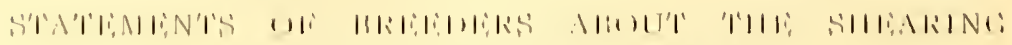

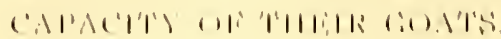

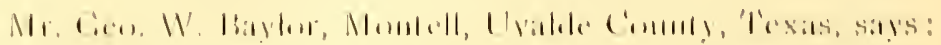

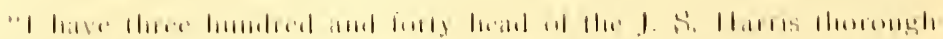

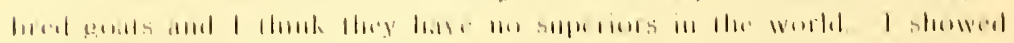

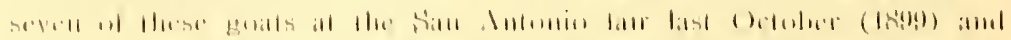

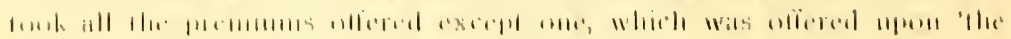

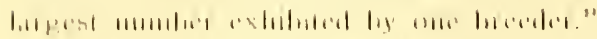

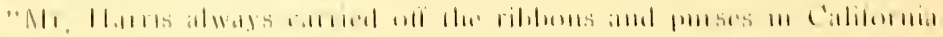

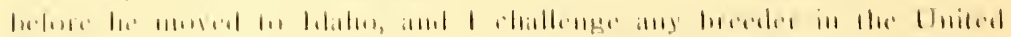

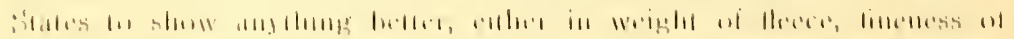

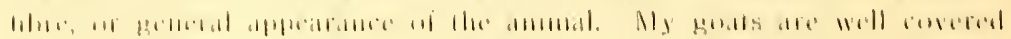

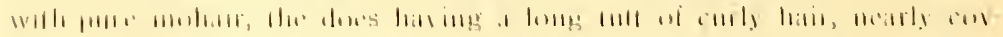

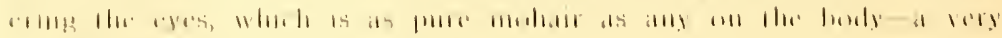

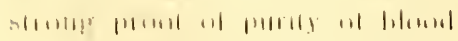

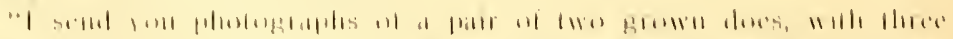

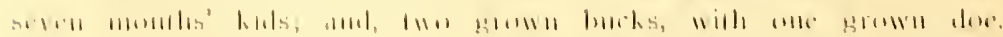

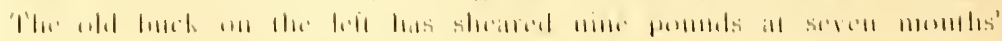

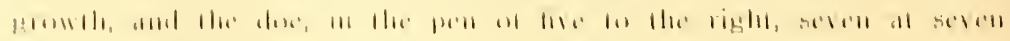

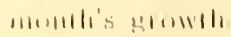

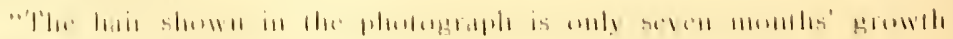

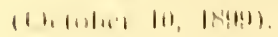

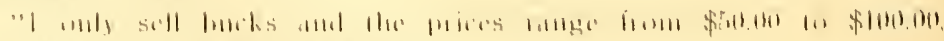

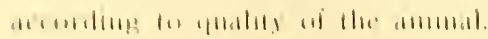

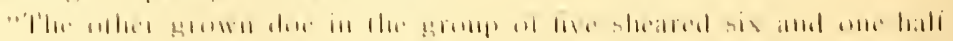

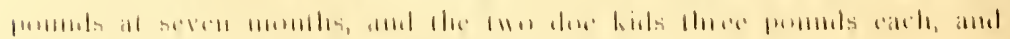

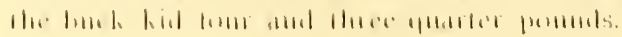




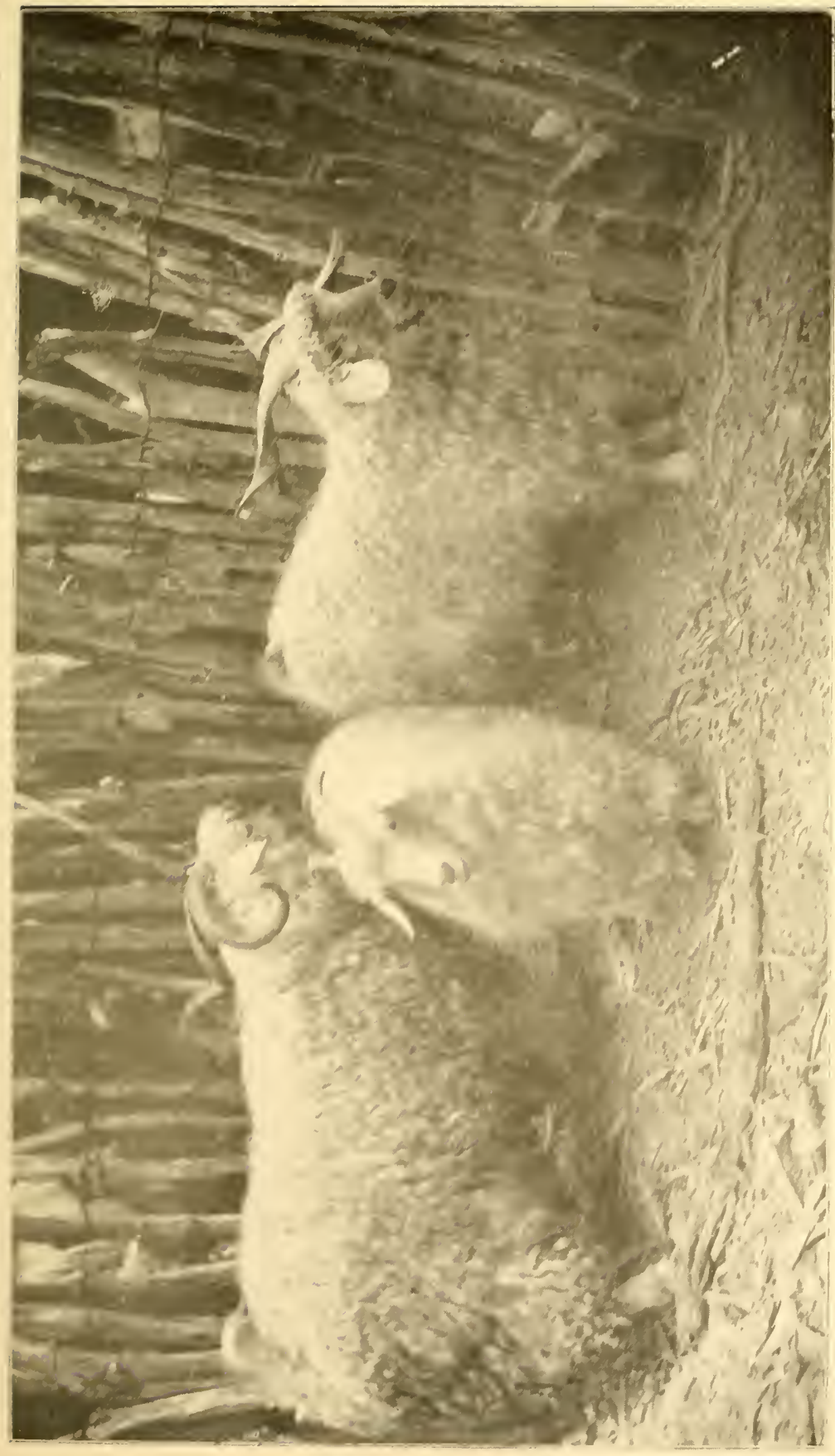



"The group of three, the big buck sheared nine pounds, the small buck six pounds, and the doe five and one-half pounds, at seven months."

\section{Mr. W. G. Hughes, Hastings P. O., Kendall County,} writes:

"Reierring to my flock of thoroughbred Angora goats, I would state that I purchased the entire flock from Col. W. W. Haupt, of Hayes County, some years ago, and have since tried to avoid any retrogression in the quality of the stock which Col. Haupt deserves great credit for having brought to a high state of perfection. I have shipped bucks into twenty-four different States in the last twelve months or so, from Washington and Idaho in the Northwest, to New York and Massachusetts in the East, and as far South as Louisiana and Florida. I made an exhibit at the Omaha Exposition in 1898, and carried off most of the premiums that were offered, and I can conscientiously say there are no goats in the United States that are any freer from base blood than my own. I have been breding to combine a strong constitution with a good, well distributed fleece of fine mohair, and $I$ think I have attained it.

"I cannot do better in this connection than by giving you Col. Haupt's reply to a request I made that he write a statement as to the breeding of the goats while in his hands, which is as follows:

$$
\text { “. Kyle, Hays County, Texas, April 5, } 1899 .
$$

“. Mr. W. G. Hughes, Hastings, Texas:

"Dear Sir-I got all my pure bloorls irom Col. Richard Peters, of Atlanta, Georgia, into whose hands fell the original flock of Angoras imported by Dr. J. B. Davis, of South Carolina, in 1849.

"These were the finest goats ever Lrought here, unless others have been imported in recent years. Mr. Peters (who died in 1899) made other importations of which he sent me samples, but I discarded them. He imported some greasy fleeced goat;, like Merino sheep, and sent me samples of the fleece and asked my opinion of them. I informed him the fleece was no finer, and after the grease was washed out it was no heavier, and that all the difference I could see in it was the extra trouble of scouring the fleece. We discarded them.

"I wrote to Kitching \& Bicknell, of New York, if I could find a billy from any flock in California, or elsewhere, that would increase the weight of my fleece, without detriment to its fineness. They said I could not. And under date of December 1i, 1888, they wrote me about my six months' clip as follows:

" "It is the best lot we have had this season. We sold a lot today, not as good as yours, for thirty- three and one-third cents and yours will go to thirty-five cents. We can get a fancy price for yours, as it is fine, clean, silky and lustrous, and of good length." , 
"Mr. spoke so much of his large yield and fine fleece, that I ordered one of his billies. I reshipped it back to him.

"So my pure bloods, ab initio, till the day 1 sold then to you, have been bred by me with most scrupulous care, and no foreign matter mixed into them, and I can truthfully say their blood is perfectly pure, if it left Asia Minor pure; and it is doubtful if this can be said of many other flocks in the United States.
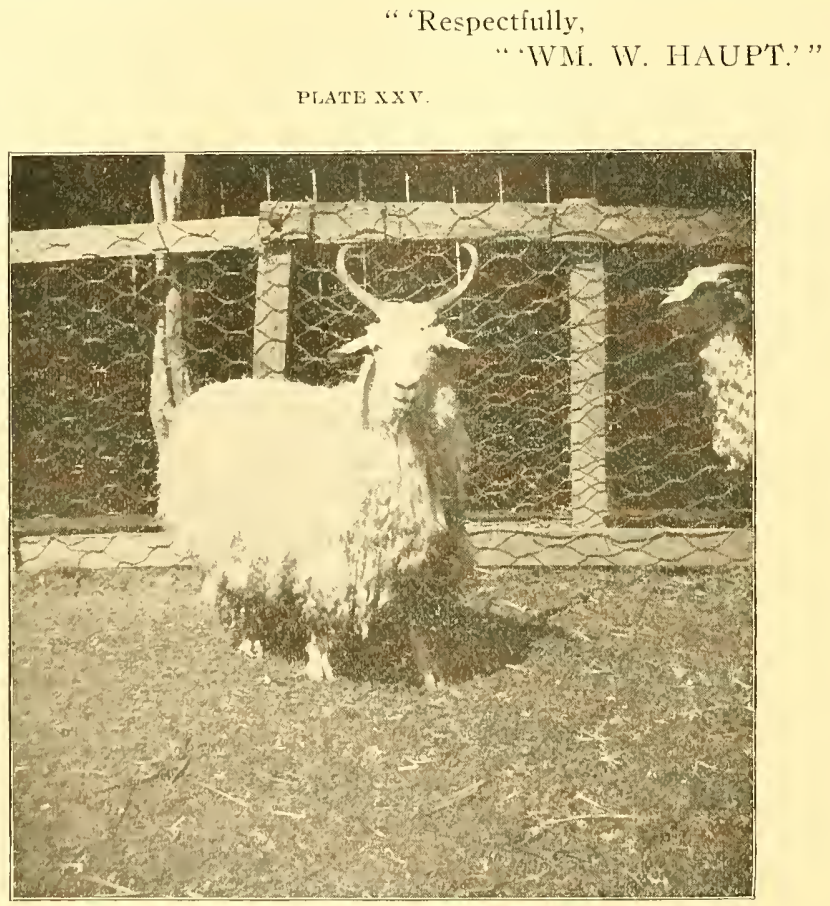

THOROUGHBRED ANGOFA BUCK.

Under two years old; bred and raised by $\mathrm{Mr}$. W. G. Hughe: Kendall Connty. Texas, ont of "Haup" brats. showing eroht mosths' fieece.

"P. S.-At one time I paid Col. Peters eight hundred dollars $(\$ 800)$ for seven nannies and a billy, but that was ten or fifteen years after I moved to this place. "W. W. H.",

Mr. W. R. McKee, Junction City, Kimble County, writes:

"My flock of goats was started from the Parish stock in 18:3\%.

"My does average five pounds and wethers seven pounds. Weight of carcass, 100 pounds for wethers and eighty-five for does. Have used bucks of the finest kind I could procure. 
"Many of my best does shear over six pounds and these I always select for my stud flock.

"My price for males has been $\$ 15.00$ to $\$ 25.00$

"Many of my goats hold their fleece very late in the spring, and I have some that do not shed at all.

Mr. Jeff. Pepper, Rock Springs, Edwards County, writes:

"My flock of goats was started from pure-bloodèd stock raised by W. D. Parish, of Texas.

PLATE XXVI.

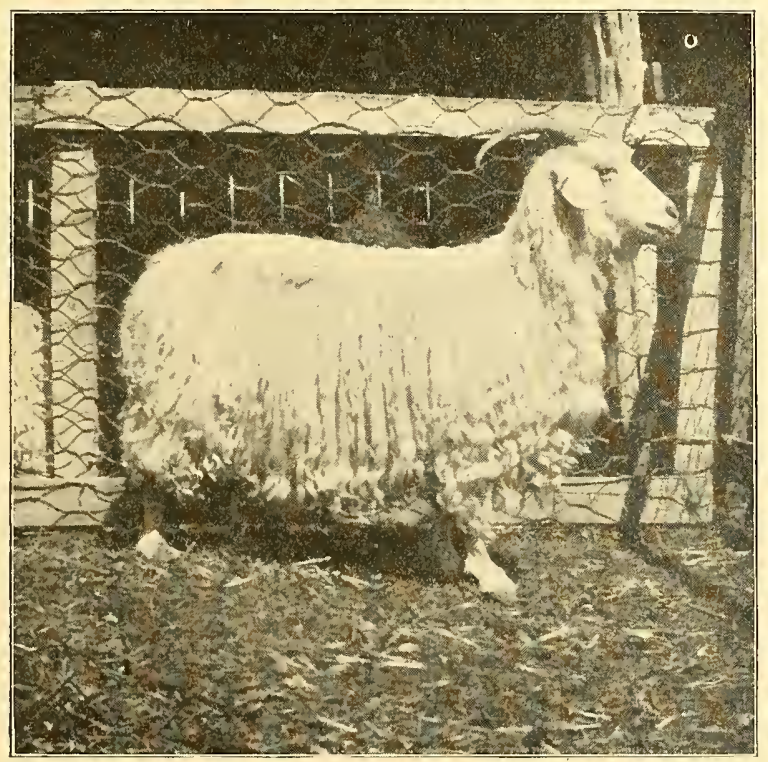

THOROUGHBRED THREE-YEAR-OLD DOE.

Bred and raised by $11 \mathrm{r}$. W. G. Hughes, Hastings, Kendall County, Texas, out of "Haupt" groats. showing eight nonths' fleece.

"The average of my flock is four and one-half pounds for does and six for wethers, but I have a number of does that shear as high as six, and over, which I always select for my stud flock.

"My goats weigh 100 pounds for wethers and eighty pounds for does. The staple of mohair is thirteen inches, very fine and curly.

"My price for bucks is $\$ 25.00$, and does $\$ 10.00$."

Mr. John Brown, Sonora, Sutton County, writes:

"My flock of goats, consisting of about three thousand head, was started about fifteen years ago from pure-bred bucks purchased from 
Col. W. W. Haupt; and, of late years, I liave been breeding some of my finest does for bucks which I have sold from $\$ 15.00$ to $\$ 25.00$, according to quality.

"The shearing of my entire flock will average three pounds for does and five for wethers, but I have many does that will shear as high as six pounds, and have had some kids that shear four and one-half pounds.

"The character of my mohair is fine in fibre and about twelve inches in length.

"I have always found ready sale for all the bucks that I have raised, and they appear to have given great satisfaction."

Mr. J. M. Arnold, Montell, Uvalde County, writes:

"Our flock of goats was founded on the W. D. Parish stock. I send you photographs of two bucks that were twenty-one months old, and had their second flcece about nine months, and sheared ten pounds and eleven pounds good mohair.

"We select only our heaviest shearing does to breed for bucks, which we have been selling at $\$ 25.00$ per head.

"The weight of our bucks range from eighty to ninety pounds, and does sixty to seventy pounds."

Mr. W. M. Landrum, Laguna, Texas, writes:

"My flock of pure-bred Angoras was originally started from the 'Peters' stock. My does shear from five pounds to eight pounds of pure mohair per head. I always make a selection of my finest and heaviest shearing does to breed for bucks, which generally shear eight pounds to ten pounds per head.

"The weight of my bucks vary from eighty pounds to 100 pounds; does from seventy, to eighty, pounds.

"My prices range for bucks from $\$ 40.00$ up to $\$ 300.00$; and for does from $\$ 50.00$ to $\$ 100.00$ per head."

Rev. D. S. Babb, Sonora, Sutton, County, Texas, writes:

"My flock of Angoras was started twenty-five years ago from goats that came from Col. Richard Peters, of Atlanta, Georgia, and I have used 'Landrum' bucks since, more or less.

"My does shear from three pounds to five pounds; wethers from four pounds to eight pounds; kids from two founds to four pounds.

"Weight of wethers 100 pounds; does seventy-five pounds.

"Mohair well covered over the chest, body and belly, measuring from twelve to cighteen inches.

"My price for bucks ranges from $\$ 10.00$ to $\$ 50.00$, according to individual qualities." 


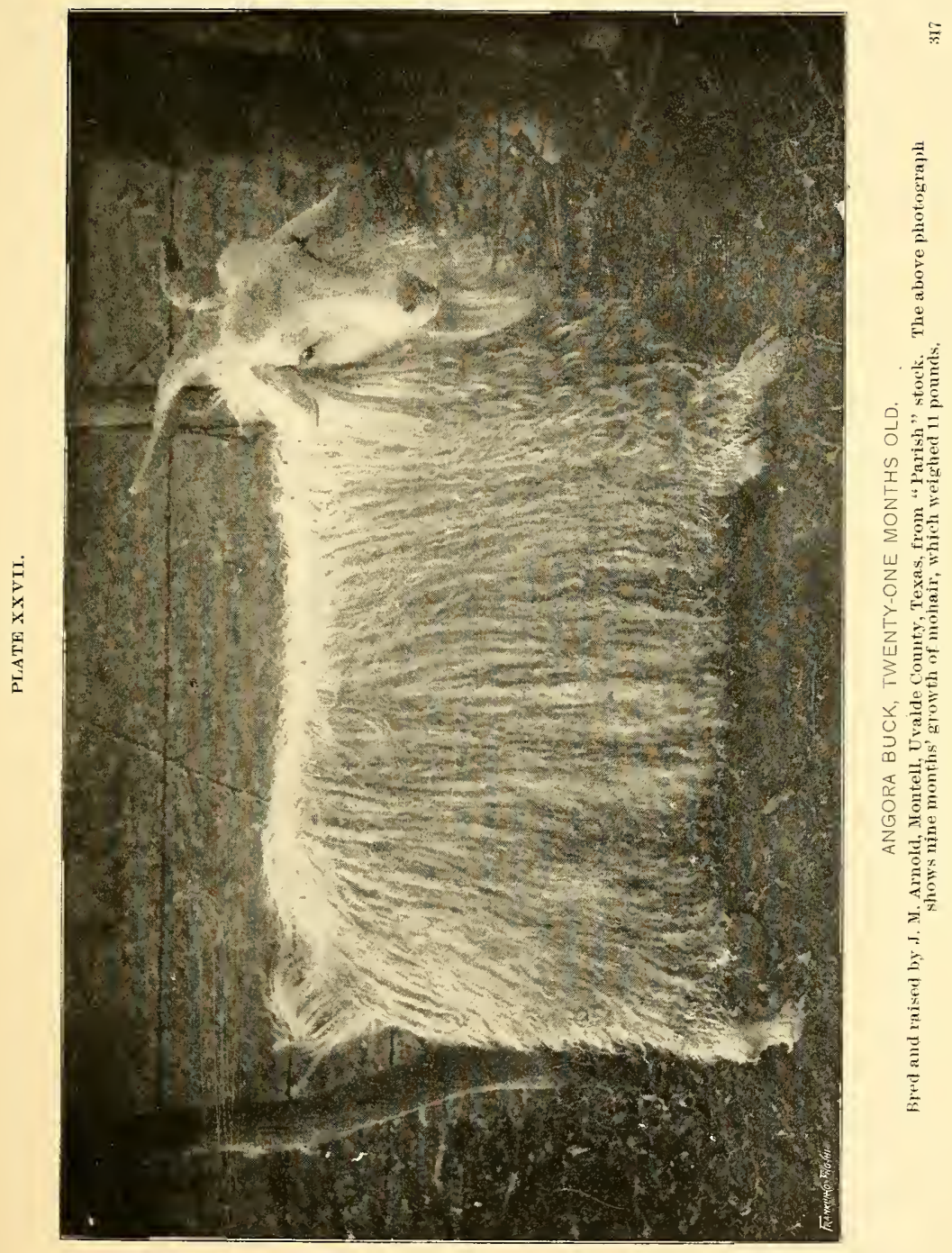



Mr. Henry Fink, Leon Springs, Texas, writes:

"Our flock of pure-bred goats originated from the W. D. Parish goats whose entire flock we purchased when he retired from the business nearly twenty years ago. We have made a practice of raising bucks for breeding purposes, and have been selling them at the rate of $\$ 20.00$ each; and breeding does, $\$ 15.00$.

"The shearing capacity of our bucks range generally between six and seven pounds, and the does three and one-half to four pounds. Staple of mohair eleven inches."

Mr. H. T. Fuchs, Tiger Mill, Texas, writes:

"My flock of goats was started in 1882 from pure-bred bucks purchased from Col. Robt. W. Scott, of Kentucky.

"I have bred them with great care for density of fleece, and fineness of fibre.

"My does shear five pounds and weigh fifty pounds gross. The staple of mohair hangs in long ringlets from ten to twelve inches.

"My prices have, heretofore, been $\$ 15.00$ to $\$ 25.00$ for bucks, according to quality."

Hon. Robt. H. Lowrey, Camp San Saba, Texas, writes:

"My goats were started from the 'Peters' stock in 1875, and I added some 'Parish' stock up to 1879 .

"I have made a practice of selecting my best does for breeang bucks, which I have always found sale for.

"My present prices range from $\$ 10.00$ to $\$ 15.00$ for does, and $\$ 15.00$ to $\$ 25.00$ for bucks.

"The staple of my mohair is twelve to fourteen inches. Weight of animal about sixty pounds net for males."

Mr. Robt. H. Wyatt, Sonora, Sutton County, writes:

"I purchased my first bucks from the Rev. D. S. Babb flock of goats, in this State, and have used great care in my selections ever since. Have always selected them from flocks well known for purity of blood.

"My does shear three and one-half pounds; wethers four and onehalf to eight pounds.

"Weight of my goats is about 100 pounds for wethers and seventyfive pounds for does.

"I sell bucks at $\$ 10.00$ to $\$ 25.00$, and does $\$ 5.00$ to $\$ 10.00$."

Mr. H. W. Galbraith, Monte11, Texas, writes:

“My first pure-bred bucks were of the 'Landrum' stock, and I have since used some 'Divine' and 'Harris \& Baylor' goats. 
"The average of my flock is four pounds for wethers, three pounds for does, and two pounds for kids, but I liave many individual goats that will shear much above these weights."

Messrs. Dougliten \& Luttrell, Lipa!1, Texas, writes :

"Our flock of goats was started in 1881.

"The average shearing capacity of the does is three pounds, but many will go much above this weight.

"The males weigh close to 100 pounds, and females about seventyfive pounds.

"The staple of mohair is fine and measures about twelve inches in length.

"We sell breeding bucks at $\$ 20.00$ and does $\$ 5.00 . "$

Mr. Tonı. S. Evans, Exile P. O.; Texas, writes:

"I purchased my full-blood goats from W. M. Landrum in 1885.

"My flock averages three pounds for does and four for wethers, but quite a good many will do much better.

"My staple of mohair is nine inches with a growth of six months.

"My does weigh eighty-five pounds.

"I have not made a practice of raising bucks for breeding purposes but can recommend W. M. Landrum stock."

Mr. D. G. Avery, Marathon, Texas, writes:

"My flock of goats was started by F. Garst from goats purchased from C. P. Bailey, of San Jose, Cal.

"The average of does is three and one-half pounds.

"Staple of mohair thirteen inches in length.

"Weight of animals 130 pounds for male and ninety pounds for female.

"My prices are $\$ 25.00$ for bucks and $\$ 5.00$ to $\$ 15.00$ for does."

Mr. J. W. Garrett, Mountain Home, Texas, writes:

"My flock was started from 'Fink' goats and I have since added to them a lot of 'Divine' goats.

"Have never paid very strict attention to breeding for bucks. I sell my choice bucks at $\$ 10.00$, and does at $\$ 5.00$.

Col. B. I. Crouch, Pearsail, Texas, writes:

"I am not engaged in breeding Angoras at the present time, but feel a very deep interest in the industry. I bred them with considerable satisfaction and profit from 1872 to 1833 ." 


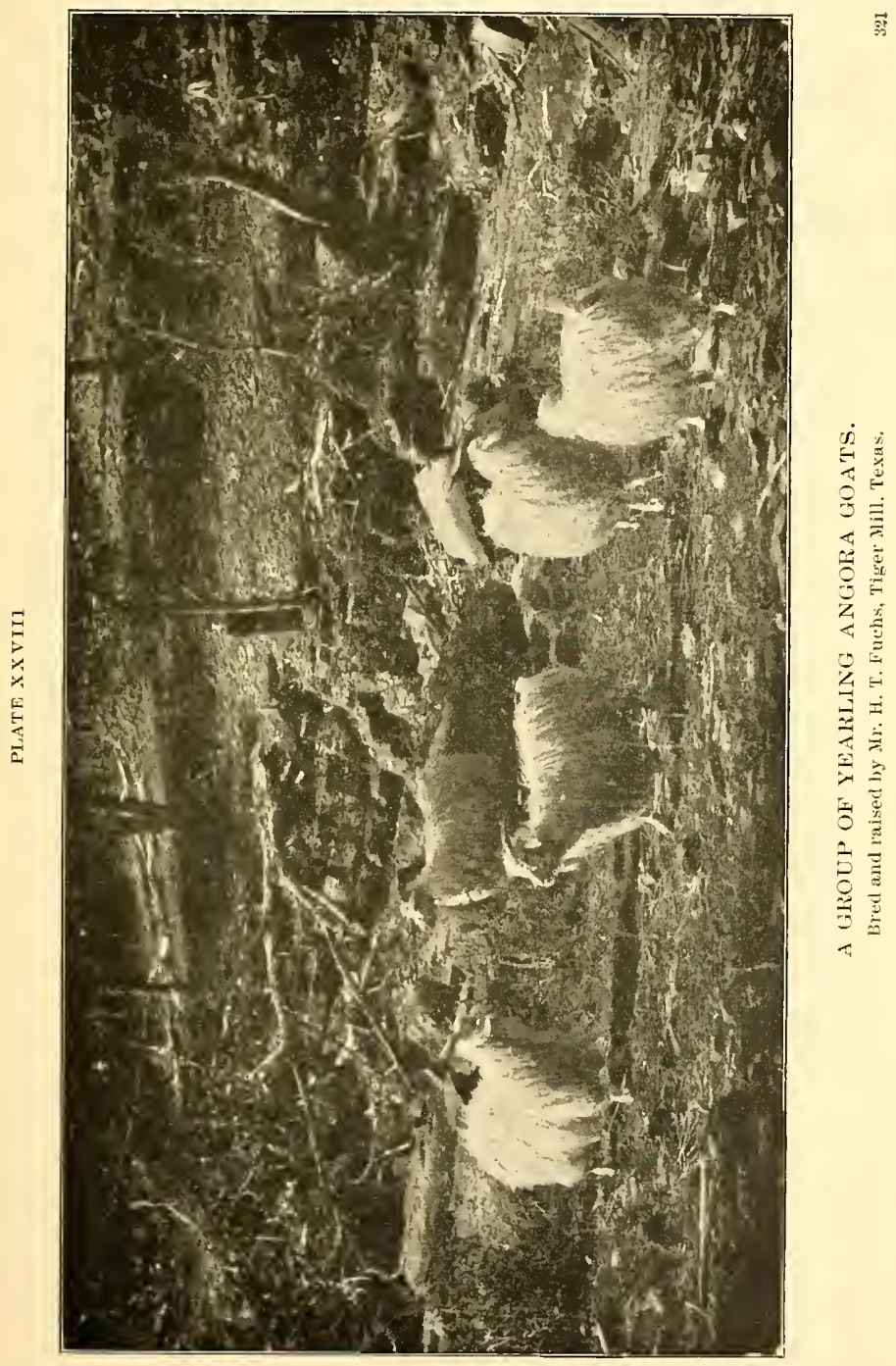



Col. W. W. Haupt, Kyle, Texas:

"I sold all my goats to Mr. W. G. Hughes, of Hastings P. O., Texas, in 1893."

Mr. O. Dowell, * Filorence, Oregon, writes:

"Ny goats weigh heavy-185 pouncis for bucks, and 145 pounds for does, gross.

"The does shear between two and one-half and three pounds, and wethers five pounds, of eleven and one-half inch mohair.

"I do not raise bucks for sale, but can recommend Geo. A. Houck, of Eugene, and Oscar Tom, Angora, "Oregon."

Mr. T. H. Hawley, Monmouth, Oregon, writes:

"Our goats shear four pounds for does and seven pounds for wethers. but many will go above this.

"We sell bucks at $\$ 10.00$ and does $\$ 5.00 . "$

Mr. W. D. Claggett, Salem, Oregon, writes:

"My flock of goats was started with bucks from the 'Eutichides" importation in 1867.

"Ny does shear from four to six pounds and have a staple twelve to fourteen inches in length.

"I have been selling breeding bucks at $\$ 25.00$. My goats are exceedingly fine wooled, but are not large in frame."

Mr. N. Woodward, Dallas, Polk Connty, Oregon, writes:

" $\mathrm{My}$ docs range from three pounds to six pounds of mohair, twelve inches long.

"I sell breeding bucks from $\$ 10.00$ to $\$ 25.00$, and does at $\$ 5.00$ to $\$ 10.00$, according to quality.",

Mr. Scott Obye, North Yamhill, Oregon, writes :

"My flock of Angora goats averages four and three-fourths pounds for does, and five and three-fourths pounds for wethers, but I have many does that shear as high as seven and seven and one-half, and have had one go as high as eight pounds. The staple of my mohair measures fourteen and one-half inches in length.

"I have been selling bucks for breeding purposes at $\$ 20.00$ to $\$ 25.00$, and does $\$ 10.00$ to $\$ 15.00$, according to quality."

*Mr. O. Dowell is the President of the "Coast Mohair Association." Florence, Oregon, of which Frank H. Rodgers, Gardner, Oregon, is Secretary. 
Mr. James McDonald, Morrison, Oregon, writes:

"My flock was started in 1883.

"My does shear, now, an average of five pounds. I have been breeding for bucks and sell at $\$ 10.00$ per head for both bucks and does.

"My bucks shear from seven to nine and one-half pounds, of twelve inch mohair, and have had some go as high as thirteen inches."

Mr. Oscar Tom, Angora, Oregon, writes:

"I have been raising my goats chiefiy for breeding bucks, which I have been selling at $\$ 10.00$, and my culled does at $\$ 5.00$.

"My does shear four pounds each of mohair, eight to twelve inches in length."

Mr. D. A. Walker, Carlton, Oregon, writes:

"I started with old Spanish goats twenty-seven years ago. My does now shear very near five pounds (4 14-15 pounds), of twelve inch mohair.

"I have only got 125 head, as I have made a practice of culling out every year, picking out the oldest and poorest shearers.

"I do not sell my best goats, but can refer buyers of breeding bucks to A. Blackburn, North Yamhill."

Mr. _ Masters, Cleveland Oregon, says:

"My flock of goats was started by my father, the Rev. C. B. Masters, now of Coos County. He was an old breeder, and bred them with great care until he became too old to give them the proper attention, when he sold them to me.

"They were originally started from the IV. M. Landrum goats, of California, in 1872.

"My does shear from three pounds to seven pounds, and wethers from five to eight pounds; staple of mohair nine to eleven inches.

"I have only paid a little attention to breeding for bucks, and have sold at $\$ 10.00$ to $\$ 25.90$ for bucks, and $\$ .5 .00$ to $\$ 15.00$ for does, according to quality."

Mr. A. Blackburn, North Yanhill, Oregon, writes:

"My flock of goats was started from goats purchased from D. C. Stewart \& Son, who got their start from 'Landrum.'

"My flock shears four pounds for does, and six pounds for wethers, but I have many that will go much over this.

"My staple is eleven inches in length. 


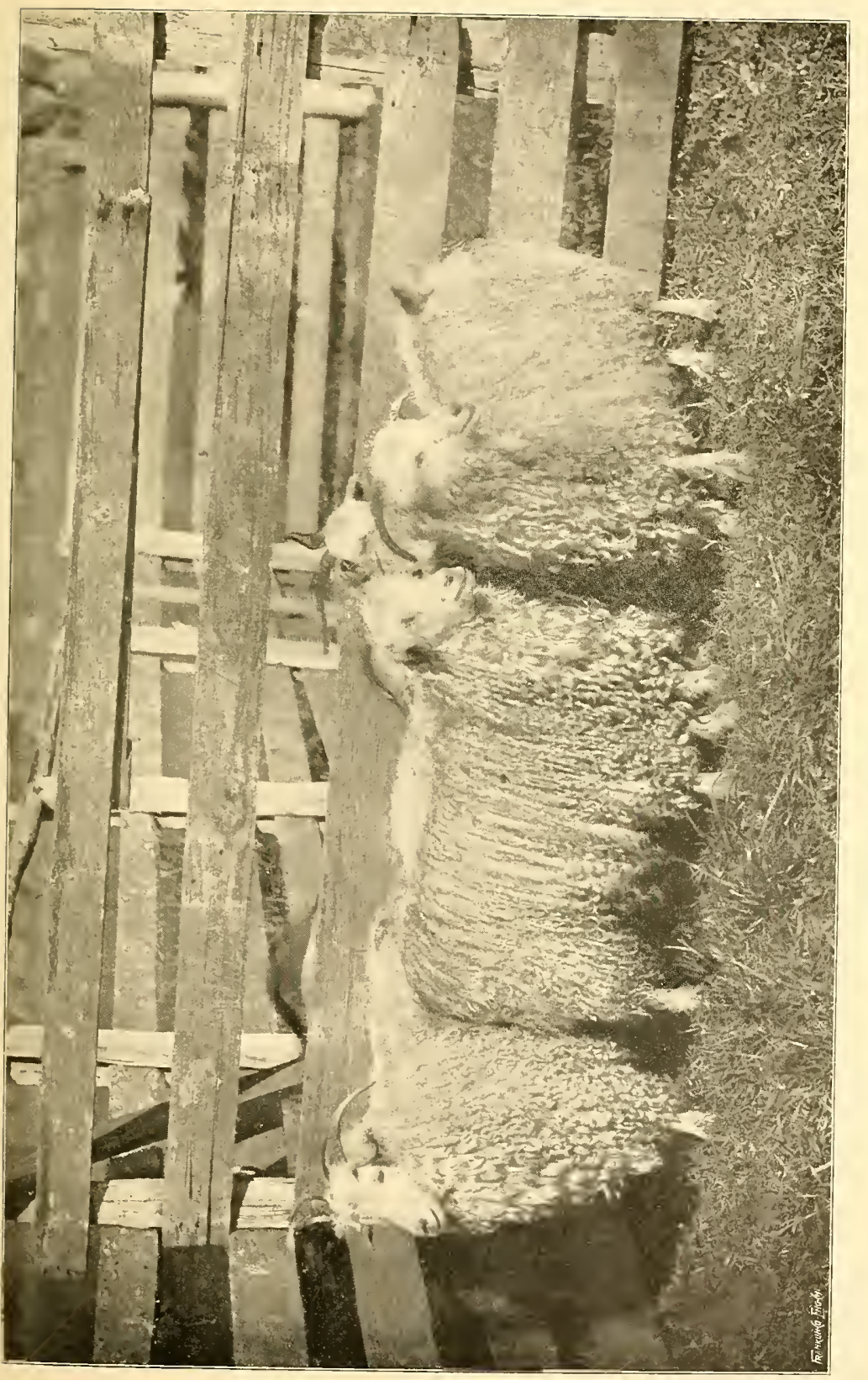

认̂

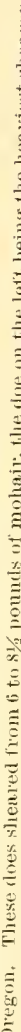

E

0
0 

"I have been breeding for bucks, which I scll at $\$ 10.00$ up to $\$ 25.00$. according to quality. My does I do not sell.

"I recently purchased a buck from W. G. Hughes \& Co., of your State, which is a good goat."

\section{Mr. J. M. Hassler, Larwood, Oregon writes:}

"My does shear from three to four pounds of mohair, eight to twelve inches in length. I have raised some breeding bucks, which sheared from seven to nine pounds, and have sold all the way from $\$ 8.00$ to $\$ 25.00$, according to quality. I will give you a statement of my experience with fifty head of goats purchased in April, 1895, for $\$ 87.50$ :

1895. Sold, mohair, $\$ 31.40$; and goats, $\$ 35.00 \ldots \ldots \ldots \ldots \ldots \ldots 640$

1896. Sold, mohair, $\$ 60.35$; goats, $\$ 2.2 .75 \ldots \ldots \ldots \ldots \ldots \ldots . \ldots 310$

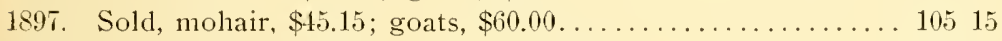

1898. Sold, mohair, $\$ 83.70$; goats, $\$ 23.00 \ldots \ldots \ldots \ldots \ldots \ldots \ldots 10670$

1899. Sold, mohair, $\$ 93.60$; goats, $\$ 209.50 \ldots \ldots \ldots \ldots \ldots \ldots 30 . \ldots \ldots$

And I have on hand still 78 head.

$\$ 66447$

Mr. Geo. A. Houck, Eugene, Oregon, writes:

The flock of goats which I now own was started originally by $\mathrm{Mr}$. Ari Cantrell between 1860 and 1870 , who was the pioneer goat breeder in this State.

Mr. Cantrell purchased about 150 head of three-fourths to seveneighths grades from Landrum \& Butterfield at $\$ 12.50$, and paid $\$ 1500$ for a pure blooded buck and one yearling doe. He afterwards purchased pure bred bucks from Landrum \& Rogers of California. He bred for fine silky fibre and his best goats became very small in consequence,-as well as very tender and delicate in constitution.

My father purchased his entire flock in 1885, and put with them two bucks purchased from C. P. Bailey. Mr. Cantrell showed me three does he said were direct descendants from his full blood doe that, he purchased originally, and from the offspring of these, bred from a "Bailey" buck, I secured a buck that sheared ten and a half pounds.

"I never saw a better breeder than he was, and one of his kids sheared as high as eleven and one-fourth pounds last spring. I have never offered to sell any goats for breeding purposes until 1897 and have sold since then at $\$ 15.00$ to $\$ 25.00$ according to quality.

"I keep a register of their breeding. I am breeding for carcass, constitiution and weight of fleece. My flock consists of about 1500 head." 


\section{CALIFORNIA. Philo Ogden, Upper Lake, Cal. :}

"I started my flock of goats with full-blood bucks from C. P. Bailey of San Jose California.

"My does average five pounds and wethers seven. My mohair measures thirteen inches in length. My wethers weigh 100 pounds and does eighty pounds. I have never made a practice of raising any bucks for sale, but intend doing so in the future."

\section{Mr. James H. Dunison, Upper Lake, Cal., writes:}

"My does average four pounds and wethers five pounds. The whole flock will average three and a half, taking in the kids. The staple of my mohair is thirteen inches long. I have not made a business of raising breeding bucks, but can recommend W. W. Green of this county."

Messrs. Conklin Bros., Newvilie, Cal., writes :

"Our flock of thoroughbred goats was started with three does and one buck imported from Turkey by $\mathrm{Mr}$. Eutichides, in 1870 by Mr. Julius Weyand (deceased) who purchased them from Dr. Cummings, and they afterwards passed into our possession, and have been kept absolutely free from any crossing with common goats ever since.

"Mr. Weyand was a highly educated man, and was very systematic in all his work; and his register was kept up with great care and exactness, which we have continued upon the same system as he inaugurated, therefore we claim our flock of 'thoroughbreds' are thoroughbred indeed.

"We bred one buck that sheared nine pounds in the fall, and three pounds and three ounces in the spring, making twelve pounds and three ounces for the twelve months' growth. This is the heaviest goat we ever sheared. From six to nine pounds is about the average weight of our bucks, more of them the heavier than the lighter weight. Our rec. ord of breeding is so systematic that we can select and tell exactly how each goat is bred, by its number.

"We have a large flock that we keep no record of that appear to be as fine as our thoroughbreds. We have made a business of selling bucks for breeding purposes at from $\$ 35$ to $\$ 50$. The staple of our mohair is thirteen inches in length. Weight of males 165 and females 120. We think our thoroughbred flock has no superior in the State."

Mr. Jas. Wilder, Paskenta, Cal., writes :

"I have been in the goat business eleven years on a small scale. I never had over 450 head on my place at one time. I would refer you to Mr. Wm. Harland of Williams Station; Conklin Brothers and C. W. Foreman, both of Newville, Glen County, and John Hull, Croamville, Glen County, who are all breeders of Angora goats." 


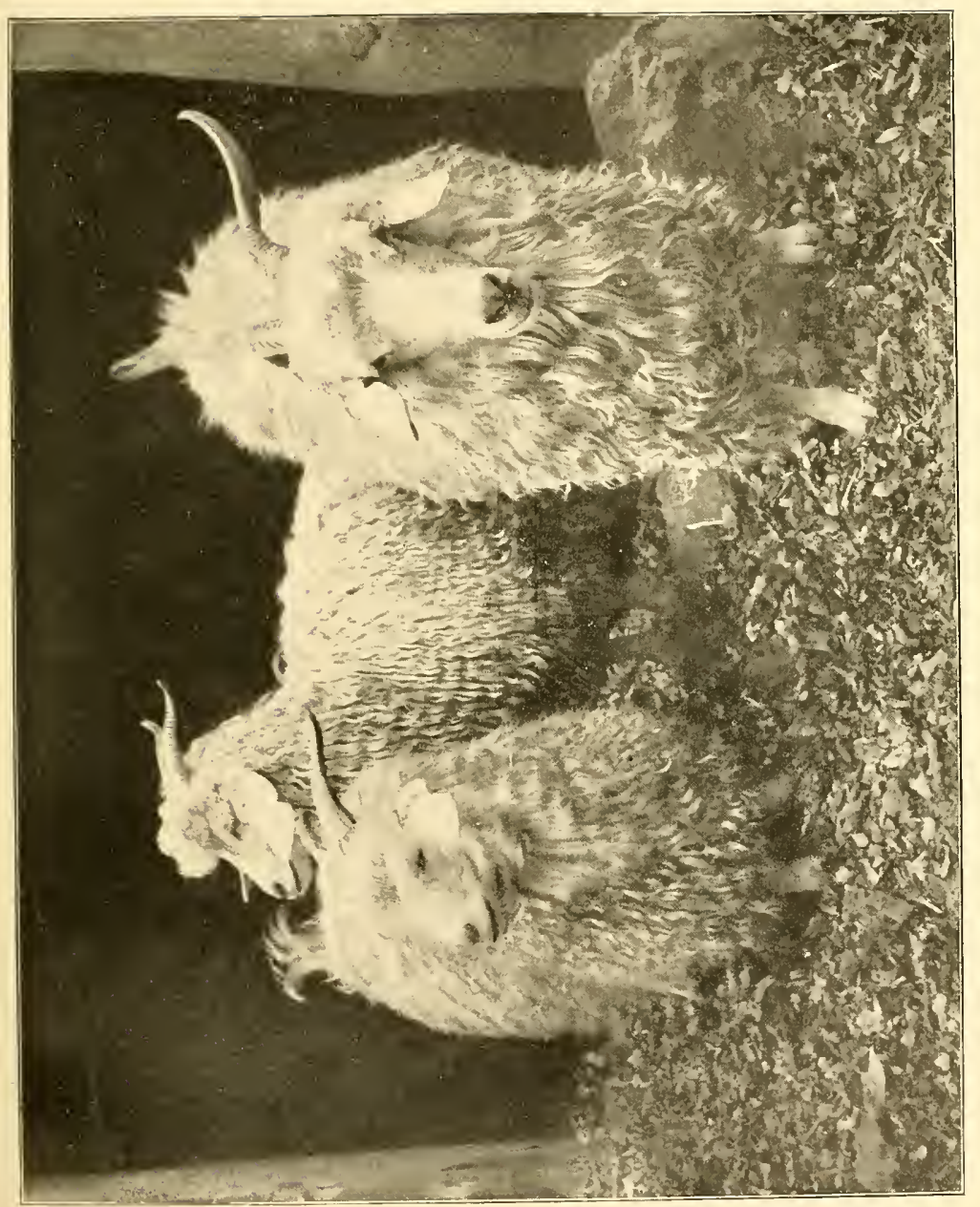

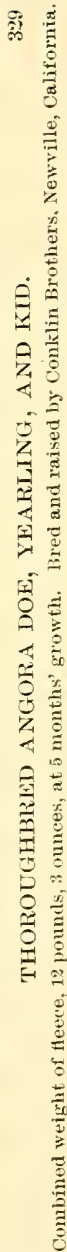



Mr. A. Moon, Ono, Snasta County, Cal., writes:

"My flock was started with pure bred bucks purchased from Conklin Brothers of Newville, in 1895.

"Ny does average between three and four pounds mohair, six tc eight inches long at six months clip. I do not raise bucks for breeding purposes, but can recommend Conklin Brothers."

Mr. Jacob Oaks, Paskenta, Cal., writes:

"I purchased my first breeding bucks from Conkin Brothers in 189:- and can recommend them. I am a general farmer and I do not raise goats especially for breeding purposes. My does average three pounds and wethers five pounds of twelve inch mohair.

Mr. E. L. Maze, Upper Lake, Cal., writes:

"My flock of Angoras average four pounds for the does and six pounds for wethers, but many individual goats will shear above this average. The weight of our wether goats is 100 ponds a $d$ does seventyfive pounds.

"We breed and sell breeding bucks at $\$ 50.00$ and does at $\$ 20.00$.

Mr. J. M. Wimmer, Nillville, Cal., writes:

"My band of goats was started with bucks bought from J. S. Harris, now of Oakley, Idaho.

"I started in 1878 with 120 head of doe kids, about three-fourths grades, and have been breeding to the best bucks I could get. I have wethers, in the band that will shear eight and nine pounds and does that will shear five and six, and kids that will shear four; but three pounds is about what the whole band will average.

"I have not made a practice of breeding bucks for sale."

Mr. C. P. Bailey, San Jose. Cal., writes:

"My first pure-blood bucks came from the 'Chenery' importation to Boston, Massachusetts. My band averages four pounds for does, five and a half for wethers and two for kids, but I have many individual goats that will shear much heavier. My mohair ranges from eight to ten inches. I have made importations of breeding bucks from South Africa."

"The following is an extract from the Associated Press cables, with reference to a sample of mohair grown by me, which I sent to Bradford, England, for examination:

"A stir has been caused in England by a mohair fleece grown in California, and it is stated that if fleeces of the same uniform quality can 
be grown there the triumph of the United States as a mohair producer is assured. The American grown mohair fleece which has been exhibited for the past week was forwarded by C. P. Bailey of San Jose, Cal. The fleece is that of a two-year-old graded doe and the quality of the hair has been the wonder of all who have seen it."

"One of the leading merchants, in commenting on it, said:

"I have now in my warehouse about two hundred thousand dollars worth of mohair both Turkish and Cape, and I am entirely sincere when I state that there is not a better fleece in the whole lot. I will buy all the American mohair like that at the market price and I do not know but that I would pay more than the market price. I say unhesitatingly that the sample fleece is as good mohair as is grown."

Mr. R. J. Linton, Ager, Cal., writes:

"I breed largely for breeding purposes and sell bucks at $\$ 50$ and does $\$ 50$. I keep up a register of my pure-bred flock."

"My band of goats was started in 1883. My present shearing is three and a half pounds for does, four and a half for wethers and two and a half for kids. Staple of mohair six inches in length. I sell my best shearing bucks at $\$ 25$ and does $\$ 15 . "$

Mr. E. Weistrand, Cooney, N. M., writes :

".The average shearing of my Angoras is as follows: Does, three to five pounds; wethers, five to seven pounds; kids, two and a half to four pounds.

"I do not make a practice of breeding bucks for sale. I purchased four bucks from J. S. Harris of Oakley, Idaho in 1897, and they are the best I have seen in New Mexico."

Mr. J. C. Hightower, Rindosa, N. M., writes:

"My Angora goats average four pounds for does, six pounds for wethers and two pounds for kids. Staple of mohair eleven inches.

"My price for bucks is $\$ 10.00$ and does the same. My bucks shear about seven pounds."

Mr. D. C. Taylor, Lake Valley, N: M., writes:

"I commenced the goat business thirteen years ago. I was dead broke and bought ninety-nine Mexican does on time at $\$ 1.50$ each. My first bucks came from J. M. Arnold, of Texas. I have since used ' $\mathrm{C}$. P. Bailey' bucks and have used one 'Landrum' buck. I now have about 2600 goats (1100 does and 1500 wethers and bucks). They are all extra good. I have not a doe that will shear less than three and a half pounds up to six and a half pounds, and wethers from four to seven. My bucks sheared last spring ten pounds each. 


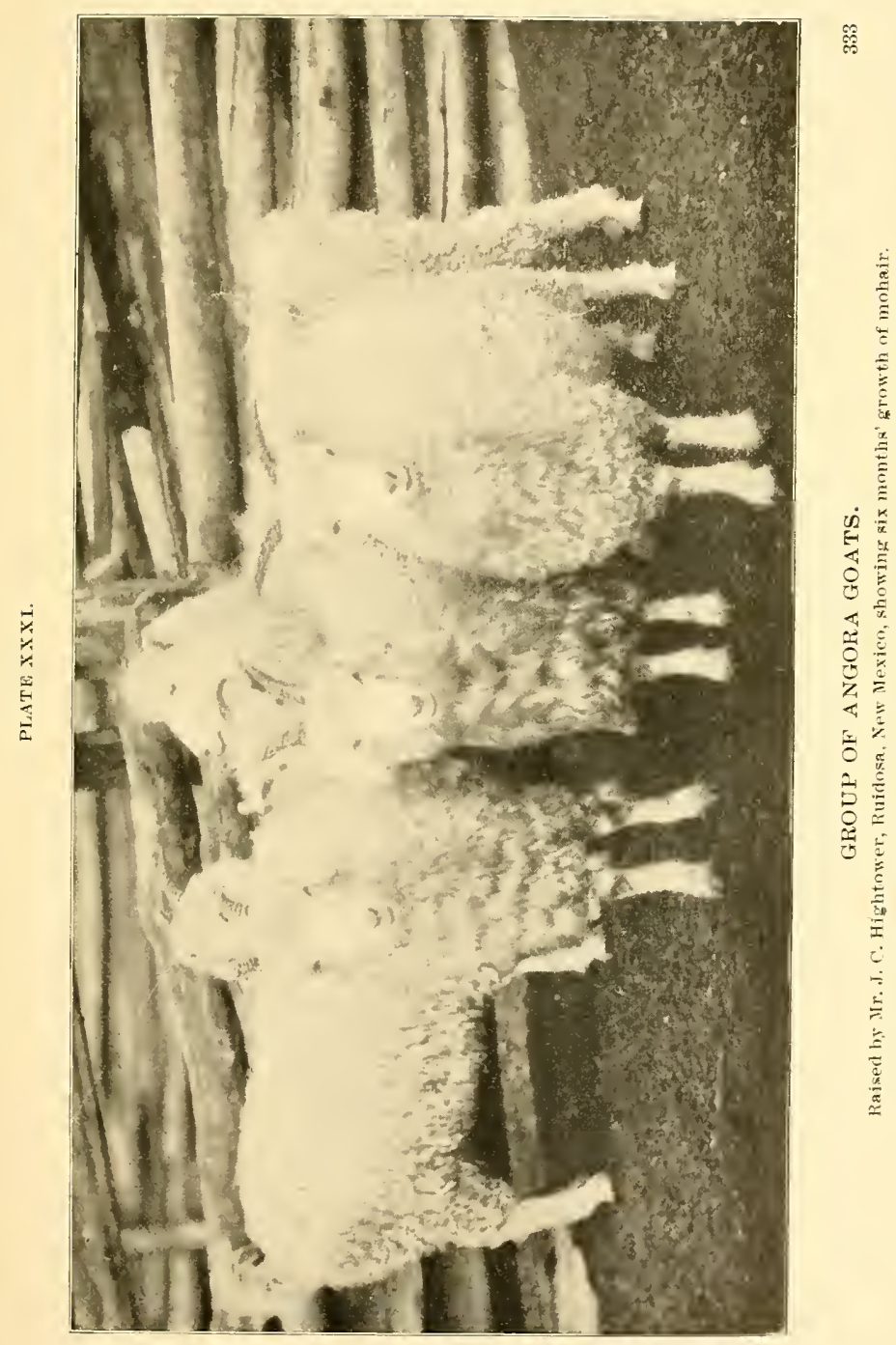



"I sell bucks at $\$ 25$ each with mohair (not dog hair) all around their eyes and face and down to the hoofs, that I think will make eleven pounds, bucks at two years old. I sold twenty-two bucks last fall.

"My bucks have five or six inch mohair now (July) and about eight months more time to grow before shearing. A very few of my goats shed any which I think is a big thing.

"I think the possibilities of the Angora goat are as great as the sheep and you know what the Americans did with the old 'Spanish merino.' I am trying to get on top. Have nothing else to do, and do not need any money."

PLATE XXXII.

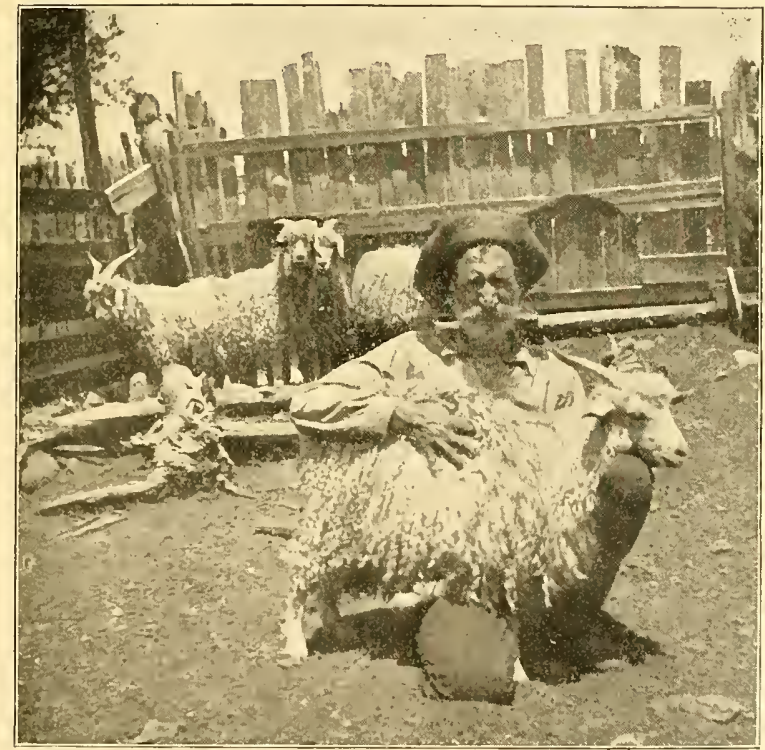

YEARLING ANGORA BCCK.

Raised l, Mr. D. C. Taylor, Lake Valley, New Mexico, showing seven months' growth of mohair.

\section{A. D. Norcop, Sepan, N. M. :}

"My first bucks came from C. P. Bailey. My does shear an average of three and a half pounds, wethers five and a half, and kids two pounds. Mohair eleven inches. My wethers weigh 120 pounds. I have not yet sold any of my best goats."

The Onderdonk Live Stock Company, Lamy, N. M., write: 
"We have on hand at the present time 8000 head of Mexican goats and about 1800 Angoras. Have only started with Angoras this year (1900) and have none for sale as yet."

\section{Dr. J. R. Standley, Platteville, Iowa, writes:}

"I became interested in the Angora go t industry in 1893. My first buck came from the Col. Scott flock of Kentucky, and I have since purchased the entire flock of 'Peters' goats from the estate of the late Col. Richard Peters of Atlanta, Georgia.

"The weight of my wethers is about 100 pounds and for does eighty pounds. Mohair measures thirteen and a half inches, well distributed over the body, chest and belly. I send a photograph of some of the does. My price for bucks ranges from $\$ 40.00 \mathrm{up}$, and from $\$ 15$ up for does, according to individual merit."

Mr. S. S. McKibben, Earlham, Madison, Connty, Iowa, writes :

"My first introduction into the Angora goat business was in 1895 . through Dr. J. R. Standley of this State. I have since handled goats largely and have sold upwards of five thousand head, principally does, which I have received altogether from Texas. I am now breedng a flock of about one hundred very choice does to my hornless buck 'Admiral Dewey,' which I regard the finest type of Angora goat in the United States, combining both mohair and mutton qualities to perfection. I have not yet sold any of my buck kids from 'Dewey,' only having about four, but will be prepared to supply them from my present (May 1900) crop of kids which I shall dispose of at $\$ 50$ to $\$ 100.00$ according to individual merits. I send you a photograph of 'Dewey' with two of his kids taken in September."

Mr. J. C. Morton, Indianola, Iowa, writes:

"I became interested in the Angora goat in 1898, purchasing some very choice does from Texas, which show an average oi three pounds sach. I got them for the purpose of clearing brush land which I have accomplished, and have concluded to keep them for breeding. Have been selling bucks from $\$ 10.00$ up according to quality."

Messrs. Morgan \& Morgan, Clay, lowa, write:

"We started with the Angora goat in 1897 from goats purchased of Dr. J. R. Standley of Platteville, Iowa. The does shear three to four pounds and produce a very fine mohair fourteen inches in length. Have been selling our bucks at $\$ 15.00 \mathrm{up}$; and does, $\$ 10.00 \mathrm{up}$, according to merit." 


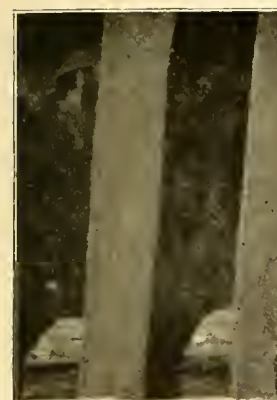

1)

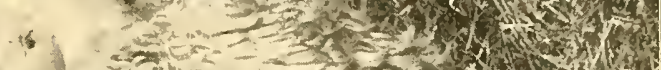

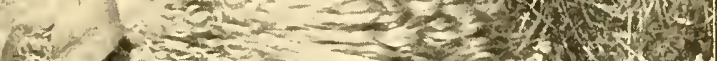

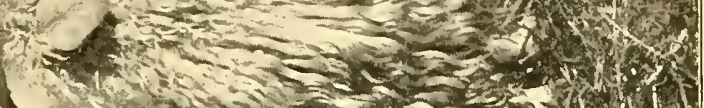

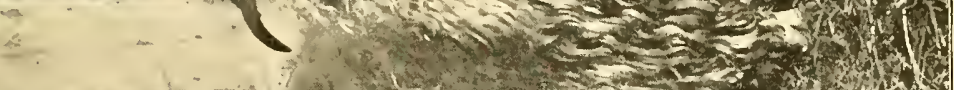

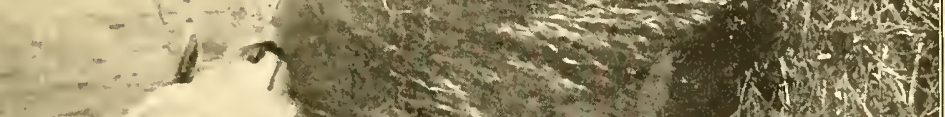

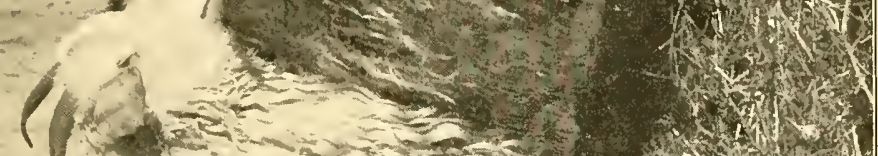

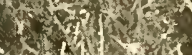

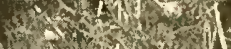
sticosis $+$ $=$ 1 .

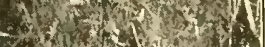
Ant $2 x^{2}$

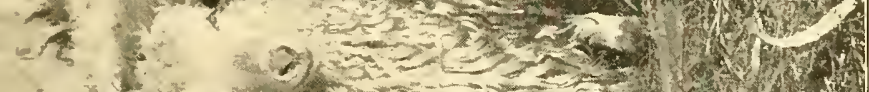

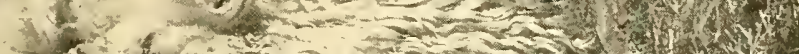

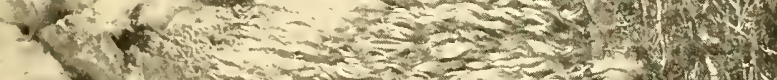

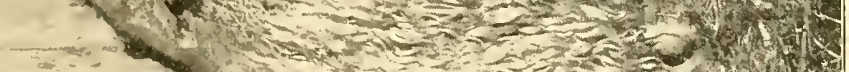

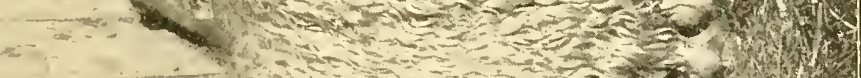

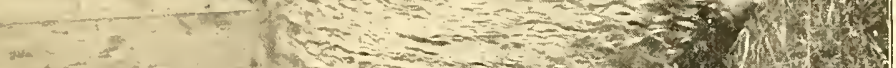

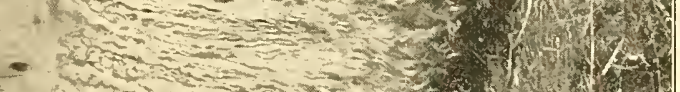

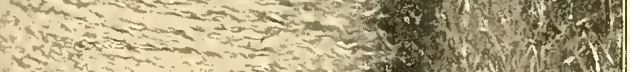

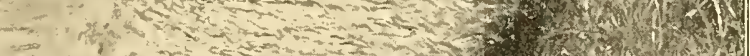
(1) (1)

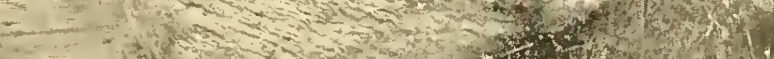
(S)

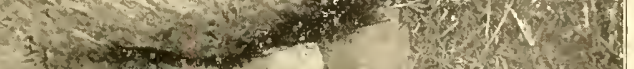

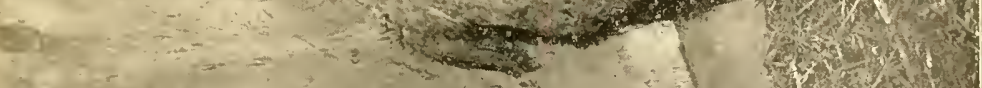
5.9. 

Mr. J. R. Barnette, Globe, Ariz., writes:

"I purchased my first pure-bred bucks from Wm. M. Landrum of Laguna, Texas, in 1898. My does shear two and a half to three pounds, wethers four to four and a half pounds. Mohair twelve inches. Have not made a practice of selling bucks for breeding purposes yet. $\mathrm{Iy}_{\mathrm{y}}$ price for high grade does is $\$ 1$ to $\$ 5$ each.."

Mr. Mrm. Horn, Camp Verde, Ariz., writes:

"I do not breed any goats for breeding purposes. My flock consists of grades shearing one and a half to two pounds for does, and two to two and a half pounds for wethers. Eight inch staple.

"Have been asking $\$ 3$ to $\$ 1$ per head for my goats."

Mr. Ira Harper, Clifton, Ariz., writes

"I only have 190 head at present (September, 1899). Have sold and killed fifty head wethers that netted me $\$ 2.50$ for the meat. I generally sel my wethers at eighteen months old and some at twelve months.

"My entire flock averages two and a half pounds mohair measuring six inches long."

Mr. J. F. Holder, Payson, Ariz., writes:

"I purchased my first bucks from C. P. Bailey of San Jose. Cal.

"My flock shears three pounds for does, four pounds for wethers. Mohaiv from nine to twelve inches.

"Have been selling bucks to my neighbors at $\$ 15.90$ each."

Mr. T. Clome Miles, Silver Bend, Mont., writes:

"My first bucks came from Sargent Brothers, Colorado. My flock shearsthree and a half pounds for does and five pounds for wethers, with a staple of nine inch mohair.

"Ny price for best breeding bucks is $\$ .50 .00$ and does $\$ 20.00 . "$

Mr. S. S. Brannin, Marysville, Mont., writes:

"My Angora goats shear for does three pounds and wethers four and a half pounds. I have never made a practice of breeding bucks for sale. My price for breeding does is $\$ 5.00$ per head."

Mr. J. S. Harris, Oakley, writes:

"I have divided my flock of goats into three parts in order to be able to supply breeders with bucks more easily than from this point, which is very inaccessible. One of my subdivisions is located at Salem, Oregos, in company with Mr. J. B. Early; another is at Montell, Uvalde County, Texas, in company with Mr. Geo. IV. Baylor; and, the third, I have kept here. 
"They are all practically the same kind of stock, as I have had only the one strain of blood for many years, which I selected myself in Asia Ninor in 1875. I claim to have as pure-bred goats as can be found in the world.

"For a number of years after my return from Asia there was very little general interest taken in the Angora goat industry in this country: and for that reason I did not save many more bucks than I wanted tc use in my own flock. I made wethers out of my males, and depended entirely on the proceeds from mohair for the profit in handling them which has been very satisfactory. The recent revival in the demand for breeding stock has encouraged me to save all my male kids; and being situated so far from the center of trade I have divided my flock as above stated. I have raised one buck that sheared as high as eighteen and a half pounds of mohair in twelve months in two searings, and fifteen pounds at one shearing. I would give a thousand dollars to have another like him raised in Asia Minor."

Dr. Tuttle, Tacoma, Wash., writes:

"I received my first goats from Mr. McCorkle of Oregon. I have only a limited unmber, and have sold my bucks for $\$ 25.00$ for breeding purposes. My does shear six pounds of thirteen inch mohair, bucks eight pounds."

Mr. Clıris Niellson, Burlington, Wyo., writes:

"My first buck came from Bailey of California, through Mr. Bromley of Utah. The flock consists of about 1500 head (August, 1899) and shears four pounds for does, six pounds for wethers, of twelve inch molhair. I have been selling breeding bucks at $\$ 50.00$ and does at $\$ 8.00 . "$

Mr. Jos R. Hamblin, Kanab, Utah, writes:

"I began breeding the Angora goat in 1897. My does shear two and a half pounds and over, wethers three and a fourth and over. My finest moliair is fifteen inches, some of it only twelve inches.

"I do not raise any bucks for sale."

Mr. R. C. Johnston, Lawrence, Kansas, writes:

"I have only been interested in Angera goats about one year. Was attracted to them by their great utility as brush exterminators, and have imported and sold no less than five thousand head from Texas, which have been distributed mainly in Kansas, and some in Missouri.

"I have decided to make the Angora goat a prominent feature in my farming interests in the future, as I regard them as being one of the most valuable species of live stock that I can raise. I purchased from Gunzer Brothers, Texas, their entire flock of goats only a month or two 


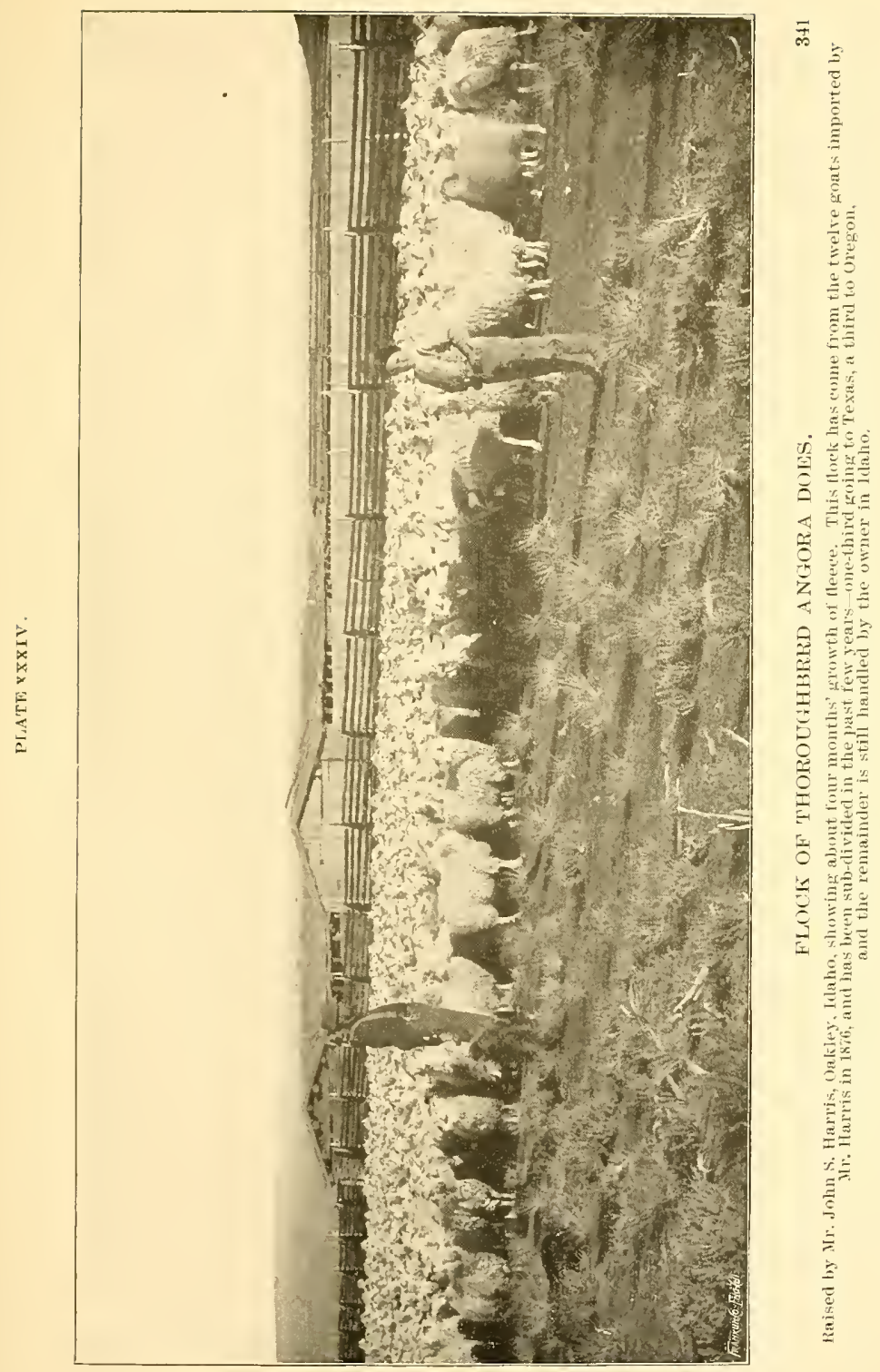



ago, which consists of about 500 head of very beautiful goats shearing fully an average of three and a half pounds of fine mohair twelve inches long, in Texas, which will probably make them five pound shearers in this climate. Many of the does will shear upwards of five and six pounds at this time, which I shall select and use for a stud flock and expect to sell my bucks at $\$ 25.00$ and upwards, according to shearing qualities. The does I do not care to sell yet.

"The 'Gunzer' flock originated from the 'Devine' goats, which came out of the 'Peters' stock, and they out of the 'Davis' goats, originally imported from Asia Minor."

Mr. Wm. I. Seever, Secretary "Missouri Historical Socie1s," St. Louis, Mo., writes:

"I purchased my first Angora goats from Dr. J. R. Standley of Iowa, in 1898. I have only a small number of them on hand and have none for sale at present. I know that the following farmers have some, but as to their price, or disposition to sell, I am not familiar:

“A. A. Glassey, Cuba, No.

"Sligo Furnace Co., Sligo, Mo.

"H. M. Ruime, Pacific, Mo.

"John L. Hooker, Clementine, Mo.

"Charles T. Moore, Nashville, Ill.

"George Dressendorfer. Macedonia, Mo.

“C. M. Buck, Union, Mo.

"B. S. Knapp, Rolla, Mo.

“G. Pauls, Eureka, Mo.

“.T. L. Chamberlain, Rolla, Mo.

"Wv1n. C. Dickinson, Rolla, Mo.

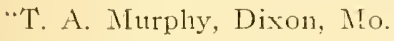

"John Regsby, Newton, Phelps County. Mo.

"Charles Ruepple, Stanton, Mo.

"Henry Frauz, Rolla, Mo.

"J. H. Canada, Mexico, Mo."

Mr. A. Lippincutt, Sheridan, Mo., writes:

"I first became interested in Angorá goâs in 1898 through Dr. J. R. Standley of Iowa. My does shear five pounds of mohair, eight inches long. I have been selling bucks at $\$ 10$ to $\$ 1$ j and does $\$ 6$ to $\$ 10$."

Mr. I. K. Young, Woodward, O. T., writes:

"I purchased my first Angora goats in 189. from Francis Garst. Iy does shear three pounds and wethers five pounds, mohair measures thirteen inches. Weight of wethers 100 pounds and does serenty-five pounds. My price for breeding bucks is $\$ 25.00$ and does $\$ 15.00$ per head." 
Mr. O. D. Hill, Kendalia, West Va., writes:

"I commenced handling the Angora goat in 189?, which were perhaps the first that were taken into West Virginia.

"My does shear about three pounds and wethers as high as six to eight pounds. Mohair is very long and ranges about eighteen inches. My price for breeding bucks has been $\$ 25.00$ per head, and "breeding does the same."

Estate of James A. Bell, Bell Hill, Conn.:

"Mr. Kansas N. Bill, the executor of his father's estate. writes that they became interested in the Angora goat upwards of twenty years ago, through Mr. Terrell of Cheshire, who obtained them from Col. Richard Peters of Atlanta, Georgia.

"Have always had a sale for them at $\$ 18$ to $\$ 25$ per pair.

"He mentions the following other persons who are raising the Angora in Connecticut:

"Mr. James B. Palner, Lisbon, Conn.

"Mr. D. H. Van Hosear, Hurlburst, Conn.

"Mr. C. B. Wood, North Lynne, P. O. address, Chicago, I11."

NORTH CAROLINA. Lafayette Holt, Burlington, N. C.:

"I purchased my first Angora goats in 1893.

"Have not been breeding for bucks, but will probably do so later on." 


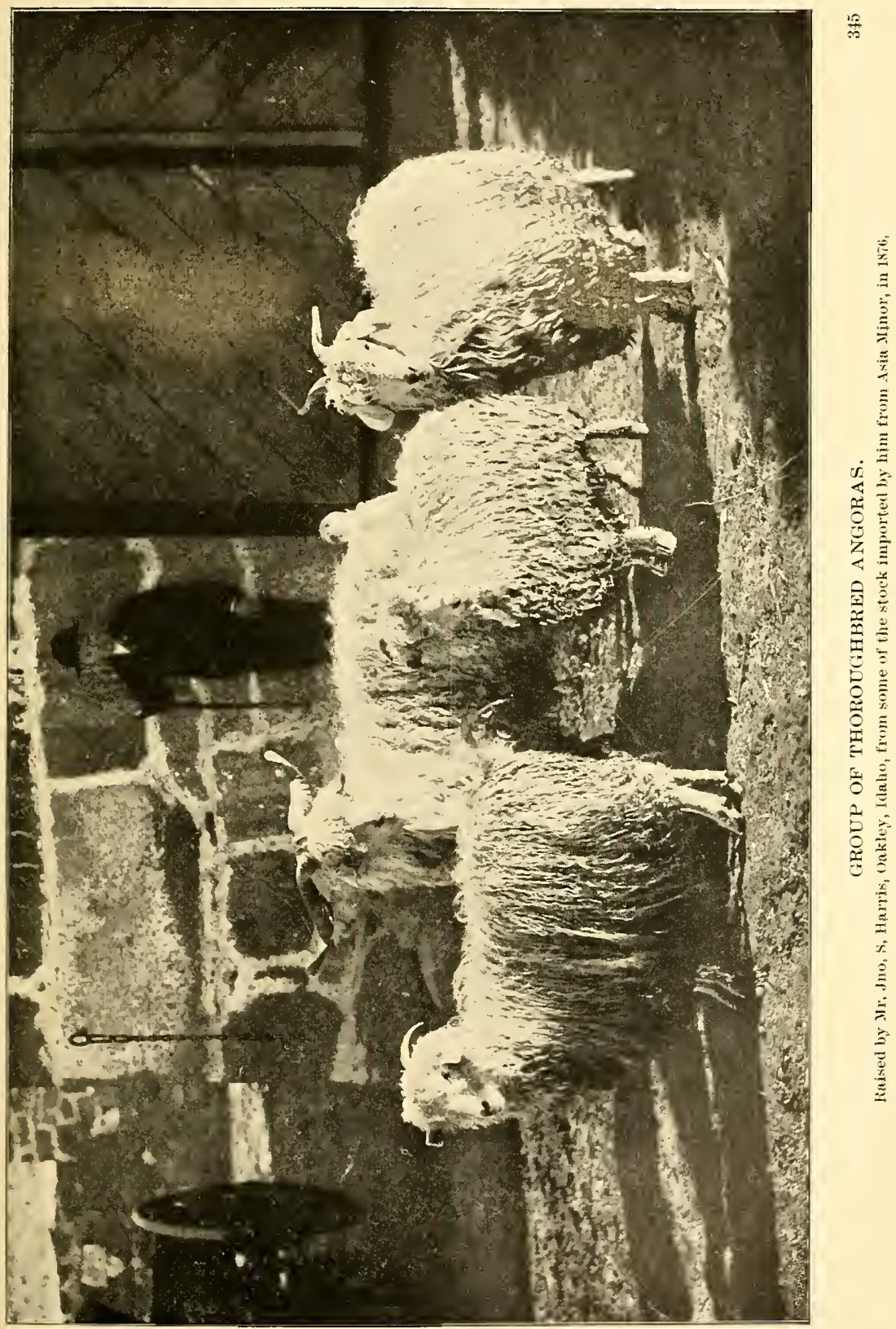





\section{CHAPTER XXV.}

CLEARING BRUSHY LAND, AND HOW THE WORK IS DONE.

The greatest profit in breeding the Angora goat is, perhaps, in connection with the clearing up at some old, worn-out farm that is grown up with briars and brush, and restoring it to a condition of fertility and usefulness; or, by purchasing some native forest or stump land and converting it into good farming land. The latter plan has been followed, and is still carried on, with great success, in Iowa, Oregon, and California; and, the old States, in the East, offer many oppoitunities to carry out the formar. which can be done by the purchase of some of the abanloned farms in that section.

In the more central States, like Missouri, Kansas, and Arkansas, farmers are troubled with a most aggarvating kind of growth, known as buck brush, which produces a small red berry that birds are very fond of, and they distribute them over the face of the whole country to such extent that, in some places, entire fields have been covered by the brush, which throws out a runining root, and, in a very short time, the pastures become practically worthless. No kind of stock will touch it, and it was a serious question among the land owners where it exists, as to what they could do to exterminate, or at least keep it back. They had heard of the Angora goat's great fondness for brush of all description, and the first experiment with them solved the problem, and it is getting to be quite common now for farmers in this section to have a small flock of these goats.

In many other parts of our country and in Canada, the "Canadian thistlc" is the bane of the farmer, and stringent laws are employed to keep this worthless weed from spreading. The Angora goat regards this as one of the choicest kinds of diet, and takes great delight in eating it whenever it can be found. 
It is quite obvious that if a breeder can connect the raising of this animal for mohair, upon such lands as I have mentioned, the profits will be much larger than where he is compelled to rent land for the simple support of his stock.

I have collected quite a mass of testimony from practical breeders who have had experience in their several States in clearing land which will assist new beginners in learning how this work is carried on.

Dr. J. R. Standley, of Platteville, Iowa, is deservedly entitled to the credit of introducing this practice into his State, which he began in 1893 , by the purchase of some three or four hundred goats in Texas. His neighbors thought he was certainly demented when they saw him actually turn loose these animals on his beautiful farm, but they very soon began to realize that there was much method in the doctor's madness. Reference has already been made to the great success he acheived, and plates XX and XXI, will convey a more correct idea of how effectually his work was accomplished-making out of a worthless thicket of brush a most attractive and beautiful pasture.

Plate XIX shows a small bunch of Angoras at work on the farm of Mr. S. S. McKibben, of Earlham, in Madison County. It will be observed that the goats have gotten the brush all destroyed in the enclosure they are in, and are trying to reach the brush in the neighboring field, rather than eat the grass in their own.

The third illustration, or plate XXII, was taken on the farm of the Hon. A. H. Edwards, of Audubon. Iowa, who writes me as follows:

"I have had but limited experience with goats. I have used them for clearing up a pasture of eighty acres, in which about forty acres was densely covered with 'grubs,' (a species of burr-oak dwarfed, probably, by plains fires, as our land is naturally prairie.)

"I have had in the pasture an average of 100 sheep and 400 goats for five months, and forty head of cattle for one month. Three weeks ago the oak leaves within reach of the goats were gone. I send you a photograph of my field showing the good work done by them."

Dr. J. R. Standley, of Plattville, Iowa, prepared the following paper, at my request, giving a very clear statement of his experience in the matter of 

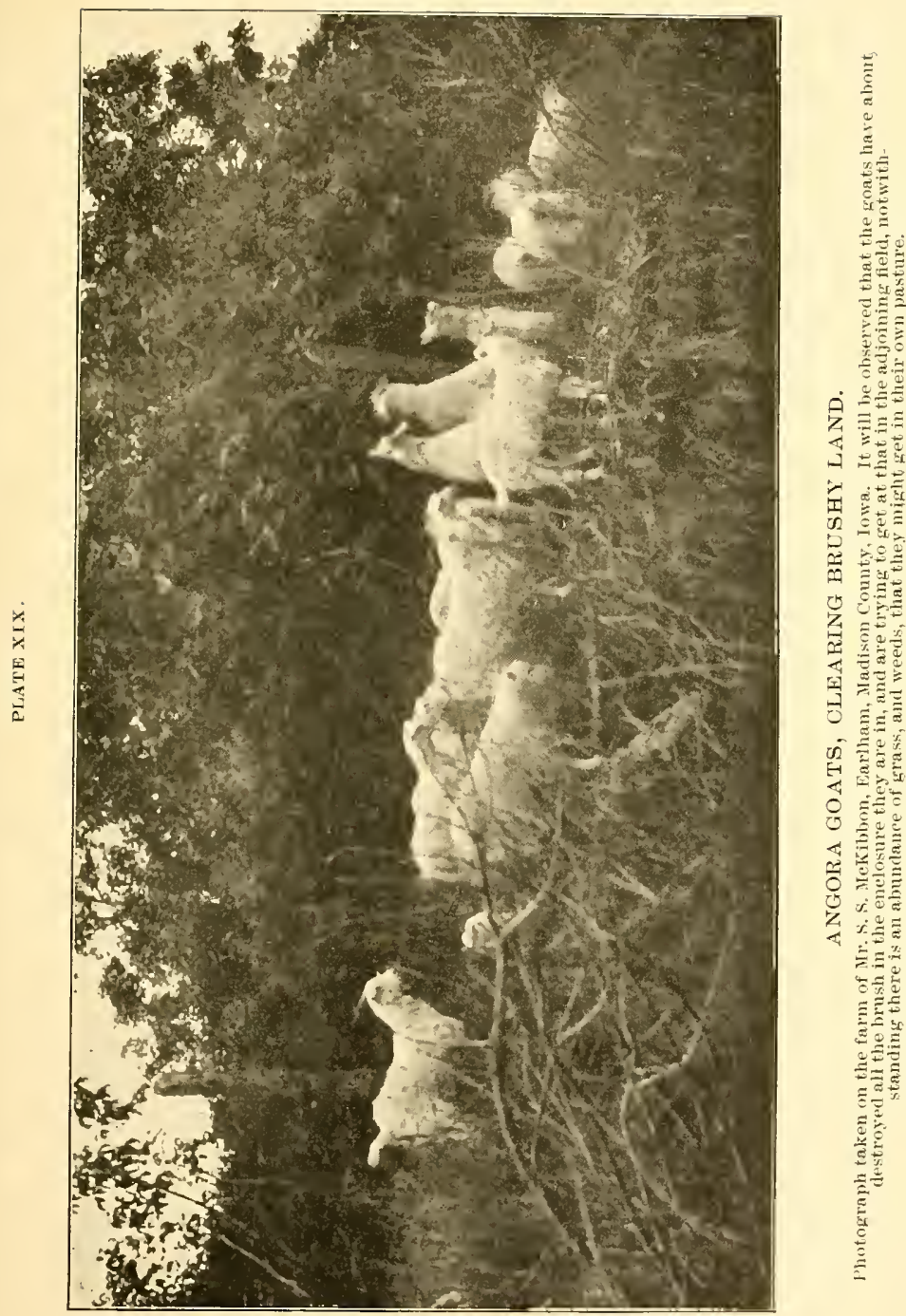



\section{HOW TO CLEAR BRUSH LAND WITH GOATS.}

"To commence this article I want to say that my exeperience in clearing brush land with goats has been entirely with Angora goats. most of them pretty well bred with about 300 'full-bloods.'

"I can see no reason why the common goat would not be just as good.

"I suppose I was the first man who ever tried keeping goats for clearing land of brush. I want to say, here, that I was in such a fix, I was compelled to do something. I had on hand several hundred acres of land known as 'barnes,' and worse, some of it, for a great portion of it was so densely covered with hazel, plum, crab-apple, box-alder, witchhazel, and other varieties of undergrowth known in this country, that hundreds of acres did not produce a single spear of grass of any kind, and not many weeds. Millions of acres of land in the middle Northwest of the United States is today so set with undergrowth that it is impossible to get even the worth of the annual taxes out of the land, in the common way of pasturing the kinds of live-stock heretofore kept in this country.

"Little, very little, seems to be known of the use of goats in reelain1ing the wilderness. The nian who clears brush-land in the old way. by grub, hoe and plow, is behind the times.

"Think a little, kind reader: It is worth from five or six lollars per acre to fifteen or twenty dollars per acre to clear brush land, and even then a great deal of the very best kind of grass land is too rough to plow. And besides, along streams, there are so many nooks and bends and bluffs, that never could be plowed; and, the pastures, many of them, after they have been pastured many years, become set in briars, buckbrush or turkey-berry, so that the grass nearly all dies. A few Angora goats will kill all this, and make more grass than if they were not in the pasture.

"You ean conmence by cutting everything the goats cannot bend down, trees, bushes, etc. Never cut hazel; they like the old hazel best, and kill it better than the spronts.

"To fence for goats, 26 inch woven wire, and two or three barbed wires above, is the best fence I have ever made. I have some oldfashioned rail fence, Osage hedge, and seven-barbed-wire fence that turn them, but the first named. I eall the best.

"Two years is sufficient to kill hazel, and any stumps of any timber that grows in this country (Southern Iowa).

"Some people think goats kill brush by eating it, but this is not so. Goats do not eat the brush, they only denude the brush of its leaves, and continue so to do, which makes the brush sick to the very extrenity of the roots, causing the roots to die as soon as the tops of the brush, consequently, no sprouting. Land cleared in the old way will have more or less sprouts for many years, and nooks and bends in branches and fence corners which are a never-ending eye-sore. 
"The goats do it more perfectly than any way. I have several hundred acres now as clean as a lawn, and as well set in grass, by the work of these pesky little animals. And not only clear of brush, but it is the common remark of all who visit my place that $I$ have no weeds, or comparatively none.

"Now for one minute more, kind reader, give me your full attention.

"Say eighty acres of brush-land, bringing no revenue, is furnished with a good fence and two hundred Angora goats, good grade, that will shear three pounds per head of good staple mohair, mostly eight inches in length, worth now thirty-six cents per pound; this eighty acres will furnish all the feed the goats need for one-half the year, the other half, feed as sheep. 600 pounds of mohair at 36 cents, $\$ 216.00$. It is fair to say that one-half of this $\$ 216.00$ is for the use of the eighty acres of land which is not worth anything for other stock.

"I have simply given these figures to show that the goats will give near, or about, the same revenue as the same number of sheep, and live during the summer, on what no other animal will live on. Now, count three years to clear this land, and set it in grass, and you have the nice sum of $\$ 324.00$ to the credit of your goats, and also the clearing of the eighty acres, worth surely $\$ 800.00$. And aga'n, if your goats are one-hə.lf or more femaies, you have raised young as well, and as many as a like number of sheep.

"Now, you have eighty acres of clear land and the clearing has cost less than nothing. Can you afford to leave that brush? Verily, no! Buy goats. If you can not get good grade Angora goats, buy common goats, and pure-bred bucks, and make money on the goats while you are clearing your land. When your land is cleared sell to that neighbor who needs them; he will want them before you are through with them.

I am fully of the opinion that it will pay to keep Angora goats as weed exterminators. The goat being a browsing and not a grazing animal makes him doubly valuable to the man with brush land.

"It is not my desire to go into the uses to which the Angora goat may be put (except in a cursory way), except the clearing of brush land. This is not the only prfit of the Angora, by any means. Mohair, meat, skins to make rugs and mats, and milk, are sources of revenue from the goat.

"Yes, verily, I believe the Angora goat a more profitable animal than the sheep, aside from his very superior qualities as a browser.

"I do not wish to over-draw the Angora, neither do I believe I have so done. Nor do I wish to convey the idea that the sheep is an inferior animal. While I believe the Angora goat a better animal than the sheep, I think the sheep the next best animal." 


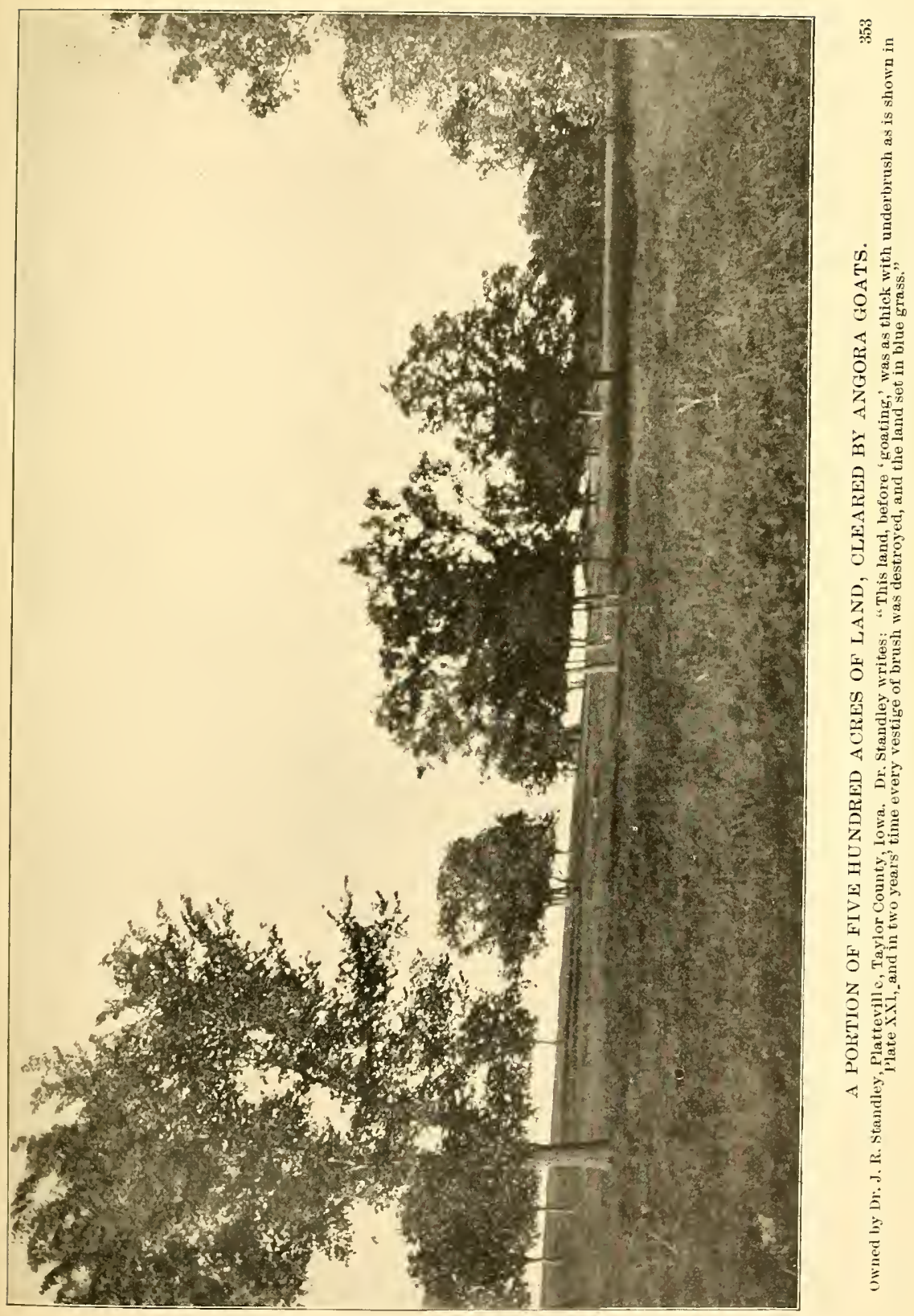





\section{S. S. MeKibben, Earlham, Madison County, says:}

"Referring to your inquiry as to the experience I have had with clearing off brush land by the use of Angora goats I would state, I was first attracted to the plan by reading a short article from the pen of Dr. J. R. Standley of Platteville, Iowa, and I later visited his farm and saw the wonderful work he had accomplished. Ipurchased a few at first and satisfied myself that they would do all that was claimed for them and I then determined to engage in the business of raising the Angora as a farm animal, for profit, and dealing in them generally. I began this business in 1897-98, and have imported from Texas and sold to other farmers in this State no less than five thousand head of these animals. I have thoroughly removed all the brush on my farm, and have had to secure other places to hold goats that I have received during the past year. The Angora goat is, in my judgment, one of the most profitable animals the farmers of any country can keep where they are troubled with either weeds or brush. They will eat, and do well, on any of the brush that grows in Iowa, such as sumac, hazel, buck-brush, elder, dog-mood, etc., but they do not take to the hickory very well; yet, if confined for some time they will remove this, too.

"One bundred goats to forty acres of brush land will be quite enough to use. and they will kill it out in two years. The manure which these animals will drop, and distribute, over the land is really worth more than the little feed that is necessary to throw them in the winter time, to say nothing of the improved grazing character of the land, which will be made into a most perfect blue grass pasture in our section of the State."

\section{Capt. J. Murray Hoag, of Maquoketa, Iowa, says:}

"I find the Angora goat a veritable gold mine as a brush exterminator. They not only clear the ground of brush and weeds but enrich it evenly as they work, thus giving the blue grass, natural to our soil, a chance to grow luxuriantly. As money makers sheep are not in it with the Angora. They not only live but thrive upon that which we consider of no value. They are free from the many diseases common to sheep. Dogs soon learn to keep their distance. Their hair as a textile fabric ranks next to silk, and lastly they are pleasant to handle and an adornment to the farm. You are I think, right in recommending good grade does and full blood rams for the average buyer, as pure bred does are almost beyond the reach of conservative men. By this combination good shearing goats are the immediate result and a prize flock yours in the near future. I am buying some high priced Angoras in both California and Texas, to say nothing of an importation I am making from South Africa, as my plan is to have representated in my flocks the 
best obtainable strains, at same time I would consider it a slow business. but for the grade Angoras I have and am getting in considerable numbers.

"Sell all the grade Angoras you can and the day is not far distant when your patrons will reap their reward and thank you for directing them aright."

Mr. J. C. Morton, Indianola, Iowa, says :

"I got my goats mainly to clear brushy land and they have done it to my entire satisfaction. Not less than five goats to one acre of land is required to clean it up properly, unless the brush is very thin. They will kill all kinds of brush they can reach.

"It is only necessary to confine them on the land you want to clear and they will do the rest of the work."

Mr. A. R. Tate, Wintersett, Iowa, says:

"Goats are being very extensively used for clearing land in Iowa.

"The way I do it is to cut down the timber and let it sprout for a couple of years. They seem to kill it much faster the $n$ if the sprouts atre close to the stump. They will kill hazel better if you do not cut it down."

\section{Messrs. Morgan \& Morgan, Clay, Iowa, say:}

"Angora goats are being used very largely in our State for clearing brush land. Our expericnce has been $\epsilon$ ntirely satisfactory excepting with black hickory.

"Large trees may be cut down and the goats will keep the sprouts from ever growing and will finally kill the root."

Mr. I. J. Booth, Cresco, Iowa, says:

"I have only handled goats a short tinse but am well pleased with the way they clean up brush and weeds. As to brush they beat the world. They take any and all kinds, oak, cherry, baswood, hickory, elm; in fact every green thing including weeds of all kind, except it may be the mullin. They will eat the thistle. My wood lot is as clean as a road from both brush and weeds, and with clover to their knees. It requires cattle with them to eat the grass. Horses love to eat around them. Hundreds of people have visited my ranch to see how they can clear brush land. Just cut down any large trees and they will do the balance of the work without any urging. If I were a younger man I would make the Angora business a specialty." 


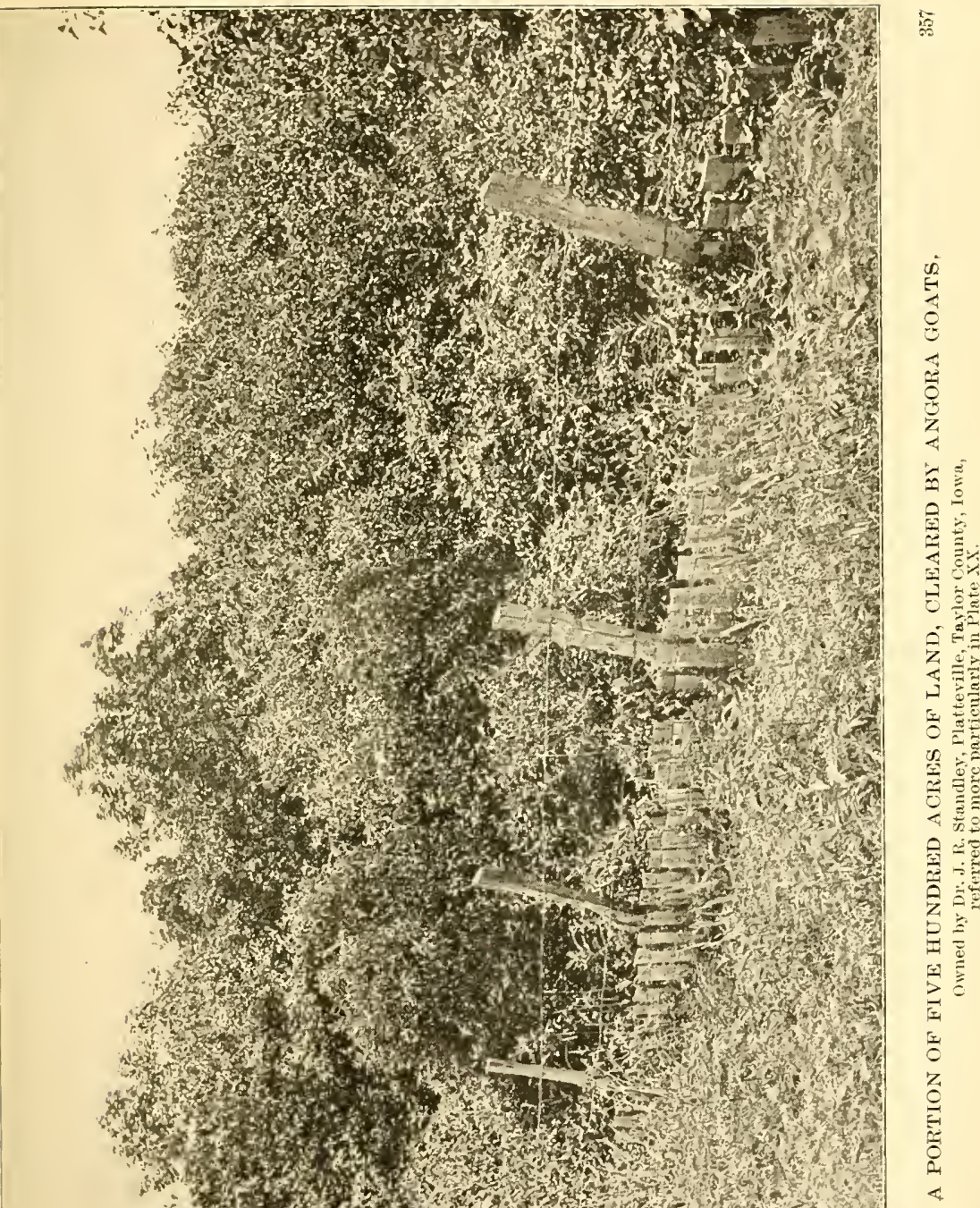



Hon. Thes. H. Tongue, Hillsbcro, Oregon, says:

"Yes, goats are going to be used rery extensively, for cleaning brush land in this State. I have some for this purpose, otherwise, I think I would prefer sheep. My experience in this matter has been very satisfactory and I am, now, not only keeping all the goats I raise, but purchase whenever I can find a suitable opportunity. There are, however, very lew goats for sale, and those who have them are learning to use them in cleaning land, very profitably. Some years ago. I had slashed off land, burned the underbrush when dry in the fall, seeded with grass, but it had grown up in a few years and soon became valueless. I finally hit upon the plan of using goats. My practice is to cut all the brush in the spring or summer, run fire through $\mathrm{i} \hat{\mathrm{t}}$, and burn it up when dry in the fall, then seed with grass, and the next spring begin to pasture goats to keep down the leaves and sprouts of the brush. About two or three years in this way succeeds pretiy well in killing all the growth. In . the meantime, the grass becomes well set and furnishes good pasture until the stumps are rotted out sufficiently for the plow. It is dificult to say how many goats are required, more the first year than after. It depends upon the thickness of the growth.Our undergrowth consists of hazel, fine maple oak and other small shrubbery. If this is very thick for the first year it would perhaps take three or four goats per acre, but for ordinary brush land, two to three goats per acre seems sufficient. I have now in the vicinity of 100 acres where the brush has been pretty well killed by this process. The stumps are nearly rotted out, and in a very short time it will be ready for the plow. I have about 300 acres more that I am preparing to treat in like manner. The benefit that the goats do in this particular far more than compensates for the care, feed and keeping. In my judgment, the fleece and increase is clean profit."

\section{Mr. N. Woodword, Dallas, Oregon, says:}

"I first cut down the brush land and large trees, and then let the goats run on them until there is no more sprouting. and I then take them off until they all sprout again, and get about two weeks' growth. and I put the goats back again; and I leep this up until everything is dead. It usually takes two or three years to kill it out. and about the same time for the stumps and roots to rot out. Our land is covered with fir and oak. The oak trees are small, about the size of good fire wood, from $21 / 2$ to 12 inches in diameter, and from 25 to $3^{0}$ feet high. There is no kind of brush in Oregon but what a goat will eat."

Mr. O. Dowell, Florence, Oregon, says :

"Ny goats will eat all kinds of brush that grows here except the alder. We have great variety of brush, including seren or eight kinds 
of evergreens. I am clearing up brush in bottom land. I slash the brush and trees, then I burn the brush and immediately sow it to grass. In this climate it will make a good pasture nearly all winter. After it is up fotr or five inches, I turn my cattle, hogs, and goats in, and the goats keep down the sprouts. Goats will kill brush that has not been slashed, if they are confined on it long enough. I think it will take fifteen or twenty goats to kill one acre of heavy brtush, such as grows here. Some of it is so thick that a man can not walk through it."

Mr. D. A. Walker, Carlton, Oregon, says:

"Goats will eat all kinds of brush in this country, but poison oak and mountain 1aurel."

Mr. Geo. A. Houck, Eugene, Oregon, says:

"As for clearing brush, the Angora is a profitable investment here, even at ten cents for mohair, as he makes more land every year, and our coast mountains are capable of supporting at a low estimate five millions of goats, there being a country ten miles wide, and three hundred miles long, that is practically unsettled along the west side of Oregon, and is excellent feed for goats. The way I clear brush, I slash grtubs, about twenty inches high in winter, makins feed for the goats: then when the sprouts come out in the summer, they lieep it down, and will kill oak in two seasons if kept on the pasture all the time."

Mr. A. Blackburn, N. Yamhill, Oregon, says:

"Nine-tenths of the goats owned in this State are used for cleaning up brushy land. We cut down all they can not reach the tops of. They will destroy hazel, ash, and willow, in a year; and oak in three years. I know of no brush that they will not cat. From one to three goats to the acre, according to the quantity of brush, is the usual number employed in the work."

\section{Mr. J. H. Hawley, Monmouth, Oregon, says:}

"Goats are used extensively for clearing brush. They are used exclusively for clearing brush land in this State. The ustal way is to give them access to the pasture, and the brush will disappear in proportion to the number of goats used."

1.Ir. Frank H. Kogers, Gardiner, Oregon, says:

"I have found the Angora invaluable in the matter of clearing up bruslyy and fern lands. In this locality they feed mostly, or browse. on sallall, thimbleberry, salmonberry, elders and fern, the latter being the great drawback to upland pasture land, as it grows so rapidly and 
thick as to shade ont all other growths. Goats will peel the eliler trees, some, in winter time, not exceeding four inches in diameter; all willows: and all elders; some cherry trees (wild); but they do the best good destroying the young sprouts of brush each season; the young fern as it comes up in the spring; and the buds; and bull thistles: and otherobnoxious weeds. Cattle do not object to runining in the same pasture with goats, and I regard them a great adrantage for they remove a great many weeds that are objectionable to cattle and a great eye-sore to the owner of the land."

\section{Mr. James MeDonald, Morrison, Oregon, says:}

"Goats are rery iond of any kind of sprouts from the stump of the trees that are cut down. We have the oak, fine maple, cherry, and hazel. We cut it down when it is in full leai, and in the fall we set fire to it. and the goats do the rest."

\section{Mr. W. D. Claggett, Salem, Oregon, says:}

"Goats are very extensively used for cleaning brush land in our State. They will eat nearly anything that grows here and we think they are a most profitable animal, much more so than sheep."

"People are just beginning to find out the value of the goat for ridding the farm of brush and weeds. The way I clear brush land is as jollows:

"The vallcys and foot-hills are covered with brush, principally oakgrubs, spotted with ierns and small citus. The land is first fenced. the brush and timber cut down, and burned, and then goats are turned into the pasture, which are lept there until all stumps and small brush is dead. It requires from two to four years to kill oak grubs and from one to three goats to the acre to keep sprouts down. They will certainly externinate all kinds of brush and are the 'dead medicine' on all kinds of thistles. I will venture to say I can turn my goats into the worst patch of 'Canada thistle' that grows, and they will exterminate them. They will never go to seed. The first thing the goat does is to take out the bloom."

\section{Mr. Scott Obye, N. Yamhill, Oregon, says:}

"Goats are extensively used for clearing brush in this State. The number that it requires for one acre depends altogether on the character of the brush. The brush should first be slashed and then dried and burned, and when the sprouts begin to grow, put the goats on the land, and they will keep it eaten down, and will clear it in three years: and in most cases a fine stand of grass, for goats are excellent fertilizers, as well as land cleaners. Other stock make 130 objection to pasturing with them. In ordinary browsing. two goats to the acre is enough." 


\section{Mr. Oscar Tom, Angora, Oregon, says:}

"Large timber and brush is slashed, or cut down in winter, or spring, burned when dry, sown to grass, and the goats kcep the sprouts down. Where there is trash on the ground and small brush, and fire will run, it is burned over, and then sown down with grass, and the goats are then turned in, and they will tranp the soil, set the grass seed and keep the brush from sprouting again, or as we call it, they will 'grub' the land. Where there is much fern and one can set a burn occasionally it is best to burn early in the spring. It does not hurt the grass roots much, and it makes better range for the following winter.

"Goats will eat all kinds of brush that grows here, and all kinds of weeds except the nettle, and I never saw a goat that would eat these. They are especially fond of thistle. They eat the blooms as fast as they appear, and will keep them down provided there are not too many for the number of goats."

Mr. E. R. Williams, Redding, Cal., says:

"I girdle my large trees and cut the small ones down, and the goats do the balance.

"We have nearly every kind of brush that you can mention."

Messrs. Conklin Bros., Newville, Cal., say:

"Goat, wil! destroy any kind of brush they can reach the top of, and will keep large trees from growing when once cut down. They will not let sprouts grow if confined."

Mr. EL Maze, Upper Lake, Cal., says:

"The best way to destroy brush on land is to burn off the forest by cutting down some of the small brish and placing it around the larger trees. Every bush and tree that is killed by the fire will produce a new growth which males the best goat feed, and they will keep it down so close that in a few years will kill the roots, and your land is cleared of brush."

Mr. J. M. Wimmer, Millville, Cai., says:

"The way to make goats effective in killing trees, or bushes, is to cut the trees and bushes down, and when the stumps sprout turn the goats in and they eat the sprouts off. This, if followed up for two or three years, will kill the stumps."

\section{F. G. Smith, Skaggs Springs, Cal., says:}

"Some years ago, I moved into the mountains on a tract of land whose chief value consisted in the red wood and tan oak timber, which, on account of the distance to market is for firewood, is of no value, 

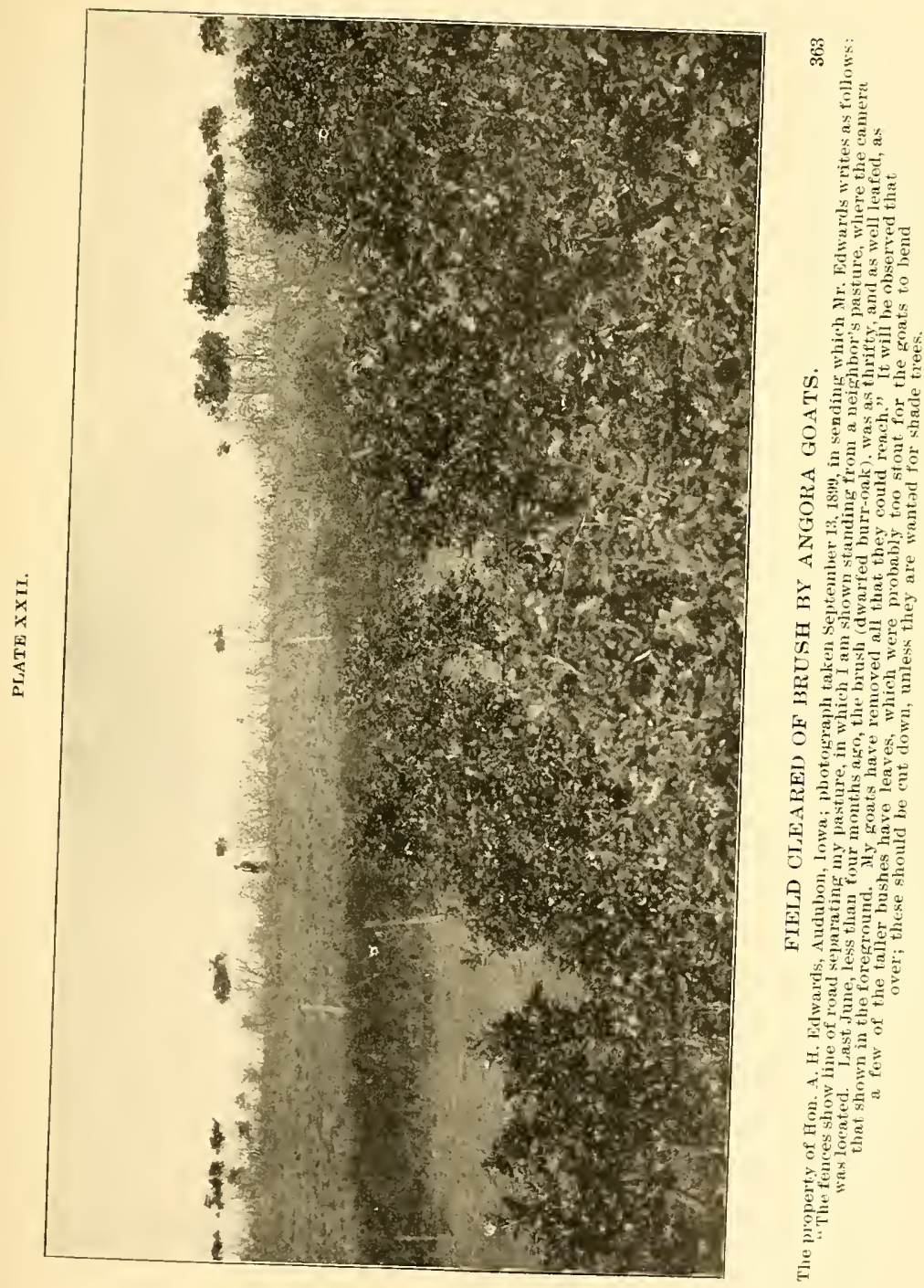

and acres of dense growth of various kinds of brush. Aside from a range for logs, there was not grazing land enough to keep 100 sheep. After casting about what use to make of the trush, I finally decided to try a small bunch of goats. I heard of a man who had a small lot to sell, and from him I bought sixty head of does at $\$ 1.50$. They were about onehalf to three-quarter Angoras.

"As to clearing the land, I have not made a special object of the matter of enclosing a certain tract of land with that end in view. I can only speak in a general way. At the time I bought my start in goats, we built a shed and enclosed about twenty acres of land on a small stream. Near the waters, stand large red wood trees, a narrow fringe, outside of this were a variety of shrubbery, and saplings, with patches of grass growing between. The brush growth consisted of hazel, buckeye. pin oak, manzanita, and mountain laurel (termed pepper wood), black oak and madrone saplings. The goats were confined here until we thought they were used to their new location. How long I do not remember; long enough, however, until they had siripped the leaves off every thing within reach. They seemed to take kindly to everything except the laurel and poison iry (or poison oak as it is culled in Calitornia). This latter vine or shrub is eaten by horses and hogs, but goats seem to be indifferent to it. The hazel and buckeys seemed their first choice; these were stripped in short order. Then they went after the smooth, thin bark of the madrone saplings. These were girdled as high as they could reach. Oak and maple brush was also acceptable. The following winter the saplings were cut down, also the tall brush, the tops of which were beyond the reach of the goats. and hrown into piles, ready for burning when they got dry; the stumps and stubble of course remained standing. The following spring this enclosure, which contained also an acre or two of good grazing land, was used as a kid pasture; in June, when the kids were about two montlis old, they were turned out with the does to shift for themselves. After that the buck and a small bunch of does were liejt up until November. The result was that there were but few sprouts left on the stumps, and the sanc process was repeated several seasons. or until we moved the corrals to another part of the ranch. The third year the hazel had entirely disappeared, also the small-fry of other brtish. The stumps of the saplings, and small trees were dead and decaying. Three years ago, we had abcut ten acres of land cleared for grazing purposes. The trees, a young growth of black oak and a springling of madrone, were cut down in windrows to facilitate burning later on. The stumps of both of these species of trees are, if left to themselves, the most persistent sprouters imaginable, and the land would have been covered in a few years, with an almost impenetrable mass of brush and saplings. The land was not fenced, but being on a high ridge, it was a favorite stamping ground for the goats. They roam over it 
nearly every day. The stumps are standing, but not a sprout is to be seen on any of them. I know a man who had a very brushy tract of 100 acres or more; he turned about thirty head of goats on it. and, of course, they failed to clear it, as the area was out of all proportion to the number of animals. Where goats are to be utilized for such a purpose it would be necessary to enclose a tract of land proportionate to the number of animals at your disposal.

"We have dense brush thickets, eight to ten feet high, composed of pin-oak, grease-wood, manzanita, and a number of other species of brusli wood. Nothing but hogs go through them. We open ont such places with fire. With favorable wind and weather, a fire started below will sweep up a mountain side in short order, leaving nothing but short stubles behind. When the brush is not so thick it will run through it and open it out for the goats. After that, if the territory is not too large, the goats will keep open runways through it in all directions. This proceeding gives lots of browse. In speaking to ny neighbor about this subject the other day, he mentioned a number of farmers in the valley who keep small bunches of common goats for neat. They have nice open pastures, while those of their adjoining neighbors who keep none, are overrun with brush and weeds. He also tells me that his goats keep down the mountain laurel, or pepper wood."

\section{Dr. Tuttle, Tacoma, Mash. :}

"Confine goats to brush land so th.ıt they cannot get out, and they will eat all the small brush that they can reach and will bark the smaller trees; and, if the larg ${ }^{\Delta} \mathrm{r}$ ones are cut down, they will keep all sprouts from growing so that the tree will soon dic."

\section{- Bucoda, Wash.:}

"My goats have been confined in a pasture this summer, and there is fine maple, soft maple, alder and elder ash, dogwood, boxwood, willow, hard hack, whitefire, redfire, cedar, all of which they eat freely of. They have the fir and cedar girdled up as ligh as they can reach, and about two and a half inches inches in diameter; the willow and other hard woods up to about four inches in diameter and about five feet high. They are sure death to all small brush, weeds, and thistles (common bull thistle)."

Mr. R. C. Johnston, Lawrence, Kansas, says:

"My experience in handling the Angora goat during the past nine months has been that, those who purchased them wanted them for clearing up their pastures and brush land, more than for anything else. My personal experience in clearing upland has been very satisfactory. They will eat the leaves of every bush that grows in Kansas, and are the only 
animal that will eat and kill out buck biush, a bush that grows two or three feet high, and bears a small berry in the fall. It has runners like the strawberry. The birds distribute, and stock scatter the seed by walking through it, and the result is it is ruining many of our finest pastures.

"The Angora will eat all weeds that grow in the State as well. Our people are just beginning to realize their great value in converting worthless products of the farm into gold; utilizing that which every farmer must labor and spend money to get rid of.

"I have found quite a large demand for them from the farmers in Missouri, Arkansas and Iowa, for the samc purpose as we are using them for. They will bark some bush, like sumac, crab apple, etc. I expect to see a very large industry developed in this, and ineighboring States. in this valuable animal.

"They can be made to return a much greater revenue from mohair, and the sale of their meat, than can possibly be made out of sheep. They are much hardier, and longer lived; are hee from disease; and will live upon what a sheep, horse or cow will not touch. Their meat will bring very near the same price per pound, as the sheep. Indeed, I believe it will soon bring more, for it is superior, because it is a much healthier animal, and their meat will soon be preferred to that of sheep. I have gone far enough wth the Angora to feel quite confident that it will be a very popular class of stock with farmers, and I shall not be surprised if it does not displace the sheep in many cases."

Mr. A. Lippincutt, Sheridan, Mo., says:

"Goats are used altogether for cleaning up brushy land. I couldn"† say exactly the number of head required to the acre. They eat all kinds of brush that grows here, except hickory or walnut. They are death on weeds. Blue grass has no attraction for them. They will peel trees five and six feet high."

Mr. Wm. J. Seever, Secretary Missouri Historical Society; St. Louis, Mo., says:

"I have travelled considerable through the Ozark (hill) region of Missouri, a country that, when the timber is removed, will grow a crop of sprouts and underbrush through which a dog can hardly travel. On a number of such tracts of land, where small flocks of goats were kept, I could not help but notice the effects of their work. They will absolutely clean it of everything that they can defoliate, large saplings included. Being the owner of a tract of just such land which was costing me $\$ 6$ to $\$ 10$ per acre to clean up, I concluded to try the goats. My experience has been of but six months' duration, but I am satisfied they are invaluable on a well-ienced farm, and will more than repay their cost 
and keep, if kept only for this purpose. I have but a few head, mostly grades, and, on my farm, I have never seen one graze. They are also inveterate weed destroyers, and the only animal I know of that will eat the Canada thistle clear to the roots, a weed pest which most States legislate against, which no four-footed animal will touch, and the twofooted one likewise, unless compelled to.

"In this brush country, the defoliage of the larger growth by goats is interesting and goat sense clearly applied. I have seen, time and again, two, three or four animals, bear down with their weight young trees that a single animal could not bend, hold the tree in position until every leaf was eaten off. This repeated once or twice would kill it. Certain species will be barked as high as can be reached."

Mr. C. D. Tuthill, Tuthill, Minn., says :

"Goats are not, as yet, used to any grcat extent for killing out brush in Minnesota. but they should be. Brushy land can be cleaned cheaper with them than by any other means, and it is immaterial what kind of brush it is."

Mr. A. G. Wilcox, Hugo, Minn., says:

"Goats have not been used much ir our State for clearing land, but they certainly ought to be.

"When I first got goats I had fences that were all right for sheep and pigs, but the goats would go through somehow, and were some tronble until I put tp a woven wire (Lamb's) of the Page type, and that was all right. No trouble since.

"I enclosed twelve acres of open timber grown up to oak and hazel, to a height of four to six feet. The shade was too dense in places to grow any grass, but there were some places where the grass was very fine. The goats did not eat any grass, and I turned in horses enough to pasture it down close. The goats began on the brush and gradually cleaned it out, stripping off every leaf and twig, and leaving only bare poles. By September 1st, the brush was as dead, in appearance, as if a fire had swept through it, and I do not believe it will ever leaf out again.

"A piece of about three acres which was eaten out by them last fall is dead and the brush is already falling down and rotting. legs.

"They will strip leaves off as high as they can reach on their hind

"I think they easily pay their way as brush eaters.

"I want mp pastures cleared of brush but I leave my large trees for shade as there are only enough to make a fine open timber pasture." 


\section{Mr. C. S. Horn Chicago, I11., says:}

-Abott the first of the year (1899) I purchased an eighty-acre tract of brush land and was in a quandary as to how to get rid of the undergrowth and shrubs. In talking to some friends regarding the matter, the goat was suggested as being the best means, and I decided to purchase a carload of them and put them to work. About May 1st, 1 received them, and am highly pleased with the result of the experiment. I believe they have done more for me than five men would have done in the same time, working ten hours a day. I certainly can recommend them as being the surest and best remedy for rough, unbroken pastures. 'They are willing workers, will not 'strike' on you for higher wages, and will do excellent work. I shall probably want more goats next spring."

\section{Col. J. Wash. Watts, Montville, S. C., says:}

"I never knew of the Angora goat being used for exterminating brush. I know they prefer to browse rather than to graze, and that they soon clear their pastures of briars, brush, and weeds, but we had too few to depend on much work of this kind.

"I have owned a good many, from time to time, but in changing my residence I let my son, John D. Watts, of Laurens, S. C.. have my goats. Our trees are mostly oak and pine, which the goat cannot 'bark; but they clean up briars and brush, willows, and such small trees.

"There are so few kept in our State that very little is known of their habits."

Messrs. Miller \& Sibley, Franklin, Pa., say:

"From the experience we had with the Angora goat we found them io be invaluable as brush exterminators. One hundred can do the work of six men.

"The ground should first be cleared, and the goats will do the rest by keeping the sprouts from growing. We found they would destroy everything except poison laurel."

\section{Mr. Lafayette Holt, Burlington, N. C., says:}

"Goats are not common in North Carolina. They can be made very useful in clearing up brushy land. I do rot know of any large lots.

"I am well convinced they will clean up old farms and brushy land in fine shape. The great objection I have to them is they will destroy my peach and fruit trees." 
Mr. O. D. Hill, Kendalia, W. Va., says:

"Goats are not used for clearing up brush in this section, but I am well satisfied they will destroy anything in the shape of trees, bushes, briars or weeds, unless it may be poison ivy, and laurel."

Mr. James A. Bill, Bill Hill P. O., Conn., says :

"I keep my goats (about 75) for the purpose of keeping down brush and weeds, principally, though I derive a considerable revenue in selling males for breeding purposes. My experience has been that they are not at all particular as to what kind of brush they have to eat. They will take most anything that comes in their way. I have been breeding them for the past thirty years, and have found them the most profitable part of my farming."

WEST TEXAS. It may appear strange to many who have always pictured Texas as one vast stretch of prairie that trees and brush thickets are becoming very dense in many portions of the State, and, unless something is done to check the growth, large sections will soon become worthless for grazing cattle. This is more particularly the case in the Southwest, beyond the Colorado River; and, strange as it may seem, this growth has taken place in the last twenty-five years. I can very well remember when it was possible to distinguish an animal as far as the eyesight could reach, in places that are now so thickly covered with mesquite, live oak shin oak, sumac, etc., that it is impossible even to ride a horse through it.

The explanation of this is doubtless due to the fencing of a country which was formerly open, and the home of the buffalo and other wild game; to hunt which, the high prairie grass would have to be burned off every fallandwinter. Travellers, too, would often set fire to the grass from their camp fires by accident, which would, sometimes, burn for weeks at a time, lilling all kinds of vegetation. This is, no doubt, the way that all tree life in this section of Texas had been destroyed which is now coming back, because the ranchmen are careful to guard against fires getting started within their enclosed ranches.

There has never been any attempt made toward removing this growth of brush, but it is quite evident the time is very near when some agency must be employed to do so, or many of our finest cattle ranches will have to be abandoned. 
Mr. Wm. R. Mckee, of Junction City, Kimble County, tells me that he has some neighbors who have cleaned a considerable amount of brush land such as shin oak, live oak, sumac, etc., by the aid of the goat, and that he had done so himself with a portion of the land he is now cultivating on the Llano River. He says:

"Cut down all brush and then turn in the goats and they will keep down the young sprouts. Let the goats remain on the ground one-half the day in the spring up to October 1 st.

"It takes about seven goats to the acre.

"My neighbors, B. F. Pepper, and J. D. Armstrong (since deceased), have cleared considerable land in this way. They will exterminate everything except the mesquite in two years' time."

Mr. B. L. Crouch, Pearsall, 'Texas, says:

"The black chapparell in this porticn of the State is too stubborn for the goats to destroy to any extent though they will check its spread. They are a success destroying the cockle-burr, in fields, and pastures."

It is not unlikely if the black chapparell referred to by $\mathrm{Mr}$. Crouch was first cut down and burned, as is done in Oregon, it would greatly assist the goat in getting rid of the growth. 


\section{CHAP'TER XXVI.}

HOW TO TELL THE AGE OF AN ANGORA GOAT.

The age of an Angora goat may be learned, approximately, by an examination of their teeth, which are thirty-two in number, (twenty-four grinders, and eight incissors) the same as witli sheep. The eight incissors are located on the lower front jaw bone, six of which are born with the animal, and two, (one on either end of the set) a few months after birth. There are no teeth on the upper front jaw.) The eight incissors are first called "Milk tecth," which disappear, and are replaced by a permanent set, as the animal advances in life.

The first two, (the central and largest) become loose and are pushed out by two new teeth within a year or eighteen months after birth, when it is called a "yearling" or "two tooth."

The second two, (on either side of the first,) are next removed in about two or two and one-half years, when the animal is said to be a "two-year-old."

The third two, (on either side of the second,) when the animal is between three and three and half years of age, and then it is called a "three-year-old."

The fourth two, (on either end of the whole set,) when the animal is four years old, and over, when it is called a "full month."

After this period, the age must be guessed at, and can only be conjectured through the general appearance of the animal, the character of the horns, and condition of the teeth. At the age of four, the animal is supposed to be in its prime, after which it will begin to descend in the scale of vitality, and as a producer of mohair, though the changes will be so slight as to be hardly observable from year to year. 
The incissor teeth will sooner or later begin to wear on top, and will gradually wear away until they are mere stubbs, and quite even with the gums of the mouth, which, ordinarily, takes place about ten to twelve years of age, when they are called

"toothless." This wearing process, however, is governed by the character of food the animal has to eat. If it has very little sand, or grit, the teeth will probably remain sound for a much longer time. Fifteen and sixteen years, is not an uncommon age for goats to keep their teeth in fairly good shape; and if they have clean, soft, food to eat there is no reason why they should not remain even longer than this. Many instances of twenty, and twentytwo years are known.

The general appearance of the incissor teeth are about the same in all goats, but are smaller in some than others; and: the two end teeth, are sometimes very small indeed. 


\section{CHAPTER XXVII.}

HOW TO FEED ANGORA GOATS FOR MARKET.

The Angora is a quick feeder, and will take on more flesh than a sheep in the sanie length of time. The best age to feed is after they have reached maturity, or between four and six, although they will fatten easily at any age. They take to any kind of grain almost as soon as they are placed in the feed-lot and will, consequently shrink very little, owing to their changed condition of life.

Two bushels of corn, with as much clean timothy, or clover, hay as they want, ought to put them in prime shape, fed in sixty days. Corn should be fed lightly at first, say one quarter to one-half, pound for the first few days and gradually increased for a week or ten days when they should have all they can eat. When corn is fed on the cob, the cob should be broken in two, or more pieces. Wheat screenings makes a very fine feed. Indeed, the Angora will do well on any kind of grain. They should have free access to water, and hay and a shelter to go in and out at will. If they are troubled with lice they shoud be dipped, (see "Lice on Goats") as the continued itching interferes with their feeding properly. The following letter from Mr. Jas. R. Hamilton of San Angelo, Texas, who has perhaps fed and shipped more sheep and Angora goats than any single shipper in the State of Texas during the past ten years, will give his views about Cotton Sced Meal and Hulls as a fattening feed:

"San Angelo. Texas, Nov. 25th, 1899.

"Wm. L. Black, Ft. McKavett, Texas.

"Dear Sir-Answering your favor of 19th, in regard to feeding goats will say. I consider cotton seed meal and hulls the best feed for goats, or mutton either. I think the winter time is the best time to feed and 
the animals should be put on feed before they shrink too much with cold weather and bad range. If in fair flesh when put on feed, sixty to seventy days will finish them. If iat they will always sell on the market about fifty cents per hundred lower than fat sheep. You should begin to feed about one quarter of a pound of meal to three of hulls and increase the ratio of meal, proportionally, for fifteen days, at that time, would aim to have the ratio of meal about one pound to two and a half of hulls per day per head.

"Yours truly,

"J. R. HAMILTON."

Mr. S. S. McKibbin of Earlham, Madison County, Iowa. writes as follows:

"I have fed the Angora goat wether for market and was agreeably surprised at the rapidity with which they can be iattened. If they are received in the spring, and are allowed to run on our hazel thickets unti] fall, it will take but very little corn to 'finish' them. If taken direct from the range it is best to start in slow and gradually increase the feed. I started with one-half pound corn to the ration and gradually increased this until I gave them free access to the feed and I think two pounds a day is all that a goat will require. They can be made ready for market in sixty days. I had a plain straw shed in the lot for shelter, and a stack of hay and oat straw for them to go to at will."

Mr. R. C. Johnston, Lawrence, Kansas, says:

"I fed and fattened 500 wethers last fall and am feeding 500 more now (April, 1900). I have been surprised to see how easily and rapidly they can be fattened on corn. I feed shelled corn and wheat straw. They fatten in one-third less time than sheep and my exeperience has been so satisfactory I intend feeding goats hereafter for the profit in feeding."

Mr. Tyson of Blair, Nebraska, in a letter to Mr. A. L. Johns of Chicago, which may be read under Chapter XV. on "Angora Tenison," says:

"That his profits had been fully as great taking into consideration the money invested, as he ever made in feeding sheep." 


\section{CHAPTER XXVIII.}

DISEASES OF THE ANGORA GOAT.

If there is any one feature, above another, that should commend the Angora goat to the American farmer, it is his complete immunity from disease. They have been handled in the United States for over fifty years, in the North, South. East and West, with the same uniform exemption from sickness, a record that no other kind of live stock can boast of in this, or any other country.

In South Africa they are subject to both scab and pleuropneumonia, or a contagious lung-sickness, supposed to have been communicated to their goats by some imported stock during the latter part of 1880 ; and, although prompt measures were used to check the spread of the disease it had so good a start, it was impossible to stop it until a large number of the animals had died, or were slanghtered, estimated to have been 38,200 head

Referring to this unfortunate affair Mr. Schreiner says:

"Pleuro-pneumonia is indigenous to Asia Minor, being most common and dangerous in low-lying anc' damp situations. It does not exist always in a severe form, but at times it assumes an epidemic character, and a most virulent and deadly form sweeping the Angoras off by hundreds of thousands. There is no record of it having appeared out of the country to which it is indigenous, except in the outbreak in the Cape Colony. On its appearance here it was quite unknown to veterinary science, so Mr. Hutcheon had to break new ground. It is a contagious disease, closely analogous to pluero-pneumonia in horned cattle; and if it had not been promptly stamped out. would have obtained a general hold on the Angoras of this country, and have needed ceaseless combating, just as lung sickness in cattle does. In time, like other diseases which are so deadly on their first introduction to a new country, it would probably have assumed a milder form; but it needs no argument to prove that Mr. Hutcheon did the country an inrstimable service in eradicating it at once. 
"The disease in the Colony was in a most virulent form; every goat in every flock in which it appeared was attacked, and the mortality rumning sometimes as high as eighty per cent. The death rate was highest among those first attacked in any flock, probably because they werc peculiarly susceptible, and lowest among those last attacqed. It is a disease conveyed by direct contagion and not an infectious one. The germs are not conveyed great distances by the wind. The course it runs may be divided into two periods: First, a period of incubation. or latency, from seven to ten days; second, in full strength, from ten to. thirteen days, the exact course depending on the susceptibility of the animual.

"It is remarkable how long the discase was latent in the imported goats. Some of them were observed to have it when the consignment left Constantinople in the last of October. It did not break out during the voyage, nor was it, in the first instance, observed among the imported goats in the Colony. In both outbreaks it appeared among Colonial flocks as soon as the imported goats were put to them, at Mount Stewart. at the end of December, and in Bedford a month later, two and three. months after the shipment left Turkey. The fact that it did not break out during the royage and until Colonial flocks became infected, may perhaps be accounted for on the supposition that some of the imported goats having had the disease in Turkey, retained diseased lungs, as is sometimes the case with horned cattle here, that have recovered from lung sickness and yet are capable of irfecting healkhy cattle, because their lungs remain more or less locally injured and diseased for a long time. With regard to others, it would seem that they had either had the disease and recovered, or that coming from a country where it is always prevalent, to some extent, often in mild form, they were not very susceptible. If the report be true that, after the Mount Stewart outbreak, several of Mr. Evans' imported rams,* which had, so 'far, been healthy, contracted the disease and died, the above supposition would seem to have strong support; it would seem to prove that such animals. had somehow secured an immunity in Turkey, but that the disease having been conveyed to the Cape flocks had acquired a virulency sc potent that the immunity they had hitherto enjoyed was not capable of being sustained. But, whatever the explanation, it is certain that thesc goats brought the disease from Turkey. South Africa should guard itself well against its reintroducton." See Schreiner, pp. 223-2.24.

It is quite possible, as Mr. Schreiner says, that, the Turkish goats carried the disease to Cape Colony, but it would be very. hard to convince an American jury to think so from the explan-

*It is difficult to say whether this is intended to refer to a goat or a sheep, which is a good illustration of the importance of using the terus. "buck" for male and "doe" for female goats. 
ation that he makes. It is to be loped they may never have any more such trouble but it would be well for American breeders to keep both Turkish and Cape Colony goats in quarantine for a reasonable time after arrival if they should import any, in order to be certain they are entirely free from both pleuro-pneumonia, scab and Asiatic mange, all of which diseases they seem to be liable to. Whatever the cause may be, the United States is certainly favored over all other nations in breeding Angoras for. with the exception of a few minor complaints, not a single breeder in any of the States, has ever discovered any sickness among them.

SCAB.

This very troublesome disease seens to be natural with sheep, but the insect that produces it will not live on a goat. I have kept Angoras in a flock of sheep that were infected with scab, for weeks at a time, and have never seen the slightest indication of the disease on any of them, and have never heard of a breeder who has known of their having it.

Mr. Schreiner says:

"The Boer goats are subject to a very virulent kind of scab, produced by a different acarus to that whicin affects Angoras. In the early days, when it was not understood how to cope with scab, and when there were no dipping tanks, it was not uncommon in a severe drought, for whole flocks to be exterminated by this disease. See Schreirer page 174."

A siatic scab is said to have been brought to this country by an importation made by Mr. Eutichedes in 18\%0. Referring to it in a pamphlet published in 1872 by Maj. Wn1. E. Sweet, assisted by Mr. Wm. M. Landrum, the latter gentleman says:

"Mr. Eutichedes did not know anything about the disease until his goats were found dying off at a fearful rate with it. He wrote to Asia for a remedy and was advised to use sulphur and lime, in a hot bath, but it faiied to effect a cure. I gave him a remedy. Tobacco, and corrosive sublimate. I have heard of but twelve dying since, which were too far gone to recover."

Reyarding the renedv Mr. Landrum says:

"(100) One hundred pounds of strong tobacco, (400) four hundred gallons of water. (10) ten ounces corrosive sublimate dissolved in double 
the quantity of sal amoniac, with warm water, or a tobacco decoction and mix the whole before dipping. Pulverize the medicine frst. as it dissolves faster. The lip should be warm when used."

And he adds :

"We may never be troubled again. There are several remedies that will cure the scab if taken in time. In fact, most of the remedies. used for scab in sheep will cure the mange, or scab in goats if applied strong enough. Tar and grease is good but the remedy is rather expensive and tedious. Tobacco and corrosire sublimate is cheapest and most effective, and will never hurt the goat unless he gets strangled by plunging and swallows too much of the decoction. Too much sublimate will produce irritation and kill the goat. The parasite of the scai in goats is a different parasite from that in sheep and does not readily. if ever, take hold of a sheep."

\section{WORMS.}

Goats are seldom troubled with worms internally, or in the nose, as sheep are; but, like all other animals in the South. are strbject to have an attack from the scrow-worm, if they are injured in a manner that will cause blood to flow. At shearing time this is common, unless the shearers are careful not to cut the skin.

These worms are produced from an egg, deposited on the cut, by a large, green $\mathrm{fly}$, called a blow $f l y$. which prevails only in hot weather, and are especially troublesome in Texas.

Chloroform is a quick, and effective remedy, and calomel is. also: but, these are nore expensive than carbolic ointment, which is more commonly used, as well as some of the prepared sheep-dips, for curing scab, particularly "Cannon's Dip," which will destroy them very promptly.

Tape worms are occasionally found, though very seldom. if the animals are kept in a thriving condition. Turpentine administered in half ounce doses upon an empty stomach will be found effective. Regular salting, with plenty to eat will be founc ${ }^{2}$ the best way to prevent goats from having tape worms.

\section{FOO'T-ROT.}

Some Anerican breeders have reported that their goats are troubled with foot-rot, which is no doubt the case, if they have been allowed to range on marshy land, but it is more than like- 
ly most of the cases are only sore fect produced from wading in water, or walking over damp grass, caused either by rain or heavy dew, which is quite common. This, however, will seldom last very long after the animal has been moved to a dry range.

There is no doubt but that foot-rot will result from confining the animals to a pasture that has very damp soil.

Pozedcred bluc stonc, after first trimming the hoof, will effect a cure; or a solution of nitratc of silicr. Pinc tar is also a very good remedy.

\section{SCOURS.}

Are likewise mentioned by some breeders which is usually the result of something the animal has eaten, and can be corrected by removing the flock to a different range. Or, if only a few goats are affected, by taking these out of the flock; and giving them dry feed for a few days.

\section{POVERTY IN WINTER.}

Poverty is perhaps the most fruitful cause for much of the so-called sickness that the American goats have. It is very unwise to permit goats to get very poor in flesh if it is at all possible to avoid it, and a little money expended in grain, or cottonseed, will often return a very large profit by saving the lives of goats that would otherwise die for the want of sufficient nourishment during the winter.

During the winter of 1899 some alarm was created among a few Oregon breeders, caused by what seemed to be a new kind of disease, and in referring to the matter the "Oregon Agriculturist and Rural Northwest" of Portland, says:

"A number of Angora goats have been received at the Oregon Experiment Station this winter which were supposed to be attacked by the disease reported in many localities last winter. Post mortem examination of these goats failed to disclose any new disease. One of them was found to be wholly sound internally; another was affected with tape worm, while another had an affected liver. Dr. Withycombe is inclined to the opinion that the mortality among the goats is for the most part due to no special disease, but a low condition of the system at this time of the year which makes them easily succumb to various 
diseases, colds, etc. He recommends as a preventive more care in providing food and shelter from the rains. The Experiment Station will. however, continue the investigation of the matter as thoroughly as possible."

The same paper adds:

"Dr. McLean. State Veterinarian, a few days ago visited Marion County to ascertain what was the trouble with a flock of goats, onethird of which had died within a few days. He pronounced the trouble a dietic one resulting from improper and insufficient food and advised the changing of the goats to another pasture in which brush was abundant. After the change, so far as heard from, no deaths occurred."

\section{CHANGE OF CLINATE.}

Some cases of sickness, and death, have been occasioned by moving- Angoras from the South to the North during the winter months. This is not at all unreasonable when we reflect upon the radical change that the animal is called upon to undergo. Mr. S. S. McKibbin of Earlham, Iowa, has had considerable experience in this respect, and says:

"I have never lost a goat when they were taken to Iowa in the spring or summer, but have invariably lost more or less when they were received during cold weatther."

\section{PILES}

Or something of a like nature, will sometimes appear in goats, more particularly on old ones, though it will occasionally be seen on young does. A good remedy is to tie a string, tight, around the part exposed, and let it slough off. Or it might be cut off, and seared with a red hot iron, if it should bieed too much.

\section{ABORTION.}

Goats are rarely troubled with abortion unless they have eaten something that disagrees with them during the period of gestation. A sudden change of weather, over-feeding, pasturing on frosty herbage, sudden alarm, or, being chased by a dog. or wild animal, may produce abortion. 
A goat is very fond of acorns, and when these are abundant wil! often gorge themselves with them which frequently causes them to abort.

A doe if regularly fed and watered, and kept well protected from stormy weather will seldom miscarry.

\section{POISONING.}

Will occur once in a while from eating some kind of weed, or bush, but will rarely ever kill the animai.

A dose of castor oil, linseed oil or other purgative medicine, will usually afford relief.

Rattle snake bites are less frequent than one would suppose they would be in some sections of the United States. This will always cause great inflammation and will surely result in death if an artery is cut: but. when this is not the case, the animal will recover in a day or two.

The most common remedy is to pick, or puncture, the swollen part with some sharp pointed instrument, for which purpose the Mexican herders think the leaves of the "Spanish dagger," (a plant common to Southwest Texas and Mexico) is the best.

If the bite is seared with a red-hot iron, or is burned. with a lighted match, or some other flame, in order to produce a blister, it will have the effect to draw out the poison, and if this is repeated several times (always breaking the blister and washing the parts before making another) it will draw out all the virus deposited by the snake, but of course this remedy must be used immediately after the animal has been bitten, as otherwise the poison will be too much distributed through the system to be withdrawn by the action of the heat.

\section{LICE ON GOATS.}

This can not properly be called a disease as it is not constitutional, and is very similar to fleas on a $\log$, or lice on a chicken. They are easily seen and can be readily removed; but, as a general thing the American breeders have paid but little attention to the matter until quite recently, when a number have concluded it is best to dip the animal in some lind of solution to remove them. 
The only evil effects resulting from lice is a continual itching, which prompts the animal to scratch itself, with its horns, 130 doubt causing more or less loss of hair, as well as to disarrange the fleece. If the animal is relieved of this annoyance it will naturally thrive better; and, when it is intended to be fed for market, a good dipping will certainly be worth much more than one-half the feed. Indeed it is very doubtful if a goat will ever be able to reach its best condition in flesh as long as it is troubled with lice.

I sold a thousand head of young wethers to Mr. William Hatcher, an extensive feeder of sheep in Sycamore, Illinois, in 1898, that were not taking on fat as well as he thought they slould, and, after running them through a dipping vat they inproved with remarkable rapidity.

The kind of dip to use is altogether a matter of choice. Many of the sheep dips will lill lice but some are more expensive than others, and some very troublesome to prepare.

Dr. J. R. Standley of Platteville, has always found arscnic the most practical remedy, which is said to remove lice so effectually as to make it mnecessary to dip more than once in two years. One pound of arsenic to sixteen gallons of water are the proportions he recommends.

Lime and sulphur will kill them, but it is very liable to blind the goat.

Tobacco and corrosive sublimatc has been recommended. (See remedy under head of Scab).

The carbolic dips will doubtless remove then as well.

In South Africa the "Cooper Dip," is almost the universal remedy, which is composed largely of arsenic.

A great variety of these dips are on the American markets, and it would certainly be wise for breeders of the Angora goat to use them. There is very little doubt in my opinion, but that the increased growth of fleece, which is always incident to an improved condition of the animal, will more than return the cost of dipping, to say nothing of the more attractive appearance of the fleece, and the great relief that it will naturally afford the poor animal. 


\section{CHAP'TER XXIX.}

\section{CARE AND MANAGEMENT OF THE ANGORA GOAT.}

In pastures. If you are raising goats in an enclosed pasture it is only necessary to see that your fencing is of a kind that will keep them within bounds, and that you have sufficient brusli, and water for them to subsist on.

A shed or house, to shelter them in, in bad weather, is a necessity in the Northern States; but, in a warm climate this can be dispensed with, though it is better to provide something of the kind there, as well; for, a few cold rainy days will reduce the flesh on a goat much more than twice the number of days of starvation will do; and, besides this, it is always well to have shelter for them after shearing, and for the little kids during the kidding season. A very good way to economize on space in making shelter for goats is to build platforms in the order of steps, sloping to the eves of the roof. The first step, or platform, should be three feet from the ground, which the goats will soon learn to jump; the remainder need only be one foot high, which will admit of three platforms, or steps, three feet wide, for a ten foot wide, shed, seven feet high, which, practically, gives nearly twice the capacity of the ground space. Goats are very fond of a high place to sleep on, and they will all want the "upper berth."

Salt should be given at regular intervals, say once a week, unless it is arranged so they can get it whenever they want it, which is the better plan, and with a small number, is more economical. Rock salt is very good, though I have always preferred to use granulated.

With these provisions, the instinct of the animal will guide it better than you can; the fleece will be heavier, and the animal will keep in much better condition than under herd. A goat is 
PIATEXXXVI

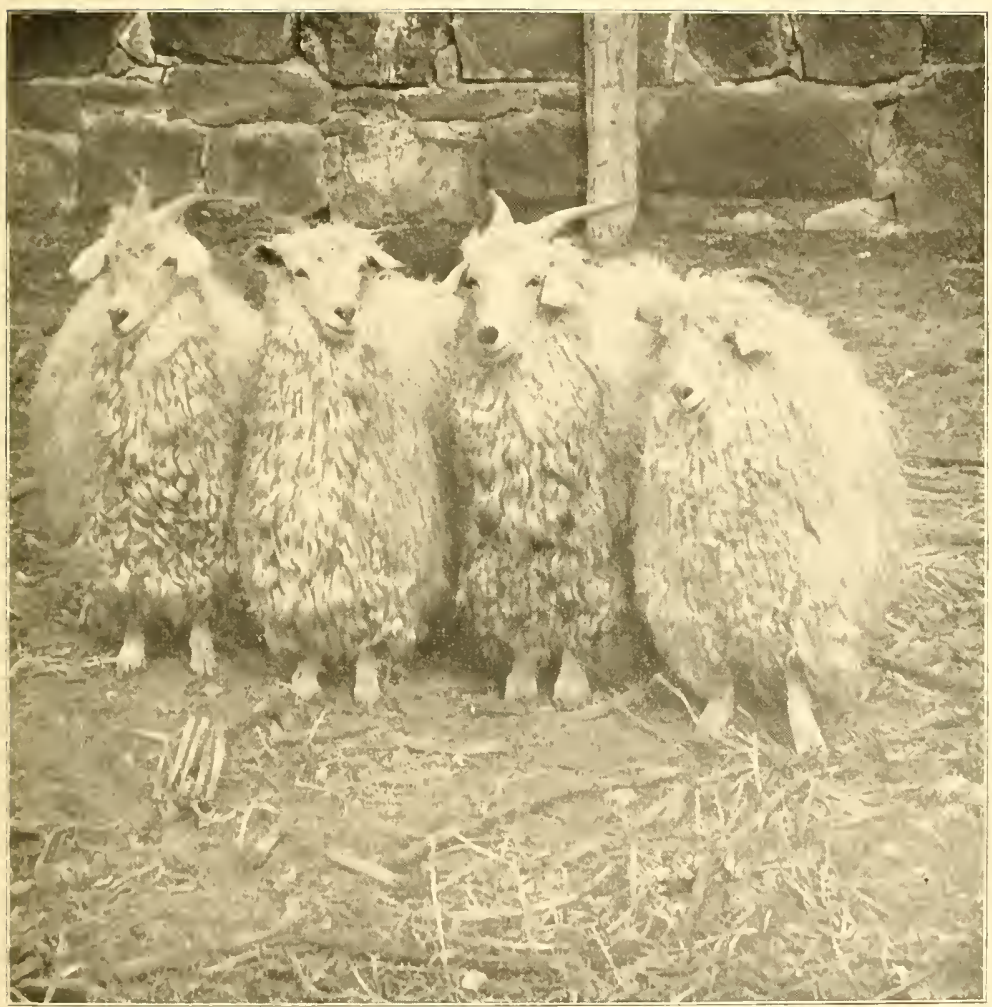

THOROUGHBRED ANGORA KIDS--A ATER WVANING.

Bred and raised by Mr. Jno. S. Harris, Oakley, Idaho, from stock imported from Asia Minor in 1876. 

naturally very domestic, and will soon become attached to homesurroundings; and, if a shed is provided will seek it whenever it is necessary, but unless it is a very bad night, they will prefer to bed outside in the open air.

Pasturing with other stock makes $n 0$ difference whatever, and is rather an advantage, as the goat will eat what a cow or horse will leave, and the removal of the brush, briars, and weeds, will make the pasturage much better. If there should be any hogs in the enclosure they should be removed during the kidding period, or they are liable to devour many of the young kids soon after birth, or during the first few weeks of their lives. They are very sleepy little things and will seek a shady spot and sleep for hours at a time until they are two or three months old when they will begin to follow the mother in her daily rounds. Sheep may be run in the same pasture with Angoras without any danger of their crossing.

Dogs are not liable to kill a goat if there are a number of grown wethers or bucks in the flock. When they make an attack, the goats generally bunch together, and the younger ones, get under cover of the wethers. whose defiant air will soon intimidate the dog: but, it must not be supposed that there is no loss from this source. Oftentines a few young goats will become separated from the flock and be killed; and, in a country where the wolf and wild-cat abound, there is considerable loss. particularly in the small kids.

Foncing made of seven barbed wires is quite close enough to hold goats provided the stays are placed, say four feet apart so that the wires will not spread. A goat will not jump over a fence but will crawl through it very much like a hog, and, unless the wires are kept tight it is difficult to confine them. A rail-fence is very good if it is constructed properly. It should be built so that the panels will not lean outward, as a goat can climb up a very steep place if he can find a foot-hold. A rockfence will not do at all, unless it has a shelf on top. The best kind of fencing is made from wowen wire, and, taking into consideration the repairs on other kinds, I an inclined to think they are the cheapest in the end. A four foot worn wire fence will hold them with perfect safety. 
Brceding. The pure-bred, or the very high-grade does, come into season between August and September, and are susceptible up to first of February. They, ordinarly, produce one kid, but will occasionally have twins. more especially the older ones. Lower grades are more prolific and some have been known to breed twice a year.

The bucks come into season between the months of July and August, and, if they are permitted to rum with the does at will, the kids will begin to come in February or March. The buck, if pure, may run with the does from first of February to first of July without risk. The common buck will breed at any time of the year, and low grade Angoras are liable to do so.

Great care should be observed in removing buck kids when they are five months old, as they are remarkably precocions, and will often breed at that early age. I have known a buck at eight months of age to produce ninety kids. The doe kids should be removed before the buck is turned into the flock as it is best not to breed these until the following season.

The poriod of gcstation is between one hundred and fifty and one hundred and fifty-five days; or, about five months.

The breeding of does should be governed by the climate in which they are being kept, and it should be so arranged that the kids will not be dropped before vegetation has fairly started. It is quite common for a doe to refuse to own or even recognize her young owing to this cause, and it is therefore best to always be on the safe side, and be a little late, rather than in advance of the season, as this will insure a full flow of milk on the part of the mother, and there will then be no losses in kids if reasonable attention is given.

One buck is sufficient for fifty does turned loose, or he will serve as many as two hundred if kept up and "hand-bred."

If there are a large number of breeding does it is well to hold the bucks in a separate enclosure and place one-half with the flock in the morning and the other half in the evening.

The bucks should be fed about one pound of corn, or two pounds of oats, night and morning during the breeding season Corn on the cob should be broken in pieces. Barley or wheat makes a good feed. The entire flock should be fed a little grain, 
in the winter months, with hay, clover, or oat straw. Com in ihe shock is very good, and with this assistance, and the freedom of the pasture, to browse on the live twigs and dead leaves, they will go through the winter very satisfactorily. Cotton sced or cotton sced mcal, and hulls, makes very good feed also.

Goats are very fond of all kinds of nuts that they can break easily. They are especially fond of the acorn, and when the yield is large will often eat too many, which is liable to cause abortion. If eaten in moderation they will do no harm.

On the open range, if goats are held under herd, and restrained of their liberty, it is proper to locate in some place where a variety of brush is to be had, and within close proximity to good clean water.

Range, and water, are the great essentials to success, and the wider the range the better. It is difficult to estimate the exact number of acres that are necessary for any given number of goats, owing to the difference in browsing facilities. The judgment of the breeder numst be brought into play in this regard. It is not an uncommon mistake for flocks to be held too long in one place. They should be moved as often as once a month, and oftener if convenient to do so, which will give the brush a chance to grow new leaves, and thus keep the entire range fresh, and in good condition.

Almost any kind of brush will answer, and if there are weeds to be had in addition, it will be that much the better.

Water should be as near to the range as possible, not over two miles from camp. It is supposed by many that goats do not require water, but this is a great mistake, and they will certainly suffer if they are deprived of it when they want it. In the winter months they will drink very little and have been known to do without it altogether for months at a time; but, it is best to give them the opportunity of drinking at least once a week during the cold weather, and oftener, as spring approaches. In the heat of summer they should have water once a day though it is quite common to only water them cocry other day.

Salt should be fed once a week, in such quantity as they will eat up clean. Between twenty-five, and fifty, pounds will be 
quite sufficient for a flock of 1500 for a single salting. It is usually placed in small piles either on the clean grass, or a rock. It is well to have a regular day to salt, and the flock will soon learn to look for it, and will remind the herder of his neglect if he should fail to remember it.

Shcltcr, from cold rind, is very necessary, and in selecting a camping place this should be taken into consideration. The slope of a hill, on the south side of a thicket of brush; or, behind a high bluff, is a very good spot for the winter; and in summer, a high position on the sloping side of a hill, is very suitable. It would be better, of course, to have a covered shelter as there are many cold rains during the year which will make goats shrink very considerably; and, the losses after shearing and in kids, during a kidding season, will more than cover the cost of building sheds if it were practicable: but, the fact of having to move camp so often presents an obstacle that is hard to overcome in this particular. The only remedy I can conceive of is, to have portable sheds made something like a tent, which could be moved from camp to camp. They can be made in sections of ten or fifteen feet, with hooks to connect them to each other, and in this way a shelter of any required dimension could be had at a comparatively reasonable cost.

Flocks are generally made up of one thousand to twelve hundred head, though it is quite easy for a herder to attend a much larger number, and as high as twenty-five hundred in one flock is not uncommon. The smaller the number the better, however, as they are more apt to receive better attention from the herder and a greater supply of food. The wethers are placed in a separate flock, usually, which is known as the "dry flock;" and, at weaning time the kids may be put with them, which is commonly done except when there are enough to make a flock of zwanlings when a few old docs are required to gradually educate the little fellows how to herd. There is no serious objection to mircd hords except at breeding time, when the brecding flock should bo kept entirely separate, and distinct from all others.

Culling out old does is an important work to attend to, in shaping up a breeding flock, and if you are not able to tell ages by an ear mark, the teeth should be the guide, and all does that 
have poor mouths should be left out, as well as any ill-shaped or poorly graded animals. It is customary to cull out does after they are six years old, as they have then seen their best days and will go down in the scale of vitality, and as producers of mohair after that period. They will make very good breeders, however, up to a much greater age, and it is not advisable to cull out well graded stock, under ten or twelve y ars, muless you want to reduce your holdings.

Brceding. on the open range, is done practically the same as in a pasture. One buck should be provided for fifty does, and they should be placed with the flock, alternately, one-half in the morning, and the other half in the evening. The bucks should be fed grain night and morning, which greatly assists the herder in making the necessary change in animals as they will cone forward for their regular feed, into the feeding pen, or corral, when they can be shut in and the others turned into the flock with very little trouble. Thirty days time is quite enough to serve all the does, which is the custom on all large ranches, when all of the bucks should be removed to either the dry (wether) Hock, or turned into a small pasture.

The kccping of bucks is a great annoyance unless you have proper arrangements for doing so. When they come in season (July 1) they will be restless and will try to rum away, which they often succeed in doing and will sometimes get with the breeding flock a month or more before they are wanted, which makes great trouble at the kidding period. The best plan is to have a small buck-pasture, made of seven barbed wires, with stays every four feet apart to secure them.

Herding is a very simple kind of work, apparently, but it calls for more skill than one would suppose, for goats, to do well. Any one can herd, but there are, comparatively, few who can herd properly, and it may therefore be called a professional occupation. The Mexican is perhaps the best class to be found for this work, as they have been more or less trained to it in their native country.

The herder should be ready to leave his camp as soon as the flock leaves the bed-ground; and, in place of staying at the 
rear end, driving them on, he should be in the extreme front, holding the leaders from traveling too fast. The animals should be allowed to scatter over as much territory as they care to, as long as they remain in sight of each other. Bclls should be placed on about one, to one hundred head, which should be fastened securely by a leather strap and buckle, around the neck of the animals. These are a great help to the herder, in many ways, and will often guide goats into the flock that may have ventured a little too far off. In the evening the counitng of the bellgoats and other noted animals, will afford reasonable assurance to the herder that he has not lost any during the day.

Loose hording, or, in other words, pernitting the goats to go and come at will, has never been very satisfactory except with a small flock of fifty, to one hundred, which can find browsing without going too far away. If a lot of kids are raised by hand they will become very much attached to a place and will rarely ever stray off; but old goats are hard to locate, and give much trouble.

Shcphcrd dogs are all right in the hands of one who understands them, but it is not wise to permit every herder to use them for they often do more harm to the goats, then a fine range will do them good. A herder, as a rule, keeps a dog to relieve himself of walking. This makes him lazier than he naturally is and in a short while will want the dog to do all the work and he draw all the pay. The most serious objection is that, dogs are seldom trained properly, or, it may be, that the herder is just commencing to teach one, which will run the goats continually, and bite them.

If the dog has been raised with the flock from a puppy it will afford great protection to the flock, and is very useful. I know of a number of ranchmen who have small flocks that they keep with the assistance of dogs trained to go out in the morning and bring the flock back to the corrals in the evening. A large $\log$ is the best, as these are less liable to be afraid of a coyote or wild cat. A puppy should be placed with a doe that is giving milk before its eyes are open. It is best to have two, as it will make them bolder and they are company to each other.

Corrals are only used for penning goats when it is necessary to doctor any of them, or work the flock. These can be made 
more cheaply out of brush, cut down and placed in a circular form large enough to hold the entire flock, with a smaller corral alongside, communicating through a gate. In case of a blizzard, or very stormy night, it is proper to corral the goats, but, ordinarily, they will do better to bed on the outside.

A cutting clute is a very necessary thing, which is, usually, placed at headquarters where the shearing is done. This is used for separating or "cutting-out" certain goats from the flock for any purpose. It is usually placed on one side of the corral, and is constructed out of $1 \times 6$ plank about three feet high, wider at the entrance, and narrowing down to about fifteen inches wide at the centre, which width is continued to the exit, where a gate is hung. giving entrance to two corrals. A man holds the cutting gate, and as the goat approaches he works so as to have the animal go into either corral he desires.

1 dipping cat is another essential on a well-arranged goat ranch. This should be placed convenient to water and constructed so that the goat can swim through a vat made narrow enough so that it cannot turn around.

At the exit an inclined plank should be placed, leading from the vat, to a dripping platform, where it can rest until the medicine has dripped back into the vat.

It is customary to make these vats fifteen to 100 feet long, about three and one-half feet deep, and eighteen inches wide on the top. tapering to twelve inches at the bottom. They are sometimes constructed out of rock and cement, which is the most economical in the end, though a little more expensive at the start. The dripping pen is also the best when made out of masonry, though it is quite common to use $2 \times 12$ lumber for the vat, and ordinary inch plank for the dripping pen, with a railing, made like an ordinary fence, to hold the animals while they are dripping.

If only a small number are to be lipped a large molasses barrel can be used and if this will not do, a small portable vat large enough for one animal can be made..

A camp rustlcr should be provided for every four flocks, whose duty is to move camp, haul water and provisions to 
herders, make corrals, hunt up stray goats and do whatever work may be necessary in connection with the ranch when not employed at his regular duties.

A herder's outfit consists of:

One smali A tent.

One baking skillet, small.

One coffee mill, small.

One bread pan, small.

One frying pan, small.

One coffee pot, small.

Knife and fork.

One large and one small spoon.

One tin cup and one tin plate.

One kettle for heating water.

One barrel for drinking wate:

The herder is supposed to furnish his own blankets and bedding. He is furnished regular rations monthly, which are as follows :

Thirty pounds of flour.

Eight pounds of beans.

Four pounds of sugar.

Four pounds of rice.

Onc pound of baking powder.

Twelve pounds of fat bacon or lard.

Four pounds of coffee.

One quarter of fresh goat meat a week, which is, sometimes, changed for lean bacon.

Stearing is governed largely by the inclination of the goat to shed its hair. In the Southern States this usually begins in February; and, in many cases, nearly all the animals will lose their entire fleece by the first of March, which necessitates shearing sometimes in very cold weather.: It is best to delay shear-

* It was Laurence Sterne, I think, who said, "God tempers the wind to the shorn lamb;" but, if this was ever a law of nature, it was changed long before Texas engaged in raising sheep, and goats, for I have seen both lambs and kids frozen to death the night after they had been shorn of their fleece. 
ing -until the weather is mild, if possible; but, inasmuch as the does sometimes begin to drop kids early in March, it cannot well be delayed beyond the first days of this month, in many of the States.

The first of April for the South and the first day of May for the North, would be a very good season if it can be so arranged.

Some breeders shcar taics a year, which they maintain is made necessary owing to the extrenc length of the hair. Others claim that goats can be made to produce more mohair if shorn twice, which is true, but it is not advisable to shear more than once unless your mohair will measure over six inches at each clipping. 'Take for instance an animal that will produce a seveninch staple in twelve months' growth: If shorn in the fall it will shear say five inches, and, in the spring,perhaps, three more; but both clippings will be very much inferior to a single clip of seven inches, and will sell for considerably less per pound; hence, what is gained in one respect is lost in another.

The shearing season in 'Texas is the harvest for a large number of Mexicans who organize in gangs, or companies, of from ten to fifty, under a captain, who enters into a contract with different owners for shearing at a stated price per head, either with board or without it, as the owner may prefer. The price is: usually, two cents per head with board, or two and one-half cents without. The captain is supposed to superintend the shearing and see that the men under him do not injure the animals. for which service he expects a little extra pay, usually $\$ 1.00$ for each thousand goats shorn.

A saccepr, and a cook, must be provided, who are paid by the lay, which is paid by the owner when board is furnished, and by the shearing company when they board themselves.

Ordinary sheep-shears are commonly used, but it would be much better to have a clipping machine to do this work for it is a very important matter to have a uniform staple, and it is impossible to obtain this by the old-fashioned shears. The loss that results from careless clipping of mohair in the Lnited States cannot be much less than twenty per cent. in noilage or short hair, 
which has been already referred to under chapter: "How to F'repare Mohair for Market."

The sacking of mohair is arranged by suspending the sack in a frame, and pressing it down by the weight of a man who gets in and tramps it as close as he can by his own weight. Ordinarily 175 to 200 pounds can be very easily packed in a six-foot burlap wool sack, which is quite enough.

An iron ring is first fastened around the mouth of the sack which is then placer in the frame.

Each class of mohair should be kept separate, both as to length of staple and fineness of fiber, and all colored flecces should be packed in a small pocket and then be deposited in one of the larger sacks.

Shoaring sheds are usually made with poles and brush to shade the men, and plank, or wool sacks, for a floor. It is, of course, best to have a proper shed, constructed with pens on the side to hold the goats, and sufficient space for packing and storing the clip.

The kidding scason is perhaps the busiest time of all others on a goat ranch, which calls for an enlarged working force, and a considerable increase in expenses. About one month before this season commences (as before stated this should be governed by the climate where the goats are being bred in), the kidding camps should be selected, and corrals made so that there may be no confusion when the little strangers begin to arrive. The camp rustler can generally find time to make these at odd times, which are constructed practically the same as all other working corrals. It is well to select a spot that will combine shade from the sun, and protection from the cold wind, for the season includes both of these extremes of weather, in many places. The corrals should be made large enough for as many does as are in the flock, with a small corral connecting to place motherless kids in. One such corral should be made for each three hundred kids, and when these have come, the flock should be moved on to corral No. 2, where three hundred more are left, and so on to the end. 
Two men should be placed in charge of each corral, the one to herd the does, and the other to attend the kids, and see that they do not receive injury, and that they all get sufficient nourishment from their mothers. If any doe should fail to suckle her kid she shouldbetied every night by the horns, and by one hind leg as well, close to where her kid is tied, until she is willing to own it. The herder should range near the corral and come into camp at noon and evening to let the kids suckle. It is, sometimes, necessary to mark the kids in order to tell them from others, but this is only resorted to when the doe is a poor mother. Different colored paints are used, placed on certain portions of the body, always observing to mark the kid with the same colored paint and in the same place as the mother.

In case of twin kids, one is usually given to some doe that may have lost her own, which she will soon learn to recognize if the plan of tying her, over night, is practiced for a few nights.

The most common way of holding kids is. tying them by one leg to a peg, driven into the ground, even with the surface, so that the string will not become entangled. This string should be of hemp, about twelve or fifteen inches in length and should be changed from one leg to the other whenever it begins to bind. It is not unusual for kids to suffer very severly if this is not attended to properly, and in many cases the little animal will have a very sore foot which will often slough off. When kids are two or three weeks old they can be turned loose and allowed the freedom of the corral.

A much more humane way of confining them is in a pen. made about three feet square by about sixteen inches to twenty inches high, which the mother can easily jump into and is quite high enough to hold the little animal until it is large enough to be turned loose in the corral.

Kids.-The kids should not be allowed to go out with the flock until they are about two months old, as they are liable to steal off into some thicket of brush and be lost.

As soon as it is practicable to do so, the kids in different corrals should be bunched together and thus reduce expenses in labor. Great care should be used to keep the doe with the 
kid for some time after birth, so that she may become fully acquainted with it, which she does very soon through the scent, and will always be able to pick it out of any number in this way.

Kids that are dropped during a cold, drizzling rain are almost certain to perish, and hence, a shelter will pay very well at this season, which has been fully explained under my treatment of "Sheds."

I'LATE XXXVII.

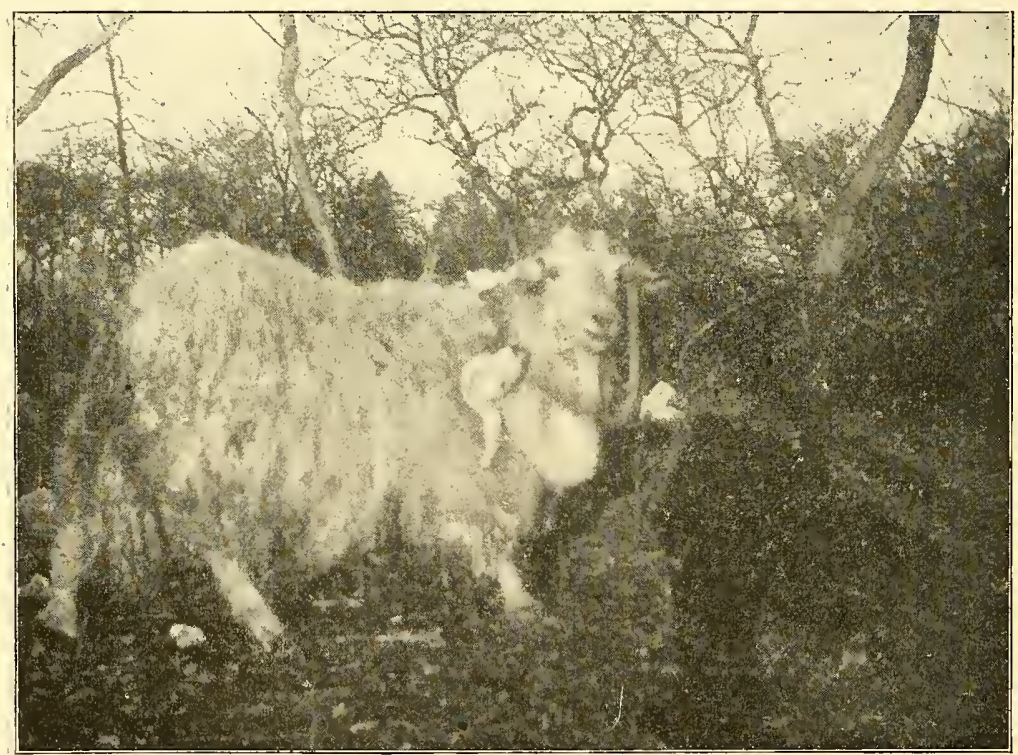

A DOE BIINGING HER KID TO CAMP.

This is a cnstom followed by liexican herders. The kid is tied by "all fours," and suspended on the neck of the mother. as shown in the plate.

When kids are dropped on the range the mother should not be disturbed, and if inclined to be restless, she should be tied either by the horns, or by one leg, to some convenient tree, near her kid, until the flock is ready to return to camp, when the camp helper should come out and assist in collecting up those that have been dropped.

A common way of conveying them to camp is by tying their legs togetter and suspending them on the neck of their nother, 
as shown in plate XXXVII. This is a very good way to keep from mixing them, and it is not at all inhuman, as the little things do not seem to suffer any evil effects from it.

Castrating should be done as soon after the kid is able to stand up, as practicable-say in one week after birth. The end of the bag is first cut off with a sharp knife and the little seeds drawn out until the tender cord that holds them breaks asunder. This operation seems to give little or no pain when the animal is less than one month old, but the longer it is delayed the more painful and dangerous the operation becomes. A lot of early altered male kids are hard to distinguish from the females when they are a year old, while the late altered ones look "staggish," and resemble the buck somewhat.

Docking, or cutting off the tail, is unnecessary.

Marking, is commonly done by cutting off a part of one, or both, ears, which greatly disfigures the animal, but this makes no material difference, except with fancy stock. A system of notches is sometimes used to distinguish age an sex which is very useful in cutting out from a flock as the animals pass through the chute. To tell sex alone, it is quite common to alternate the ear mark on the doe, and wether, kids, for instance: The wethers are marked in the right ear, and the does, in the left.

Punching a hoic in the ear has been abolished for the reason that the goat is liable to have the ear torn by catching it in the brush.

Tattooing is a very good method to use in nurking purebred stock, which can be done wit! colored inks on either ear withont the slightest disfiguration.

Branding on the cheek, or nose, in addition to some kind of ear-mark is sometimes practiced, and is perhaps the surest way of being able to distinguish a goat that has been stolen, and the ear-marlice changed.

IVild animals that depredate upon goats consist mainly of the corote, or prairie wolf, and wild cat. The fox will sometimes steal a kid but is not considered very troublesome. 'The coyote is perhaps the worst of all owing to his greater cunning, and 
strength. They will not molest a flock in camp very often, though they will occasionally venture up to the outer line, and catch a goat while the herder is asleep. A camp fire will often keep then away. They are more to be dreaded when a bunch is cut off from the flock and are lost for a night or two. It is on these that the coyote gets in his work. He will, generally, get them scattered and destroy the last one if they are ont a few nights. All this talk about goats being able to defend themselves from the attack of a wild animal is news to me. Some writer in Dr. Hayes' book claims that he put some goats in his flock of sheep to protect them from wild animals. If this is a fact they must have been a different species of goats from the kind that are raised in Texas. The loss from this source has been fully five per cent., on an average, and has been nutch greater than this with some individual flocks.

The lobo, a very large kind of coyote, will often do great damage to a flock. The use of strychnine is a very good way to get rid of them, but, both the coyote and lobo, are very cunning about taking the bait, and it should be put in the meat in snall capsules. The carcass of a dead horse is a good thing to poison on a range, and will often remove a number of these pests, if well poisoned with strychnine.

Trapping them is often resorted to, which is followed as a steady occupation by quite a number of men, who receive pay by the head from the owner of the range, in addition to a bounty offered by many of the States. 


\section{CHAPTER XXX.}

NOTES FRON PRACTICAL BREEDERS.

For the purpose of learning with what success the breeding of the Angora goat had been attended, in different parts of the Lnited States, as well as the different customs of breeders in handling the animal, I sent out the following list of questions:

1. Do you find ready sale for vour wether goats?

?. What country would you prefer to import new blood from.

3. Are you in favor of a register for thoroughbred goats?

4. Have you found your section well adapted to raising goats?

万. Do you herd your goats?

(j. Do you run them in a pasture?

¿. Do you pen them every night?

8. Do you have sheds for them in winter?

9. Have you found goats better able to defend themselves from wild animals than sheep are?

10. Do you feed your goats in winter?

11. Have your goats ever been troubled with disease?

12. Do you practice dipping for lice?

13. Have you found goats objectionable to run with other kinds of stock?

14. Do you shear your goats once or twice a year?

15. What do you consider a fair crop of kids from 100 does?

16. Do you have many twin kids?

1\%. Do you have many black, yellow, or off-colored kids?

18. What has been your percentage of loss from death per vear?

19. Are goats used much in your State for clearing brush land? 
To the foregoing questions I received the following replies:

Rev. D. S. Babb, Sonora, Texas, says:

"I only herd my goats when kidding.

"A six-wire fence will hold them.

"I pen them at night only in stormy weather.

"Have never shedded them.

"I have seen as many as 2,000 goats in one flock.

"If goats are not kept under herd, or very carefully watched, I estimate ten per cent. loss from wild animals, and strays.

"I do not dip for lice regularly.

"I think it is best to shear twice a year.

"I breed generally 25 th October.

"I do not have many twins from high grades, and but a few offcolored.

M. R. H. Wyatt, Sonora, Texas, says:

"I have found our country very good for goats.

"I only herd during kidding time.

"I loose herd them at other times.

"A seven-wire fence will hold goats, or a five-wire fence with pickets, or rock underneath, say two feet high.

"I always pen at night. Have never shedded.

"I find goats are good to protect the young kids from attack of dogs or wolves.

"I have never fed any in winter.

"I have never dipped for the lice.

"Have never had any disease.

"I usually breed October 25th."

Mr. John Brown, Sonora, Texas, says:..

"We have, in recent years, had no trouble in selling our mutton goats to feeders, but formerly had very little demand for them.

"Am in favor of importing new blood from any place that we car find better stock than we have already.

"I keep some goats in pasture, though most of them in flocks. My fence is a seven-barbed wire.

"I never pen goats except when I am working with them in kidding time. I do not shed them, but it would be the better plan.

"I run 1,500 head in a flock.

"I never feed, but it would be of grent advantage sometimes.

"I estimate cost of running goats 40 cents to 45 cents per head per year.

"I dip for lice. 
"Begin kidding 1st of April.

"We have generally twenty or twenty-five per cent. twins.

"Very few colored kids.

"Our losses are about one per cent. from death.

"A goat will shear one pound more that is sheared twice a year. but it will not sell for as much by 6 cents to 10 cents per pound as if slieared only once."

\section{Mr. H. IV. Galbraith, Montell, Texas, says:}

"We sell muton goats readily at either local markets, in San Antonio, or Kansas City.

"We do not need any new blood from either Turkey or South Africa.

"We run from 1,250 to 1,500 in a flock.

"We estimate 48 cents per head the expense of keeping goats, including shearing, kidding, and range.

"We sometimes dip for lice, though not as a regular thing. When we do, we use lime and sulpluur.

"We begin breeding the 1st to 20 th of October.

"Have very few twins and seldom any off-colors.

"Wre have less than five per cent. losses, not including those killed by wolves.

"I raise dogs with my goats which I find a very great advantage, enabling me to bed out regardless of the wild animals."

Mr. Wm. M. Laudrum, Laguna, Texas, says:

"We have no trouble now in selling all our wether goats.

"I am in favor of importing new blood from the Cape of Good Hope.

"I think it will be a very difficult matter to have a register for Angora goats.

"I have found them better adapted to this part of Texas than any other kind of stock.

"Ve herd our goats sometimes and pasture sometimes.

"Our fencing is made of barbed wire.

"We only pen at times.

"We keep anywhere from 500 to 2,000 in a flock.

"The goat is, perhaps, better able to protect itself from wild animals than a sheep, but will not do so always.

"Foot-rot is the only trouble we have had in the form of disease, and this only occurs where the pasture is wet or muddy.

"It is well to dip goats in tobacco and corrosive sublimate, dissolved in salamoniac, for the lice. (See receipt under diseases.)

"Low-grade goats will increase at the rate of 125 per cent. to 150 per cent. High grades, eighty per cent, to 100 per cent. 
"Pure breeds have twins about one to ten does.

"Low grades will often have off-colored kids.

"Percentage of loss from death is about three to five per cent."

Mr. Jeff Pepper, Rock Springs, Texas, says :

"We run 1,200 head in a flock.

"Cost of keeping goats we estimate at 25 cents per head.

"We begin breeding October 15th."

Mr. Henry Fink, Leon Springs, Texas, says:

"We would prefer to pasture goats, but cannot do so on account of wolves.

"We run them in flocks from 800 to 1,200 .

"Wolves seem to kill goats as easily as they do sheep.

"We only feed poor goats in winter cotton seed.

"Estimated cost of running goats, 20 cents per head, including sheáring.

"We begin breeding October 1st.

"Our losses average two per cent., except losses from wolves."

Mr. J. M. Arnold, Montell, Uvalde Connty, Texas, says:

"We have no trouble to sell wether goats anywhere, but usually shif: to Chicago.

"I do not think we have any need to import new blood, as I believe we have as good as there is in Turkey or South Africa.

"We have found this country excellent for goats.

"We run from 1,200 to 1,600 head in a flock.

"We only feed one stud flock in winter. We feed corn and wheai bran.

"We estinate cost of expense of handling goats 50 cents per annum. including shearing.

"We occasionly have sore feet, owing to rainy weather. They should never be penned in a muddy or wet pen.

"We dip sometimes for lice. Use 'Cannon's Dip.'

"We find goats advantageous to pasture with other stock.

"We shear in October" and March.

"Begin breeding October 10th.

"We have very few twins of late years. No off-colors to speak of.

"Some kind of shelter for goats in cold rains in winter, would be of great advantage. If kept dry, cold will not injure them. TVe bed flocks in camp, and nerer pen except to count, or shear. or when kidding.

"If they are penned in a damp corral they will take what is termed 'foot evil.' It is not 'foot rot,' but a very troublesome disease of the 
feet, and they are never troubled with it when they have a dry placc to travel and herd over.

"I have found Angora goats to be the most profitable animal we could raise here. Have been breeding them for twenty years, and I look for a grand future for the business in the United States.

"We have never used them for exterminating brush but have observed they will make a grassless thicket a meadow in a few years. Mountain ranges are greatly benefitted by goats, as regards growth of grass."

Mr. C. Dissler, Juno, Texas, says :

"We do not dip for lice, but after shearing use coal oil, which we apply with a rag, and find it removes them.

"We breed October 1st.

"Have but few off-colored kids; some red ones.

"Our losses are not heavy."

Mr. James Patterson, Junction City, Texas, says:

"We have had no trouble in selling mutton goats.

"We run 1,500 to 2,000 in a flock.

"We estimate 60 cents per head the cost of keeping a goat per year.

"IVe use sulphur and lime when dipping for lice.

"We begin breeding November 10th.

"Our losses from death are about one per cent.

Messrs. Doughten \& Luttrell, Lipan, Texas, says:

"We find a ready market for our mutton goats at Fort Worth.

"We pasture our goats only in winter. In summer we run them in flocks from 700 to 1,400 head.

"We do not think there is much difference between goats, and sheep, as far as dogs and wild animals are concerned.

"We feed cotton seed and hay in winter, costing us 20 cents for two bushels seed for the head.

We begin kidding generally by March 10th."

"Out of 600 does we had one pair of twins this year, and four black or off-colored ones."

Col. IV. W. Haupt, Kyle, Texas, says:

"For a goat-proof fence, I make one of barbed wire, with the three bottom wires five inches apart, then widen. ground.

"I feed in bad weather cotton seed or corn, sprinkled on the

"My goats never cost me a cent. I allow them to run loose. 
"I dip in anything but a sulphur dip.

"I have found goats an advantage with other stock.

"We shear twice a year or we would lose goats by tangling up in brush and briars.

"We begin breeding as soon as they come in season in the fall.

"Have twins very seldom in pure and high grades. No off-colored kids except from goats under third cross.

"Never saw a goat die."

Mr. Geo. W. Baylor, Montell, Texas, says:

"I keep some goats in a six-barbed wire fence, but herd the most of them.

"I only pen my thoroughbreds, and shed them as well.

"I run 1,200 to 1,500 in a flock.

"No sickness or disease, but have had some few die from poison.

"We use Zenolium, or Little's Dip, for lice.

"They do finely with cattle, and no drawback to the cattle.

"We kid in March.

"The higher the grade the less twins. Three per cent. off-colored in grade flock. None with the thoroughbred flock."

Hon. B. L. Crouch, Pearsall, Texas, says:

"I am no longer in the goat business, but cheerfully give my experience when I was handling them.

"I never had any trouble to sell fat goats.

"From Oakville, to El Paso, I think, equals any place in the world for raising goats.

"A seven-barbed wire is enough to pasture goats.

"I always bedded my goats. Never penned them at night.

"I used to run 1,500 to 2,000 head in a flock.

"As to their self-protecting quality, I found that they could outrun sheep, but wolves are very fond of them.

"Cost of keeping goats from 30 to 40 cents. It depends on locality.

"I used to dip in sulphur for lice.

"I don't think it is proper to run sheep and goats together, the latter travel too fast.

"Kidding should begin here about March 1st.

"Ninety to 100 per cent. is an ayerage kidding.

"I do not recollect my percentage from losses. I owned goats from 1872 to 1893 .

"If we could get rid of the wild animals, Texas would be a paradise for the goat.

"I think the present tariff on Mexican breeding goats should be removed in order to enable breeders to get some does from that country free of duty. 
"I also favor a high rate of duty on mohair to encourage the American breeders of goats. We ought to raise all of our mohair and goat skins, and can easily do it with proper tariff to encourage the industry.

"It seems to me that associations should be formed to bring in more thoroughbred goats, as was done in the forties and fifties by the Illinois farmers with the short horn cattle, which has resulted in such great benefit to them and the United States at large."

Mr. D. G: Avery, Marathon, Texas, says:

"I find market for wether mutton in El Paso without trouble.

"Our mountains are especially fine for goats.

"We run 2,000 in a flock.

"Cost of keeping we estimate at 30 cents per head.

"I do not dip for lice but think we ought to do so. I favor lime and sulphur.

"We begin kidding March and Aprii.

"With large flocks, ninety per cent. increase is about our experience. In small flocks the increase should be greater.

"Our losses are greater some years than others, but usually very small."

Mr. J. W. Garrett, Mountain Home, Texas, says:

"Our country is adapted to raising goats as well as any I have ever seen.

"We run from 1,500 to 1,750 in a Hock.

"I have no sheep, but the wolves bother my neighbors' sheep much more than they do my goats.

"The cost of running goats depends on how many you have in flock. We estimate about $12 \mathrm{I} / 2$ cents.

"We begin breeding October 15th to November 1st. triplets.

"About two thirds of our old does have twins, some of them

"WVe have some yellow kids."

Hon. R. H. Lowry, Camp San Saba, Texas, says:

"We run 500 to 1,500 head in a flock.

"The only objection I see to goats in a pasture with other stock is they tramp the grass down.

"We begin breeding October sth to 10 th.

"We have very few twins and very few off-colored kids."

Mr. H. B. Marshall, Austin, Texas, says :

"We have no trouble to sell all our mutton goats in Austin.

"Am building a cedar picket fence to pasture my goats. 
"I only have about 500 head.

"My kids generally come about March 20th.

"Do not have many twins; and, about one in a hundred offcolored.

"My losses have never exceeded two per cent."

Mr. J. D. Hunter, Junction City, Iexas, says:

"The altitude of our country is 1,800 feet above sea level.

"We have a wire, and picket, fence.

"We begin breeding in October.

"A crop of kids with us is often 150 per cent.

"Our losses are nothing except by wolves or cayotes."

Mr. Tom S. Evans, Exile, Texas:

"We have found ready sale for mutton goats in local markets and Kansas City.

"The altitude of our section is 1,200 to 1,400 feet.

"We herd mostly, but pasture some.

Our pasture fence for goats is a seven barbed wire, with stays every three feet apart.

"We only shed occasionly.

"We run 1,000 to 1,500 , but prefer 1,000 in a flock.

"We only feed a little in winter. Sorghum and cotton seed.

"We estimate cost of keeping goats at 30 to 40 cents per year.

"We begin kidding about March 20th to 25th.

"We have from twenty-five to fifty per cent. of twin kids.

"Seldom any off-colored; a few black ones once in a while."

Mr. H. T. Fuchs, Tiger Mill, 'Texas, says:

"I sell my wether goats as mutton in my own neighborhood, without any difficulty.

"I am in favor of a register, if it can be conducted honestly.

"My goats always come to the pens at night.

"Small flocks do better than large ones.

"I have lost heavily from wolves.

"We sometimes cut live oak bushes in winter to feed.

"Have had some to die from eating green persimmons.

"Have never dipped for lice, but think it is a good plan.

"I find goats a benefit to other stock rather than a disadvantage.

"We shear in September and March.

"We have nothing but pure white kids."

Mr. Wm. R. McKee, Junction City, Texas, says:

"I allow my goats to run loose, except during kidding time, when I place them under herd. 
"My pasture fence has only six wires.

"I pen only for the purpose of doctoring for screw worms, or during the kidding period and for shearing.

"The cost of keeping my goats does not exceed 20 cents per year per head.

"I begin breeding by the 15 th to 20 th of October.

"Loss from death is not very great.

"I consider my goats as of great benefit to my other stock in keeping down underbrush, and eating up noxious weeds.

"I have never had any difficulty in selling my wether goats for mutton purposes."

\section{Hon. Thos. H. Tongue, Hillsboro, Oregon, says:}

"Our pasture fence is principally rail the corners kept straight with stakes wired together.

"We pen and shed only in the winter. I have found that they require shelter from rainy weather more than sheep do.

"Have had much less trouble from dogs than with sheep.

"The cost of keeping is very small. We consider it practically nothing. brush.

"We feed but very little in the winter, and then only straw and

"Have never known of any disease among goats in this state.

"I have never had occasion to dip. I feed sulphur with the salt I give them and this seems to keep them free from lice.

'Have had best success in breeding commencing latter part of November or first oi December.

' $M y$ percentage of kids has been very small, but $I$ attribute it to cariessness of ny hired hands-a want of knowing how to manage them.

"Have tery few off-colored kids.

"Very few losses from deatlu. It is rare for a goat to die except frrim old age."

Mr. Geo. A. Houck, Engene, Oregon, says:

"'T'lie altitude of our country is 500 feet, and is well suited to the Angoras

"We fence with four boards and wire, or six rails, also two boards and tour wires.

"We only shed our namnies.

"We usually keep 50 to 150 namies, and 500 hundred wethers in a flock.

"The wethers will protect themselves against dogs and wolves, but the namies will not.

"We only fead oak brush in winter. 
"We figure on paying expenses with 40 cents per head.

"Have always sheared once, but intend to shear twice hereafter.

"I begin breeding November 10 th to 20 th.

"Have had no off-colored kids in ten years.

"My losses are light, chiefly from old age and accident.

"As to importing new blood, if we could get good ones, it would be a good thing to do; but if we canrot, we can make them good enough from what we have."

Mr. Scott Obye, North Yamhill, Oregon, says :

"We have our fencing of rails, or planks, whichever is most convenient.

"We do not pen at night, and only shed the goats in bad weather.

"We run 1,000 head in a flock.

"We feed only oak brush in stormy weather.

"We consider the cost of keeping gcats nothing.

"We have been troubled some with foot-rot.

"We consider goats a benefit to other stock in same pasture.

"We begin breeding the last of September.

"Have twins only from grades; none from thoroughbred stock.

"Have only had one colored kid in seven years' breeding.

"We have no losses."

Mr. D. A. Walker, Carlton, Oregon, says:

"I sell my wethers to my neighbors.

"I run my goats loose. Do not pen, except in winter, when I pen and shed them.

"I only cut brush for them to eat in winter.

"Cost of keeping nothing, except shearing, 5 cents per head.

"I breed November 1st.

"Have only a few twins. No off-colors.

"Goats that are starved during the summer are liable to take scours in winter, and, owing to the impaired condition of their constitution, may die. Ny father lost quite a number one winter from this cause.

"I keep my goats for shearing, not for grubbing."

Mr. O. Dowell, Florence, Oregon:

"We have never had occasion to sell any of our wether goats.

"Fencing for goats needs to be built up perpendicular; matters not what it is made of, if not rock.

"Sometimes I feed hay and roots in winter.

"Twenty-five cents per annum will cover expense of running goats.

"I use a tobacco dip for lice.

"All of my two-year-olds bring twins, and sometimes three and four. 
"Have very few off-colors.

"My goats are very large: wethers weigh 185 pounds and does. 145 pounds grown.

"They shear two and one-half pounds for does, and five pounds for wethers.

"My ranch is about four miles from the ocean. The bottom land is only forty feet, and the hill land 100 to 300 feet above sea level.

"I began keeping goats a little over three years ago. The increase in that time has been seventy-five head from five old nannies. Over half my kids have been males. When I got them they had foot rot very badly. It took me four or five months to cure it. I used vitrol and pine tar. Since cured of that they have bren perfectly healthy in every respect. Some of my neighbors brought in some goats that died from leeches in their liver.

"Some of my goats take the billy in August and September and drop kids in January, and some bring kids again in August. Some that have twins in winter, bring only one in summer. I had one nannie that had four kids at one birth, and several that had three."

Mr. A. Blackburn, North Yamhill, Oregon, says :

"VVe have sheds where our goats can go if they care to have shelter.

"We are not troubled with wolves here, but in Southern Counties, goats are raised where sheep have been destroyed by wolves.

"We feed straw in winter on rainy days.

"We estimate cost of keeping 25 cents per head per year, if they have a good brushy range.

"IVe use the McDougal Dip for lice.

"Shearing twice should be given up by all breeders as it is ruining the market.

"WVe begin breeding here November 5th.

"We only have a few twin kids, and sometimes a sandy color.

"Our death rate is about four per cent."

Mr. J. M. Hassler, Larwood, Oregon, says :

"We have a rail fence around our goat pasture.

"Ve have sheds for them to go to at will.

"We feed only straw in bad winter weather.

"We estimate the work they do inclearing land more than pays. for the expense of keeping them.

"We use Wakley's Dip for lice.

"We breed in November.

"We do not have many twins, and occasionly a black or yellow kid.

"We lose about three to five per cent. from death in young stock. 
"We are troubled with foot rot some, caused by too much damp: low pasture. I have a remedy and mine have not been troubled for two years."

Mr. J. H. Hawley, Monmouth, Oregon, says:

"We sell wethers readily to farmers.

"We have plank fencing for goat pastures.

"We only pen in case of storms.

"We feed only when snow is on the ground. Feed straw and chop grain.

"We don't figure that goats cost us anything but salt..

"We breed middle of November.

Mr. Frank H. Rogers, Gardiner, Oregon, says:

"'The altitude of our section is only 200 feet.

"Our goats run loose. We pen and shed them every night.

"I have found them very much more able to protect themselves against dogs than sheep are. They generally take a stand, and intimidate a dog by the bold front they all present.

"In winter I feed clover and timothy hay.

"I estimate cost of keeping goats 25 cents per head.

"Have had some liver fluke or leacl, mange and hoof rot.

"We use different kinds of sheep dip for lice.

"We begin kidding usually the first of April.

"Have but few twins. No off-colored kids."

Mr. Oscar Tom, Angora, Oregon:

"I only have a small number (about eighty does), and usually sell all my male kids as bucks, consequently I do not sell wethers.

"My section is mountainous and I do not herd my goats.

"They come home at night, and if they are attacked by animals of any kind will rum home in the day time.

"I estimate the cost of keeping then as nothing.

"The only disease I have had to contend with has been foot-rot, and the occasional poisoning of one from eating poison ivy.

"I consider goats advantageous to run with other stock.

"I begin breeding usually the first of November.

Mr. Masters, Cleveland, Oregon, says:

"I find ready sale for all my wethers to farmers, who use them for clearing brush land.

"I fence with pickets, five feet high

"Foot rot is all the trouble we have had in the form of siçkness or disease. It seems to be the same as the sheep have. 
"I breed September 15th.

"I cull and sell all my old goats, which keeps my losses small from death."

Mr. James McDonald, Morrison, Oregon, says:

"I find ready sale for my wethers to my neighbors, who use them for mutton.

"The altitude of our section is 250 fiet.

"I make my pasture with poles woven with wire.

"They come to the shed themselves.

"I do not figure that my goats cost me anything for keeping.

"Have been troubled some with scours, lately.

"I don't dip for lice, but think I ought to.

"I breed November 10th."

Mr. N. Woodward, Dallas, Oregon, says:

"Pasture fences made from rails are used; also from posts. I like the latter best.

"I only pen and shed my goats in winter.

"I find that a bunch of wethers, with a lot of does, is a safeguard against attacks from wolves.

"I feed hay and straw in winter.

"I think goats should not be herded with sheep.

"I breed the first of November.

"I have no black or off-colored kids.

"I regard the Angora goat as being a very useful and valuable animal, not alone for their wool, but for their meat as well, and for clearing land."

Mr. IV. D. Claggett, Salem, Oregon, says:

"I make fences out of barbed wire ard boards.

"I find that old goats will defend themselves against wolves. but they are bad on kids.

"I do not shed, or pen, them at night.

"I feed nothing but brush.

"I estimate they cost me nothing to keep.

"Have had some dysentery.

"I dip with tobacco for lice.

"I breed in November.

"Twins only come from my grade goats.

"I have a few yellow and blue kids.

"In small bands of goats the loss is trifling." 
Messrs. Conklin Bros., Newville, California, says:

"In fencing to enclose goats we use three seven-inch boards and one barbed wire. Woven wire is taking the lead and is being used in preference to anything else.

"We run our flocks in lots of 800 or 900 head.

"We have found grown goats more capable of resisting dogs than sheep are, but the kids are liable to be destroyed by them if away from the flock.

"We find a ready market in San Francisco for all the wether goats we wish to sell.

"We estimate the cost of keeping goats in our section at about 25 cents per head per year.

"We consider goats are a great advantage to run with other stock, rather than a disadvantage.

"We begin breeding our goats November 20th.

"We think five per cent. should cover all losses.

"At the present time (July 15), we liave our goats on the summit of the coast range, at an aititude of 7,900 feet, where all vegetation is green and growing, and the climate is very cool and water as cold as ice. Snow is on the ground and the goats delight to wallow in it. This, we think, causes the mohair to grow earlier and faster, than in the warm climate of our winter range in the Sacramento valley. It seems that nature tries to provide a coat to correspond with the climate."

Mr. E. I. Maze, Upper Lake, California, says:

"I generally run 1,000 to 1,500 head of goats to a flock.

"We estimate cost of keeping them 20 cents per head per year.

"We think the goat is much more capable of resisting the attack of dogs, or wild animals, than the sheep is.

"We begin breeding about November 1st."

Mr. J. M. Wimmer, Millville, California, says:

"We only have occasion to feed a little during the winter months, which is generally our older goats.

"I figure the cost of keeping 50 cents to 60 cents per year.

"Goats sometimes get poisoned, but nearly always will recover from it.

"Our kidding season begins the middle of April.

"If our goats are in good condition, we estimate on a loss of three per cent. to four per cent. per annum."

Mr. F. G. Smith, Skaggs Springs, California, says:

"Ifind ready sale for wether goats in San Francisco.

"I only pen my goats during kidding time. 
"I shear one time-in January or February.

"We aim to have our kids come after March 15th.

"We have more twins some years than others.

"Have never had one black kid in seven years.

"Our percentage of loss is very small. Mainly old does.

"Fencing.-Many people have the idea that goats are very breechy, but it is not so. My first enclosure was a board fence, four and onehalf feet high, such as is seen along railroad lines; boards sixteen feet long, and posts eight feet apart, five boards to a panel. I used wire on one occasion and first put my posts twelve feet apart, but found that the goats would crawl through, so I placed a post in between the others making them only six feet apart, which answered well. Picket fences are largely used in California, made from redwood timber, split in small sizes and driven in the ground, six to the yard. A common brush fence, properly constructed, will turn goats.

"Kidding.-I turn my goats out early in the morning and drive them back about $9 \mathrm{o}^{\prime}$ clock, where they remain until $4 \mathrm{p}$. m., when they are allowed to feed again until sundown. As most of the kids come during the time they are in the corral, we have very little trouble in 'packing' them to the corral. We have a specially prepared place for the kids inside of a rough building which consists of a row of stalls $3 \times 3$ feet, into which a doe and her lid are shut up for the night. If the kid has not suckled, it is assisted or forced to do so. This building opens into a small pasture, as the does have little desire to leave their kids for several days, they are turned into this pasture with their kids and looked after morning and evening to see that they suck. After a short time the does are turned into the range and the kids are allowed to run in the pasture until they are two months old, when they are placed in the flock with their mothers.

"Last year I sent a carload of fat wethers to San Francisco, which netted me $\$ 2.40$ each for the meat. They were all large, heavy-fleeced animals. I had arranged in advance with a butcher to handle them, for which service he received 50 cents per head.

"I have heard of some shipments to Sin Francisco that did not net the shipper 75 cents per head, owing to the fact that no arrangement had been made about selling them."

Mr. C. P. Bailey, San Jose, California, says:

"We run our flocks in lots of 1,500 to 2,000 head.

"Have found goats more capable of resisting wild animals than sheep are.

"We sometimes feed kids alfalfa in winter.

"We estimate cost of keeping at 60 cents per head per year.

"We sometimes dip our goats for lice. Use black-leaf tobacco dip.

"We begin breeding October 1st to November 25th." 
X. Y. Z., Ono, California, says:

"We run our goats in flocks of 300 .

"Have two large sheds connected with our corrals.

"I lose quite a number from wild animals.

"Cost of keeping 5) cents to $\$ 1.00$ per head, according to cost of labor.

"Have had goats eleven years and never had any disease among them.

"I keep cattle on same range with my goats and find they both get along well together.

"We shear twice a year, as snow hangs in the wool in winter in great balls if allowed to get long.

"We have kids come in April.

"The poorest wooled does have mostly twins.

"Have a few red kids.

"This section of California is mountanous and every one has a small flock of goats from twenty-five to 300 head.

"The last few years cayotes have been very destructive. Some people raise a dog with the kids and it terds them well when there are only a small number.

"When we have a heavy crop of black oak acorns, I do not raise over fifteen per cent. of my kids; the most of them die as soon as born, or are born dead. I suppose it must be caused by the acorns,as I never loose any, or have any trouble, except following a heary crop of these acorns. A few acorns will not affect them serious!y.

"Butchers buy all our wethers in this country, and pay $\$ 1.50$ to $\$ 2.00$ each for them. I deliver mine dressed, at the mines, near here, and get 5 ccnts, to 6 cents, per pound. and get about 30 cents for my skins, sheared.

"I have never bought a pure bred Angora buck.* I buy or trade for one every second y'ar, and get the best I can in this part of the country."

Mr. Wm. Richter, Ico, California, says:

"We find sale for wether goats anywhere in the State

"Stock goats sell for $\$ 2.00$ to $\$ 3.00$ per head.

"The altitude of our County is 1.000 feet above sea level.

"We herd our goats with a dog, and run them in flocks of 1,000 head. They herd them and bring them home every night, and keep wild animals from bothering them.

(*Foot note- - If the reader will observe XYZ's report on shearing, he will sec that he only receives two pounds from wethers, one and onehalf from does, and one pound from. kids, which is no doubt owing to the need of purer bucks.) 
"Have found goats more capable of defending themselves against dogs than sheep.

"We estimate cost of keeping goats nothing.

"We begin breeding in October.

"We have a great many twin kids every other year.

"We figure our per cent. of loss nothing from death."

Mr. Jas. H. Dunison, Upper Lake, California, says:

"We have only found a market for our wethers in late years. We sell at San Francisco, now, without trouble.

"I am decidedly in favor of importing new blood. That is, what is needed.

"We run them in flocks of 1,000 head.

"We find them more capable of protecting themselves from wild animals and dogs than sheep are.

"I do not feed in winter but I think it will pay to do so.

"I estimate cost of keeping 15 cents to 20 cents per hear.

"Regarding disease, goats sometimes get poisoned. They call it blind staggers."

Mr. Philo Ogden, Upper Lake, California, says:

"We find ready sale for our wethers at home markets.

"Our altitude is -2,000 feet above sea level.

"We pasture our goats and use board and picket fencing.

"We estimate cost of keeping, per year, $\$ 1.00$ per head.

"We begin kidding April 1st.

"We have about ten per cent. twins.

"No colored kids."

Mr. Jacob Oaks, Paskenta, California, says :

"IVe find market for our wether goats in small towns.

"Our altitude is 1000 feet.

"We have known them to bunch up and fight dogs.

"We estimate cost of keeping, 15 cents per head per year.

"We begin breeding October 25.

"We have a great many twins and very often triplets.

"I started in with only a few goats for meat purposes, and soon had quite a flock of them which I let out on shares, as I have no brush land on my farm now."

E. R. Williams, Redding, Cal. says:

"Am in favor of starting a register and importing new blood wherever we can get the best.

"Any ordinary close fence will hold goats. 
"I regard them an adrantage to other stock, rather than a disadvantage when they are liept in the same pasture.

"We begin breeding in October.

"Some of my neighbors are bothered with "crooked kids." They say it is acoms. I think it comes from in-breeding.

"I have dogs trained to stay with my goats. It is a great success with small Hocks.

"We have but rery few losses from death. Have lost some from eating buckeye and milk weed. I dose them with lard.

"There are quite a number of goat raisers in this section."

Mr. R. J. Linton, Ager, California, says:

"I butcher all ny own wether goats and market them at Y'reka.

"The altitude of our country is son feet.

"We run them in flocks of too.

"Ve find that goats are more capable of defending themselves from dogs or wild animals than sheep are. They stand and look at them when sheep will run away.

"Cost of keeping is a boy"s wages. $\$ 10.00$ per month.

"I intend to practice dipping for lice though I never have done so yet. I shall use tobacco stems.

"We begin breeding Norember 1st.

"Have rery" few black kids."

A. Moon, Ona, Cal.:

"We sell our mutton goats at our home market.

"Pastlire sometimes and herd sometimes.

"Ou1" fencing is made from pickets.

"Have only about 500 head.

"We only feed clover hay in bad. snowy weather.

"Cost of keeping is very small.

"Begin breeding Norember 15th.

"Have very few off-colored kids."

Mr. Tas. Milder, Paskenta, California, says:

"We only pen goats in winter time.

"Have never lost a goat by wolves. The wild cats are very bad on young kids.

"We estimate cost of rumning goats. 25 cents to 35 cents, according to how they are rum.

"Ile begin breeding Norember 1st."

Mr. I. I. Osorne, Lowrey. Tehama County. California, says :

"I have only been in the goat business six years. I commenced with 200 nannies. My goats are of the Julius Weyand stock. I have 
sold 400 head. and still have 1,100 head. My range is better than it nas ever been. Goats are good property now, and they are easily handled.

"I have sheds 200 feet long for kidding. I have pens for does and kids along one side of my shed, about twenty inches high, so that nannies can jump in to their kids. When the kid is large enough to jump out, I let him go with his mother. I find this easier than picketing them out with rope.

"I raised 500 goats this spring.

"My range, before I got goats, I could not run twenty-five head of cattle on: now I can run 150 head of cattle. Goats are the stock for brushy land; they clear the land and the grass takes its place.

"My goats shear four pounds a year. I shear twice a year. My fall clip cleared me 27 cents, and my spring clip $261 / 2$ cents.

"I take lots of interest in my goats. I think they are the stock for a poor man to raise. When I started in the goat business, I borrowed $\$ 650.00$ and paid ten per cent. interest on it; now I have paid off that note and bought 1,600 acres of land just off my goats. I got my range for 2.5 cents an acre, and wouldn't sell it today for $\$ 2.00$ an acre."

\section{Mr. D. C. Taylor, Lake Valley, N. M., says:}

"I think we have the best goat country in the world in the Black Range Mountains. Altitude 6,000 feet. Dry climate (only about six inches rain, on an average per year, and nearly all this in July). Plenty of evergreen brush, and plenty of range. Water is scarce, on which account a watered place commands a large free range. I only own three forty-acre tracts, and control 30,000 acres of range.

"I had about 800 does this (1899) year and will raise about 783 kids, with one $\$ 10.00-a-m o n t h$ Mexican boy for herder.

"I have my pens so arranged that two men can save all the kids from 1,000 does with very little labor. It is all in knowing how.

"I shear my dry goats twice a year: my breeding does only once."

Mr. I. C. Hightower, Ruidosa, N. M., says:

"I sell my wethers at home without trouble.

"I find this country well adapted to the goat business. Altitude is 0,500 ieet.

"I run 1,200 in a flock. I have seen as many as 3,000 head in one flock.

"I estimate to cents as cost of keeping per year.

"I breed about November 15th.

"Percentage of loss from natural causes is small, probably two per cent., but sometimes the loss is heavy after shearing, unless they are protected by sheds." 
Mr. A. D. Norcop, Separ, N. M., says:

"This is what might be called a semi-desert country. Brush is scarce. We have sotol, corahanoo palmyra, or dagger, mesquite, grease wood, etc., etc. Higher up in the Burro Mountains we have what is known as mahogony oak, juniper, and other brush.

"We don't think it advisable to run goats with other stock in this country. Our water is scarce, and I don't think horses, or cattle, like to drink at the same trough with goats. Besides this, the goats are often either killed or injured by the larger stock when they are watering at the same time.

"I have Mexican herders.

"I sell our mutton at Silver City.

"I have known of goats killing the cayote when the latter has sneaked into their corral or pen.

"I estimate cost of keeping goats here, 25 cents per head per annum.

"I have never dipped for lice but intend to begin the practice as I consider it would be an advantage to the animal.

"I do not have very many twin kids, and but a few off-colored kids which I usually kill."

Mr. E. Weistrand, Cooney, N. M., says:

"I think we have the finest goat country in America.

"I run 1,000 nannies in a flock.

"I begin breeding in November.

"Have no off-colored kids."

The Onderdonk Live Stock Co., Lamy, N. M., say:

Our experience has been greater with the common (Mexican) goat than with the Angora; but we are of the opinion the latter class are much better adapted to this climate than the former. They seem to be better able to stand the cold weather; and, with no greater care, will take on more Hesh than the common goat.

"We have purchased a range of 28,000 acres of land which we have fenced, not so much to hold our goats as to prevent any of our neighbors' stock ranging on our property.

"We herd in bands of 1.500 to 1.600 head and have drilled wells, at conventent distances (four to six miles apart), and have iocated at the wells corrals for working and 'kidding' our goats.

"We have properly trained Collie dogs to assist our shepherds. They seem to be very useful in gathering up any stray goats, and in herding the flock.

"We are greatly troubled with cayotes. and are looking for some kind of dog that will attack them, or keep them off our range. 
"Regarding the acquiring of land in this country, the cost of it, etc., I can give you very little information ontside of our own experience. We are pasturing on our own land. Of course, the Government land is free grazing, and we suppose it can be acquired by the usual laws of the United States relating to that matter; probably at a cost of $\$ 1.50$ an acre and upwards.

"The cost of digging wells varies according to the situation. We have our own machine and employ drillers by the month, but previous to this we contracted the work at $\$ 1.50$ per foot for the first hundred feet, and $\$ 2.00$ per foot for the second hundred feet. We have some fine wells thirty-five (35) feet deep, and some two hundred and thirty-five (235) feet deep, depending on the situation; as in some places the ground is soft and easily drilled and in other places it seems to be composed of rolcanic rock and is extremely hard. I think, however, it would be safe to say that wells one hundred (100) feet deep would average $\$ 1.50$ per foot."

"I only pen my goats in winter.

Mr. A. R. Tate, Wintersett, Iowa, says:

"I feed rough hay, fodder,etc.

"I count the cost of keeping very little.

"My goats run with cattle and seem to get along well with them.

"I breed for April kids. kids.'

"I have one pair of twins in about eight does. Only a few colored

\section{Dr. J. R. Standley, Platteville, Iowa, says:}

"I have had no trouble to sell all my wether goats at any of our large markets.

"I do not think it necessary to import new blood. Think we have as good as we could get anywhere.

"The altitude of our country is 800 feet.

"I use twenty-four-inch woven wire and two barbed wires above.

"I only pen in cold, rainy weather.

"I have had some kids killed by dogs, but never any old goats.

"I feed goats about the same as sheep. The cost of keeping is about the same also.

"I have never had a sick goat.

"I use arsenic, one pound to sixteen gallons of water, for a dip to kill lice.

"I think a few goats are an advantage to other stock in same pasture.

"I breed December 1st.

"I have had very few twins; about one per cent. off-colors.

"I have had no loss by death, to speak of." 
Messrs. Morgan \& Morgan, Clay, Iowa, say:

"We have no trouble in selling muiton goats in Chicago.

"The altitude of our country is 2,000 feet.

"Our goat pasture is enclosed with a woven-wire base, twenty-six inches high, and two barbed wires on top.

"They take good care to go into the shed when they want to, without any driving.

"We feed goats fodder, same as sheep.

"We estimate cost of keeping, 50 cents per head.

"We use a tobacco dip for lice.

"We breed in November."

Mr. I. J. Booth, Cresco, Iowa, says:

"I feed clover and oats in winter.

"Some of my goats have swelling of the throat, like bronchitis.

"I use carbolic acid and water for a dip to kill lice.

"I breed November 20th."

Mr. J. C. Morton, Indianola, Iowa, says:

"I use woven wire (Kitselman's).

"I feed in winter, hay and a little corn.

"Cost of keeping is $\$ 1.00$.

"A few of mine have sore feet.

"I breed in November."

Hon. A. H. Edwards, Audubon, Iowa:

"I have found Angoras do very well in this section.

"I place all my wethers in Chicago market without any difficulty.

"I enclose my goat pasture with five wires.

"I only shed them in winter.

"I feed grain and hay in winter.

"I dip in 'Cooper Dip' for lice."

Mr. S. S. McKibben, Earlham, Iowa, says:

"My experience in breeding the Angora goat has been limited, but I have gone far enough to know that our country is admirably adapted to them, and that they will produce a larger amount of mohair of a smoother and better character, than in Texas, where I have received nearly all my goats from.

"I have sold goats to possibly 500 different parties, in lots varying from a single animal, up to as many as 200; and I have not yet heard of any dissatisfaction; but, upon the contrary, all are well pleased with them, and many of them interd to increase their holdings. 
"I breed in December so that $I$ have my kids come at a time (May) when vegetation is well started, and it gires me ample time to shear in April before the kidding begins.

"I feed shock corn to 'rough' my goats through the colder months (unless there are plenty of hazel nuts), and they have iree run to a stack of oat straw, or some other kind of 'roughness.'

"I think it is proper to let them go to water and salt whenever they are so inclined.

"Ny experience has been that if the goats are brought into the State of Iowa during the spring or summer months, they will do better than if brought here in the winter.

"My losses have been almost entirely confined to stock that I have imported from Texas in cold weather."

Mr. J. R. Barnette, Globe, Arizona, says:

"I find a local demand for mutton.

"The altitude of our section of country is 4,000 feet.

"I loose herd my goats.

"Never pen them except to work with them.

"Do not shed any.

"I only have about 900 head. 1,500 can be run in one flock easily, and with greater profit of course.

"I do not think there is much difference between sheep and goats as far as wild animals are concerned. I have seen a little cayote scare a big flock of goats nearly to death.

"I usually breed October Ist.

"I have but few twins in my better grades of goats.

"Goats are kept here strictly for mohair."

Mr. J. F. Holder, Payson, Arizona, says:

"I find sale for all my mutton goats at the local mining camps.

"I run 300 to 1,000 in a flock.

"I find wild animals troublesome at times.

"I estimate cost of keeping, 45 cents per year.

"I begin kidding, generally, May 1st.

"I am in favor of importing new blood for stud flocks, and any others who want them, but if the average breeder would try to get the best bucks they can from our home stud flocks, instead of using any $\$ 10.00$ buck, because he 'looks well,' and 'nearly' as good as a Harris and Baylor, or a Landrum buck. they would have much better blood than they now have, and the United States standard of mohair would go up rapidly. 
"I do not herd my goats, I just watch them a good distance off (loose herd them). Goats are not like sheep, and have to be driven to feed and back to the ranch when night comes. The goat wants his liberty and will stay fatter the year round, and produce more mohair, if they are turned loose, and permitted to go where they prefer. If you give them plenty of fine salt, or sheep salt, they will come home at night and lay in, and around, the corral, and leave next morning when they get ready. Follow along after them and see that nothing bothers them, but do not restrain them, and they will do better and produce you more mohair, and of a better quality.

"I think black, or colored, kids are an indication of bad blood. I had several blue-backed kids last year, but as I am cutting out all the time, and breeding up at the same time, I have very few kids that were blue or red this year.

"I select bucks on individual merit, and some on 'long breeding,' but mostly on the grade and quality of the buck's offspring. I don't give a snap for the gęneral appearance of a buck if his kids are above the average standard. I buy a buck for his ability to get kids-one that will put mohair of a superior kind all over them."

Mr. Ira Harper, Clifton, Arizona, says:

"I find my section well suited to the Angora.

"Our altitude is 7,000 feet.

"I don't herd but let them run loose. I only have about 300 .

"My goats always run home when anything disturbs them on the range.

"My flock has only cost me plenty of salt."

"I let my bucks run with my flock all year. I think November is the proper month to breed.

"I have about twenty-five per cent. of kids.

"I attribute my success to plenty of salt.

"I have had wethers to come back home after they had been driven ten miles away, which is something a sheep has not sense enough to do."

\section{Wm. Horn, Camp Verde, Arizona:}

"I butcher my own goats (wethers) and sell them at home.

"I think this section is a little too cold.

"I herd my goats with dogs.

"I have about 400 head.

"I find them almost the same as sheep, as far as wild animals are concerned.

"I feed alfalfa hay in winter.

"My expense is about 40 cents per year per head. 
"Have had some 'catarrh."

"I kid in April, generally.

"About five per cent. off-colored kids."

Mr. C. D. Tuthill, Tuthill, Minn., says:

"I am convinced that the Angora goat is one of the most profitable animals we can propagate.

"I have demonstrated to my entire satisfaction that I can produce meat for my family and hired hands cheaper from goats than from any other class of live stock, and I believe it to be the most healthful, as well as tempting to the appetite.

"Since I have been keeping goats, and eating their rich, juicy meat, I have a far greater regard for the good sense of Rebecca when old Isaac was blind and wanted a savory dish. She did not select a boned turkey, or stewed oysters, but a tender young kid. And the milk of the goat is the healthiest known, and many invalids could be nursed back to health; and the lives of many sickly children saved by simply using goat's milk.

"I had one grade Angora nanny (doe) that would give me three quarts per day. This same doe not only brought forth. but raised ten, kids in five years.

"I have pastured goats with horses, with sheep and hogs, and have never had anything but the best results. I do not believe there is a case on record where the goat has crossed with the sheep.

"I use our mutton wethers at home.

"I have found this section most admirably adapted to raising the Angora.

"I fence with seven barbed wires, posts ten feet apart.

"I only have about 10in head.

"I feed wild hay and corn fodder in winter.

"I begin breeding May 1st.

"Occasionally an off-colored kid.

" $\mathrm{My}$ goats cost me less than $\$ 1.00$ per head per year.

"Loss from death is little or nothing."

Mr. A. G. Wilcox; Hugo, Minn, saỵs:

"We use our muton goats at home.

"I fence with woren wire.

"I only shed them in bad weather.

"My flock consists of seventy-five.

"I find my older goats more capable of resisting dogs, but the kids about the same as sheep.

"I feed hay, corn fodder and oats in winter.

"I estimate $\$ 1.00$ per head the expense of keeping. 
"I use 'Cooper's Dip' for dipping ‘o kill lice.

"I begin breeding in Decenber.

"About five per cent. twins.

"Occasionally a reddish or yellow kid.

"Have had no losses from death.

"When I got goats first, we had fences that were all right for sheep and pigs, but were ro restraint to goats. They would go through anything we had, and were a great nuisance. In the spring I built a woven-wire fence (Lamb's) of the Page type, and that held them. No trouble since."

Mr. E. Graves, Princeton, Minn., says:

"I purchased my first goats from Mr. C. D. Tuthill.

"I have found this section very well suited to raising goats.

"I feed only good hay in winter.

"Have never known of any disease among them.

"I begin breeding in January.

"I would not farm without goats. I find that my sheep keep much healthier since I have had goats."

Mr. A. Lippincutt, Sheridan, Mo., says:

"I use woven wire for fencing.

"I feed straw and corn fodder.

"Estimate cost of keeping, 50 cents per head per year.

"Begin breeding November 1st.

"Have no off-colored kids.

"Have had no deaths or disease."

Mr. L. B. Dougherty, Liberty, Mo., says:

"I only had fifty head of nannies. Kept them five years. Liked them very well. Kept no account of shearing or other statistics. Made nothing out of the venture, but could with proper care make them very profitable. Don't know any one in our country who owns goats."

Mr. W. J. Seever, St. Iouis, Mo., says:

"The altitude of the section where I have goats is 900 feet.

"I fence with seven barb wire.

"Only have to shed in bad weather.

"I have found goats will invariably face a dog, and will generally intimidate the brute with his boldness.

"They earn more than they cost to keep.

"Have never heard of any disease.

"I regard goats as being a great advantage to other stock in the same pasture. 
"Referring to mutton qualities, I irequently visit our stock yards and have noticed that fat Angora goats are snapped up very fast by the packers, at prices higher than I care to pay for breeding purposes. I have seen fat wethers bring prices equal to sheep, and a few thin does made but little difference in the sale."

Mr. J. Clome Miles, Silver Bєnd, Mont., says:

"I have found Montana a fine goat country.

"I have only about 350 head, which I pen every night, in winter and spring.

"I find them very little trouble, and only feed them occusionly in. winter with wild hay.

"They are free from all diseases.

"I dip them, when necessary, for lice, with lime and sulphur.

"I begin breeding December 10th.",

Mr. S. S. Brannin, Marysville, Mont., says:

"The altitude of our country is 5,000 feet, and is very finely suited. to raising goats.

"I herd my goats some, and let them run loose as well, at times.

"I pen in the winter and shed them too.

"I only have about 700 .

"I breed November 1st.

"About four-filths of my does have iwins.

"No off-colored.

"My losses seldom exceed two or three per cent,

Mr. J. S. Harris, Oakley, Idaho, says:

"I do not sell any wethers.

"Our country, I think, is too cold and blustery to raise goats to the best adrantage. The cost is too great compared with milder climates and percentage of increase much less.

"I herd my goats and feed alfalfa hay in the winter months.

"I dip with Zenoleum, which I think is very good.

"I begin breeding November 15 th.

"The increase here is about seventy-five per cent.

"Death rate is seldom over five per cent.

"I rarely have twin kids, and very seldom any off-colored.

"If we are to import any new blood, I prefer that they should come from Turkey."

Dr. Tuttle, Tacoma, Wash., says :

"I have not found this section very well adapted to raising goats.

"I allow my goats to run loose, and have my bucks with them the year round. 
"I keep them in pasture in straight rail fence.

"I only pen them in winter, and shed them in bad weather.

"I feed only when weather is bad in the winter. Mostly hay, and oat straw,

"The cost of keeping hardly exceeds 25 cents per head.

"I have had the scours attack some of my old does.

"I do not dip for lice. horses.

"I think goats are objectionable with milch cows, but not with

"My kids begin to come about March 1st."

Name omitted, Bucoda, Wash., says:

"I find ready sale for my muttons to home butchers.

"The altitude here is 140 feet.

"We make our pasture fence out of 1ails and posts.

"We only pen during rainy season.

"We have never been bothered with dogs or wolves.

"We do not have to feed much in winter.

"Aside from pasture, 15 cents per head will cover expenses.

"Have never dipped for lice, but intend to begin doing so.

"My cows and horses feed with them all right.

"I breed middle of October.

"After they are two years old, two-thirds of them have twins.

"Have no off-colored kids.

"Have only lost six old goats in eight years."

Mr. Chris Niellson, Burlington, IYyo., says:

"I find sale for wethers among my neighbors.

"We run 1,500 in a flock, but they will do better in smaller flocks.

"The old ones are less liable to destruction from wild animals than the kids.

"I estimate 50 cents per year expensc of keeping.

"I have dipped with lime and sulphur for lice, but it is not good.

"I breed here middle of December.

"Have a good many twins, but very few off-colored.

"My goats have been sent to Utah, where I formerly ranched htem, but I shall remain here."

Mr. Jos. R. Hamblin, Kanab, Utah, says:

"I have very poor sale for wethers.

"My place is excellent for goat raising. Altitude 4000 feet.

"I herd my goats on account of wild animais.

"I run 1,500 to 2,000 head in a flock. 
"I estimate cost, 30 cents per head per year.

"Ve begin kidding May 1st.

"Nearly all our yearlings have twins, but very few off-colors.

"From my experience with the Angora, I have found them to be very intelligent and interesting animals. While they are very persistent and contrary, it is very easy to control and handle them. They are very sensitive to wet, cold weather, yet they can endure a great deal.

"As to drouth, scarcity of water and heat, I believe the goat is the hardiest of all animals. The female is a very good mother, and most excellent multiplier, seldom having less than two; and, although a good suckler, will not care for more than one of them, unless proper care is taken. The kid is very stupid when young, and cannot stand wet, cold weather. As it grows, however, it adapts itself to the climate and becomes quite playful. They are very nice, but troublesome, pets. The coyote loves to catch them; the wild cat is even more fond of them, and these two animals cause much loss in young kids unless great care is taken.

"I have found the most practical way of kidding is to stake or pen each kid, or pair of kids, separately, for at least three weeks. If you pen, have it just about large enough for the mothers and kids, leaving a low place for the mother to jump in, or cut, and too high for the kid to jump out. If you stake the kids you should attach a string to the left, or right, fore foot (string about two feet long), and tie fast to a peg driven down close to the surface of the ground. If you stake twins, the one by the right, and the other by the left fore leg, and stake them to the same pin. If there should be more than two, tie them all so that they may have free play, and yet be together.

"The old scientific theory of handling kids with gloved hands is very absurd, for we have learned by experience that you may carry a kid a long distance, and the main thing is to have the mother (who will naturally follow the kid when you pick it up to carry it away) to smell of the kid, to be sure it is her own, and you will have no more trouble with her."

Mr. R. C. Johnston, Lawrence, Kan.. says:

"I have found our section of country very well adapted to raising the Angora.

"The altitude is 1,000 feet above sea level.

"I fence with barbed wire, seven strands, five inches apart from the ground for four wires; and seven inches, nine inches, and twelve inches. for the remaining three strands; posts ten feet apart, and stays every three feet. This makes a goat proof as well as a good stock fence generally.

"I pasture my goats always, and pen them crery night. 
"I have never had any trouble from either dogs or wolves. I put 'bells on quite a number.

"I feed corn fodder, hay and straw in winter.

"I estimate cost of keeping, 35 cents to 45 cents per head per year.

"Have never had any disease of any kind.

"I have practiced dipping for lice, with arsenic.

"I have my kids to come in April."

Mr. J. K. Young, Woodward, Ok., says :

"I market my mutton goats in Karsas City.

"The altitude of our country is 3,000 feet.

"I herd my goats on bunch grass, and scrub oak brush.

"I only have to shed in spring and bad weather.

"I run flocks of 1,000 to 1,500 .

"I feed only in severe storms, dry hay.

"I estimate cost of keep, 25 cents.

"I begin breeding December 1st.

"About twenty-five per cent. twins. No off-colors."

Mr. O. D. Hill, Kendalia, West Va., says:

"The altitude of our country is 1.500 feet, and I have found it to be very well adapted to the Angora.

"My goats rum loose, and I seldom pen them.

"In winter I occasionly feed some corn, but only in bad weather.

"I estimate cost of keeping, 50 cents per year or less.

"Have never had any sickness.

"I breed twice a year. Cannot say what the regular increase will be, but would estimate on 150 per cent., judging from the breeding of my own goats.

"Ny kids are all pure white."

Mr. Jas. A. Bill, * Bill Hill P. O., Conn., says:

"I have found our" state equally as well adapted to the Angora goat as it is to sheep.

"I only herd in winter, and pasture in summer.

"I only pen in winter.

"I have about seventy-five head. They are much more capable of defending themselves from dogs than sheep are.

* Since the above report was made, Mr. Jas. A. Bill has died, and his son, Mr. Kansas N. Bill, writes me under date of April 16th, that the industry is rapidly gaining in Connecticut, and that he has sold every thing they had except twelve head of does. 
"I feed in winter hay and grain, the same as sheep.

"The cost of keeping is about the same.

"Have never known any disease.

"I practice dipping for lice and use a carbolic dip.

"They are in no way objectionable to other kinds of stock.

"I breed early in May, and the increase is about on a par with that in sheep.

"I have a good many twins, but no colored kids. at all.'

"The percentage of loss is little or nothing, and ought to be none

Col. J. Wash. Watts, Montville, S. C., says:

"I commenced breeding the Angora goat soon after they were imported into this country in 1849 . I found them to be well adapted to this climate.

"I usually kept them in pastures, but would sometimes herd them.

"Our fencing was made of rail. I think wire is better.

"I always penned them at night, and housed them in bad weather.

"I never kept over 200 at one time.

"I learned that the dog would not molest the goat near as much as they do sheep. An old goat will run after a dog.

"I always fed cotton seed in winter.

"My estimate of the cost of keeping them was 50 cents per head per year.

"They have never had any disease that I know of, but I heard of some having foot rot, and a few of them mange.

"I always used tobacco for dipping to remove lice.

"I sheared in April, and if left later, they would shed.

Would breed in August or September.

"Eighty to ninety per cent. was considered an average increase.

"The pure bred has twins very rarely, and no off-colored kids.

"Loss from death was not more than two per cent."

Mr. Lafayette Holt, Burlington, N. C., says:

"I find ready sale for my surplus stock at home, where they are slaughtered for mutton.

"The altitude of our country is 1.800 feet.

"My pasture fence is made from rails and wire.

"I do not shed my goats except in bad weather.

"Only keep a small number.

"I usually feed in winter, hay, fodder, etc.

"Have been bothered some with staggers.

"I do not dip for lice.

"I breed in September. 
"An Angora buck will keep off dogs from a flock of sheep.

"I believe any one who has a sickly child. and will put up with the odor from a buck goat, can make the child well and strong, by letting him use him as a plaything, hauling a little wagon, etc."

Dr. M. Barrett, Maidens, Ya., says:

"I have been raising the Angora for the past twenty years. and find them strong, hearty and prolific.

"Have never lost any from disease, and I think they are just the meat we ought to raise.

"They are but very little trouble an 1 no expense, as they get their own living if let loose on a farm.

"They frequently kid twice in a year.

"I have never made use of their hair, except for padding, as it is a little coarse.

"They grow very large and usually get their growth at three years old.

"I keep them chiefly for home consumption, though I sell occasionly at $\$ 2.00$ for mutton. I think they will soon take the place of sheep for mutton. My kids, at six months, dress thirty-five to forty-five pounds, giving a nice lot of tallow, superior to mutton, as it keeps in warmest weather.

"The skins are pretty and useful for making robes and rugs. I value goats more than sheep.

"I have several goats now, seventeen years old, still fat and hearty." 


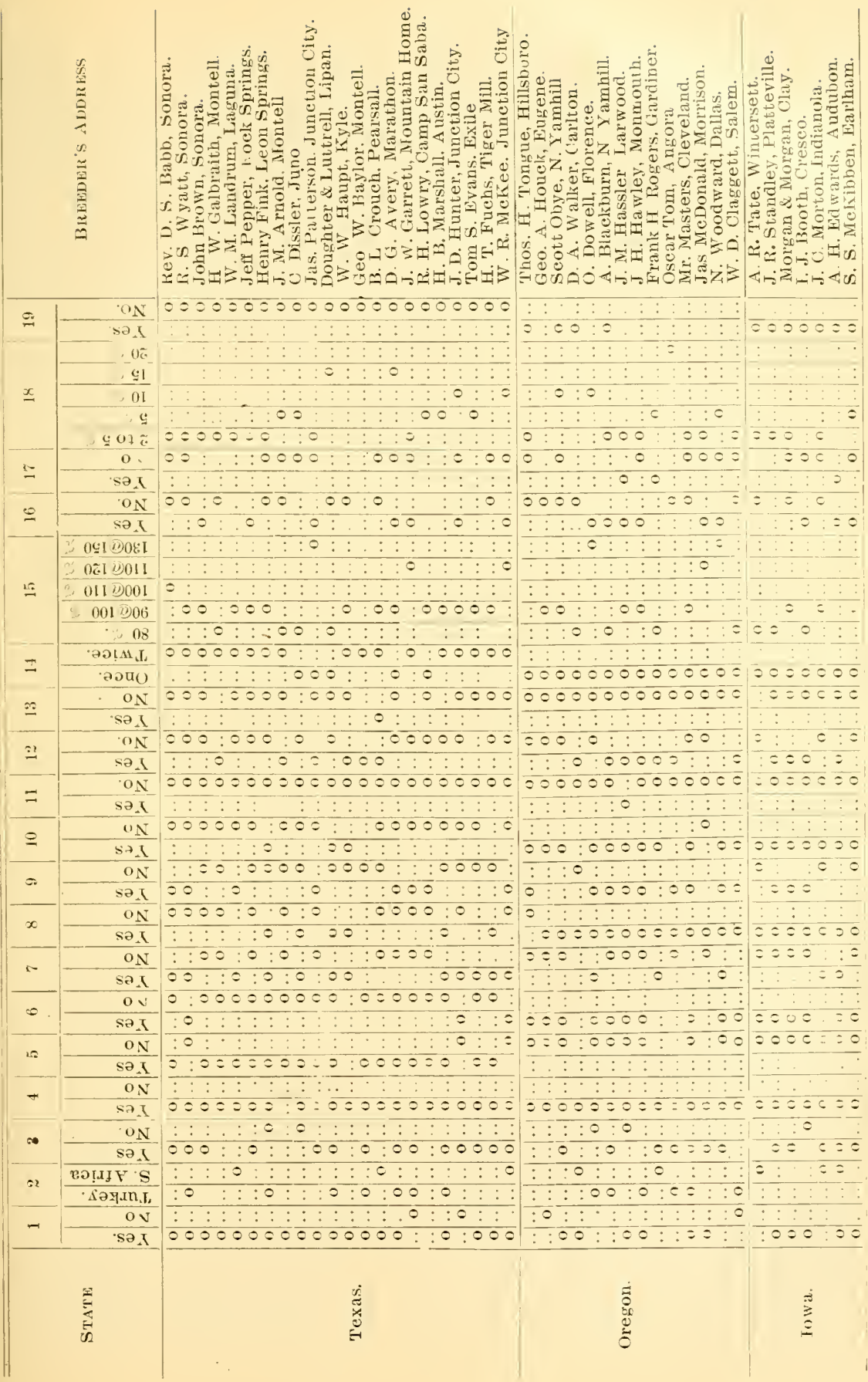




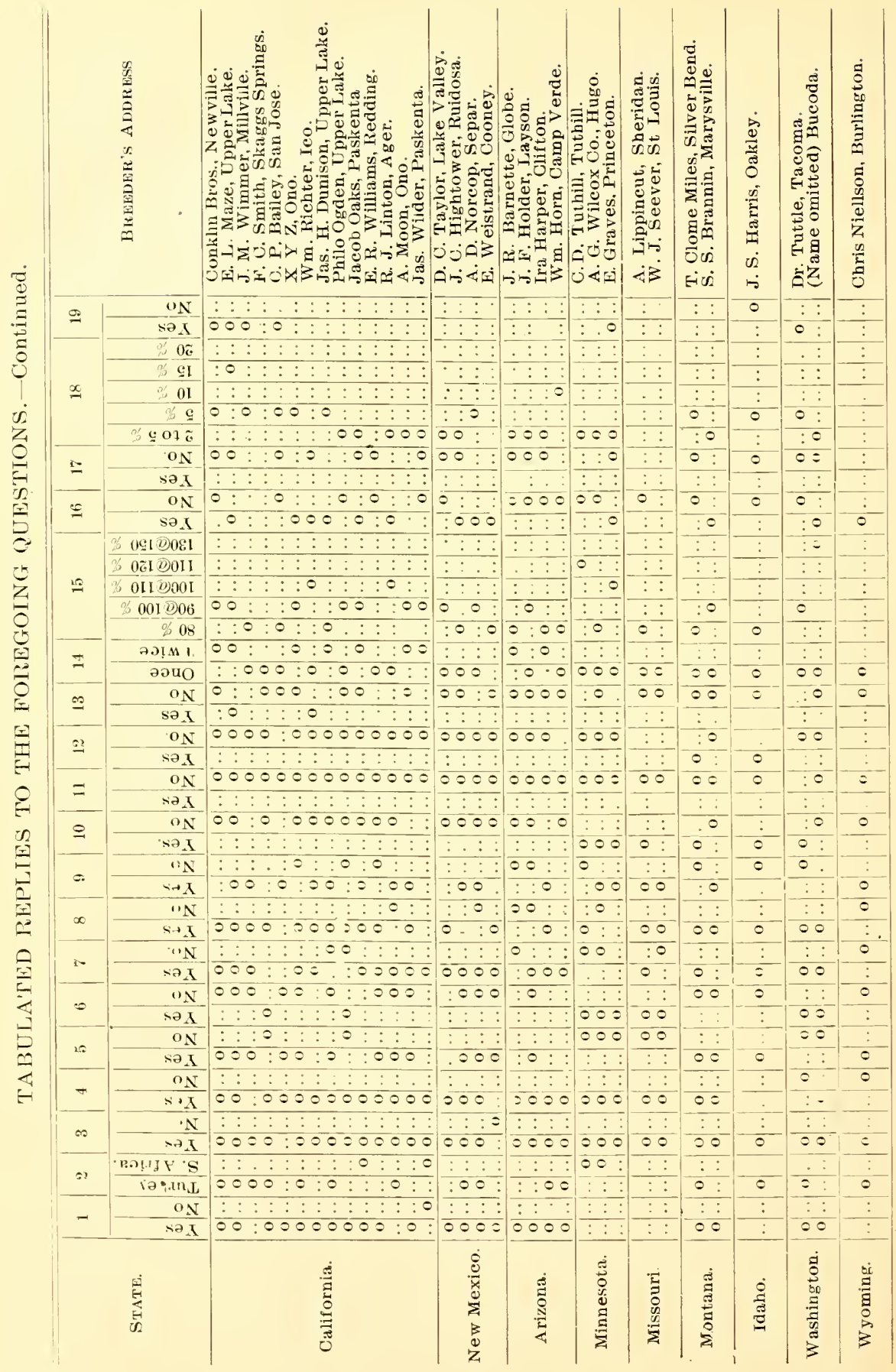




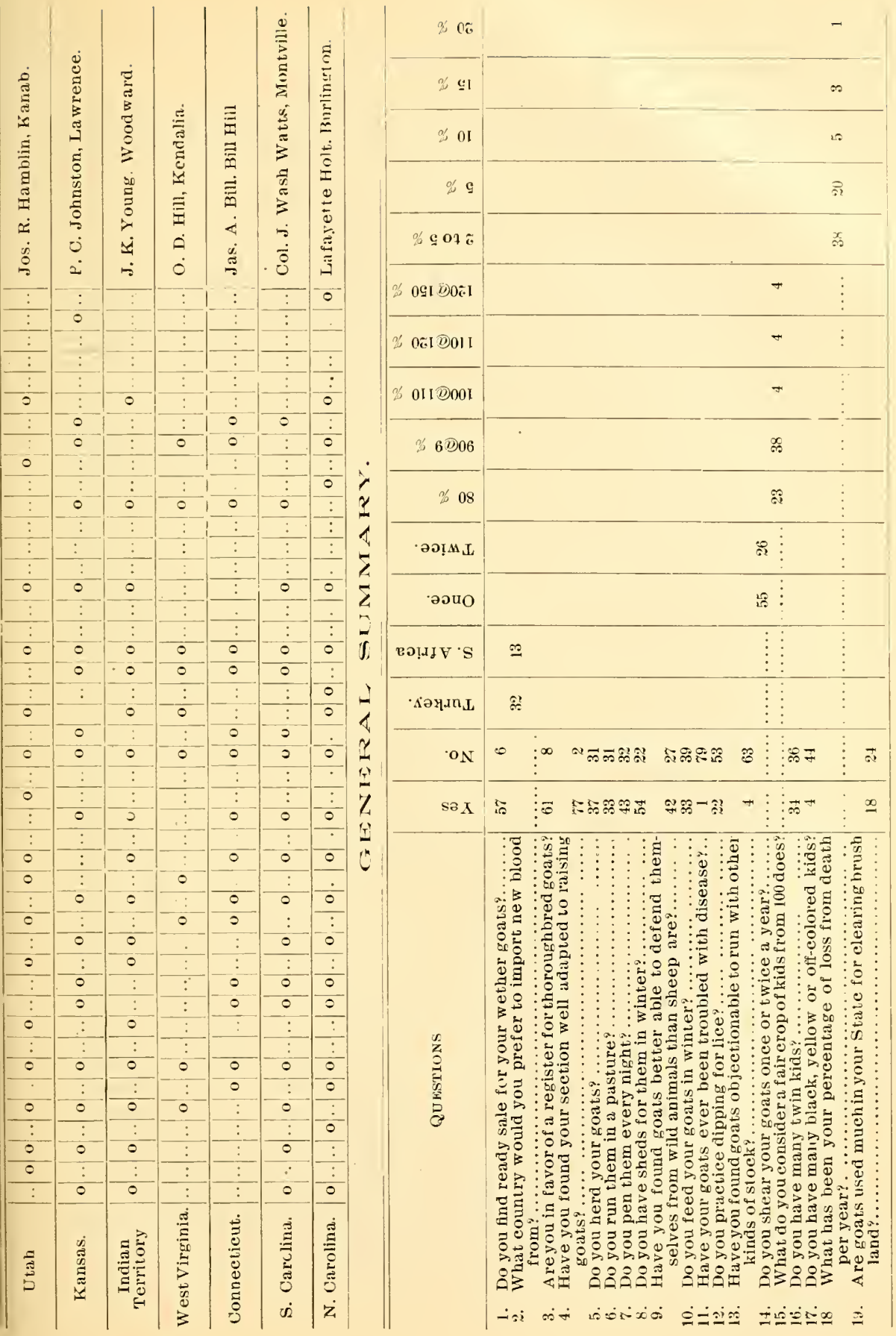


The following letter from Mr. F. Garst, who was, for many years, a prominent breeder of Angora goats in New Mexico, will be of interest:

“Cold Water, Kansas, May 12th, 1900.

"Mr. Wm. I. Black, Fort McKavett, Texas:

"Dear Sir:-I have yours in regard to goats. I have been away for some time this spring, and this is the first clince I have had to write. I will not undertake to answer your questions, but will make you a simple statement of what I did with a bunch of 500 goats in twelve years.

"In 188., I bought 500 head of nannie goats of C. P. Bailey, of San Jose, Cal., and they were from seven-eights to thirty-one-thirty-seconds grade. I bought in February, and moved them to New Mexico in the fall. I took them to the Sacramento Mountains, in Lincoln County (now Otero County).

“After running them twelve years, I had sold over $\$ 20,000.00$ worth of stufi from them (amongst the sales were 1,800 head of goats), and at the end of twelve years. I had 6,000 head of goats left. I paid Bailey $\$ 6.00$ a head for the goats, and after rumning them a year, I had 700 head, and they stood me at about $\$ 9.00$ per head. I was under very great expense in moving and getting located. My thoroughbreds, both bucks and nannies, cost $\$ 100.00$ per head; I don't recollect just how many I bought.

"Goats will not jump over a fence, if they can jump on top of it, thep they will go over. They are the best grubbers I know of, as they furnish themselves and an income besides.

"My goats were a secondary consideration with me, as $\mathrm{I}$ was running a cattle ranch on the same range with them, and would at times have to be away from home. so could not give them the attention I would have liked to.

"Maxwell, of "Maxwell Land-Grant Farm," I think, took the first Angora goats into New Mexico, as far as I know. This must have been at least ten years or more before $I$ went there. There must have been about seventy head of them. Don't know what became of them.

"A man by the name of Casas brought a good bunch from near San Jose, Cal., and located them on the Rio Grande, below Las Cruces. These cane several years before mine. He did not do much good with them, and finally died, and Col. Rymerson, of Las Cruces, got them. and moved them to the Organ Monntains, where they did better. Since Rymerson's death, I don't know what became of them.

"I can't tell you anything about goats in this State (Kansas), as I never have looked it up. My experience has been principally in New Mexico. "Yours,

"FRANK GARST." 
'The following letter from Mr. W. G. Hughes, of Hastings, Texas, who has been a very successful breeder of Angoras for a number of years, will be instructive:

"Col. W'm. L. Black.

"Hastings, Kendall Co., Texas, July 15, 1899.

"Dear Sir-In answer to your request for some notes on my system of handling Angora goats, I would like as a preface to draw attention to the fact, that results, and the methods by which individuals arrive at them, are valuable only as abstract guides to others who intend to follow the same line of business; and, their problem if they are to profit by such experiences, is, to apply the ideas which they thus derive to their own conditions and surroundings.

To begin with: I bed my goats as much as posible on a hill-side, haring such a slope that a good hard rain effectually washes away the manure. I believe that this keeps the lice from bothering them to any noticeable extent. as lice seem to increase on them when they are corralled every night in dirty pens. I think that gcats should have access to water at least once a day and that they should have salt where they can get it; rock sait at the bedding ground is a convenient form in which to furnish it.

"In the fall I put the billies with the nannies on October 15th, using two or three billies to one lundred nannies. I do not consider it necessary or judicious to leave them in more than five weeks, as this is sufficient to practically serve the whole flock, the first kids coming about March 1:3th and the last about April 1Eth. Any scattering ones that would come after them by continuing breeding, are usually more trouble than they are worth, as by stopping on April 18th, the whole nanny flock is ready to move to a different range about the middle of May, without any impediment of kids that are too young to go all day with the others. and moving to a new range is of great assistance to the goats, as during kidding they have necessarily been herded somewhat closely around the kidding canp.

"At the home pens I hare a shed in the shape of a right angle with the point to the north: the shed is 300 feet long and twelve feet deep, and has a hay rack along the back, inside. It is very useful during a bad spell of weather.

"I leave the flock at one of the camps all winter, only returning for bad weather and for handling them during shearing in spring and fall, and for kidding in the spring.

"In this latitude it is safe to commence shearing the first suitable day aiter March 1st provided you have sheiter for the goats in case o cold, wet weather, soon after shearing. I generally begin the first Monday after March 1st and figure on getting through during the week and 
before 12 th or 14 th, by which time the first kids may be expected; and from the commencement of the spring shearing until the flock moves to a new range about May $15 \mathrm{th}$, it is kept at the home pens where the shed is. A good many kids are born during the night, but most are born between about 11 a. m. and 2 p. m., and I find that by getting the flock out in good time in the morning and having it return to the pen about 11 o'clock or soon after, that the bulk of the kids will be born after the flock returns at that time, and before it goes out again at $2 \mathrm{p} . \mathrm{m}$. I think this is because getting a belly full of food during the morning hastens the process of kidding. It is needless to say that having the kids born in the pen is much more convenient than having to 'pack' them back from the range and except, for a few days, when the busiest part of the kidding is in progress, there will not be born during the few hours of the afternoon feeding, more than the herder with an extra hand can conveniently bring back to the pen. I do not stake out my kids, as I think it tends to stunt their growth and it is liable to result in loss of many kids during the bad weather.

"The great secret in raising kids is to give the nanny sufficient ofportunity to thoroughly know her own kid, without being confused and rattled by other kids until she gets 'mixed up' on the question of identity. To do this it is necessary to let her be undisturbed with her own kid for twenty-four hours before leaving it, eitner in a separate small pen, or a large pen with others in her condition, where there is a minimum of disturbing influences: while thus kept in, she should have access to water and a little hay. Aftar she knows her kid pretty well, she can go out with the flock, but on return should be put in a pen with not over twenty-five other nannies and their kids until the kids are a week or ten days old, when, except in exceptional cases, she will know her own kid among one hundred or so.

"I divide them up every evening by tunning all the nannies that have kids through a narrow chute with four cut gates at the middle of the chute, two on each side. Each gate leads into a separate pen, and the chute terminates in a large pen.

"I know the pen into which to cut the goats, as these have a different color for each pen painted on the base of the horns. When a pen is filled up and six to ten days old, it is turned into the large pen at the end of the chute, the nannies marked on the nose to designate the change, and new arrivals begin to fill up the small pen that is thus cleared. During the summer there is but little to watch for except wolves, and worms in sores, until the fall shearing, which should be done early enough to allow the hair on the goats to grow again sufficiently to serve as a protection by the time cold weather may be expected.

"I generally shear late in September, as if shorn earlier there is more danger from worms in shear cuts, and if shorn later, it tends to disturb 
the general equality of the length of staple in the clips, which should be as long as possible to obtain best results, but I do not consider it advisable to add to the length of one clip by taking it from another unless for some other reason. Shearing towards the end of September gets it well out of the way and enables one to have pretty close track of such doctoring as is necessitated by shear cuts, before October 15, when the billies are put in, and which was the season with which these suggestions commenced.

The following letter from Mr. J. C. P. McLendon, of Texas whose experience in breeding the Angora goat was of such an interesting nature, I am sure it will be read by many of the present breeders with a great deal of profit:

"Dripping Springs, Hays Co., Texas, Sept. 21, 1899.

"Mr. Wm. L. Black, Ft. McKavett, Texas.

"Dear Sir-I am in receipt of your circular letter, also of one handed to me by A. L. Davis. Jr., of this place. I am not now in the Angora goat business. In 1876 , I came in possession of fifty head of Mexican ewes. I culled out twenty-four head of young, white, short-haired, ewes, and one large, long-haired, white one. I then sent to Col. Peters of Georgia, for a pair of pure Angora kids, buck and ewe. Bred the buck, by line, to these, using a system of ear-marks to distinguish the different grades. Later, I sent to Col. Scott of Kentucky, for one buck and four ewes. Gave Peters $\$ 50$ per head and Scott $\$ 40$ per head. The buck and one ewe from Scott were the best and only pure, perhaps, of the seven head I bought. I make this statement from looks, and the test of breeding. I do not intend censure to either Peters or Scott. They were both honest and conscientious breeders. I found it impossible to breed out entirely the long, coarse hair in the progeny of the long-haired ewe above referred to. I sold all of these, with cullings of lower grades, culling and selling every year.

"The largest clip from a single pure buck obtained was eight and a half pounds; from a single ewe five and a half pounds; from grades eight pounds; from wethers four pounds; from ewes down to two and four pounds. Three-quarter grades would frequently shear two pounds for ewes, four pounds for wethers from one to three years old. After three years for breeding ewes and four for wethers and bucks, the clips would begin to decrease in weight.

"The highest grades I reached was the eighth cross, 255-256. After the fourth cross, the grades, in appearance compared favorably in length and weight of fleece with the pure-bred. The mohair on the grades, even on half-breeds from smooth short-haired ewes, except in length. was equal in lustre and fineness, to the pure. 
"Most of the grades from the Peters buck shed their mohair, bu from the Scott buck retained it after shearing, growing on like the woo on sheep. I had no disease among my goats except occasionally a case of lung worms. Was troubled a good deal with goat lice. I believe dipping should be practiced after shearing, and a change of range and bedding ground every eight or ten wecks. I tried shearing one a year, and, then twice, in October and November, according to weather, and again in spring. The two shearings gave better results. Used good shelter in wet weather; fed hay, straw, and some cotton seed when needed. No stock can compare with the goat to clean up brushy and weedy land. They eat very little grass if they can get weeds and brusin. If not overstocked, they make the range better for cattle, horses and sheep.

"I occasionally had a slight tinge of red from my crosses from the Peters buck, in both graded and pure nannies. From my observation in breeding I believe we have the foundation for improvement equal to anything we are likely to import, unless it be from the Cape and I would advise all breeders to test any importations before breeding to a selected flock that had been brought up to high standard by careful breeding. Angoras, with me, would breed only once a year, like deer, and seldom brought but one kid. To improve a flock, one kid is enough. I sold my goats six years ago. Cause-wolves and my inability to get careful and trustworthy herders.

"I have no records by me, but above gives you practically my experience in goat raising. Will add that to my taste, no better meat was ever placed on table than a roast from a fat two or three year-old Angora wether. I do not like the meat of the common goat.

Respectfully.

"I. C. P. M'LENDON." 


\section{CHAPTER XXXI.}

IS IT ADTISABLE 'TO START A REGISTER FOR ANGORA GOATS?

This question is by no means a new one. It has been asked over and over again. and was seriously agitated upwards of twenty years ago. Whenever it has been brought up, the question has always been advanced: "What have we got to register?" and after some discussion about the merits of certain flocks of goats, the matter would be dropped. There can be no doubt about our having many Angora goats in every way worthy of being registered, but hardly any two breeders have exactly the same type of animal, and this seens to have been the difficulty in the past. Each breeder appears to have had his own idea, as to a perfect Angora, and the result has been that no agreement could ever be reached as to what points should be used for a standard.

In Turkey they know very little, and care much less, for such a system; and, the breeders in South Africa, seem to have had very much the same trouble as we have had.

We have some flocks that were started from the original "Davis," or "Peters," stock, which have become individualized as the "Scott," the "Haupt," the "Landrum," and the "Divine" goats.

Then we have the "Parish" goats which originated frum pure blooded stock from a direct importation from Turkey; and, later, we have the "Harris" goats, which were started from an importation made by Mr. Harris himself, selected by lim in person, who has kept them scrupulously free from any foreign mixture ever since they landed in this country.

The Conklin Bros., of California, claim to have started a flock from pure-bred goats, imported by Mr. Eutichedes in 
1880; and, there are doubtless other breeders who have purebred goats that they can trace to one, or other, of the importations that have been made into the United States.

There is no reason why a register should not be established for sucli animals as I have referred, to but it would seem to be a difficult matter to embrace all of them under one common register unless they all have the same characteristices, which is doubtful.

We can probably learn much upon this subject from our neighbors in the sheep industry, who have passed through. practically, the same experience that we are just entering.

The sheep industry was started about the beginning of the present century (1808) by Mr. Humpi.reys, our, then, Minister to Spain, who brought home with him some two hundred head of Spanish Merinos, resulting in the cstablishment of the worldfamous breed of "American Merinos;" and, from which, a number of sub-breeds have sprung, such as the "Dickinson" Merino, started by Mr. Wm. R. Dickinson, of Stubenville, O.: the "Black Top" Spanish Merino, started by Mr. Wm. Berry, of Washington, Pa.; and the "Improved Black Top" Merino: all of which differ in some particular points, yet, date their origin from the original "Humphrey" sheep.

Mr. IVm. Jarvis, of V'ermont, imported a lot into his State, from which the celebrated "Vermont" Merino originated; together with several other well known breeds stich as the "Standard Delaine," the "Nationa! Delaine," the "Improved Delaine," and many others which it is unnecessary to mention.

The sheep referred to differ very slightly from one another, yet the breeders of each are jealous of the peculiar points they possess, and maintain a distinct and separate association to make proper rules and regulations to govern any matters of difference that may arise from time to time, together with a register through which every member of the association can record his individual sheep.

The "Davis," or "Peters:" the "Chenery," "Diehl \& Brown," "Eutichedes," and "Harris" importations of Angora goats occupy the same relative position in the goat industry, as the 
"Humphrey" and the "Jarvis" importations do to sheep; and the "Scott," "Haupt," Landrum" and "Parish" goats the same as the "Dickson" Merino, the "Black Top" Merino, and other individual breeds of sheep that have sprang out of one or other of the original importations.

The "Hornless" type, mentioned by Mr. S. S. McKibben, of Earlham, Iowa, is very much on a par with the "Dickinson" Merino, which is a hornless breed of sheep, and it is to be hoped the breeders of this type of goats will begin at once and establish an association of "Hornless," or "Polled Angora Croats," through which they may be able to record their increase.

The breeders of the "Non-Shedding" variety referred to by Mr. J. C. P. McLendon, of Texas, certainly ought to try and preserve it through a special register, as well as any other valuable types of Angora goats which may originate in the future.

Many breeders believe it is necessary to make a new inportation from Asia Minor before we can begin an American register, because such a long time has elapsed since any of our importations were made. This would seem to be wholly unnecessary, although I would be giad to see another importation made, provided we can improve on what we already have. But if we are to be governed by the written testimony of a number of reliable Turkish authorities, we would not be able to find any purer-bred stock in Asia Ninor-if indeed as pure-as we now have in our own country.

I am aware of the fact that the very essence of a register of live stock is to enable a purchaser to trace the lineage of an animal through flocks of reliable breeders, to the original importation; and this would be difficult, if not mpossible, to do with most of our present stock of goats. Are we then to be forever barred from establishing a register for the fine goats we now have, simply because the breeders have been careless about starting a register?

The principle is, without doubt, a correct one, provided the foreign stock has maintained a condition of purity; but, in the present case, it seems to me it would be more in keeping with 
common sense if the Turks were to start a register based upon American goats, than for the Americans to begin a register from goats imported from Asia Minor.

And, with reference to South Atrica, Mr. Schreiner says:

"It is perhaps, impossible to say exactly how many Angora goats have been imported, but it is safe to say, in all, they number over 3000 . They have come from numerous districts in Asia Minor, and are representative of the general run of Turkish goats. There has been no uniformity among the goats imported: they can not be said to be representative of any definite type, or types. Each animal stands solely on its own individual merits, and not as the representative of any type. In the future there may be certain fixed varieties among Angora goats, as there are today among Merino sheep, but, at present, no such varieties exist. Some very superior animals have been imported; but. Mr. Binns says, the very best have never left Turkey. A great many mongrels have also been imported, and Angoras are, today, as mixed at the Cape (except the best stud flocks) as they are in Turkey. However, notwithstanding the fact that many thoroughly bad animals have been imported, so inferior as certainly to injure rather than improve even the average Cape flocks; yet, owing to the suitability of the Cape climate and pasture to the Angora goat, and particularly to the superior intelligence of the Cape breeders and their adoption of more modern, and scientific, methods of breeding; the quality of the best stud flocks has been raised to so high a standard of excellence that Turkey would probably profit by obtaining new blood from the Cape, for use in its very best flocks. On the other hand, considering the inferior type of farmers engaged in the industry in Turkey and the primitive and unscientific methods of breedng in vogue there, further importations to the Cape seem wholly inadvisable, unless under the auspices of the Angora Goat Breeders' Association, and unless twc of the very best judges in the Colony, go to Turkey to select the goats. Failing this, the Cape industry will best advance without assistance from Turkey. It but remains for the Cape farmer to have a clear conception of what kind of fleece he desires his goats to produce, and then to work unswervingly towards the realization of that conception. The breer? here is in a most plastic state yet, but the leading breeders are gradually and sulely, fixing it, and, what is more hopeful, gradually, bringing their goats towards uniformity to one type." (See Schreiner, p. 216-218.)

It is to be hoped there will be found some way out of the difficulty, for it would certainly be very proper to have registers for all goats that have valuable characteristics, and have been bred to points a sufficient length of time to thoroughly fix the same. 
Bearing upon the question of importing goats from Turkey, the following letter from the Hon. H. S. Jewett, United States Consul at Siras, Turkey, to Hon. Thos. H. Tongue, member of Congress from Oregon, who is personally interested in Angora goats, and has taken a deep interest in the industry, will be interesting.

The letter is taken from the "Texas Stockman and Farmer," of San Antonio, Texas and reads as follows:

\section{ANGORA GOATS.}

"H. S. Jewett, United States Consul at Siras, Turkey, in a recent letter to Hon. Thos. H. Tongue, nember of the House of Representatives. Washington, D. C., anent the Angora goat industry, says: 'In further answer to your inquiries in regard to Angora goats for importation to the United States, I send you the following information obtained from the British Consul at Angora: The average price of a picked Angora hegoat of the best class is $\$ 17.66$, and for a she-goat of the same character $\$ 6.60$. The best age for a he-goat is from two and one-half to three and one-half years old, and the expression 'picked goat' means a goat exclusively chosen from that age. The average price of the best class of hegoats without selection form age is about $\$ 15.40$. In some cases, of course, a particularly fine he-goat might go as far is $\$ 22$ or $\$ 26.40$, or the proprietor might refuse to sell him at any price.

"The average annual yield of the best picked he-goat is nine and onehalf pounds, and of the same class of she-goats five and one-half pounds. The average yield of he-goats of the second class is about five and onehalf pounds and of the third class about four pounds. The best class of mohair is not to be found at Angora itself, but at Ghereda and Kibris in the district of Boli, province of Castamoun, and it is in that district that the most recent purchases for export have been made. The prices above quoted are for the goat as purchased on the spot and do not include commission, export and transportation charges. A certificate of health is necessary or desirable for each goat before it is purchased. It would be entirely useless to purchase Angora goats from this country unless an imperial permit for exportation had been previously obtained at Constantinople. I think that perhaps such a permit could be obtained more easily and with less expense by some private native person than by our minister or general Consul. The government might not wish to give a permit to an official representative. In any case to obtain a permit requires time and money. It is said to be a long and costly process. It is said that the Angora goat when transplanted requires a periodical infusion of new blood from the old stock to prevent degeneration. A work entitled, 'The Angora Goat,' would no doubt give valuable informa- 
tion on this and other questions concerning this animal. Goats are sent from this country to South Africa. George Kypelogion, a merchant of respectable standing of Angora has acted as agent on behalf of George Gatheral, an Englishman, in the purchase of goats for export to South Africa."

It might be well, perhaps, for breeders in a certain district or county where really fine Angoras are being bred, to get together and organize an association for the purpose of registering a standard-bred Angora, the points of which to be agreed on by those interested.

But it would seem to me hardly possible to ever expect to conbine all of our fine goats in a State, or in the United States, under a single State or National register.

Since the foregoing chapter was written, a meeting of Angora goat breeders was held in Kansas City, Mo., which resulted in starting the "American Angora Goat Breeders' Association," of which

Mr. T. H. Mastin, of Kansas City, was elected President,

Mr. R. C. Johnston, of Lawrence, Kan., Vice-President,

Mr. T. J. Eamen, Treasurer, and

Mr. M. T. McIntire, Secretary; together with the following Board of Directors :

Dr. J. R. Standley, of Platteville, Iowa.

Benj. F. Elbert, of Des Moines, Iowa.

L. A. Allen, of Kansas City, Mo.

T. H. Mastin, of Kansas City, Mo.

W. H. Woodlief, of Woodlief, Kan.

Robt. C. Johnston, of Lawrence, Kan.

Wm. L. Black, of Fort MeKavett, Texas.

Dr. J. R. Standley was elected Inspector and it is the intention of the Association to inspect such flocks of goats as clain to be "thoroughbred," whenever the owners of the same express a desire to have their goats registered, when a certificate will be given to them for such as come within the standard agreed upon.

It is not the intention of the Association to deal with any peculiar "points" beyond a well-formed animal, having a fleece 
of pure mohair evenly distributed over the body, particularly on the chest and belly.

Such points as shape of horns, character of fleece (whether wavy or in ringlets), length of staple, weight of carcass, etc. etc., are considered to be of minor importance and can only be controlled by a special association, which is recognized as being the only practical way to register "fancy points." But purity of blood is considered paramount to all others, and as being to the best interests of all, that these should be registered, in order to protect every one interested in this new industry from the unscrupulous breeder, who will represent his stock as being pure, when he has no right to do so.

In addition to this the Association, which is practically national in character, contemplates the general advancement of the industry throughout the United States by the collection of information, awarding of premiums for excellence of breeding, ect., etc.

The register is to be known as the "American Angora Goat Record," and is to be published annually, in book form. for free distribution.

The revenue derived from fees for registration is to be used for the general good of the industry. The actual expenses of the Inspector, and Secretary, for labor performed, and for printing and stationery, etc., being the only expense that is to be paid out of the general fund, and the surplus to be disposed of as the directors may deem proper.

A "Combination Sale" is to be held in October of each year at Kansas City, which --ill enable breeders to select breeding sires for themselves, anu dispose of such stock as they may have no further use for.

Only breeders of good reputation and standing can become members of the Association.

The officers are to consist of a President, Vice-President, Secretary, Treasurer and Inspector, who are to be elected annually.

The affairs of the Association are to be governed by a Board of Directors, not to excee! thirteen, who are to be selected from among members annually. 
There is no doubt such an Association will be of incalculable benefit, and it is hoped that all the breeders will become nembers of it. Most of the present officers are comparatively new in the industry, but are men of high standing. Mr. Mastin is a capitalist and a large land owner, who has learned of the great value of the Angora goat, and is the owner of quite a number of them at this time.

Mr. R. C. Johnston is proprietor of the electric light and gas plant in Lawrence, Kan., and is also a new beginner.

Mr. T. J. Eamen, the 'Ireasurer, and Mr. W. T. McIntire, the Secretary, are both members of the well known Kansas City Live Stock Commission Co., of which Mr. L. A. Allen, one of the directors, is Vice-President.

Mr. Benj. F. Elbert, of Des Moines, Iowa, is a retired banker and a large land owner.

These gentlemen have no object in view, beyond the development of an industry which they believe possesses great merit, and are prepared to withdraw from the management of the Association whenever the members see proper to elect their successors. Upon one of my recent visits to Kansas City, several of them that I had the pleasure of meeting, expressed the hope that the next meeting would be attended by a large number of representative breedors throughout the United States, and that many of them would bring their best stock to the "combination sale," which is their intention to have inmediately after the meeting.

It is expected that the "combination sale" will result in great benefit, as well as profit, to many of the breeders who attend them. Oftentimes a breeder may want to change the sire of his flock but does not know where he can replace him. Or, he may be in search of an animal possessing certain characteristics, either in form or fleece.

It has been related of Mr. Robt. Bakewell, to whose genius is due the wonderful change that was made in the cattle of England during the latter part of the Eighteenth Century, and who was the immediate founder of the now famous breed of "Leicester sheep," that he has been known to search years for 


$$
\text { Register for Angora Goats. }
$$

an animal possessing certain points that he was wanting to use in his experiments. Such a condition need never confront the American breeders of the Angora goat if they will take advantage of the plan now proposed, to concentrate the various types of Angora goats under one roof, annually.

It is well kown that the selection of the best of each generation, and mating them. has been the means of bringing all of our other fine classes of live stock up to the high standard of excellence they now enjoy, and it is therefore to be hoped that all breeders in the United States who are ambitious of seeing the Angora goat superior to all others in the world, will unite with the "American Angora Goat Breeders" Association," and join hands with the Board of Directors in their efforts to make it such.

It is not the intention of the Directors to force any of the measures they have adopted unless they meet with the unqualified approval of a majority of the breeders who may become members of the Association. The most of them realize they have much to learn concerning the Angora goat, which is a comparatively new animal to them, and for this reason they earnestly desire the hearty co-operation of all the old and progressive breeders in their efforts to advance and promote this young but promising industry. 

Appendix. 

A Paper on the

Cashmere Goat

$$
\text { of Asia. }
$$




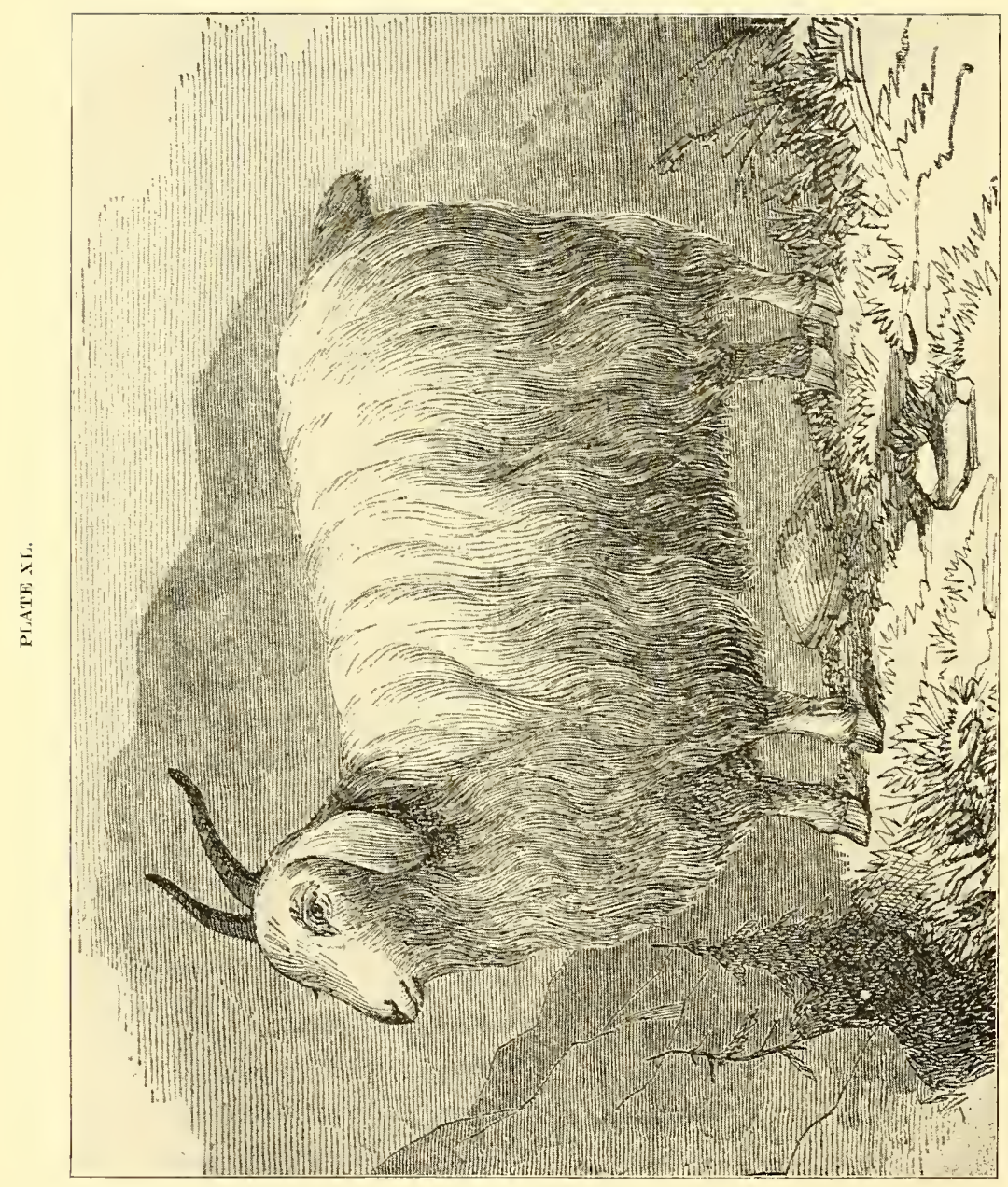




\section{CASHMIERE GOAT.}

There las always been so much doubt as to the true character of the goats that Dr. Davis, of South Carolina, first imported into the United States, many claiming they were of the "Cashmere" breed and not "Angora." I have thought it might be at least interesting, if not of some practical value, to the present breeders of the Angora goat to make some special reference to the "Cashmere" goat itself.

Dr. Davis always maintained that:

"The Cashmere, Persian, Angora, and Circassian, yoats are all one and the same animal, changed in some respects by altitude, though but little by latitude."

Mr. D. J. Browne, an able writer on agricultural subjects took exceptions to the claim that Dr. Davis had made, and wrote the following article, which appears in the report of the Department of Agriculture for 185i, page 56 .

\section{Mr. Browne says:}

"The Cashmere and Thibet goat are the same. The regions called Cashmere, and Thibet, adjoin each other, and the western portion of the latter. which is called little Thibet, is included in the dominions of the Maharaja of Cashmere. This goat is found also in the country of the Kirghiz, in Central Asia, at the bend of the U,ral, north of the Caspian Sea. It is of the size of the domestic varieties most common in Europe, and the United States, and is covered with long, flat, and falling silky hair beneath which there is, in winter, a delicate greyish wool which constitutes the fabric of the costly Cashmere shawls of commerce. Only three ounces of this wool are, on the average, obtained from each goat. ** The Angora is of a silvery white. with long and silky hair of one sort only. ** Dr. Davis is therefore, obviously misled in supposing that the four varieties of goats named by him are identical." See Pat Off. Report, $185 \bar{i}$, p. 56.

It will be observed that M[r. Browne claims that the Cashmere only produces "three ounces" of under-wool, or down: while Dr. Davis sars the goats he had, produced one pound. 
And Mr. S. Holmes Pegler, a well-known authority on the Angora goat, and author of "Advantages of Goat Keeping," states that the Cashmere yields one-half pound or eight ounces.

The following description of the Cashmere goat is by Mr. Pegler, and was taken from the Encyclopedia Britannica:

"This animal has a delicate head, with semi-pendulous ears, which are both long and wide. The hair varies in length and is coarse and of different colours, according to the individual. The horns are very erect. and sometimes slightly spiral, inclining inwards, and to such an extent in some cases as to cross. The coat is composed, as in the Angora, of two materials: but in this breed it is the undercoat that partakes of the nature of wool and is valued as an article of commerce. This undergrowth, which is of a uniform greyish-white tint, whatever the colour of the hair may be. is beautifully soft and silky, and of a fluffy description resembling down. It makes its appearance in the autumn, and continues to grow until the following spring, when, if not removed, it falls off naturally; its collection then commences, occupying from eight to ten days. The animal undergoes during that time a process of combing by which all the wool and a portion of the hair. which of necessity comes with it, is removed. The latter is afterwards carefully separated. when the fleece. in a good specimen, weighs about half a pound, being worth between half to three quarters of a rupee. It is sold by the turruk of twelve pounds. This is the material of which the far-famed and costly shawls are made, which at one time had such a cemand that, it is stated '16,000 looms were kept in constant work at Cashmere, in their manufacture. Those goats having a short, neat head, very long, thin ears, a delicate skin, small bones, and a long heavy coat are. for this purpose. deemed the best. There are several varieties possessing this valuable quality. but those of Cashmere. Thibet, and Mongolia, are the most esteemed. About the year 1816. a small herd of Cashmeres was introduced into France with a view to acclimatize and brecd them for tne sake of their wool, but the enterprise failed. A few were purchased and brought over to England by Mr. C. T. Tower, who, by careful treatment, so far succeeded with them that, in course of time he had a shawl made from their fleece, which turned out to be of good quality. At the death of the owner. some years later, the herd, which had then deteriorated through in-breeding, was presented to the Queen, and placed in Windsor Park." See Ency. Brit., Vol. X, 709. 
About thirty years ago an eminent breeder of sheep in Australia, Sir Samuel Wilson, imported from Jndia, at an expense of $£ 300$, sterling (about $\$ 1,500.00$ in American money), a pair of "Cashmere goats" for the purpose of experimenting with the breeding of them in that climate. His experience was not any more satisfactory with these than it had been with a lot of "Angoras" that he had brought in about the same time from Asia Minor, and was not followed up many years.

In 18.3, this gentleman wrote a pamphlet giving some very interesting facts about "Angora" goats in Australia, from which the following extract is taken touching the "Cashmere" breed:

"The late Prince Albert had a small flock of the pure Cashmere goats at Windsor. With the enlightened foresight, for which he was distinguished. he was always in the van whenever any gool work could be done for the benefit of agriculture, or the increase of the prosperity of the people of England. Desiring to have some fabrics manulactured from the fleece of his Cashmere flock, a quantity of the wool, and hair, as it is shorn from the goats, was sent to a large manufacturer. 'I ne separation of the wool from the hair being, at that time. from the imperfection of the machinery in use, a very dificult operation, a great number of ladies assisted the manulacturer by taking small portions of the neece anu picking by hand, the wool from the hair. Such was the enthusiasm caused by the experiment that over a thousand persons of all grades and conditions, were engaged in the work. Each person so employed receired as remuneration an elegantly engraved certificate, stating that the holder had assisted in bringing to a successful result the exepriment of His Royal Highness in the manufacture of Cashmere goats' wool. Some brocades and two beautiful shawls were produced by Messrs. Haley, the manufacturers, and the hair was also made into a coarse fabric which was shown in contrast with the finer textures."

"Notwithstanding the success of this experiment and the high nature of the requisite textures made from Cashmere wool, I am far from thinking the Cashmere goat of equal value, in an economic point of view to the Angora. The immense amount of labor required to free the Cashmere wool from the coarse hairs, and the very small quantity of wool produced by each animal, are dfificulties that are not to be surmounted."

It was the opinion of Sir Samuel Wilson that the amount of fine wool on the "Cashmere" could, by proper breeding, be very largely increased, and he refers to an experiment in this 
regard that was made by a M. Pollonnau in 1818, with some "Cashmeres" that had been imported into France by Baron Ternatx, a few years before:

"'The object of the experiment, he says, was to produce an animal with the wool, or down, more abundant than in the Cashmere race and with the hairy coat more silky, and finer.' The experiment with the first cross, with an Angora goat, increased the length of the under fleece, or down, fully twice the length it was on the Cachmere, and it was the opinion of Baron Ternanx that the fleece of the cross between the two breeds, in consequence of its special qualities, would have produced fabrics superior to the most beautiful of those hitherto introduced."

Mr D. J. Browne also makes some reference to this matter in the letter I have just quoted from referring to Dr. Davis, although the name of M. Pollonnan is not spelled exactly the same as above, there is very little doubt but that they are intended to mean the same person.

Mr. Browne says:

"There is some evidence of the importation of both the Thibet, and the Angora goat, into France at different times. *** It is well known that in 1819 a Mons Jaubert brought some 400 or 500 Thibet goats from the Kirghiz Territory to France having started from the former country with 1300. Those which survived the journey were received at Marseilles by a Mons Tessier, and by him placed in various situations in France. A doubt was at one time expressed as to the purity of the breed of these goats, but no good reason was advanced as to the basis of such a doubt. Their fleece did not prove abundant enough for profit, however, until 1823. when a Mons Polonceau caused a cross to be made between the Thibet, or Cashmere and Angora goat with great success insomuch that, instead of three, thirty ounces of down was obtained from each of several of the cross-breeds; and, it is adided, of a superior quality, being of a finer and longer staple, while the animals themselves were quite hardy and more docile. In 1824 some of the Thibet goats were conveyed from France to the county of Essex. in England, by a Mr. Towers, but the number was not regarded as sufficient, nor is there any record of the result." (See Pat. Off. Report, 185.5, p. 5.5.)

It is to be regretted that there is no further record of this interesting experiment in France, but it is of great value to know that such a marked improvement in the "Cashmere" was made in the short time the experiment lasted. 
In this connection I would call the readers attention to the experiment of Dr. J. B. Davis, of South Carolina, with the goats he had imported into this country in 1849 . In a communication to the Patent Office in 1853, Dr. Davis says:

"In the third cross upon the Cashmere, we may expect a valuable experiment by changing the fine under-nool, or down, into a conjoint and uniform covering of wool." See Pat. Off. Report, 1853, p. 21.

\section{Sir Samuel Wilson was of the opinion that}

"By selection the wool might be increased by slow degrees, and the kinky hairs lessened until a wool-bearing animal, with a fleece finer than the finest Merino wool, and as free from kinky hairs, of its early progenitors, as is the champion Merino at Skipton, or Mudgee (where the best specimens of the Merino in the world are to be seen) from the hairy mantle of its orine ancestor, the Argali, of the Caucasus. Possibly the result might sooner be reached by a cross of the Angora producing a rariety of intermediate forms, and making the breed more plastic, and lessening the force of heredity, giving more scope for selection. $\mathrm{O}$ cross-breeding, however, I am not an admirer, and think the desired end is to be attained in a more satisfactory way by a long course of selection carried out in an intelligent manner, and with a fixed purpose kept constantly in view. Have we no skilful breeder in Australia who will undertake this task and bequeth it to his children if incomplete in bis lifetime?"

It will be remembered that some of the early (18.5.5-56) breeders of the "Davis" goats in Tennessee claimed to have produced a fleece ranging from three pounds to seven, which ther sold at six dollars, to eight dollars and fifty cents, per pound to the manufacturers of shawls in Paiseley, Scotland, (see Chapter XVIII.) In view of the experiments referred to in the foregoing extracts the opinion is forced upon me that, possibly the 'T'ennessee breeders had a strain of blood (which we know came direct from the hands of Dr. Davis in South Carolina) practically the same as mentioned by Mons Pollounau of France, only of a much higher type, which in subsequent years they lost by inadvertently mixing their pure goats with the common blood of our country, and finally resulting in a complete change in the character of the fleece. 
It would indeed be very interesting if the suggestion made by Sir Samuel Wilson could be carried out in practice by some American breeder; and, in the absence of the pure "Cashmere" it is not unlikely that one of our native Rocky Mountain goats would make an excellent substitute. 


$$
\begin{gathered}
\text { A Paper } \\
\text { on the } \\
\text { Rocky Mountain Goat } \\
\text { of the } \\
\text { United States. }
\end{gathered}
$$




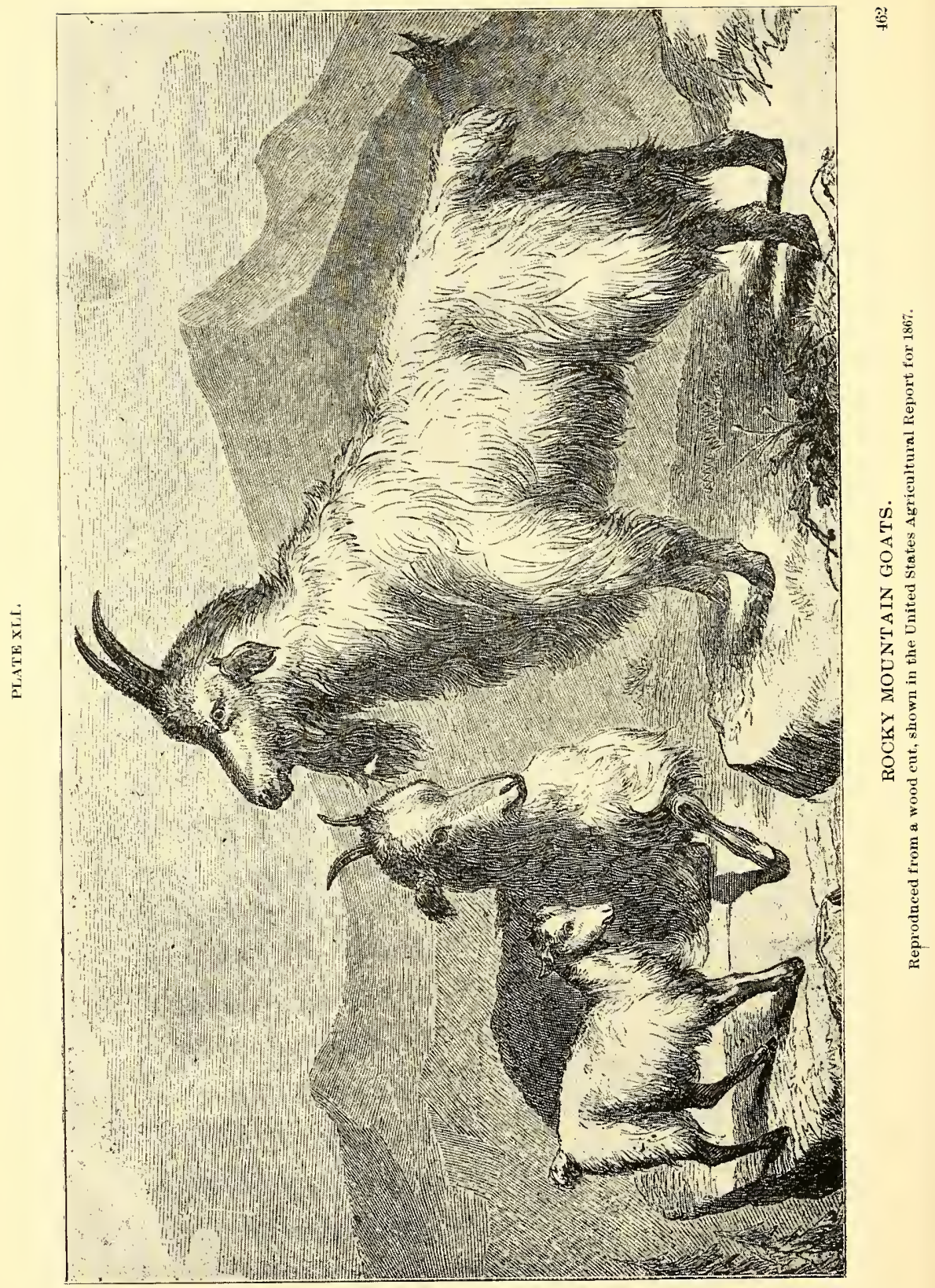




\section{ROCKY MOUNTAIN GOAT.}

'i he following description is giver of the Rocky Momntan goat, Capra Americana, by the late Prof. Spencer F: Baird, an American naturalist, who was connected with the "Smithsonian Institute" of the Lnited States for some time prior to his death, which took place in 188 .

"This beautiful animal is frequently confounded with the big horn or mountain sheep, from which it differs in many important characteristics. It is of the size of the domestic sheep, and bears no inconsiderable resemblance to the Merino breed in the way in which the fleece hangs down on the sides. The body, neck, and head, resemble those of the common goat. The horns are small, awl-shaped, and pointed, and nearly erect, with but a slight curvature backwards. Both horns and hoofs are black. The animal is entirely white with the exception just named. The body is covered with long, straight hair, considerably coarser than the wool of the sheep, but softer than that of the common goat. This hair is abundant on the shoulders, neck, tack, and thighs; a considerable tuit of it, attached to the chin, forms a beard. There is likewise much of it on the chest and lower part of the throat. The tail is short, and, though clothed with long hair, is almost concealed by that which covers the rump. Under the hair of the body, there is a close coat of fine, white wool. The hair on the face and legs is short, the fetlocks short, and, with the hoofs, perpendicular. The small posterior hoofs do not touch the ground.

"To the agriculturist and manufacturer, the mountain goat affords a promise of importance which we may well hope to see realized. No wild species can compare with it in the excellence of its fleece, which, even in its original state, is as fine as that of the celebrated Cashmere goat. Careful management, under domestication, would, no doubt, increase this character to an extraordinary degree. Hence, it is not remarkable that attention should have been directed to this species with a view to its cultivation. The Higliland Society, at one time, made an effort to introduce this animal into Scotland, where it was supposed it would thrive. Owing, however, to the inaccessibility of its nature, it was found impossible to obtain specimens. At the present time. such might perhaps be procured through the agency of the 'American Fur Company, to one of whose posts. Fort Benton. on the Upper Missouri, above the falls, skins are occasionally brought. 
"A competent wool-grower in Scotland, to whom the subject was referred, reported that the wool which forms the chief covering of the skin is fully an inch and a half long, and of the finest quality. It is unlike the fleece of the common sheep, which contains a variety of different kinds of wool, suitable to the fabrication of articles very dissimilar in their nature, and requires much care to distribute them in their proper order. The fleece under consideration is wholly fine. That on the fore part of the skin has all the apparent qualities of wool; that on the back part, very much resembles cotton. The whole fleece, is much mixed with hairs, and on those parts where the hairs are long and pendant there is almost no wool.'

"The mountain goat inhabits the lofticst peaks of the Rocky mountain range, seldom coming down to the plains. They frequent the steepest precipices, and have much of the habit of the common goat. The species is common on those high lands of the Rocky Mountains whence flow the four great rivers, the Mckenzie, the Columbia, the Missouri and the Nelson, each one emptying into a different ocean. Their range is between the parallels of 400 and 640 . The only point within the United States where they are well known is about Ft. Benton, whence we have seen a single hunter's skin. No animal is less known to our naturalists, there being not a single preserved specimen, to the best of our knowledge, in any museum within the United States. Travellers who speak of the 'mountain goat,' sometimes refer to the big-horn, the female of which has horns much like those of a goat." (See U. S. Pat. Off. Report, 18j1, p. 120 .

In my chapter on "Science in Breeding, Etc." (XVIII), I have copied a letter from Mr. S. S. Bramnin of Marysville, Montana, a breeder of Angora goats, who had hunted and killed one of the Rocky Mountain goats, and his description of it is quite interesting.

There is very little doubt but that a cross of this animal with the "Angora" would be valuable. 
A Paper on

the

Llama and Alpaca

of

Peru, S. A. 


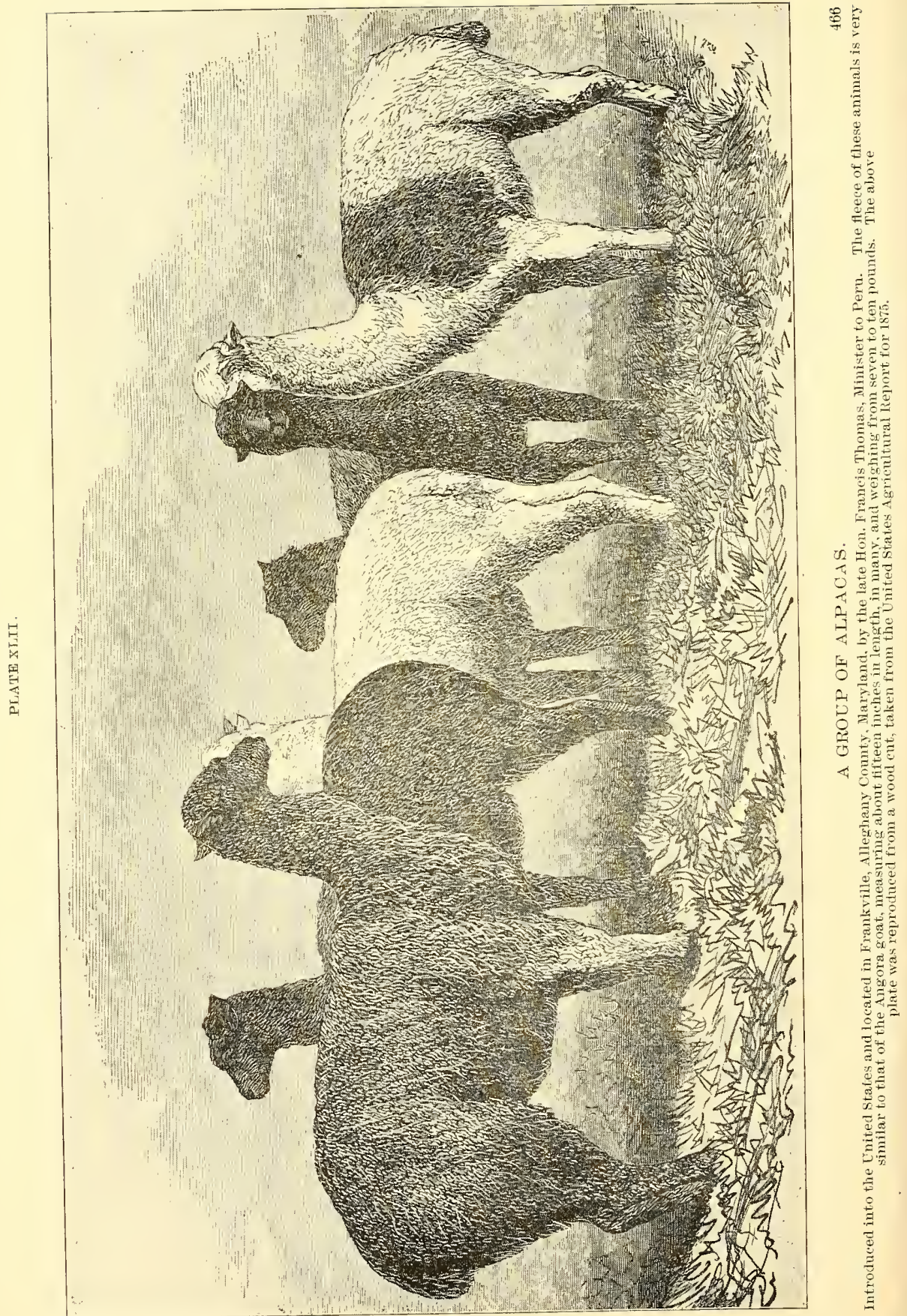




\section{LLAMA AND ALPACA.}

Considering the fact that it was through the fleece of the llama and alpaca that the Angora goat was first brought into prominence, it will not be out of place, perhaps, to make some reference to this very peculiar, but valuable, class of animals which are almost exclusively confined, at the present time, to Perı, in Soutl America.

The following paper was contributed to our Agricultural Department in $185 \%$, by Mr. D. J. Browne, from whose writings I have already quoted in connection with the Cashmere goat: Their Geographical Distribution, Organization, Food, Habits and Probable Adaption to Certain Regions of the United States.

"On the lofty Cordilleras of the Andes, in South America, considerably below the line of perpetual snow, from Chili nearly to the equator, there abound at least three kinds of animals known under the names of 'Guanaco.' or 'Llana;' 'Paco,' or 'Alpaca;' and the Vicuna; the latter of which, according to the classification of Cuvier, is merely a variety of the llama. This also agrees with the opinion of Inca Garcilaso de la Vega, who says, in the year 1811, that the domestic animals of the Peruvians are of two kinds-the greater and the smaller-which they as a common name, call 'llama,' that is cattle or sheep. The larger kind they call 'huanacu-llama,' on account of the resemblance it bears to the wild animal known in Peru by the name of 'huanacu,' from which it differs only in color; for the domestic llamas are to be met with as various in their colors as horses; but the wild llamas are uniformly of a chestnut color. The larger kind bears a great similitude to a camel, except that it is deficient in the hump upon its back, and is not so large. The small kind they call 'paco-llama,' which is only reared for its flesh and wool. The 'vicunas' are not very unlike goats in their appearance, except that they have no horns. are larger, and are of a leonine color, or more ruddy. They live in the highest mountains and groves, and particularly love those cold regions of solitude, which the Peruvians designate by the common name of 'punas;' neither are they annoyed by frost and snow, but are rather created by them. They go in flocks, and run most swiftly; and such is their timirlity that, at the sight of man or wild beasts, 
they instantly hurry into inaccessible retreats, and thereby elude their pursuers. There were formerly a great number of these animals here, but they are now becoming much more rare in consequence of the promiscuous license of hunting them. Their wool is very fine, resembling silk or the fur of the beaver, and the natives deservedly hold it in high estimation; for, besides other properties, it is also said to resist heat and impart coolness to the wearer.

"The llama (Auchenia glama) ordinarily, is from four to five feet in height, of a light-brown on the back and sides, and under the belly uniformly white. Sometimes, however, it is dun, grey, or even inclining to purple, and very seldom parti-colored or black. The hair is long. of a texture between silk and wool, but not curled.

"The alpaca, (Auchenia Alpaca) is smaller than the llama; its usual height being only four feet. It appears more corpulent, however, owing to its possessing a much longer and more profuse clothing of hair, which sometimes, is from eight to twelve inches in length on the sides, rump, and breast. The fleece of an old individual is represented to weigh twenty or thirty pounds. It partakes of various colors, often being particolored, but more frequently white than the other species.

"The most frequent breeds are said to come from the central provinces; and here it may not be irrelevant to observe that there are two varieties of alpaca, differing in size, figure and fleece. The breed called 'coyas' is the most diminutive, and is esteemed for the smallness of bone and symmetry of form. It is chiefly confined to the Cusco range of mountains, more particularly to that part of it intervening between the ancient city of the Incas and Haumanga. It is thought to be a remnant of the old royal flocks, or those once owned by the priests of the sun, who are represented as having the choicest breeds. That territory was, besides the principal theatre of agricultural operations, the seat of power, and the centre of Peruvian civilization:

"The Peruvians dry the flesh of the llama as well as that of the alpaca, which they are very fond of eating.

"The order to which the genus Auchenia belonss. offers to the eye of the naturalist but a very small anatomical difference of conformation from that containing the camel, properly so called. The feet are not, like those of that quadruped, entirely padded with an elastic sole, but the two toes are separated, each having strong, horny nails, or hoofs, nearly resembling the talons of a bird, with a thick cushion, or pad beneath. These animals are also dissimilar in the formation and arrangement of their teeth, having on each side of the upper jaw one canine tooth more than the canel, but are deficient in a second canine tooth in the lower jaw. Their incisors project fully half an inch from the muzzle-bone, so as to meet the pad fitted above, by which means, and with the aid of the tongue and cleft lip, they are not only enabled to draw together and 
clip short grass mpon the ground, but aiso, with their long necks, pointed muzzles, and the oblique posture which the head can assume, to collect luerbage growing on the hedges, and in the interstices of rocks seven feet high, as well as the tops of hedges and tall shrubs. Their teeth are, at the same time, so strong and interlock in such a manner that they easily crush and masticate vegetable substances too hard and tough for ordinary cattle. The absence of the hump and of the callosity on the breast, also constitute striking points of difference between these animals and the camel. The llama, however, has a conformation resembling the camel's hump, being provided with an excess of nutritive matter, which lies in a thick bed of fat under the skin, and is absorbed as a compensation for an occasional want of food. Some of these animals, as in the camel, have collosities on the knees of the fore-legs, and, like them, kneel down in the same manner. Their stomachs and those of the camel, in some respects, are similarly organized. That of the llama, according to Sir Fiverard Home, has a portion of it, as it wrere, intended to resemble the reservoirs for water in the camel; but these have no depth, being only superficial cells, and have no muscular apparatus to close their mouths and allow the solid food to pass into the fourth cavity, or digesting stomach. without going into these cells. But the stomachs of these quadrupeds certainly must have some kind of internal mechanism for retaining water or secreting a liquid substance; for it has been remarked, along the flanks of some parts of the Andes, that they live far above any lakes or streams, and abstain from drink a great portion of the year: and further, it luas been observed, that in a state of domestication, they never manifest any desire to drink so long as they can obtain an abundance of succulent herbage. From the peculiar organization both of the camel and the llama, we are led to infer that each is evidently fitted by nature for the endurance of great hardships and privations-the one amidst the sands of the desert, under a burning sun; the other on the wastes of some of the loftiest mountains of the globe, with a region of perpetual snow above. The slight variations of their conformation, such as that of the foot, are modifications of nature which befit them for their respective abodes. A luabitation amongst the rocks would be mechanically impossible for the dromedary, whilst the burning plains would be as little suited to the paco.

"The liama, in its natural liabitat on the Andes, at an elevation of irom $\$, 000$ to 12,000 feet above the level of the sea, far above any lakes or streams, feeds through choice, on a sort of rushy grass, or reed, called 'ichu, which grow's in abundance where it is said these animals are never known to drink so long as a sufficiency of green, succulent herbage can be obiained. They also derive subsistence from the mosses and lichens which fringe the rocks among their native haunts, or by browsing upon tender shubs. They adapt themselves to almost any soil or situation, 
provided the heat is not oppressive or prolonged, and the air is pure, possessing a hardiness of constitution admirably well adapted to the nature of their birth-place, where, during half the year, snow and hail incessantly fall; whilst in the higher regions, nearly every night during summer, the mercury sinks below the freezing point, and the peaks are perpetually covered with accumulations of ice or snow. It is astonishing that the temperature of the air on mountains so peculiarly situated and exposed to the full glare of the vertical sun, should be so much chilled as almost to present the desolate aspect of the Arctic regions; and yet such are the tracts upon which the vicuna and the guanaco abound and run wild, far above the abode of man, and are hunted for their flesh and skins. It is remarkable, however, that they do not inhabit Quito, Santa Fe, Caracas, etc., although the climate of the mountains of those parts is similar to that of High Peru.

"The comparatively small size of these animals, as well as the vegetable forms by which they are surrounded, clearly indicates that the climate of the Andes is not favorable either to animal or vegetable growth. It has also been remarked, that there the human species is subject to the same law; man decreasing in bulk and stature in proportion as he dwells near the mountain summits. In Peru, the winter sets in towards June, and is severely felt on the highlands, where the snow remains upon the ground six, and in some places, eight months in the year. As soon as the narrow and green strip of land bordering on the Pacific is passed the traveller begins to ascend the slopes; and when he attains the first table-land, observes a complete change in the climate and the appearance of vegetation. Except in the 'yungas,' or hollows, where an alluvial soil has been collected, and where the Indian plants his sugar-cane, banana, and esculent roots, the country wears a naked and barren aspect.

"The female llama and alpaca go with young eleven or twelve * months, and rarely produce more than one at a birth. They are weaned when half a year old, but are not put at work before they have completed the third year. They begin to bear when two years old.

"The llama and alpaca, as well as the alpaca and ricuna, can be induced to breed together, and of the former union there are frequent instances to be met with in Europe as well as in Peru. From this alliance, a beautiful hybrid results, if possible, finer to the eye than either parent, and also more easily trained to work, but, like the mule, it does not procreate.

"From the sterility of this hybridous race, it would follow that the alpaca is a distinct variety of the llama tribe, differing as much from its allied species as the horse does from the ass; and, consequently, that the two domestic animals of the Peruvians were not brought to their present

*According to investigations made by Dr. J. L. Hayes, only seven months is the period of gestation. See Hayes, p. 149. 
state by means of crossing. Their inter-mixture is a modern expedient by the Spaniards. It is a rule of the vital economy, that life only springs from life, and every being is consequently endowed with the property of generating an offspring, inheriting a nature similar to its own. When the species vary, this rule ceases to act; whence, although possessing a strong physiological resemblance in many important points in their organization, there must necessarily be some material difference between the llama and aipaca in the functons of generation, which it is more than presumable equally extends to the wild species, and that difference produces an irregularity at variance with Nature's laws, constituting an essential condition of life. It appears from the report of MI. Bory de Sitint Vincent, a distinguislied naturalist, who accomanpied the French army into Spain, under Marshal Soult that he observed in the Zoological Garden of Don Francisco de Theran, at SanLucar de Barrameda, in Andalusia, three alpa-rigonias (the cross between the vicuna and alpaca), the fleeces of which were much longer, and six times heavier than those of any other variety. The Spaniards were proud of this acquisition, thinking that they had obtained a new race of wool-bearing animals, calculated to people their hills and repair the loss sustained through the decline in their Merino flocks. By the experiment of crossing. however, they defeated the very object they had in view, as the animals gradually died off, without leaving any offspring, and in the course of a few years there was scarcely one individual to be found in the kingdom.

"The Perurians are careful not to overload either of these animals, the burden of which is generally about 100 pounds, thougli for a short distance, on good roads, they occasionaly carry twelve or fifteen pounds more. They are usually docile and willing to perform their task, if gently treated, but, if provoked, they express their anger by turning back their ears and spitting into the face of their offender, even if ine be three of four yards off. 'Their food is never prepared for them, but when unemployed, they are suffered to graze on their native mountains, often pasturing in company with the wild species: but they are so much accustomed, and apparently attached to mankind, that they never exchange servitude for freedom. Those animals which have been brought to Europe and the United States appeared to thrive well for a time on the same sorts of food as eaten by cattle and sheep, but the inferior kinds of browse, grass or hay, with a due proportion of potatoes, carrots or other succulent roots were preferred by them to rich pastures and farinaceous grains. 'Too liberal an allowance of nutritious and stimulating food to an animal extremely abstemious cannot, therefore, be regarded other than injurious. Its peculiarly formed stomach is not adapted to dry, hard food, the best proof of which is its habitual abstinence from drink. In Puru, the llama is sometimes treated with maize or millet, in their green, soft, silky stagc. 
"In regard to the diseases of these animals, it has frequently been remarked that when they are taken down to the lowland towns, and are there kept for much length of time, they perspire freely, as soon as the hot weather comes on, and, if neglected, a scurf, or rash, forms on the skin. In their new character, the coat, of course, is carefully preserved as being ornamental; but, if it is shorn off, and the animal is bathed in the cool part of the day, before the system has been heated by exercise, or the natural warmth of the climate, the sufferer invariably recovers in a short time. This cooling remedy, it has been nbserved, the animals themselves naturally seek; for, when taken down to the heated atmosphere of the plains. should this rash break out, both these animals instinctively go in search of a refreshing stream, not for the purpose of drinking, as has been erroneously supposed, but for bathing. and thereby preserving their health.

"For a period of nearly forty years the subject of introducing these quadrupeds into this country has been agitated, and several attempts have been made to engraft them into our husbandry. As well known instances of this, it may be recollected that the late Col. Skmner published an extended notice of these animals in the 'American Farmer' in Baltinore, advocating their adoption, in 18:21: the 'American Agricultural Association,' of the City of New York, raised a fund by subscription for their introduction in 1816 . A present of several of them was made by the Peruvian Government to the Hon. Daniel Webster, when Secretary of State; and the early part of the past winter, a car of llamas and alpacas were shipped to Baltimors, on speculation, from. Guyaquil. But, owing to the apparent inadaptability of these animals to the climate and elevation of the Atlantic and Gulf States, all the experiments hitherto made proved futile. To succeed, then, as a last resort, we have only to direct our attention to those rast elevated tracts known under the name of the 'Great Plains,' at the east of the Rocky Mountains; and iying, principally, between longitude twenty degrees, and thirty degrees west from Washington, extending from Texas to the Arctic Sea. The plains contain but little timber, or woods, and individual trees are rare. They mostly have a gentle slope from the west to the east, though, in some instances, gracefully undulating, clad with thick. nutritions grasses, and teeming with animal life. The soil, though compact, is a fine calcareous mould. The climate is comparatively rainless, stornts being rare, cxcept during the melting of the snows on the monntain crests, which swells the rivers, like the Nile, to irrigate, rather to drain the neighboring tracts. The herbage, which is perennial, edible, and nutritions throughout the year, is peculiarly adapted to the dryness of the soil, and the temperature of the air. It consists, principally, of the 'Gramma,' or 'Buffalo,' grass, and covers 
the ground an incl in height, having the appearance of a delicate moss. During the melting of the snows, in the immense mountain masses beyond the Great Plains, the rivers yield a copious evaporation in their long and sinuous courses: storm-clouds gather on the summits, roll down the mountain flanks, and discharge themselves in vernal showers. In this temporary prevalence of moist atmosphere, these relicate grasses grow, seed in the root, and are cured into hay upon the ground by the returning drought. It is in this longitudinal belt of eternal pasture that the llama and alpaca would thrive, if at all, in any part of our domains, where infinite herds of aboriginal cattle, the buffalo, the elk, the antelope, and wild horses abound, as well as the mountain sheep, the white and black tailed deer, and innumerable smaller game. They could be imported from Peru to a number of a few hundreds. by the way of the Gulf of California and the Gila, and presented as a token of friendship to the immense population of nomadic Indians, or their chiefs, by whom they should be protected under the prohibitory laws.

"Could these animals be suffered to remain ummolested for ten or twenty years, if successful, they would probably increase to thousands. and even millions, ever after, while immense profits would result from their flesh, skins, and wool, besides using them as beasts of burden, in places inaccessible to the camel or the mule." (Agtl. Dept. Report, 185.)

Dr. John L. Hayes added a very interesting account of "The Alpaca and Its Congeners," in an appendix to his rork on the Angora goat in 188:. This able writer had evidently investigated very closely into the experiments that had been made in different parts of the world, in trying to acclimate this animal in other countries, and, notwithstanding there had been no really successful result, he was strongly in favor of outr government making another attempt to localize them in the United States.

The following are his remarks upon "Experiments in Acclimation :

"As these pages are intended, in a large part. for agricultural readers, to whom the possibility of acquiring new domestic animals is of special interest, they will, naturally, inquire as to the success hitherto attained in acclinating these animals, and especially the alpaca, the most desirable acquisition, out of Puru. 
"The immortal Buffon said, of the domestic species in question, in 1765, 'I conceive that these animals would be an excellent acquisition for Europe, and would produce more real good than all the gold of the New World.' A French naturalist, hardly less celebrated, and the highest authority on acclimation that has ever lived, Isadore Geoffroy Saint Hilaire, said in 1848 , 'When an attempt shall be made upon a well chosen point on the Alps, or the Pyrenees, the success is as assured as that of any new enterprise can be.' With all the influence of these great names, and the numerous efforts which they have prompted, the attempts to secure the alpaca or llama in Europe as permanent acquisitions have been hitherto fruitless, although the partial success, upon the whole, furnishes strong grounds for believing that further attempts should not be abandoned.

"I will just recount the experience in England, obviously a most unfavorable country on account of its moist climate. The first alpaca seen in England was in 1809. The Duchess of York had four or five alpaca pets; but they gave no increase. In 1817. Mr. Burnett, of Burks, imported two alpacas, and from this stock reared fifteen young. The Earl of Derby, who had a passion for the acclimation of animals, entered into the enterprise of raising alpacas with great spirit, and in 1811 wrote: 'I certainly know of nothing likely to prevent the propagation of the animals in this country.' It is said that he afterwards changed his opinion. The alpacas of the Farl of Derby eventually came into the hands of Mr. (afterwards Sir) Titus Salt, who devoted much attention to their culture. He finally arrived at the conclusion that "while the alpacas could endure the most intense cold. they would be unable to withstand the humidity of the climate of England.' Further attempts to acclimate the alpaca in England seem to have been thence forth abandoned.

"An English author, William Walton, who published a book on the alpaca in 1811, said that there was 1: obstacle to the acquisition of the alpaca by France on the Alps and the Pyrenees, except the incapaciay of 'Frenchmen.' While the results in France certainly do not refute Mr. Walton's reproach, they evince no lack of zeal. But although Buffon, in his extreme old age, declared ' $I$ persist in belicving that it would be as possible as it would be useful to naturalize these three species of the aninals of Puru,' nothing was done in this direction until the commencement of this century, when the Empress Josephine revived the idea of Buffon. In 1804 she obtained orders from the King of Spain for the transmission to France of a flock of the three then known species of these animals from his kingdom of Peru. Thirtyfive animals were embarked from Buenos Ayres. On the voyage they did well until the provision of potatoes gave out, when twenty-seven died. The survivors were landed in Spain, but, on account of the wars, 
never reached France. Subsequently, at a period not mentioned, William II, King of Holland, obtained a certain number of alpacas and llamas, which he established in one of his parks. Notwtihstanding the low and humid locality, they multiplied to such an extent that the flock reached the number of thirty head. In 1849, the French Minister of Agriculture purchashed this flock, consisting of eighteen llamas and twelve alpacas, which arrived in good health; but, instead of beng carried to the mountains, they were placed at Versailles, and all died. In 18.5, the Imperial Society of Acclimation of France, engaged the services of a M. Roehn, an enthusiast in the project of naturalizing these animals, and familiar with them in their native country, who, after surmounting fatigue and difficulties impossible to describe, landed at Bordeaux thirty-three alpacas, nine llamas, and one vicuna, which were the only remains of some hundreds with which he started from Peru. The last record of this flock, made in 1861, is that those which survived, unfortunately a small number, are now distributed in different suitable localitics, and are in a good state.'

"An enterprise, which for some time promised very brilliant results, was undertaken about 18..2, by Mr. Clarles Ledger, an Englishman (whose observations I have before frequently referred to), who had been employed in purchasing alpaca wools in Puru for English houses. Induced by the promise of a premium of $\{10,000$, made by the Colony of New South VIales, for the introduction of a flock of Alpacas, he devoted six ycars of inexpressible toil and difficulty to this enterprise. His difficulties were greatly enhanced by the necessity of removing the animals clandestinely, their exportation being prohibited by the Perurian government. Starting from the interior in February, 1858, with 415 head of llamas, alpacas, and vicunas, he arrived at the port of Caldera, in May, with 32-2 animals. Thence embarking for Sidney in New South Wales, he arrived at that port in Scptenber with 260 head in excellent condition. The flock, immediately on its arrival. was driven to an elevated locality, the district of Mammera, „60 miles from Sydney, a point previously selected by $M[r$. Ledger. He writes to a friend soon after their arrival, 'The animals are admirably recovered, in spite of the heat of the season, and the privations of the royage. The next report we have of the alpacas is a letter from Mr. Edward Wilson, a distinguished propagator of acclimation in Australia, published in the 'Times' in 18:3\%. He says, 'The alpacas of Mr. Ledger have rapidly multiplied. They are exempt from every malady. and appear to accommodate themselves better to the indigenous plants than to the clover and lucerne and other cultivated plants first given to them. The propagation of the alpaca in Australia is only a question of time. It is really sad, in view of the subsequent results which 1 am compelled to state, to see the extravagant hopes that this intrepid enthusiast built upon his enterprise. He 
declared that the descendants from his animals alone would be sufficiently numerous before fifty years to supply an exportation of wool of the value of fifteen million pounds sterling.

"'The final report we have of this crterprise, from which so much was hoped, is in 1978, and is as follows:

". At first the experiment of Mr. Ledger presented most encouraging prospects; the herds continued healthy, and increased in numbers; but gradually the subtle influences of the loss of their native mountain climate became apparent, the creatures drooped, their numbers dwindled and for the present the undertaking must be regraded as a complete iailure.*

"Some of the alpacas brought from Peru by M. Roehn in 1849, were landed in New York. I have no information as to their further destination or ultimate fate." Sze Hayes, p. 159-162.

In the Report of the Hon. Frederick Watts for 1875, our then Commissioner of Agriculture, I find the following:

"In the latter part of $13 \%$, correspondence was had between the Com. missioner, and Hon. Francis Thomas, late minister to Peru (since deceased) concerning a small flock of alpacas which that gentleman had imported from Peru and placed on his farm at Frankville, Alleghaney County, Maryiand. In a letter of October 8, 1875, Mr. Thomas, inclosing a sample of the wool of four months' growth, remarked: 'The fiber of a fleece of twelve months' growth often exceeds fifteen inches in length, and the fleeces arerage from seven pounds to ten pounds $f$ in weight. The animals live to an age of twenty, twenty-five and sometimes thirty years; are too large, and bold, to be worried by dogs. and are very docile, and tractable. I think you will concur with me in the opinion that this experiment which $I$ an conducting is well worth the expense which I have incurred, especially when we eonsider the public benefit which would acerue in case of my success. The illustrations here given are photographs of several of my flock.

"Attempts have been made at various times in this country, in Europe, and in Australia, to introduce the alpaea, but generally, without profitable results. Various eauses have contributed to the failure of these efforts. Sometimes the confinement on shipboard, during a long royage, has nearly destroyed the stock. Again the animals, when brought to their destined abode, have been placed on luxurant elover pasture, or other feed, so much richer than the coarse herbage of their native regions that disease has fastened on the whole flock.

*Encyclopaedia Britannica, art. "Alpaca," ed. of 1878.

$\uparrow$ Dr. Hayes says: "The adult llama furnishes an annual fleece of from twelve to fourteen pounds and exceptionally of twenty." (See Hayes, p. 150 . 
"The alpaca is indigenous in the mountain regions of Peru, and thrives in the highest inhabited districts of the Andes, where the cold is more severe than in most parts of the United States. Accustomed to the riccisitudes of such regions, and inured to cold, damp, hunger, and thirst, it is especially adapted to bleak hill districts. Yet, it is said to do well in most localities where the air is pure, the heat not oppressive, and water, for bathing, readily accessible. The latter is stated to be indispensable to the health of the animal, which, when deprived of this requisite. soon becomes ferered, and infected with scab.

"While the introduction of the alpaca into this country still remains a matter of experiment, there is no known reason why such experiment should not be successful, when properly conducted, in localities affording some approximation to the native conditions of the animal. Not to mention many elevated situations in the Atlantic. Northern, and Central States; the regions lying along the Rocky Mountain ranges have been indicated as presenting good opportunities for such trials." See Agtl. Dept. Report, 1875, p. 437.

It appears to me there are many places in the United States where the llama and alpaca. could be made to thrive equally as well as in their native country, and in view of the remarkable success that has attended the introduction of the Angora goat in our country, notwithstanding the many failures in other continents, it would certainly seem to justify the appropriation of a few thousand dollars upon the part of our government in making an experiment that is likely to result in so much general good. It is hardly reasonable to expect individuais to take this risk in the face of so many apparent failures in other countries. It is not known, in fact, that the experiment of the Hon. Francis Thomas was a failure or not. This gentleman seems to have died soon after he brought the stock from Peru, and placed them on his farm in Maryland. It is more than likeiy his heirs were not in sympathy with him in the enterprise and paid little, or no attention, to the animals after his death and permitted them to die for want of proper attention. The same fate might have followed our experiment with the "Angora" goat. Dr. J. P. Davis of South Carolina, brought over from 'Turkey' the first of these in 18+9, and died not many years after. If he had not succeeded in placing them in the hands of a gentleman of the public spirit and enterprise of Col. Richard I'eters of Georgir, 
we would not today be enjoying the fruits from our "Angora Goat Industry." Col. Peters practically founded this industry at the risk of a considerable sum of money in an early day when we could hardly expect our government to take part in any such matter; but, in this day and time it is unreasonable to expect individuals to risk their capital in an enterprise that is calculated to be of national benefit, which the successful introduction of the Alpaca would certainly result in.

An experiment of this nature can be carried out with reasonable assurance of success, and it is to be hoped that Congress will be generous enough to make the necessary appropriation to import, say one hundred females with a sufficient number of males and distribute them either in the hands of individuals in our Rocky Mountain districts, where they are more than likely to thrive, or divide them up in several parcels and place them in charge of the Experimental Stations in such States as may seem best. 
A Paper on

the

I b e x

of Asia. 
PLATE XLIII.

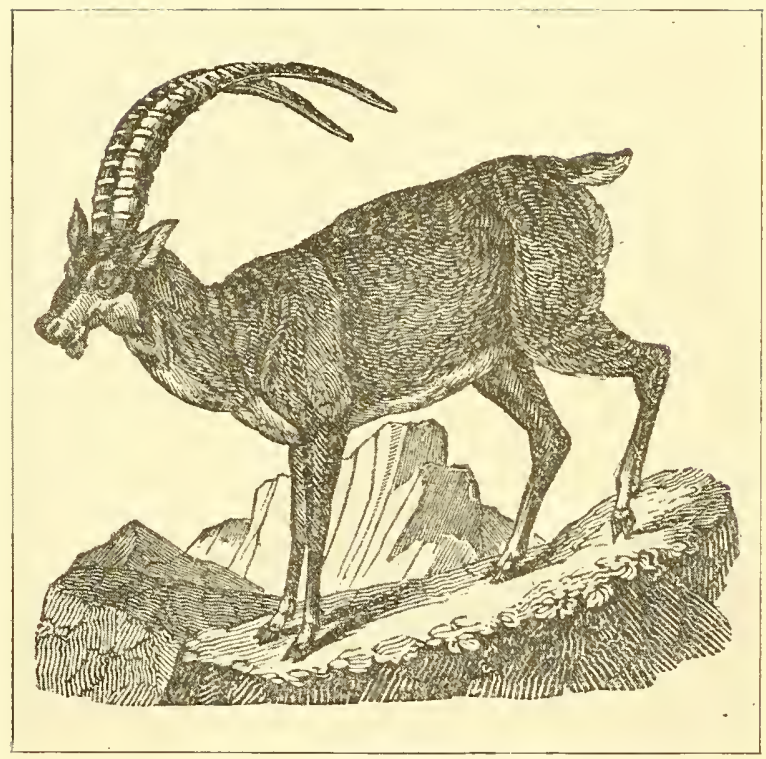

IBEX. 


\section{THE IBEX.}

It is claimed by some naturalists that the Angora goat originated from a cross between the "Ibex" and "Domestic Goat," an opinion however that appears to have very little support beyond the fact that the animal is quite common in Asia, and if taken when young can be easily tamed.

\section{According to Tschudi}

"Young tamed Ibexes were frequently driven to the mountains, along with the goats in whose company they would afterwards voluntarily return. Even wild specimens have been known to stray among the herds of goats although, strange to say, they at all times shun the society of the chamois."

This, together with the fact that the two animals grow "beards." and the "horns" are somewhat of the same nature, would seem to constitute the only ground for such an opinion. In order that the reader can form his own judgment upon this subject, (although I do not regard it as being of any material importance). I have taken the following description of the animal from the Encyclopedia Britannica, together with the accompanying illustration as shown in plate XLIII.

'.'Ibex' is the common name of several closely allied species of ruminant mammals, belonging to the genus capra, or goats, inhabit ing the loftiest regions of Europe, Asia, and Africa. The European ibex, or steinboc, capra iberr, abounded during the middle ages among mountain ranges of Germany. Switzerland, and the Ural, but has since disappeared from the greater part of this area, being now almost wholly confined to the Alps, which separate Valais from Piedmont, and to the lofty peaks of Savoy, where its continued existence is mainly due to the action of protective game laws. The Ibex is a handsome animal measuring about four and a half feet in length, and two and a half feet high; its skin is covered in summer with a short fur of an ashy grey colour, and in winter with much longer yellowish-brown hair, concealing a dense fur beneath. A short beard is present in the male in winter, but, as it disappears altogether in spring. Darwin regards this appendage as rudimentary. The horns, especially in the male. form a striking feature; rising from the crest of the skull, they bend gradually backwards, 
attaining a length, in old specimens of about two feet; they are thick and flat, and have the anterior face ridged with knotty transverse bands. In the female, the horns never exceed half a foot in length, and are much less rugose than in the male. The front legs are somewhat shorter than those behind, which enables the Ibex to ascend the mountain slopes with more facility than it can descend, while its hoofs, according to "Tschudi, are 'as hard as steel, rough underneath, and when walking over a flat surface, capable of being spread out.' 'These, together with its powerful sinews, enable it to take prodigious leaps, to balance itself on the smallest foothold, and to scale almost perpendicular rocks. The Ibex lives habitually at a greater height than the chamois, or any other of the Alpine mammals, its vertical limit being the line of perpetual snow. There it rests in sunny nooks during the day, descending at night to the highest woods to graze, and retiring at sunrise to its snowy fastnesses. This return journey forms the Ibex hunter's opportunity. To get within gunshot the hunisman has usually to approach from above; accordingly, he ascends to the limit of perpetual snow, and there passes the night among the daily haunts of the Ibex, lying in wait from early dawn for its return. The Ibexes are gregarious, feeding in herds of ten to fifteen individuals; the old males, however, generally live apart from, and usually at greater elevations than, the females and young. They are said to give out a sharp whistling sound, not unlike that of the chamois, but, when greatly irritated, or frightened, they make a peculiar snorting noise. The period of gestation in the female is ninety days, after which she produces, usually at the end of June, a single young one, which is able at once to follow its mother. These, when caught young, and fed on goat's milk can, it is said, be readily tamed; and, in the sixteenth century, young tamed Ibexes were, according to Tschudi, frequently driven to the mountains along with the goats, in whose company they would afterwards voluntarily return. Even wild specimens have thus been known to stray among the herds of goats. although, strange to say, they at all times shun the society of the chamois. The Ibex was formerly hunted largely for its flesh and skin; but, although the latter, owing to its scarcity, now commands a high price, the difficulty arising from the operation of the game laws, and above all the difficulty and danger, inseparable from the sport, have reduced the number of hunters, to a few hardy mountaineers, who find in the pursuit of the Ibex, the keenest enjoyment of life. For weeks, the sportsman will follow a track across fields of ice, along narrow ledges, over precipices, and across chasms, nearly frozen to death at night, and often with little more than a crust of bread for sustenance, yet considering himself more than repaid by the sight, at last, of his prey grazing within range of his rifle. Its flesh is said to resemble mutton, but has a flavour of game." Ency. Brit. Vol. XII, p. 605. 


\section{Formula}

for Dressing the Angora

Goat Skin 



\section{I n d e $x$}





\section{N D E X}

PAGE

Abortion in Angora does.................................. 381

Abrams, J. V., reference to, by Col. W. W. Haupt........... 76

Acorns, reference to ....................286, 38.., 389, 416

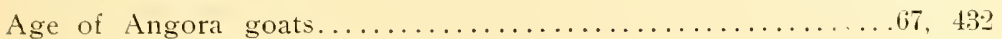

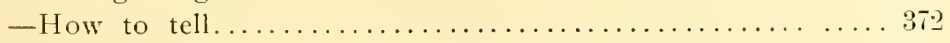

Aiken, Hon. D. Wyatt, reference to.................... 243

Alabama. reference to Angora goat industry in............ 90

"Albany Times," extract from concerning "Davis" goats........ 20.2

Alder brush, reference to...................... 359, 3660

Allen, Col. Richard, letter from concerning early "Davis" goats... 192

Allen, L. A., reference to.................... 446,448

Allshorn, Dr. Adolph $H$., reference to goat's milk............ 289

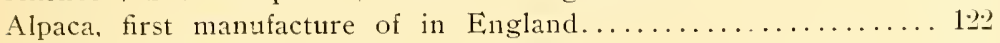

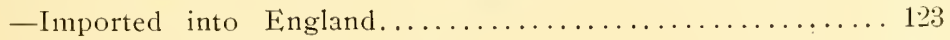

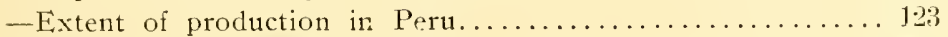

Alpaca, and Llama, description of ................. 467

-Reference to introduction of, into United States......... 4.

-Experiments in acclimating..............13, 474, 475

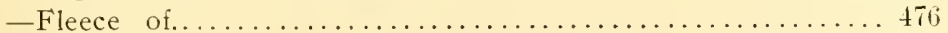

-Age of................................. 476

Ambler, Dr. D. C., first to introduce Angoras into New York..... 69

American Angora Goat Breeders' Association, reference to....... 40

American Angora goat record, reference to................. 447

"American Farmer," reference to concerning Llamas and Alpacas.. 47.2

American Institute, report of concernin:s "Davis" goats.......... 191

Angora, and Cashmere, goats, experiments in crossing. . . . . . . . 458

-Opinion of Sir Samuel IVilson on crossing............ 45t

-Reference to.................................. 187

"Angora." Col. Richard Peters decides on name of the "Davis" goats 198

Angora goat, when, where, and how, did it originate..........

-First mention of ..............................

-Dr. Hayes opinion as to introduction in Asia Minor.......

-Jno. S. Harris opinion as to origin............... 29

Angora goat, distribution of, into other countries............ 34

-Reference to, by M. Tournefort.................... 34

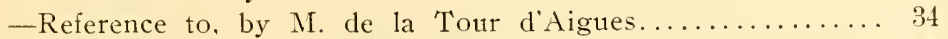

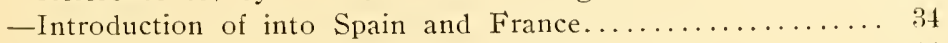

—Embargo placed on exportation of, from Turkey.......... 36 
-In Canada.................................. 39

-Early variety, character of $\ldots \ldots \ldots \ldots \ldots \ldots \ldots \ldots 41,91,187$

-Importations of, into the United States.............. 48

-Ancient custom of bathing them in wine............... 91

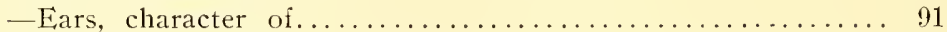

-Number of, in different States.................... 104

- Impossible to sell in large numbers, for slaughter.......... 114

-Feeding of, for market........................ 155

-Pure-bred variety extinct....................... 178

-In Turkey nearly all are cross-breeds................ 178

-Difference in............................... 181

-Dr. John Bachman's reference to................... 196

-Pure-breeds, opinions as to what point it has.....213, 214, 215

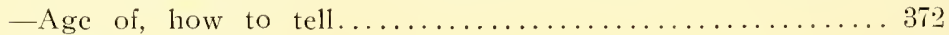

-Milking qualities............................. 281

-Difference between it, and sheep, as to meat........... 375

-Skins, how to dress with the hair on................ 485

- Estimate of the value of in Turkey................. 445

-Estimate of shearing capacity in Turkey............. 445

Angora skins, tariff on ........................... 166

- How they are graded in market................... 147

- How to prepare them for market.................. 147

Angora lace trimming, reference to..................... 127

Angora, province of, description of ..................... 31

Angora venison, as a salable product..................... 154

-And mutton, compared, as to value.............15t, 155,156

-Different from common goat meat................. 158

Arizona, reference to Angora industry in................. 93

-Notes of breeders in.......................... 434

-Reference to territory............................ 302

Arkansas, reference to Angora industry in................. 96

Arlington Wills, reference to, by Dr. Hayes............... 128

Armstrong, J. D., reference to.............................. 371

Arnold, Brothers, one of the early breeders in Texas............ 76

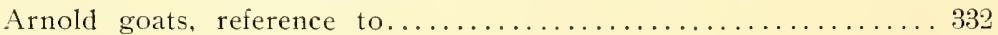

Arnold, J. M. statment of, concerning his Angora goats......... 316

-Notes from, on practical breeding............... 404, 433

-Remarks of, concerning non-shedding Angoras........... 226

Arsenic, as a remedy for lice on goats.................... 383

Ash brush, reference to ............................ 360

Asiatic goats, reference to by Dr. Jno. Bachman......... 196, 197

-Skins of, reference to........................ 16 \&

Asiatic mange, reference to ........................... 378

Asia Minor, reference to, by Jno. S. Harris.................. 91 
"Atlanta Constitution," extract from conccann "Davis' goats .. 60

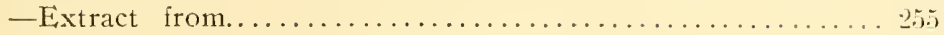

Austria, reference to Angora goat industry in................ 110

-Introduction of the Llama, and Alpaca into............ tis

Babb, Rev. D. S., one of the early Texas breeders.............

-Statements from, concerning his Angora goats...........316;

-Notes from, on practical breeding.............4 40. 433

"Bább," goats, reference to............................ 319

Bachelder, Hon. N. J., letter from concerning land in New Hampshire 296

-Reference to Angora goat industry, in New Hampshire.... 95

Bachman, Dr. John, opinion about Angora meat........... 15.5

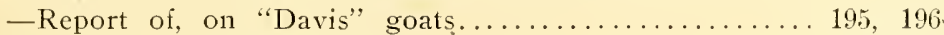

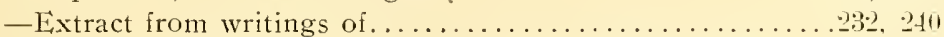

Bailey, C. P., importations made by, from South Africa... 51, 84

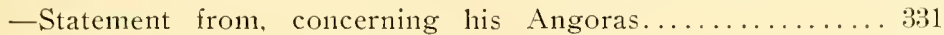

-Reference to mohair grown by ................... 339

-Notes from, on practical breeding.............415, 434

“Bailey," goats, reference to.....320, 327, 328, 332, 335, 339, 340. 436

Bailey, Hon. J. W., reference to abandoned farms in Maine....... 295

Baird, Prof. Spencer F., description of Rocky Mountain goat..... 463

Bakewell, Robt., reference to $\ldots \ldots \ldots \ldots \ldots \ldots \ldots \ldots \ldots \ldots \ldots . \ldots 48$

Barnes, Almont, concerning available pasturage in United States... . 30.2

- Reference to bulletin concerning goats.............. 108

Barnette, J. R., statement from, concerning his Angoras......... 339

-Notes from on practical breeding.............. 43,431

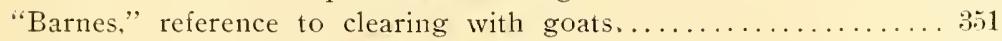

Barrett, Dr. M., experience in breeding in Virginia........... 66

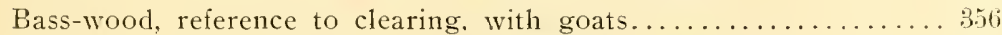

Baylor, Geo. W., remarks on non-shedding Angoras, etc........2.28

-Reference to Col. W. D. Parish .................. is

- Statement from, concerning his Harris \& Baylor goats . . . . . 310

-Associates with Jno. S. Harris.................. 9?

-Reference to transfer of goats from Idaho, by Jno. S. Harris. 339

-Notes from on practical breeding............... 406, 433

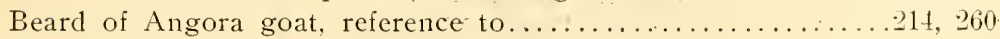

Belon Father, first mention of the Angora goat.............. 26

Bell, Hon. C. J., letter from concerning Angoras in Vermont..... 95

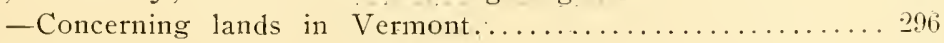

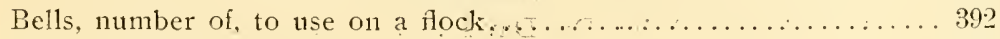

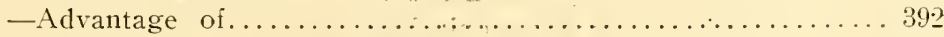

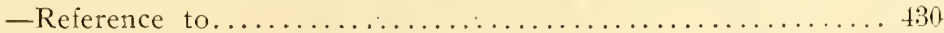

Berry, Wm., reference to sheep industry.................

Bevington, Dr., of Iowa, reference to................... 101 
Bible, references in $\ldots \ldots \ldots \ldots \ldots \ldots \ldots \ldots \ldots \ldots \ldots 2,264,266$

- Testimony concerning the goat, and, hair of........ 25, 11 i

"Billy," reference to use of term.............. 263, 261, 26.

Bill, James A., statement from, concerning his Angoras........ 34t

-Concerning Angora goats in Connecticut........... $90^{\circ}$

- Reference to clearing brushy land..................... 370

-Notes from on practical breeding..............4430,435

Binns $H$. O., observations on cross-breeding in Turkey........ 177

-On different types of Angora goats................ 181

-On original type of the Angora gat............... 187

- Opinion of, as to pure-bred Angoras................. 213

-Reference to .......................... 23. 265

Black, Mrs. N. P., reference to the transfer of the "Peters" goats.. 62

Blackburn, A., reference to clearing brush with goats........... 360

-Notes from, on practical breeding.............111, 433

- Goats raised by, commended....................... 4

-Statement from, concerning his Angoras.............. 324

Black Hickory, reference to clearing with goats............. 356

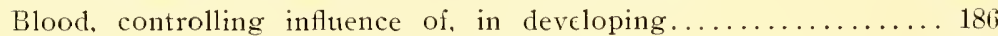

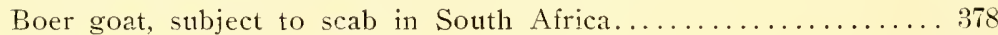

- Reference to ..................................... 179

Bokara, goats of, described by Jno. S. Harris.............. 28

Booth, I. J., reference to clearing brush land ............... 356

-Notes from on practical breeding............. 42.2, 433

Boston, reference to Angora goats in.................. 47

Boulier. M., observations on cross-breeding............... 253

-Reference to losses of pure-blooded stock in Turkey........ 216

-Reference to terms applied to goats................ 265

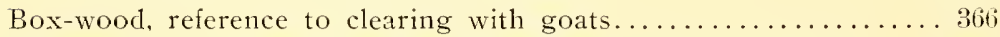

Boyden, Jno. A., one of the early breeders in North Carolina..... 93

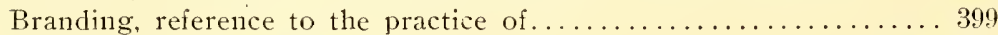

Brannin, S. S., reference to ....................... 304. 464

-Reference to climate of Montana.................. 93

-Statement from, concerning his Angoras............ 339

-Notes from on practical breeding.............4 497, 434

-Letter from, concerning Rocky Micuntain goat............ 241

Brandt, M.. description of Cashmere $₫($ at................. 27

-Description of a pure-bred Angora................213

Bradford, England, erection of Mohair mills in............. 123

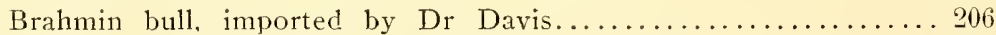

Breeding, original Angora goats only bred one kid.......... 42

-Observations on, by Col. J. Wash Watts............ 54

-Observations on, by Col. Richard Peters.............64

-Notes from practical breeders................ 403 to 135 
PAC $\mathrm{F}$
269

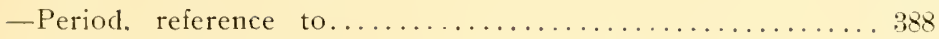

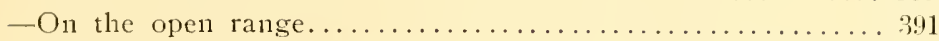

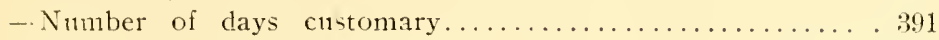

-Seasons for different sections... ............... to 437

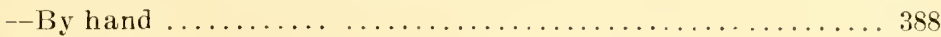

Bri ish Columbid, adaptabil ty of, in raising A dyora. ........ 40

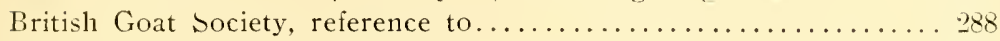

Broadbent, Sir Wm., observations of, about milk............... 289

Bromley, Mr., of Utah, reference to................... 340

Brown, John, reference to Col. W. D. Parish............. 78

-Remarks of concerning non-shedding Angora .......... 225

-Statement from, concerning his Angoras.............. 315

- Notes from, on practical breeding..............4.2, 433

Brown, D. J., remarks of concerning Cashmere goats......... 455

—Reference to crossing the Cashmere and Angora .........458

- Description of the Llama, and Alpaca.............

Brush, serious nature of $\ldots \ldots \ldots \ldots \ldots \ldots \ldots \ldots \ldots \ldots \ldots \ldots \ldots \ldots \ldots$

-Reference to clearing...98, 101, 102, 351, 355, 356, 359. 360,

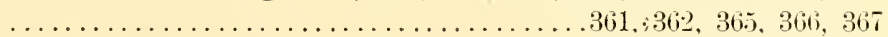

-Reference to the cost of clearing................ 352

--Reference to number of ginats required......... 355, 356. 360

-Equal to "peaches and cream," to a goat.............. 21

-Opinion of Dr. Davis, relative to the South................

-Observations about, by Col. Robt. W. Scott........... 64

-Goats commonly used to clear, in Oregon............ 84

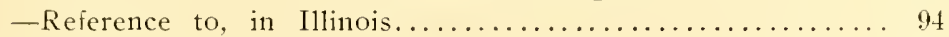

Bruner, T. K., reference to industry in North Carolina........... 93

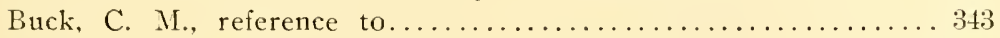

'Buck," reference to the $\operatorname{term} \ldots \ldots \ldots \ldots \ldots \ldots \ldots \ldots \ldots \ldots \ldots, 265$

Bucks. how to decide on, opinions of breeders..............2.2.

-Reierence to selecting. . . . .

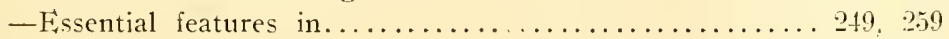

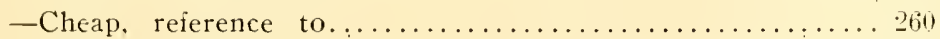

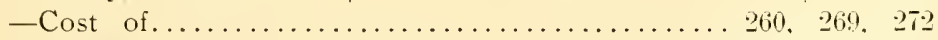

-Proper number for brecding...........271, 272, 388, 391

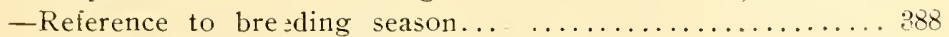

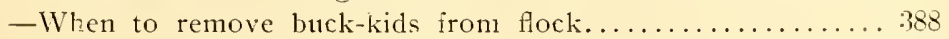

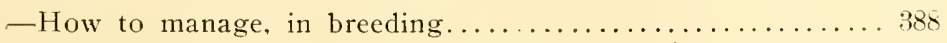

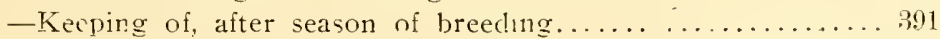

Buck-brush, reference to clearing................. 351, 35.5, 367

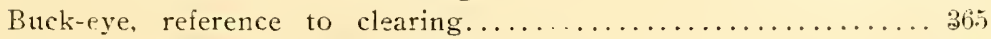

Burdette-Coutts. Baroness, reference to ................ 288

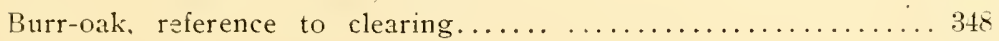

Butter, from goat's milk.................... 284 
California, notes from breeders in..................... 434

-Reference to first importation of Angoras into......... 79

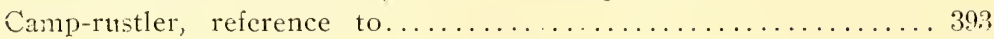

Camping outfit for shepherds..................... 272

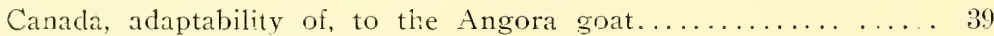

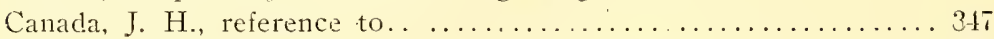

Canada thistle, reference to clearing with goats................

Cannon's dip, as a remedy for screw worms.............. 35

Cantrell, Ari, introduction of Angoras into Oregon........... 84

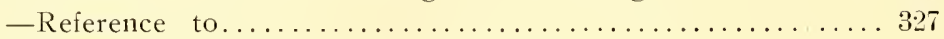

Cape Colony, first introduction of Angoras, into.......... 35

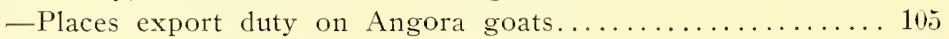

- Reference to increase in mohair product............... 246

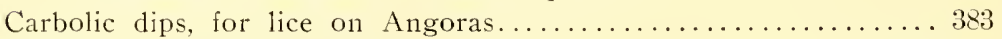

Carcass of Angora, difference in size of ..............212, 217

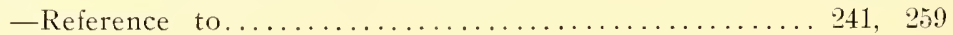

Carding Mohair, what constitutes.................... 14:

Care and management of Angoras, chapter on....................... 384

Carolina, North, reference to Angora industry in............ 93

Carolina, South, Dr. Davis' opinion of Mohair grown in......... 46

-First to handle the Angora in the United States........... 52

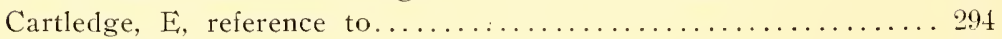

Cashmere goat, reference to by Dr. Hayes.............. 27

-Reference to by Jno. S. Harris.................... 86

-Reference to by several committees................ 192

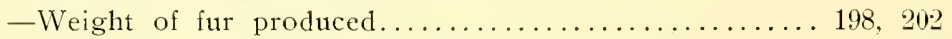

-In possession of J. C. Hightower................... 198

-Letter from Col. Richard Allen, relative to................ 199

-Extracts from newspapers relating to................. 201

-Exchanged by Dr. Davis with Earl of Derby............ 206

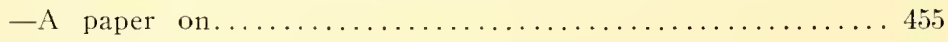

-Description of by D. J. Browne............... 45j

-Descripton of by S. Holmes Pegler............... 456

-Dr. Davis' opinion on.......................... 455

Cashmere, wool, reference to manufacture of in England........ 45i

-Opinion of Sir Samuel Wilson on................. 457

-Experiments in crossing with Angora............... 458

-Dr. Davis' experiments in crossing................. 459

_Great value of $\ldots \ldots \ldots \ldots \ldots \ldots \ldots \ldots$ 199, 201, 202, 203, 204

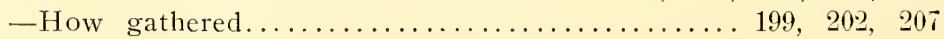

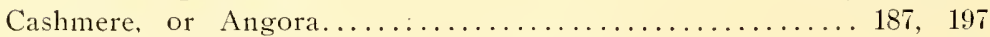

Cashmere shawls, reference to manufacture of .............. 125

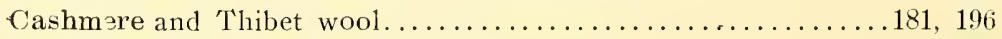

Castrating, when, and how, it should be cone .............. 399

Cattle and sheep, receipt of for 33 years in Chicago.......... 158 
Coyote, reference to................................. 399

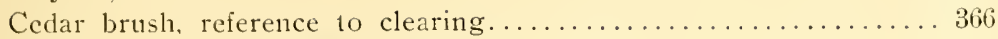

Census of Angora goats, in the United States................ 103

-Letter from H. N. Williamson, concerning............ 10 .

- Letter from Wm. R. Payne, concerning............. 108

Chamberlain, T. I., reference to ..........................

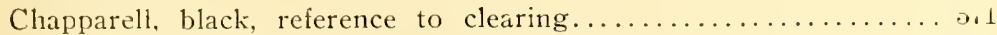

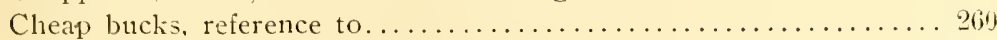

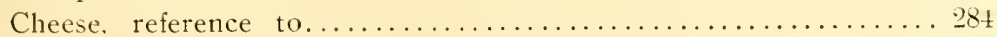

Chew, R. B., reference to......................... 299

Chenery, Winthrop W.. experience with Angoras in Massachusetts. . 70

"Chenery" goats, reference to.......................... 442

Cherry, brush, reference to clearing..............356, 360, 361

Chicago Live Stock Commission Co., letter from............. 156

Chicago meat packers unwilling to buy Angoras............... 114

Chilton. Jos. R., committee report on "Davis" goats............ 191

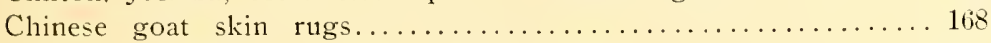

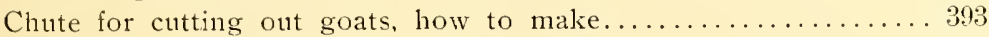

-System used by W. G. Hughes................. 435

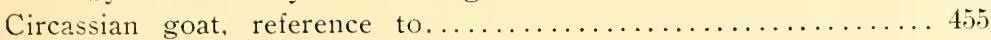

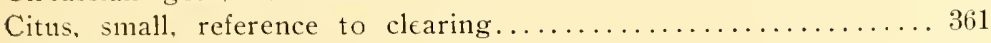

Claggett, W. D., observations on clearing brush............. 361

- Statement from concerning his Angoras.............. 323

-Notes from, on practical breeding..............413, 433

"Claridges Farmer," extract from..................... 300

Claridge, R. R., reference to.................... T6

Clearing brush land, reference to.....351, 355-6, 359 to $362,36 \mathrm{~s}$ to 367

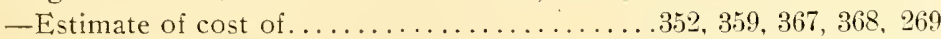

-Number of goats required.......355, 356,359,360,361, 366, 371

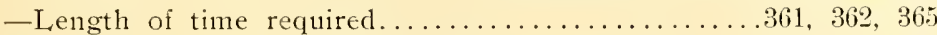

Cleveland, Hon. Grover, remones tariff on Mohair............. 162

Climate of United States, adaptibility of, to the Angora goat..... 47

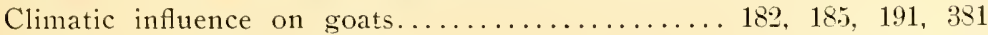

Clipping machines, reference to ...................... 395

"Coarse Mohair," what constitutes.................... 14?

Coast Mohair Association, reference to . . . . . . . . . . . . . . . 323

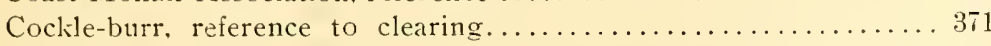

Colorado, reference to .....................94, 294, 302

Colored Mohair, reference to ....................... 396

Colored kids, reference to by practical breeders.........403 to 435

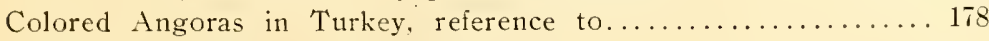

"Combing Mohair," what constitutes................... 141

Combination sale of Angora goats, reference to............ 447

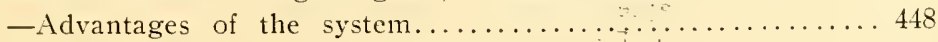

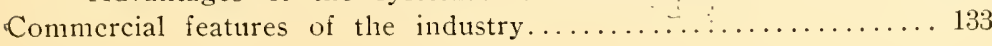


Committee reports on "Davis" goats............ 191, 192., 193

Conolly, Capt., description of manner of manufacturing Mobair... 118

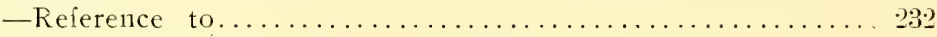

Conklin Bros., letter from ......................... 2.23

-Statement from concerning their Angoras............. 3:8

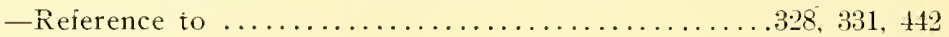

- votes from, on practical preeding.............414, 434

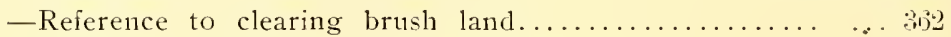

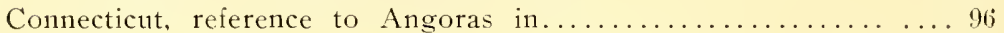

-Reference to area adapted to Angoras in............. 297

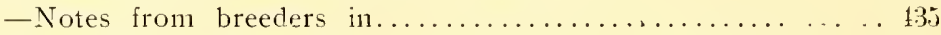

Constantinople merchants, try to prevent export of Angora goits.. 37

Consumption, reference to disease...................

Cooper's dip, recommended for lice on Angoras............... 383

-Reference to by breeders.................... 4.26

"Country Gentleman," extract from in $1850 \ldots \ldots \ldots \ldots \ldots \ldots \ldots . . .169$

- Extract from concerning importation of Price Maurice..... 50

Corn, as a feed for fattening Angoras.................. 375

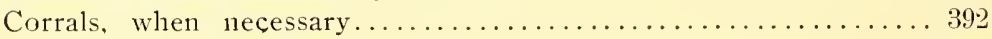

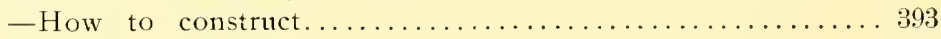

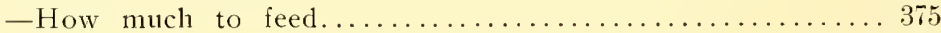

Cost of bucks, reference to ........................ 260

Cost of keeping Angoras, opinions from breeders........ 403 to 435

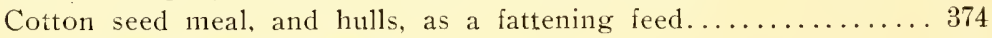

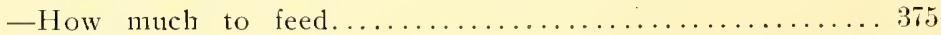

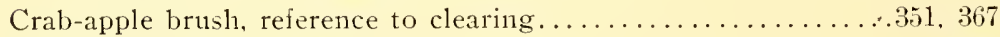

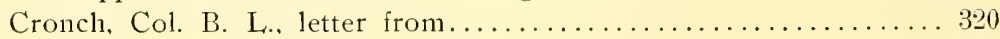

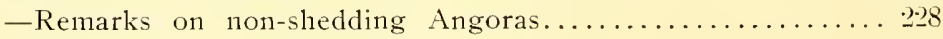

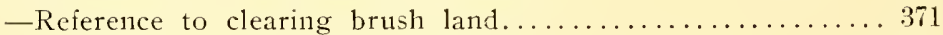

— Notes from on practical breeding................ 16,433

- Reference to tariff on goats, and Mohair............ 406

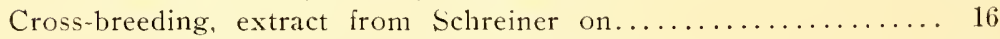

- Observations of Col. J. Wash Watts on............. 54

- In Asia Minor, encouraged by demand for Mohair......... 123

-Dr. J. B. Davis' first experiments................ 177

-Col. Richard Peters' experience with............... 177

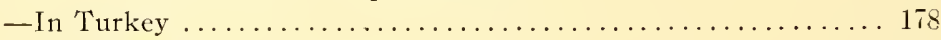

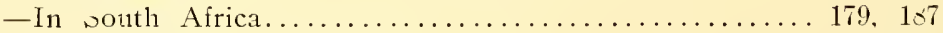

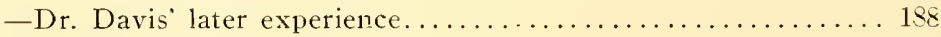

-Report of Dr. Jno. Bachman on................ 195

-Opinion of Col. Robt. W. Scott on................ 207

-Opinion of Col. W. W. Haupt on................ 211

-Statement concerning, by M. Tchihatcheff............ 216

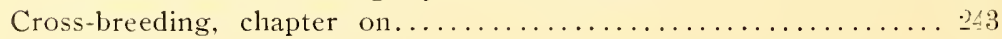

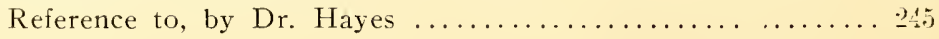




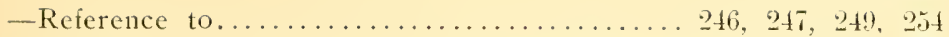

-In Turkey, reference to........................ 253

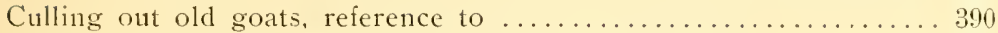

Cumberbatch, H. A., description of Province of Angora............ 31

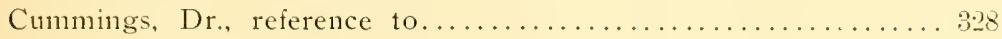

Currie, Sir Philip, permit granted, to export Angoras......... 36

Dakota, North, reference to Angora goat industry in.......... 93

-South, reference to Angora goat industry in ........... 93

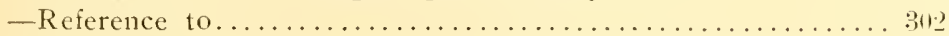

Davenport, Col. B., introduces Angoras in Virginia.......... $60^{6}$

Davis, Dr. J. B., opinion concerning brush land in the South....... 2.

-First to import Cashmere Goats to the United States........ 34

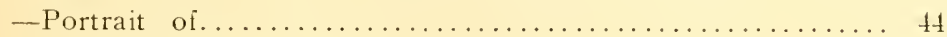

-Biographical sketch of ..................... th

-Opinion concerning stock best adapted to the South........ 46

-Opinion concerning raising of Mohair in the United States... t6

- Sale of pure-breeds to Col. Richard Peters.............. ti

-First experiment with crossing on common goats.......... 17

-Concerning improvement in Cashmere goats ............. 18 i

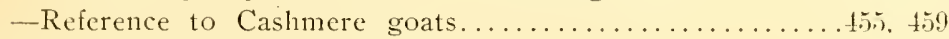

Davis. Col. Zimmerman, letter from................ 46

-Letter concerning the "Davis" goats..................

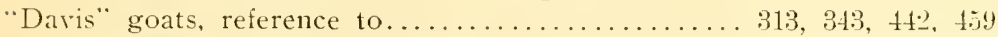

-Reports on, by committees............. 191, 19.-, 19.5

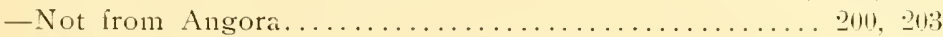

- Microscopic examination of fleece of ................

-Testimony of his daughter as to character of ........... Q

“Davis Cashmere goats," reference to.................. 19\%. 199

Darwin, Prof. Charles, on origin of goats................. 29

-Extract from concerning breeding, etc.......... 236 , 39

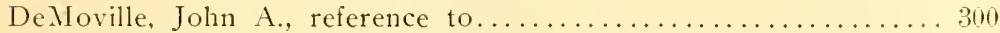

Derby, Farl of, introduction of Angora goats into England........ 34

-Exchange made with Dr. J. B. Davis for Cashmeres....... 200

Devine, J. P., reference to by Col. IV. IV. Hatpt............. Ti;

-Observations of respecting climate of Texas............

"Devine" goats, reference to.............. 319, 320,343, 442

Diehl. Hon. Israel H., concerning climate of the United States... 47

-Reference to importation of Angoras in $1870 \ldots \ldots \ldots \ldots \ldots$. 4 .

- Reference to early breeders in the United States..........6. 67

-Description of spinning Mohair in Turkey............ 118

-Reference to the manufacture of Mohair............. 12t

-Commissioned to visit Asia Minor................ 12.

-Reference to different types of Angoras.............. 181 
-Opinion of as to pure-bred Angoras................ 215

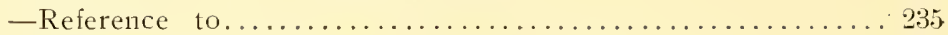

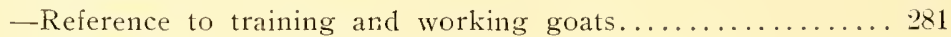

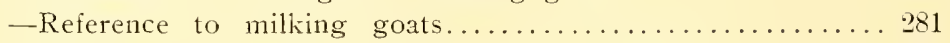

-Reference to cheese, and butter, from goats............ 284

Diehl and Brown. importation of ..................48, 23.

-Reference to character of goats imported.............. 49

"Diehl and Brown," goats, reference to................ 44]

Dipping Angora goats, reference to................. 374., 383

-Opinions of breeders, on ..............4 402 to 435

Dipping vat, where to locate, and how to construct.......... 393

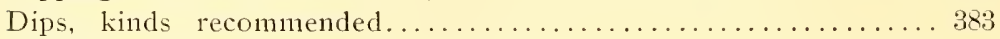

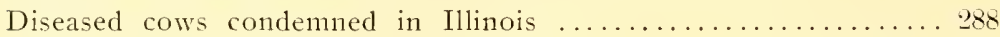

Diseases, freedom from in Angora goats.......... 195, 367, 355

-Experience of Chas. S. Brown in New York............. 69

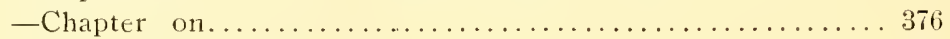

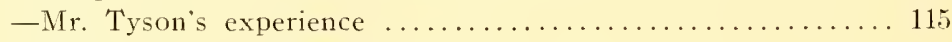

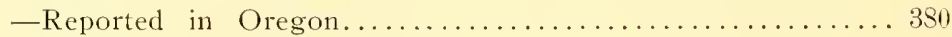

-Dr. M. Barrett's experience.................. 67

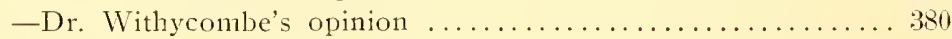

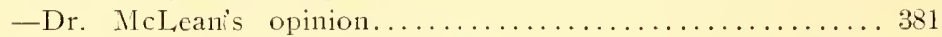

-Experience of practical breeders............ to. to 435

Dissler. C.. notes from on practical breeding..........4 40.5, 433

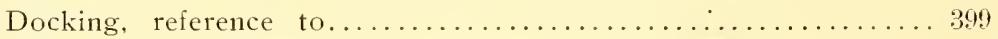

Bodge, J. R., reference to importation by Price Maurice........ 50

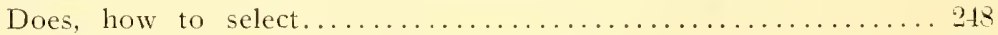

-When to cull out of breeding flock................ 390

- That do not own their kids. how to manage ............ 397

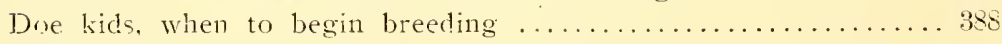

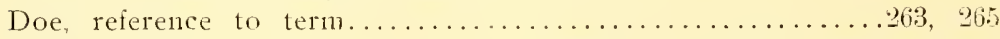

Dogs, reference to........... 195, 200, 355, 387, 403, 416, 420

- Not advisable to permit all herders to use........... 39.

-Raised by a doe very usefuil...................... 418

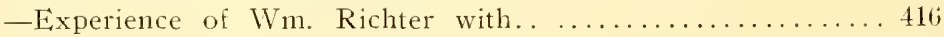

—Experience of E. R. Williams, with.............

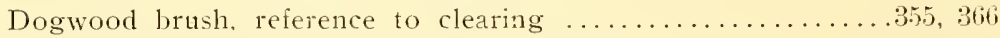

Doughter \& Luttrell, remarks on non-shedding Angoras.......... .

-Statement from concerning their Angora goats........... 320

—Notes from on practical breeding..............40.5, 433

Dougherty, L. B., experience with Angoras............... 4.26

Dowell, O., statement from concerning his Angoras............ 323

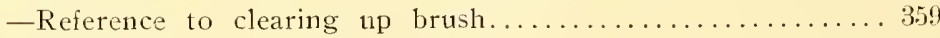

—Notes from, on practical breeding.............410, 433

Dressendorfer, George, reference to......................... 343 
Dunison. James H., statement from concerning his goats........ 328

-Notes from, on practical breeding............. 417, 434

Dye, Hon. Franklin, concerning land in ITew Jersey............. 298

Eamen, T. F.. reference to ................... 446, 448

Early, J. B., reference to.......................... 339

-Associates with Jno. S. Harris.................... 92

Ears of the Angora, referred to by J. S. Harris................ 91

-Remarks on by Mr. Schreiner.................. 187

-Remarks on by Dr. Jno. Bachman... ............... 196

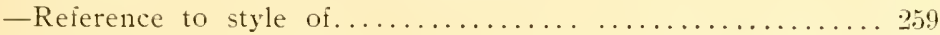

-Reference to...............213, 214, 215, 216,259

"Eastern Province Herald," extract from................. $36^{\circ}$

Edwards, Hon. A. H., letter from concerning brusl clearing. . . . . . 348

-Notes from on practical breeding............4.2, 433

Elberst, B. F., reference to................ 10., 446, 448

Elder brush, reference to clearing............... 355, 360, 361

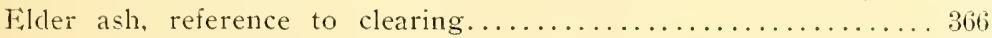

Elliott. W. H., committee report, on "Davis" goats............ 191

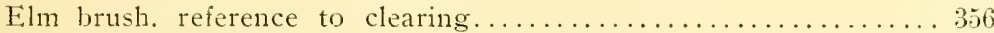

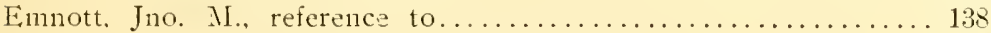

England, first introduction of Angoras into............... 34

Eutichedes, A., importation of Angoras into the United States...... 49

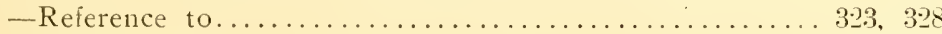

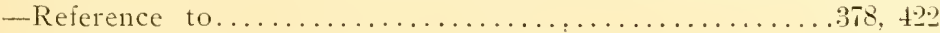

Erans. J. B., reference to Angoras owned by.................. 180

Erans. Tom S., remarks concerning non-shedding Angoras......... 2.27

- Statement from concerning his Angoras................... 320

-Notes from on practical breeding.............. 408, 433

"Ewe," reference to term as applied to goats........... 263,265

"Examiner." of Gallatin. Tenn., extract from ...............203

Expense of keeping goats................269, 272, 273

Experiments in acclimating the Llama and Alpaca........... 473

Exportation of Angoras prohibited in Turkey................ 36

Failure of industry in Missouri, reference to.............. 68

Farms abandoned, reference to .....................295, 296

Farr Alpaca Co.. reference to....................... 128

Faure. Sir P.. opposes Cape Colony export duty............... 108

Featherstone. R., reference to Angoras ired by............... 180

Feeding Angora goats, reference to by E. R. Johns . . . . . . . . 155

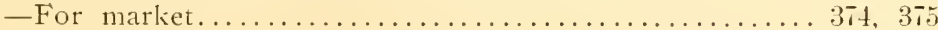

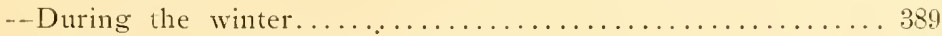

- Reference to by practical breeders............ 40.2 to 435 
Feeding milch goats, reference to ................... 86

Fences, reference to by Col. Robt. IV. Scott............... 64

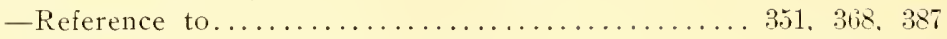

-Reference to, by practical breeders ............. to $40 . \ldots 5$

Firn brush, reference to clearing...............

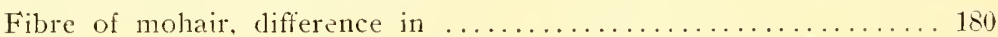

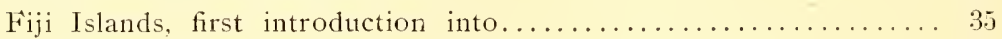

Fink \& Co., reference to importation from South Africa.......... 51

Fink, Henry, statement from about his Angoras.............. 319

-Notes from, on practical breeding .............404 to 439

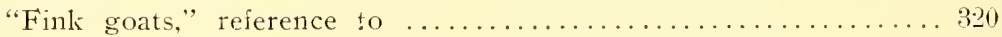

Fir brush, reference to clearing. . . . . . . . . . . . . . . 3.59

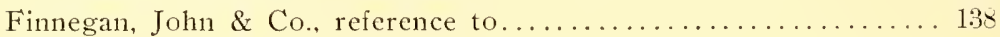

Fiske, L. S. \& Co., reference to..................... 138

Fleeces, weight of original goats imported by Harris . . . . . . . 91

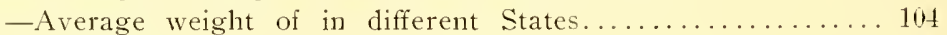

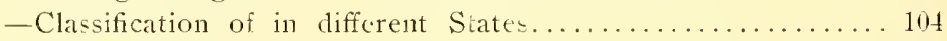

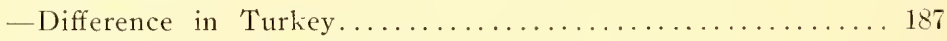

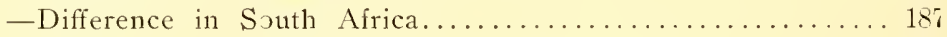

- Value of carly American ...................... 19.

-Reference to by Dr. John Bachman................ 197

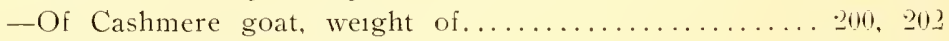

-Of pure Angoras, opinions on............... 13,216

-Reference to....................2. $29.290, \quad 250$

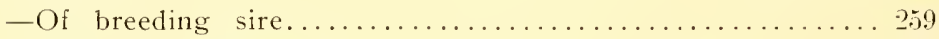

-Weight of, reference to ........................

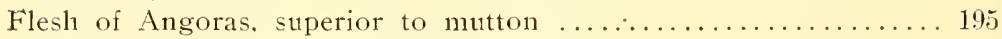

Flint \& Sargent, importation into California............... 83

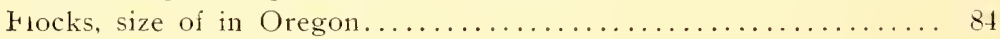

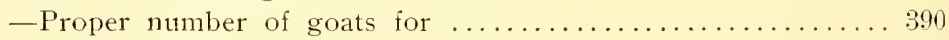

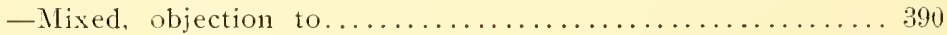

-Reference to sizes, by practical urceders..........4.2 to 435

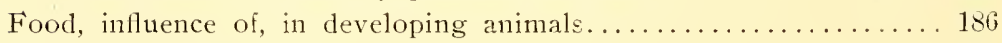

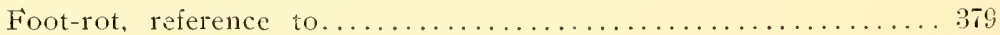

-Rcmedy for................................ 379

-Reference to by Wm. M. Landrum................ 403

-Reference to by Jno. M. Arnold................... 404

Foreman, C. W., reference to ......................

Formula for dressing Angora skins.................... 485

Foster R. C., concerning Davis' Cashmere goats............... 199

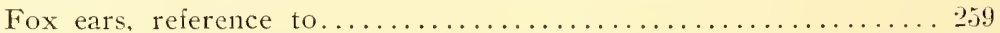

France, first introduction of Angoras into..................... 34

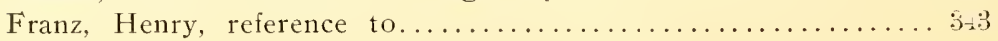


PAGE

Fuchs. H. T., statement from about his Angoras.............. 319

- Notes from on practical breeding...............408, 433

-Opinion concerning non-shedding Angoras ............ 225

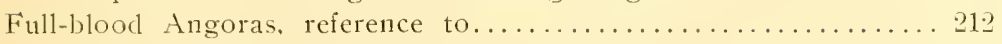

- Use of, injured the industry at the start ............. 110

Full-blood vs. pure-bred ..........248, 248, 250, 251, 254, 25.5, 256

Fulmer. F. S., experience in Virginia................. 66

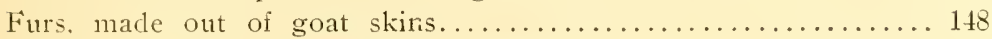

Fur, from Cashmere goat, how gathered......... 199, 209, 207

Gaibraith. H. W., statement from about his Angoras........... 319

- Notes from, on practical breeding.............4 403, 433

Garrett. J. W., statement from, about his Angoras............ 320

- Notes from on practical breeding............... 407,433

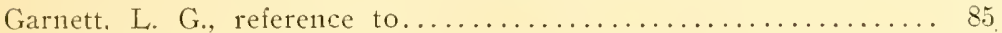

Garrard. W. C., reference to Angoras in Illinois.............. 94

Garst, Frank, reference to................. 85, 320, 343

-Letter from giving his experience with Angoras........... 436

Garvin, Hon. J. B., letter from concerning land in West Virginia.. 299

Gatherall. Garvin, on climatic infiuence in Turkey............. 18.

Gatherall, George, letter concerning shipment to South Africa in 189536

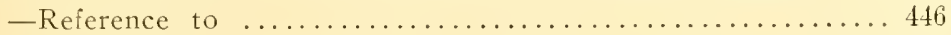

-Reference to cross-breeding in Turkey............... 253

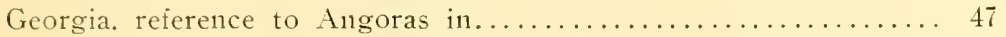

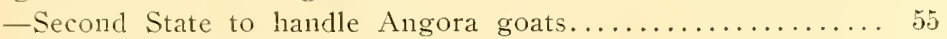

-Reference to area in adapted to goats............................ 303

Geredah Angoras, imported by Col. Richard Peters............. 49

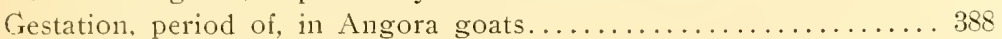

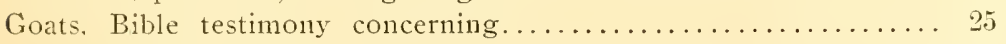

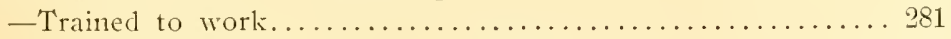

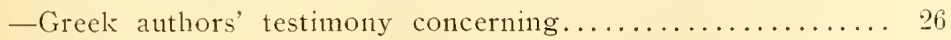

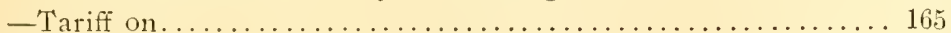

Goe. General J. S., experience in Pennsylvania................. 69

Gohl. Hon. T. S., letter from about land in Connecticut........ 297

Goodrich. Charles J., committee report on "Davis" goats........ 19.

Gordan. C. F., reference to Angoras n Fiji Islands............... 35

Grades of Mohair, reference to ............................ 141

-Should be made standard.....................141, 153

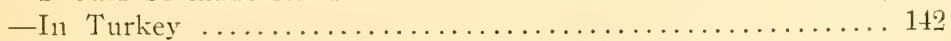

Grading up Angoras, experience of J. C. P. McLendon ........ 435

Gradỹ. Hon. Henry W., interview with Col. Peters............ 61

Graves. E.., notes from on practical breeding............. 426,434

Gray \& Gilmore, importation of Angoras into California......... 83

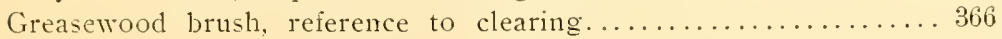


Green (W. W.) goats, reference to....................... 328

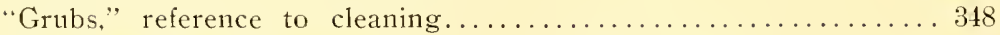

Guadalupe Island, reference to, by Dr. Hayes............. 38

-Reference to raising goats on $\ldots \ldots \ldots \ldots \ldots \ldots \ldots \ldots \ldots . .230$

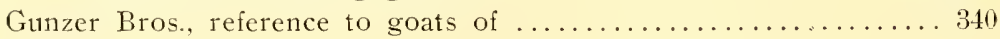

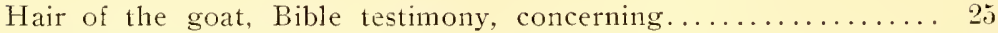

-Greck Authors, testimony concerning ............. 26

Hair of the Arigora, will not mix with common goat hair ....... 17t

Hair, red camels, reference to ...................... 191

Hair, two kinds on one Angora..............191, 198, 207, 208

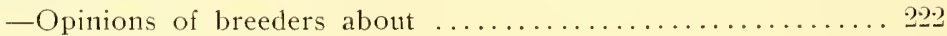

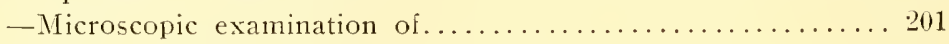

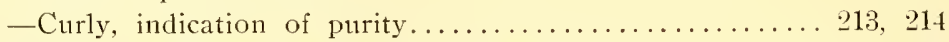

Hall, Wm., purchases Butterfield \& Son's Angoras ........... 89

Hamilton, James R., letter concerning feeding Angoras........... 374

-Notes from, on practical breeding............428, 435

Hamilton, Hon. John, letter from about lands in Pennsylvania.... 297

Hamilton, Jamess R., letter concerning feeding Angoras ........ 374

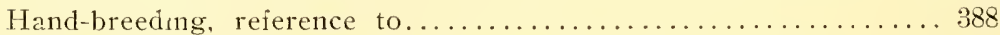

Hard-hack brush, reference to cleaning ......................... 366

Hardy, Col. Wm., introduces Angora goats into Arizona....... 93

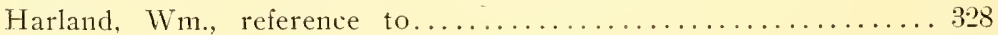

Harper, Ira, statement about his Angoras................. 339

- Notes from on practical breeding............4 4,434

Harris, John S., opinion as to origin of Angoras............ 29

-Account of journey into Cachmere................ 28

-Reference to sample of 2.2 -inch Mohair................ 39

-Reference to Diehl \& Brown importaton.............. 49

-Reference to exports of Angoras from Turkey.......... 78

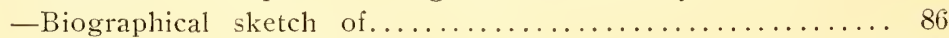

-Reference to non-shedding Angoras................ 230

-Concerning Idaho as a goat country............... 302

- Statement from concerning his Angoras.............. 339

-Notes from on practical breeding............. 427, 434

"Harris," goats, reference to............. 310, 331, 332, 442

Harris \& Baylor goats, reference to................ 319, 423

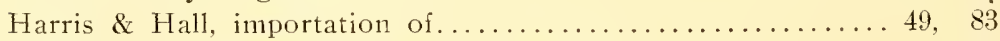

Hassler, J. M., statement about his Angoras................. 327

-Notes from on practical breeding..............411, 433

Hatcher, Wm., reference to feeding Angoras................. 382

Haupt, Col. W. W., biographical sketch of.............. 71

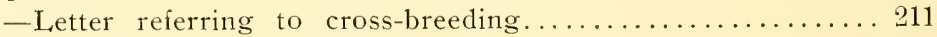

-Remarks on non-sherding Angoras................ 228 
PAGE

-Reference to cross-breeds................. 254, 255

-Letter from concerning $\mathbb{W}^{\prime}$. G. Hughes' goats............ 313

-Notes from on practical breeding.............. 405, 433

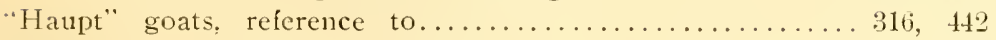

Hawley, J. H., reference to clearing land.................. 360

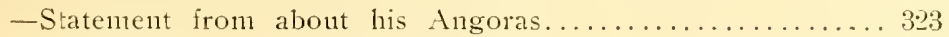

-Notes from on practical breeding.............. 412. 433

Haycs. Dr. J. I., opinion concerning introduction of Angoras into Asia Ninor........................... 27

-Opinion of, concerning Cashmeres ...............

-Opinion why the industry did not succeed in the United States 109

-Reference to Angoras in Australia................... 110

-Reference to manufacture of Mohair................ 121

-Reference to the applicaton of Mohair...................

-Reference to the application of skins for rugs.......... 127

-Reference to pure-bred Angoras..................... 213

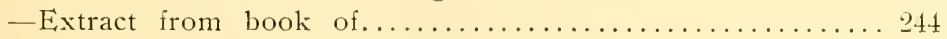

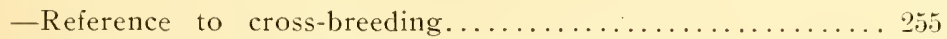

-Reference to the Alpaca and its congeners............. 473

Hazel brush, reference to clearing. .351, 355, 356, 359, 36ю, 361, 365, 368

Head, Dr. James M., reference to goat raised by ............. 2133 Head of the Angora goat, opinions abont.......213, 214, 215, 216 Heever, Hon. Van den, supports export duty in South Africa....... 10 Henderson, Col., first importation to Cape Colony........... 3is Herding goats, cost of.......................... 269 -Opinions from practical breeder $3 \ldots \ldots \ldots \ldots \ldots \ldots 42$ to 435

-Loose. reference to ......................... 392

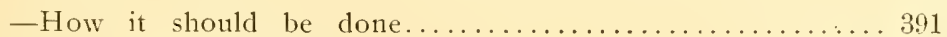

Herder's ontfit, reference to .................. 27?. 394

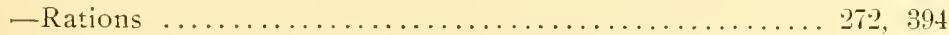

Hermans, E. J.. letter concerning land in Washington.......... 301

Hickory brush, reference to clearing........... 355, 356, 367

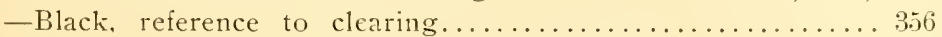

Hightower, J. C., statement from about his Angoras. . . . . . . . . . . 33?

-Remarks on non-shedding Angoras .............2.29.230

- Notes from on practical breeding............... 419. 434

- Reference to Angoras with two coats of hair ............ 198

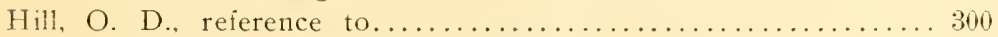

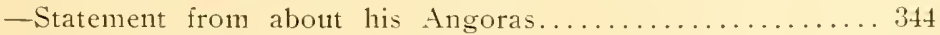

- Notes from on practical breeding..............4. 430. 435

-Reference to clearing brush........................ 370

Hill, Albert J., letter from concerning British Columbia......... 40

Hoag. Capt. J. Nurray, letter from...................... 10 .

-Reference to clearing brush land........................ 
Hockley, Mr., opposes export duty in South Africa........... 108

Hoerle, G. A., reference to importation by Fink \& Co......... 51

-Reference to Angoras with two kinds of hair.......... 208

-Opinion of, as to point of a pure-breed.............. 215

-Reference to non-shedding Angoras.................224

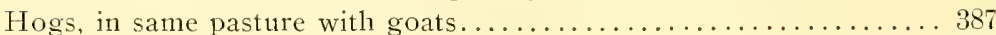

Holder, J. F., statement about his Angoras ............... 339

—Notes from concerning practical breeding.......... 423,434

Hottins, S. B., certificate of merit about Dr. Standley mohair. . . . . . 161

Holt, Lafayette, referring to Angoras in North Carolina........ 93

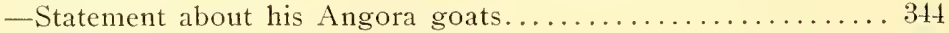

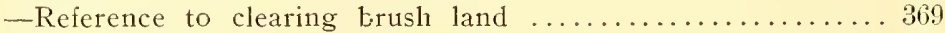

-Notes from on practical breeding.............. 431, 435

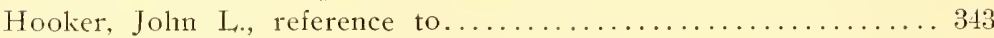

Horn, C. S., reference to clearing brush land.............. 369

- Reference to Angoras in Illinois..................94

Horn, Wm., statement about his Angora goats............... 339

--Notes from on practical breeding.............424, 434

Horns of Angoras.........187, 212, 213, 214, 215, 216, 217, 259, 291

Hornless Angoras, concerning buck imported.............. 49

-Reference to by S. S. McKibben. . . . . . . . . . . . . . 102

-Reference to.............216, 221-3, 2-25-8, 231-3, 336

Houck, Geo. A., concerning industry in Oregon............. 84

-Remarks on non-shedding Angoras................28

- Statement from, about his Angoras...................... 327

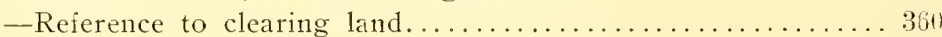

—Notes from, on practical breeding .............409, 433

"Houck" goats, reference to.......................... 323

Hughes, W. G., concerning advantages in Tennessee........... 300

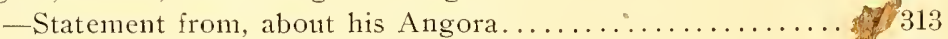

- Letter from, on practical breeding................... 437

-Remarks on non-shedding Angora.................2.20

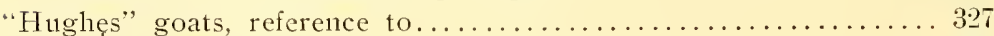

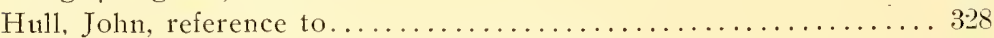

Humphrey, Wm., reference to sheep industry............... 442

Hunter, J. D.. Notes from on practical breeding...........408, 433

Hutchins \& Co., reference to................................ 138

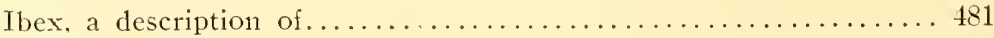

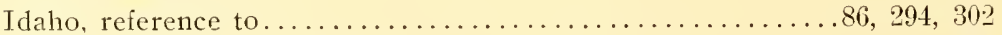

Illinois, reference to Angoras in.................... 47

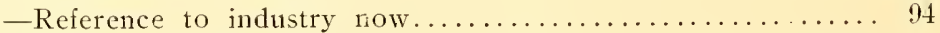

Importing Angora goats-how it may be done............... 445

-Opinons of breeders on .................. 402 to 435 
PAGE

Importations of Angora goats into the United States..... 18, 49, 51

Importations from South Africa................... 51

Incidental, or by-products of Angora goats..............

Increase, estimate in breeding, by Sir Sam's WVilson............ 11.

Increase, percentage of, opinions of breeders .........40. to 432

In-breeding, reference to.. ........................... 25

Indiana, reference to Angora goats in......................

Indian Territory, notes from breeders in................ 43;

Industry in Angora, why it has been so backward. . . . . . . . . . . 109

-Dr. Hayes opinion why it has not grown............. 109

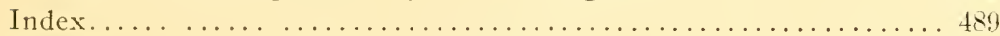

Iowa State fair, the system of, commended................ 18

Iowa, reference to Angoras in, by Hon. I. H. Diehl. . . . . . . . . . . . 18

-Notes from breeders in. . . . . . . . . . . . . . . . 433

-Reference to industry at the present time............ 96

Ivy, and laurel, injurious to Angoras..............

"James' History of Worsted Manufacture." extract from . . . . . . . 1.2.

Japan clover, observations of Col. J. Wash Watts............. it

Jarvis. William, reference to sheep industry .............. 44 ?

Jastremski, Hon. Leon, letter from, about Louisiana........... 301

Jaubert, Mons., concerning Cashmere goats in France............ 458

Jewett, Hon. Wm. J., concerning Angoras in Turkey........... 445

Johns, A. L.. letter from, about Angoras in stock yards.......... 15.5

Johnson, O. O., reference to Angoras in North Dakota............ 93

Johnson, R. C., reference to Angoras in Kansas............... 94

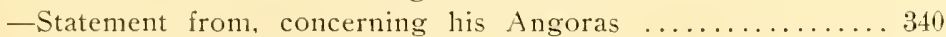

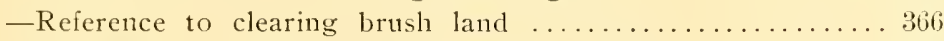

-Reference to fattening Angoras for market................

-Notes from, on practical breeding ............. 429,435

_Connection with Angora Goat Breeders Asssociation......446, 448

Johnson. R. P., committee report on "Davis" goats............ 192

Johnson, Cuthbert W., reference to milking................ 284

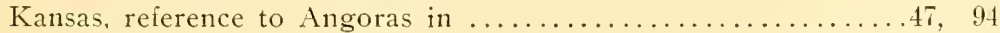

-Notes from breeders in ...................... 435

Kemp, reference to.............211, 2.27, 2.29, 230, 248, 250, 250

Kentucky, reference to Angoras in................... ti

Kennedy, John, letter from, concerning non-shedding Angoras...... 231

Kennedy, Chas. F., letter from, about Angoras in Indiana........ 95

Kids, two at a birth due to crossing ....................... 187

-Reference to, by Dr. John Bachman ............... 196

-That do not shed first hair ................

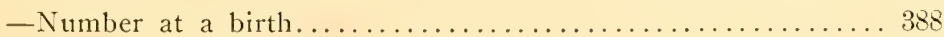

-When they should come $\ldots \ldots \ldots \ldots \ldots \ldots \ldots \ldots \ldots \ldots . \ldots . \ldots . \ldots 8$ 
PAGE.

-Reference to weaning ..................... 390

-Reference to marking with paint ................ 397

-Twins, how to manage ..................... 397

- Reference to staking ....................397, 4\%9

- Reference to penning ....................397, 499

-When to be allowed to go with Hock ............... 397

- Estimate of increase of, by breeders .............4112 to 435

- Crooked and deformed.....................416, 418

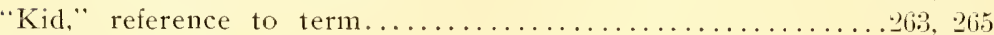

Kid Skin, reference to $\ldots \ldots \ldots \ldots \ldots \ldots \ldots \ldots \ldots \ldots \ldots \ldots \ldots \ldots$

Kidding season, reference to ........................ 384

- Hogs should be removed from pasture .............. 387

- How to regulate work during. ..................... 390

- Reference to, by Col. Robt. W. Scott ............... bit

-Original Angora, only had one $\ldots \ldots \ldots \ldots \ldots \ldots \ldots \ldots \ldots$

Kitching \& Bicknell, reference to . . . . . . . . . . . . . . 138, 388

Knapp, B. S., reference to.......................... 343

noiner, Hon. Geo. W., letter from concerning land in Virginia. . . . . 299

"Kurd" goat, Peglar's description of $\ldots \ldots \ldots \ldots \ldots \ldots \ldots \ldots \ldots$

-Reference to, by M. Botlier ..................5. 9.54

- Crossing with the Angora ....................... 178

Kypelogion, George, reference to ................... 440

Lace Trimming, reference to $\ldots \ldots \ldots \ldots \ldots \ldots \ldots \ldots \ldots \ldots \ldots$

Lamp mats, reference to ........................ 979

Landrum, Wm. M.. reference to Guadalıpe Island . . . . . . . . . . . . 38

- Shears an Angora having 2.2-inch mohair ............. 39

-Reference to Chenery importations ................4 48

- Reference to Diehl \& Brown importation .............. 49

- Reference to A. Eutichides importation .............. 49

-Reference to importation of Geredah goats ........... 49

-Reference to Harris \& Hall importation .............. 49

-Biographical sketch of ...................... 79

-Remarks on non-shedding Angoras ............... 2.27

- Reference to ............................. 2832

-Reference to hornless Angoras ................. 238

- Reference to Asiatc scab .......................... 378

-Statement from, concerimg his Angoras ............ 16

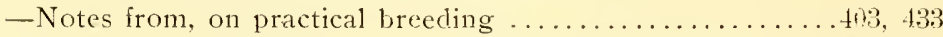

"Landrum" goats, reierence to . . . 316, 319, 320,324, 392, 339, 4.8, 449

Iandrum \& Butterfield, reference to ................... 327

Jandrum \& Rodgers, reference to ...................... 227

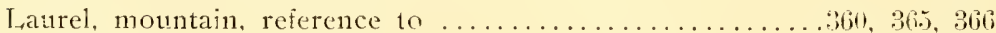

Laurel, poison, reference to ...................... 369

Laurel and $I_{v y}$, reference to ...................... 5 5 
PAGE

Lea, Orerton, reference to .......................... 300

Leafe, R. B., first introduction of Angoras on Fiji Islands ........ 35

Lee. Dr. R. J., reicrence to goat's milk. . . . . . . . . . . . . . . . 290

I.ee, C. C., opposition to export duty in South Africa ........... 106

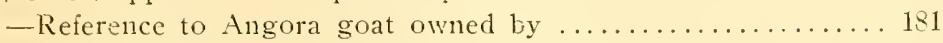

Ledger, Charles, reference to Llama and Alpaca ............ 4is

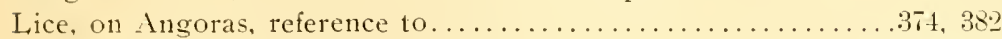

-Dippng for, opinions of breeders ................. 402 to 435

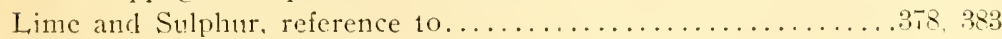

Jinde, J. C. \& Ce.. reference to.................... 138

Linton. R. J., statement from, about his Angoras.............. 332

-Notes from, on practical breeding ..............118, 134

Lippincut. A., statement from, about his Angoras............ 34 3

-Reference to clearing trusl $\ldots \ldots \ldots \ldots \ldots \ldots \ldots \ldots \ldots \ldots . \ldots \ldots$

-Notes from, on practical breeding ................ 46,434

Llama sliawls, reference to............................

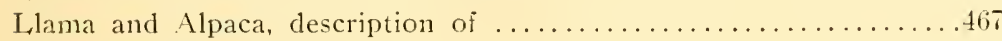

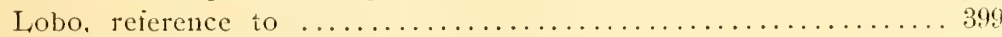

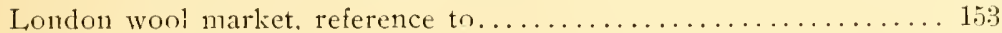

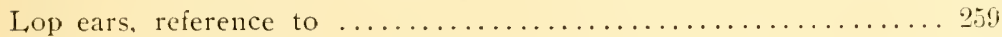

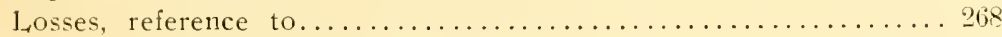

-Estimates of by practical breeders . . . . . . . . . . 40 2 to 435

Louisiana, reference to Angora goats in $\ldots \ldots \ldots \ldots \ldots \ldots \ldots \ldots$

-Reference to lands in................................... 301

Lowry. R. H., one of the early breeders in Texas............ 76

-Renarks on non-shedding Angoras ................2. 28

- Statement about lis Angora goats .................. 319

- Notes from, on practical breeding ..............4 40 433

Luckie, W. F., reference to non-shedding bucks ................

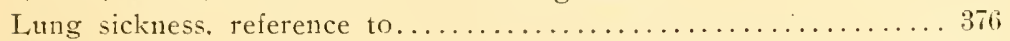

Maasdorp, Hon. G. H., opposes export duty in South Africa ... 106, 107

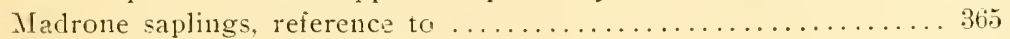

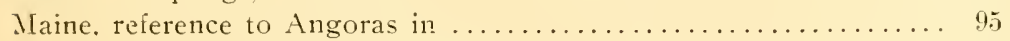

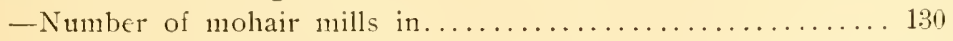

-Reference to area in, suitable for Angoras..............29.5, 309

Maltese goats, reference to ............... $43,247,255,436$

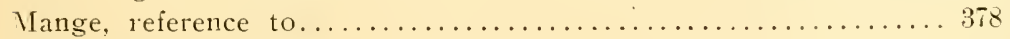

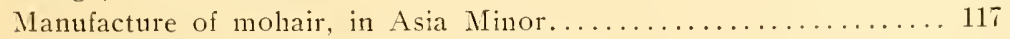

-Described by Hon. Israel H. Diehl . . . . . . . . . . . . 118

-Reference to, by Dr. J. L. Hayes ................. 121

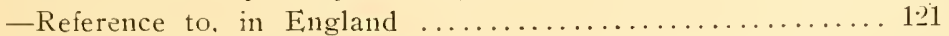

-In the United States ........................ 129

-In the Unted States, encouraged by Hon. Isaac Newton..... 124

-Application of products ......................... 


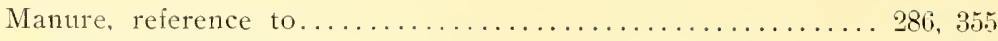

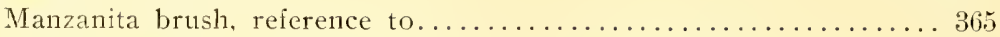

Mapes. James J., committee report on "Davis" goats........... 192

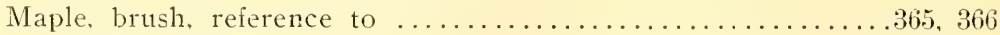

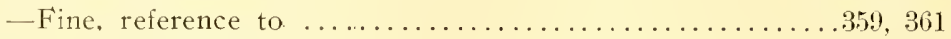

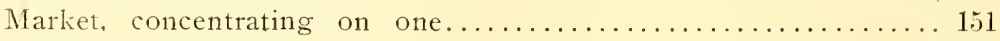

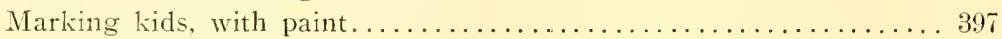

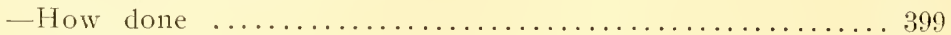

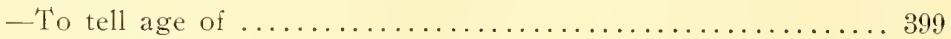

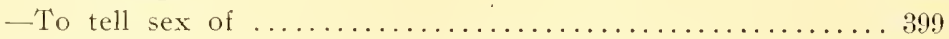

Marshall, H. B., reference to non-shedding Angoras............. 228

-Notes from, on practical breeding ...............407, 433

Maryland, reference to Angora goats in................. 4 i

-Reference to Angora goats in, by Hon. Geo. A. Porter...... 69

- Reference to lands adapted to goats in................ 299

Massachusetts, reference to Angoras in .................. 47

Experience in, by W. W. Chenery ................ 70

- Extract from newspaper concerning abandoned farms in.... 70

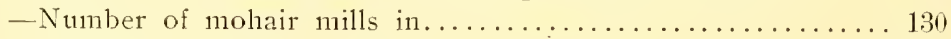

-Reference to lands, suitable for Angoras .............. 297

Masters, Mr.. statement from, about his Angoras............. 324

-Notes from, on practical breeding .............412,433

Masters. Rer. C. B., reference to ...................... 324

Mastin, T. H., reference to .................... 446,448

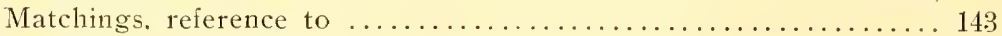

Maugher, M., letter concerning Jno. S. Harris............... 90

Maurice, Price, reference to importations by ............... 50

Maxwell land grant farm, reference to.................. 436

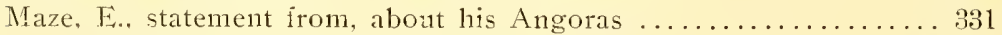

-Notes from on practical breeding ...............414, 433

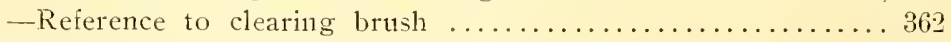

Meat of the Angora, opinion of Dr. Barrett ............. 67

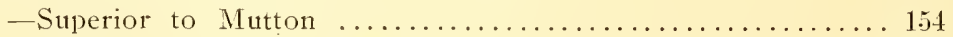

-Opinion of Dr. Jno. Bachman ................. 155

-Report of committee on ....................... 19e

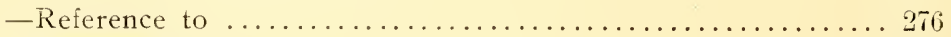

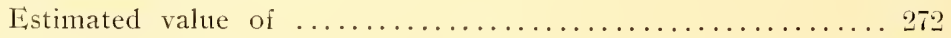

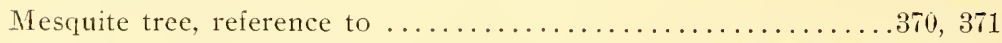

Mexican goats, reference to ...........230, 243, 247, 268, 271

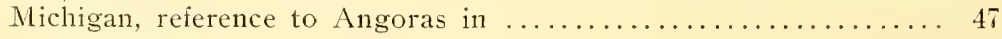

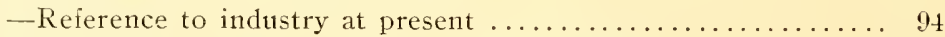

"Midland News and Karoo Farmer," extract from .............. 106"

Milk of goats, reference to, by Col. J. Wash. Watts ........... 55

-Great benefit of, with children ..............289, 290 


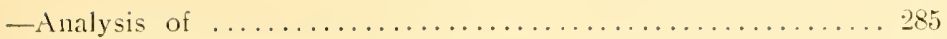

Milking qualites $\ldots \ldots \ldots \ldots \ldots \ldots \ldots \ldots \ldots \ldots .281,284,287,228,425$

Miles, ' $\Gamma$. Clome. introduces Angoras into Montana ............ 93

- Statement from, about his Angoras . . . . . . . . . . . . . 339

-Notes from, on practical breedin. .............. 4.7 .434

Miller \& Sibley, reference to clearing brush................ 369

Minnesota, reference to Angoras in $\ldots \ldots \ldots \ldots \ldots \ldots \ldots \ldots .47,93,368$

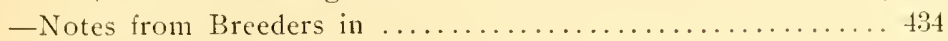

Missouri, notes from breeders in . .................. 434

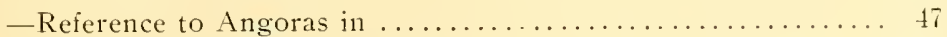

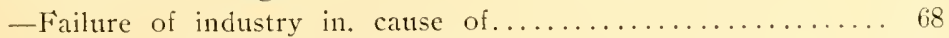

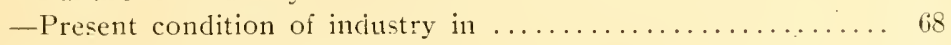

Mississippi, reference to Angoras in ................... 96

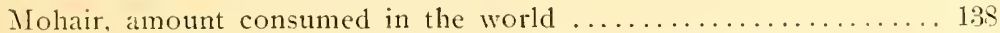

- Adrantages of United States climate in producing. . . . . . . 139

-Estimated amount of, required by railroads for seats ....... 140

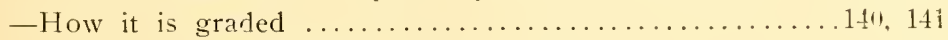

- Necessity for a national standard grade.................. 141

- How to determine value of . . . . . . . . . . . . . . 14 ;

- How manipulated by manufacturer .............. 1:8, 149

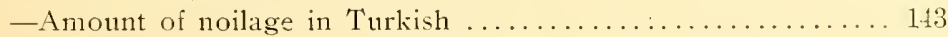

-Amount of noilage in United States .................. 143

-Very coarse, used for dolls' hair, wigs, etc............... 143

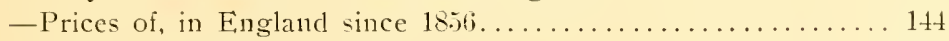

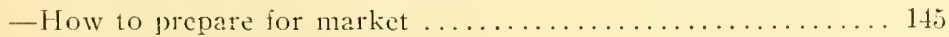

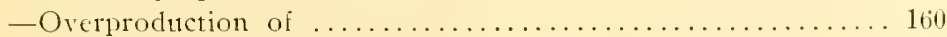

-Tariff on .................................... 161

-Spinning capacity of, compared with wool ............ 164

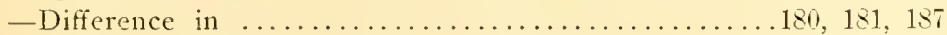

-Length of, can be increased by breeding ................ 174

-Climatic influence on ..................... 18.5, 191

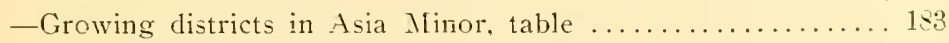

-Difference in lengths of $\ldots \ldots \ldots \ldots \ldots \ldots \ldots \ldots \ldots .212,214,215$

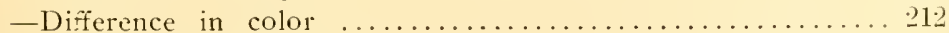

-First shipment from Cape Colony .................. 36

-Superiority of America1i .................... 47

- Certificate of merit conccrning Iowa mohair ............. 101

- Amount produced in different States .................... 104

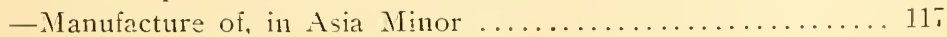

- Not allowed to be exported from Asia Minor ............ 117

-When first shipped into England .................. 121

- How the product was encouraged in Turkey ............. 123

-Products ot . . . . . . . . . . . . . . . . . .

-Great durability of products ................... 128 
- Amount consumed in the United States ..............130, 131

-Imports into the United States from 1890 to $1894 \ldots \ldots \ldots \ldots \ldots 130$

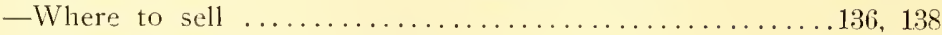

-Value of, governed by fashions ............. 136, 139

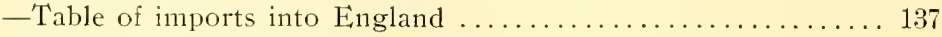

-Estimate of yield from 1,500 Angoras in ten years........ 269

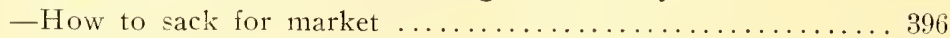

-Greasy, or oily, remarks on by W. G. Hughes............ 226

-Most salable length ........................... 259

- Reference to market value of .................. 27 2

-In Turkey, what districts produce the best ............. 434

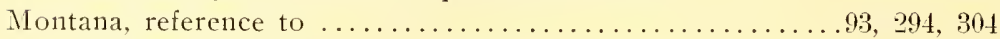

-Range of, supposed to develop large frames ............ 19?

"Montana Stockman and Farmer," extract from ............... 304

Montgomery, Ward \& Co., reference to catalogue of.......... 168

Moon, A., statement from about his Angoras................ 331

- Notes from, ois practical breeding ..............418, 434

Moore, Chas. T., reference to ..................... 343

Morgan \& Morgan, statement about their Angoras.............. 336

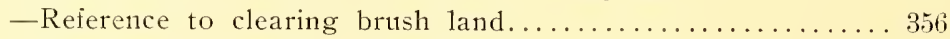

-Notes from, on practical breeding .............429, 433

Morton, I. C.. statement fron, about his Angoras............ 336

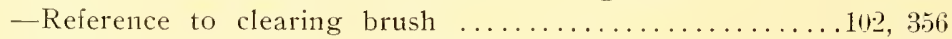

-Notes from, on practical breeding ..............422, 433

Moses, reference to ..............................263

Mosenthall, A. \& Co., last importation into South Africa .......... 38

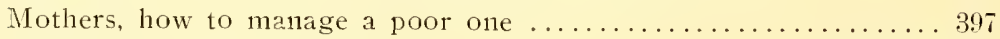

Mountain Laurel, reference to ..................360, 365, 366

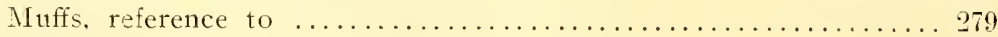

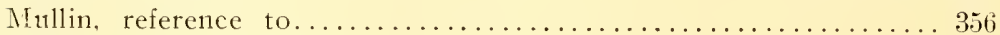

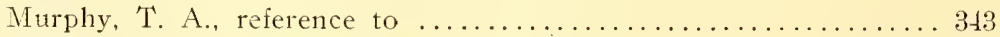

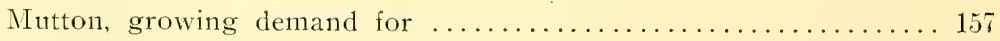

-Table of receipts at Chicago .................... 157

-Compared with cattle ....................... 157

McCorkle, Mr., reference to ............................ 340

McDonald, James, statement from, about his Angoras ......... 324

-Remarks on non-shedding Angoras ................ 29.

-Reference to clearing brush .................... 361

-Notes from, on practical breeding ..............13, 433

McDottgall's dip, reference to ........................ 411

McIntire. $W . T$. relerence to $\ldots \ldots \ldots \ldots \ldots \ldots \ldots \ldots \ldots \ldots \ldots . \ldots \ldots, 448$

McKee, Wm. R., statenent about his Angoras ................ 314

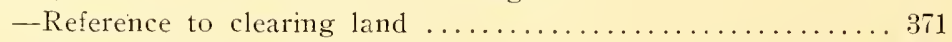

—Notes from on practical breeding ..............408, 433 
PAGE

McKeen, B. Walker, letter from, about land in Maine........... 295

- Tietter from, about Angoras in Maine ............... 9.

McKinley, Hon. Wm., restores tariff on mohair ............. 16 ?

McKibben, S. S., reference to Angoras in Iowa ............... 10.

-Reference to hornless Angoras ...............20.35, 443

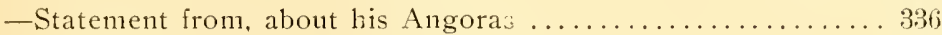

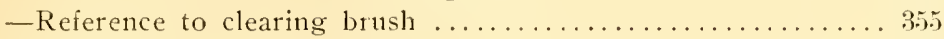

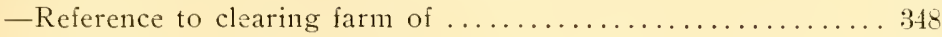

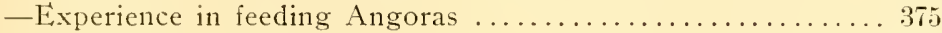

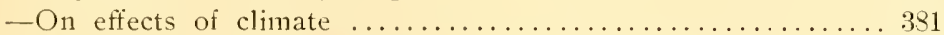

-Notes on practical breeding . . . . . . . . . . . . . . 433

MeLendon, I. C. P., concerning non-shedding Angoras.......... 2.2?

-Letter from, concerning breeding .................. 439

McLean, Dr., opinion as to cause of death in many cases .......... 381

"Nanny," reference to term as applied to goats.........263, 264, 265

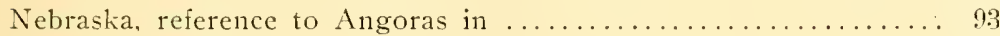

Nettle, reference to ...................................

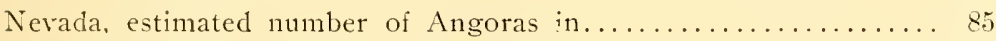

New Hampshire, reference to Angoras in ............... 95

-Reference to lands in . . . . . . . . . . . . . . . . . . 290

New Jersey, number of mohair mills in ................. 130

- Reference to lands in, suited to goats . . . . . . . . . . . 298

Ner: Mexico, reference to ..................294. 30.2, 30.5

-First Angoras introduced into ................

Newton, Hon. Isaac, reference to breeding Angoras in United States, 12.t

- Reference to manufacture of mohair in United States ...... 125

- Reference to manufacture of Cashmere wool ............ 125

Newspaper extracts concerning "Davis" goats................. 191

New York, reference to Angora goats in................. 17

-First Angoras introduced..................... 69

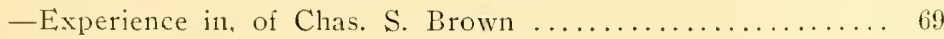

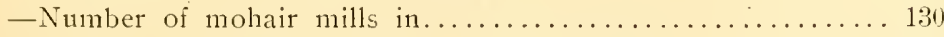

- State lair committee report on "Davis" goats ............ 191

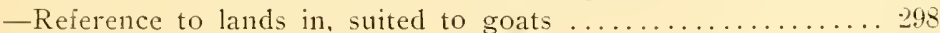

Nillson. Chris., statement about his Angoras ........................ 340

-Notes from, on practical breeding..............28, 134

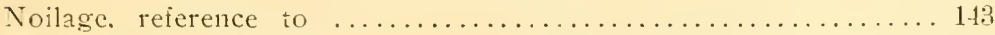

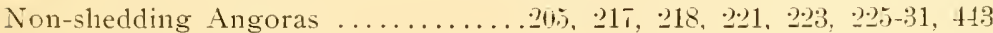

-On Guadulupe Island ........................ 39

- Letter from J. C. P. McLendon ..................23

-Letter from Conklin Bros.....................2. 23

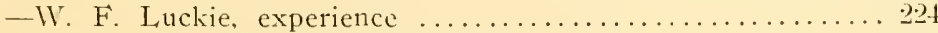

-Geo. A. Hoerle, experience with.................. 29 
Norcup, A. D., statement about his Angoras................ 335

- Notes from, on practical breeding .............420, 434

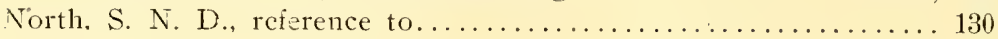

Notes from practical brceders ....................401 to 435

Oak brush, reference to $\ldots \ldots \ldots \ldots \ldots \ldots \ldots \ldots 35,359,360,361,368$

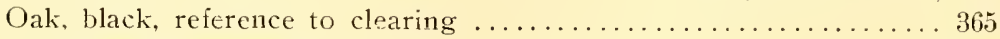

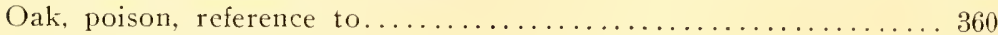

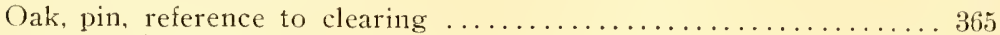

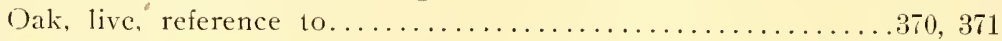

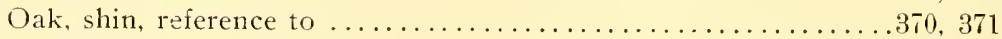

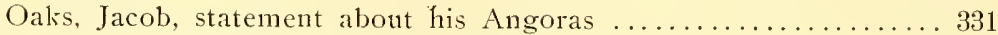

-Notes from, on practical breeding ..............17, 434

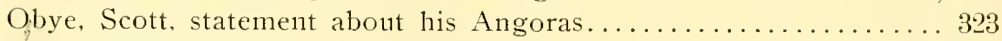

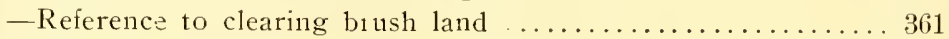

- Notes from, on practical breeding ..............410, 433

Off-colored goats, reierence to ................209. 211,212

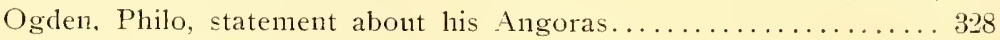

—Notes from, on practical breeding .............417, 434

Dlio, reference to Angora goats in ................. 47

-Remarks of S. S. Williams ................... 69

Oklahoma, reference to Angoras in .................. 94

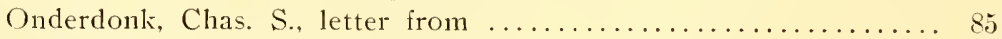

Onderdonk Live Stock Co., reference to ................ 85

-Statement from, about their goats................ 335

-Notes from, on practical breeding ................ 420

Oregon, when the Angora was first introduced .............. 84

- Climate adapted to growing mohair ................ 84

-Angoras largely used for clearing land ................ 84

-Angora Goat Breaders' Association, officers of .......... 85

- Mohair clip of, opinion of H. M. Williamson ........... 105

-Reference to ......................291,30.2, 360

- Notes from breeders in ..................... 433

"Oregon Agriculturist and Rural Northwest," extract from. .106, 295, 380

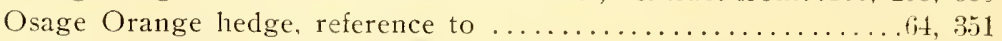

Osborne, J. J., notes from, on practical breeding ........... 418

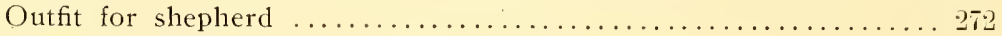

Outram, Benj., reference to manufacture of Alpaca ............. 122

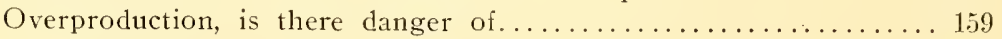

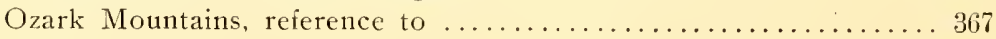

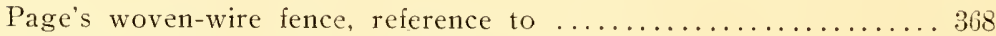

Paine, Brig.-Gen. A. E.., opinion on Casimere wool ........... 68

Paine, Hon. Thos. H., reference to lands in Tennessee ......... 300 
PAGE

Paiseley, Scotland, Cashmere wool exported to......192, 200, 203, 459

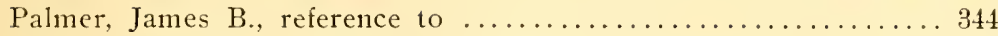

Parish, Col. W. D., purchase of two imported Angoras ........... 49

-Reference to, by Col. W. W. Haupt ............... 76

-Reference to, by Geo. W. Baylor.................. is

-Made no direct importations from Turkey ............. 78

- His first Angoras referred to by Jno. S. Brown .......... if

-As a factor in building up industry in Texas ........... 78

"Parish" goats, reference to..........216, 314, 315, 316, 319, 443

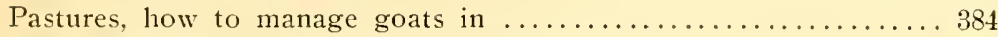

Pasturing goats with other stock, reference to .............. 387

Patterson, James, notes from, on practical breeding .........405, 433

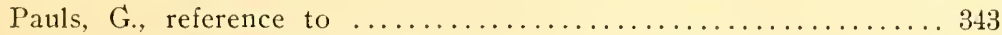

Payne. Wm. R., letter concerning census of Angoras............. 103

-Reference to mohair grown in the United States.......... 105

-Prominent factor in mohair trade................. 138

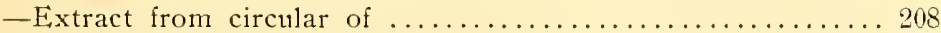

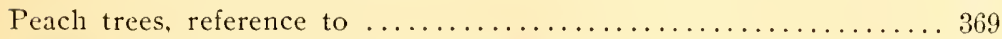

Peglar, S. H., description of Kurd goat ................. 26

-Opinion of, as to pure-bred Angoras ................ 213

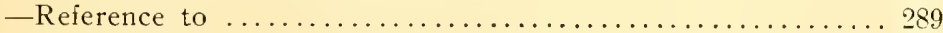

-Description of Cashmere goat ................. 456

Pennsylvania, reference to Angoras in $\ldots \ldots \ldots \ldots \ldots \ldots \ldots \ldots . \ldots \ldots$

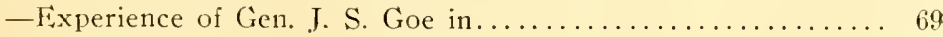

-Experience of I)r. F. F. Robinson ................. 69

-Letter from Miller \& Sibley ..................... 69

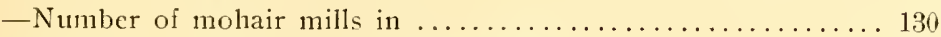

-Referenc to lands in, for goat raising ............... 297

Penning goats, reference to, by practical breeders .........442 to 435

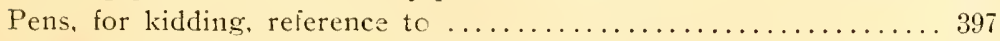

Pepper, Jeff, statement from, about his Angoras ............. 315

- Notes from, on practical brecling..............404 to 435

Pepper, B. F., reference to............................. $3 \pi 1$

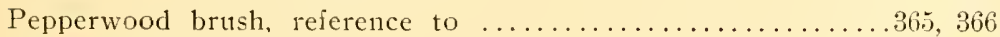

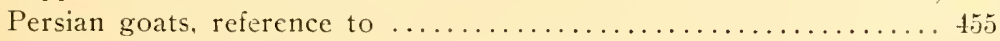

Pets, reference to ............................... 280

Peters, Col. Richard, goats, reference to.................... 229

-Extract from writings of ....................... 249

-Reference to breeding grade bucks ................. 250

-Reference to terms applied to goats ................. 265

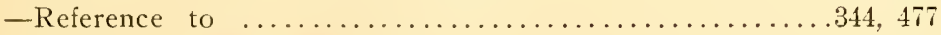

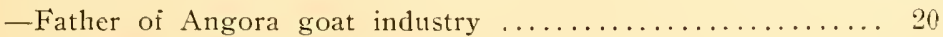

-Purchases the "Davis" goats ................. 47 
-Importation of Angoras ....................... 49

-Biographical sketch of ...................... 55

-Observations in breeding and handling...........6., 69

- Reference to, by Dr. Hayes..................... 110

-Experience with cross-breeding ................... 177

- Premium awarded to ........................ 192

-Opinion as to breed of the "Davis" goats ..........197, 198

-Opinion about shedding mohair................... 218

"Peters" goats, reference to, by Dr. Jno. Bachman............. 195

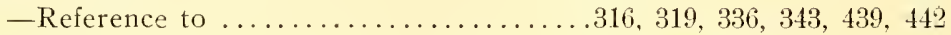

"Philadelphia Ledger," extract from about "Davis" goats . . . . . . . 202

Phillips, Jos., reference to ....................... 300

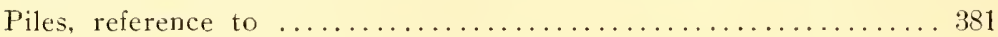

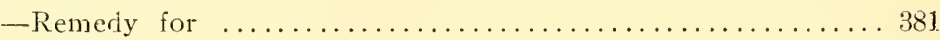

Place, Mr. W. H., observations about milk ................ 286

Plaster, Dr. P. C., observations abont Angora............... 95

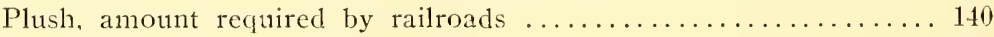

Plum brush, reference to ...........................

Pleuro-pneumonia, epidemic in Cape Colony ................ 376

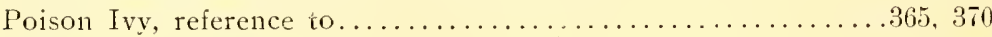

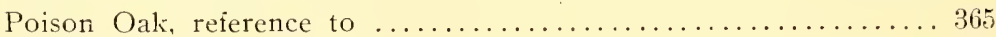

Poison laurel, reference to................................. 360

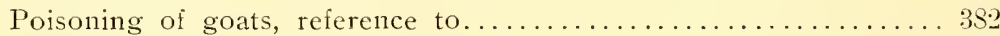

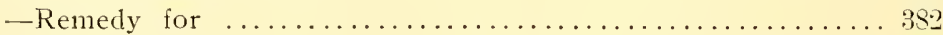

Polled Angora goats ................225 to 228,231 to 233

Pollonau, Mlons, reference to....................... 458

Pollonceau, Mons, reference to $\ldots \ldots \ldots \ldots \ldots \ldots \ldots \ldots \ldots \ldots \ldots . \ldots . \ldots$

Poor, H. V., reference to plush used by a ailroads ............ 140

Porter, Hon. Geo. A., reference to Angoras ............... 69

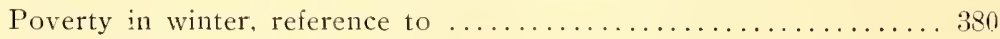

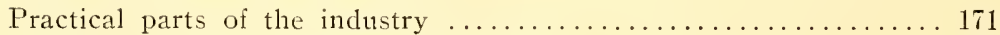

Prices of mohair in England since $1856 \ldots \ldots \ldots \ldots \ldots \ldots \ldots \ldots . \ldots \ldots 4$

"Presbyterian Herald," extract from ..................... 202

Products from mohair ......................... 126

-From mohair that are standard ................... 131

Profits on 1,500 Mexican does ...................... 269

Profits on 1,5010 Angora does ...................... 270

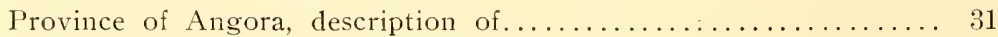

Puppy raised by a goat very useful . . . . . . . . . . . . . . . 392

Pure-bred vs. full-blood............248, 249, 250, 251, 254, 255

Pushm, or fur, from Cashmeres .................. 29

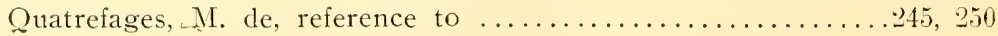




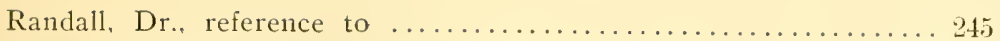

Range for goats, reference to ................................. 294

- Number of acres required for handling . . . . . . . . . . . . . . 389

- How to handle on the open....................... 389

"Ram," reference to term as applied to goats.............263, 26.5

Rations for shepherds, cost of...................... 272

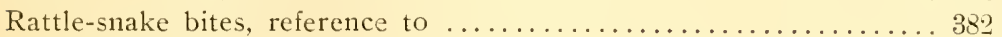

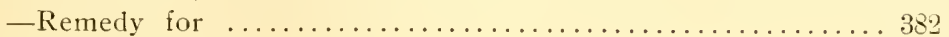

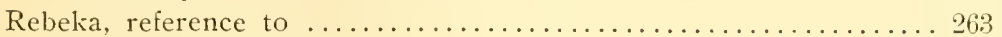

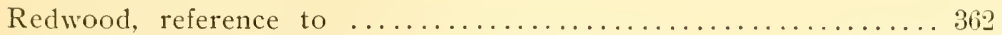

Register for Angora goats, opinion of breeders ..........402 to 435

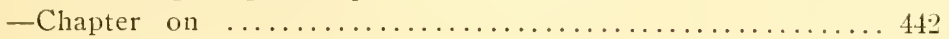

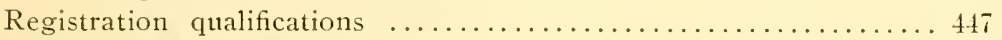

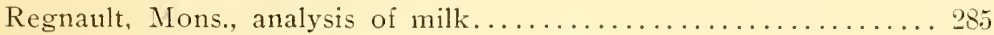

Regsby, John, reference to....................... 343

Rennick, James, committee report on "Davis goats............... 191

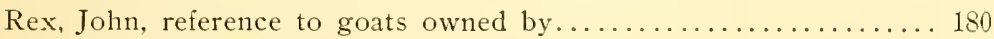

Rhode Island, number of mohair mills in................ 130

Richter, Wm., notes from, on practical breeding ...........416, 434

Rippey, J. R., letter from, concerning Missouri............68, 113

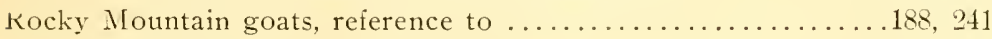

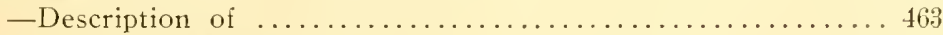

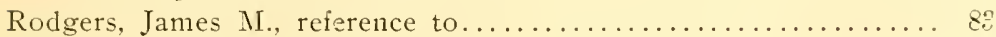

Rogers, Frank H., reference to ...................293, 294

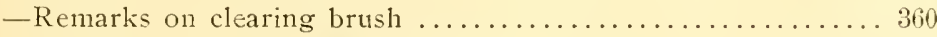

-Notes from, on practical breeding ..............412, 433

Rugs, made from Angora goat skins .................... . 150

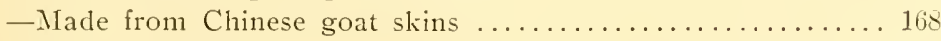

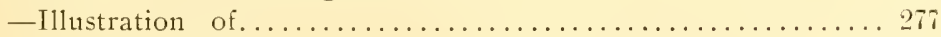

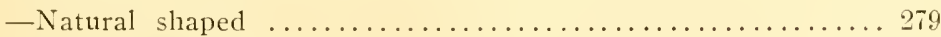

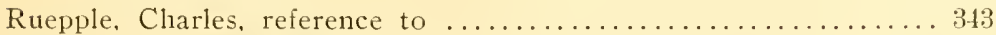

Ruime, R. H., reference to......................... 343

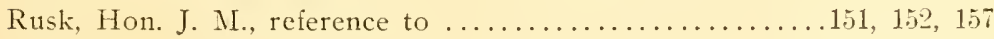

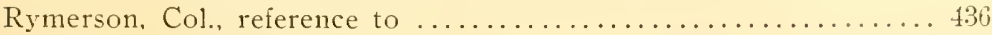

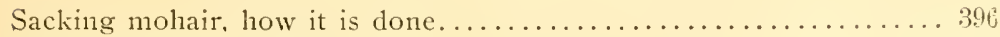

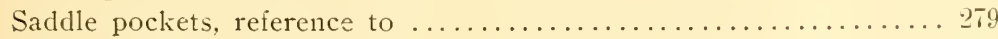

Saddle girths, reference to . . . . . . . . . . . . . . . . . . . . 280

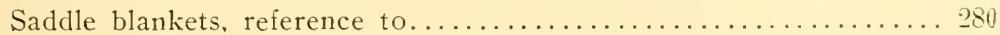

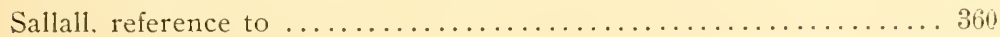

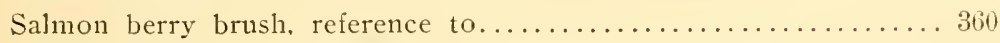

Salt, Sir Titus, first importation of Angoras into England ........ 34

-Co-operates in building up South African industry ........ 35

-Benefits resulting from his enterprise ............... 121 
-First experiment with Alpaca................... 122

-Erection of mohair mills in Bradford ................. 123

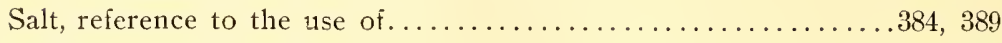

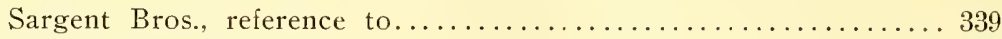

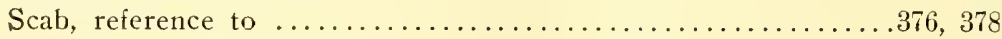

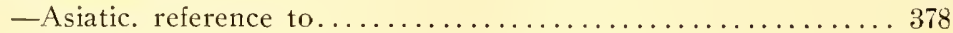

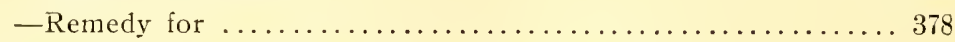

Schreiner, S. C., extract from, concerning crossing ........... 16

-Extract from, concerning early Angoras.............. 41

-Extract trom, concerning Australia ................ 50

-On effects of crossing with the common goat $\ldots \ldots \ldots \ldots \ldots . . \ldots 187$

-Extract from, concerning hornless goats .............. 232

-Remarks on pleuro-pneumonia .................. 376

-Concerning cross-breeding in Turkey..............253, 254

- Remarks on scab, in Cape Colony.................... 378

-Reference to terms applied to Angora goats............. 265

-Remarks on South African Angoras ................... 444

Schaffer, Dr. Geo. L., nricroscopic examination of hair ......... 200

Scott, Col. Robt. W., observations of, on the Angora goat ........ 64

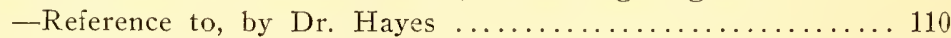

-Description of Angora with two coats of hair ........... 207

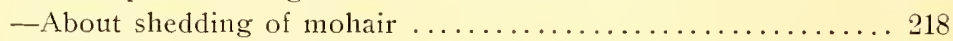

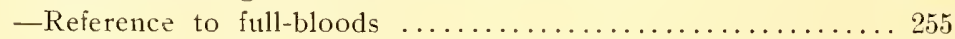

-Reference to kemp ........................... 256

-Reference to terms applied to Angoras .............. 265

"Scott" goats, reference to ....................... 336, 439, 442

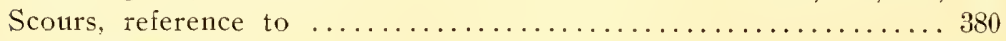

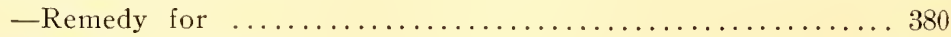

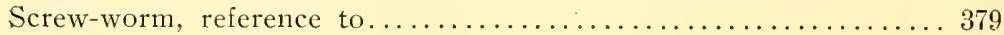

- Remedy for . . . . . . . . . . . . . . . . . . . . . . 379

Seever, Wm. J., reference to industry in Missouri $\ldots \ldots \ldots \ldots \ldots \ldots 68$

- Statement from, concerning his Angoras . . . . . . . . . . . 343

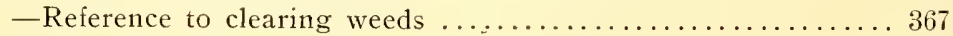

- Notes from, on practical breeding ..............426, 434

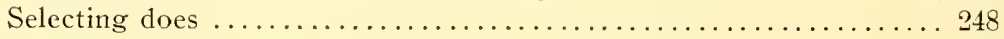

Shearing, observations of $\mathrm{J}$. P. Devine in $1877 \ldots \ldots \ldots \ldots \ldots \ldots \ldots 77$

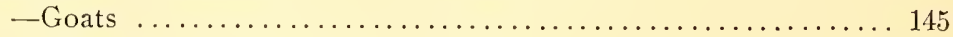

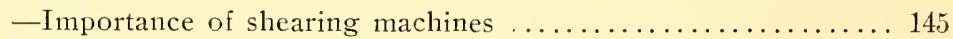

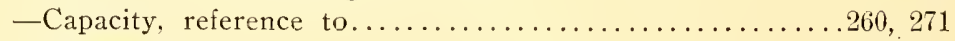

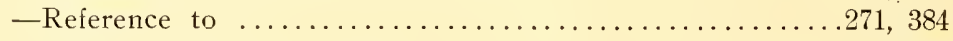

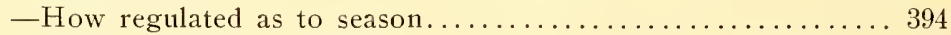

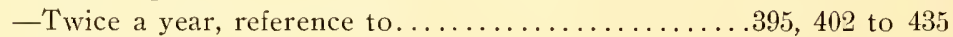

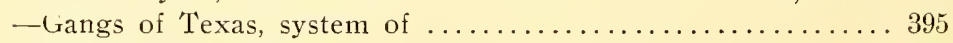

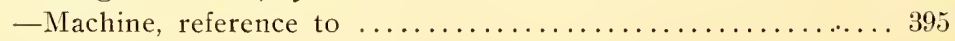


- Capacity of best Angoras in Turkey ................. 445

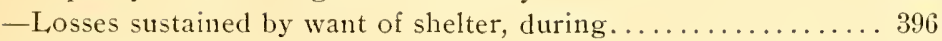

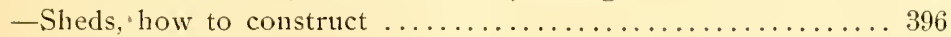

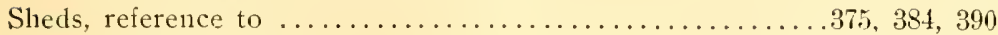

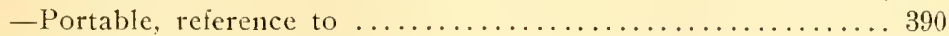

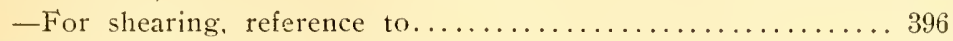

Shedding goats, reference to, by breeders.............402 to 435

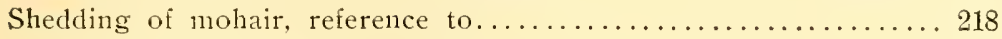

-At different seasons of the year .................. 222

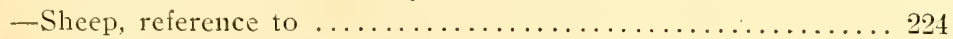

Sheep, receipts of, in Chicago for thirty-three years............ 158

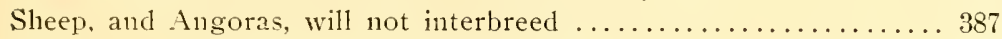

Shelley, Dr. Chas. Edward, reference to goats' milk .............. 290

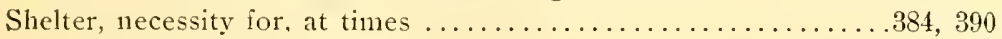

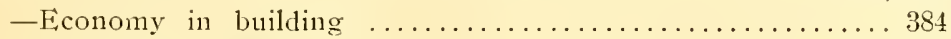

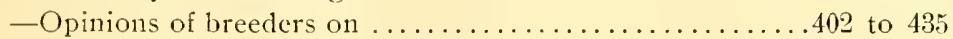

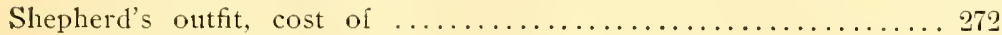

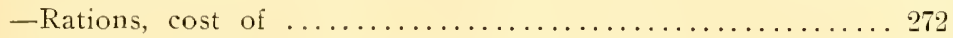

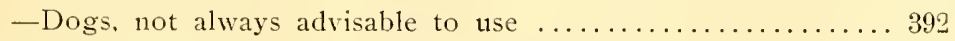

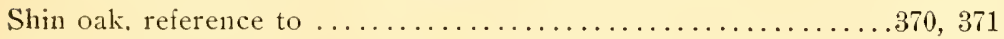

Shivland \& Thomas import Angoras into California ........... 83

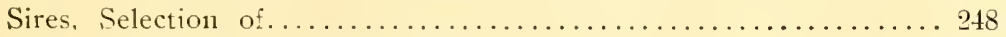

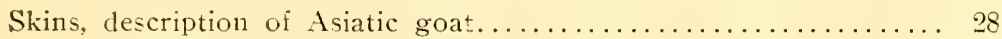

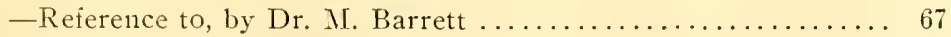

-Used for rugs............................... 127

- Angora, how to prepare for market ................ 147

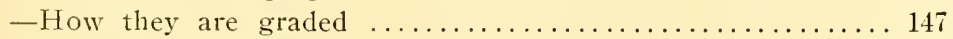

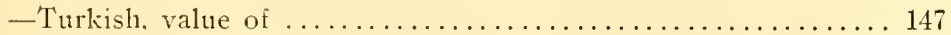

-Cape of Good Hope, value of ...................... 147

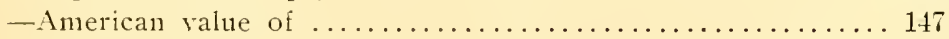

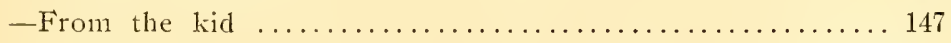

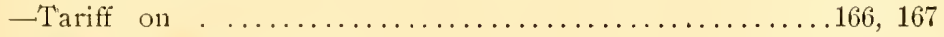

- Largely used by furriers ....................... 148

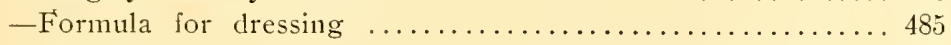

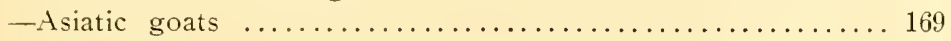

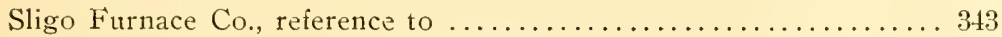

Smith. C. D.. letter concerning Michigan ................. 94

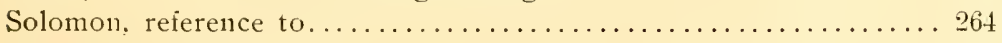

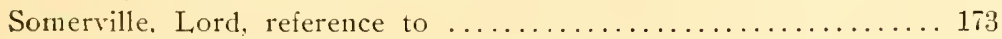

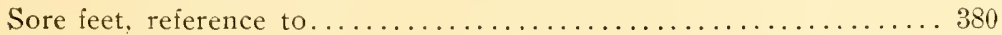

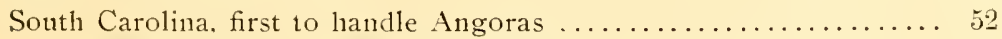

-Letter from Col. J. Wash. Watts ................ 53

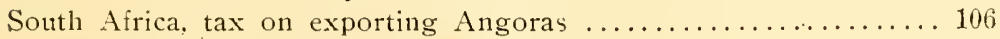

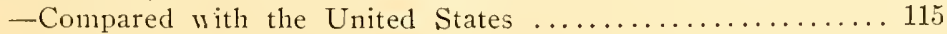

-Imports of mohair from ..................... 138 
South African breeders, reference to buying bucks . . . . . . . . . . 260

"Southern Central Agricultural Association," report of committee.. 195 "Southern Farmer," letter to, from Col. W. W. Haupt ............. 211

-Extract from ............................. 255

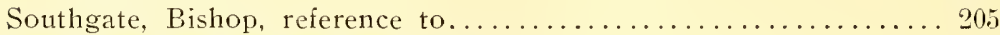

Spain, first introduction of Angoras into................. 34

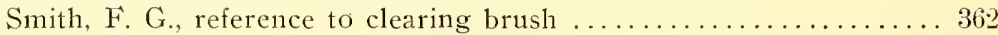

—Notes from, on practical breeding..............414, 434

Spofford, Dr. F. A., reference to Dakota ................ 93

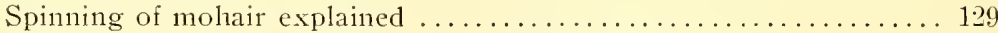

Standley, Dr. J. R., statement about his Angoras .............. 336

- Credit due, for introducing goats as brush cleaners ....... 20

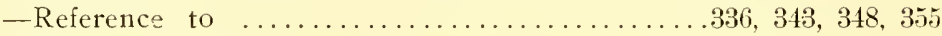

-Purchase of the "Peters" goats.................. 62

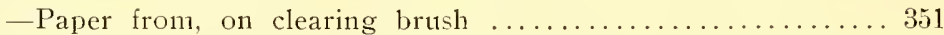

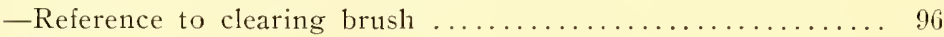

-Reference to dipping for lice...................... 383

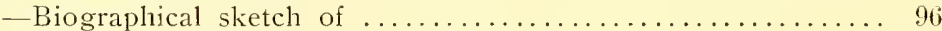

- Notes from, on practical breeding ..............421, 433

—Certificate of merit concerning mohair .............. 101

-In connection with American Angora Goat Breeders' Ass'n.. 446

-Remarks on non-shedding Angoris . . . . . . . . . . . . 229

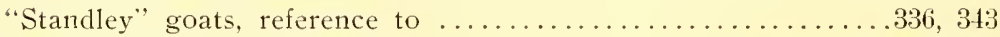

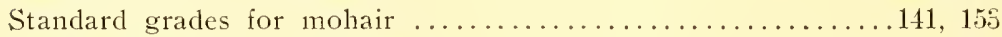

Staking kids, how it was done. . . . . . . . . . . . . . . . 397

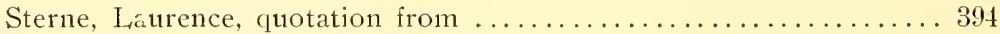

Stewart, D. C., \& Sons, reference to ................... . 324

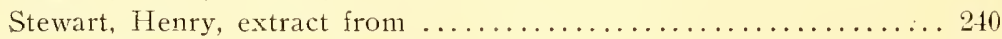

Stump, Hon. J. B., reference to.................... 85

Stiles, Hon. W. H., reference to .................50, 243

"Stockman and Farmer," extract from .................... 445

Stockwell, Hon. J. W., letter about Massachusetts .............. 297

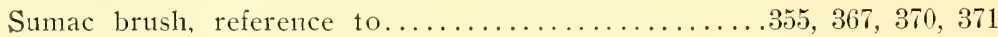

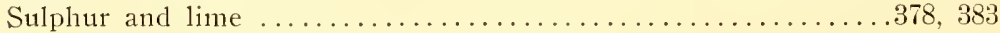

Sweet, Maj. W. E., reierence to Asiatic scab ................ 378

Sumner Cashmere Co., experience of................... 68

"Sumner (Tenn.) Flag," extract from................... 203

Table showing increase of Angoras, by Sir San'l Wilson ......... 112

-Of mohair growing districts in Turkey............. 183

—Of profits on 1,500 Mexican does . ................ 269

-Of profits on 1,500 Angora does . . . . . . . . . . . . 270

—Referring to shearing capacity of Angoras in United States, 308, 309

Tabulated list of replies from breeders ..........433, 434, 435 
PAge

Tanning the Angora goat skin ......................... 485

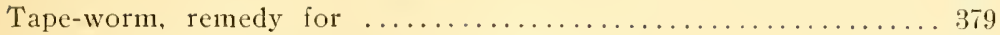

Tariff on Angoras, exported from Cape Colony ............... 106, 164

-Embargo on exporting from Turkey ..............36, 164

-Reference to, as a means of encouraging the American industry, 131

-On mohair at present time .......................... 161

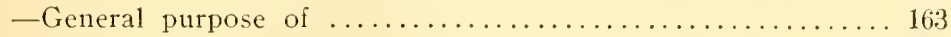

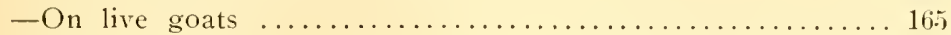

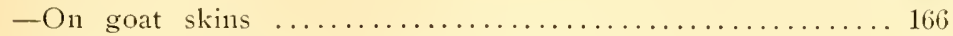

-On goat skins, who are benefitted now .............. 168

-On Mexican goats and mohair. referred to by B. L. Crouch. . 406

Tate, A. R., reference to eleaning brush land ........................ 356

-Notes from, on practical breeding ................ 433

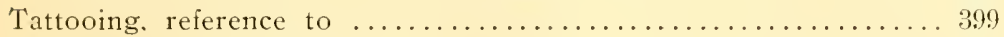

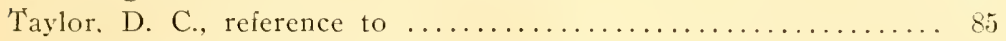

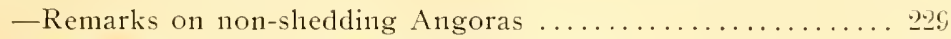

-Statement from, concerning his Angoras............... 38 ?

- Notes from, on practical breeding ..............419, 434

Tchihatcheff, M., reference to cross-breeding in Turkey .......... 216

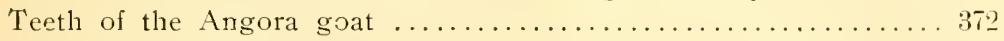

Tennessee, observations on breeding in, by Col. R. Williamson..... 68

-Opinion of Brig.-Gen. E. A. Paine .............. 68

-Reference to Angoras in, by Hon. I. H. Diehl ..........47, 68

-Reference to area for goat raising .......................... 300

-Opinion of W. G. Hughes as to advantages of .......... 300

Ternaux, Baron, reference to crossing the Cashmer and Angora .... 458

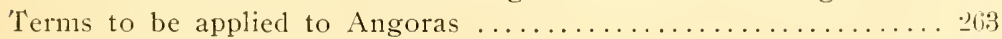

Terrell. Mr., reference to............................... 34

Tessier, Mons., concerning Cashmere goats in France .......... 458

Texas, reference to Angoras in, by Hon. I. H. Diehl ........... 47

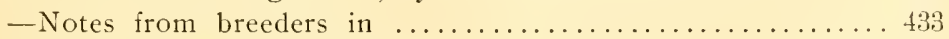

-Estimated number of goats in ..................... 79

Texas, West, advantages of, for goat raising ............... 298

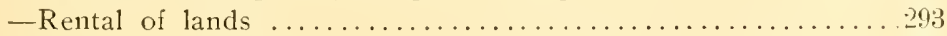

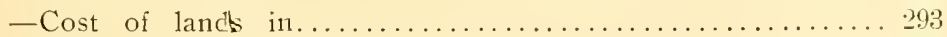

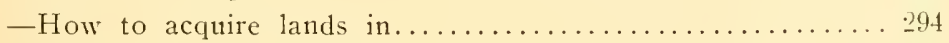

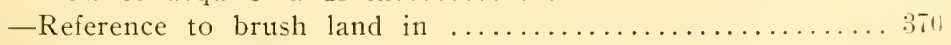

"Texas Stockman and Farmer," extract from.............. 440

Thibet goat, reference to........188, 196, 197, 202, 203, 205. 206. 45i)

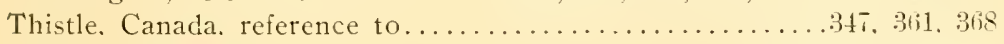

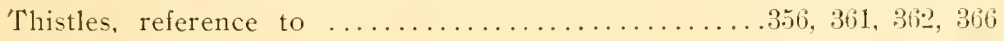

Thimbleberry brush, reference to........................... 360

Thomas \& Cook, prominence in English mohair trade .......... 13t;

Thomas, Hon. Frances, concerning Alpacas ............. 476 


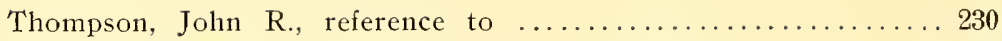

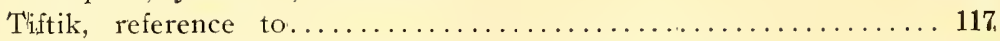

Tobacco and corrosive sublimate as a remedy for scab........378, 383

Tom, Oscar, remarks on non-shedding Angoras .............. 229

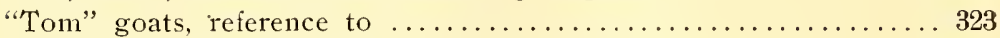

Tom, Oscar, statement about his Angora goats .............. 324

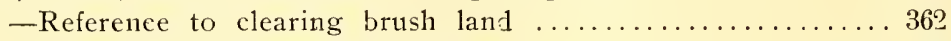

-Notes from, on practical breeding ...............12, 433

Tongue, Hon. Thos. H., raference to clearing brush . . . . . . . . 359

- Notes from, on practical breeding .............4 409, 433

-Letter to, from Hon. H. S. Jew ett ............... 445

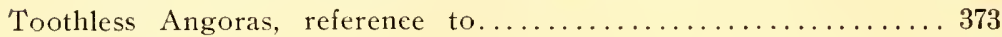

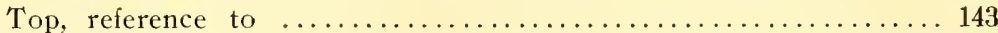

Tour de Aignes, M. de la, reference to ............. 244, 247

Tournefort, M., report to French king about Angoras ......... 34

Tower, C. M., reference to Cashmere goats ...........456,458

Trapping wild animals .......................... 400

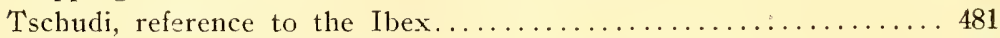

Turkey, imports of mohair from, into England ..........137, 138

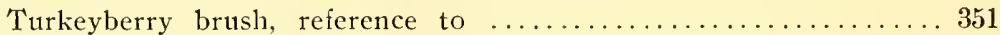

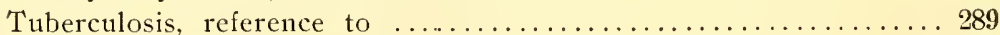

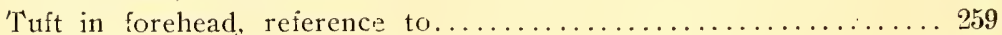

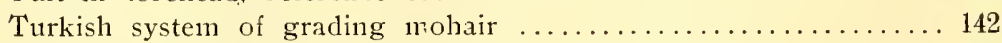

-Angora goat skns, value of.................. 147

-Angora goat skins, how prepared................ 147

Tuthill, C. D., introduces first Angoras into Minnesota ........ 93

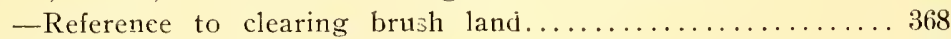

-Notes from, on practical breeding .............25, 434

Tuttle, Dr., statement concerıing his Angoras .............. 340

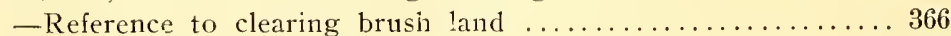

-Notes from, on practical breeding.............. 7 i, 434

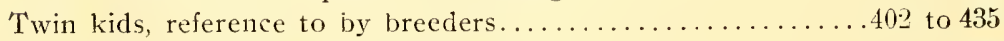

Tyson, Mr., on feeding Angora goats ................... 155

-Of Blair, Neb., on feeding Angoras .................. 375

United States, first introduction of Angoras ............... 45

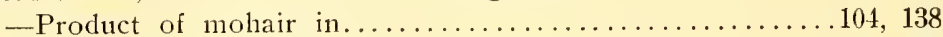

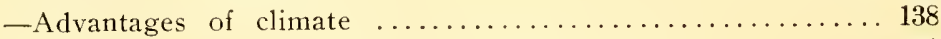

-Agricultural Society report on "Davis" goats............ 192

- Number of Angora goats in .................. 104

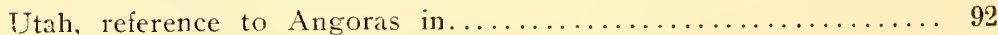

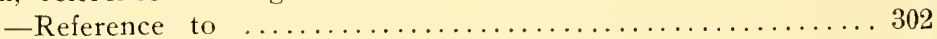

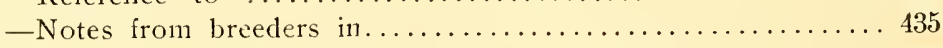

Utrecht velyet, number of men employed in making .......... 126

- Largely used for United States railroad cars............. 128 
PAGE

Value of mohair, how to deternine .................. 143

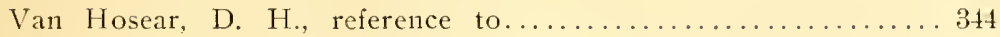

Vat, for dipping Angoras, how to construct ................ 393

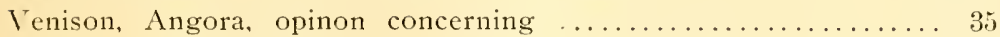

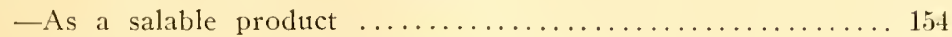

-Opinion of Dr. John Bachman ................ 155

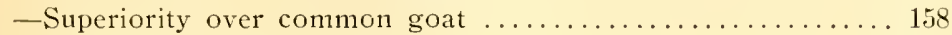

-Reference to term applied to meat ................... 266

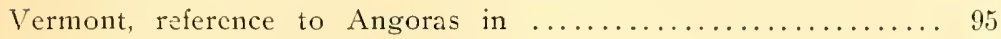

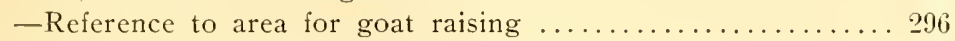

Virginia, first Angoras introduced into.................. 66

-Reference of Dr. Hayes to Col. Herman Haupt ........... 66

-Observations of F. S. Fulmer .................. 66

-Observations of Dr. M. Barnett ................ 66

-Reference to area in, for goat raising................ 299

Wakeley's dip, reference to $\ldots \ldots \ldots \ldots \ldots \ldots \ldots \ldots \ldots \ldots \ldots \ldots \ldots \ldots$

Walker, John, reference to breeding in Missouri...........68, 113

IValker, D. A., statement about his Angoras ................ 324

-Remarks on non-shedding Angorcs ................. 229

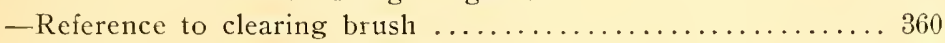

-Notes from, on practical breeding ...............410, 433

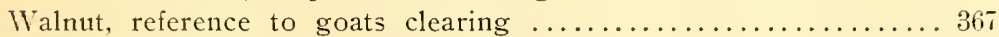

Washington, reference to Angoras in $\ldots \ldots \ldots \ldots \ldots \ldots \ldots \ldots . \ldots 2$

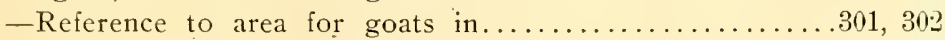

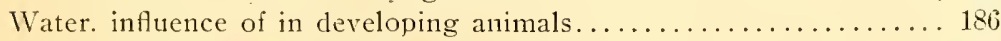

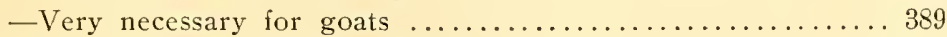

Water Oxen imported by Dr. Davis ................... 206

WVatts, Col. J. Wash., reference to importation of Mr. Stiles ...... 50

-Letter from, concerning Angora industry ........... 53

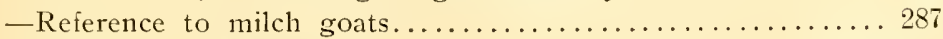

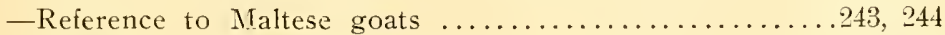

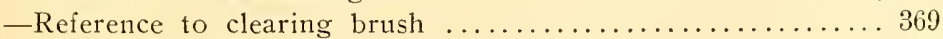

- Reference to breeding grade bucks ............... 250

-Notes from, on practical breeding .................. 435

Watts, Hon. Frederick, refercnce to A!pacas ............ 476

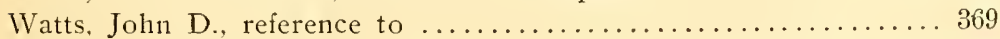

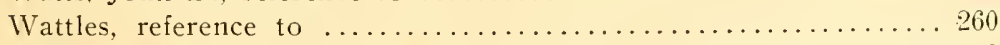

Weeds, removal of, by Angoras ...........352, 355, 356, 367, 368

"Weekly American Banner," of Jazoo, Miss., extract from ....... 201

Weiting, Hon. Chas. A., letter concerning land in New York ..... 298

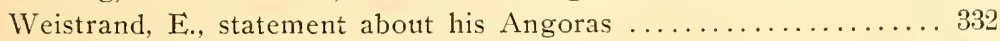

-Notes irom, on practical breeding .............. 420,434

Wells, cost of digging, in New Mexico................. 421 
PAGE

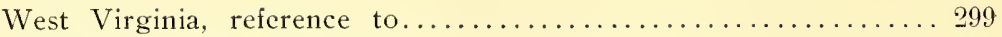

Wether goats, experience of breeders in selling ..........402 to 435

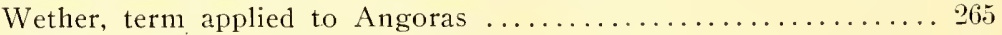

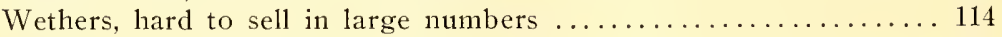

White, Mrs. H. K., letter concerning Dr. Davis ............. 45

-Letter concerning "Davis" goats................. 198, 204

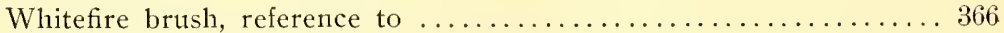

Wheat screenngs, as a feed for goats ...................... 374

Weinaud, Mr., advocates export duty in South Africa ........... 108

Wilcox, A. G., reference to clcaring brush .............. 368

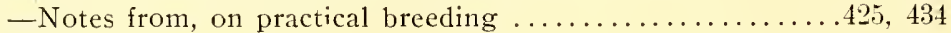

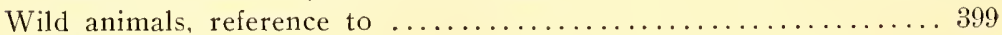

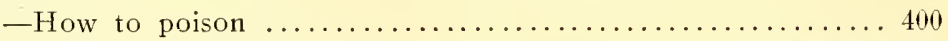

-Reference to, by breeders ....................404 to 435

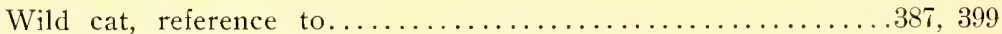

Wilder, James, remarks on non-shedding Angoras ............ 229

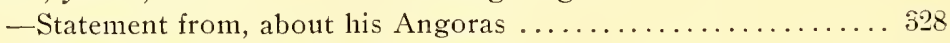

-Notes from, on practical breeding ..............418, 434

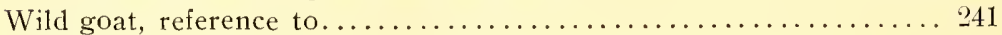

Williams, E. R., reference to clearing Erush.............. 36 ?

- Notes from, on practical breeding .............418, 434

Williams, S. S., remarks about Cashmere goats ............. 65

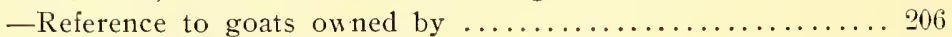

Williamson, H. M., letter from about census of Angoras.......... 105

Williamson, Col. R., obscrvations on breeding............ 68

Williamson, Adams \& Co. goats described................. 199

Wilson, Hon. John, interest manifesterl in Angora industry....... 108

Wilson, Sir Samuel, reference to Australia ................. 111

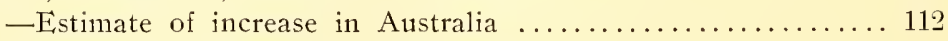

-Reference to Cashmere goats ................... 457

-Opinion concerning improvement................. 459

Wimmer, J. M., statement about his Angoras ................ 331

-Notes on practical breeding .................414, 434

Winter feeding, observatons of Col. Scott $\ldots \ldots \ldots \ldots \ldots \ldots \ldots \ldots 64$

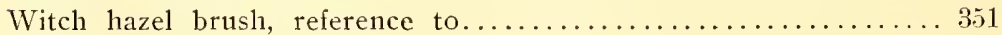

Withycombe, Dr., opinion on reported disease .............. 380

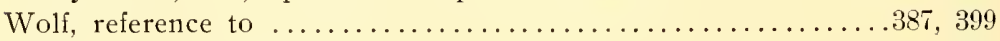

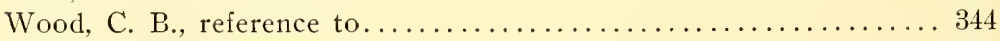

Woodward, N., statement about his Angras ............... 328

-Reference to clearing brush.................... 359

-Notes on practical breeding .................413, 433

Woodlief, W. H., reference to ...................... 446

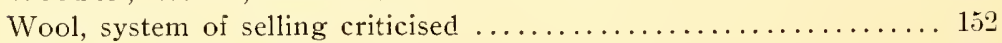

Worms in Angoras ................................. 379 


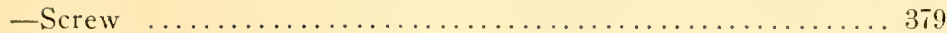

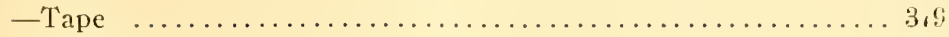

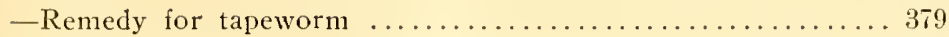

Woven-wire fencing $\ldots \ldots \ldots \ldots \ldots \ldots \ldots \ldots \ldots \ldots \ldots \ldots \ldots \ldots \ldots \ldots \ldots \ldots \ldots, 368,387$

Wyatt, Robt. H., statement about his Angoras ............... 319

-Notes from, on practical breeding ..............402, 433

Wyoming, reference to Angoras in...................... 92

-Reference to ................................. 294

-Notes from brceders in ... ................. 434

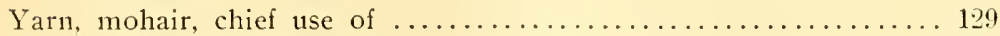

Young, Brigham, introduces Angoras into Utah............ 92

Young, J. K., notes from, on practical breeding............4 430, 435

Zinoleum dip, reference to......................... 497

Zwart Ruggens Association opposes cxport tax in South Africa.... 106. 






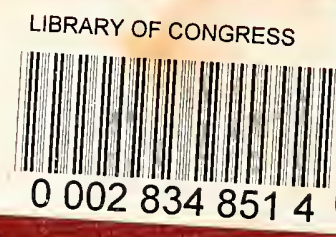

